\title{
Caprock Canyonlands Archeology: A Synthesis of the Late Prehistory and History of Lake Alan Henry and the Texas Panhandle-Plains Volume I
}

Douglas K. Boyd

Prewitt and Associates, Inc.

Follow this and additional works at: https://scholarworks.sfasu.edu/ita

Part of the American Material Culture Commons, Archaeological Anthropology Commons, Environmental Studies Commons, Other American Studies Commons, Other Arts and Humanities Commons, Other History of Art, Architecture, and Archaeology Commons, and the United States History Commons

Tell us how this article helped you.

This Article is brought to you for free and open access by the Center for Regional Heritage Research at SFA ScholarWorks. It has been accepted for inclusion in Index of Texas Archaeology: Open Access Gray Literature from the Lone Star State by an authorized editor of SFA ScholarWorks. For more information, please contact cdsscholarworks@sfasu.edu. 
Caprock Canyonlands Archeology: A Synthesis of the Late Prehistory and History of Lake Alan Henry and the Texas Panhandle-Plains Volume I

\section{Creative Commons License}

\section{(c) (1) $\Theta$}

This work is licensed under a Creative Commons Attribution-NonCommercial-No Derivative Works 4.0 International License. 


\section{CAPROCK CANYONLANDS ARCHEOLOGY: A Synthesis of The Late Prehistory and History of Lake Alan Henry and The Texas Panhandle-Plains}

\section{Volume I}

by

Douglas K. Boyd

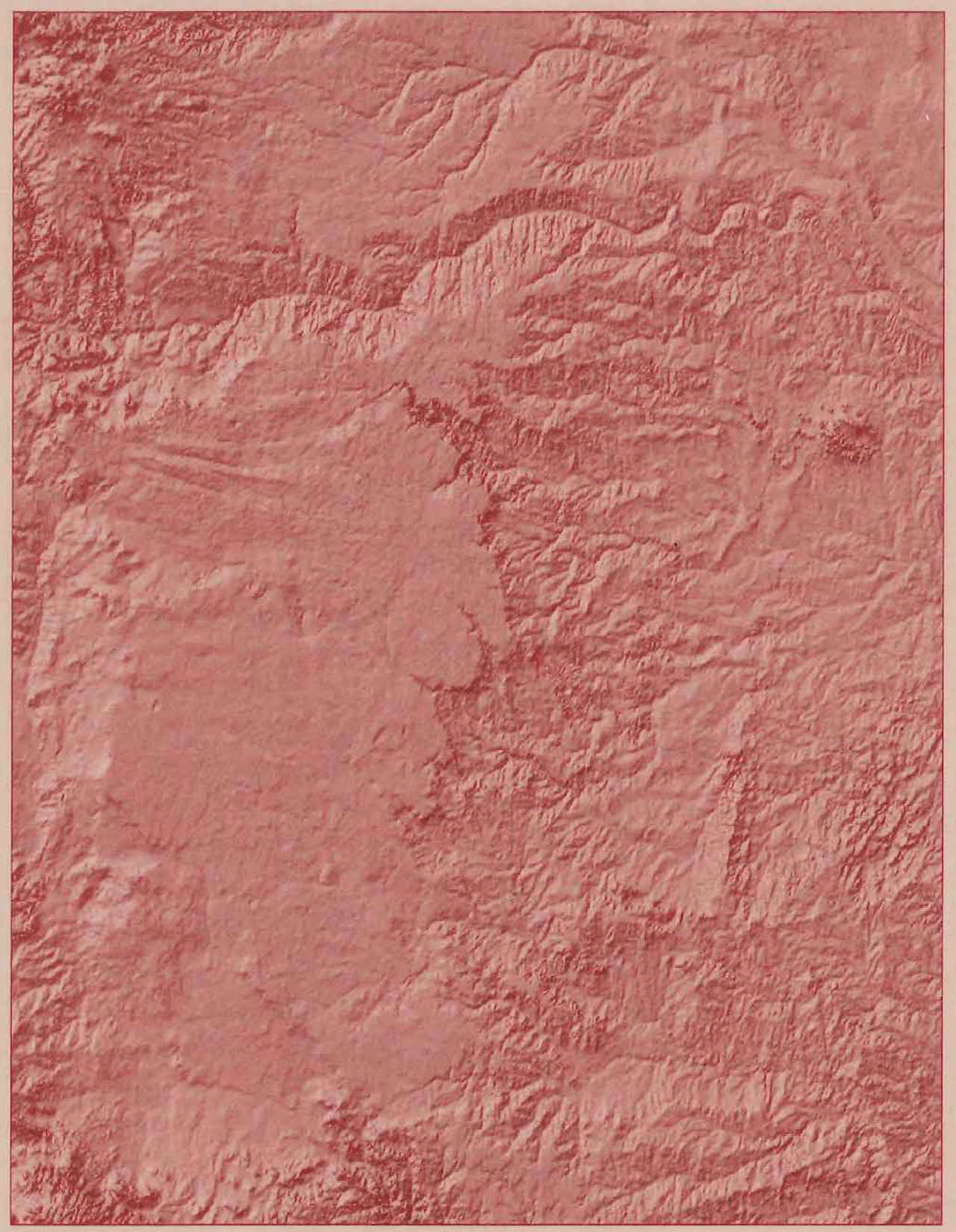

REPORTS OF INVESTIGATIONS, NUMBER 110

TEXAS ANTIQUITIES COMMITTEE ARCHEOLOGY PERMIT NO. 954 


\section{Prewitt and Associates, Inc. Consulting Archeologists 7701 N. Lamar, Suite 104 Austin, Texas 78752-1012 (512) 459-3349}

\section{Lake Alan Henry Reports}

Phase I Cultural Resources Investigations at Justiceburg Reservoir on the Double Mountain Fork of the Brazos River, Garza and Kent Counties, Texas, by Douglas K. Boyd, Martha Doty Freeman, Michael D. Blum, Elton R. Prewitt, and J. Michael Quigg. 2 vols. Reports of Investigations No. 66.1989 (xiv + 643 pp., maps, illus., appendixes).

Phase II Investigations at Prehistoric and Rock Art Sites, Justiceburg Reservoir, Garza and Kent Counties, Texas, by Douglas K. Boyd, James T. Abbott, William A. Bryan, Colin M. Garvey, Steve A. Tomka, and Ross C. Fields. 2 vols. Reports of Investigations No. 71.1990 (xiv +571 pp., maps, illus., appendixes).

Phase II Historical Investigations at Justiceburg Reservoir, Garza and Kent Counties, Texas, by Martha Doty Freeman and Douglas K. Boyd. Reports of Investigations No. 72.1990 (ix + 156 pp., maps, illus., appendix).

Archeological Survey of Wildlife Mitigation Lands, Justiceburg Reservoir, Garza County, Texas, by Douglas K. Boyd, C. Britt Bousman, and Martha Doty Freeman. Reports of Investigations No. 79.1991 (vii + 75 pp., maps, illus., appendix).

Data Recovery at Justiceburg Reservoir (Lake Alan Henry), Garza and Kent Counties, Texas: Phase III, Season 1, by Douglas K. Boyd, Steve A. Tomka, C. Britt Bousman, Karen M. Gardner, and Martha Doty Freeman. Reports of Investigations No. 84.1992 (xii + 256 pp., maps, illus., appendixes).

Data Recovery at Justiceburg Reservoir (Lake Alan Henry), Garza and Kent Counties, Texas: Phase III, Season 2, by Douglas K. Boyd, Jay Peck, Steve A. Tomka, and Karl W. Kibler. Reports of Investigations No. 88. 1993 (xxvi +494 pp., maps, illus., appendixes).

Data Recovery at Lake Alan Henry (Justiceburg Reservoir), Garza and Kent Counties, Texas: Phase III, Season 3, by Douglas K. Boyd, Jay Peck, Steve A. Tomka, Karl W. Kibler, and Martha Doty Freeman. Reports of Investigations No. 93. 1994 (xx + 395 pp., maps, illus., appendixes).

Caprock Canyonlands Archeology: A Synthesis of the Late Prehistory and History of Lake Alan Henry and the Texas Panhandle-Plains, by Douglas K. Boyd, Steve A. Tomka, and Martha Doty Freeman. Reports of Investigations No. 110, 2 vols. 1997 (xiv +585 pp., maps, illus., appendixes). 


\title{
CAPROCK CANYONLANDS ARCHEOLOGY: A SYNTHESIS OF THE LATE PREHISTORY AND HISTORY OF LAKE ALAN HENRY AND THE TEXAS PANHANDLE-PLAINS
}

VOLUME I

by

\author{
Douglas K. Boyd \\ with Contributions by \\ Steve A. Tomka \\ and \\ Martha Doty Freeman
}

Co-Principal Investigators: Elton R. Prewitt and Ross C. Fields

REPORTS OF INVESTIGATIONS, NUMBER 110

Prewitt and Associates, Inc.

Consulting Archeologists

Austin, Texas

September 1997 


\section{VOLUME I}

CHAPTER 1: Lake Alan Henry Archeology and the Caprock Canyonlands

CHAPTER 2: Environmental Diversity in the Texas Panhandle-Plains

CHAPTER 3: Changing Perspectives in Texas Panhandle-Plains Archeology

CHAPTER 4: Archeological Research at Lake Alan Henry

CHAPTER 5: Historic Sites Investigations at Lake Alan Henry and in the Texas Panhandle-Plains

CHAPTER 6: Summary of Native American Archeology at Lake Alan Henry

CHAPTER 7: Analysis of Archeological Data from Lake Alan Henry

CHAPTER 8: Late Holocene Paleoenvironment of the Southern Texas Panhandle-Plains

VOLUME II

CHAPTER 9: The Late Archaic Period, ca. 2000 B.C. to A.D. 500

CHAPTER 10: Late Prehistoric I Period, A.D. 500 to $1100 / 1200$

CHAPTER 11: Late Prehistoric II (A.D. 1100/1200-1541) and Protohistoric (A.D. 1541-1750) Periods

CHAPTER 12: Summary of Late Holocene Native American Adaptation in the Texas Panhandle-Plains REFERENCES CITED

APPENDIX A: Inventory and Summary of Lake Alan Henry Archeological Sites

APPENDIX B: Chronometric Dating at Lake Alan Henry

APPENDIX C: Concluding Studies

Series Technical Editor: Linda Nance Foster 


\section{DEDICATION}

This synthesis is respectfully dedicated to the memory of Billy R. Harrison (1938-1996) and to Jack Hughes (1921-) — friends and colleagues who spent most of their professional careers in pursuit of the prehistory and history of the Texas Panhandle-Plains. 



\section{TABLE OF CONTENTS}

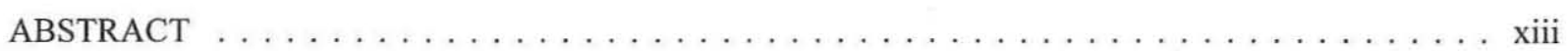

ACKNOWLEDGMENTS $\ldots \ldots \ldots \ldots \ldots \ldots \ldots \ldots \ldots \ldots \ldots \ldots \ldots \ldots \ldots \ldots \ldots$

CHAPTER 1: LAKE ALAN HENRY ARCHEOLOGY AND THE CAPROCK CANYONLANDS

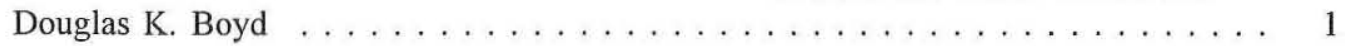

CHAPTER 2: ENVIRONMENTAL DIVERSITY IN THE TEXAS PANHANDLE-PLAINS

Douglas K. Boyd and Steve A. Tomka . . . . . . . . . . . . . . . 7

Geology and Geomorphology $\ldots \ldots \ldots \ldots \ldots \ldots \ldots \ldots \ldots \ldots \ldots \ldots \ldots \ldots \ldots$

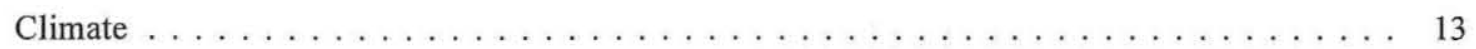

Hydrology and Distribution of Water $\ldots \ldots \ldots \ldots \ldots \ldots \ldots \ldots \ldots \ldots \ldots \ldots$

Modern Spring Data: Implications for Interpreting Prehistory . . . . . . . . . . 23

Historical Documentation of the Inequitable Distribution of Water Resources . . . . 28

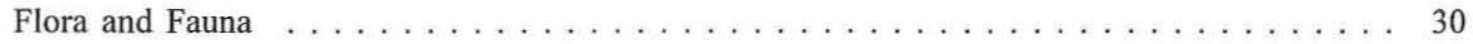

Summary and Conclusions $\ldots \ldots \ldots \ldots \ldots \ldots \ldots \ldots \ldots \ldots \ldots \ldots \ldots \ldots \ldots \ldots \ldots \ldots \ldots$

CHAPTER 3: CHANGING PERSPECTIVES IN TEXAS PANHANDLE-PLAINS ARCHEOLOGY

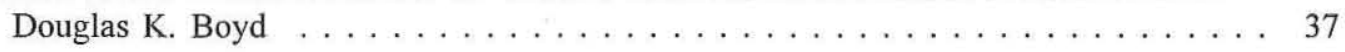

Brief History of Archeological Research $\ldots \ldots \ldots \ldots \ldots \ldots \ldots$

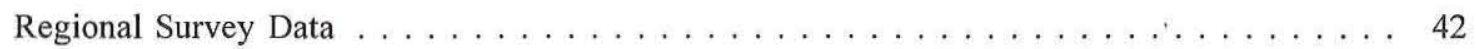

CHAPTER 4: ARCHEOLOGICAL RESEARCH AT LAKE ALAN HENRY

Douglas K. Boyd and Steve A. Tomka . . . . . . . . . . . . . . . . . 55

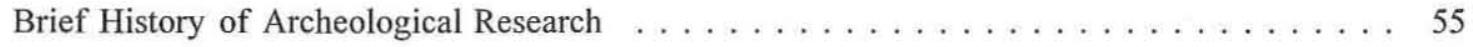

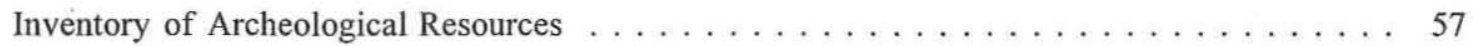

Native American Sites Research Context . . . . . . . . . . . . . . . . 57

A Model of Late Holocene Human Adaptation . . . . . . . . . . . 58

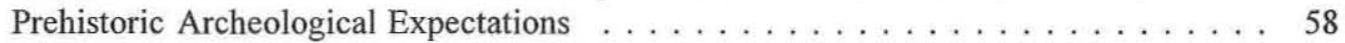

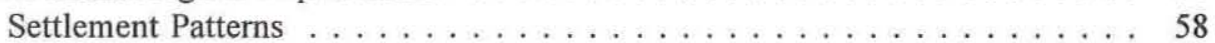

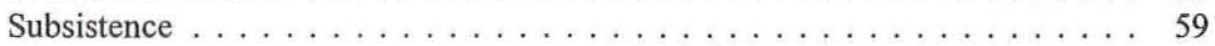

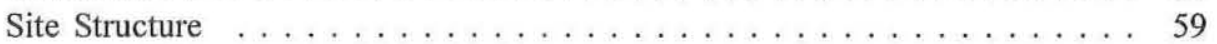

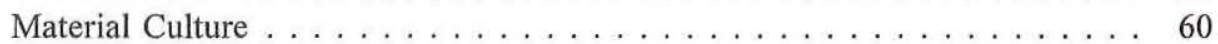

Protohistoric Archeological Expectations . . . . . . . . . . . . . . . . 60

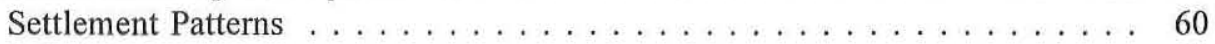

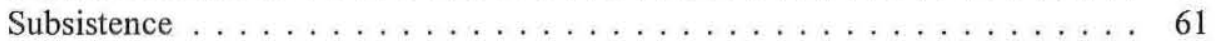

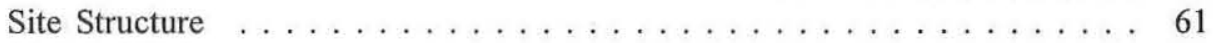

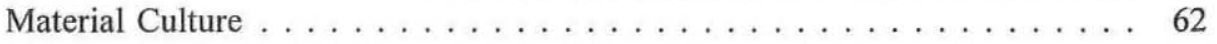

Euro-American Sites Research Contexts $\ldots \ldots \ldots \ldots \ldots \ldots \ldots \ldots \ldots \ldots \ldots$

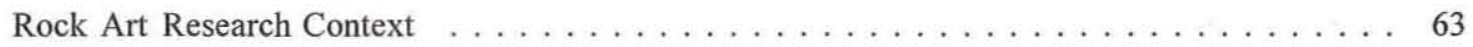

CHAPTER 5: HISTORIC SITES INVESTIGATIONS AT LAKE ALAN HENRY

AND IN THE TEXAS PANHANDLE-PLAINS

Martha Doty Freeman and Douglas K. Boyd . . . . . . . . . . . . . 65

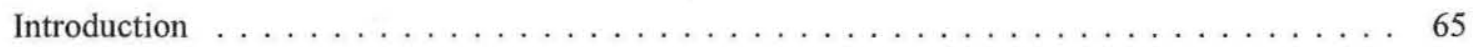


Inventory of Historic Properties at Lake Alan Henry . . . . . . . . . . . . . . . . . 65

Intensively Investigated Historic Sites at Lake Alan Henry . . . . . . . . . . . . . . 68

41GR528, Buffalo Hunters' Camp/Grave . . . . . . . . . . . . . . . . . . 69

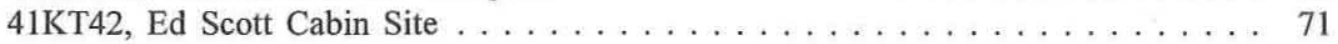

41GR474, Jeff Justice Homestead Site . . . . . . . . . . . . . . . . . 73

Brief History of the Texas Panhandle-Plains and Review of

Historic Properties Investigations . . . . . . . . . . . . . . . . . . . 80

Euro-American Exploration, Expansion, and Conflict with

Native Americans, $1540-1870 \mathrm{~s} \ldots \ldots \ldots \ldots \ldots$. . . . . . . . . . . . . . . .

Development of a Post-Contact Cultural Landscape, $1870 \mathrm{~s}-1945 \ldots \ldots$. . . . . . . 85

Buffalo Hunting . . . . . . . . . . . . . . . . . . . . . . . . . . . . . . . . . . . . . . . . . . .

Hispanic Sheepherding . . . . . . . . . . . . . . . . . . . . . . . . . . . . . . . . . . . .

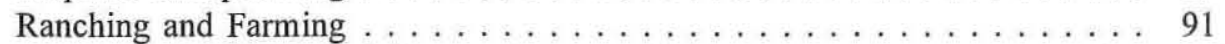

The Railroad, Town Building, and Industrial Development . . . . . . . 95

CHAPTER 6: SUMMARY OF NATIVE AMERICAN ARCHEOLOGY AT

LAKE ALAN HENRY

Douglas K. Boyd and Steve A. Tomka . . . . . . . . . . . . . . . . . . . . . 99

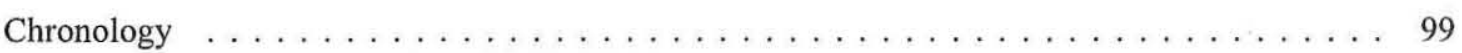

Geomorphology . . . . . . . . . . . . . . . . . . . . . . . . . . . . 102

The Upstream Segment . . . . . . . . . . . . . . . . . . . . . . . . . . . 104

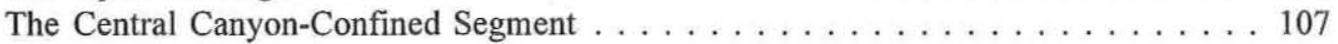

The Downstream Segment . . . . . . . . . . . . . . . . . . . . . . 107

The Uplands . . . . . . . . . . . . . . . . . . . . . . . . . . . . 109

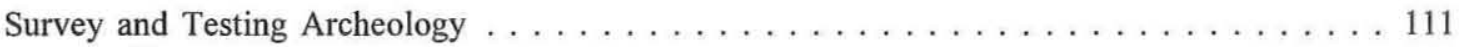

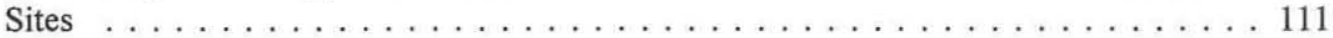

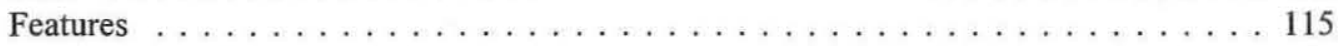

Burned and Fire-Cracked Rock Features . . . . . . . . . . . . . 115

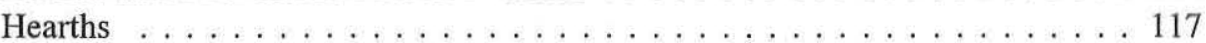

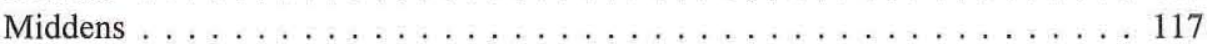

Cairns . . . . . . . . . . . . . . . . . . . . 117

Bedrock Mortars . . . . . . . . . . . . . . . . . 118

Structures and Related Features . . . . . . . . . . . . 118

Native American Rock Art . . . . . . . . . . . . . . . . . . . . . . . . . . . . 118

Rock Art at Lake Alan Henry . . . . . . . . . . . . . . . . . . . . . . . . 119

Rock Art in the Texas Panhandle-Plains . . . . . . . . . . . . . . . . . . . 122

Fort Chadbourne Type . . . . . . . . . . . . . . . . . . . 123

Antelope Creek Type . . . . . . . . . . . . . . . . . . . 126

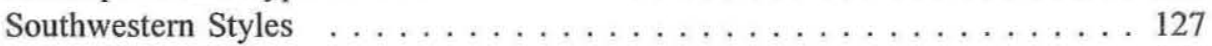

Pecos River Style . . . . . . . . . . . . . . . . . . . . . . . . . . . . . . . . . . . . . . . . . . . .

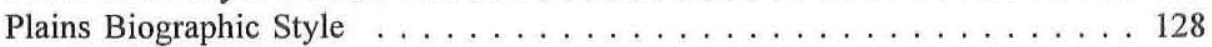

Summary and Conclusions . . . . . . . . . . . . . . . . . 130

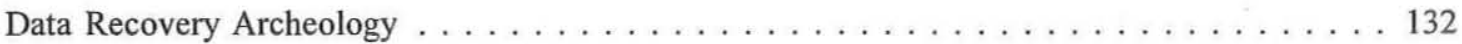

41GR291, Sam Wahl Site . . . . . . . . . . . . . . . . . . . 132

41GR303B, Cat Hollow Site . . . . . . . . . . . . . . . . . 145

41GR383, Gobbler Creek Bridge Site . . . . . . . . . . . . . . . . 148

41GR484, Grape Creek Bench Site . . . . . . . . . . . . . . . . . . . . . . . . . . . . . . .

41 GR546, Boren Shelter No. $1 \ldots \ldots \ldots \ldots \ldots \ldots \ldots$

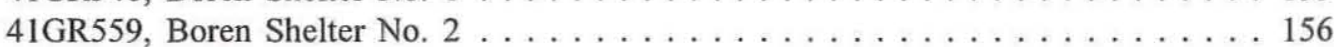

$41 \mathrm{KT} 33$, South Sage Creek Site . . . . . . . . . . . . . . . . . 162 
41KT51, Headstream Site . . . . . . . . . . . . . . . . . . 168

41KT53, Longhorn Site . . . . . . . . . . . . . . . . . . 173

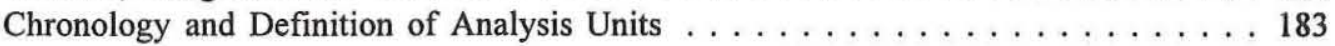

CHAPTER 7: ANALYSIS OF ARCHEOLOGICAL DATA FROM LAKE ALAN HENRY

Steve A. Tomka and Douglas K. Boyd . . . . . . . . . . . . . . . . . 187

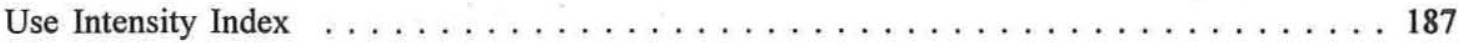

Temporally Diagnostic Artifacts . . . . . . . . . . . . . . . 190

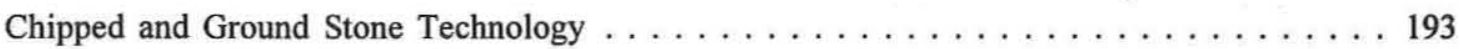

Assemblage Composition . . . . . . . . . . . . . . . . . . . . . . . 193

Richness and Evenness . . . . . . . . . . . . . . . . . 193

Morphofunctional Categories . . . . . . . . . . . . . . . 197

Lithic Material Procurement . . . . . . . . . . . . . . . . . . . . . . . . . . 200

Tool Design and the Nature of the Artifact Assemblages . . . . . . . . . . . . 204

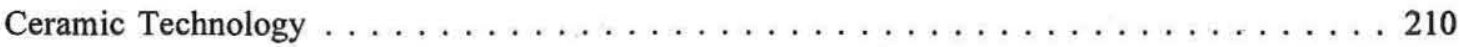

CHAPTER 8: LATE HOLOCENE PALEOENVIRONMENT OF THE

SOUTHERN TEXAS PANHANDLE-PLAINS

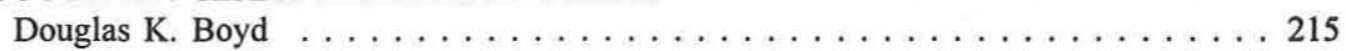

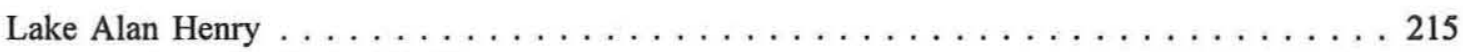

Geoarcheological Evidence . . . . . . . . . . . . . . . . . . . . . . . 215

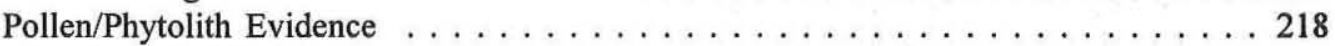

Macrobotanical Evidence . . . . . . . . . . . . . . . . . . . . . . . . 219

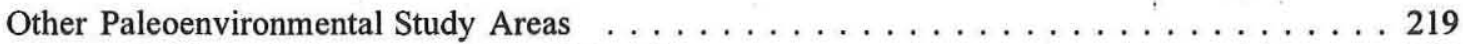

Lubbock Lake Landmark and Vicinity . . . . . . . . . . . . . . . . . . . 219

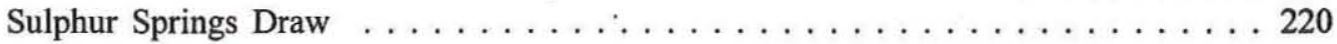

Red Lake Dam . . . . . . . . . . . . . . . . . . . . . 221

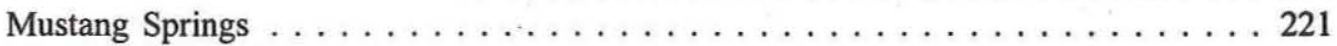

Mitchell Reservoir . . . . . . . . . . . . . . . . . . . 221

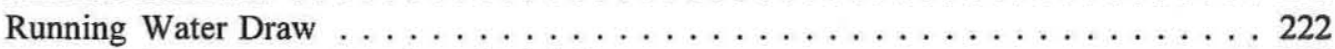

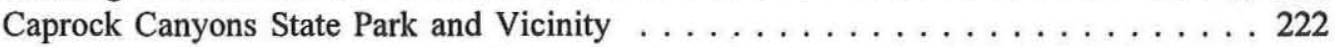

Marks Beach . . . . . . . . . . . . . . . . . . . . . . . . . 223

Palo Duro Canyon . . . . . . . . . . . . . . . . . . . . . . . . . . 223

Mackenzie Reservoir and Lower Tule Canyon . . . . . . . . . . . . . . . . 224

Bailey County Sand Hills . . . . . . . . . . . . . . . . . . . . . . . 224

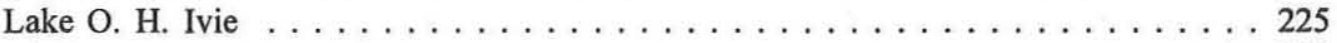

Blackwater Draw . . . . . . . . . . . . . . . . . . . 225

Rattlesnake Draw . . . . . . . . . . . . . . . . . 226

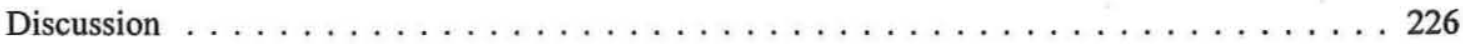




\section{LIST OF FIGURES}

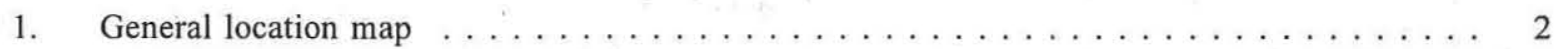

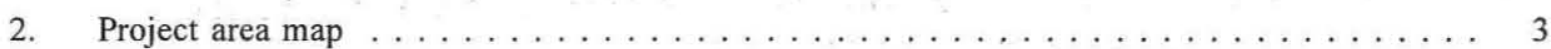

3. Natural/archeological regions of the Texas Panhandle-Plains $\ldots \ldots \ldots \ldots \ldots \ldots$

4. Surface geology and generalized regional cross section of the Texas Panhandle-Plains $\ldots \ldots 10$

5. Topography of the Texas Panhandle-Plains $\ldots \ldots \ldots \ldots \ldots \ldots \ldots \ldots \ldots$

6. Monthly distribution of annual precipitation in the Texas Panhandle-Plains, 1951-1980 _ . . 15

7. Monthly distribution of annual precipitation for 1989 and 1990

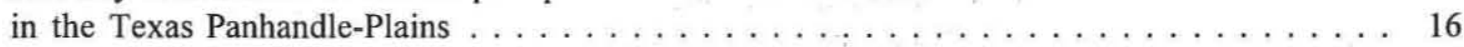

8. Drought in the Texas Panhandle-Plains, $1892-1990 \ldots \ldots \ldots \ldots \ldots \ldots \ldots$. . . . . . . 17

9. Distribution of surface water resources in the Texas Panhandle-Plains

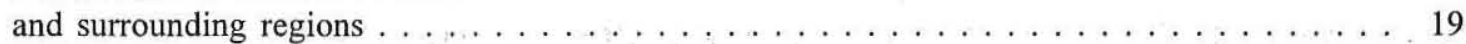

10. Distribution of major freshwater and saltwater spring-producing ground water

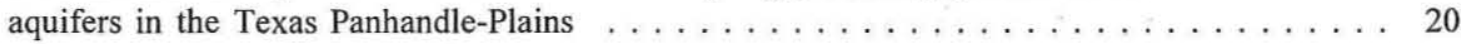

11. Distribution of springs in a selected portion of the Texas Panhandle-Plains . . . . . . . 26

12. Comparison of total area and density of springs by subregion for a selected

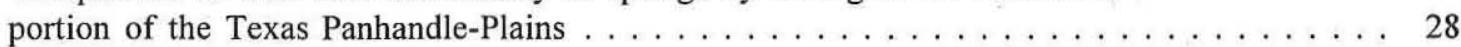

13. Map of archeological survey areas in the Llano Estacado, Caprock Canyonlands,

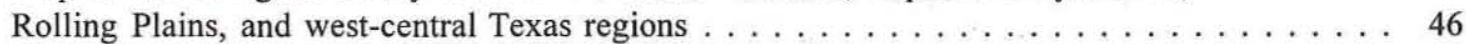

14. Comparison of Native American site densities by region $\ldots \ldots \ldots \ldots \ldots \ldots$

15. Temporal distribution of prehistoric site components by region $\ldots \ldots \ldots \ldots \ldots \ldots \ldots$

16. Tracing of hand-carved native sandstone marker of the grave of

A. W. McCormick at $41 \mathrm{GR} 528 \ldots \ldots \ldots \ldots \ldots \ldots \ldots \ldots \ldots$

17. Site map of $41 \mathrm{KT} 42$ showing features and surface collection grid $\ldots \ldots \ldots \ldots \ldots \ldots$

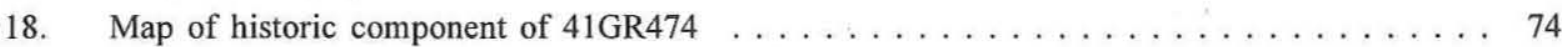

19. Stratigraphic cross sections of the dugout at $41 \mathrm{GR} 474 \ldots \ldots \ldots \ldots \ldots \ldots \ldots$

20. Photograph of the 41GR474 dugout excavation in progress $\ldots \ldots \ldots \ldots \ldots \ldots \ldots$

21. Plan views of the dugout at 41GR474 showing various structural elements $\ldots \ldots \ldots \ldots$

22. Historic range of the American bison $\ldots \ldots \ldots \ldots \ldots \ldots \ldots \ldots \ldots \ldots$

23. Historic features associated with the buffalo trade in the Southern Plains $\ldots \ldots \ldots . \ldots 88$

24. Ranches on the western Rolling Plains, from $1877 \ldots \ldots \ldots \ldots \ldots \ldots \ldots \ldots$

25. Map of the context area for "Livestock and Crop Production, 1870-1945" . . . . . . . . 94

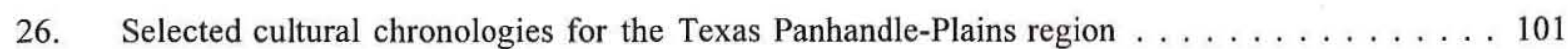

27. Map of the Lake Alan Henry project area showing geomorphic locations

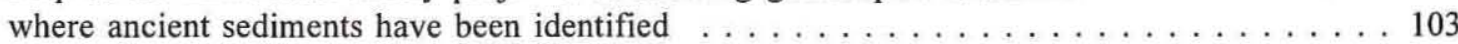

28. Generalized valley cross sections showing the topography of different segments of the Double Mountain Fork of the Brazos River in the project area 
29. Schematic illustration of erosional and depositions landforms of the Double Mountain Fork of the Brazos River in the vicinity of Lake Alan Henry . . . . . . . . . . . 105

30. Generalized geomorphic cross section of the Double Mountain Fork valley in the upstream segment of Lake Alan Henry . . . . . . . . . . . . . . . . . . . . 106

31. Generalized geomorphic cross section of the Double Mountain Fork valley in the central canyon-confined segment of Lake Alan Henry . . . . . . . . . . . . . . . . 107

32. Generalized geomorphic cross section of the lower Grape Creek valley at its confluence with the Double Mountain Fork in the downstream segment of Lake Alan Henry . . . . . . . . . . . . . . . . . . . . . . . . . . . . . . 108

33. Generalized geomorphic cross section of the Double Mountain Fork valley in the downstream segment of Lake Alan Henry . . . . . . . . . . . . . . . . . . . . . 109

34. Distribution of Native American rock art sites in the Texas High Plains and Lower Plains regions . . . . . . . . . . . . . . . . . . . . . . . . . . . . . 123

35. Examples of historic motifs from Lake Alan Henry rock art sites . . . . . . . . . . . . 130

36. Examples of historic motifs from other Texas Panhandle-Plains rock art sites $\ldots \ldots \ldots 131$

37. Map of 41GR291 showing extent of the site, surface features, 1988 test

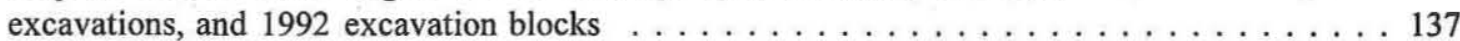

38. Map of north-central portion of 41 GR291 showing locations of data recovery mechanical excavations, hand excavcations, and cultural features . . . . . . . . . . 138

39. Graph of calibrated radiocarbon dates from 41 GR291 . . . . . . . . . . . . . . . . 139

40. Series of photographs showing excavation of the pithouse, 41 GR291 . . . . . . . . . 141

41. Photographs of storage pits at various stages of excavation, 41GR291 . . . . . . . . . 142

42. Plan, profile, and photograph of baking pit Feature 29, 41GR291 . . . . . . . . . . 143

43. Plan and profile drawings of Feature 12, 41GR291 . . . . . . . . . . . . . . . 144

44. Map of 41GR303B showing the topographic setting, 1988 test units, and 1992 excavation units . . . . . . . . . . . . . . . . . . . . . . . . . . . . . . . . 147

45. Three profiles showing the burned rock scatter in the main excavation

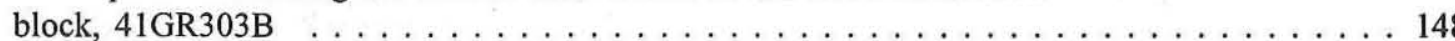

46. Detailed map of the excavation block at 41 GR383 showing locations of

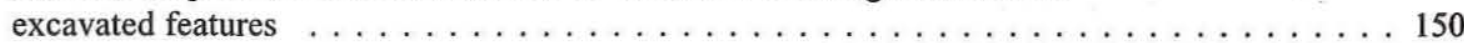

47. Photographs of burned rock features, $41 \mathrm{GR} 383 \ldots \ldots \ldots \ldots \ldots$

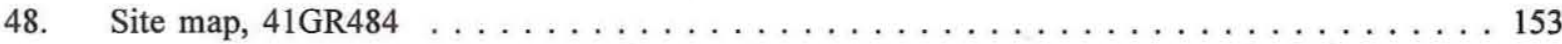

49. Photograph of superimposed hearths at 41 GR484 . . . . . . . . . . . . . . . . . 154

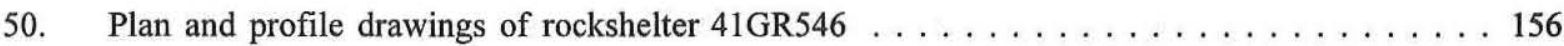

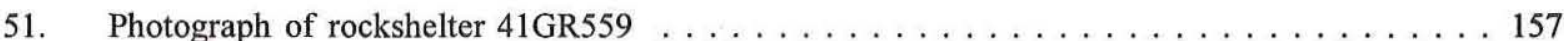

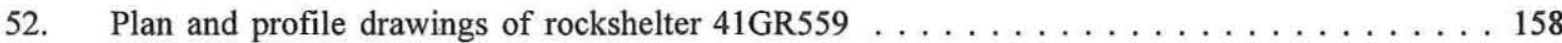

53. East-west profile of rockshelter fill depicting two sediment zones and detailed profile of Excavation Unit 20, 41GR559 . . . . . . . . . . . . . . . . . . 159

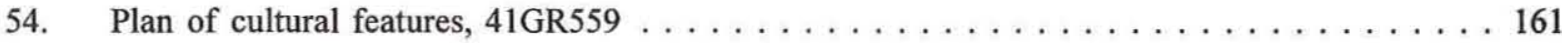


55. Coliapsed east-west profiles indicating the stratigraphic positions of features and corresponding calibrated radiocarbon date ranges inside rockshelter 41GR559

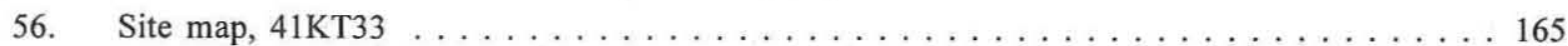

57. Detailed map of the eastern portion of site $41 \mathrm{KT} 33$ showing locations of random sample units and all excavations

58. Topographic map of the Grape Creek valley showing the locations of

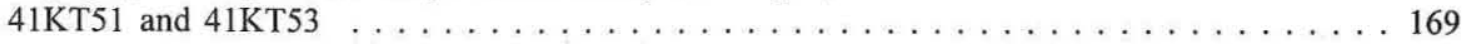

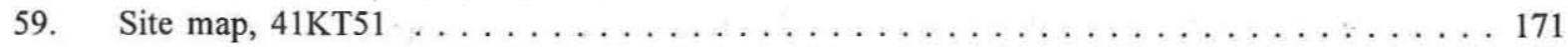

60. Map of 41KT53 showing the extent of the magnetometer survey, all excavation units, and numbered excavation blocks . . . . . . . . . . . . . . . . . . . . 174

61. Map of 41KT53 showing locations and numbers of excavation units and the

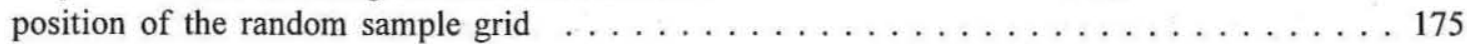

62. Distribution of cultural features and hypothesized tipi structure at $41 \mathrm{KT} 53 \ldots \ldots \ldots$

63. Plan, profile, and photograph of unlined basin hearth at $41 \mathrm{KT} 53 \ldots \ldots \ldots \ldots \ldots$

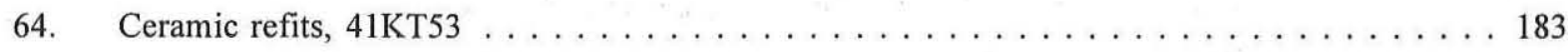

65. Graph of calibrated radiocarbon dates from data recovery sites at Lake Alan Henry . . . . 184

66. Schematic illustration showing chronological sequence of the analytical units defined for data recovery sites at Lake Alan Henry . . . . . . . . . . . . . . . 188

67. Comparison of use intensity indexes for data recovery analysis units by

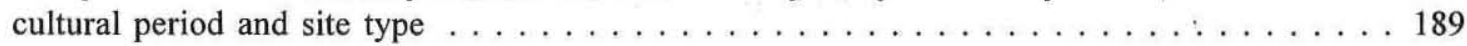

68. Comparison of projectile point frequencies for selected analysis units by time period . . . . 192

69. Monte Carlo simulation of assemblage richness vs. sample size $\ldots \ldots \ldots \ldots \ldots \ldots$

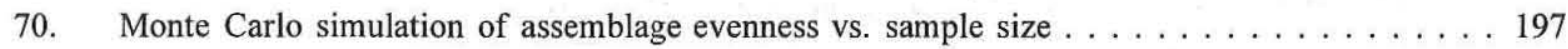

71. Map of nonlocal Texas chert sources represented in the Lake Alan Henry

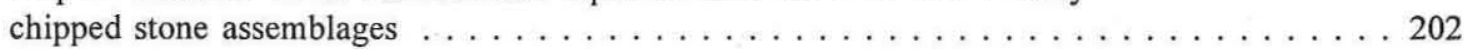

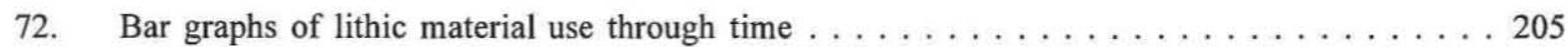

73. Frequency distribution of complete manos based on working surface area $\ldots \ldots \ldots 7$

74. Middle to late Holocene paleoenvironmental study areas within a $250-\mathrm{km}$

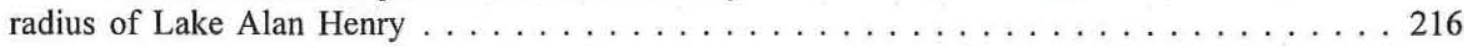

75. Geomorphic history of the Double Mountain Fork of the Brazos River valley

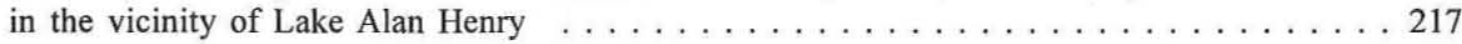

76. Generalized geomorphic and paleoclimatic reconstruction for the southern Panhandle-Plains of Texas . . . . . . . . . . . . . . . . . . . . . . . . . . . 227

77. Comparison of regional paleoenvironmental reconstructions for the Southern Plains . . . . 230 


\section{LIST OF TABLES}

1. Summary of lithic resources in the Texas Panhandle-Plains $\ldots \ldots \ldots \ldots \ldots \ldots \ldots$

2. Temperature, frost, and growing season data for the Texas Panhandle-Plains $\ldots \ldots \ldots 18$

3. Summary of total area and number of springs by subregions for a selected

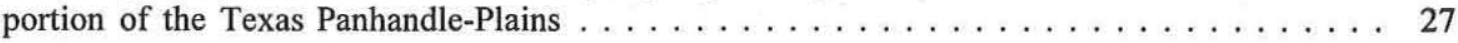

4. Summary of pre-twentieth-century differences in the distribution and quality of surface water resources in the Texas Panhandle-Plains $\ldots \ldots \ldots \ldots \ldots \ldots$

5. Major cultural complexes and phases recognized in the region $\ldots \ldots \ldots \ldots \ldots \ldots$

6. Archeological surveys in the Texas Panhandle-Plains and surrounding areas $\ldots \ldots \ldots 44$

7. Comparison of Native American site density for selected survey projects $\ldots \ldots \ldots \ldots$

8. Summary of prehistoric components for selected survey areas using diagnostic artifacts $\ldots \ldots 51$

9. Published archeological investigations in the Lake Alan Henry project area $\ldots \ldots \ldots \ldots . .56$

10. Summary of archeological site inventory for Lake Alan Henry $\ldots \ldots \ldots \ldots \ldots \ldots$

11. Inventory of historic Euro-American sites at Lake Alan Henry $\ldots \ldots \ldots \ldots \ldots$

12. Lake Alan Henry sites with historic Anglo-American rock art components . . . . . . 68

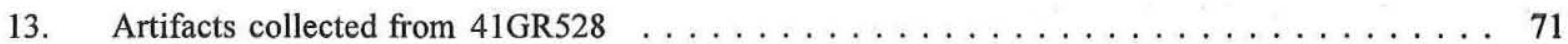

14. Surface-collected artifacts from $41 \mathrm{KT} 42 \ldots \ldots \ldots \ldots \ldots \ldots \ldots \ldots \ldots \ldots \ldots$

15. Functional comparison of historic artifacts in the dugout and trash fill

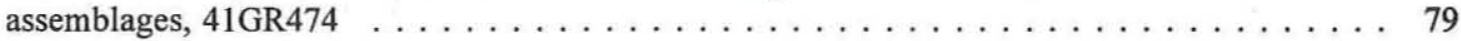

16. Functional comparison between 41GR474 artifact assemblages and other late-

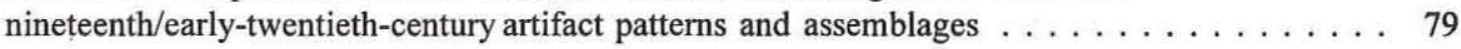

17. Buffalo hunting on the Rolling Plains, 1874-1879: Expected property types $\ldots \ldots$. . 87

18. Summary of New Mexican pastor sites in the Texas Panhandle-Plains . . . . . . . . . . 90

19. Summary of archeological investigations of Texas Panhandle-Plains dugouts associated with late-nineteenth- and early-twentieth-century ranching $\ldots \ldots \ldots \ldots \ldots 6$

20. Temporal distribution of 106 radiocarbon dates from all phases of archeological investigation at Lake Alan Henry . . . . . . . . . . . . . . . . . . . . 100

21. Site type definitions used at Lake Alan Henry $\ldots \ldots \ldots \ldots \ldots \ldots \ldots \ldots \ldots \ldots \ldots$

22. Summary of Native American sites at Lake Alan Henry by level of investigation . . . . . 113

23. Spatial distribution of Native American sites at Lake Alan Henry . . . . . . . . . . . . 114

24. Summary of Native American archeological components at 290 Lake Alan Henry sites . . . 115

25. Spatial/temporal distribution of Native American archeological components

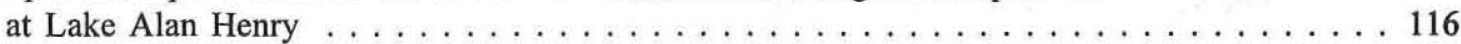

26. Summary of Native American rock art sites at Lake Alan Henry $\ldots \ldots \ldots \ldots \ldots \ldots$

27. Frequency of identifiable motifs in Native American rock art at Lake Alan Henry . . . . 122

28. Native American rock art sites in the Texas High Plains and Lower Plains regions . . . . . 124 
29. Historic motifs and artistic conventions in Texas Panhandle-Plains rock art sites . . . . 129

30. Summary of excavations at data recovery sites at Lake Alan Henry $\ldots \ldots \ldots 133$

31. Artifacts recovered from all phases of work at data recovery sites at Lake Alan Henry . . . 134

32. Summary of radiocarbon dates from cultural contexts at data recovery sites

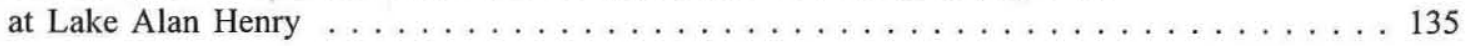

33. Summary of features by type and temporal affiliation, $41 \mathrm{GR} 291 \ldots \ldots \ldots \ldots$

34. Comparison of artifact assemblages assigned to the early and late occupation

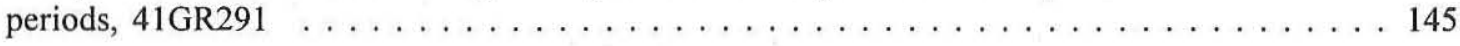

35. Summary of artifacts from the lower and upper zones, 41GR303B $\ldots \ldots \ldots \ldots \ldots$

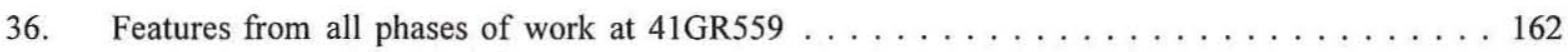

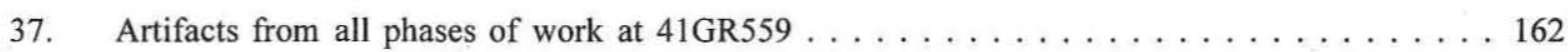

38. Vertebrate faunal remains from all phases of work at 4 IGR559 $\ldots \ldots \ldots \ldots \ldots$

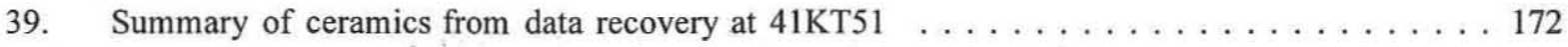

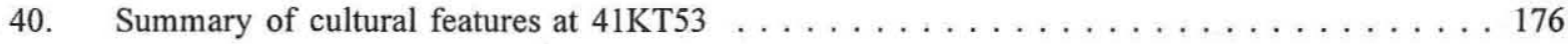

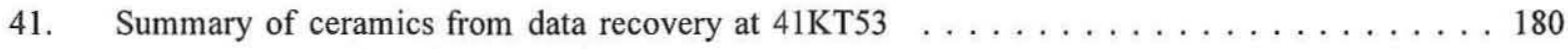

42. Summary of analysis units for data recovery sites at Lake Alan Henry $\ldots \ldots \ldots \ldots$

43. Use intensity for data recovery analysis units $\ldots \ldots \ldots \ldots \ldots \ldots \ldots \ldots$

44. Summary of artifact assemblages for selected data recovery analysis units

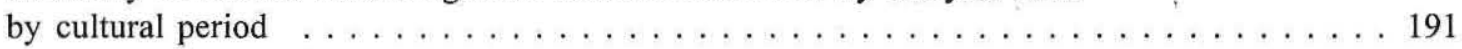

45. Comparison of artifact categories by analysis unit within the Late Prehistoric I sample . . . 194

46. Comparison of artifact categories by analysis unit within the Late Prehistoric II sample . . . 194

47. Comparison of artifact categories by analysis unit within the Protohistoric sample $\ldots \ldots 195$

48. Comparison of combined artifact assemblages by time period $\ldots \ldots \ldots \ldots \ldots$

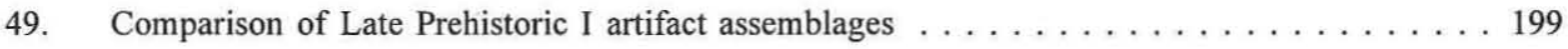

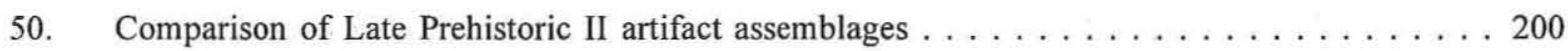

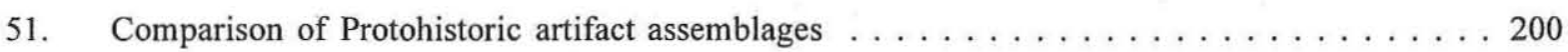

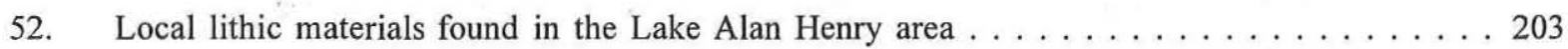

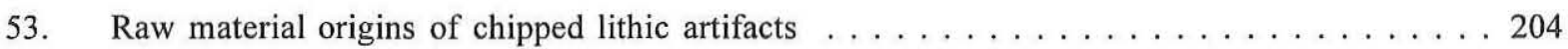

54. Comparison of ground stone tools by analysis unit and time period $\ldots \ldots \ldots \ldots$

55. Comparison of raw material for manos by time period $\ldots \ldots \ldots \ldots \ldots \ldots \ldots \ldots \ldots \ldots$

56. Comparison of the degree of unifacial tool retouch by time period $\ldots \ldots \ldots \ldots$. . . 209

57. Summary of ceramics from Protohistoric sites $41 \mathrm{KT} 51$ and $41 \mathrm{KT} 53$ by

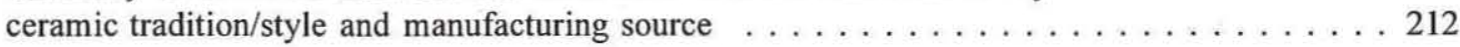

58. Summary of ceramic vessels from Protohistoric sites $41 \mathrm{KT} 51$ and $41 \mathrm{KT} 53 \ldots \ldots \ldots 214$ 


\begin{abstract}
Archeological investigations at Lake Alan Henry, in Garza and Kent Counties, Texas, between 1987 and 1993 generated much archeological data relevant to interpreting late Holocene human activities. This review goes beyond the project boundary to synthesize the late prehistory and history of the Texas PanhandlePlains, with special emphasis on the north-south band of rugged canyons found along the Caprock Escarpment, herein defined as the Caprock Canyonlands. This synthesis looks at the human past from an ecological perspective, correlating shifts in subsistence, technology, and settlement patterns with inferred changes in paleoclimate, flora, and fauna. Past fluctuations in bison population size, undoubtedly related in many complex ways to changes in climate and grassland biotic communities, are emphasized as critical ecological factors affecting long-term patterns of human habitation in the Southern Plains. In addition, other factors identified as having affected human subsistence and settlement are the region's highly seasonal food supply, participation in inter- and extraregional exchange networks, and intercultural conflicts.
\end{abstract}

With climatic conditions more or less comparable to those of today, Late Archaic (2000 B.C. to A.D. 200) peoples adopted a mobile hunting lifestyle and roamed across the vast grassland prairies of the southern High Plains and Rolling Plains in search of bison. Exotic burial artifacts indicate that these nomadic bands were involved in a vast exchange network extending at least as far as the Texas Gulf Coast and the mountainous regions of western Oklahoma and/or Trans-Pecos Texas. Beyond their heavy reliance on bison, however, not much is known about these peoples whose remains are defined archeologically as the Little Sunday complex. Their lifestyle disappeared or changed when bison populations dwindled during the transitional Archaic (A.D. 200 to 500).

During a mesic interval spanning the Late Prehistoric I period (A.D. 500 to 1100/1200), Native peoples adopted a foraging strategy centered around intensive procurement and processing of wild plant foods, perhaps supplemented by limited horticulture, and accompanied by hunting of deer and smaller game. Presumably because of less-favorable grassland conditions, bison populations were so low that bison hunting was not a viable economic pursuit. There appear to have been at least two main groups of people inhabiting the Panhandle-Plains at this time. One group, archeologically recognized as the Lake Creek complex, may have originated from the westward spread of Plains Woodland peoples or ideas, while the other, called the Palo Duro complex, represents the eastward spread of Jornada Mogollon influence among Panhandle-Plains peoples. Burial evidence suggests that the peoples of these two divergent cultural traditions were hostile toward each other.

Concomitant with a drying episode evident over all of the Southern Plains and much of the Greater Southwest, large numbers of bison returned to the Texas Panhandle-Plains around A.D. 1100, and Native peoples once again adopted bison hunting lifestyles during the Late Prehistoric II period (A.D. 1100/1200 1541). While peoples along the Canadian River in the northern Texas Panhandle adapted to the drier climate by incorporating horticulture and bison hunting within a Plains Village tradition, at least two groups living in the Caprock Canyonlands practiced nomadic bison hunting-foraging lifestyles. Defined archeologically as the Tierra Blanca and Garza complexes, either or both of these groups may represent new arrivals in the Southern Plains. Intersocietal exchange with sedentary Anasazi farmers became an important economic pursuit for the bison hunters during this period. Although complex and still poorly understood, the Panhandle-Plains groups continued to intensify their bison hunting and Pueblo trading activities throughout the Protohistoric period (A.D. 1541-1750). Increased mobility and hunting efficiency due to the acquisition of horses, along with increasing Spanish demand for bison products, further intensified the Plains-Pueblo exchange. Competition for hunting territory and trade alliances with sedentary peoples may have exacerbated hostilities between the two main groups of nomadic Southern Plains bison hunters. 


\section{ACKNOWLEDGMENTS}

This synthesis stems from a multiyear archeological research effort at Lake Alan Henry, conducted by Prewitt and Associates, Inc., of Austin, Texas, and funded by the City of Lubbock, Texas. Four City of Lubbock officials were most helpful and are thanked for their cooperation and coordination of the archeological investigations: Terry Ellerbrook, current Director of Water Utilities, and his immediate predecessors Dan Hawkins and Sam Wahl, and Mike Gilliland, Associate Civil Engineer. For the engineering firm of Freese and Nichols, Inc., of Fort Worth, Sue Andrews served as Technical Representative for the first few years of our work, and Barbara A. Nickerson served in this capacity for the remainder of the time. Robert F. (Skipper) Scott IV has served as the archeologist for the lead agency, the Fort Worth District of the U.S. Army Corps of Engineers. For the Texas Historical Commission, James A. Bruseth (Director of the Department of Antiquities Protection) and Nancy Kenmotsu (now with the Texas Department Transportation) have reviewed the various projects for Section 106 and Antiquities Code of Texas compliance.

The supervision and guidance of many folks at Prewitt and Associates was largely responsible for the successful completion of the project. Elton R. Prewitt and Ross C. Fields, who served as Principal Investigators, were the chiefs who kept the warriors in line for the past nine years. Geomorphologists during various phases of work were Michael D. Blum, James T. Abbott, C. Britt Bousman, and Karl W. Kibler; Jay Peck served as Co-Project Archeologist during one field season. Jeanine Cuellar, former Laboratory Director and current Assistant Business Manager, and Karen Gardner, current Laboratory Director, were responsible for keeping the various projects on track. This report was edited by Fields and Senior Editor Linda Nance Foster, and the illustrations were prepared by Senior Cartographer Sandy Hannum. Linda Foster prepared the final report for publication.

Many individuals contributed ideas or insights during the authors' study of the prehistory and history of the Caprock Canyonlands (in alphabetical order): Jim Abbott, Britt Bousman, Jim Couzzourt, Brett Cruse, Phil Dering, Lain Ellis, Meeks Etchieson, Ross Fields, Martha Freeman, Colin Garvey, Jack Hedrick, Margaret Howard, Jack Hughes, Lee Johnson, Karl Kibler, Zoe Kirkpatrick, Chris Lintz, Bob Mallouf, Jay Peck, Elton Prewitt, Mike Quigg, Kathy Reese-Taylor, David Robinson, Curtis Schaafsma, Brian Shaffer, Emmett Shedd, David Snow, and Regge Wiseman. While many of the ideas presented herein were developed through consultation and communication with these individuals over a period of many years, this does not mean that they agree with my interpretations of the data. I take full responsibility for the interpretations proposed herein, as well as any errors of omission or oversight. Special thanks go to retired West Texas State University Professor of Anthropology Jack T. Hughes, whose more than half-century of Plains archeology experience has had a considerable impact on the study of Panhandle-Plains prehistory and this synthesis. A posthumous thank you goes to Bill Harrison, former Curator of Archeology at the Panhandle-Plains Historical Museum, for his many ideological contributions to this volume.

Douglas K. Boyd

July 1996 


\section{LAKE ALAN HENRY ARCHEOLOGY AND THE CAPROCK CANYONLANDS}

by Douglas K. Boyd

In 1987, Prewitt and Associates, Inc. (PAI) of Austin, Texas, conducted an archeological survey of an 8,600-acre tract of land where the City of Lubbock planned to build a lake to serve as one of its municipal water supplies. Located on the Double Mountain Fork of the Brazos River in Garza and Kent Counties, Texas, the initial study of the proposed Justiceburg Reservoir (which was later officially named Lake Alan Henry) locality was the first in a series of cultural resources field investigations that lasted over 6 years and included additional surveys, site testing and assessment of National Register of Historic Places eligibility, and data recovery at numerous Native American, historic, and rock art sites (Figure 1). At the conclusion of the fieldwork in 1993, 380 archeological sites had been documented in 11,280 acres, and various levels of archeological testing or data recovery had been completed at dozens of these sites. The project offered PAI an opportunity rare in today's archeological world - to follow the cultural resources studies of a major reservoir project through all of its phases, from initial survey to data recovery.

Because the cultural resources studies were coordinated with the reservoir's planning and construction schedules, the fieldwork was spread out over five seasons. This afforded PAI the luxury of being able to think critically about its findings between seasons, assess the field methods and analytical techniques employed, learn from its mistakes, and apply this knowledge to the next season's work. The continuity of the cultural resources studies was further enhanced because several key project personnel were involved in every phase of the work, and many people served on field crews for two or more seasons. Consequently, the project was able to maximize the recovery and interpretive potential of a great deal of archeological data. The investigations have been a long and continuous learning process and, by the time the dam at Justiceburg Reservoir was completed and the waters of Lake Alan Henry began to impound, a great deal of archeological knowledge, as well as data, had been accumulated. ${ }^{1}$ After nine years of field, laboratory, and library research, the investigators now have a much greater understanding of the archeological remains encountered in the project area and across the entire region. This report is a synthesis of the prehistory and history of the Texas Panhandle-Plains, as seen from Lake Alan Henry (Figure 2).

Three factors governed the format and scope of this archeological synthesis. One is the geographic location of the project area relative to the surrounding ecological and environmental zones. The second factor is the temporally biased nature of the archeological record in the project area. The third factor is the lack of substantive historic archeological research in the region. Each of these factors is discussed separately below.

The Panhandle-Plains of Texas traditionally is divided into only two major physiographic regions-

\footnotetext{
${ }^{1}$ All records and collections generated by the Lake Alan Henry project are curated at The Museum of Texas Tech University in Lubbock.
} 


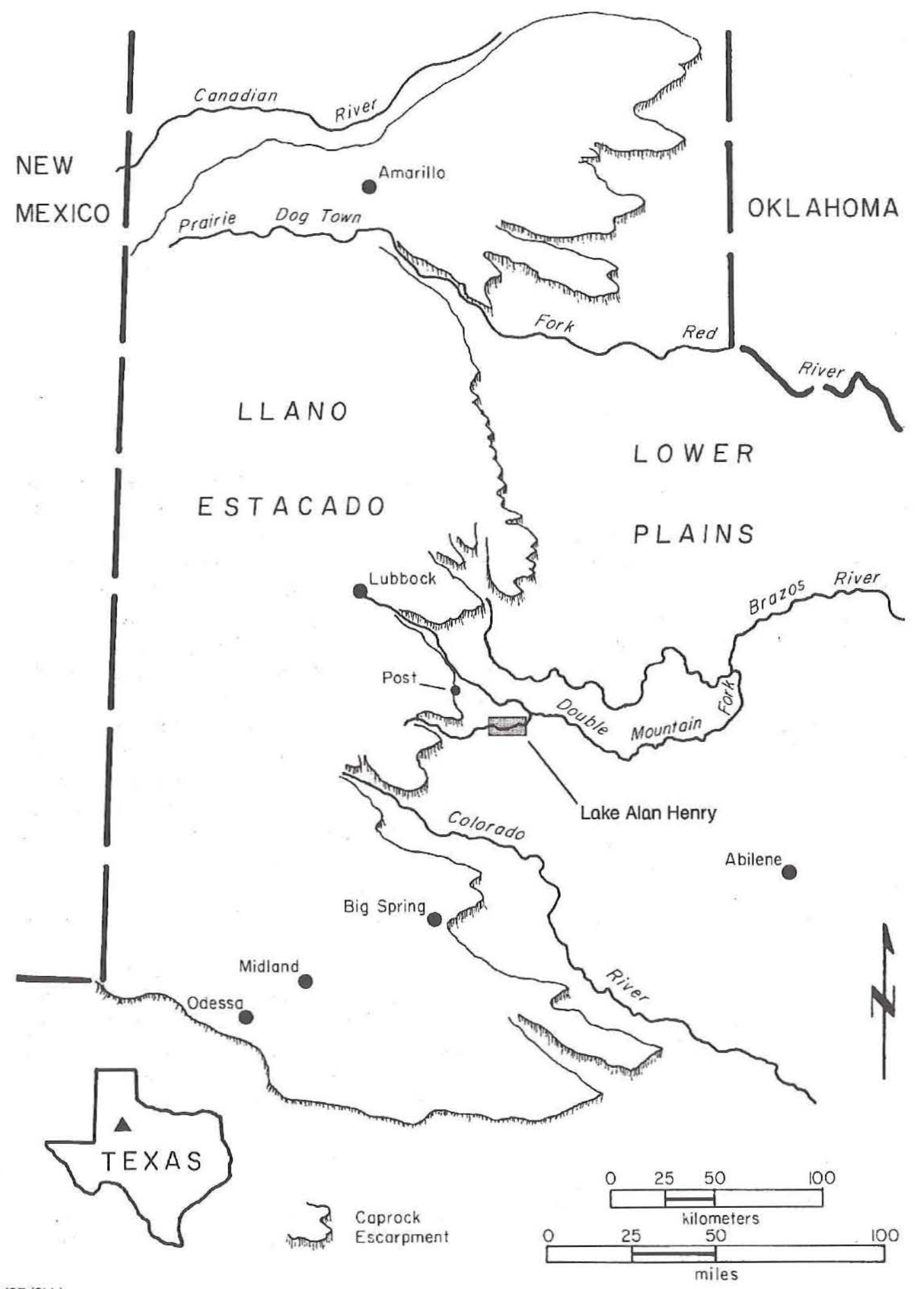

PAI/97/SLH

Figure 1. General location map. 


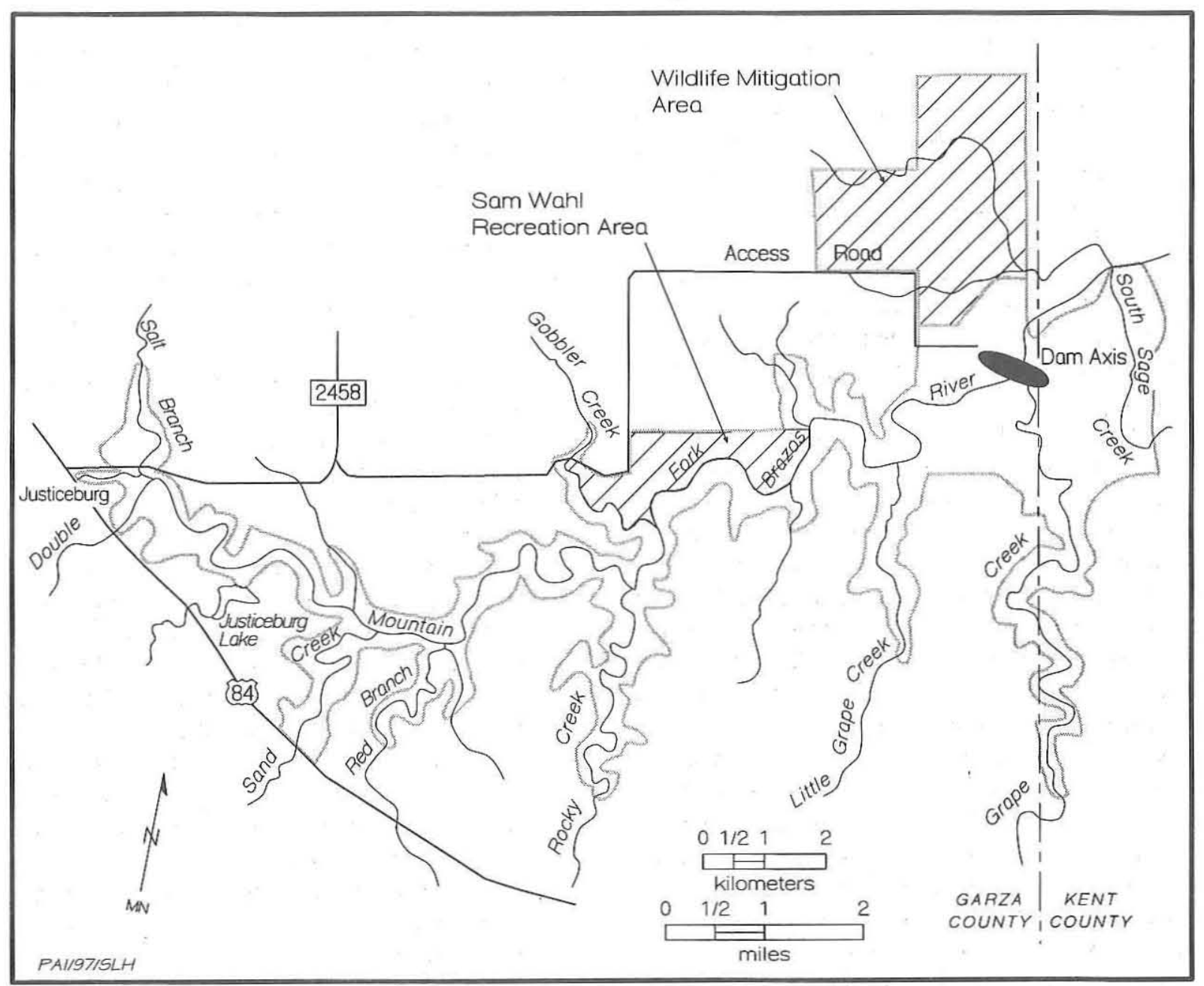

Figure 2. Project area map.

the southern High Plains (or Llano Estacado) and the Lower Plains (or Rolling Plains). These regions are distinct in many ways, and each is broadly characterized by its own physiography, climate and hydrology, flora and fauna, and, of course, archeology. Major differences between the archeology of the High Plains and Lower Plains have long been noted. What became apparent during the course of the investigations at Lake Alan Henry, however, is that the archeology of the project area does not fit neatly with that of most of the Lower Plains. The greatest similarities are seen in the rugged canyonlands up and down the Caprock Escarpment, and not to the east in the vast expanse of rolling hills that comprise most of the Lower Plains. Emerging from this research, then, is the concept of the Caprock Escarpment as its own archeological region with characteristics that are intimately related to, yet distinct from, the archeology of the High Plains and the rest of the Lower Plains.

The eastern edge of the High Plains is well defined by a distinctive topographic feature known as the Caprock Escarpment. This feature also serves as the western boundary of the Lower Plains. When one looks more closely, however, it is clear that the Lower Plains actually consists of two subregions that are divisible primarily by their distinctive geology and topography. The eastern three-fourths of the Lower Plains is characterized by eroded Permian redbeds and rolling plains topography. In contrast, a long thin strip along the Caprock Escarpment is characterized by exposed layers of erosion-resistant Pliocene Ogallala Formation caliche and Triassic Dockum Group sandstones and rugged canyonland 
topography. The term "Caprock Canyonlands" is chosen as the most fitting name for this north-south corridor that divides the High Plains from the Rolling Plains. As used here, Caprock Canyonlands refers to one of two subregions of the Lower Plains (the other being the Rolling Plains), and it should not be confused with the Caprock Canyons State Park in Briscoe County.

The environmental characteristics that make the Caprock Canyonlands unique are discussed in the following chapter, but the important point is that it should come as no surprise to find that the archeology of the region also is unique. This is not an entirely new revelation, and many archeologists have commented on the distinctive nature of the Caprock Escarpment zone and its archeology. This synthesis is, however, the first attempt to formalize the concept of the Caprock Canyonlands as a unique archeological subregion. The primary justification for recognizing this ecological zone as an archeologically significant region is that the Caprock Canyonlands is, and always has been, an oasis within the otherwise arid landscape of the Southern Plains. Water is today, just as it was in the past, the single most critical resource dictating the distributions of plant, animal, and human communities throughout the northwestern portion of Texas. Prehistoric and historic peoples who lived in the Southern Plains recognized this fact, and they adapted their lifestyles and settlement patterns accordingly. Consequently, one important goal of this synthesis is to define how the Native American archeology of the Caprock Canyonlands differs from that of the adjacent regions.

The biased nature of the archeological record at Lake Alan Henry also had a direct bearing on the form that this synthetic archeological overview would take. It was observed at Lake Alan Henry, and has been observed during other archeological projects along the Caprock Escarpment as well, that the vast majority of archeological sites and components date to the late Holocene. As is demonstrated later, this is due largely to the region's geologic and geomorphic history. More specifically, it appears that widespread erosional stripping of most late Pleistocene and early Holocene sediments from the canyonlands occurred during the mid-Holocene Altithermal. In archeological terms, the Caprock Canyonlands is characterized by a paucity of early sites and an abundance of Late Archaic, Late Prehistoric, Protohistoric, and Historic sites. Consequently, this synthesis deals only with the late Holocene archeology of the Caprock Canyonlands and Panhandle-Plains and does not examine the region's Paleoindian and Early to Middle Archaic archeology.

The third factor that dictated how this synthesis evolved and the final form it would take relates to historic archeological research in the Texas Panhandle-Plains. A quick scan through the chapters will highlight the fact that the historic resources in the region receive little attention relative to prehistoric and protohistoric resources. The reason is quite simple - precious little substantive archeological data are available for historic sites (i.e., sites with evidence of Euro-American or Anglo-American occupations or activities). Compared to prehistoric archeology, historic archeological research is still in its infancy in the Texas Panhandle-Plains and, indeed, across the entire state. Great progress has been made in recent years, but there is still a serious lack of focus and direction for historic archeology in the Panhandle-Plains. It was far beyond the scope of this synthesis to attempt to summarize the wealth of historic archival and potential archeological resources covering the entire Panhandle-Plains in any coherent manner. Realizing that such an effort would be futile and still not do the resource base justice, an alternative course of action was chosen. After summarizing the historical contexts developed specifically for Lake Alan Henry and reviewing the historic archeological site investigations in the project area, only a cursory attempt at regional comparisons is made. More important than trying to mesh the Lake Alan Henry historic archeological data into an almost nonexistent regional historic archeology database, the remaining effort is directed toward defining future research goals for historic sites archeology in the region.

This report is organized into 12 chapters and 3 appendixes. Chapter 2 presents and defines the Caprock Canyonlands as a distinct ecological subregion and describes the geographic and seasonal variability in the distribution of resources. A history of Texas Panhandle-Plains archeology is presented in the first half of Chapter 3, but it is not a standard chronological listing of archeological players and investigations. Rather, this brief historical summary identifies various regional archeological or culture history syntheses that have been done over the years to illustrate critical changes in the theoretical perspectives and directions of archeological research. The second half of Chapter 3 presents a summary of 
regional archeological survey data that highlights the broad differences between the archeology of the Caprock Canyonlands and of the surrounding regions. This chapter concludes with the idea that more-refined spatial and chronological analyses are needed to support meaningful reconstructions of Panhandle-Plains prehistory.

Chapter 4 summarizes all of the archeological research that has been conducted in the Lake Alan Henry project area, from the earliest site recording in the 1950s to the multiyear investigations of PAI in the 1980s and 1990s. The chapter also outlines the research contexts used by PAI to guide its investigations. Different research contexts that were used to direct research and evaluate archeological sites are defined for Native American resources (i.e., prehistoric and protohistoric sites and components), historic resources (i.e., Euro-American/AngloAmerican sites and components), and rock art resources (includes sites and components with both Native American and Euro-American rock art).

Chapters 5, 6, and 7 summarize the Lake Alan Henry archeological resources, data, and interpretive findings. Historic site investigations in the project area are summarized in Chapter 5, along with a regional historic overview that discusses the current state of historic sites archeology. Investigations of Native American archeology in the project area are summarized in Chapter 6, including a description of the entire resource base and data generated from the survey and testing phases, a discussion of the Native American rock art in the project area and throughout the region, and summaries of data recovery investigations at each site. This chapter ends with a definition of analysis units (i.e., discrete chronological groups of archeological features and artifacts that approximate components) recognized through data recovery investigations. A detailed analysis of these archeological data is the subject of Chapter 7. Analysis units are grouped by temporal/cultural periods and then compared and contrasted to support inferences of prehistoric and protohistoric Native American behavior and lifestyles in the project area.

Paleoenvironmental evidence for the southern portion of the Texas Panhandle-Plains is summarized in Chapter 8. It begins with a discussion of paleoenvironmental data from Lake Alan Henry, and then expands out to look at other paleoenvironmental study areas within a $250-\mathrm{km}$ radius of the lake. The chapter ends with a gross paleoclimatic reconstruction of the southern Panhandle-Plains and compares this scenario with paleoclimatic reconstructions from other parts of Texas and Oklahoma.

Chapters 9, 10, and 11 are the nuts and bolts of the regional synthesis. A chapter is devoted to each of three major temporal/cultural periods-Late Archaic, Late Prehistoric I, and Late Prehistoric II/ Protohistoric. For its respective time period, each chapter keys in on the important cultural groups (i.e., archeological entities called complexes and/or phases) that have been identified by researchers as having occupied the Caprock Canyonlands and surrounding areas. Regionally important archeologicalsites, where intensive investigations (primarily testing and largescale excavations) have produced a significant body of archeological data relating to specific cultural groups, are discussed individually. Archeological data resulting from site investigations are critically evaluated, both quantitatively and qualitatively. The regional data are then compiled, compared, and contrasted to formulate interpretations for each of the identified cultural entities. For each cultural group that occupied the Caprock Canyonlands, the following topics are considered: (1) chronology, based primarily on absolute dating; (2) subsistence and site function; (3) seasonality and residential mobility; (4) reconstruction of settlement patterns or land-use strategies; and (5) geographic range and relationships with other cultures in adjacent areas.

The final chapter summarizes the interpretations presented in Chapters 9 through 11 . Chapter 12 presents a succinct reconstruction of late Holocene Native American adaptations in the Texas PanhandlePlains and relates the archeological data back to the Native American sites research design summarized in Chapter 4. Discussions highlight significant differences in subsistence strategies and land-use patterns between time periods. Suggestions for future directions for Native American archeological research in the Panhandle-Plains also are made in Chapter 12.

Two of the three appendixes present tabular summaries of archeological data for Lake Alan Henry. Appendix A summarizes basic site data for the 380 archeological sites recorded in the 11,280acre project area. Appendix B summarizes the radiocarbon, thermoluminescence, and archeomagnetic dating done during all phases of archeological work at Lake Alan Henry. The final appendix summarizes the methods and results of three special studies that were initiated during earlier phases of work but only recently were completed and thus never published in any of the previous reports. The 
special studies discussed in Appendix C are (1) a tree ring study of cross sections of Quercus fusiformis (escarpment live oak) to determine the utility of the species for dendrochronological dating and climatic reconstruction; (2) an attempt to radiocarbon date pigment from a Native American rock art site; and (3) caging of a Native American rock art shelter as a means of site protection. 


\section{ENVIRONMENTAL DIVERSITY IN THE TEXAS PANHANDLE-PLAINS}

by Douglas K. Boyd and Steve A. Tomka

The traditional view of the Texas PanhandlePlains is that it is composed of two regions: the High Plains and the Lower Plains. The Llano Estacado, the southernmost portion of the High Plains, is isolated from the rest of the High Plains by the Canadian River valley; it is the single dominating physiographic feature in the southern Great Plains and is distinctive from everything around it. To the east, the Lower Plains consists largely of undulating hills exposed by erosion. While the notion that the High Plains and Lower Plains are environmentally unique is accurate, it is a gross oversimpification. Sandwiched between the Llano Estacado and the Lower Plains is the Caprock Escarpment. This meandering north-south line marks the eastern edge of the Llano Estacado, and the current landscape is the result of over a halfmillion years of headward stream erosion eating away at the High Plains plateau. It is often thought of as a single dividing line, but the Caprock Escarpment is more realistically viewed as a series of rugged canyonlands that separates the Llano Estacado from the Rolling Plains (Figure 3). Although the western edge of the Llano Estacado in New Mexico is marked by the prominent Mescalero Escarpment, there are no extensive canyonlands or distinctive environmental niches comparable to those found along the Caprock Escarpment.

A number of terms are used in this chapter to denote geographic/ecological regions, and these same terms also are used in later chapters to refer to archeological regions. The entire study area is within the Great Plains region, as defined based on topography, vegetation, and rainfall by Webb (1931: $3,34)$. Southern Plains refers to the southern end of the Great Plains, an area that encompasses the Texas Panhandle-Plains, the eastern portion of New Mexico, western Oklahoma and the Oklahoma Panhandle, and parts of southern Colorado and southern Kansas. The Llano Estacado refers strictly to the isolated plateau in northwest Texas and eastern New Mexico that is cut off from the rest of the southern High Plains by the Canadian River. In Texas, High Plains refers to the featureless flatlands of the Llano Estacado while Lower Plains refers to everything east of the Caprock Escarpment. The Lower Plains region is further subdivided into two distinct subregions: the Caprock Canyonlands and the Rolling Plains. The terms Texas Southern Plains and Texas Panhandle-Plains are used in a general sense to denote the Great Plains area within the state's boundaries and include both the Llano Estacado and Lower Plains regions. When used alone, Panhandle-Plains includes not only the High Plains and Lower Plains in Texas but also the Lower Plains in western Oklahoma.

The term Caprock Canyonlands is a fitting name for the north-south corridor that divides the High Plains from the Rolling Plains. It is borrowed from Flores (1990), whose book, Caprock Canyonlands: Journeys into the Heart of the Southern Plains, is a treatise on the unique ecological character of the rugged canyons along the Caprock Escarpment. Notably, the Natural Heritage Policy Research Project (1978), an ecology study sponsored by the Lyndon B. Johnson School of Public Affairs at The 


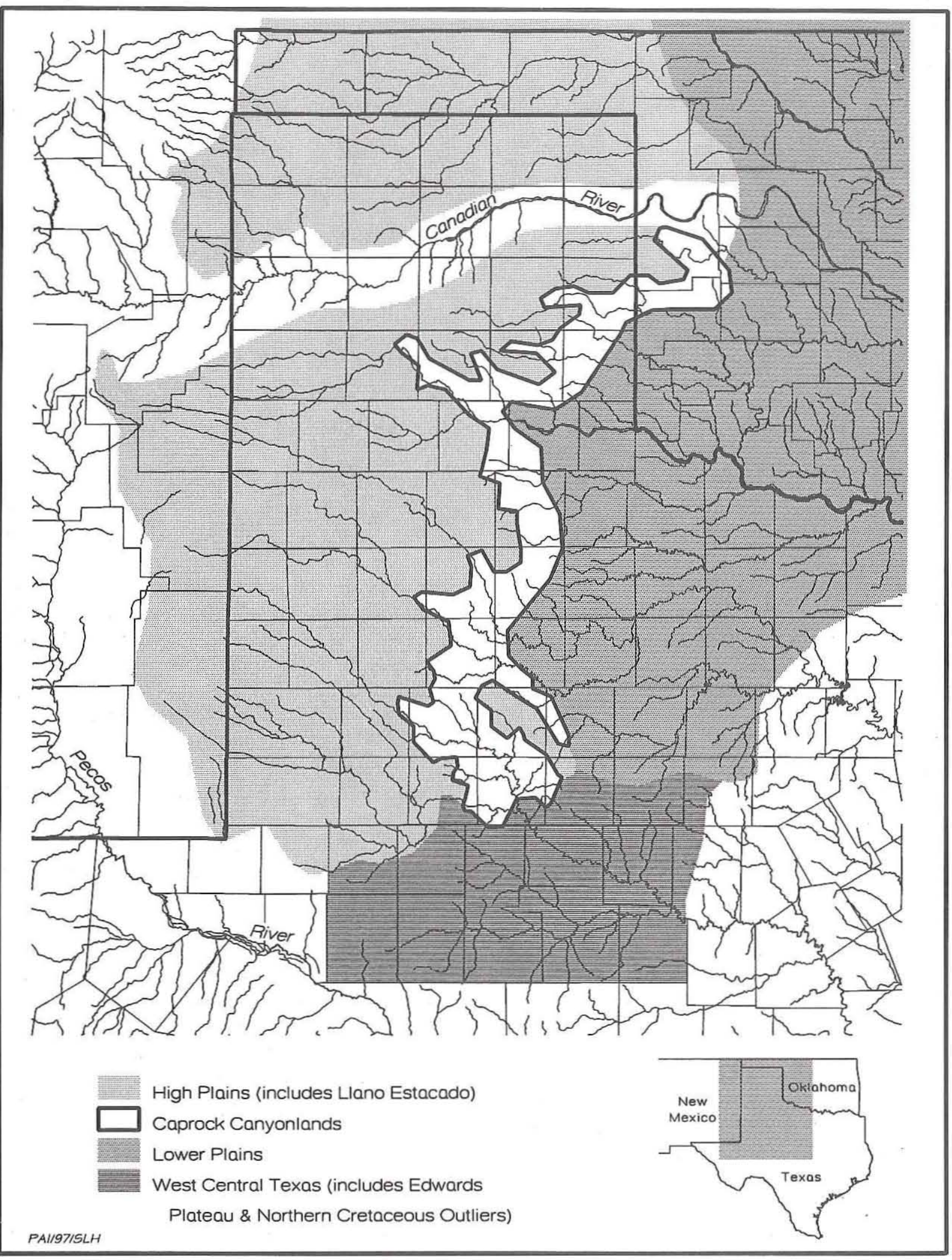

Figure 3. Natural/archeological regions of the Texas Panhandle-Plains. 
University of Texas at Austin, calls this area the "Escarpment Breaks" and recognizes that it is a distinct ecological subregion of the Rolling Plains (see Diamond et al. 1987:203-205; Flores 1990:4). The Natural Heritage Policy Research Project also recognizes the Canadian Breaks as a subregion of the Rolling Plains for the same reasons.

The National Park Service recognized the ecological importance of the escarpment canyonlands as early as the 1920s. In 1934, they considered the development of a million-acre "National Park of the Plains" that focused on the canyonlands along the Red River, including Palo Duro Canyon. For various political reasons, the National Park Service never followed up on any of its proposals, but the State of Texas has since created two small parks along the Caprock Escarpment-the 16,400-acre Palo Duro Canyon State Park and the 13,906-acre Caprock Canyons State Park (Flores 1990:160-165). Just as modern man finds the ecology of the Caprock Canyonlands to be unique and inviting, so too did the prehistoric Native Americans.

The presence of this narrow band of canyonlands had a significant impact on prehistoric human subsistence strategies and settlement patterns in the Southern Plains. Because of this, it also is appropriate to think of the Caprock Canyonlands as a distinctive archeological region.

The boundaries of the natural/archeological regions shown in Figure 3 are approximations based on a combination of topography, surface geology, vegetation areas, and geographic regions (Arbingast et al. 1973; Bureau of Economic Geology 1992; Curtis and Ham 1972; Johnson 1931; Natural Heritage Policy Research Project 1978; Raisz 1957; Renfro 1973; Williams and McAllister 1979). These regional boundaries are only slightly different from the natural region and subregion boundaries shown in the Natural Heritage Policy Research Project (1978:Figure 2). The primary differences are that the Canadian River valley and Caprock Canyonlands regions in Figure 3 are wider than the Canadian Breaks and Escarpment Breaks (respectively) subregions defined by the Natural Heritage Project. The Caprock Canyonlands region also extends slightly farther north into western Oklahoma. The natural/ archeological zones used in this synthesis more closely follow the regional geology for two main reasons. The distribution of surface water and aquifer-related springs is considered to have been a critical factor influencing human settlement patterns on a regional scale, and water resources are largely controlled by geologic factors. Thus, the boundaries between surface outcrops of the Ogallala Formation, Triassic Dockum Group formations, and Permian formations represent important demarcation lines.

For similar reasons, the southern border of the Rolling Plains natural/archeological region stops along the Callahan Divide, the drainage divide between the Brazos and Colorado River systems. The Callahan Divide also is marked by the northernmost extensive exposures of Cretaceous limestones, which generally occur just south of Interstate Highway 20 from Cisco west to Sweetwater. Although the traditional Rolling Plains region includes extensive Permian redbed exposures in portions of Coke, Coleman, Concho, McCulloch, Runnels, and Tom Green Counties, the widespread presence of Cretaceous limestones across this area is significant. For this synthesis, this northern Cretaceous area is included in the West Central Texas natural/archeological zone.

As defined in this synthesis, the Caprock Canyonlands region generally includes all areas within the Texas Panhandle-Plains (excluding the Canadian River) that have significant surface outcrops of Ogallala and/or Triassic Dockum Group formations, as well as all areas of rugged canyonland topography (i.e., high relief) that are within or in close proximity to these outcrops. The regional boundary between the Llano Estacado and the Caprock Canyonlands is well defined, but the precise boundaries between the Caprock Canyonlands, the Rolling Plains, and west-central Texas are more tenuous.

\section{GEOLOGY AND GEOMORPHOLOGY}

The existence of the Caprock Canyonlands is due to regional bedrock geology and geomorphology (Figure 4). While climatic conditions certainly played a role, the geology was the major factor controlling the region's long and complex geomorphic history. The presence of erosion-resistant layers of indurated caliche and sandstones, interspersed with erodible shales, mudstones, siltstones, and clays, determined the patterns of erosion that would shape the Rolling Plains and Caprock Canyonlands.

The Panhandle-Plains is basically a layer cake of geologic deposits that are being exposed by the headward erosion of the several major river valleys (see Figure 4). The entire sequence is best repre- 


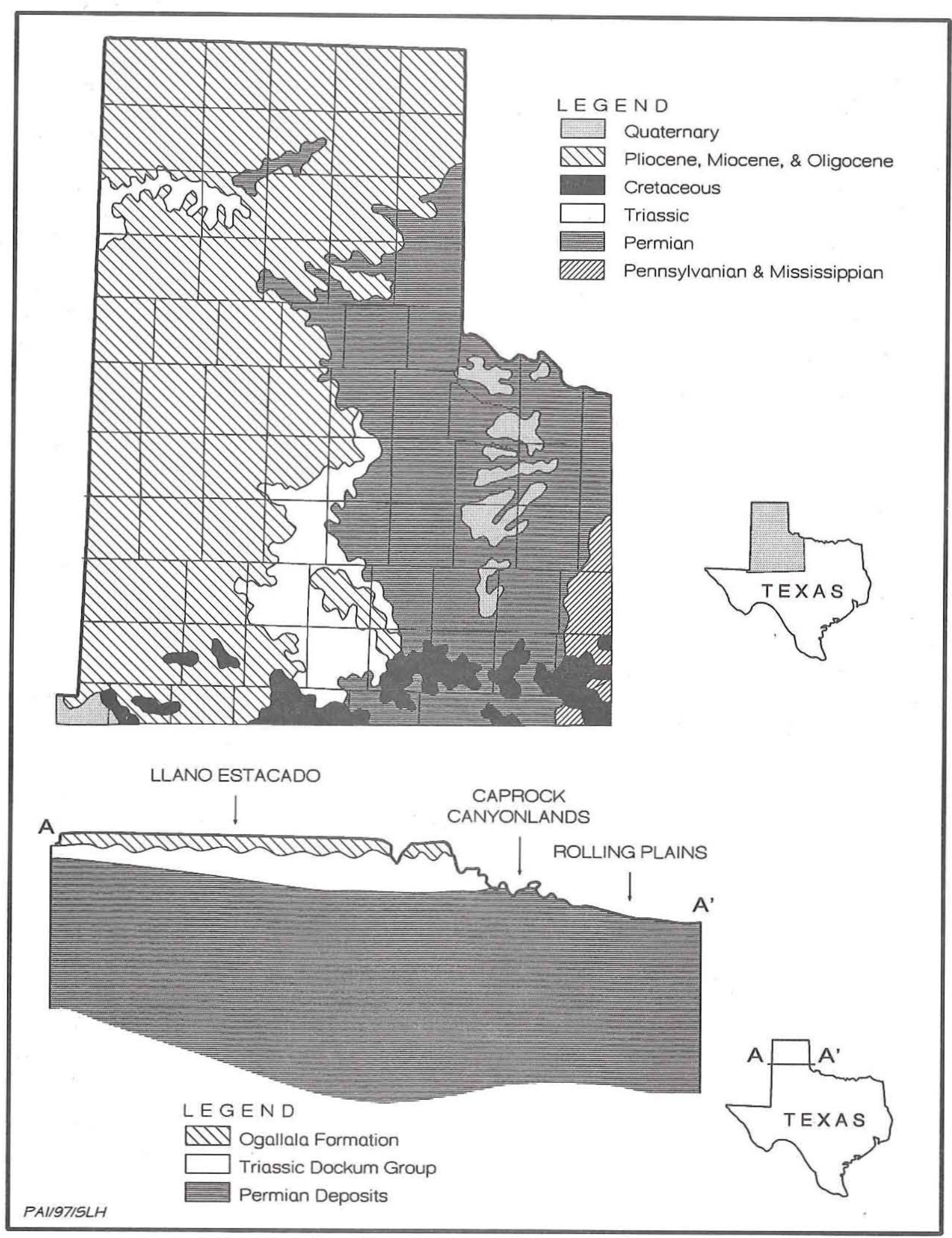

Figure 4. Surface geology and generalized regional cross section of the Texas Panhandle-Plains (after Dutton et al. 1979:Figure 7). 
sented in Palo Duro Canyon (Matthews 1969). The bottom layers of the cake are a series of alternating early Permian shales, clays, mudstones, and sandstones. They are predominantly marine deposits laid down on an ancient sea floor and are generally red in color, hence the name Permian redbeds. Bands of hydrous calcium sulfate, or gypsum, are common. These salts were precipitated out of seawater when the water level was low for long periods of time. The dissolution of salts from subsurface Permian deposits has created small cavities and sinkholes in parts of the Lower Plains (Gustavson et al. 1980). As discussed later in this chapter, the gypsum also has a significant impact on the quality of surface waters over a vast portion of the Rolling Plains.

The next layer of the cake is the late Triassic Dockum Group composed of the Tecovas and Trujillo Formations. There is an unconformity, representing some 50 million years or so, between the early Permian and late Triassic deposits. The Triassic deposits are alternating layers of sandstones, mudstones, and shales deposited along the fluctuating shoreline of an ancient sea, as indicated by the presence of a variety of fossil fish, reptiles, amphibians, and birds in different layers. Exposures of these multicolored beds in Palo Duro Canyon have been called the "Spanish Skirts" because they appear as alternating bands of various shades of red, maroon, purple, orange, brown, and gray.

Another unconformity, representing over 100 million years, is evident because the Jurassic and Cretaceous deposits are missing over most of the Panhandle-Plains. The Tertiary-age Ogallala Formation sediments were deposited directly atop the eroded Dockum Group surface in most areas. The Ogallala sediments are a series of layered sands, gravels, and clays which can be roughly divided into upper and lower units (Holliday and Welty 1981). The lower unit is composed of fluvial and lacustrine sediments, primarily sands and gravels, that were deposited within a giant alluvial fan coming off the Rocky Mountains in New Mexico. A major component of the lower Ogallala unit is the extensive alluvial clastic deposits that are now known as the Ogallala or Potter gravels. Named for Potter County, this deposit was originally called the Potter Formation, but it has since been redesignated as the Potter member of the Ogallala Formation.

The extensive outwash plain was subsequently covered by eolian sediments that compose the upper unit of the Ogallala Formation (Gustavson 1986). This unit is capped by a well-developed, massive caliche layer which formed during an extended period of landscape stability and eolian deposition. The Ogallala caliche forms the bluff edge of the Caprock Escarpment of the Llano Estacado (Baker 1915). The Ogallala Formation is best known as the primary ground water aquifer underlying much of the Great Plains of the United States. Gustavson and Holliday (1985) provide a good summary of the Ogallala Formation and clarify many of the misconceptions regarding its depositional history.

The only significant divergence from this Permian-Triassic-Tertiary sequence is that Cretaceous limestones are present in the southern end of the Llano Estacado. These northernmost Cretaceous remnants (Brand 1953) are rather thin and are covered by the Ogallala Formation except along the southern Caprock Escarpment and in a few isolated locations on the southern Llano Estacado. The limestone layers become progressively thicker and are the dominant surface unit to the south, where they stand as large remnant mesas (i.e., the Callahan Divide) and eventually merge with the extensive limestone region known as the Edwards Plateau.

The southern High Plains was once more extensive than it is today. It has been slowly whittled away by the headward erosion of the Canadian, Red, Brazos, and Colorado River systems during the past half-million years. The same erosional processes are dominant today, and the Caprock Escarpment is continuing its retreat. As the escarpment retreated throughout the late Pleistocene, the Ogallala and Dockum Group Formations eroded away and tremendous quantities of Ogallala gravels were dumped as alluvial/colluvial fans. Large accumulations of these redeposited Ogallala gravels are still found across most of the Lower Plains. These Quaternary gravel deposits are known as the Seymour Formation in the western Rolling Plains, while those in the eastern Rolling Plains are called the Lingos Formation (Caran and Baumgardner $1988,1990)$. Some 600,000 years ago, the eastern edge of the High Plains was located as far east as Knox and King Counties, as evidenced by extensive deposits of Seymour gravels (Hood 1978; Hood and Wright 1979). Based on estimated rates of retreat (Gustavson 1986), the Caprock Escarpment may have been located in the vicinity of eastern Garza or western Kent Counties some 223,000-366,000 years ago as evidenced by the presence of Lingos gravels (Boyd et al. 1989:10, 126-130). Because all of the Quaternary-age gravel deposits across the Caprock Canyonlands and Rolling Plains were derived pri- 
marily from the Ogallala gravels (and to a lesser degree from Triassic conglomerates), it is not surprising that a great deal of similarity is evident over a vast area. The lithology of the Seymour gravels in the Truscott and Crowell Reservoir areas of Knox and King Counties is strikingly similar to the lithology of the Lingos gravels in the Lake Alan Henry area of Garza and Kent Counties (Boyd et al. 1990:132-138, 242). One primary difference is that small quantities of Cretaceous limestones, fossils, and cherts are found in the Lingos gravels in the Lake Alan Henry area. Because of the proximity to the northern Cretaceous remnants, one would expect Cretaceous materials to be present throughout the southernmost Lingos gravels and to increase in frequency from north to south.

The Quaternary erosional phase resulted in the dissected modern landscapes of the Canadian River valley, the Caprock Escarpment, and the Rolling Plains. These areas are characterized by considerable relief and rugged topography, but, as the name suggests, the Rolling Plains is generally less rugged than the Canadian River valley and Caprock Canyonlands. The Rolling Plains has been eroding for a much longer time, and the overlying deposits have been stripped away down to the Permian layers except for the sporadic occurrence of Seymour and Lingos gravels. The characteristic undulating or rolling hills of red Permian mudstones give the region its many names. In addition to the Lower or Rolling Plains, the region also has been called the Red Bed Plains, Eroded Plains, Western Rolling Plains, and Low Rolling Plains.

Because the Ogallala caliche and Triassic sandstones are resistant to erosion, they are the prominent bluff- and ledge-forming layers throughout the Caprock Canyonlands. The region is defined largely by the distribution of Triassic Dockum Group formations on various state geological maps (e.g., Bureau of Economic Geology 1992; Renfro 1973). Gustavson and Simpkins (1989) describe a variety of geomorphic processes, such as surface runoff and fluvial erosion, spring sapping and seepage erosion, piping, mass wasting, and rotational slumping, that are responsible for the erosion and retreat of the Caprock Escarpment. The cumulative actions of these erosional processes over vast periods of time have resulted in the formation of steep escarpments and deep canyons all along the edge of the Caprock. The canyons usually occur in an intricate dendritic pattern at the head of smaller drainages along the Caprock (see Gustavson and
Simpkins 1989:Figure 29), or as long, deep canyons where prominent streams and major rivers cut far up into the Llano Estacado (e.g., Palo Duro, Tule, and Blanco Canyons; see Flores 1990:10).

In contrast to the eroded Caprock Canyonlands and Rolling Plains landscapes, the isolated plateau called the Llano Estacado is a flat, nearly featureless plain broken only by occasional ephemeral stream valleys (or draws) and small basins called playas (that seasonally hold rainwater) or pluvial lakes (that intersect the underlying Ogallala ground water aquifer) (Figure 5). The Llano Estacado is capped by a thin veneer of Quaternary eolian sands, called the Blackwater Draw Formation, which continue to accumulate today and are constantly being reworked by the unceasing High Plains winds. Many of the larger pluvial lakes and playas contain various Pleistocene lacustrine sediments that have been defined as the Blanco, Tule, Double Lakes, and Tahoka Formations. Evans and Meade (1945), Frye and Leonard (1965), Reeves (1976), and Holliday $(1988,1989 b)$ provide detailed information on the Quaternary and Pleistocene deposits on the southern High Plains.

A wide variety of lithic resources are found across the Texas Panhandle-Plains, with the largest quantity and best quality being found in the Canadian River valley and the Caprock Canyonlands. The Llano Estacado is virtually devoid of stone resources. The distribution and descriptions of these resources have been presented elsewhere (Banks 1990; Boyd et al. 1990:128-138, 1994:16-23; Caran and Baumgardner 1988, 1990; Frederick and Ringstaff 1994; Gustavson and Finley 1985; Holliday and Welty 1981; Hood 1978; Hood and Wright 1979; Mallouf 1989; Wyckoff 1989) and are only summarized in Table 1. Holliday and Welty (1981) provide the most complete summary, but it is interesting that they refer to them as "Lithic Resources of the Eastern Llano Estacado" when there are almost no lithic resources on the Llano. In fact, all of the lithic source areas that they discuss are located in the Canadian River valley and in the Caprock Canyonlands.

Nonlocal lithics (i.e., from outside the Texas Panhandle-Plains) are generally rare, but several materials are found with some consistency. Obsidian is found in many sites throughout the region, and the sources generally have been traced to specific localities at Malad, Idaho, or in the Jemez Mountains of New Mexico, with the latter being much more common. Dakota orthoquartzite, from the 


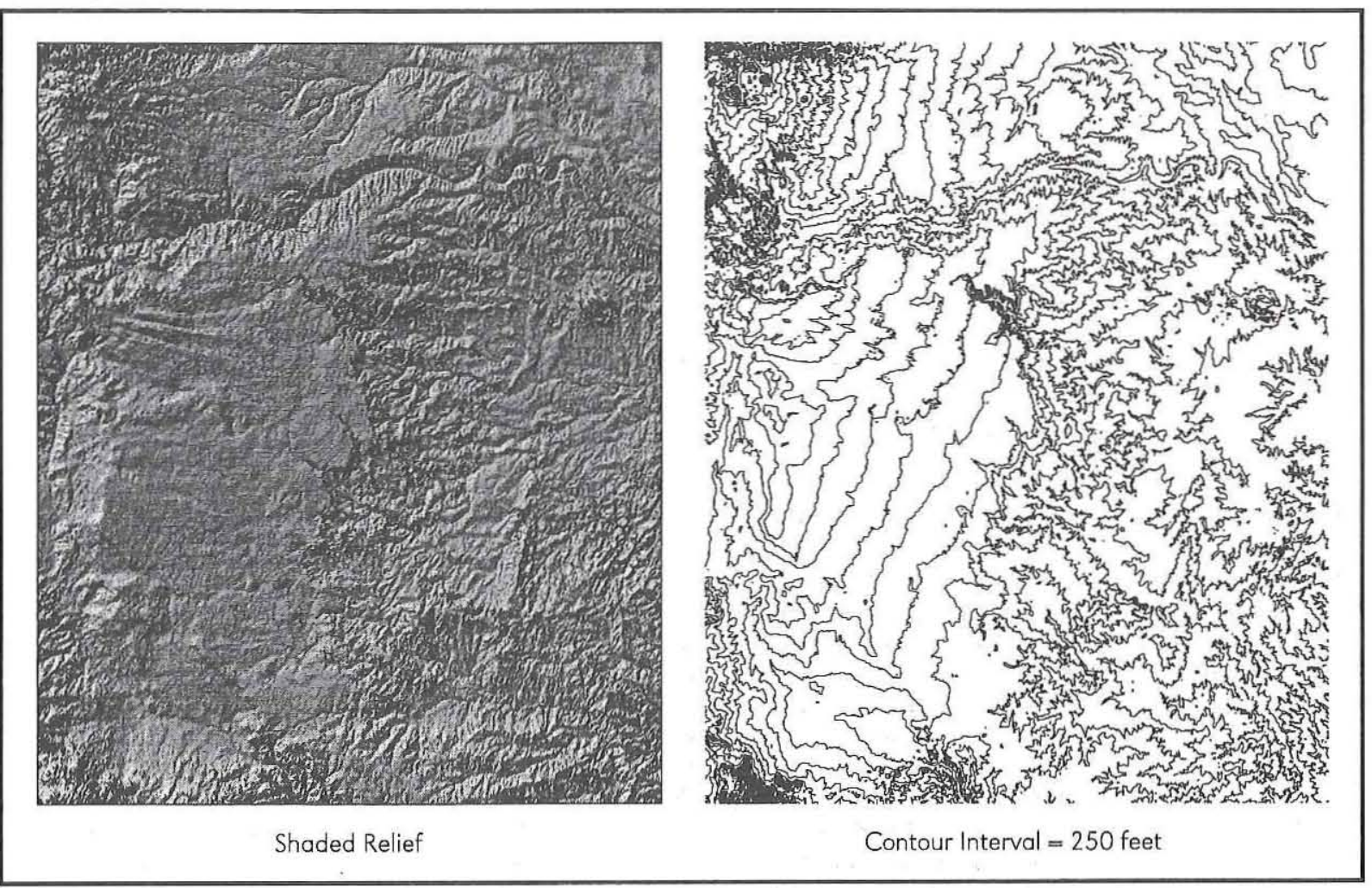

Figure 5. Topography of the Texas Panhandle-Plains.

Dakota Formation of northwestern New Mexico (Hughes and Hood 1976), is found occasionally but is much more common in the northern Panhandle. Some chipped stone artifacts, usually in the northern part of the Panhandle-Plains, are made of exotic materials such as cherts from the Day Creek Dolomite (roughly equivalent to the Permian Quartermaster Formation that produces Alibates agate) of western Oklahoma, Flint Hills cherts from northcentral Oklahoma and south-central Kansas (including Florence Formation cherts), or novaculite from Arkansas and Oklahoma (Banks 1990). Pecos River gravels may be the sources of some undefined materials that are found on the southern Llano (Holliday and Welty 1981). Occasional artifacts are made of various igneous materials identified as rhyolite or diorite (often generically called greenstone) that are derived from southern New Mexico or western Texas (e.g., the Davis Mountains) or possibly from the east (e.g., southern Oklahoma or Arkansas) (Thurmond 1991a). A hydrothermally altered form of kaolinite, occasionally found in the southern Panhandle-Plains, may come from a source in the Big Bend region of Texas (Alex 1990) and/or from other as-yet-undiscovered sources.

\section{CLIMATE}

The Southern Plains has been classified as subhumid to semiarid (Rathjen 1973:16-17), but regardless of the name one chooses to call it, the region's climate is characterized by relatively low precipitation. Webb (1931:17) observed that "the distinguishing climatic characteristic of the Great Plains environment . . . is a deficiency in the most essential climatic element-water." This fact, perhaps more than any other environmental characteristic, has always determined the nature of cultural adaptations. As Green (1973:21) has observed, it is not the fact that the region is semiarid (with precipitation falling midway between that of humid and arid regions) that is significant. Rather, it is the unpredictable nature of the distribution of precipitation, both in terms of annual and long-term cycles, that is of critical importance to human populations. "It is this undefinable aspect of semiaridity that gives the Plains their distinctiveness" (Kraenzel 1955:12). 


\begin{tabular}{|c|c|}
\hline & $\begin{array}{l}\text { TABLE } 1 \\
\text { SUMMARY OF LITHIC RESOURCES IN THE TEXAS PANHANDLE-PLAINS }\end{array}$ \\
\hline & CANADIAN RIVER VALLEY \\
\hline $\begin{array}{l}\text { Knappable } \\
\text { Stone }\end{array}$ & $\begin{array}{l}\text { Alibates agate crops out in primary form in Permian dolomites in Moore and Potter Counties and in } \\
\text { secondary form as Canadian River river gravels downstream as far as western Oklahoma. Tecovas } \\
\text { jasper crops out in the western Canadian River valley, principally in Oldham and Potter Counties. } \\
\text { Ogallala Formation gravels* are widespread and abundant over most of the valley. }\end{array}$ \\
\hline Other Stone & $\begin{array}{l}\text { Permian dolomite and Triassic and Permian sandstones used for structural building materials, grinding } \\
\text { stones, and hearthstones. Ogallala gravels (mostly quartzites) were used for manos, hammerstones, } \\
\text { hearthstones, and boiling stones, and were crushed up for use as pottery temper. }\end{array}$ \\
\hline & LLANO ESTACADO \\
\hline $\begin{array}{l}\text { Knappable } \\
\text { Stone }\end{array}$ & $\begin{array}{l}\text { Very rare on the Llano and no significant outcrops of silicified and opalized caliche (or opalite) in } \\
\text { many exposures of Ogallala caliche (or calcrete). Limited outcrops of Cretaceous Antlers Sands on } \\
\text { the southern Llano (i.e., in Andrews and Martin Counties) provide some chippable pebbles. }\end{array}$ \\
\hline Other Stone & $\begin{array}{l}\text { Very rare on the Llano. Scattered outcrops of Ogallala caliche provided material for hearthstones and } \\
\text { boiling stones. Cretaceous limestones occur in limited quantities on the southern Llano. }\end{array}$ \\
\hline & CAPROCK CANYONLANDS \\
\hline $\begin{array}{l}\text { Knappable } \\
\text { Stone }\end{array}$ & $\begin{array}{l}\text { Ogallala gravels are found all along the Caprock Escarpment and Lingos gravels* provide abundant } \\
\text { materials throughout the region. Silicified caliche and opalite are also present (but not consistently) } \\
\text { along the escarpment. Limited resources are present in the Triassic conglomerates. Tecovas jasper } \\
\text { crops out sporadically in primary form in Triassic Dockum Group exposures; the principal known } \\
\text { outcrops are in Briscoe County, but others probably exist. Cretaceous cherts (cf. Edwards Group) are } \\
\text { found in the southern portion of the canyonlands, as far north as Borden County, but no primary } \\
\text { outcrops have been located. Some Cretaceous cherts are present in the Lingos gravels in the southern } \\
\text { canyonlands. }\end{array}$ \\
\hline Other Stone & $\begin{array}{l}\text { Triassic (and to a lesser extent Permian) sandstones are abundant and constituted the primary source } \\
\text { of material for use as hearthstones and for making grinding tools. Ogallala and Lingos gravels were } \\
\text { the sources of materials for manos, hammerstones, and boiling stones. }\end{array}$ \\
\hline & ROLLING PLAINS \\
\hline $\begin{array}{l}\text { Knappable } \\
\text { Stone }\end{array}$ & $\begin{array}{l}\text { Lingos and Seymour gravels* were the main source of quartzites and cherts for making stone tools. } \\
\text { Over most of the region, these gravels are derived from Ogallala gravels (and to a lesser extent from } \\
\text { Triassic conglomerates), but some Cretaceous cherts are present in the gravels in the southern end of } \\
\text { the Rolling Plains. }\end{array}$ \\
\hline Other Stone & $\begin{array}{l}\text { Permian sandstones and Lingos/Seymour gravels were the primary sources of materials used for } \\
\text { grinding stones, hearthstones, and boiling stones. }\end{array}$ \\
\hline * Ogallala, & $\begin{array}{l}\text { os, and Seymour gravels include a wide range of siliceous materials, primarily orthoquartzites, } \\
\text { Potter chert (a siltstone), but limited quantities and sizes of fine-grained cherts are also present. } \\
\text { of these gravels varies considerably across the Panhandle-Plains. }\end{array}$ \\
\hline
\end{tabular}

Precipitation in the Texas Panhandle-Plains ranges from ca. 14 to 28 inches per year. It increases rather consistently from west to east across the region but does not vary much from north to south. Figure 6 compares the annual precipation for four localities in the Llano Estacado, Caprock Canyonlands, and Rolling Plains of Texas. When these long-term averages are compared, there are only minor differences in the annual distribution across the Panhandle-Plains, although the overall 


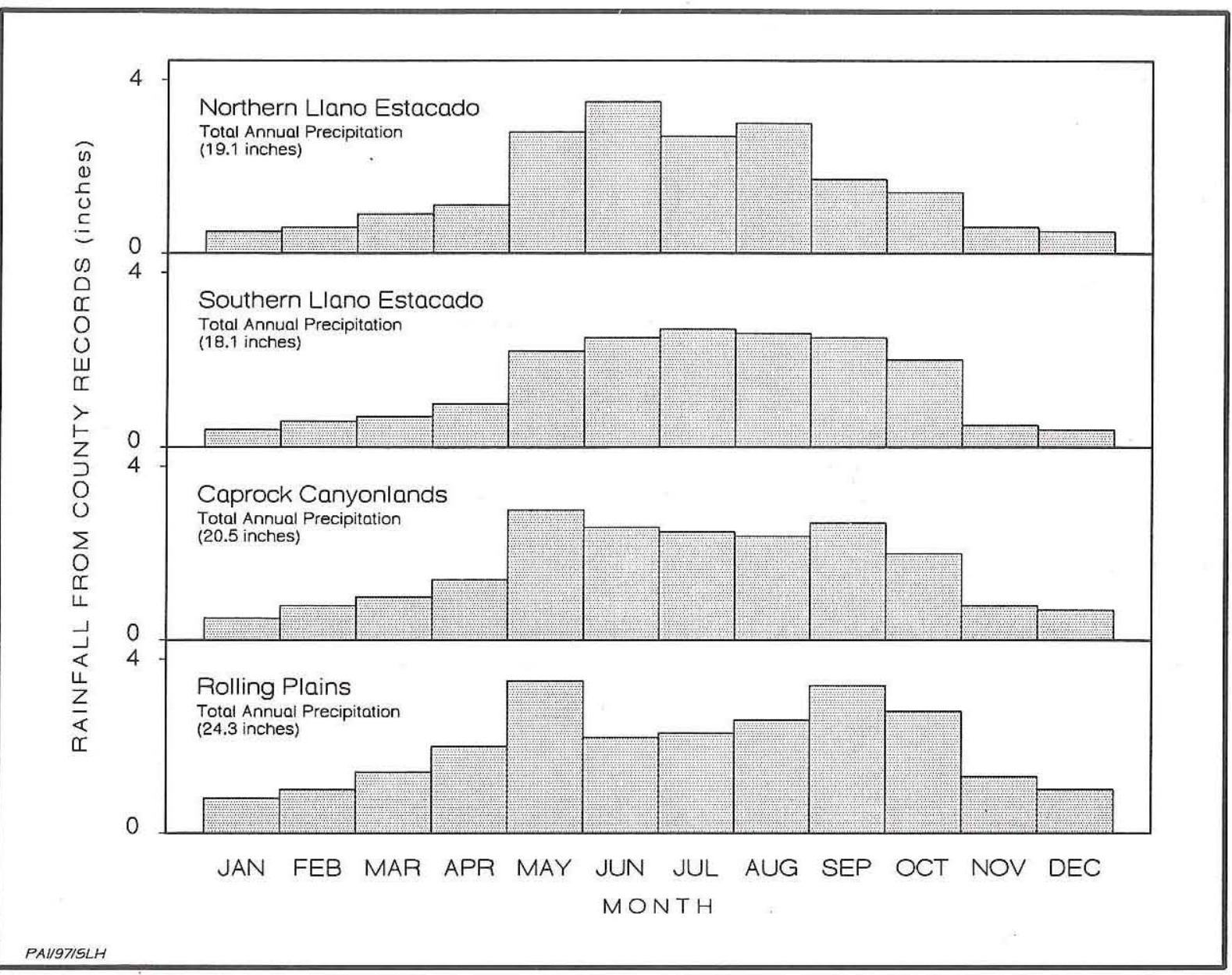

Figure 6. Monthly distribution of annual precipitation in the Texas Panhandle-Plains, based on 30-year normal records from 1951 to 1980 in Kingston (1991:117-122).

rainfall is higher in the Rolling Plains. Precipitation across the region is unevenly distributed throughout the year, with most of it occurring in the form of rainfall during the warmer half of the year. Rainfall occurring between May and October accounts for 79 to 80 percent of the annual precipitation on the Llano Estacado, 74 percent in the Caprock Canyonlands, and 69 percent in the Rolling Plains. In spring and early summer, rainfall usually arrives in the form of intense thunderstorms, often accompanied by severe conditions. Lightning, hail, and tornadoes are frequent occurrences during thunderstorms. Because of extremely high evaporation rates, particularly in summer, the total amount of moisture available for use by plants and animals is often lower than the precipitation amounts suggest (Webb 1931:20). The Llano Estacado tends to be dryer than the Caprock Canyons and Rolling Plains during the colder months. While it varies considerably during each day and from season to season, the average relatively humidity is fairly consistent over most of the Panhandle-Plains, ranging from 31 to 73 percent at Amarillo, 32 to 77 percent at Lubbock, and 38 to 75 percent at Abilene (Bomar 1983:Table F-4).

The 1992-1993 Texas Almanac presents annual precipitation data by region showing that, during the 30-year-period from 1931 to 1960 , the High Plains averaged 18.51 inches per year while the Low Rolling Plains (which includes the Caprock Canyonlands) averaged 22.99 inches (Kingston 1991:606). The 30-year-record for 1961-1990 produced similar annual averages with 18.88 inches in the High Plains and 23.77 inches in the Low Rolling Plains. Thus, 
the Lower Plains consistently receives about 4.5 inches precipitation more per year than does the High Plains.

Because the monthly and annual precipitation data reflect "normal" conditions and are based on means and averages, they are extremely important for understanding broad regional patterns. Unfortunately, they obscure one basic fact regarding Panhandle-Plains weather-that it is never normal and is consistently unpredictable. Comparing the monthly precipitation amounts reported in the Texas Almanac (Kingston 1991) for the High Plains and the Low Rolling Plains in 1989 and 1990 illustrates just how seasonally unpredictable the weather can be (Figure 7). The month of June, for example, was extremely variable in both regions. June 1990 precipitation in the High Plains and Low Rolling Plains was 4.3 and 3.5 inches less, respectively, than the June 1989 amounts.

Droughts are a fact of life on the plains. In regard to the Texas Panhandle, Rathjen (1973:17) observed that droughts have "had a profound, continuing influence upon the history of the land." Precipitation data for the past century show that droughts occur on a fairly regular basis but that drought conditions do not always occur simultaneously in the High Plains and Rolling Plains (Figure 8). Droughts recorded in historic times are relatively short (i.e., no more than a few years) in duration, but paleoclimatic evidence suggests that in prehistoric times there may have been extensive periods (i.e., hundreds or thousands of years) when droughtlike conditions prevailed, such as Antevs's (1948, 1955) "Altithermal period" during the early to middle Holocene.

One predictable aspect of Panhandle-Plains

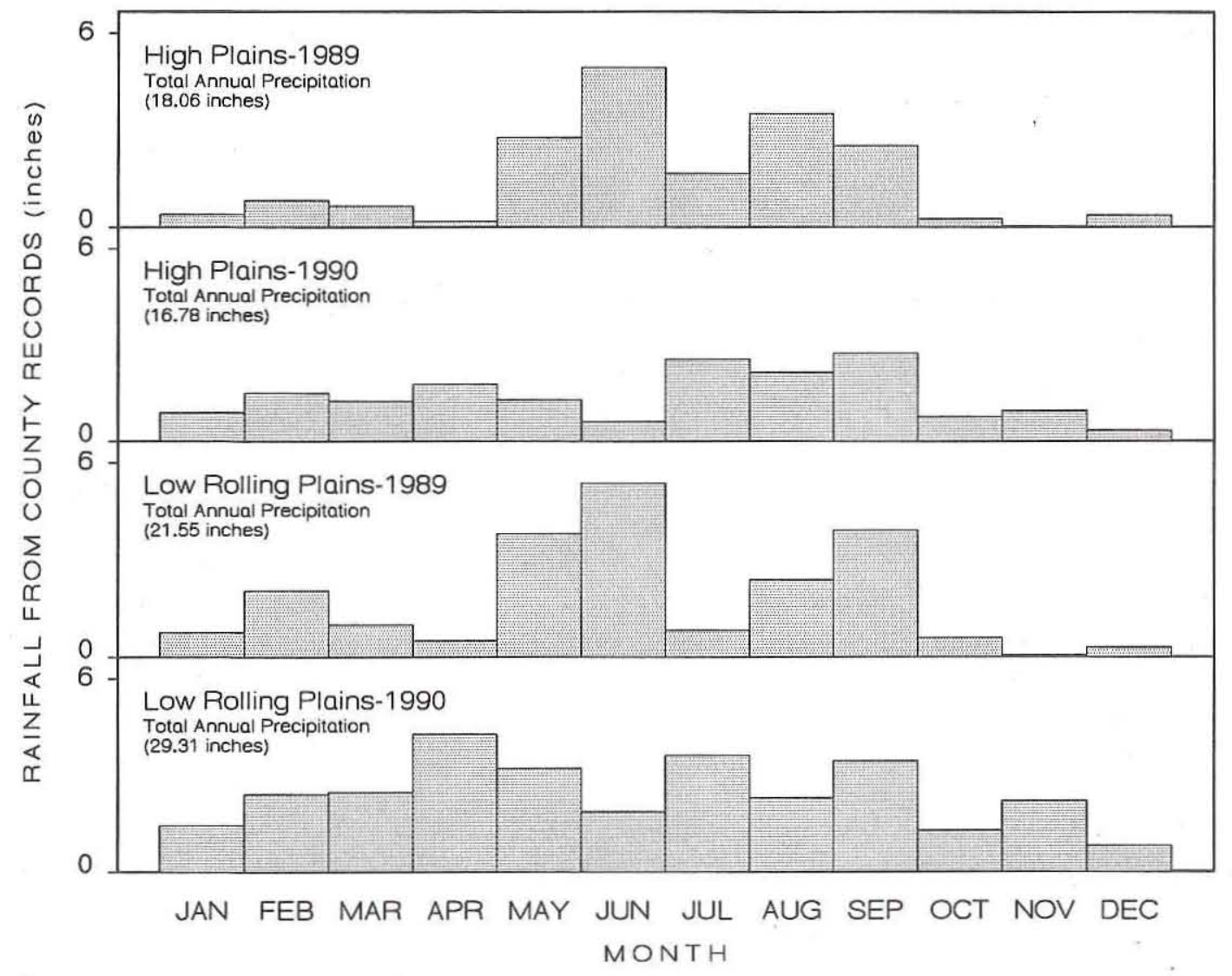

PAIISTISLH

Figure 7. Monthly distribution of annual precipitation for 1989 and 1990 in the Texas Panhandle-Plains (data from Kingston 1991:608). 


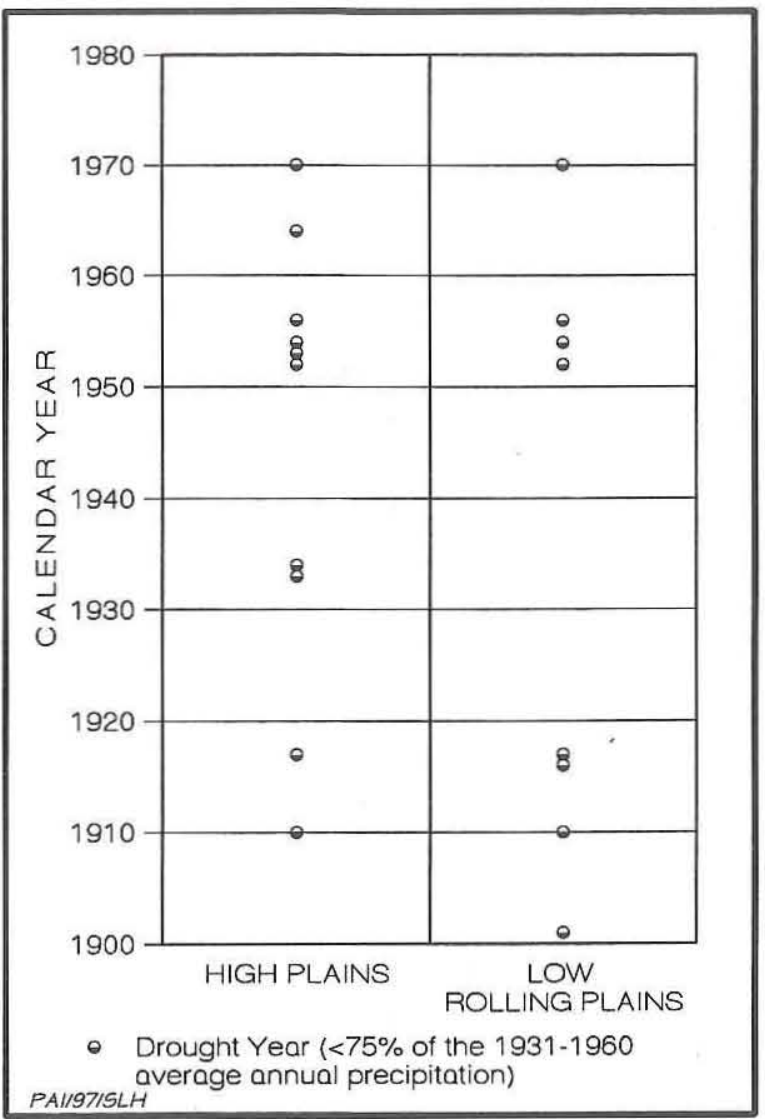

Figure 8. Droughts in the Texas Panhandle-Plains, 1900-1980 (data from Kingston 1991:606).

weather is the seasonal variation in temperatures, punctuated by unpredictable extremes (Table 2). The length of the growing season generally increases from north to south and from west to east. While spring and fall temperatures tend to be moderate, summers are generally hot and winters are generally cold, but the following examples show that extreme conditions can occur for extended periods (Bomar 1983:Tables B-3, B-4, B-9, and B-10). In a single year, subfreezing temperatures have been recorded for as many as 130 days at Amarillo, 124 days at Lubbock, and 89 days at Wichita Falls. The record number of consecutive freezing days in these localities is 31,27 , and 35 , respectively. In contrast, as many as 26,29 , and 79 days with temperatures over $100^{\circ} \mathrm{F}$ have been recorded in a single year at Amarillo, Lubbock, and Wichita Falls, respectively. The record number of consecutive days with temperatures exceeding $100^{\circ} \mathrm{F}$ is 7,10 , and 42 , respectively, for these localities. Consequently, it appears that long, cold spells are more common on the
Llano Estacado, while long, hot spells are more common in the Lower Plains.

The most extreme cold occurs when intense Arctic fronts, called blue northers, blow southward across the Great Plains bringing blizzard conditions characterized by large accumulations of snowfall and strong winds. Extreme snowfalls of up to 61 inches in a single storm have been recorded in the Texas Panhandle, but the average snowfall accumulation ranges considerably (Bomar 1983:Tables A-1 and F-1). The northern Panhandle averages 15.2 (Amarillo) to 17.7 (Spearman) inches per year, but snowfall averages are considerably less to the south, ranging from 3.7 inches (Midland) to 11.2 inches (Muleshoe). Yearly snowfall accumulation also is less in the Rolling Plains, ranging from 5.4 inches (Abilene) to 8.9 inches (Childress).

The wind is another factor that bears mention. In complex ways, the atmospheric winds that push the warm fronts, cold fronts, thunderstorms, tornadoes, and blizzards across the Great Plains are intimately related to all aspects of Texas's weather (Bomar 1983). Except for coastal areas, "the wind blows harder and more consistently on the Plains than it does in any other portion of the United States" (Webb 1931:21), and it is most intense in the Texas Panhandle (Webb 1931:23). Prevailing winds during all seasons are generally from the south, southwest, or southeast (at Abilene, Amarillo, and Lubbock), and average wind speeds range from 11 to $16 \mathrm{mph}$ (Bomar 1983:Table F-2). Wind extremes of 46,58 , and $70 \mathrm{mph}$ have been recorded at Abilene, Amarillo, and Lubbock, respectively (Kingston 1991:112). It is not a coincidence that the dwelling of choice for nomadic Plains Indians was the tipi, one of the most wind resistant portable tents in the world. Retired anthropology professor Jack Hughes (personal communication n.d.) observes that "only White men put up square tents on the windy Plains."

\section{HYDROLOGY AND DISTRIBUTION OF WATER}

The distribution of surface water in the Great Plains is certainly the most critical factor that controlled prehistoric and historic human settlement patterns (Webb 1931:3). Because of the cyclical and volatile nature of Plains weather, surface waters derived solely from rainfall are seasonally predictable at best, and more often than not they are totally 
TABLE 2

TEMPERATURE, FROST, AND GROWING SEASON DATA FOR THE TEXAS PANHANDLE-PLAINS*

\begin{tabular}{|c|c|c|c|c|c|c|c|}
\hline & \multicolumn{2}{|c|}{$\begin{array}{l}\text { Temperature } \\
\text { Means }\left({ }^{\circ} \mathrm{F}\right)\end{array}$} & \multicolumn{2}{|c|}{$\begin{array}{l}\text { Temperature } \\
\text { Extremes }\left({ }^{\circ} \mathrm{F}\right)\end{array}$} & \multicolumn{2}{|c|}{ Annual Freeze Dates } & \multirow{2}{*}{$\begin{array}{l}\text { Length of } \\
\text { Growing Season } \\
\text { (\# of Days) }\end{array}$} \\
\hline & $\begin{array}{l}\text { Max. } \\
\text { July }\end{array}$ & $\begin{array}{l}\text { Min. } \\
\text { January }\end{array}$ & Highest & Lowest & $\begin{array}{l}\text { Last in } \\
\text { Spring }\end{array}$ & $\begin{array}{l}\text { First in } \\
\text { Fall }\end{array}$ & \\
\hline $\begin{array}{l}\text { Northern Llano Estacado - } \\
\text { Potter County Record (Amarillo) }\end{array}$ & 91 & 22 & 108 & -14 & Apr. 17 & Oct. 24 & 190 \\
\hline $\begin{array}{l}\text { Southern Llano Estacado - } \\
\text { Hockley County Record (Levelland) }\end{array}$ & 92 & 23 & 113 & -16 & Apr. 15 & Oct. 28 & 196 \\
\hline $\begin{array}{l}\text { Caprock Canyonlands - } \\
\text { Crosby County Record (Crosbyton) }\end{array}$ & 93 & 24 & 110 & -06 & Apr. 10 & Nov. 2 & 206 \\
\hline $\begin{array}{l}\text { Rolling Plains - } \\
\text { Knox County Record (Munday) }\end{array}$ & 98 & 29 & 116 & -09 & Apr. 3 & Nov. 6 & 217 \\
\hline
\end{tabular}

unpredictable. In terms of human exploitation, this means that enterprises depending solely upon rainfall-dependent water sources are risky business. This is true for dry-land Panhandle farmers today, and it was true for the Native American peoples who preceded them. The alternative to rainfalldependent water sources is ground water, whether it emerges from natural springs or is pumped from deep under ground. The presence of ground water aquifers and springs within the region has significantly altered the dependability and predictability of surface water resources. In turn, the distribution of all surface waters, including those derived from springs, has had a significant impact on plant, animal, and human populations on the Great Plains.

Excluding modern manmade lakes, surface waters in the Panhandle-Plains occur in only a few basic forms: in stream channels associated with four major river systems, in small basins called playas, in larger basins called pluvial lakes, and as springs and seeps found in locations where ground water aquifers are exposed or the water table is shallow. The most critical aspect of these surface water resources, in terms of understanding past human behavior, is that they are not evenly distributed across the region. Rather, the quantity, quality, and predictability of surface water varies greatly by subregions. Figures 9 and 10 show the distribution of all surface waters, including major rivers, pluvial lakes, and major spring-producing ground water aquifers. These figures do not tell the whole story, however, and one must look closely at the distribution of water resources to understand the relationship between prehistoric man and the Panhandle-Plains environment.

Because aquifer-related resources are emphasized as one of the most critical factors for understanding the human past in the region, a few general points regarding springs, ground water aquifers, and their relationships to surface waters are worth noting. First, springs, which are defined by Brune (1981:9) as "spillways through which the overflow of surplus ground water passes," occur only in areas where aquifers are found at or near the surface. Second, because the occurrence of springs correlates with surface geology and topography, their distributions are predictable. Third, all ground water aquifers are ultimately recharged by rainfall, but they act as temporary water storage vessels and play a significant role in saving and redistributing the precipation that falls across the region. Precipitation may enter a ground water aquifer in one area (e.g., on the High Plains), only to be transported and emerge again in another area (e.g., along the Caprock Escarpment). In this sense, springs significantly increase the effective catchment areas or drainage 


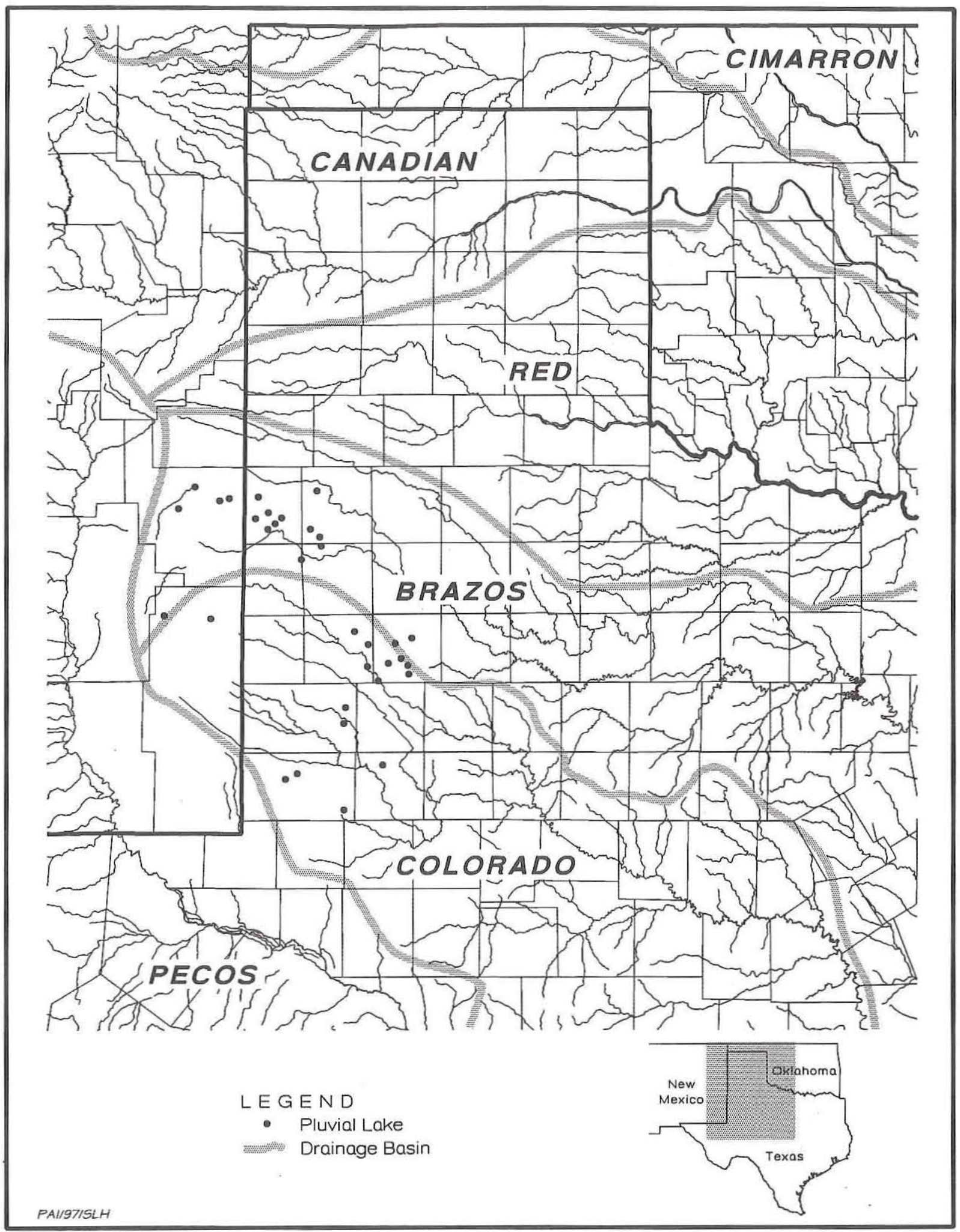

Figure 9. Distribution of surface water resources in the Texas Panhandle-Plains and surrounding regions. Map shows major rivers and streams and 33 pluvial lakes on the Llano Estacado (from Wood and Jones 1990:Figure 1). Seasonal playas are not shown. 


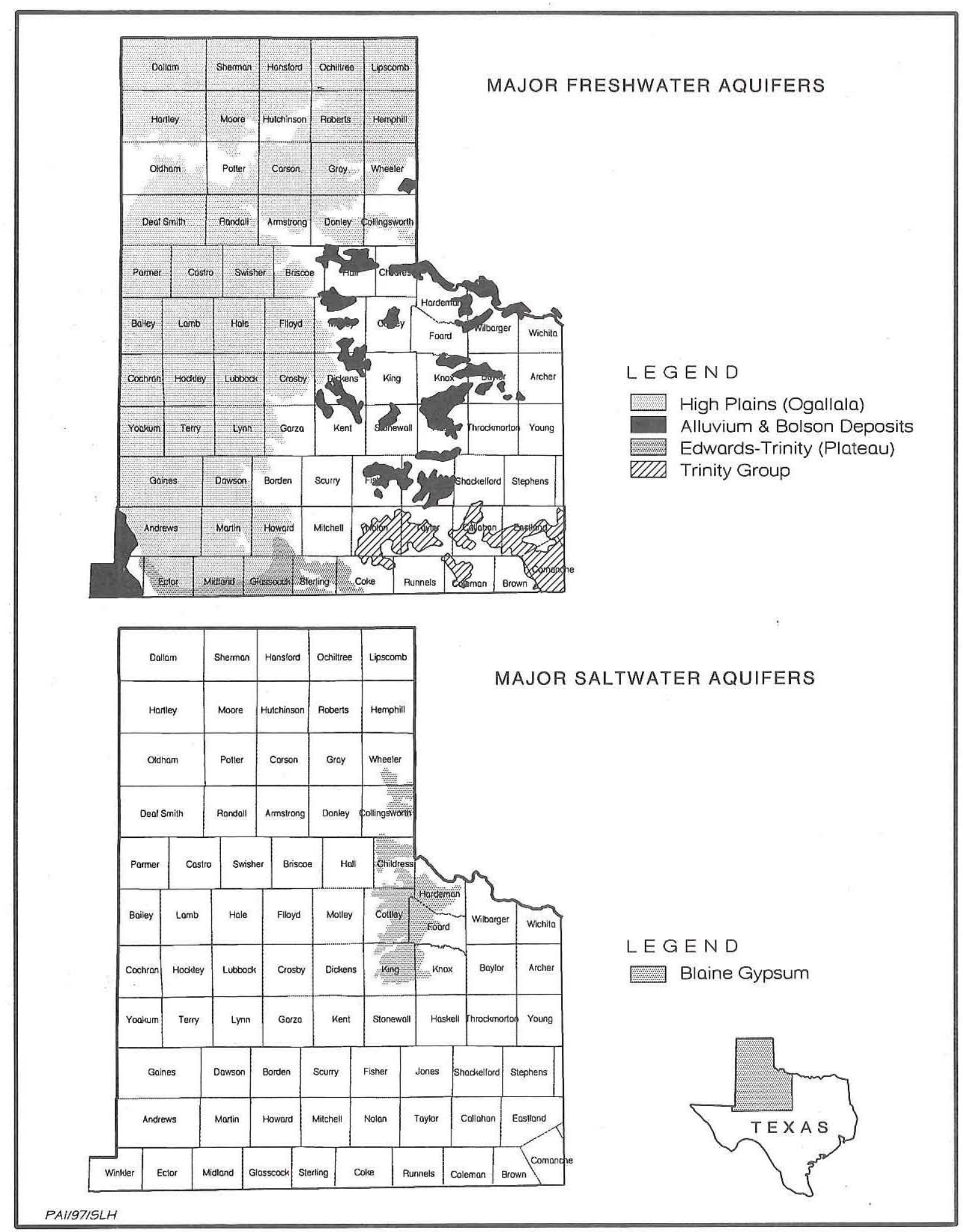

Figure 10. Distribution of major freshwater and saltwater spring-producing ground water aquifers in the Texas PanhandlePlains. Springs generally occur around the margins of these aquifers (from Texas Department of Water Resources 1984:Figures 2 and 3). 
basins of the lakes and streams where they occur. Fourth, springs flow as a result of water pressure, and the amount of water that emerges (called spring discharge, the quantities are measured in cubic feet or liters per second) varies considerably according to many variables, such as the amount of water an aquifer contains and the size and relative location of the spring opening. Gravity springs, which are found in areas where aquifers are exposed below the level of the water table, are the most common type. Less common are artesian springs that occur where water is pushed to the surface through nonaquifer strata by water pressures from the underlying aquifer. Fifth, aquifers and springs are not all equally affected by climatic cycles. For minor aquifers and small springs, water table levels and surface discharges may be significantly affected by short-term (i.e., seasonal) fluctuations in precipitation. The water tables and discharges of major aquifers and larger springs are much less susceptible to short-term fluctuations and may or may not be affected by long-term climatic fluctuations. Extended droughts are known, in both historic and prehistoric times, to have caused declines in aquifer water tables and decreases in, or cessation of, spring discharge. During these periods, it may be expected that springs would have been differentially affected. Largely depending upon their locations relative to the ground water source (i.e., whether they emerge from the top or bottom of an aquifer), some springs may have dried up while others continued to flow at the same or only slightly decreased rates. Sixth, unlike water derived from precipitation, which is relatively pure when it hits the ground, the quality of spring waters may vary greatly, depending primarily upon the chemical composition of waterbearing geologic strata or the strata through which it percolates. In addition, poor-quality spring water will have a significant and detrimental effect upon the quality of all surface waters (i.e., lakes, streams, and rivers) with which it mixes.

The geographic distribution of surface waters in the Panhandle-Plains (see Figure 9), particularly aquifer-related sources, is related to a complex set of variables involving a combination of subsurface geology, geomorphology, and surface topography. While there is considerable variation on a local level, the significant regional differences between the nature and occurrence of surface waters on the Llano Estacado, the Caprock Canyonlands, and the Rolling Plains are most important here. In regard to prehis- toric use of water resources, two assumptions must be stated. First, it is assumed that water derived from rainfall would not have been particularly useful to hunter-gatherers in semiarid settings without some type of catchment and storage technology. Lacking evidence for such technology, it is further assumed that human utilization of the Panhandle-Plains was strongly influenced by the spatial distribution and temporal availability of surface water, but that it was ground water-based resources, such as springs and spring-fed rivers and lakes, that were of particular importance. If these assumptions are correct, it is possible to make further predictions about how past human populations utilized the landscape, although one must first understand the entire hydrological system in operation across the Panhandle-Plains rather than only its isolated components.

The Canadian River, which eventually empties into the Arkansas River, cuts deeply into the High Plains while the headwaters of the Colorado, Brazos, and Red Rivers are found on the surface of the Llano Estacado. All of these rivers flow across the High Plains and Lower Plains toward the Gulf of Mexico in a general east-southeast direction. While the main branches of these systems are large rivers, they are typically underfit streams that formerly (prior to and during the Pleistocene) carried a much greater volume of water than they do today. These once-mighty rivers are now relatively small channels within broad valleys. Springs are found in many locations along these drainages where water-bearing aquifer strata are exposed.

On the Llano Estacado, the drainages of the Colorado, Brazos, and Red Rivers are only ephemeral draws today, although some segments may have been perennial at some times in the past. The channels of the rivers and major tributaries become increasingly large as they leave the High Plains, cut through the canyonlands, and head out across the Rolling Plains. Not only did these rivers carry large quantities of surface runoff, but they also were fed by occasional springs on the Llano and by numerous springs along the margins of canyons where ground water aquifers are exposed. Today, even the downstream areas in the Rolling Plains are little more than ephemeral streams because they have been dammed in many places, and severe overuse of ground water for industrial, municipal, and agricultural purposes (particularly on the Llano) has lowered water tables to the point that the flow of most springs has been slowed or stopped. Prior to 
modern times, the volume of water transported would have fluctuated considerably, largely on a seasonal basis, but the rivers and most larger streams east of the Caprock Escarpment were apparently perennial.

Besides the fluvial systems, surface waters in the Panhandle-Plains also occur in small basins called playas or pluvial lakes (Frederick 1993; Ostercamp 1987; Reeves 1965). Playas are shallow circular basins that are ubiquitous across most of the High Plains, but they also occur, although much less frequently, in the Lower Plains. Various sources estimate the number of playas on the High Plains of Texas and New Mexico at 17,000 to 30,000, and the Bureau of Economic Geology (Gustavson et al. 1995:2) states that there are "more than 20,000." Since the bottoms of these basins are lined with a thick layer of impermeable Randall clay, they hold water for a short time after rainy seasons (Steiert 1995:14). In wet years, playas may hold water year-round, but even large playas may be completely dry for years at a time during severe droughts. Throughout the Southern High Plains, playas serve as the major source of water for recharge of the Ogallala aquifer (Gustavson et al. 1995).

Playas vary considerably in size, from only a few dozen meters in diameter to nearly $1 \mathrm{~km}$, and the size of their drainage basins varies considerably as well, from only a few acres to thousands of acres. Playas in the northern Llano Estacado (i.e., the Texas Panhandle) tend to be more variable in size but are generally smaller than the less-numerous playas on the southern end of the Llano. The density of playas on the Llano Estacado ranges from as low as 2.9 acres of playas per square mile in some areas to as high as 19 acres of playas per square mile in others (Steiert 1995:14-15). Consequently, the total volume of water that playas may hold varies greatly across the Llano, but the most important fact is that all playas hold water only for as long as it takes to evaporate and then remain dry until the next rain. Commenting on the fickle nature of playas, Steiert (1995:10) observed that "Timing is everything in finding water in the playas. ..." He goes on to conclude that "Playa lakes are as unpredictable as the weather that creates them. These ephermal pools can give - or take-life and livelihood on the Llano Estacado" (Steiert 1995:37).

Pluvial lakes are usually much larger than playas (some greater than $3 \mathrm{~km}$ in diameter), but they are much less common. Only about 40 are known and all occur on the southern Llano Estacado where the water table is shallow (Gustavson et al. 1995:3; Ostercamp 1987; Reeves 1990:Figure 15; Wood and Jones 1990:Figure 1). Their distinguishing characteristic is that pluvial lake basins are spring fed. Spring waters may emerge from the bottoms of the basins or from associated drainages that empty into them. In contrast to the playas, which are recharged only by precipitation, most spring-recharged pluvial lakes were perennial water sources prior to the nineteenth century. County maps show that there are about 45 named natural lakes on the southern Llano Estacado. Many of these are documented historically as having been important spring-fed water sources, as indicated by Brune's (1981) discussions of springs in the following counties: Andrews, Bailey, Gaines, Hockley, Lamb, Lynn, and Terry. Although minor fluctuations in the water table may have occurred regularly and some pluvial lakes may have dried up on occasion, most pluvial lake springs would not have been impacted by short-term climatic shifts. Another distinguishing characteristic of pluvial lakes is that they are very salty because evaporation of the lake water leaves behind salts that are present in the ground water. Over time, most pluvial lakes have accumulated massive amounts of salt, and they are often called salt lakes, saline lakes, or alkaline lakes. While the water contained in pluvial lakes is often too salty to drink, the spring vents generally provide fresh water. Although some pre-Tertiary strata (primarily Cretaceous) are exposed at some of the larger pluvial lakes, most of the pluvial lakes intersect the Ogallala Formation, which is the primary source of spring water in most cases.

Because the vast Ogallala aquifer underlies all of the Texas High Plains, this area has been called the "Land of the Underground Rain" (Green 1973). Without modern irrigation technology, however, these vast ground water reservoirs were inaccessible to prehistoric peoples except at springs (or by hand digging wells in a few areas where the water table was very shallow). Consequently, it was the distribution and density of springs, rather than the underground aquifers per se, that was of critical importance to preindustrial peoples in the PanhandlePlains.

The surface water situation in the the Caprock Canyonlands subregion (see Figure 3 ) is different from that on the High Plains. Not only do the river systems carry water from the Llano Estacado into 
the Caprock Canyonlands, but the densest concentration of springs, and the best-quality spring water, are found in the canyonlands. Springs emerging from the vast Ogallala aquifer, various Triassic (i.e., Dockum Group) aquifers, and to a lesser extent from Quaternary alluvium aquifers discharge large amounts of fresh water into the fluvial systems in the canyonlands. Because the entire subregion is blanketed with exposures of Ogallala, Triassic, and Quaternary strata, springs are ubiquitous. In comparison to the Llano Estacado, the density of springs and the overall amount of surface water are significantly higher in the Caprock Canyonlands.

Farther to the east in the Rolling Plains, springs emerge from two main sources: Quaternary alluvium and Permian aquifers. Springs are relatively abundant, but they are not as widely or densely distributed in the Rolling Plains as they are in the Caprock Canyonlands. Although the overall availability of surface water in the Rolling Plains is significant, especially in comparison with the Llano Estacado, water quality becomes an extremely important factor in this subregion. The generally poor quality of surface water in the Rolling Plains may be attributed to one primary factor-the widespread presence of subsurface and exposed Permian strata containing bedded salts (e.g., gypsum). Large quantities of spring waters that discharge from Permian aquifers are so salty, often many times more salty than seawater, that they are not palatable. Many of the Permian springs are classified as saline because the water contains more than $3,000 \mathrm{mg} /$ liter of dissolved solids. While the discharge may be tremendous, the water is often unusable by animals or man. Brune (1975) and Richter and Kreitler (1986) note that many major and minor saline springs are found in one large section of the Rolling Plains, primarily in Childress, Cottle, Hall, Kent, King, and Stonewall Counties of Texas and in Beckham and Harmon Counties of Oklahoma. The salty waters from these springs essentially ruin the surface waters of all of the streams and rivers into which they discharge. Not coincidentally, these are the areas where the U.S. Army Corps of Engineers has concentrated its "chloride control" projects in an effort to dam the major saline drainages and prevent them from contaminating surface waters downstream. Richter and Kreitler (1986:1) note that a vast portion of the Rolling Plains "is characterized by numerous salt flats, springs, and seeps, highly mineralized ground water at shallow depth, and high chloride loads in surface streams." They estimate that the streams in this area carry a combined average chloride load of 3,000 tons per day. Salt springs are concentrated along sections of the North, Elm, Salt, Prairie Dog Town, and Little Red Forks of the Red River; the North, Middle, and South Forks of the Pease River; the North and South Forks of the Wichita River; and on various tributaries along the Salt Fork of the Brazos River (see Richter and Kreitler 1986:Figure 1). Comparing the water quality across the state, Arbingast et al. (1973:14) show that the surface waters within a ca. 18-county area of the Rolling Plains are contaminated by highly concentrated dissolved solids at concentrations of more than 2,530 parts per million.

\section{Modern Spring Data: Implications for Interpreting Prehistory}

Because of the differences in the density and quality of surface waters, particularly those derived from ground water aquifers, it seems that the canyonlands along the Caprock Escarpment would have been an oasis compared to both the Llano Estacado and a large portion of the Rolling Plains. To test this proposition using quantifiable data, we must turn to modern studies of Texas springs. The most notable of these are by Gunnar Brune (1975, 1981). These studies, particularly the 10 -year study reported by Brune (1981), present a wealth of valuable data that covers most of the state. The data are useful in many ways, but for three principal reasons they must be used cautiously for interpreting conditions in the past.

First, past cultures probably did not share our modern view of ground water reservoirs and springs. Modern spring studies are biased by their emphasis on ground water reservoirs as a resource for largescale economic exploitation. By the early twentieth century, all Texas ground water aquifers of any size had been exploited extensively for agricultural, industrial, and municipal use (e.g., Brune 1981:3539; Nativ 1988:5; Texas Department of Water Resources 1984:7-9). By monitoring the drilling and pumping in recent years, these aquifers have been studied and ranked according to their sizes and estimates of the amounts of water that they contain. Similarly, modern studies such as those by Brune (1975, 1981) classify springs according to their average discharge and water quality based on 
detailed chemical analyses. These, and many other similar studies, were done primarily for water management agencies such as the Texas Water Development Board. While the resulting data are informative in a general sense, these facts and figures are not particularly relevant to the study of past cultures. Prehistoric peoples, whether they were hunter-gatherers or hunter-gatherer-horticulturalists, certainly did not judge springs by these modern standards.

It seems reasonable to assume that prehistoric peoples would have classified springs, and other water sources as well, according to their own needs. Whether consciously or unconsciously, they undoubtedly were concerned with many variables that are not important within a modern frame of reference. The relative sizes of springs may have been of little importance because all freshwater springs, even ones that are considered small by modern standards, would have been useful to small bands of huntergatherers. Prehistoric peoples may have been much more concerned with the quality of spring and surface waters because many sources would have been unusable to them (and would still be so today without modern water-treatment technology). Other factors that prehistoric peoples probably considered when evaluating springs and water sources would have been related to the nature and occurrence of other resources in the immediate vicinity. For example, some springs may have been intensively utilized because suitable areas for establishing a camp or residential base were present close by. The plants and animals clustered around some springs and spring-fed tributaries may have been of equal or greater importance than the water itself. Still other springs, particularly those located adjacent to game trails, may have been used primarily as hunting locations.

The second problem is that modern spring data do not accurately reflect conditions in the past. Springs in Texas today discharge only a fraction of the water that they once did. Because of extensive ground water pumping during the twentieth century, most Texas springs had already been seriously depleted, and some had already dried up, before anyone compiled data on spring flow (Brune 1981: 35-39; Texas Department of Water Resources 1984:7-9). Brune (1975:9) notes that by 1975, 65 (23 percent) of the 281 known "major and historically significant springs" of Texas had dried up, and a significant decline in discharge had been docu- mented for most of the remaining springs. Because of these twentieth-century alterations, it is difficult, if not impossible, to postulate what spring discharges might have been at various times in the past. This is particularly true for springs located on or around the margins of the Llano Estacado because the ground water in this area was exploited earlier and more intensively than in any other part of Texas (Bowden 1977:112-121).

This does not mean that the data have no relevance to the past, however. Modern spring and aquifer data may be used to predict, in a general way, the effects that long-term climatic shifts throughout prehistory may have had on aquifers and springs. The fact that intensive irrigation has significantly lowered the water table of the Ogallala aquifer underlying the Texas High Plains has been extensively documented (e.g., Bowden 1977:115125). Although the twentieth-century decline in the Ogallala water table and the disappearance of springs on the Llano Estacado are obviously a direct result of intensive pumping of ground water, the resulting conditions may mimic conditions during extended and extreme droughts such as Antevs's $(1948,1955)$ proposed Altithermal period. It is likely that the water tables of all of the major and minor aquifers in the Panhandle-Plains would have been lowered to some extent during periods of severe aridity. Numerous hand-dug water wells dating to the middle Holocene, found in various parts of the Llano Estacado, provide evidence that native peoples had learned to cope with such drought conditions (see Chapter 8). Although this evidence suggests that many springs may have dried up in the past, it also demonstrates that native peoples had an extensive knowledge of aquifer-related water sources that allowed them to continue exploiting them even during extended droughts. The near-absence of springs on the Llano Estacado in the late twentieth century may be a useful analogy for what conditions may have been like during the Altithermal.

The third problem with the modern spring data presented by Brune (1981) is that many springs were missed in this statewide survey. Despite the fact that Brune made a serious attempt to locate all springs in each county using a variety of sources (e.g., published and unpublished maps, documents, and reports), field checked each one to verify conditions, and interviewed informants as to conditions in the past, it was impossible to locate and evaluate them all. Many current and former springs 
are not documented in any records and are relatively unknown to modern inhabitants. Most of the springs that Brune may have overlooked are probably small in modern terms (i.e., a relatively low discharge), but even these small springs were important to prehistoric populations. As an example, archeological surveyors at Lake Alan Henry observed over 15 active small springs and numerous seeps in the 11,280 -acre project area, but only one of these (i.e., Reed Springs in Garza County) had been previously documented and mapped by Brune (1981:194). In the 2,240-acre wildlife habitat area at Lake Alan Henry alone, at least a dozen prehistoric sites are clustered around three principal spring areas (Boyd et al. 1991:51). Consequently, the modern spring data presented by Brune (1981) are not sufficient to quantify, with a high degree of accuracy, the number of springs present in any particular region today or in the past.

Further complicating the interpretability of the data is the likelihood that Brune's (1981) sample of springs is not entirely consistent for all areas of the state, particularly various parts of the PanhandlePlains. Springs in the Caprock Canyonlands (such as those at Lake Alan Henry) are much more likely to have been overlooked in an extensive statewide survey because large tracts of land are sparsely populated and/or privately owned. In this area, many small springs are undocumented in easily accessible historical records (e.g., county maps and histories) and are unknown to locals except perhaps for individual ranchers on whose land they occur. Notably, some of the former landowners at Lake Alan Henry were unaware that some of the smaller springs existed. Conversely, it is not very likely that Brune's (1981) survey missed many springs on the Llano Estacado. Existing and former springs are so rare on the Llano that they are well known to most local residents and are generally well documented in local historical accounts. Because springs may have been documented more consistently in some areas and missed in others, it is likely that Brune's (1981) spring survey data are slightly biased. In all probability, the actual density of springs in the Caprock Canyonlands is underrepresented by the data.

There is no particular reason to think, however, that Brune's (1981) data do not represent a somewhat consistent sample of medium to large springs in various parts of the state. Once this assumption is made explicit, and acknowledging that overall spring density is probably underrepresented in the Caprock Canyonlands, the locational information may be viewed as a generalized representation of the geographic distribution of Texas springs. The pattern of spring distributions shown on Brune's (1981) "Location of Springs and Seeps" map clearly reflects the expected subregional differences that have been outlined above, based on various lines of geologic, geomorphic, and topographic evidence. Based on this map, Figure 11 shows the distribution of springs in a portion of the Texas PanhandlePlains encompassing 33 counties. This area was intentionally selected because it avoids the Canadian River valley, northern Panhandle, and the southern Panhandle-Plains where the precise boundaries between the Llano Estacado, Caprock Canyonlands, and the Rolling Plains are harder to define. Despite a few minor discrepancies between the plotted locations of springs and the numbers on Brune's (1981) map, several patterns are clear. Most notably, springs are much more densely distributed in the Caprock Canyonlands and on the Rolling Plains. These spring locations do tend to be somewhat clustered along major and minor drainages and along the Caprock Escarpment, but they are more evenly distributed across the landscape.

In contrast, springs on the Llano Estacado are sparsely distributed in general, and they tend to be rather clustered in most areas. Their occurrence correlates with specific topographic/geomorphic features. When the southern Llano Estacado (i.e., in Gaines, Dawson, Andrews, Martin, and Borden Counties) is added to the area shown in Figure 11, there are an estimated 157 springs across the entire Llano. Except for 13 springs that cannot be associated with any specific landforms based on Brune's (1981) plotted locations and descriptions, all of the other Llano Estacado springs are associated with creeks or draws (an estimated 99 springs) or with pluvial lakes (an estimated 45 springs). The lake springs are present primarily in the southern Llano, while the springs along creeks and draws are more common in the central and northern areas. In some cases, spring locations can be traced all along major drainages that intersect the Ogallala aquifer. For example, the linear pattern of springs in Bailey, Lamb, and Hale Counties clearly marks the locations of Blackwater and Running Water Draws.

When the area and number of springs for each county are compared by subregions (Table 3 and Figure 12), it is clear that there is considerable 


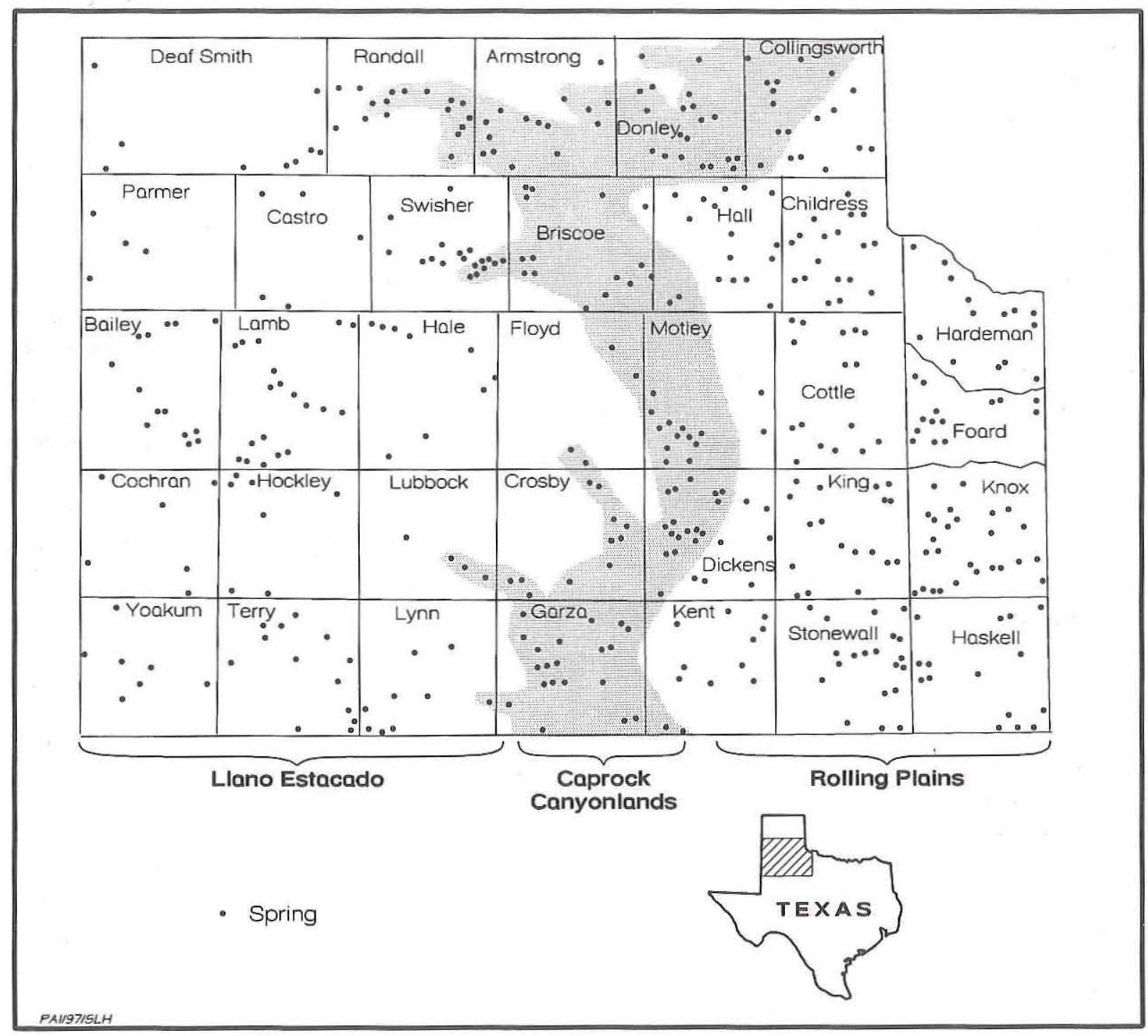

Figure 11. Distribution of springs in a selected portion of the Texas Panhandle-Plains. The Caprock Escarpment is plotted from individual county maps, and the boundary between the Caprock Canyonlands and the Rolling Plains is adapted from Figure 3.

variation in the nature of the sample. The Llano Estacado, for example, makes up 50.5 percent of the sample area, while the 118 springs there account for only 26.1 percent of all the springs. These differences are even more obvious when the number of springs is translated to spring density by region. The Caprock Canyonlands is the smallest geographic area and is about one-third the size of the Llano Estacado sample area. The density of springs, however, is three and one-half times greater in the Caprock Canyonlands (one spring per 35 square miles) than on the Llano Estacado (one spring per 128 square miles). The Rolling Plains falls between the Llano Estacado and the Caprock Canyonlands, both in terms of size and density of springs (with one spring per 52 square miles); if the saline springs were factored out, the density of freshwater springs in the Rolling Plains would be significantly less. It is interesting, and apparently not coincidental, that the varying density of springs across the Panhandle-Plains generally corresponds with the varying density of Native American sites as discussed in the following chapter. 


\begin{tabular}{|c|c|c|c|c|c|c|c|c|}
\hline \multirow[b]{3}{*}{ County } & \multicolumn{7}{|c|}{ TABLE 3} & \\
\hline & \multicolumn{4}{|c|}{ Square Miles by Subregion } & \multicolumn{4}{|c|}{ Number of Springs by Subregion } \\
\hline & $\begin{array}{l}\text { Llano } \\
\text { Estacado }\end{array}$ & $\begin{array}{l}\text { Caprock } \\
\text { Canyonlands }\end{array}$ & $\begin{array}{l}\text { Rolling } \\
\text { Plains }\end{array}$ & Total & $\begin{array}{l}\text { Llano } \\
\text { Estacado }\end{array}$ & $\begin{array}{l}\text { Caprock } \\
\text { Canyonlands }\end{array}$ & $\begin{array}{l}\text { Rolling } \\
\text { Plains }\end{array}$ & Total \\
\hline Deaf Smith & 1,498 & 0 & 0 & 1,498 & 9 & 0 & 0 & 9 \\
\hline Randall & 738 & 184 & 0 & 922 & 5 & 12 & 0 & 17 \\
\hline Armstrong & 457 & 457 & 0 & 914 & 1 & 14 & 0 & 15 \\
\hline Donley & 186 & 747 & 0 & 933 & 0 & 20 & 0 & 20 \\
\hline Collingsworth & 0 & 460 & 459 & 919 & 0 & 10 & 8 & 18 \\
\hline Parmer & 885 & 0 & 0 & 885 & 4 & 0 & 0 & 4 \\
\hline Castro & 899 & 0 & 0 & 899 & 5 & 0 & 0 & 5 \\
\hline Swisher & 811 & 90 & 0 & 901 & 10 & 8 & 0 & 18 \\
\hline Briscoe & 90 & 794 & 18 & 902 & 0 & 14 & 1 & 15 \\
\hline Hall & 0 & 109 & 795 & 904 & 0 & 2 & 15 & 17 \\
\hline Childress & 0 & 0 & 713 & 713 & 0 & 0 & 18 & 18 \\
\hline Hardeman & 0 & 0 & 697 & 697 & 0 & 0 & 14 & 14 \\
\hline Bailey & 827 & 0 & 0 & 827 & 14 & 0 & 0 & 14 \\
\hline Lamb & 1,018 & 0 & 0 & 1,018 & 19 & 0 & 0 & 19 \\
\hline Hale & 1,005 & 0 & 0 & 1,005 & 9 & 0 & 0 & 9 \\
\hline Floyd & 833 & 159 & 0 & 992 & 0 & 4 & 0 & 4 \\
\hline Motley & 30 & 534 & 426 & 990 & 0 & 12 & 2 & 14 \\
\hline Cottle & 0 & 0 & 902 & 902 & 0 & 0 & 16 & 16 \\
\hline Foard & 0 & 0 & 708 & 708 & 0 & 0 & 14 & 14 \\
\hline Cochran & 775 & 0 & 0 & 775 & 6 & 0 & 0 & 6 \\
\hline Hockley & 909 & 0 & 0 & 909 & 7 & 0 & 0 & 7 \\
\hline Lubbock & 828 & 73 & 0 & 901 & 1 & 3 & 0 & 4 \\
\hline Crosby & 541 & 361 & 0 & 902 & 0 & 11 & 0 & 11 \\
\hline Dickens & 73 & 398 & 434 & 905 & 0 & 17 & 7 & 24 \\
\hline King & 0 & 0 & 913 & 913 & 0 & 0 & 18 & 18 \\
\hline Knox & 0 & 0 & 855 & 855 & 0 & 0 & 26 & 26 \\
\hline Yoakum & 800 & 0 & 0 & 800 & 7 & 0 & 0 & 7 \\
\hline Terry & 891 & 0 & 0 & 891 & 13 & 0 & 0 & 13 \\
\hline Lynn & 857 & 36 & 0 & 893 & 8 & 1 & 0 & 9 \\
\hline Garza & 135 & 761 & 0 & 896 & 0 & 20 & 0 & 20 \\
\hline Kent & 0 & 82 & 821 & 903 & 0 & 2 & 10 & 12 \\
\hline Stonewall & 0 & 0 & 920 & 920 & 0 & 0 & 20 & 20 \\
\hline Haskell & 0 & 0 & 910 & 910 & 0 & 0 & 15 & 15 \\
\hline Totals: & 15,086 & 5,245 & 9,571 & 29,902 & 118 & 150 & 184 & 452 \\
\hline Percents: & 50.5 & 17.5 & 32.0 & 100.0 & 26.1 & 33.2 & 40.7 & 100.0 \\
\hline
\end{tabular}




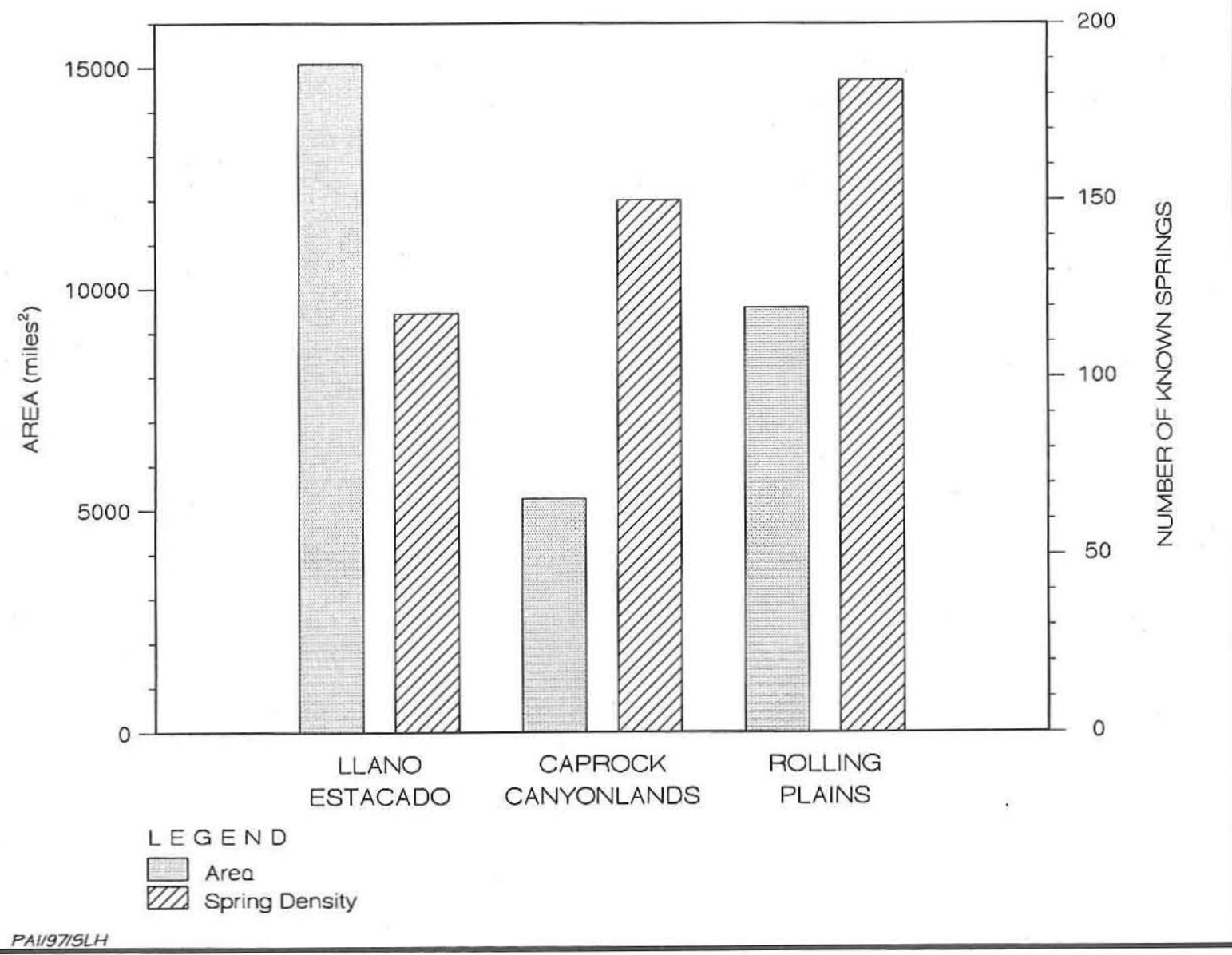

Figure 12. Comparison of total area and density of springs by subregions for a selected portion of the Texas PanhandlePlains (based on 33-county area shown in Figure 11 and spring data shown in Table 3).

\section{Historical Documentation of the Inequitable Distribution of Water Resources}

Besides the modern data on spring distributions, there is considerable historical evidence that emphasizes the unequal distribution of water resources across the Panhandle-Plains. There are many historic accounts, a few of which are mentioned below, that support the conclusion that the Caprock Canyonlands was an oasis compared to the surrounding areas. Many historic observations indicate that productive freshwater springs were abundant in the Caprock Canyonlands prior to the twentieth century; at the same time, other accounts attest to the problems of finding any water on the Llano Estacado or of finding palatable water in parts of the Rolling Plains.

In his discussion of the decline of Texas springs, Brune (1981:38-39) notes the abundance of springs in Blanco Canyon, in Crosby County, during historic times. In 1878, a settler observed that "one could not travel a half a mile without seeing a good spring" in the canyon. Discharge measurements for seven springs in Blanco Canyon recorded 78 liters per second in 1938, but this had dropped to only 2.3 liters per second in 1975. There are no discharge measurements for these springs prior to 1938, and the water table had already been lowered significantly by this time. Despite intensive pumping of Ogallala ground water, there are still some active seep springs in Blanco Canyon today.

During his 1852 exploration of the upper Red River, U.S. Army Captain Randolph Marcy described the "gyp" water springs and streams of the Rolling Plains. As the expedition traveled upstream (westward), they suddenly came upon a massive sandstone 
gorge where a tremendous freshwater spring was found (Marcy 1853). Researchers have noted that Marcy was not actually on the main branch of the Red River but was probably in the Tule Canyon Narrows when this discovery was made (Flores 1990:106-108, 114; Hughes 1978:34-35). This account clearly notes that the expedition encountered mostly unusable gyp water over a large portion of the Rolling Plains, but that the water suddenly became fresh as they entered the Caprock Canyonlands.

In his diary documenting the U.S. Army survey of the headwaters of the Red River in 1876, Adolph Hunnius made notes on the regional geology. He observed that springs were abundant in the shales of Cita and Tule Canyons, in Randall and Swisher Counties, but that the sandstones marked the eastern extent of freshwater springs in the Lower Plains. Baker (1985:43-45) identifies these shales and sandstones as Triassic-age deposits. In reference to the sandstone layer, Hunnius stated that "this rock supports the last good water in descending order, and springs or running water found lower than this will be apt to be alkaline" (Baker 1985:44). It is clear that the surveyors found no freshwater springs once they crossed into the Permian redbed formations of the Rolling Plains.

That water sources on the Llano Estacado are rare, but occur primarily at pluvial lakes and clustered along draws, is well documented by Brune (1981). Although most springs have now dried up due to overpumping of the Ogallala aquifer, there are considerable historical data indicating that there were many dependable permanent water sources prior to the irrigation age. For example, Brune (1981:284) states that "Many springs once flowed on Blackwater Draw. In early settlement days it was possible to travel by boat from Muleshoe to Earth, in Bailey and Lamb Counties, through a chain of spring-fed lakes." $\mathrm{He}$ also notes that in early historic times, Mustang and Sulphur Springs Draws in Martin County were "chains of spring-fed lakes connected by running water" but that many of the springs dried up temporarily during the severe droughts of 1885-1886 and 1907-1910 (Brune 1981:302-303). The idea of traveling by boat on a Llano Estacado draw is quite a stretch of the imagination for modern Panhandle-Plains residents.

Because springs were so sparsely distributed on the Llano Estacado, finding water was a life-anddeath situation in many cases. In 1877 , for exam- ple, a group of buffalo hunters led 60 black troopers of Company A, 10th Cavalry, onto the southern Llano Estacado chasing a renegade band of Comanches. The expedition, under the command of Captain Nicholas Nolan, left its temporary supply camp northwest of Fort Concho on July 9 and headed out onto the Llano. One of the officers later noted that the expedition was "experiencing difficulty in procuring water, on account of the great drought this year," but they ended up "at a place called Double Lake, in Lynn County, where a small quantity of alkali water was obtained" (Nunn 1940: 361 ). On the morning of July 26 , scouts reported that a group of about 40 Indians had passed nearby, and the command took off after them. They followed their trail most of that day, but by the following evening the Indians had all scattered, and the search had to be abandoned. The command was becoming disoriented, and the guide, an experienced Mexican comanchero, took eight men to search for water. When they had not returned by the next morning, the main command struck off on its own. They wandered for most of the day but, failing to find the guide or water, then decided to head back toward the Double Lakes where they knew water could be found. By this time the men were in very bad shape and were drinking the blood of the horses that died. The command finally made it back to the Double Lakes after having wandered about on the Llano for nearly four days ( 86 hours) without water. Although perilously close to disaster, they reached water just in time. All things considered, they were lucky in that they only lost four troopers (dead or presumed dead), but all of their horses had died or been stolen by Indians (Webb 1952:II:282-283). Nunn's (1940) first-hand account of this incident testifies that the Llano Estacado could be a harsh and unforgiving place.

Even a slight drop in the shallowly buried water table of the southern Llano Estacado could be a serious problem. Hand-dug water wells found in middle Holocene deposits along High Plains draws (see Chapter 8) provide evidence that Early to Middle Archaic peoples had learned to cope with the Altithermal drought and the problem of a lowered water table. This same technique was used by historic Indians, and as many as 20 to 60 water wells were encountered in at least three separate draw localities by Lieutenant-Colonel William Shafter during his 1875 expedition against the Comanches on the southern Llano (Shafter 1933). 


\section{FLORA AND FAUNA}

The Panhandle-Plains hosts a wide variety of native plants and animals even today. Modern activities such as farming and ranching, pumping of ground water, damming of surface waters, and commercial and industrial development have certainly impacted the biological diversity of the region. Most notably, numerous species of animals, birds, and plants have disappeared from, or are now endangered in, the region (Flores 1990:105-110). In addition, many non-native plant and animal species have been introduced, and the distributions of the indigenous species have been greatly altered.

A comprehensive review and comparison of the native flora and fauna of various regions and subregions within the Texas Panhandle-Plains is beyond the scope of this study. For discussions of biological communities that characterize parts or all of the region, the reader is referred to Boyd et al. (1989), Davis (1974), Etchieson et al. (1979), Flores (1990), Gould and Thomas (1975), Hughes and Willey (1978), Jones et al. (1985), Kenmotsu (1981), Kirkpatrick (1992), Lintz (1986), Rowell (1967), Scudday and Scudday (1975), Sikes and Smith (1975), Thompson (1987), Wendorf and Hester (1975), and Wulfkuhle (1986). There are some obvious and not-so-obvious biological distinctions between the subregions that warrant consideration here, however.

The most significant differences in floral and faunal communities are between those on the Llano Estacado and those of the Lower Plains. Subtle differences also distinguish the floral and faunal communities of the Caprock Canyonlands from those of the Rolling Plains. The Caprock Canyonlands includes some species that are absent on the Llano and the Rolling Plains. However, the primary distinction in the biology of the Caprock Canyonlands is quantitative rather than qualitative. Many plants and animals are found over most of the Panhandle-Plains but are significantly more abundant in one or another subregion. In addition, the canyonlands is an area where relict Pleistocene populations are concentrated.

While the entire Panhandle-Plains is within the Kansan biotic province, the primary biological distinction is that the Llano Estacado is a true shortgrass prairie, while the Lower Plains is a mixedgrass prairie/mesquite savanna (Blair 1950). Prior to the development of modern agriculture, the Llano
Estacado was a vast grassland that was devoid of trees except along major stream channels. The southern High Plains grassland was interrupted only by thin strips of riverine environments, and prairie fires were an important factor in the grassland ecology until modern times. Whether induced naturally (e.g., by lightning) or by man, prairie fires played an important role in maintaining the ecological health of the grassland ecosystem (Flores 1990: 60-61; Haley 1929). By controlling fires, modern man has allowed most of the natural prairies to be taken over by unwanted invaders. Except for a few isolated prairie remnants (preserved on mesa tops, for example), true Llano Estacado short-grass prairie communities no longer exist.

Many of the same plants and animals found on the Llano Estacado may also be found in the Lower Plains mixed-grass mesquite savanna, but this region also is host to many other forms of wildlife. Compared to the Llano Estacado, riverine environments in the Lower Plains are well timbered, most notably in the canyonlands. The dependable water supply and the shelter in the Caprock Canyonlands support a rich diversity and an unusually high density of flora and fauna. The canyonlands are home to many species of plants and animals that are not found, or are much less common, in the Rolling Plains. It also is clear that some remnant canyonland populations are holdovers from more-mesic periods in the past. Long-term fluctuations in precipitation have probably had significant impacts on the plant and animal communities, but the relationships remain poorly understood.

Flores (1990:105-111) notes that the diversity of flora and fauna in the Caprock Canyonlands is a result of several factors. Part of the diversity is attributed to an unusual mix of flora and fauna that converge in the region from the east and west. Southwestern arid-adapted species are found alongside more-mesic-adapted species common to the east or in mountainous habitats to the north. Part of the biological diversity is attributed to the diversity of geology, topography, soils, and other conditions found in canyonland areas. In regard to the diversity of flora, Flores (1990:109) states that:

This kind of rich multiplicity was possible in the canyons because of the extraordinary range of soils, moisture regimes, and shade conditions and because geology proceeds so rapidly here. Slumps, rockfalls, landslides 
produce unending disturbances, perfect for herbs that thrive in subclimax conditions. And deep canyons, steep slopes, cool north exposures, sunny dry ridges are classic locations for refuge species.

Additional diversity in canyonland flora and fauna is attributed to relict populations that were widespread during the Pleistocene but survived the onset of drier conditions only in the canyonlands. For example, a wide range of typical Rocky Mountain plants is present in the canyonlands as holdovers from cooler, wetter Pleistocene times. The Rocky Mountain juniper once thrived in the canyonland habitat. Because they were intentionally selected for harvesting by pioneer loggers, Rocky Mountain junipers are now nearly gone from most parts of the Caprock Canyonlands, but they were once abundant there (Flores 1990:108). It also is notable that the northernmost populations of escarpment live oak and pecan are found in isolated parts of the southern Caprock Canyonlands (see Chapter 8).

Many animals are, or were, primarily canyonland dwellers. Some were holdovers from Pleistocene times, while others simply preferred the rugged and rocky canyon habitat. These include a wide range of reptiles, amphibians, birds, and rodents. At least one mammal species, the Piñon mouse (or Palo Duro mouse), inhabits only a small area along the Caprock Escarpment and is an endemic subspecies evolved from a Pleistocene relative (Davis 1974: 209-210; Flores 1990:109). Many species of carnivores are, or were, found along the Caprock Escarpment because they prefer to den in rugged, rocky settings (Davis 1985:85-136; Flores 1990: 107-109). Gray wolves were once abundant in the Panhandle-Plains. While they may have hunted over a large territory, they tend to den in the rocky cliffs in the canyonland country (Davis 1974:123-126). Other carnivores that inhabit the canyonlands today and/or lived there in the past include black bears, coyotes, raccoons, ringtails, minks (known from faunal remains recovered at Lake Alan Henry), striped skunks, bobcats, cougars, and red, swift, and gray foxes.

In terms of human exploitation, the principal large game animals that roamed the Panhandle-Plains were deer, pronghorn, and bison. These animals were not evenly distributed across the region, and they tended to prefer one or another subregional habitat, at least on a seasonal basis (Davis 1974;
Jones et al. 1985). Deer and pronghorn may migrate locally on a seasonal basis, but they prefer different types of habitat. While mule deer prefer more-open spaces than whitetail, both species prefer the brushy or wooded riverine habitats of the Caprock Canyonlands and Rolling Plains over the treeless Llano Estacado. Even today, deer populations are generally highest in the canyonlands. In contrast, pronghorn prefer to graze in the open and avoid being trapped in confining canyonland areas. Although nearly extinct by the early twentieth century, reintroduced pronghorns are now most common in the gently rolling terrain along the margins of the Canadian River valley, in open areas on the margins of the Caprock Canyonlands, and in the Rolling Plains. It may be assumed that prehistoric hunters were well aware of deer and pronghorn behaviors and adjusted their hunting strategies accordingly.

There is disagreement regarding many aspects of bison behavior, but the best evidence suggests that bison generally preferred grazing in open grasslands during the spring, summer, and fall and in sheltered woodlands during the winter (e.g., Chisolm et al. 1986; Roe 1972). Epp (1988) and others suggest that bison may have utilized a dual pattern of migration, with some herds alternating between grasslands and woodlands and other herds remaining in the woodlands year-round. Generally, however, there were times when bison preferred grazing on the short grasses of the High Plains over the mixed grasses of the Lower Plains, although they certainly ranged into marginal areas under population pressures. The Llano Estacado would have supported large bison populations, especially when they congregated in large herds from early spring to late fall (July to September) for the rutting season (Roe 1972:94-118). While bison may have roamed the Llano Estacado and the Rolling Plains during much of the year, historic accounts for the Southern Plains note that the animals dispersed into smaller herds and moved into sheltered canyonland and riverine areas along the margins of the Plains during the coldest months (see Flores 1990:107; Roe 1972:572). Thus, one may infer that the distribution of bison within the Southern Plains was probably variable but rather predictable on a seasonal basis. It is likely that short-term climatic events (e.g., droughts or exceptionally wet periods) would have had an impact on when and where bison herds grazed. It is equally likely, however, that any deviations in 
normal behavior would have been somewhat predictable to observant prehistoric bison hunters.

The discussion above illustrates the inequitable distribution of plants and animals in the PanhandlePlains and notes that distribution patterns vary on subregional and seasonal bases. The preceding discussion also highlights the fact that the Caprock Canyonlands has always had abundant resources that were important for human populations. Flores (1990:105-110) describes the incredible range and abundance of wildlife that explorers found along the Caprock Escarpment prior to the twentieth century. $\mathrm{He}$ states that the canyonlands "were far richer in topographic and, hence, species diversity than any of the surrounding lands for hundreds of miles," and he concludes that "their native plants and animals comprise a unique blend of eastern and western types whose range perimeters just overlap here" (Flores 1990:106).

\section{SUMMARY AND CONCLUSIONS}

There are significant differences between the Caprock Canyonlands and the adjacent Llano Estacado and Rolling Plains regions in terms of geology, geomorphology, soils, topography, climate, and the nature and distribution of flora and fauna. The geology and geomorphology control the distributions of water and soils, which in turn control the distributions of plant and animal resources. Human populations utilized the landscape in accordance with the variable distributions of plants, animals, and other resources, but water was the single most important resource. In human terms, the Caprock Canyonlands was an oasis in an otherwise arid landscape. Like all other creatures, past human populations were subject to the constraints imposed by subregional environmental diversity in the Panhandle-Plains. Until modern times, the unequal distribution, quantity, and quality of resources in the area were important factors affecting prehistoric human habitat selection and adaptive behavior (e.g., subsistence activities, land-use patterns, and social organization). Bowden (1977) discusses how primitive and modern societies have coped, and are coping, with serious water problems in the American Southwest. He notes that "arid lands are a merciless place for such societal experiments. They are full of dead people and cultures because the weather fluctuates a great deal. For aridity is more than just dryness; it is guaranteed uncertainty" (Bowden 1977:21-22). As in the arid Southwest, human populations have always experienced some degree of uncertainty facing life in the semiarid Plains, but the greater concentration and predictability of resources in the Caprock Canyonlands was undoubtedly an attraction that prehistoric peoples did not overlook.

It has been proposed in this chapter that the distribution of water was the most critical factor influencing human settlement patterns in the Panhandle-Plains prior to the development of modern irrigation technology in the twentieth century. It also has been noted that aquifer-related water sources (i.e., springs and spring-fed lakes, streams, and rivers) were more reliable and predictable than precipitation-based sources (e.g., playas, draws, and minor streams), and that the overall distribution of water is quite different on the Llano Estacado, Caprock Canyonlands, and Rolling Plains (Table 4). Two points in regard to springs and aquifer-related water sources are worth emphasizing: (1) although it is impossible to quantify the number and productivity (i.e., discharge) of pretwentieth-century springs accurately, the geographic distribution of modern springs supports an interpretation that springs and aquifer-dependent surface water sources were as unequally distributed in the past as they are today; and (2) because of the inequitable distribution and varying quality of aquifer-dependent surface water, the most reliable, predictable, and geographically abundant water sources in the Panhandle-Plains were found in the Caprock Canyonlands. In contrast, water sources on the Llano Estacado and in the Rolling Plains were less densely distributed, less predictable, and/or of lesser quality.

Although it is impossible to know all of the factors that may have made particular spring localities useful or desirable to prehistoric peoples, it is possible to predict how springs may have functioned within primitive societies on a basic regional level. One of the factors that appears to strongly condition the pattern of exploitation of crucial resources among animal populations, as well as hunter-gatherers, is the spatio-temporal predictability of the resource. The studies of Dyson-Hudson and Smith (1978), Heffley (1981), Horn (1968), and Low (1979) indicate that resources that are highly predictable in their spatiotemporal occurrence tend to be exploited on a systematic recurrent basis and may even become territorially controlled or owned. On the other hand, resources that are less predictable in space or time are exploited on a less systematic basis. Based on these broad principles, it is suggested here that, given the low 


\begin{tabular}{|c|c|c|c|}
\hline \multicolumn{4}{|c|}{$\begin{array}{l}\text { SUMMARY OF PRE-TWENTIETH-CENTURY DIFFERENCES IN THE } \\
\text { DISTRIBUTION AND QUALITY OF SURFACE WATER } \\
\text { RESOURCES IN THE TEXAS PANHANDLE-PLAINS }\end{array}$} \\
\hline \multirow[b]{2}{*}{ Characteristic } & \multicolumn{3}{|c|}{ SUBREGIONS } \\
\hline & Llano Estacado & Caprock Canyonlands & Rolling Plains \\
\hline $\begin{array}{l}\text { Main aquifers } \\
\text { issuing springs }\end{array}$ & Ogallala Formation & $\begin{array}{l}\text { Ogallala Formation } \\
\text { Triassic formations } \\
\text { Quaternary alluvium }\end{array}$ & $\begin{array}{l}\text { Quaternary alluvium } \\
\text { Permian formations }\end{array}$ \\
\hline $\begin{array}{l}\text { Regional distribution } \\
\text { of springs }\end{array}$ & $\begin{array}{l}\text { Very limited distribution; found } \\
\text { only along major High Plains } \\
\text { drainages and at a few major } \\
\text { pluvial lakes. Large areas of } \\
\text { the Llano Estacado have no } \\
\text { springs. }\end{array}$ & $\begin{array}{l}\text { Widespread, found all along } \\
\text { Caprock Escarpment and } \\
\text { abundant in prominent } \\
\text { canyons. }\end{array}$ & $\begin{array}{l}\text { Limited distributions; } \\
\text { springs are common in } \\
\text { some small areas but not } \\
\text { found in others. }\end{array}$ \\
\hline $\begin{array}{l}\text { Water quality of } \\
\text { springs }\end{array}$ & Good & Good & $\begin{array}{l}\text { Variable; some springs } \\
\text { are good, others are } \\
\text { highly saline and water } \\
\text { is unpalatable. }\end{array}$ \\
\hline $\begin{array}{l}\text { Total regional } \\
\text { discharge of } \\
\text { freshwater springs } \\
\text { (in relative terms) }\end{array}$ & Very limited & Abundant & Limited \\
\hline $\begin{array}{l}\text { Seasonality and } \\
\text { predictability of } \\
\text { overall surface } \\
\text { water supply }\end{array}$ & $\begin{array}{l}\text { Playas and drainages are very } \\
\text { ephemeral and small springs are } \\
\text { seasonally unpredictable. Major } \\
\text { springs are more predictable but } \\
\text { rare. }\end{array}$ & $\begin{array}{l}\text { Drainages are seasonal } \\
\text { except for major rivers } \\
\text { and tributaries. Most } \\
\text { springs are stable and } \\
\text { predictable. }\end{array}$ & $\begin{array}{l}\text { Many major streams and } \\
\text { springs are saline; fresh } \\
\text { water is predictable in } \\
\text { limited areas. Overall } \\
\text { availability is low and } \\
\text { unpredictable. }\end{array}$ \\
\hline $\begin{array}{l}\text { Sources: Brune (197 } \\
\text { (1984). }\end{array}$ & Nativ (1988), Richter and Kreit & 986), and Texas Departm & of Water Resources \\
\hline
\end{tabular}

accessibility of precipitation in a semiarid environment, human populations would exploit the Panhandle-Plains in a pattern that would be more or less tethered to the available water resources. Of course, this is a reasonable assumption and is certainly nothing new to the modern inhabitants of the Llano Estacado, whose livelihoods depend upon intensive exploitation of the ground water. Past societies, however, were tethered only to surface water sources whose predictability was largely dependent upon the nature and location of springs.

The fact that large sections of the PanhandlePlains are characterized by differential distribution, availability, and quality of water has many implications for interpreting past human behavior. By focusing on the differential availability and spatiotemporal predictability of ground water-based resources, rather than precipitation, we can develop a series of expectations or generalized predictions regarding human utilization of the Llano Estacado, Caprock Canyonlands, and Rolling Plains.

Precipitation-based surface water on the Llano Estacado generally would have been available only on a seasonal basis. Playas and draws may have held water year-round during unusually wet periods, but they most likely held water only during the rainy season in the spring to early summer in most normal years (i.e., years with precipitation amounts close to the 30-year average of 18.5 inches per year). Consequently, the predictability of these water sources was 
extremely variable, and prehistoric populations could depend on them only during wet years or wet seasons. During extended dry periods, the occurrence of water in playas and draws would have been unpredictable at best. These sources occasionally would have been completely dry for months or years at a time.

Springs on the Llano Estacado were more predictable. They are concentrated along major draws and occur at all of the ca. 40-45 pluvial lakes in the southern part of the region. Not all of these springs were equally productive and dependable, however. Some may have even dried up during droughts. Droughts of short duration (e.g., one or two years) might have had an impact on some springs, and longer droughts (e.g., of several years duration) almost certainly did. However, the spatio-temporal predictability of these springs was generally quite good, and the native populations probably knew where to find water on the Llano even during drought periods. As is clear from accounts of historic Plains Indians, native peoples who utilized the Llano Estacado had an intimate knowledge of the location and relative dependability of springs. Even during droughts, they apparently knew which springs would still be flowing and where they could go to find water by digging wells to reach the shallow water table. Consequently, the primary factors limiting human settlement and utilization of the Llano Estacado may have been the limited geographic distribution and discharges of springs rather than their predictability. Notably, the density of springs is quite low over most of the Llano, and the springs tend to be clustered. There are vast areas of the Llano Estacado that have no springs at all and would not have supported anything but ephemeral human occupations and/or use. Intensive human occupations (i.e., anything other than short-duration occupations by very small groups) were probably possible only around certain pluvial lakes and in limited areas along the High Plains draws.

A similar situation exists in the Rolling Plains. Although springs are much more densely distributed there, they tend to be clustered primarily along river valleys or near significant exposures of Quaternary alluvium. In addition, the water sources within a large portion of the Rolling Plains were essentially unusable due to the presence of large numbers of saline springs and Permian gypsum outcrops. Like the Llano Estacado, there were probably large areas of the Rolling Plains where little or no potable water could be found. Although the location and depend- ability of freshwater springs may have been fairly predictable, their sparse distribution was certainly an important factor constraining human settlement and/or use of most of the vast Permain redbed plains. Intensive human occupations were probably possible only in limited areas along some rivers and streams, and perhaps in areas where springs were clustered along the margins of some Quaternary alluvial deposits.

In contrast to their limited distribution on the High Plains and Rolling Plains, freshwater springs would have been relatively abundant and predictable over almost all of the Caprock Canyonlands. Because of this, it can be predicted that past human populations utilized the Caprock Canyonlands more intensively and in very different ways than they used the adjacent Llano Estacado or Rolling Plains.

Past human settlement patterns in the PanhandlePlains may be further understood when the spatiotemporal predictability of resources other than water is taken into account. The near-absence of lithic materials, wood, and subsistence resources on the Llano Estacado, with the principal exception of bison (and perhaps pronghorn and migratory waterfowl), was a significant factor limiting the overall intensity of hunter-gatherer occupations. Particularly notable is the fact that the Llano grasslands might have been a bison hunter's paradise (when bison populations were sufficient to support intensive hunting) between late spring and early winter, but the High Plains would not have been a pleasant place to live during the coldest winter months. Even the hearty bison generally vacated the area and headed for the protective cover of the river valleys and canyons during extremely cold weather. Based on the sparse and sporadic distributions of subsistence resources, it can be predicted that human occupations on the Llano Estacado were generally ephemeral and took the form of seasonal camps where activities were dominantly hunting oriented, assuming that sufficient bison populations were present. It is unlikely that prehistoric peoples could have occupied the Llano on a long-term or year-round basis, with the possible exception that bison hunters could have had semipermanent habitations near pluvial lakes if their diets were supplemented by agriculture, an idea first proposed by Collins (1968:156).

The Rolling Plains certainly offered a greater diversity of other resources than did the Llano Estacado, but it was the abundance of lithic materials and wood, along with a rich diversity and concentra- 
tion of subsistence resources, that made the Caprock Canyonlands a particularly attractive region. From a seasonality standpoint, there would have been an abundant variety of plant foods available during all seasons except winter, and there would have been some game animals present year-round. Compared to the wide open spaces of the High Plains, and the Rolling Plains to a lesser extent, the canyonlands would have offered abundant shelter and protection from the elements during the coldest winter months. Hence, it can be inferred that past human populations utilized the canyonlands rather intensively and during most, if not all, of the yearly cycle. It is not suggested that any prehistoric groups occupied only one location year-round. That type of land use is unlikely given the high degree of seasonality in the availability of subsistence resources. It is perhaps more likely that prehistoric hunter-gatherers moved about from location to location to exploit a variety of canyonland, Llano Estacado, and Rolling Plains resources during the yearly cycle, but spent most of their time in the canyonlands.

Although the Canadian River valley of the northern Texas Panhandle has not been discussed in detail in this chapter, it is in many ways analogous to the Caprock Canyonlands. Both areas were intensively utilized by primitive peoples for the same basic reason-they offered an abundance and diversity of resources not found in adjacent areas. Lintz (1986:39-76) summarizes the geology, geomorphology and soils, climate and hydrology, and flora and fauna of the Canadian River valley and notes "considerable diversity in the kind and distribution of natural resources." In particular, Lintz (1986: 75-76) recognized the importance and abundance of freshwater springs emerging from the Ogallala aquifer and suggested that most springs in the Canadian Breaks would have flowed even during short-term droughts. Because of their distinctive ecological characteristics, the Caprock Canyonlands and the Canadian River Breaks not only served as havens providing abundant shelter, food, and water, but their geographic positions allowed nomadic and seminomadic hunter-gatherers and hunter-gathererfarmers quick and easy access to the resources of the adjacent Llano Estacado and Rolling Plains.

Past cultures in the Panhandle-Plains did not confine their activities to a single subregion. In fact, given the distinctive ecological differences between the subregions, it is likely that subsistence pursuits were maximized by exploiting various resources within several subregions during the course of a year. Although such an inference is conjectural, prehistoric peoples may have lived in and exploited the resources of the Caprock Canyonlands intensively for much of the year, but journeyed seasonally onto the High Plains and Rolling Plains to exploit other resources, primarily bison. In his review of Texas High Plains archeology, Jack Hughes (1991:7) observed that:

The Llano Estacado in many ways is like a great sea of grass surrounded by a rugged shoreline of upside-down hills. Just as fish are the principal resource of a sea, bison were the principal resource of the Llano Estacado, and, like many seas, the Llano appears, for the people who lived on opposite shores, to have served more as a bridge than a barrier. As with sea travel, although storms were a hazard, crossings were relatively easy and swift, either along the upland valleys or from one valley to the next.

In the chapters that follow, it is proposed that the resource-rich Caprock Canyonlands played a major role in the development and evolution of postAltithermal cultures in the Texas Panhandle-Plains. The escarpment area seems to have been a critical zone in terms of subsistence and settlement for many different prehistoric populations over many thousands of years. In a simplistic fashion, the Caprock Canyonlands may be viewed as a home base for many cultures whose seasonally oriented subsistence activities extended over a much larger territory that included the Llano Estacado and the Rolling Plains. 


\section{CHANGING PERSPECTIVES IN TEXAS PANHANDLE-PLAINS ARCHEOLOGY}

by Douglas K. Boyd

Despite the fact that scientific archeological excavations began early in the twentieth century and have continued to the present, the vast Texas Panhandle-Plains remains one of the most sparsely documented and poorly understood archeological regions in Texas. Although many archeological investigations have been conducted, it has only been within the last quarter-century that enough data have come to light to enable researchers to fully appreciate the archeological diversity and complexity of the entire region. This archeological diversity is directly related to the environmental diversity discussed in the previous chapter and supports the contention that the Caprock Canyonlands is a distinctive archeological region.

The first section of this chapter is devoted to a brief history of archeological research in the Panhandle-Plains. This discussion takes a different approach than some archeological background summaries in that its primary goal is to illustrate the changing perspectives on the region's archeology. This is done by focusing on various studies that have defined cultural phases and complexes and on archeological overviews that have summarized the archeology or culture history interpretations for the region or large segments of it. The second section analyzes selected archeological survey data in an attempt to define the archeological differences that distinguish the Caprock Canyonlands from the Llano Estacado and Rolling Plains regions.

\section{BRIEF HISTORY OF ARCHEOLOGICAL RESEARCH}

The Panhandle-Plains was one of the first regions of Texas to receive archeological attention, and at least two or three informal site investigations were conducted by members of various U.S. Army expeditions in the late nineteenth century. Lieutenant J. W. Abert described the Alibates flint quarries as the "Agate Bluffs" in 1845 (Carroll 1941:64); Lieutenant A. W. Whipple documented the major rock art site of Rocky Dell on the Canadian River in 1853 (Archambeau 1971:89; 'Whipple et al. 1856); and Lieutenant T. M. Woodruff conducted the first subsurface excavation of an Indian ruin on the Canadian River in 1876 (Baker 1985:20, 116). These investigations were done more out of curiosity, however, than a desire to systematically learn about past cultures.

Shortly after the turn of the century, Professor T. L. Eyerly and his students from the Canadian Academy, Canadian, Texas, conducted archeological excavations at the Buried City ruins on Wolf Creek (a tributary of the Beaver or North Canadian River) in Ochiltree County. Eyerly (1907a, 1907b, 1910, 1912) published the first scientific archeological reports for this part of the state. These investigations were soon followed by a host of other researchers who studied sites in the Buried City area and in the Canadian River valley in the 1920s and 1930s. Among the famous archeologists who worked in the region during this time were Warren K. Moorhead, J. Alden Mason, William C. Holden, E. B. Sayles, and Floyd V. Studer. Studer, one of Eyerly's students, became a major figure in Texas Panhandle archeology and had documented 110 major ruins by 1930 .

These early works led to the recognition of a distinctive Plains Village culture. Moorhead and 
national trend, the development and spread of organized avocational archeology, occurred simultaneous with the growth of subsidized public archeology since 1950 and has had a major impact on archeology in the Panhandle-Plains.

Many studies have made significant contributions to the development of a regional chronology and culture history for the Texas Panhandle-Plains. The studies that originally defined the cultural complexes and phases that are recognized by researchers today and relate to the late Holocene period in the Caprock Canyonlands, Llano Estacado, and/or Lower Plains are presented in chronological order in Table 5. These contributions are not considered here because the archeological manifestations are discussed in detail in later chapters. Many archeological reports on testing/excavation of specific sites also are discussed in subsequent chapters and are not mentioned in this brief history. Histories of archeological research and/or culture histories for specific areas in and around the Caprock Canyonlands are presented by Boyd et al. (1989:23-59) for Lake Alan Henry; Hughes (1978) for Palo Duro Canyon State Park and vicinity; Hughes and Willey (1978:24-31) for Mackenzie Reservoir; Johnson (1989) for the Lubbock Lake area; Judd (1977:7-12) for the 11-county South Plains Association of Governments area of the southern Panhandle-Plains; Mercado-Allinger(1982:14-18) for Caprock Canyonlands State Park; Thurmond et al. (1981:24-37) and Beene (1995) for the Lower Plains; and Wulfkuhle (1986:55-109) for the Clear Fork of the Brazos.

In a gross sense, one may trace the evolution of archeological thought in the the Texas Panhandle-
Plains through a series of regional archeological overviews that have been published over the years. When read in chronological order, these overviews show a gradual progression in the accumulation of archeological knowledge, the development of the regional cultural chronology and culture history, and the evolution of archeological method and theory.

The first true statewide synthesis of Texas archeology was An Archaeological Survey of Texas by Sayles (1935). At the time that it was written, about all that was known for the Panhandle-Plains region was that "[i]n the northern part of the State, concentrated along the Canadian River, are many house ruins" representing an agricultural group called the "Panhandle Phase" (Sayles 1935:84). The presence of Rio Grande Puebloan potsherds was used as a relative dating technique to estimate the age of this culture at about A.D. 1350. For the "Plains" portion of Texas, Sayles (1935:8) summarized the prehistoric archeology by stating that there "are numbers of small hearth sites indicating temporary use. In most cases they probably represent only hunting sites occupied by parties from adjoining areas." He also recognized that there was archeological evidence of historic Plains Indians on the Plains, some of which probably represented Kiowa and Comanche occupations.

Jackson's (1938) Picture-Writing of Texas Indians was an important contribution for the Texas Panhandle-Plains, despite the fact that so few rock art sites were known in the region at the time (e.g., only six sites were discussed for the upper 32 counties in Texas). It went beyond the traditional view that rock art was idle doodling and acknowl-

TABLE 5

MAJOR CULTURAL COMPLEXES AND PHASES RECOGNIZED IN THE REGION

\begin{tabular}{|l|l|}
\hline Complex/Phase & Reference \\
\hline Antelope Creek focus/phase & Krieger (1946), Lintz (1986) \\
Little Sunday complex & Hughes (1955) \\
Lake Creek complex & Hughes (1962) \\
Garza complex & Runkles (1964) \\
Eastern Jornado Extention & Corley (1965a, 1965b) \\
$\quad$ Querecho, Maljamar, and Ochoa phases) & \\
Summers complex & Leonhardy (1966) \\
Palo Duro complex/phase & Hughes and Willey (1978), Cruse (1992) \\
Tierra Blanca complex & Spielmann (1982, 1983) \\
Buried City complex & Hughes and Hughes-Jones (1987), D. Hughes (1991) \\
Blow Out Mountain phase & Creel (1990) \\
\hline
\end{tabular}


edged the importance of understanding rock art as an integral part of culture. Jackson studied different design elements encountered across the state and mapped their distributions as best he could through time and space in an attempt to classify the images. Jackson was fully cognizant that some images were undoubtedly prehistoric but that other motifs were made by Native Americans who were coming under European influences. He recognized that several distinctive "styles" were represented in the Indianmade pictures.

Krieger's (1946) Culture Complexes and Chronology in Northern Texas with Extension of Puebloan Dating to the Mississippi Valley was a monumental synthesis that brought together all that was known of the late prehistory (i.e., post-Archaic) of the northern portion of Texas. It attempted, rather successfully, to (1) define a series of culture complexes for the northern part of the state, (2) extend the established Puebloan ceramic chronology eastward to date these complexes, and (3) define the "time, nature, and degree of contacts between peoples of the Southwest, Plains, and western parts of the Southeast" (Krieger 1946:9). In a major section on "The Panhandle and Western Plains of Texas," Krieger defined the Antelope Creek Focus and Panhandle Aspect, noted the Puebloan influence in its architectural style, and suggested that there was "selective borrowing and acculturation" between the indigenous Antelope Creek peoples and Southwestern Puebloan peoples (1946:73). In a brief section on "Puebloan Influence or Occupation in the Llano Estacado," Krieger (1946:75-82) noted the sporadic distribution of water and its importance as a factor dictating human settlement patterns. Using the surface collections housed at The University of Texas, Krieger observed that a variety of Puebloanmade pottery is common all across the southern Llano Estacado and commented on the fact that the frequency of imported Southwestern ceramics drops off quickly east of the Caprock Escarpment (Krieger 1946:81). These ideas and observations, and many others made by Krieger (1946), are still valid and form the core of many current research problems.

Suhm et al.'s (1954) classic "Introductory Handbook of Texas Archeology" contains a short review (11 pages) of the Panhandle-Plains area, based primarily on Krieger's (1946) earlier work. They identified several important Paleo-American sites and traditions, but the Antelope Creek focus was still the only cultural complex defined for the
Neo-American period. Almost nothing was known about the Archaic period, and they identified this data gap as a critical research area. This eventually led Hughes $(1955,1962)$ to conduct investigations at the Little Sunday and Lake Creek sites in an effort to define the Panhandle Archaic and Woodland periods.

Studer's (1955) "Archeology of the Texas Panhandle" was concerned only with the Texas Panhandle Pueblo culture. He presented a basic trait list for the culture. Perceiving this culture as local people who adopted Southwestern Puebloan traits, Studer (1955:94) stated that "the economic life of the Texas Panhandle Pueblo settlements bears some similarity to that of contemporaneous Pueblo cultures of New Mexico and Arizona." While Studer still adhered to many of his old (and outdated) ideas, this summary is notable because it suggests that the disappearance of the Panhandle culture may have been related to climatic conditions (i.e., drought conditions) during the fifteenth century A.D.

Written in 1958, Kelley's (1964) "Comments on the Archeology of the Llano Estacado" noted many important Paleoindian sites and traditions but suggested a paucity of "post Paleoindian remains." Except for the Paleoindian sites, only about 35 sites on the Llano were known to the South Plains Archeological Society at the time. Only a few had been tested or excavated, and most of these were burials. This overview is notable because it established a site classification scheme that demonstrated the importance of recognizing geomorphic processes and archeological context. The proposed site types were (1) stratified sites, (2) single occupation buried sites, (3) deflation basins, (4) blowout sites, (5) rockshelters, (6) isolated burials, and (7) miscellaneous sites (includes caches and quarries). Kelley also presented thoughtful discussions of historic accounts of native peoples, the postdepositional effects of the wind on the Llano Estacado, problems with point typologies and cultural chronologies, and the relationships between radiocarbon dating, stratigraphy, and paleoclimatic interpretation.

Based on Forrest Kirkland's lifelong pursuit of recording rock art in Texas, W. W. Newcomb compiled his notes, watercolors, and drawings and published The Rock Art of Texas Indians (Kirkland and Newcomb 1967). This volume described most of the rock art known to Kirkland in 1941, provided thoughtful interpretations of the various functions of rock art within cultural contexts, and correlated rock 
art with archeological data where possible. Although Kirkland and Newcomb (1967) documented more Panhandle-Plains sites than did Jackson (1938), large portions of the region (particularly along the Caprock Escarpment) had no recorded rock art sites. Unlike their predecessor, Kirkland and Newcomb were able to make some tentative links between rock art styles/motifs and prehistoric and historic groups. They suggested, for example, a link between the prehistoric Antelope Creek peoples and certain rock art motifs found near their villages, and they recognized the biographic nature of much of the historic Indian rock art found in the Texas Panhandle (Kirkland and Newcomb 1967:213-216).

Collins's (1971) “A Review of Llano Estacado Archaeology and Ethnohistory" is a landmark study that was the first to synthesize survey and site excavation data within a culture history framework, define site types and diagnostic material culture assemblages, and formulate broad behavioral interpretations relating to subsistence and settlement pattern changes through time. This summary also discusses ethnohistoric data, speculates on extraregional cultural interactions, and defines regional archeological research problems. The Paleoindian and Archaic periods are briefly discussed, but the Archaic data at the time were still generally poor. Collins's discussions of the NeoIndian to Historic periods are particularly notable, and he identifies many key research issues that are relevant today.

Two short summaries of the Archaic period in the Texas Panhandle were done by Hughes (1976) and Bandy (1977) in an attempt to fill in one of the major data gaps noted by Collins (1971). Hughes (1976) simply presents definitions of site types for the period, defining Archaic site types as open camps, rockshelters, bison kills, flint quarries, flint caches, burials, and miscellaneous. Rock art also is mentioned, but most of the sites are thought to be post-Archaic. The summary mentions the Little Sunday complex but notes the lack of meaningful excavation data. The relative abundance of [Late] Archaic bison kills is noted but not discussed in detail. Similarly, Bandy's (1977) "Review of Archaic Cultures of the Texas Panhandle" is a summary of survey and excavation data in an attempt to establish the basic projectile point sequence and chronology within the Archaic period and define the geographic distribution of sites. The Archaic data at that time were still too minimal to support meaningful interpretations of subsistence, but the abundance of bison kills in the Rolling Plains is noted. While there are no earth-shaking revelations in either of these studies, they do demonstrate that attempts to understand Archaic cultures were being made.

From Clovis to Comanchero: Archeological Overview of the Southern Great Plains (Hofman et al. 1989) has several chapters that relate to the late Holocene cultures in the Texas Panhandle-Plains. Pertinent chapters are by Hofman (1989a) covering the Archaic periods of northwestern Texas, including the Little Sunday complex; Hofman and Brooks (1989) covering the Plains Woodland period and the Lake Creek focus; Brooks (1989) covering the Plains Village period, including the Antelope Creek phase and Buried City complex; and Hofman (1989b) covering the Protohistoric period, including the Garza and Tierra Blanca complexes. These overviews are particularly important because they consistently summarize site types, material culture, structures and features, subsistence and settlement pattern interpretations, and paleoclimatic evidence for each defined cultural period and/or complex. The articles also identify many of the critical research problems and regional data gaps for their respective time periods.

One of the more recent overviews is "Prehistoric Cultural Developments on the Texas High Plains" by Jack Hughes (1991). This is another landmark study that provides a much needed update to Collins's (1971) treatise on the Llano Estacado. Hughes concisely defines the culture history of the Panhandle-Plains region and fully integrates the subsistence and settlement pattern interpretations with paleoclimatic reconstructions. He utilizes the results of a great deal of published archeological literature but also draws on his extensive knowledge of many unpublished archeological studies conducted over the years.

Hughes begins his regional summary with the Early Archaic period and does not delve into Paleoindian archeology in the Texas High Plains. However, it is notable that Paleoindian research in this region has progressed much in some areas but very little in others. Intensive geoarcheologial work at many sites, such as Lubbock Lake (E. Johnson 1987), Lake Theo (Harrison and Killen 1978), and Rex Rodgers (Willey et al. 1978a), has significantly refined the late Pleistocene paleoclimatic reconstruction and chronological sequence of various Paleoindian traditions. These studies have also produced 
much evidence concerning Paleoindian hunting practices (e.g., projectile point technology, hunting and butchering techniques, and seasonality of kills), but precious little data on other aspects of their lives have come from sites in the Texas Panhandle-Plains. This crucial data gap is not related to limited or inadequate archeological research since archeologists have searched diligently for such evidence. Rather, it seems to be related to constraints imposed by the sparse nature of the Paleoindian archeological remains, the regional geomorphic history and the paucity of late Pleistocene-age deposits, and the difficulty in identifying nonhunting-related sites and extracting meaningful data from them. Another important avenue of North American Paleoindian research is the "early man" debate, which is alive and well, but the controversy has now shifted to a "how early is early man" debate (i.e., pre-Clovis). Like Hughes, this author has no comment on this issue.

The Early Archaic Substage (5000 to 2000 B.C.) described by Hughes is characterized by a paucity of substantive archeological data and the interpretation that human populations were quite low during this time in response to severe aridity, i.e., the Altithermal drought period. Hughes (1991:19) suggests that "even the sheltered, spring-fed canyons along the Caprock escarpment and in the Canadian breaks across the Panhandle Plains were only lightly occupied." While this statement is generally true, recent geomorphic evidence suggests that this perception may be enhanced by a serious erosional bias in the Caprock Canyonlands (see Chapter 8). In addition, recent evidence brings into question Hughes's (1991:19) contention that gouges are primarily diagnostic of the Early Archaic Substage (see Chapter 10).

Hughes's culture history of the subsequent periods (i.e., the Late Archaic, Early Neoindian, and Late Neoindian Substages) is substantially more robust because the archeological evidence for these periods is significantly better. These discussions are quite enlightening, and many of the ideas elaborated upon later in this synthesis (see Chapters 9-12) were originally proposed by Hughes.

The most recent regional overview is "Archeology and Late Quaternary Environments on the Southern High Plains" by Johnson and Holliday (1995). This short synthesis links major changes in cultural adaptations to changing paleoenvironmental conditions from late Pleistocene to modern times.
Their study is particularly good for the Paleoindian and Archaic periods and even includes a brief discussion of the "Pre-Clovis Period."

Without doubt, the regional overviews by Krieger (1946), Collins (1971), Hughes (1991), and Johnson and Holliday (1995) are the classic syntheses of Panhandle-Plains archeology and culture history. They are all notable for their broad interregional perspectives and because they identify many important methodological and theoretical research problems in Southern Plains archeology. Among the issues mentioned in these overviews are several major topics that are given considerable attention in later chapters and warrant mention here: (1) establishing chronology and defining the sequence of human adaptive strategies and cultural changes for the region; (2) reconstructing paleoenvironmental conditions and defining the relationships between paleoclimate, floral and faunal communities, and human adaptation through time; (3) defining the relationships between man and bison through time; (4) defining the extent and nature of the interaction between Southwestern Puebloan cultures and Southern Plains peoples; and (5) identifying ethnicity in the archeological record.

The brief regional overviews by Collins (1971) and Hughes (1991) both treat the entire Texas Panhandle-Plains as a single region, but they acknowledge that their study areas encompass a great deal of environmental and archeological variability. While these studies use the terms "Llano Estacado" and "Texas High Plains" for their respective study areas, the majority of the sites that they mention are actually in the Canadian River valley and in the Caprock Canyonlands. While this view is appropriate at one level of detail, it obscures many important observations regarding human behavior and adaptation. In order to advance our understanding of the relationships between man and the environment, however, we must look more closely at the archeological data with respect to environmental diversity. This culture history synthesis proposes that the archeological record of human adaptation in the Texas Panhandle-Plains does indeed reflect the environmental diversity described in Chapter 2.

\section{REGIONAL SURVEY DATA}

The first step in defining the gross archeological differences across the Panhandle-Plains is a review of the regional survey data. Although survey-level 
site data have limitations and should be used cautiously, many inferences regarding human behavior may be derived from them. Perhaps the most useful aspect of survey data is that they provide a basis for comparing the intensity of human occupations through time and space.

A thorough literature search revealed a wealth of data from many archeological surveys ${ }^{2}$ in the Panhandle-Plains region, as shown in Table 6 and Figure 13. With a few exceptions, all of the surveys listed are of areas that are over 200 acres in size and can be assigned to a specific ecological region, although some surveys (particularly pipelines) covered parts of two or more regions. The compatibility of the data resulting from the various surveys was assessed, and the discussions below concentrate on comparing data generated by intensive 100 percent pedestrian surveys. Many surveys listed in Table 6 were excluded from consideration because the data produced are not comparable for a variety of reasons. The primary problems in assessing data comparability are that (1) surveys vary considerably in the intensity of coverage, and reconnaissance level surveys are not at all comparable to intensive 100 percent pedestrian surveys; (2) smaller survey areas often cover a limited range of topographic settings and are generally not comparable to large surveys; and (3) survey methods used 40 or 50 years ago are generally not comparable to survey methods used within the past two decades. In addition, idiosyncrasies of individual surveys are often apparent, but it is difficult to determine their effects on the resulting data. For these reasons, all reconnaissance-level, incomplete (i.e., less than 100 percent), or nonintensive (i.e., less than adequate coverage) surveys were excluded, as were surveys that employed unusual site definitions or peculiar survey methodologies. Some surveys were excluded from consideration because the size of the survey area is not clearly stated or is ambiguous. With some exceptions, pipeline surveys were excluded because the size of the area surveyed (either for the entire pipeline or portions of the pipeline within specific regions) could not be determined. By eliminating the problematical cases and focusing on more or less comparable data sets, it is possible to be relatively confident that perceived differences between survey areas are likely to be

\footnotetext{
${ }^{2}$ Literature published through 1995 was reviewed, but some more-recent unpublished survey data are used.
}

culturally relevant rather than a function of methodological differences between surveys.

Once the survey data are compiled by subregions, the next step is to determine what factors, natural or cultural, are most likely to have caused significant differences in site densities between subregions. This analysis proceeds under the assumption that both natural and cultural factors had an effect. Among the potential natural factors are differential site preservation and site visibility.

In terms of site preservation, there does appear to be a geomorphic bias in that many early sites (i.e., Paleoindian and Early-Middle Archaic) may have been removed from the archeological record in specific alluvial settings in parts of the Caprock Canyonlands (e.g., the flushing of older alluvial deposits at Lake Alan Henry in the canyon-confined segments of the Double Mountain Fork of the Brazos River; see Chapter 6) and perhaps to some extent in the Rolling Plains. Notably, most large surveys in the Caprock Canyonlands and Rolling Plains subregions consist primarily of riverine areas where the effects of geomorphic bias would be greatest. This bias is taken into account below when considering the frequency of sites through time, but for the overall site database, its effects are probably limited.

In terms of the distribution of all sites in each subregion irrespective of their ages, natural processes that differentially obscure site visibility are not considered to have had a significant effect on the archeological record. All three subregions meet the following criteria on a more or less equal footing: (1) each subregion is dominated by upland settings where site visibility is excellent because cultural deposits are generally shallowly buried and erosion is the dominant process; (2) each subregion has only limited areas (e.g., in alluvial valleys and in dune fields) where continuous or recent aggradation of sediments may obscure sites, and even in these areas erosional exposures are common and site visibility is generally good; and (3) in addition to natural erosion, modern agricultural disturbances and other manmade exposures (e.g., road cuts and pipelines) further enhance site visibility. Consequently, surface survey is adequate for locating the majority of the archeological sites that exist in most parts of the Llano Estacado, Caprock Canyonlands, and Rolling Plains.

Having made these assumptions explicit and weeded out the incompatible data sets, the remainder 
TABLE 6

\section{ARCHEOLOGICAL SURVEYS IN THE TEXAS PANHANDLE-PLAINS} AND SURROUNDING AREAS

\begin{tabular}{|c|c|c|}
\hline $\begin{array}{l}\text { Key to } \\
\text { Figure } 13\end{array}$ & \multicolumn{2}{|c|}{ CAPROCK CANYONLANDS } \\
\hline $\mathrm{C} 1$ & Caprock Canyons State Park & Etchieson et al. 1977; Bagot and Hughes 1979 \\
\hline $\mathrm{C} 2$ & Champion Creek Reservoir & Tunnell 1960 \\
\hline $\mathrm{C} 3$ & Colorado City Reservoir (Lake J. B. Thomas) & Jelks 1952 \\
\hline $\mathrm{C} 4$ & $\begin{array}{l}\text { Greenbelt Reservoir (old location) (reconnaissance } \\
\text { survey) }\end{array}$ & Hughes 1959 \\
\hline $\mathrm{C} 5$ & Lake Alan Henry & this volume \\
\hline C6 & Lakeview Watershed (reconnaissance survey) & Hood and Hughes 1975 \\
\hline $\mathrm{C} 7$ & Lower Tule Canyon & Katz and Katz 1976 \\
\hline $\mathrm{C} 8$ & Mackenzie Reservoir & Malone 1970; Hughes and Willey 1978 \\
\hline $\mathrm{C} 9$ & Mitchell Reservoir & Lintz, Trierweiler et al. 1991 \\
\hline $\mathrm{C} 10$ & Mobile $\mathrm{CO}_{2}$ Pipeline (linear survey) & E. Johnson 1994 \\
\hline $\mathrm{C} 11$ & $\begin{array}{l}\text { Sand Creek Ranch (1993 Texas Archeological } \\
\text { Society Field School) }\end{array}$ & Litwinionck et al. 1997 \\
\hline $\mathrm{C} 12$ & Slaton Wastewater Facility & Jurgens 1981, 1982 \\
\hline $\mathrm{C} 13$ & SPAG-Justiceburg Reservoir (reconnaissance survey) & Campbell 1975a; Alexander 1982 \\
\hline $\mathrm{C} 14$ & SPAG-North Fork (reconnaissance survey) & Campbell 1975a \\
\hline $\mathrm{C} 15$ & SPS Transmission Line (linear survey) & Mires and Evaskovich 1992 \\
\hline $\mathrm{C} 16$ & Thurmond Ranch & Thurmond and Moore 1985; Thurmond 1991a \\
\hline \multirow[t]{2}{*}{$\mathrm{C} 17$} & White River Reservoir & Green $1962 \mathrm{a}$ \\
\hline & \multicolumn{2}{|c|}{ LLANO ESTACADO } \\
\hline L1 & $\begin{array}{l}\text { Amarillo Texas Department of Criminal Justice } \\
\text { (TDCJ) }\end{array}$ & Schroeder and Rader 1995b \\
\hline $\mathrm{L} 2$ & Bravo Pipeline (reconnaissance and linear surveys) & Wozniak 1983 \\
\hline L3 & Brownfield Landfill & Pope and Johnson 1993 \\
\hline L4 & Buffalo Lake National Wildlife Refuge & Creel 1980; Hays 1986 \\
\hline L5 & Canyon Lakes Project & Johnson and Stafford 1975 \\
\hline L6 & Caprock Electric Transmission Line (linear survey) & Staley and Evaskovich 1993 \\
\hline L7 & Central Basin $\mathrm{CO}_{2}$ Line (linear survey) & Hannus and Winham 1985a, 1985b \\
\hline L8 & Certain Tracts & Hughes 1982 \\
\hline L9 & Floydada Landfill & Johnson et al. 1993 \\
\hline $\mathrm{L} 10$ & EPNG Pipeline (linear survey) & Tucker and Montgomery 1992 \\
\hline L11 & $\begin{array}{l}\text { High Plains Ecology Project, Texas and } \\
\text { New Mexico (reconnaissance survey) }\end{array}$ & $\begin{array}{l}\text { Hester 1972; Wendorf } 1961 \text {; } \\
\text { Wendorf and Hester } 1975\end{array}$ \\
\hline $\mathrm{L} 12$ & Llano Estacado Draw Study & Kibler 1991, 1992 \\
\hline L13 & Lubbock Landfill & D. Brown 1993 \\
\hline L14 & Lubbock Lake Landmark & Johnson 1983, 1989 \\
\hline L15 & Lubbock TDCJ & Schroeder and Rader 1995a \\
\hline L16 & McAlister Park, Lubbock & Boldurian and Montgomery 1986 \\
\hline L17 & Melrose Air Force Range & Lintz et al. 1988 \\
\hline L18 & Mobile $\mathrm{CO}_{2}$ Pipeline (linear survey) & E. Johnson 1994 \\
\hline L19 & Plainview TDCJ & Schroeder and Rader 1995c \\
\hline $\mathrm{L} 20$ & Red Deer Creek Watershed & Hughes et al. 1977 \\
\hline L21 & Red Lake Dam & Quigg, Frederick, and Lintz 1993 \\
\hline L22 & $\begin{array}{l}\text { Reese Air Force Base (and Terry County } \\
\text { Auxiliary Airfield) }\end{array}$ & Johnson 1995 \\
\hline L23 & Running Water Draw & Guffee and Hughes 1974 \\
\hline L24 & Slaton Wastewater Facility & Fox 1985 \\
\hline L25 & SPAG-Blackwater Draw (reconnaissance survey) & Campbell $1975 \mathrm{a}$ \\
\hline
\end{tabular}




\begin{tabular}{|c|c|c|}
\hline \multicolumn{3}{|c|}{ Table 6, continued } \\
\hline $\begin{array}{l}\text { Key to } \\
\text { Figure } 13\end{array}$ & \multicolumn{2}{|c|}{ LLANO ESTACADO, continued } \\
\hline L26 & SPAG-Double Lakes (reconnaissance survey) & Campbell 1975a \\
\hline L27 & SPAG-Mound Lake (reconnaissance survey) & Campbell 1975a \\
\hline L28 & SPS Tolk Transmission Line (linear survey) & Montgomery 1990 \\
\hline \multirow[t]{2}{*}{ L29 } & U.S. Department of Energy, Pantex Plant & Hughes and Speer 1981; Largent 1995 \\
\hline & \multicolumn{2}{|c|}{ ROLLING PLAINS } \\
\hline R1 & Brazos Salt Pollution & Thurmond et al. 1981 \\
\hline $\mathrm{R} 2$ & Crowell Reservoir & Hughes 1972; Etchieson et al. 1979 \\
\hline R3 & Elm Creek Channelization & Cliff et al. 1991 \\
\hline R4 & Elm Fork of Red River & Northcutt 1979 \\
\hline R5 & Mangum Reservoir & Wyckoff 1963 \\
\hline R6 & Miller Creek Reservoir & Malone and Briggs 1970 \\
\hline R7 & Quartermaster Creek & Moore 1984,1988 \\
\hline R8 & $\begin{array}{l}\text { Salt Creek II Substation/Transmission Line (linear } \\
\text { survey) }\end{array}$ & Brown and Anthony 1992 \\
\hline R9 & South Bend Reservoir* & Saunders et al. 1992 \\
\hline R10 & Truscott Reservoir & Hughes 1972; Etchieson et al. 1978 \\
\hline R11 & Upper Clear Fork (reconnaissance survey) & Wulfkuhle 1986 \\
\hline \multirow[t]{2}{*}{$\mathrm{R} 12$} & Upper Red River Drainge (reconnaissance survey) & Hughes 1973 \\
\hline & \multicolumn{2}{|c|}{ WEST-CENTRAL TEXAS } \\
\hline W1 & Ballinger Reservoir & Guffee 1989 \\
\hline W2 & Elm Creek Watershed & Lynott 1979a \\
\hline W3 & Hords Creek Reservoir & Stephenson 1950 \\
\hline W4 & Lake O. H. Ivey (Stacy Reservoir) & Wooldridge 1981; Bailey et al. 1989 \\
\hline W5 & Lake O. H. Ivey Pipeline (linear survey) & Treece et al. 1992 \\
\hline W6 & Middle Concho & Hurt 1980 \\
\hline W7 & North Concho & Douthit 1978 \\
\hline W8 & Northwest Laterals & Baxter and Shafer 1974 \\
\hline w9 & Oak Creek Reservoir & Jelks and Moorman 1953 \\
\hline W10 & Robert Lee Reservoir & Shafer 1967 \\
\hline W11 & San Angelo Reservoir (Lake O. C. Fisher) & Stephenson 1949 \\
\hline W12 & South Concho River & Creel 1978 \\
\hline W13 & Southwest Laterals & Prewitt and Filson 1978 \\
\hline W14 & Twin Buttes Reservoir & Willis 1958; Etchieson 1985 \\
\hline \multicolumn{3}{|c|}{$\begin{array}{l}\text { Note: The following recent survey reports were not available at the time this table was compiled, and no data } \\
\text { from these surveys are used in this chapter. }\end{array}$} \\
\hline \multicolumn{3}{|c|}{$\begin{array}{l}\text { For the Llano Estacado: Largent and Winchell (1995a, 1995b) present results of surveys of } 500 \text { acres (in 1993) } \\
\text { and 4,200 acres (in 1994) at the U.S. Department of Energy Pantex Plant in Carson County. }\end{array}$} \\
\hline \multicolumn{3}{|c|}{$\begin{array}{l}\text { For the Rolling Plains: Beene (1995) presents results of a } 1994 \text { survey of } 7,470 \text { acres in Childress County as part } \\
\text { of the Red River Chloride Control Project; and Briscoe and Perttula (1997) present results of a } 1994 \text { survey of } \\
\text { the } 1,933 \text { acres within the Copper Breaks State Park in Hardeman County. }\end{array}$} \\
\hline \multicolumn{3}{|c|}{ *South Bend Reservoir is located along the margin of the Lower Plains/Cross Timbers regions. } \\
\hline
\end{tabular}




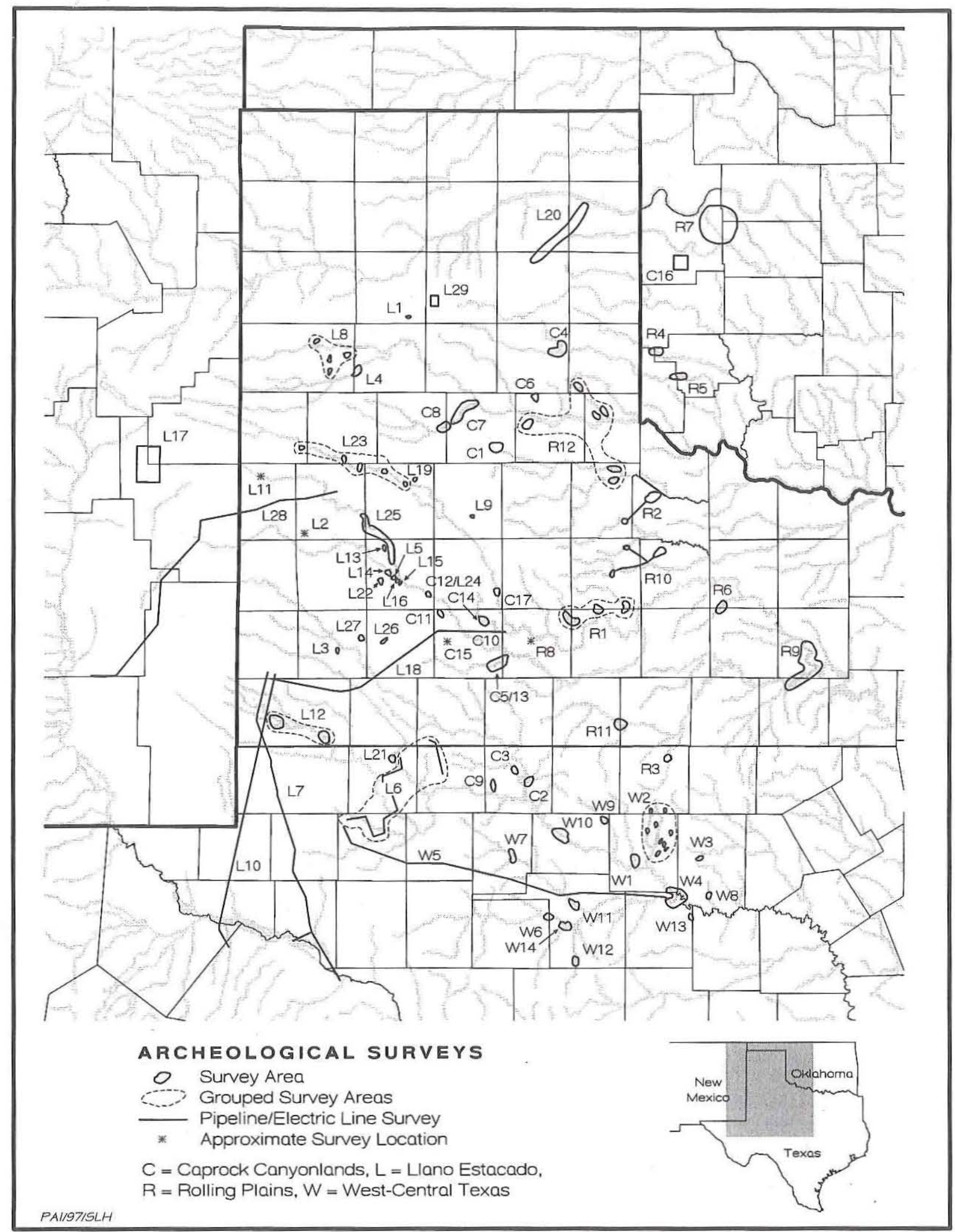

Figure 13. Map of archeological survey areas in the Llano Estacado, Caprock Canyonlands, Rolling Plains, and west-central Texas regions (see Table 6 for survey project identifications and references). 
of the regional survey data are useful for comparing Native American site densities within and between subregions (Table 7 and Figure 14). Site density (one site per $\mathrm{x}$-number of acres) is used here as a gross measure of the relative intensity of human utilization of the landscape. While such a measure could be greatly refined by taking additional factors, including site size, site function, and artifact density, into account, these data are not easy to synthesize nor are they comparable from survey to survey and across the landscape. Quite simply, the survey data are not sufficient to interpret important variables such as the number, lengths, and intensities of occupations at individual sites.

During the surveys at Lake Alan Henry, it was apparent that the site density was rather high. When all of the surveys are combined, the 11,280-acre project area contains 324 Native American occupational and rock art sites, for a density of one site per 35 acres. Even when the rock art sites are excluded, the 290 occupational sites occur at a density of one site per 39 acres. When all of the data for eight large Caprock Canyonland surveys are compared, a fair degree of consistency in site density is evident. Individual canyonland surveys range from one site per 15 acres to one site per 56 acres and average 28 . The data clearly show that the Caprock Canyonlands has a much higher site density than the other regions. This does not mean that site density is equally high across all of the Caprock Canyonlands, and undoubtedly many areas have fewer sites. Some diversity in site density is expected on a microscale, but it is likely that this sample is representative of the entire subregion. If this is true, then the site density across any large portion of the canyonlands should be as high or higher than the site density in any comparable-sized area in the Southern Plains.

In contrast, the Llano Estacado survey data range considerably, with draw localities averaging one site per 46 acres and uplands averaging one site per 289 acres. As might be expected, the spring-fed Lubbock Lake locality has the highest site dentity of all the Llano draw areas at one site per 18 acres. It should be noted, however, that these data may be slightly biased and probably overrepresent the actual site density because the intensive survey coverage and site definitions used at Lubbock Lake are not comparable to the methods employed for most other surveys. The average site density for the Llano draws, excluding Lubbock Lake, is perhaps more representative at one site per 63 acres.

Not surprisingly, surveys on the Llano Estacado uplands (i.e., generally flat areas away from draws that may or may not include small playas or very small drainages within them) indicate a very low site density, ranging from one site per 121 acres to one site per 800 acres. Some Llano uplands, such as the 640-acre Plainview TDCJ Facility, are virtually devoid of sites, and the same is undoubtedly true across much of the Llano Estacado. The results of two surveys of different parts of the Slaton Wastewater Facility in Lubbock County show very different site densities. Jurgens $(1981,1982)$ found six sites in 79 acres in Yellowhouse Canyon, for a density of one site per 13 acres. A subsequent survey of 320 acres of nearby Llano uplands (including a small playa) recorded only one site, for a density of one site per 320 acres.

The survey data for the Melrose Air Force Range in Curry and Roosevelt Counties, New Mexico (Lintz et al. 1988:Tables 12.4, 12.10, and 12.11), also illustrate the differences in the site density between the Llano upland and adjacent topographic areas. The entire survey covered 9,940 acres in a representative sample of various topographic settings within the 77,120 -acre range. The range straddles the Mescalero Escarpment along the western edge of the Llano Estacado, extends down into the relict (Pleistocene) Portales Valley, and encompasses considerable topographic variability. The only large section of true Llano uplands is an 800 -acre mesa top (an isolated remnant of the High Plains) where only one site was found. An equally low density of one site per 825 acres was documented for the "gentle slope" areas that comprise 58 percent of the survey area. In contrast, nearby areas of greater relief had much higher densities. The "steep slope" zone had one site per 96 acres, the "playa" zone had one site per 93 acres, and the "arroyo" zone had one site per 56 acres.

The paucity of systematic survey data for most of the Llano Estacado is noteworthy. Nonsystematic surveys indicate that sites may be found adjacent to small playas (e.g., Brown 1985) and that a high site density and multiple component occupations may be found around large pluvial lakes in the southern Llano (e.g., Alvey 1978; Breeding 1971; Collins 1968; Lee 1978). A high site density also may be expected in sand hills adjacent to draws (Pearce 1936): While it is true that the site density will be relatively low across most of the region, the potential 
TABLE 7

COMPARISON OF NATIVE AMERICAN SITE DENSITY FOR SELECTED SURVEY PROJECTS

\begin{tabular}{|c|c|c|c|}
\hline Survey & $\begin{array}{l}\text { Survey Area } \\
\text { Acreage }\end{array}$ & $\begin{array}{l}\text { No. of } \\
\text { Sites }\end{array}$ & $\begin{array}{l}\text { Site } \\
\text { Density }^{1}\end{array}$ \\
\hline \multicolumn{4}{|c|}{ CAPROCK CANYONLANDS } \\
\hline Caprock Canyons State Park (Etchieson et al. 1977) & 1,920 & 132 & 15 \\
\hline Caprock Canyons State Park (Bagot and Hughes 1979) & 3,573 & 144 & 25 \\
\hline Lake Alan Henry & 11,280 & 324 & 35 \\
\hline Mackenzie Reservoir & 1,144 & 73 & 16 \\
\hline Mitchell Reservoir & 1,889 & 34 & 56 \\
\hline Sand Creek Ranch & 1,320 & 50 & 26 \\
\hline Slaton Wastewater Facility (canyon area only, Jurgens 1981, 1982) & 79 & 6 & 13 \\
\hline Thurmond Ranch ${ }^{2}$ & 1,674 & 40 & 42 \\
\hline TOTALS: & 22,879 & 803 & 28 \\
\hline \multicolumn{4}{|c|}{ LLANO ESTACADO DRAWS } \\
\hline Canyon Lakes Project & 649 & 7 & 93 \\
\hline Llano Estacado Draw Study & 1,850 & 33 & 56 \\
\hline Lubbock Lake Landmark & 307 & 17 & 18 \\
\hline Sulphur Springs Draw & 1,080 & 27 & 40 \\
\hline TOTALS: & 3,886 & 84 & 46 \\
\hline \multicolumn{4}{|c|}{ LLANO ESTACADO UPLANDS } \\
\hline Amarillo Texas Department of Criminal Justice (TDCJ) Facility & 640 & 3 & 213 \\
\hline Brownfield Landfill & 140 & 1 & 140 \\
\hline EPNG Pipeline (Llano area only - acreage estimated) & 728 & 6 & 121 \\
\hline Lubbock Landfill & 220 & 1 & 220 \\
\hline Lubbock TDCJ Facility & 1,300 & 7 & 186 \\
\hline McAlister Park, Lubbock & 280 & 1 & 280 \\
\hline Melrose Air Force Range (Llano area only) & 800 & 1 & 800 \\
\hline Plainview TDCJ Facility & 640 & 0 & $640+$ \\
\hline Reese Air Force Base (and Terry County Auxiliary Airfield) & 2,950 & 4 & 738 \\
\hline Slaton Wastewater Facility (Llano area only, Fox 1985) & 320 & 1 & 320 \\
\hline SPS Tolk Transmission Line (Llano area only) & 1,729 & 6 & 288 \\
\hline U.S. Department of Energy, Pantex Plant & 2,400 & 11 & 218 \\
\hline TOTALS: & 12,147 & 42 & 289 \\
\hline \multicolumn{4}{|l|}{ ROLLING PLAINS } \\
\hline Brazos Salt Pollution & 4,004 & 39 & 103 \\
\hline Crowell Reservoir & 7,833 & 173 & 45 \\
\hline Elm Creek Channelization & 256 & 5 & 51 \\
\hline Elm Fork of Red River & 1,705 & 35 & 49 \\
\hline Miller Creek Reservoir & 3,400 & 21 & 162 \\
\hline Quartermaster Creek & 11,072 & 169 & 66 \\
\hline South Bend Reservoir ${ }^{3}$ & 37,500 & 586 & 64 \\
\hline Truscott Reservoir & 5,800 & 75 & 77 \\
\hline TOTALS: & 71,570 & 1,103 & 65 \\
\hline
\end{tabular}




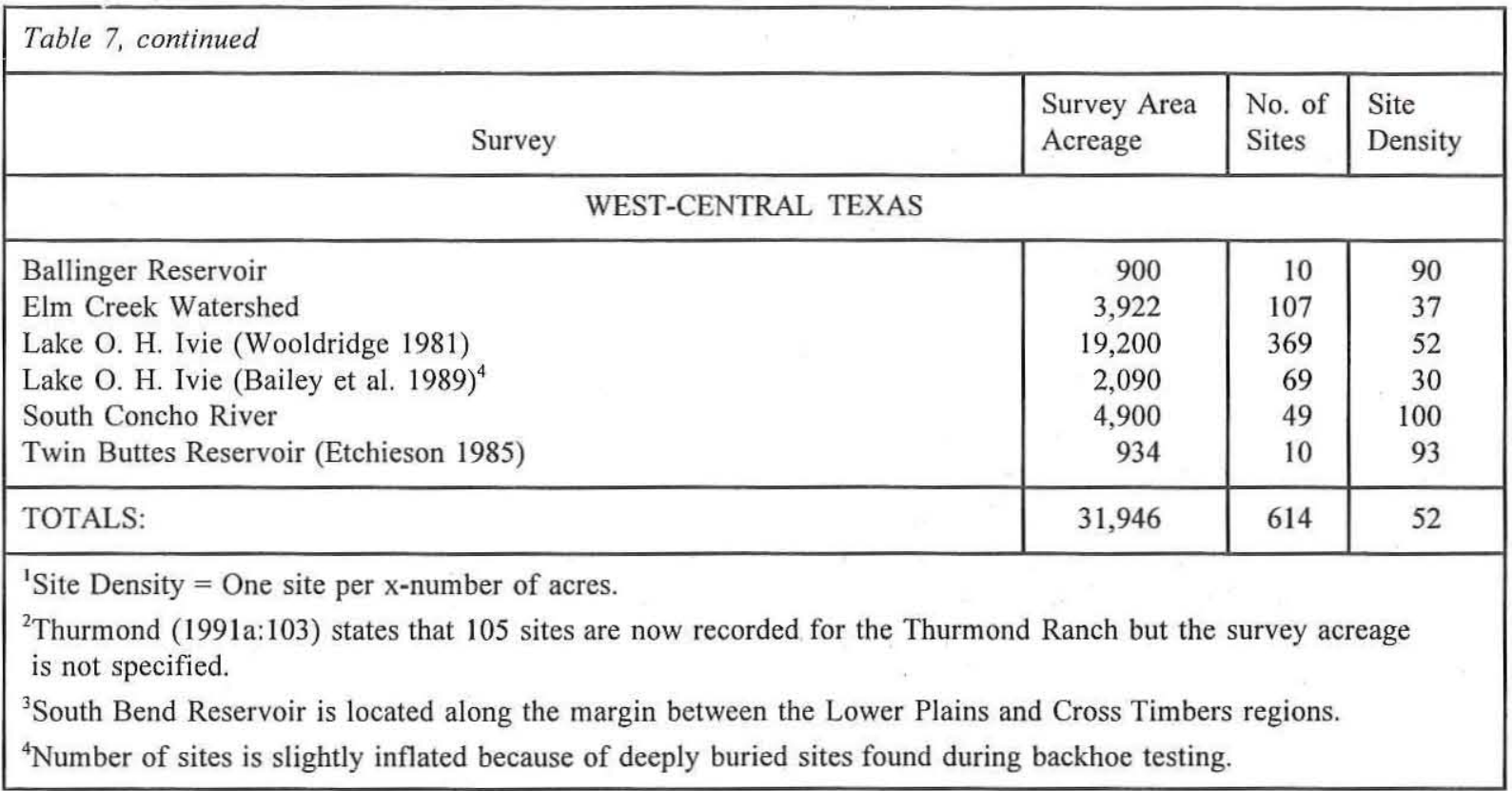

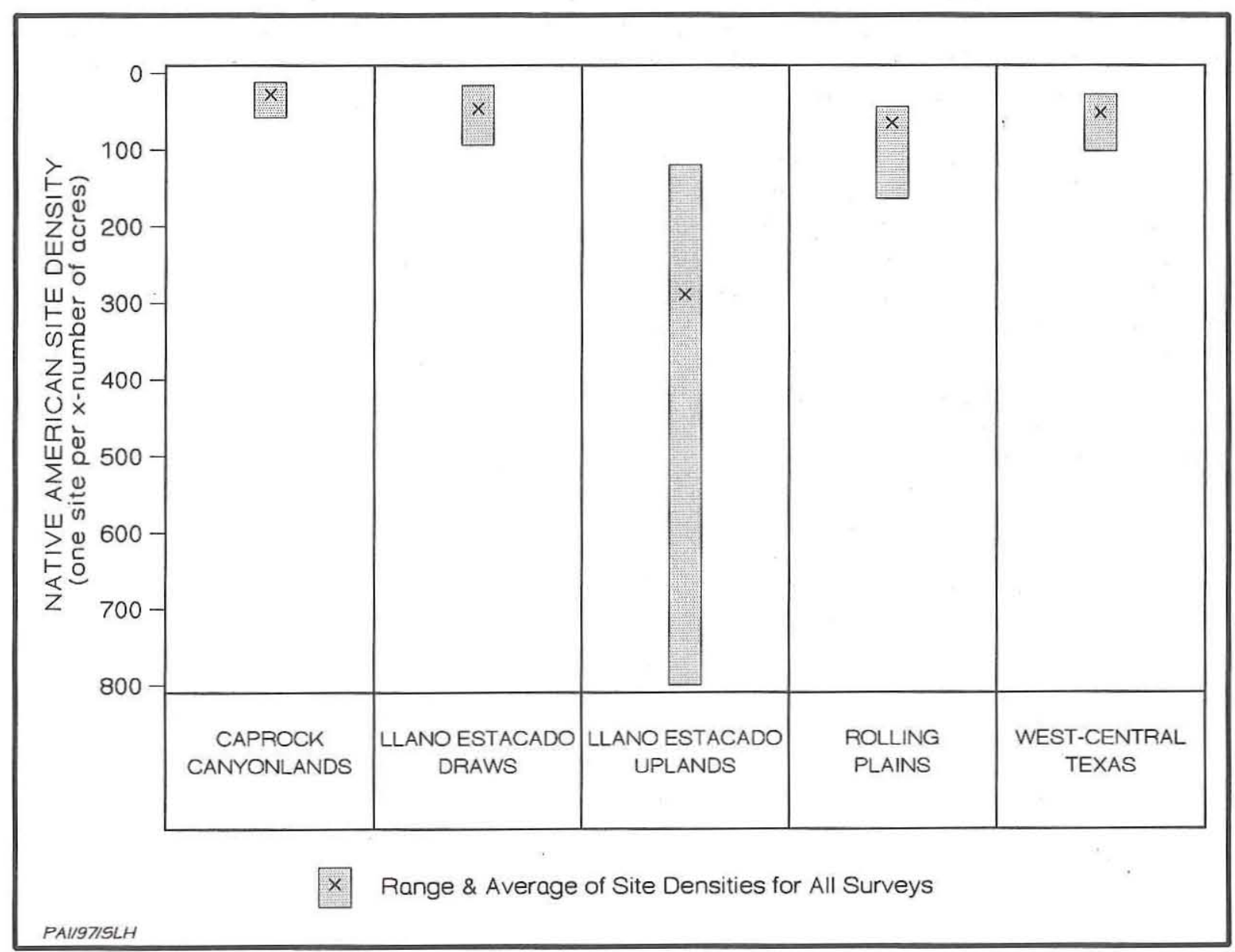

Figure 14. Comparison of Native American site densities by region. 
for archeological sites is relatively unknown for many critical areas on the Llano Estacado.

The Rolling Plains and west-central Texas regions are characterized by site densities that are considerably lower than in the Caprock Canyonlands. Surveys in the Rolling Plains show that densities range from one site per 45 acres to one site per 103 acres, with an average of 65 . A comparable density is evident even if the South Bend Reservoir data are excluded from the Rolling Plains region. Westcentral Texas surveys exhibit similar densities, ranging from one site per 30 acres to one site per 100 acres, with an average of 52. The similarity in densities between these two regions is intriguing and suggests that these topographically similar landscapes were utilized with a similar intensity by Native American groups.

From these data, it may be concluded that the Caprock Canyonlands region generally has a higher site density than the adjacent Llano Estacado and Rolling Plains. The data are interpreted as evidence that the canyonlands were occupied/utilized more intensively than were the adjacent areas. The only area of the Texas Panhandle-Plains that may have been utilized as intensively or more so is the Canadian River valley. Survey data for the Canadian River valley were not systematically reviewed and synthesized, but a high site density, perhaps comparable to or greater than that seen in the Caprock Canyonlands, might be expected given the similarities in the environments. Lintz (1986: 39-76) has argued that the Canadian River valley was intensively occupied by prehistoric human populations, both mobile hunter-gatherers and semisedentary agriculturalists, because of its unique environment and abundant resources.

Interregional variability also may be seen when the archeological survey data are compared using estimates of the age of prehistoric occupations or components represented at each site. Classifications of components into temporal groups by various researchers are often incompatible because of inconsistencies in how age assignments were made. For example, some researchers classified Marshall points into the Middle Archaic period while others classified them as Late Archaic. Some researchers classified sites as Archaic based only on the presence of Clear Fork gouges, while others did not. To avoid such discrepancies, a simpler method of identifying the temporal affiliation of prehistoric site components was used. For selected surveys, a
Paleoindian, Archaic, or Late Prehistoric component was assigned to each site that produced a Paleoindian, dart, or arrow point, respectively. The resulting data, shown in Table 8 , are gross, but they are much more comparable.

The temporal distribution of prehistoric site components, shown in Figure 15, indicates that there are significant differences between the regions. Fewer than 15 percent of the sites in the Caprock Canyonlands have produced diagnostic projectile points. This dearth of diagnostic projectile points appears to be due to cultural phenomena rather than natural ones. If geomorphic processes are responsible for destroying many Paleoindian and EarlyMiddle Archaic sites in the canyonlands, as is suggested in Chapter 8, this would account for the rarity of points dating to these time periods, but this scenario fails to explain why projectile points from later times also are relatively scarce. Instead, it is possible that the relative dearth of projectile points is related to land-use patterns or the manner in which the Caprock Canyonlands region was utilized by prehistoric peoples. As is disussed in subsequent chapters, the favored interpretation is that hunting activities were less intensive in the canyonlands relative to the surrounding regions. This interpretation seems to mesh with the settlement pattern models proposed for the Late Archaic through Protohistoric periods. The evidence does not indicate that hunting was never important to the late Holocene peoples who lived in the canyonlands. Rather, it indicates that hunting was of varying importance through time and that peoples living in the canyonlands may have conducted a significant portion of their hunting activities in adjacent regions, while activities in the canyonlands focused primarily on plant resources.

The age/component data for the Llano Estacado uplands are excluded because the site samples are too small, but the data for three Llano draw surveys are minimally interpretable. It has long been realized that certain draw localities have considerable potential for preserving Paleoindian remains. Kibler's (1991, 1992) systematic surveys along Seminole Draw provide the best quantifiable evidence, locating four Paleoindian sites but no Late Prehistoric occupations. However, the results from the other two draw surveys are quite different. In fact, the Buffalo Lake surveys identified no Paleoindian sites but revealed a high density of Late Prehistoric components (unfortunately, these surveys 
TABLE 8

SUMMARY OF PREHISTORIC COMPONENTS FOR SELECTED SURVEY AREAS USING DIAGNOSTIC ARTIFACTS

\begin{tabular}{|c|c|c|c|c|c|}
\hline \multirow[b]{2}{*}{ Survey } & \multicolumn{3}{|c|}{ Number of Sites Producing: } & \multirow{2}{*}{$\begin{array}{l}\text { No. of Sites } \\
\text { Producing } \\
\text { Pottery }\end{array}$} & \multirow{2}{*}{$\begin{array}{l}\text { Total No. } \\
\text { of Sites }\end{array}$} \\
\hline & Paleo Points & Dart Points & Arrow Points & & \\
\hline \multicolumn{6}{|c|}{ CAPROCK CANYONLANDS } \\
\hline $\begin{array}{l}\text { Caprock Canyons State Park } \\
\text { (Etchieson et al. 1977) }\end{array}$ & - & 11 & 9 & - & 132 \\
\hline $\begin{array}{c}\text { Caprock Canyons State Park } \\
\text { (Bagot and Hughes 1979) }\end{array}$ & - & 11 & 1 & - & 144 \\
\hline Lake Alan Henry & - & 24 & 16 & 5 & 324 \\
\hline Lower Tule Canyon & 1 & 6 & 4 & 3 & 46 \\
\hline Mackenzie Reservoir & - & 8 & 8 & 2 & 73 \\
\hline Mitchell Reservoir & - & 8 & 2 & - & 34 \\
\hline $\begin{array}{l}\text { TOTALS: } \\
\text { PERCENTS: }\end{array}$ & $\begin{array}{c}1 \\
0.1\end{array}$ & $\begin{array}{l}68 \\
9.0\end{array}$ & $\begin{array}{l}40 \\
5.3\end{array}$ & $\begin{array}{l}10 \\
1.3\end{array}$ & 753 \\
\hline \multicolumn{6}{|c|}{ LLANO ESTACADO DRAWS } \\
\hline Buffalo Lake National Wildlife Refuge & - & 5 & 7 & 2 & 23 \\
\hline Llano Estacado Draw Study & 4 & 2 & - & - & 33 \\
\hline Sulphur Springs Draw & 1 & 2 & - & - & 27 \\
\hline $\begin{array}{l}\text { TOTALS: } \\
\text { PERCENTS. }\end{array}$ & 5 & 9 & 7 & 2 & 83 \\
\hline \multirow{2}{*}{\multicolumn{6}{|c|}{ ROLLING PLAINS }} \\
\hline & & & & & \\
\hline Brazos Salt Pollution & - & 5 & 2 & - & 39 \\
\hline Crowell Reservoir & 3 & 38 & 5 & - & 173 \\
\hline Elm Fork of Red River & 1 & 6 & 2 & - & 35 \\
\hline Miller Creek Reservoir & - & - & 1 & - & 21 \\
\hline Truscott Reservoir & - & 20 & 6 & 1 & 75 \\
\hline Upper Clear Fork of Brazos & 5 & 13 & 7 & 2 & 33 \\
\hline $\begin{array}{l}\text { Upper Red River Drainage } \\
\text { (Hall County only) }\end{array}$ & - & 10 & 14 & 2 & 50 \\
\hline TOTALS: & 9 & 92 & 37 & 5 & 426 \\
\hline PERCENTS: & 2.1 & 21.6 & 8.7 & 1.2 & \\
\hline \multicolumn{6}{|c|}{ WEST-CENTRAL TEXAS } \\
\hline Lake O. H. Ivie (Wooldridge 1981) & 4 & 117 & 21 & 3 & 369 \\
\hline Lake O. H. Ivie (Bailey et al. 1989) & 3 & 32 & 2 & 1 & 69 \\
\hline Lake O. H. Ivey Pipeline & - & 1 & 1 & 1 & 20 \\
\hline Middle Concho & 1 & 23 & - & - & 48 \\
\hline North Concho & - & 8 & - & - & 61 \\
\hline Robert Lee Reservoir & - & 43 & 24 & - & 109 \\
\hline South Concho River & - & 11 & 3 & - & 49 \\
\hline TOTALS: & 8 & 235 & 51 & 5 & 725 \\
\hline PERCENTS: & 1.1 & 32.4 & 7.0 & 0.7 & \\
\hline
\end{tabular}




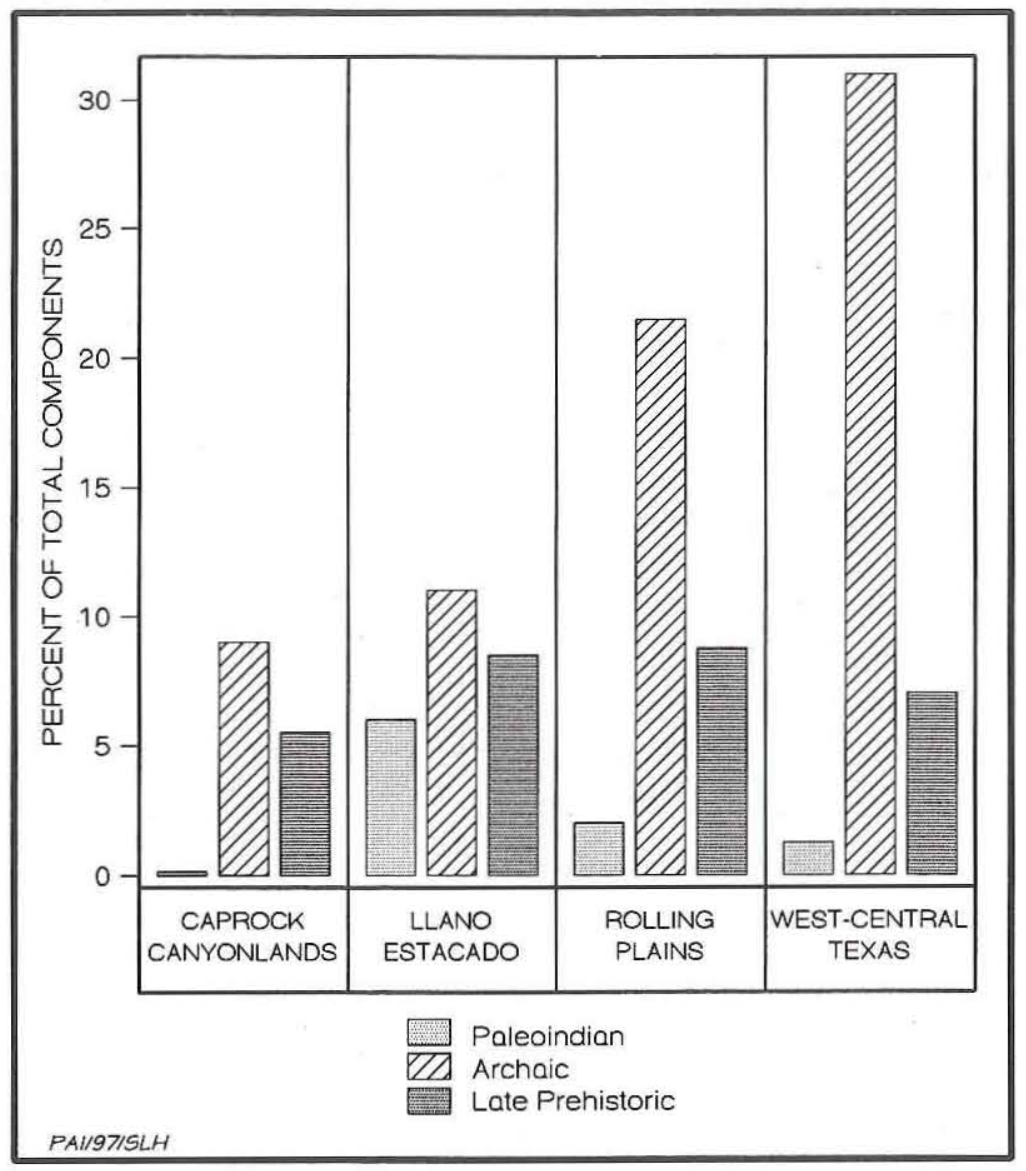

Figure 15. Temporal distribution of prehistoric site components by region (using data from Table 8).

were done many years after the lake was built, and any early sites in the valley bottom were not visible). From these data, it may be suggested that a great deal of variability in component age might be expected in different draw settings. Such variability is proposed by Kibler (1992:45), who suggests that sites on the Llano uplands are generally surficial or buried in dunes, while sites in the draws are generally buried by fluvial deposits that may or may not be exposed by erosion. While it is true that site density should be relatively low across most of the region, the potential for archeological sites is relatively unknown for many critical areas on the Llano Estacado. The bulk of the nonsystematic survey data indicate that most surface archeological materials on the Llano Estacado are Late Prehistoric in age (Alvey 1978; Breeding 1971; Brown 1985, n.d.; Collins 1968; Lee 1978; MacDowell 1986; Pearce 1936; Watts 1963). Many site occupations, particularly those in dune areas and around large pluvial lakes on the southern Llano, may date to Late Prehistoric II and/or Protohistoric times (see Chapter 11).

The Rolling Plains survey data are quite different from the Caprock Canyonlands data, and the higher frequency of Archaic components is particularly notable. This difference may be due, in part, to geomorphic conditions that scoured Early-Middle Archaic deposits out of many stream valleys in the Caprock Canyonlands. This explanation is not totally satisfactory, however, since many parts of the Rolling Plains are equally eroded. In addition, few Archaic sites are found in the Caprock Canyonlands even in the upland areas where the deposits are of the appropriate age. Not only are Archaic components more frequent in the Rolling Plains, but dart points are generally more abundant in these components as well (i.e., the Caprock Canyonlands averages 1.5 dart points per component; the Rolling Plains averages 2.4 dart points per component). It also is notable that Early-Middle Archaic dart points are not abundant in the Rolling Plains. The survey data alone are difficult to decipher, but interpretations offered later (see Chapter 9) suggest that the abundance of late dart points in the Rolling Plains reflects a greater emphasis on hunting activities during Late Archaic times.

The archeological survey data for west-central Texas indicate that Paleoindian components are rare, Late Prehistoric components are common, and Archaic components are quite abundant. Relative to other regions, the extremely high frequency of Archaic components, with an average of 2.1 dart points per component, is obvious. The primary difference seems to be that Early and Middle Archaic dart points, while nearly absent from the Caprock Canyonlands and Rolling Plains, are well represented in west-central Texas. Many researchers have noted that early Holocene human populations seem to have been low in the Plains but may have 
been relatively high in central Texas, probably in response to the dry Altithermal conditions that were most severe in the Panhandle-Plains (e.g., Brown 1989:238; J. Hughes 1991:20; Prewitt 1985:224).

If the distribution of pottery-bearing components is viewed independent of the projectile point data (see Table 8), the frequency of ceramic site occurrence is 2.4 percent for the Llano Estacado draws, 1.3 percent for the Caprock Canyonlands, 0.7 percent for west-central Texas, and 0.2 percent for the Rolling Plains. The high frequency of pottery and arrow point components in Llano Estacado draws is notable, although the sample is again skewed by data from a single locality, the Buffalo Lake National Wildlife Refuge.

It is interesting that pottery-producing components are more frequent in the Caprock Canyonlands than in west-central Texas and the Rolling Plains. The frequency of arrow point components is the opposite, however, and the Caprock Canyonlands has the lowest frequency of arrow point components (see Figure 15). This phenomenon is not likely to be due to natural processes and probably relates to cultural activities. These differences are explained if, as suggested above, the frequency of arrow points in the Caprock Canyonlands underrepresents the actual number of Late Prehistoric components because hunting activities were more common in adjacent regions. The abundance of pottery-producing sites is further explained if the hypotheses that pottery- using peoples maintained residential bases in the Caprock Canyonlands during the Late Prehistoric and Protohistoric periods are correct (see Chapters 10 and 11).

In conclusion, the regional survey data support the contention that the Caprock Canyonlands should be viewed as an archeologically distinctive region. In terms of overall site density and temporal distribution of components, the data demonstrate that there is general consistency within regions but significant differences between regions. Some degree of variability is probably related to differences in natural processes at work in these subregions (i.e., differing geomorphic histories). More important, however, is the interpretation that a significant amount of the subregional variation in survey data reflects differences in cultural behavior through time and across space. It is proposed that the Caprock Canyonlands archeological record, even at the survey level, has characteristics that reflect distinctive human adaptations to the unique environment. The survey data indicate that the resourcerich Caprock Canyonlands environmental zone was intensively utilized by Native American peoples during late Holocene times. As is argued later, the perspective proposed in this culture history synthesis is that the Caprock Canyonlands may be viewed as a pivotal ecological zone that served as a home base for many different cultural groups who roamed throughout the Texas Panhandle-Plains. 



\section{ARCHIEOLOGICAL RESEARCH AT LAKE ALAN HENRY}

by Douglas K. Boyd and Steve A. Tomka

The most intensive archeological work over much of Texas has been done in connection with large federally funded or permitted water projects. The Panhandle-Plains is no exception. Except for the Lake Meredith area, Lake Alan Henry is the largest, most intensively investigated area in the Texas Panhandle-Plains. Lake Alan Henry has been the scene of numerous cultural resource investigations that have resulted in the compilation of a major archeological database for a small section of the Caprock Canyonlands.

\section{BRIEF HISTORY OF ARCHEOLOGICAL RESEARCH}

Archeological investigations in the Lake Alan Henry area have been conducted for nearly 50 years. In the 1950s, members of the South Plains Archeological Society (SPAS) began documenting and investigating sites throughout Garza County. Since that time, SPAS has continued investigating archeological sites in the area, although much of what has been done remains unpublished. Most of the SPAS work involved only survey and site recording, but more-intensive excavations have been done at several sites. Within the current Lake Alan Henry project area, SPAS did the first recording of the rock art at the Dorward Ranch site, at Reed Shelter, and at an unnamed site across the creek from Reed Shelter; SPAS members also excavated the shallow deposits inside Reed Shelter (Table 9).

Professional archeological investigations were not conducted until the 1970s when Justiceburg
Reservoir was in the early planning stage. The South Plains Association of Governments (SPAG) sponsored an initial archeological reconnaissance of several localities within its 15-county jurisdiction. One of the areas selected for study was the proposed reservoir near Justiceburg, Texas. Texas Tech University conducted several archeological reconnaissance surveys for SPAG in 1973-1974, including one of the proposed Justiceburg Reservoir. Their work produced a series of four reports and a Master's thesis (excluding briefprogress reports). The survey of Justiceburg Reservoir documented 145 sites in 11,000-acres but made only minimal recommendations for further work, e.g., only 1 site was recommended for testing.

Subsequent to the SPAG work, local landowners funded another archeological study at Justiceburg in an attempt to slow down or stop the development of the reservoir. They felt that the archeological resources were much more significant than SPAG had made them out to be and hired Grand River Consultants, Inc. (GRC), of Grand Junction, Colorado, to reevaluate a sample of the sites. This study concluded that the SPAG survey methods and resulting data were inadequate, that the entire reservoir area needed to be resurveyed, and that the importance of the archeological resources had been grossly underestimated. Although there was a hiatus of several years, Prewitt and Associates, Inc. (PAI), began its intensive cultural resources investigations at Justiceburg Reservoir as a direct result of the recommendations made by GRC. A detailed history of the investigations at Justiceburg Reservoir 
TABLE 9

PUBLISHED ARCHEOLOGICAL INVESTIGATIONS

IN THE LAKE ALAN HENRY PROJECT AREA

SOUTH PLAINS ARCHEOLOGICAL SOCIETY

\begin{tabular}{|c|c|}
\hline $\begin{array}{l}\text { Rock art recording at three sites } \\
\text { Rockshelter excavation } \\
\text { Documentation of bedrock mortars at various sites }\end{array}$ & $\begin{array}{l}\text { Riggs } 1965 \text { a } \\
\text { Riggs } 1966 \\
\text { Kirkpatrick } 1978\end{array}$ \\
\hline \multicolumn{2}{|c|}{ SOUTH PLAINS ASSOCIATION OF GOVERNMENTS } \\
\hline $\begin{array}{l}\text { Progress reports on reconnaissance surveys } \\
\text { Series of four reports on reconnaissance surveys } \\
\text { Master's thesis synthesizing SPAG results }\end{array}$ & $\begin{array}{l}\text { Campbell 1975a, 1976b; Judd } 1978 \\
\text { Campbell 1975b, 1977; Campbell and Judd 1977a, 1977b } \\
\text { Judd } 1977\end{array}$ \\
\hline \multicolumn{2}{|c|}{ GRAND RIVER CONSULTANTS } \\
\hline Reevaluation and rerecording of selected sites & Alexander 1982 \\
\hline \multicolumn{2}{|c|}{ PREWITT AND ASSOCIATES } \\
\hline $\begin{array}{l}\text { Comprehensive survey of proposed reservoir area } \\
\text { Testing and evaluation of selected prehistoric, } \\
\text { rock art, and historic sites } \\
\text { Survey of Wildlife Mitigation Lands } \\
\text { Season } 1 \text { Data recovery and South Sage Creek survey } \\
\text { Season } 2 \text { Data recovery } \\
\text { Season } 3 \text { Data recovery }\end{array}$ & $\begin{array}{l}\text { Boyd et al. } 1989 \\
\text { Boyd et al. } 1990 \text {; Freeman and Boyd } 1990 \\
\text { Boyd et al. } 1991 \\
\text { Boyd et al. } 1992 \\
\text { Boyd et al. } 1993 \\
\text { Boyd et al. } 1994\end{array}$ \\
\hline
\end{tabular}

conducted prior to 1987 is presented by Boyd et al. (1989:30-34).

The PAI investigations consisted of six separate field projects from 1987 to 1992 and resulted in seven reports of investigations (nine volumes). All phases of work were funded and supported by the City of Lubbock, Texas, and done in consultation with the Fort Worth engineering firm of Freese and Nichols, Inc., the Fort Worth District of the U.S. Army Corps of Engineers, and the Texas State Historic Preservation Officer. This work was done in compliance with Section 106 of the National Historic Preservation Act and under permits issued under the Antiquities Code of Texas. The Phase I survey covered ca. 8,600 acres in and around the proposed reservoir in 1987. Because most of the SPAG data and site records had been lost and most of their site locations could not be correlated with any archeological remains, the PAI survey started over from scratch. The entire area was covered intensively, and 330 sites were documented. Most of the sites $(n=238)$ were considered likely to be eligible for inclusion in the National Register of Historic Places.
Phase II evaluation of selected sites was done in 1988. Various levels of testing and documentation were conducted at 67 sites. A prehistoric research design and two historic contexts also were developed to provide a framework for evaluating sites. Based on these contextual models, it was recommended that 17 prehistoric and rock art sites and 7 historic sites be considered eligible for inclusion in the National Register of Historic Places.

An additional 2,240 acres were added to the project area when the City of Lubbock purchased over three sections of land north of the proposed dam location to offset the destruction of wildlife habitat in the reservoir area. These wildlife mitigation lands were surveyed in 1990.

In conjunction with the Section 106 process, the City of Lubbock entered into a Programmatic Agreement with the Corps of Engineers and the State Historic Preservation Officer in 1990. This agreement stipulated how the National. Registereligible historic properties (i.e., cultural resources) were to be treated and initiated the archeological data recovery. Season 1 data recovery, in 1990, included investigations at one Euro-American and 
three Native American sites located in the immediate construction zone. By this time, the City of Lubbock had acquired a small tract located outside the reservoir pool and immediately downstream from the emergency spillway. The Season 1 investigations also included an archeological survey of this 440-acre South Sage Creek tract, bringing the total area surveyed to 11,280 .

Season 2 data recovery, in 1991, concentrated on two Protohistoric Native American sites in the proposed reservoir pool. By this time, the construction of the dam and related facilities had begun, and monitoring of borrow area disturbances was incorporated into the Season 2 investigations. Two new sites were added to the database.

Season 3 data recovery in 1992 consisted of investigations of four Native American sites located in the proposed Sam Wahl Recreation Area and one Euro-American site located in the upper part of the proposed reservoir pool. In addition, one important rock art site in the project area was discovered and documented at the end of Season 3.

Each of the three field seasons of data recovery involved a wide range of multidisciplinary studies and generated a separate report. The data recovery program also called for a comprehensive analysis and synthesis of Lake Alan Henry and regional archeological data. The synthetic analysis began immediately following completion of the report on the Season 3 investigations. This volume is the result of that study. A Cultural Resources Management Plan for Lake Alan Henry also was prepared but is not yet published.

\section{INVENTORY OF ARCHEOLOGICAL RESOURCES}

The archeological site inventory for Lake Alan Henry (see Appendix A) consists of 380 sites that are documented within the 11,280-acre project area in Garza and Kent Counties. These sites account for 45 percent of the total sites currently recorded for these two counties (674 in Garza and 164 in Kent), according to records at the Texas Archeological Research Laboratory as of March 1995. In contrast, the Lake Alan Henry project area accounts for less than 1 percent of the $1,148,160$ acres encompassed by these two counties.

The 380 sites at Lake Alan Henry are classified based on whether they contain archeological remains attributed to Native Americans (i.e., prehistoric or protohistoric sites) or Euro-Americans (i.e., historic sites), whether or not they contain rock art (images made by Euro- and/or Native Americans), or whether they contain a combination of archeological remains and rock art (Table 10). These classifications are used throughout this report.

\begin{tabular}{|c|c|}
\hline \multicolumn{2}{|c|}{$\begin{array}{l}\text { TABLE } 10 \\
\text { SUMMARY OF ARCHEOLOGICAL SITE } \\
\text { INVENTORY FOR LAKE ALAN HENRY }\end{array}$} \\
\hline Site Classes & No. of Sites \\
\hline $\begin{array}{l}\text { Native American } \\
\text { Euro-American } \\
\text { Rock Art } \\
\text { Native American/Euro-American } \\
\text { Native American/Rock Art }\end{array}$ & $\begin{array}{c}273 * \\
19 \\
71 \\
13 \\
4\end{array}$ \\
\hline Total: & 380 \\
\hline \multicolumn{2}{|c|}{$\begin{array}{l}\text { *Excludes } 45 \text { isolated finds that are designated } \\
\text { as sites. }\end{array}$} \\
\hline
\end{tabular}

Archival records and site history research was done for almost all of the 32 sites containing evidence of Euro-American occupation/use, but only 2 of these sites were tested and also subjected to archeological data recovery (see Chapter 5). Of the 290 sites containing evidence of Native American occupation/use, 53 were tested at varying levels of intensity (with at least one backhoe trench or handexcavated unit), but only 11 of these were further investigated during data recovery (see Chapter 6). In addition, detailed recording (beyond survey level documentation) of rock art was done at 12 of the 34 sites containing Native American images (see Chapter 6).

\section{NATIVE AMERICAN SITES RESEARCH CONTEXT}

In conjunction with the Phase II investigations at Lake Alan Henry, a detailed research design was developed to provide the necessary foundation for assessing the significance and National Register eligibility of prehistoric sites. This prehistoric context, called "A Model of Late Holocene Human Adaptation for Justiceburg Reservoir" was developed primarily by Tomka (in Boyd and Tomka 1990). This model has been the primary tool for comparing and evaluating Native American sites in the project 
area, and it is an important tool for comparing archeological data on a regional basis.

\section{A Model of Late Holocene Human Adaptation}

The model by Boyd and Tomka (1990), based on work by Binford (1980), Kelly $(1980,1983)$, and Hayden $(1986,1987)$, proposed that human subsistence strategies and settlement patterns are controlled in large part by resource distribution. Human social groups exploit resources using some combination of two different resource acquisition patterns-as logistically oriented collectors or residentially mobile foragers. Collector strategies move the food to the people by using special task groups that bring resources back to more-permanent residential camps. In contrast, foragers move people to the resources through frequent residential camp moves. Using this premise, one of the immediate goals for each season of data recovery was to determine how individual sites fit within the collector-forager continuum.

As it was originally proposed, the model suggested that a single resource, bison, was the main factor conditioning the selection of subsistence strategies and land-use patterns. The model suggested that climatic changes caused bison populations to fluctuate through time and that it was the abundance or scarcity of bison that controlled human subsistence strategy selection. It was felt that bison constituted the only sufficiently stable bulk resource in the Lower Plains that feasibly could have been exploited by humans using a logistically oriented collector strategy. During times of bison abundance, such as proposed for the Late Archaic, Late Prehistoric II, and Protohistoric periods, human populations would have acted primarily as logistical collectors to exploit the bison. However, shifts to forageroriented strategies may have occurred in response to periodic bison scarcity as a result of seasonal herd migrations and/or to seasonal availability of other subsistence resources. Thus, Late Archaic, Late Prehistoric II, and Protohistoric period settlement systems may reflect a mix of collector and forager strategies. In prolonged times of bison scarcity, such as proposed for the Late Prehistoric I period, human populations would have operated primarily as foragers and exploited a wide range of less-abundant and less-dependable resources.

Although the model was first proposed only for the Lower Plains, it clearly is applicable for most of the Texas Panhandle-Plains, although it is inadequate for Plains Village agricultural groups such as the Antelope Creek phase. The model originaliy centered around defining the role of bison in determining human subsistence strategies and land-use patterns. Bison are still considered to have been a driving force behind human adaptation in the Panhandle-Plains, but it became apparent during the course of the Lake Alan Henry data recovery investigations that the picture was more complex. Two factors necessitated changes in the model. First, the Season 2 data recovery investigations revealed that the model was inadequate for dealing with Protohistoric sites and that it had to be refined to account for the acquisition of the horse and its impacts on the mobility of Protohistoric Native American peoples. Second, the Season 3 investigations revealed the likelihood that some prehistoric cultures may have subsisted primarily upon plant resources while occupying substantial residential base camps. Thus, the model had to be further refined to allow for the possibility that there were some plant resources that were sufficiently abundant in the Caprock Canyonlands to allow bulk exploitation by humans using a logistically oriented collector strategy. It also became necessary to acknowledge the possibility that limited horticulture may have been incorporated into a logistical collector strategy.

Four major research topics pertinent to the model have been defined: settlement patterns, subsistence, site structure, and material culture. Within each of these topics, two general hypotheses dealing with regional archeological expectations are proposed. The first describes archeological expectations for sites generated under a collector-oriented strategy, and the second describes archeological expectations for sites generated under a forageroriented strategy. The first set of research topics proposes archeological hypotheses relating to prehistoric periods, while the second set proposes hypotheses relating to the Protohistoric Period.

\section{Prehistoric Archeological Expectations}

\section{Settlement Patterns}

\section{COLLECTOR SYSTEMS}

Residential base camps within collector systems may be either single-season camps oriented toward procurement and processing of bison, or multiseasonal 
base camps that were bison oriented on a seasonal basis but geared toward foraging for supplemental plant and animal resources during other parts of the year. In either case, lengthy site occupations and/or yearly reoccupations are likely, and low residential mobility and relatively high populations should be evident by site size, overall frequency of cultural materials and features, and intensity of site use. The presence of a relatively high percentage of nonlocal lithic materials and other exotic trade items may indicate large territory exploitation and participation in interregional exchange networks.

Logistically oriented collector systems may also include residential base camps that were season specific and oriented toward foraging for specific resources. Within the overall context of a collectordominated system, some residential base camps may have been solely foraging oriented and hence would appear no different archeologically than those described below.

\section{FORAGER SYSTEMS}

Residential base camps within an exclusively forager system should exhibit archeological evidence of highly mobile, relatively short term, seasonspecific occupations, although reoccupation on a seasonal basis is also likely. The sites served as base camps for daily foraging activities exploiting specific resource patches. It is possible that a single site may have been oriented toward a single resource, although it is more likely that multiple resources were exploited from a single base camp. Exclusive foragers exploited a relatively small overall territory that should be evident archeologically by low percentages of nonlocal lithic materials and few exotic trade items.

\section{Subsistence}

\section{COLLECTOR SYSTEMS}

Residential base camps that operated within a logistically oriented collector system will exhibit evidence of the bulk procurement, processing, and storage of bison, a high-yield, large-biomass resource. Exploitation of other plant and animal resources will also be evident in the flora and fauna recovered, especially at the residential sites occupied during seasons of relative bison scarcity. The overall faunal assemblages, however, will be domi- nated by bison and will be biased toward high-meatyield body parts (e.g., ribs, scapulas, and femurs) that were selectively transported from kill sites back to the camps. Food storage of bulk resources is characteristic of collector systems but is not likely to include storage pits at bison-oriented sites. Meat drying and/or salting for storage probably were important activities at bison-oriented collector sites but may be difficult to recognize archeologically (e.g., post molds indicating drying racks).

\section{FORAGER SYSTEMS}

Residential base camps generated by a forager system will exhibit evidence of exploitation of a diverse range of relatively low yield (small biomass) resources. Faunal assemblages will be diverse and may include deer, numerous small mammals such as rabbits and rodents, turtle, fish, etc. A low percentage of bison may be represented, but the overall faunal assemblage will not be dominated by any one resource. Macrobotanical and pollen remains will represent a diverse range of plant foods.

\section{Site Structure}

\section{COLLECTOR SYSTEMS}

Bison-oriented collector base camps will have well-defined site structure with spatially discrete activity areas and special-function features related to bison processing. Specific activity areas might include hide processing stations with evidence of unifacial scraping tool rejuvenation, tool manufacturing areas where the final stages of lithic reduction occurred, secondary butchering areas where selected cuts were further processed, bone grease manufacturing areas, and cooking areas where bison and/or other resources were prepared. Activity areas will be identifiable as high-frequency clusters of artifacts and/or faunal and floral remains. Horizontal patterning of activity areas may even provide evidence of community-level organization (i.e., habitation areas or structures). Due to the increased length of occupation, more-frequent site maintenance activities may have generated well-defined midden areas at these sites.

\section{FORAGER SYSTEMS}

Residential base camps generated within an 
exclusively forager system will be characterized by multifunctional and overlapping features and activity areas representing exploitation of a single resource or contemporaneous exploitation of multiple resources. Site reoccupation for exploiting different resources at different times is also likely. Although individual base camps may exhibit various degrees of specialization, overall these sites will appear unspecialized due to the similarities in the procurement and processing strategies and material culture for exploiting various low-yield plant and animal resources.

\section{Material Culture}

\section{COLLECTOR SYSTEMS}

Material culture assemblages at bison-oriented collector residential base camps will include specialized tools reflecting the importance of bison hunting (projectile points), meat processing (cutting tools such as beveled knives), and hide processing (scraping tools such as end scrapers). Manufacture and rejuvenation of these tools will be important activities represented in the lithic debitage and in staged preforms. It is expected that hide processing may be particularly well represented in campsites, and resharpening of unifacial hide-scraping tools should be evident. Lithic debitage should reflect a strategy of nonlocal material procurement and transportation of early-stage tools to base camps for the final stages of tool manufacture. Specifically, the debitage should exhibit a high percentage of nonlocal materials and a disproportionately high frequency of decorticate flakes.

\section{FORAGER SYSTEMS}

Forager residential base camps will be characterized by a generalized stone tool assemblage and dominance of local material use. Chipped stone tools will be dominated by multifunctional and expedient tools, i.e., various types of bifacial and unifacial cutting and/or scraping tools exhibiting considerable morphological variability. Lithic debitage will be dominated by local materials, and all stages of lithic manufacture will be evident by the presence of cores and complementary percentages of corticate and decorticate flakes.

\section{Protohistoric Archeological Expectations}

\section{Settlement Patterns}

\section{COLLECTOR SYSTEMS}

Although horses were introduced into the southwestern United States in 1541 (Newcomb 1961: 68 ), it is likely that a viable population of horses was not present on the South Plains until after A.D. 1598 following Oñate's initial settlement in New Mexico. Authors familiar with Southwestern ethnohistory (Bloom 1937; Kessell 1987; Worcester 1944) suggest that horses were a crucial part of Plains Apache lifeways by the mid 1600s.

The availability of horses during the Protohistoric period could have had at least three major impacts on the organization of logistical resource acquisition systems: (1) an increase in the size of the region available for exploitation; (2) greater hunting success; and (3) an increase in transport capacity. An increase in the size of the region accessible for exploitation may have led to an increase in the overall number of procurement/ processing locations and associated field camps generated in a particular region over a given hunting season. The use of horses (and possibly firearms) may have allowed and/or necessitated changes in hunting techniques (e.g., mounted surrounds vs. bison jumps) and may have significantly improved hunting efficiency. The increased size of the economically exploited region and the greater number of herd encounters may have further increased hunting success. In association with increased yields, the increased transportation capacity of bison hunting groups with horses vs. transportation solely by humans or dogs may have allowed increased seasonal sedentism at residential base camps. The acquisition of surplus bison products (e.g., hides, raw material for tools, and meat) may have allowed and motivated the maintenance of more-intensive and more-extensive interregional exchange networks.

In addition to these organizational changes, the keeping of horses may have conditioned the selection of site locations favoring settings that provided sufficient forage and water for the maintenance of herds. Similarly, as herd sizes increased, either through improved management or acquisition (e.g., raiding), the availability of horses may have contrib- 
uted to more frequent moves as forage was more rapidly depleted in the vicinity of residential campsites.

\section{FORAGER SYSTEMS}

Within year-round forager systems, or during periods of bison scarcity in mixed collector-forager systems, the availability of horses should have continued to provide the three advantages mentioned above. It is unlikely, however, that in the absence of other resources that could have been exploited in bulk, access to horses alone would have been sufficient to shift the operation of a foraging resource acquisition strategy into a collector mode. That is, increased yields due to larger areas exploited, greater hunting success, and increased transport capacity may have allowed the somewhat longer occupation of foraging base camps compared to pre-horse times. However, the overall system would have continued to operate in a foraging mode unless procurement activities geared toward the acquisition of a broad range of resources generated sufficient surplus (e.g., due to other technological innovations) to allow long-term storage.

\section{Subsistence}

\section{COLLECTOR SYSTEMS}

Even though the availability of horses might have increased transportation capacity during the Protohistoric period, the likelihood that many bison kills occurred at greater distances from residential base camps might have maintained high overall transportation costs. High transportation costs in turn might have required the relatively complete field processing of prey, resulting in the return of only selected high-meat-utility elements to residential base camps (Metcalfe and Barlow 1992). It is also likely that in contexts where kill locations were associated with nearby field camps and the hunting season lasted for a period of months, the majority of the resources (i.e., bison) returned to the residential base camps already would have been fully processed (e.g., pemmican) or stage processed (e.g., hides) and ready for storage. On the other hand, it is likely that less field processing may have occurred at kill locations found closer to residential base camps, and as a result, a greater range of animal parts may have been introduced to base camps. In summary, the availability of horses may not necessarily have increased the recognizability of residential base camps in a collector system. The evidence of bulk resource processing (e.g., large quantities of bones) may have been restricted to kill locations and field camps rather than residential base camps.

\section{FORAGER SYSTEMS}

Within year-round forager systems and during seasons of bison scarcity in mixed collector-forager systems, the availability of horses might have allowed foraging populations to concentrate more effectively on higher ranked resources (i.e., in terms of procurement vs. processing costs) such as medium-sized mammals (e.g., antelope and deer) rather than lower ranked small mammals (e.g., rabbits, etc.). As mentioned above, the availability of horses probably was not sufficient to allow a foraging system to operate in a collector mode. However, it may have allowed foraging groups a greater degree of dietary security by becoming more effective at exploiting larger prey rather than smaller, lower ranked resources. If the availability of horses provided this benefit to Protohistoric groups, then faunal assemblages derived from Protohistoric sites should contain a lower species diversity than assemblages belonging to pre-horse foragers (e.g., Late Prehistoric I). In addition, faunal assemblages from Protohistoric sites should have a greater proportion of higher ranked resources than assemblages derived from pre-horse foragers. Finally, because of the absence of bulk resources and the smaller number of individuals killed during any hunting episode, it is likely that a greater portion of medium-sized mammals procured by groups operating in a forager mode would have been returned to residential base camps compared to the pattern proposed among collectors. This could result in a residential base camp skeletal assemblage generated by foragers that is more visible archeologically than an assemblage generated by bulkprocessing collectors.

\section{Site Structure}

\section{COLLECTOR SYSTEMS}

As mentioned above, the availability of horses during the Protohistoric period may have had the effect of removing from residential base camps 
certain activities normally associated with the processing of bulk quantities of resources for storage. Because of distance, transportation, and scheduling constraints, activities such as sun-drying meat to produce pemmican may have occurred at kill locations and/or associated field camps rather than the residential base camps. The segregation of selected activities to specialized activity sites may have had the effect of reducing site structure complexity at collector residential base camps while contributing to increased site structure at locations and field camps. However, given that the processing of certain resources may have occurred in stages (e.g., hides may have been processed for temporary storage at field camps and final processing may have taken place at the residential camps), it is likely that some specialized activity areas (e.g., hide processing, smudge pits) may be evident at residential base camps established by collectors.

\section{FORAGER SYSTEMS}

It is not expected that the availability of horses alone would have significantly affected the structure of residential base camps generated by year-round foragers. The structure of residential base camps established during seasons of bison scarcity by groups operating in a seasonal mix of collecting and foraging should be similar to that of year-round forager residential camps.

\section{Material Culture}

\section{COLLECTOR SYSTEMS}

Perhaps the most readily evident changes during the Protohistoric period might have come in the composition of the material culture of groups inhabiting the Southern Plains. The availability of horses and the more-intensive participation in interregional exchange networks should have increased the proportions of nonlocal (i.e., extraregional and EuroAmerican) raw materials and finished goods present in Protohistoric artifact assemblages, and moreintensive participation in broader interregional exchange networks also may have resulted in an increase in the distances from which these materials and goods originated.

The influx of Euro-American goods made of more-durable materials (e.g., metal) and of tools that were more effective than their nativemade functional equivalents should have had an even more notable impact on the composition of tool assemblages. The replacement of chipped lithic arrow poirts and beveled knives with metal arrow points and knives may have resulted in a significant reduction in the manufacture and archeological occurrence of both of these lithic tool categories. The presence of firearms may have further decreased the reliance on native technology. The availability of metal pots and pans, axes, wedges, and hammers may have had similar effects on the numbers of ceramic vessels, cobble tools, and mano/hammerstones in Protohistoric artifact assemblages. It is likely, however, that the availability of Euro-American goods would have had less of an effect on the number of ground stone tools and unifacial scraping tools. This is suggested by a number of ethnoarcheological examples of the persistence of ground stone tool assemblages and the use of chipped lithic end scrapers among modern groups (Gallagher 1977; Hayden 1987; Webley 1990).

It is probable that during the early stages of access to Euro-American goods the extremely high replacement costs of these items, derived from their relative scarcity, would have made them highly curated. High curation rates in conjunction with relatively long use lives (especially compared to nativemade artifacts) would have reduced the frequency of Euro-American goods in archeological assemblages. As access to larger quantities of EuroAmerican goods improved (e.g., as supplies became more dependable) during the Protohistoric and early Historic periods, the proportion of Euro-American items in tool assemblages should have increased.

\section{FORAGER SYSTEMS}

Forager residential base camps will be characterized by a generalized stone tool assemblage and dominance of local material use. Chipped stone tools will be dominated by multifunctional and expedient tools, i.e., various types of bifacial and unifacial cutting and/or scraping tools exhibiting considerable morphological variability. Lithic debitage will be dominated by local materials, and all stages of lithic manufacture will be evident by the presence of cores and complementary percentages of corticate and decorticate flakes.

The availability of horses would have increased the participation of year-round and seasonal forager groups in interregional exchange networks, resulting 
in an increase in the proportions of nonlocal raw materials and finished goods in artifact assemblages. It is likely that artifact assemblages obtained from seasonal foraging groups may be indistinguishable from assemblages of the same group produced during the season when they were organized primarily as collectors. On the other hand, it is possible that, due to the relatively smaller size of the economically exploited region, the artifact assemblages of year-round foragers may contain smaller proportions of nonlocal raw materials, and the distances from which these extraregional materials were acquired may be smaller.

Although the availability of the horse may not have shifted a forager system into one operating in a collector mode, it is unclear whether improvements in technological efficiency and resulting increases in resource procurement could have led to a shift from foraging to collecting. It is likely, for instance, that increased hunting efficiency provided by firearms may have resulted in surplus yields, even in species (e.g., deer and antelope) that previously were not procured in bulk quantities. The availability of horses, in conjunction with this technological innovation, would have further increased the overall technological efficiency of foraging groups, leading perhaps to decreased residential mobility. While such a shift may have been possible late in the Protohistoric period, the unreliable supply of items and their overall low frequency may have mitigated against it during the early Protohistoric period.

\section{EURO-AMERICAN SITES RESEARCH CONTEXTS}

As part of the Phase II investigations at Lake Alan Henry, two comprehensive regional historic contexts were developed in consultation with the Texas Historical Commission. One of the historic contexts, "Buffalo Hunting on the Rolling Plains, 1874-1879" by Freeman (1990a), fell under the general theme of "Natural Resources Exploitation and Development." However, this context was applicable for only one of the historic sites in the project area. The second context developed by Freeman (1990b) is "Ranching on the Western Rolling Plains, 1877-1945" and falls under the general thematic context of "Agriculture in Texas." Since most of the other historic sites are related in some way to ranching, this context has been the primary tool for comparing and evaluating EuroAmerican sites at Lake Alan Henry. The development of these historic contexts and their use in historic archeological research in the Texas Panhandle-Plains are discussed in detail in Chapter 5.

\section{ROCK ART RESEARCH CONTEXT}

Native American' and Euro-American rock art cannot be compared and evaluated within the framework of the contexts described above. Images that are painted on or scratched into rock surfaces must be viewed under a different set of criteria than most archeological sites.

Historic Euro-American rock art is fundamentally no different from Native American rock art. The images are graphic representations which have specific meaning to the person who made them and are intended to convey a message to others in the artist's social group. The primary difference is that Euro-American rock art usually involves written messages in a language that is directly decipherable by modern archeologists. In most cases, the artist's intended meaning is clear and the functions of the images are understood within the context of the culture that produced it. No comprehensive research design for interpreting and evaluating historic EuroAmerican rock art has been developed, but these sites are discussed in Chapter 5.

Native American images, on the other hand, represent symbolism whose intended meaning has been lost or obscured through time and across cultures. Archeologists can only hope to make educated guesses about the societal function and intended meaning of most Native American rock art. This is done using the concept of style (i.e., by studying and defining stylistic variations characteristic of a particular people at a particular time) and through the use of ethnology and ethnographic analogies. No true research context has been developed for interpreting and evaluating Native American rock art in the Texas Panhandle-Plains. However, despite the fact that Native American rock art in the region is still poorly understood, the Lake Alan Henry finds have led to some initial attempts at synthesizing regional data and defining rock art styles (see Chapter 6). 
1 


\section{HISTORIC SITES INVESTIGATIONS AT LAKE ALAN HENRY AND IN THE TEXAS PANHANDLE-PLAINS}

by Martha Doty Freeman and Douglas K. Boyd

\section{INTRODUCTION}

The 1987 Phase I archeological survey of the then-proposed Justiceburg Reservoir documented 84 sites with historic components, of which 54 consisted only of historic rock art and 30 consisted of historic archeological and/or architectural remains (Boyd et al. 1989:Tables 19 and 38). In conjunction with the survey, archival research and informant interviews were used to construct a historical overview of the project area (Freeman 1989).

The 1988 Phase II historic sites investigations consisted of the recording of one previously unreported site (41KT150), archeological testing of three sites, and site-specific archival research for the three tested sites and one additional site (Freeman and Boyd 1990:99-114). In addition to the work done on these sites, a major focus of the testing phase work was the development of historic contexts. At the request of the Texas Historical Commission, Project Historian Martha Doty Freeman developed two historic contexts: "Buffalo Hunting on the Rolling Plains, 1874-1879," under the thematic heading of "Natural Resources Exploitation and Development"; and "Ranching on the Western Rolling Plains, 1877-1945," under the thematic heading of "Agriculture in Texas." Both of these historic contexts were utilized to evaluate selected historic sites in the project area and are summarized below.

In the summer of 1990 , a survey of the 2,400 acre tract of wildlife mitigation lands immediately north of the reservoir area recorded one additional ranching homestead (41GR586). During the three seasons of data recovery at Lake Alan Henry, intensive investigations at two historic sites were completed. The investigations at $41 \mathrm{GR} 474$ and $41 \mathrm{KT} 42$ provided a great deal of complementary archeological, archival, and informant information that was used to interpret the sites. Following the third and final season of data recovery work, historic Anglo inscriptions were recorded at a rock art site that was not discovered and documented until 1993 (41KT164). This brought the total number of sites with historic rock art components to 55 .

The three sections that follow accomplish several goals. The first section presents an inventory of historic sites and discusses the general nature of the sites. The next section describes the results of the intensive investigations at sites 41GR528, 41KT42, and 41GR474. The third section summarizes the status of historic sites archeology in the Panhandle-Plains within the framework of a brief regional historic overview, and it discusses the historic contexts developed for the project area and the Rolling Plains.

\section{INVENTORY OF HISTORIC SITES AT LAKE ALAN HENRY}

During the field investigations at Lake Alan Henry between 1987 and 1993, 87 sites with historic components were recorded. Of these, 32 sites are summarized in the Table 11 inventory, while the remaining 55 sites contain only Anglo-American rock art images and are listed in Table 12. 
TABLE 11

INVENTORY OF HISTORIC EURO-AMERICAN SITES AT LAKE ALAN HENRY (excluding rock art sites)

\begin{tabular}{|c|c|c|c|c|c|c|c|c|}
\hline \multirow[b]{2}{*}{ Site No. } & \multirow[b]{2}{*}{ Site Type } & \multirow[b]{2}{*}{ Visible Features } & \multirow[b]{2}{*}{$\begin{array}{l}\text { Historic } \\
\text { Context }\end{array}$} & \multicolumn{5}{|c|}{ Period of Occupation/Use } \\
\hline & & & & $\begin{array}{l}\text { Pre- } \\
1880\end{array}$ & $\begin{array}{l}1880- \\
1900\end{array}$ & $\begin{array}{l}1900- \\
1920\end{array}$ & $\begin{array}{l}\text { Post- } \\
1920\end{array}$ & $1900 \mathrm{~s}$ \\
\hline $41 \mathrm{GR} 13$ & $\begin{array}{l}\text { homestead/ } \\
\text { headquarters }\end{array}$ & house complex & ranching & & & $\mathrm{x}$ & $\mathrm{x}$ & \\
\hline $41 \mathrm{GR} 33$ & trash dump & artifact scatter only & unknown & & & & & $\mathrm{x}$ \\
\hline $41 \mathrm{GR} 203$ & housesite & rock house & $\begin{array}{l}\text { railroad } \\
\text { and town } \\
\text { development }\end{array}$ & & & $\mathrm{x}$ & $\mathrm{x}$ & \\
\hline $41 \mathrm{GR} 250$ & $\begin{array}{l}\text { homestead/ } \\
\text { headquarters }\end{array}$ & artifact scatter only & ranching & & & & $\mathrm{x}$ & \\
\hline $41 \mathrm{GR} 263$ & homestead & $\begin{array}{l}\text { dugout, house } \\
\text { foundation }\end{array}$ & ranching & & $\mathrm{x}$ & & & \\
\hline $41 \mathrm{GR} 273$ & trash dump & artifact scatter only & unknown & & & & & $\mathrm{x}$ \\
\hline $41 \mathrm{GR} 287$ & trash dump & artifact scatter only & unknown & & & & & $\mathrm{x}$ \\
\hline $41 \mathrm{GR} 288$ & trash dump & artifact scatter only & unknown & & & , & & $\mathrm{x}$ \\
\hline $41 \mathrm{GR} 289$ & trash dump & artifact scatter only & unknown & & & & & $\mathrm{x}$ \\
\hline $41 \mathrm{GR} 290$ & trash dump & artifact scatter only & unknown & & & & & $\mathrm{x}$ \\
\hline $41 \mathrm{GR} 292$ & isolated find & none & unknown & & & & & $\mathrm{x}$ \\
\hline $41 \mathrm{GR} 304$ & trash dump & artifact scatter only & unknown & & & & & $\mathrm{x}$ \\
\hline $41 \mathrm{GR} 331$ & $\begin{array}{l}\text { unidentified } \\
\text { structure }\end{array}$ & $\begin{array}{l}\text { concrete foundation, } \\
\text { stock tank; probably } \\
\text { represents a building } \\
\text { associated with the } \\
\text { townsite of Burnham }\end{array}$ & $\begin{array}{l}\text { railroad } \\
\text { and town } \\
\text { development }\end{array}$ & & & $\mathrm{x}$ & $?$ & \\
\hline $41 \mathrm{GR} 350$ & trash dump & artifact scatter only & unknown & & & $\mathrm{x}$ & $\mathrm{x}$ & \\
\hline $41 \mathrm{GR} 370$ & trash dump & artifact scatter only & unknown & & & & & $\mathrm{x}$ \\
\hline $41 \mathrm{GR} 375$ & trash dump & artifact scatter only & unknown & & & & & $\mathrm{x}$ \\
\hline $41 \mathrm{GR} 392$ & $\begin{array}{l}\text { homestead/ } \\
\text { line camp }\end{array}$ & dugout & ranching & & $\mathrm{x}$ & $\mathrm{x}$ & & \\
\hline $41 \mathrm{GR} 412$ & housesite (?) & artifact scatter only & ranching & & & $\mathrm{x}$ & $?$ & \\
\hline $41 \mathrm{GR} 443$ & $\begin{array}{l}\text { campsite/ } \\
\text { homestead }\end{array}$ & $\begin{array}{l}\text { rock house (dugout?) } \\
\text { and corral }\end{array}$ & $\begin{array}{l}\text { ranching } \\
\text { (sheepherding) }\end{array}$ & $?$ & $\mathrm{x}$ & & . & \\
\hline
\end{tabular}




\begin{tabular}{|c|c|c|c|c|c|c|c|c|}
\hline \multirow[b]{2}{*}{ Site No. } & \multirow[b]{2}{*}{ Site Type } & \multirow[b]{2}{*}{ Visible Features } & \multirow[b]{2}{*}{$\begin{array}{l}\text { Historic } \\
\text { Context }\end{array}$} & \multicolumn{5}{|c|}{ Period of Occupation/Use } \\
\hline & & & & $\begin{array}{l}\text { Pre- } \\
1880\end{array}$ & $\begin{array}{l}1880- \\
1900\end{array}$ & $\begin{array}{l}1900- \\
1920\end{array}$ & $\begin{array}{l}\text { Post- } \\
1920\end{array}$ & $1900 \mathrm{~s}$ \\
\hline $41 \mathrm{GR} 449$ & $\begin{array}{l}\text { oil pumper's } \\
\text { house }\end{array}$ & $\begin{array}{l}\text { oil pad and house } \\
\text { complex }\end{array}$ & $\begin{array}{l}\text { petroleum } \\
\text { industry } \\
\text { development }\end{array}$ & & & & $\mathrm{x}$ & \\
\hline $41 \mathrm{GR} 460$ & $\begin{array}{l}\text { unidentified } \\
\text { rock wall }\end{array}$ & rock wall only & unknown & & & & & $\mathrm{x}$ \\
\hline $41 \mathrm{GR} 470$ & $\begin{array}{l}\text { railroad/ } \\
\text { resort } \\
\text { complex }\end{array}$ & $\begin{array}{l}\text { Santa Fe Lake, dam, } \\
\text { pumphouse, trash } \\
\text { dumps (near community } \\
\text { of Justiceburg) }\end{array}$ & $\begin{array}{l}\text { railroad } \\
\text { and town } \\
\text { development }\end{array}$ & & & $\mathrm{x}$ & $\mathrm{x}$ & \\
\hline 41GR474* & $\begin{array}{l}\text { homestead/ } \\
\text { headquarters }\end{array}$ & $\begin{array}{l}\text { dugout and house } \\
\text { complex }\end{array}$ & ranching & & $\mathrm{x}$ & $\mathrm{x}$ & $\mathrm{x}$ & \\
\hline $41 \mathrm{GR} 522$ & $\begin{array}{l}\text { Justiceburg } \\
\text { cemetery }\end{array}$ & crypt, ca. 76 graves & $\begin{array}{l}\text { railroad } \\
\text { and town } \\
\text { development }\end{array}$ & & & & & \\
\hline 41GR528* & $\begin{array}{l}\text { campsite/ } \\
\text { grave }\end{array}$ & $\begin{array}{l}\text { artifact scatter and } \\
\text { grave headstone }\end{array}$ & $\begin{array}{l}\text { buffalo } \\
\text { hunting }\end{array}$ & $\mathrm{x}$ & & & & \\
\hline $41 \mathrm{GR} 530$ & housesite & artifact scatter only & unknown & & & , & & $\mathrm{x}$ \\
\hline 41GR565 & housesite & $\begin{array}{l}\text { house complex, } \\
\text { stock tank, windmill }\end{array}$ & ranching & & & $\mathrm{x}$ & $\mathrm{x}$ & \\
\hline 41GR586 & $\begin{array}{l}\text { homestead/ } \\
\text { headquarters }\end{array}$ & $\begin{array}{l}\text { dugout, housesite, } \\
\text { corral complex }\end{array}$ & ranching & & & $\mathrm{x}$ & $\mathrm{x}$ & \\
\hline $41 \mathrm{KT} 42 *$ & line camp & $\begin{array}{l}\text { rock foundation and } \\
\text { artifact scatter }\end{array}$ & ranching & ? & $\mathrm{x}$ & $?$ & & \\
\hline $41 \mathrm{KT} 58$ & homestead & house complex, cistern & ranching & & & $\mathrm{x}$ & $\mathrm{x}$ & \\
\hline $41 \mathrm{KT} 84$ & line camp & dugout, rock structure & ranching & & $\mathrm{x}$ & $\mathrm{x}$ & & \\
\hline $41 \mathrm{KT} 150$ & $\begin{array}{l}\text { line camp } \\
\text { (homestead?) }\end{array}$ & dugout & ranching & & $\mathrm{x}$ & & & \\
\hline
\end{tabular}

Only one of the 32 sites is related to buffalo hunting, while a small number are associated with railroad construction, town building, and the petroleum industry $(\mathrm{n}=5)$. The majority $(\mathrm{n}=13)$ are related to agriculture. This last group includes line camps or homesteads with dugouts or single structure foundations and more-extensive homesteads/ headquarters with dugouts, above-ground houses, and related features such as barns and corrals. Most of these sites can be tied to important early ranching families in Garza County through archival records and informant interviews.

Eligibility for inclusion in the National Register of Historic Places has been evaluated for most of the historic sites (see Appendix A). Many of these sites were assessed as ineligible following initial survey- 
TABLE 12

LAKE ALAN HENRY SITES WITH HISTORIC ANGLO-AMERICAN ROCK ART COMPONENTS

\begin{tabular}{|c|c|c|c|c|c|}
\hline \multicolumn{5}{|c|}{ Garza County } & \multirow{2}{*}{$\begin{array}{r}\text { Kent County } \\
41 \mathrm{KT} 50\end{array}$} \\
\hline 41GR51 & 41GR305 & 41GR418 & $41 \mathrm{GR} 475$ & 41GR552 & \\
\hline $41 \mathrm{GR} 54$ & 41GR307 & $41 \mathrm{GR} 419$ & 41GR494 & 41GR553 & $41 \mathrm{KT} 54$ \\
\hline $41 \mathrm{GR} 242$ & $41 \mathrm{GR} 308$ & $41 G R 428$ & $41 G R 516$ & 41GR556 & $41 \mathrm{KT} 60$ \\
\hline $41 \mathrm{GR} 244$ & $41 \mathrm{GR} 313$ & 41GR437 & 41 GR517 & 41GR557 & $41 \mathrm{KT} 65$ \\
\hline $41 \mathrm{GR} 283$ & $41 \mathrm{GR} 315$ & $41 \mathrm{GR} 445$ & 41GR525 & 41GR558 & $41 \mathrm{KT} 72$ \\
\hline $41 \mathrm{GR} 284$ & $41 \mathrm{GR} 317$ & $41 \mathrm{GR} 448$ & 41GR526 & 41GR559 & 41KT73 \\
\hline $41 \mathrm{GR} 285$ & $41 \mathrm{GR} 321$ & $41 \mathrm{GR} 455$ & 41GR536 & 41GR567 & $41 \mathrm{KT} 76$ \\
\hline $41 \mathrm{GR} 294$ & 41 GR322 & 41GR464 & 41GR537 & & $41 \mathrm{KT} 164$ \\
\hline $41 \mathrm{GR} 295$ & $41 \mathrm{GR} 333$ & 41GR465 & 41GR545 & & \\
\hline $41 \mathrm{GR} 298$ & $41 G R 416$ & $41 G R 473$ & $41 \mathrm{GR} 550$ & & \\
\hline
\end{tabular}

level documentation based solely on lack of integrity. Others have been assessed relative to the buffalo hunting and ranching contexts (Boyd et al. 1991:56-57; Freeman and Boyd 1990:115-131). Sites that relate to railroad and town development or petroleum industry development, however, have yet to be fully evaluated because no historic contextual frameworks have been constructed. Archeological investigations beyond initial site recording were conducted at only three of the Lake Alan Henry historic sites: 41GR474, 41GR528, and 41KT42. These investigations are discussed below.

Historic rock art sites are locations where Anglo-Americans (as opposed to Native Americans) carved their names, usually accompanied by a date and often by symbols of association (e.g., cattle brands), into a natural sandstone rockface. At Lake Alan Henry, where such sites usually occur in protected areas such as overhangs and shelters, all markings with dates older than 1945 were recorded as historic sites or components. Historic writings often occur in conjunction with, and occasionally have destroyed, Native American rock art images (see Chapter 6). Modern inscriptions (some as recent as 1990 were observed in 1993) generally were not recorded unless they were found on or adjacent to a panel of Native American rock art. Many of the names that are scattered across the project area are associated with late-nineteenth- and early-twentieth-century ranchers, cowboys, farmers, and prominent businessmen who were important in the history of the settlement of the region, or townspeople associated with communities such as Justiceburg. The names and dates represented at historic rock art sites are summarized by Boyd et al. (1989:Table 22, 1994:Table 96). From a functional perspective, historic writings are similar to modern graffiti in that the authors intended to convey simple messages such as "I was here" or "this is my territory." Although these inscriptions do contain a certain amount of historical information, there is usually no mystery involved in interpreting their meaning. Thus, the research potential of such sites is often fully realized through initial recording, and all historic rock art components were assessed as being ineligible for inclusion in the National Register of Historic Places. However, rock art inscriptions can be used to complement oral history research, and oral histories can be used to interpret inscriptions (e.g., informants may be able to identify symbols or link names and dates with specific families or events).

\section{INTENSIVELY INVESTIGATED HISTORIC SITES AT LAKE ALAN HENRY}

Historic sites that were intensively investigated, both archeologically and archivally, consist of one site that relates to the buffalo hunting context and two sites that fall under the ranching context. Site 41GR528, a buffalo hunting camp and an associated grave, was surface-collected during the testing phase, but because of its severely eroded condition, the campsite component was assessed as being ineligible for inclusion in the National Register of Historic Places. The testing phase investigations, however, effectively mitigated the campsite and exhausted its 
research potential. Being located in a stable setting high on a hilltop and not endangered by projectrelated impacts, no investigation of the gravesite was conducted. Testing of the two ranching sites, 41GR474 and 41KT42, found them to be eligible for inclusion in the National Register of Historic Places, and additional archeological work was recommended to mitigate the adverse effects of lake construction. Both sites were investigated further during the data recovery phase. The investigations and interpretations of these three sites are summarized below.

\section{GR528, Buffalo Hunters' Camp/Grave}

Site 41GR528 consists of an isolated grave, marked only by a hand-carved headstone made of native sandstone, on a hilltop overlooking an eroded area containing a surface scatter of artifacts. The site is situated along Sand Creek about $4 \mathrm{~km}$ southeast of Justiceburg. The initial recording of the site in 1987 (Boyd et al. 1989:624-625) documented the headstone inscription and cultural materials that were observed, but no artifacts were collected. Interviews with local informants confirmed that the site had been collected before and provided stories relating the site to local ranching lore. Notes also were made on Emmett Shedd's collection of artifacts from the site.

Additional archeological work done in 1988 (Freeman and Boyd 1990:111-112, 152-155) consisted of detailed recording of the headstone (Figure 16), surface collection of a small sample of diagnostic artifacts, recording of the surface collection of Virgil Streety, and informant interviews with local residents and collectors. Along with the research done to compile the buffalo hunting context, additional archival research was conducted to further define the nature and function of the site.

The artifacts recovered from the site are summarized in Table 13. From a chronological standpoint, the patent dates on the glass closure, the primers, the .45-70- and .44-caliber cartridges, the square nails, and the tin cans all indicate a latenineteenth-century period of occupation/use. From a functional perspective, the majority of the artifacts are either clothing and personal items or firearmsrelated artifacts. The latter group is the most diagnostic because these artifacts are indicative of hunting using large-caliber weapons, molding of lead bullets, and reloading cartridges. The chronological information and the activities represented by the artifact assemblage suggested that the site could be a buffalo hunters' camp dating to the late 1870s.

Archival research and informant interviews did not confirm the site function or the association of artifacts with McCormick's grave. An unsuccessful attempt was made to identify McCormick in the St. Louis census records of 1870. According to informants, there had been a dugout located in the bluff near the artifact scatter below the grave (Justice 1988; Shedd 1988). Based on a story that another local resident had told them, the informants assumed that the dugout had been occupied by cowboys, of whom A. W. McCormick was one.

The land where the site is located belonged to the State of Texas until it was patented by the Great Northern Railway Company in 1873 and subsequently acquired by Jeff D. Justice in 1901. Although there is no record of use of the land for ranching prior to 1882 when a private ranch leased the land from the railway company for grazing, several ranches had been established in the vicinity in the late 1870s (Freeman and Boyd 1990:111112). It would not have been unusual for a nearby ranch to have had a line camp on state- or railroadowned lands since the entire area was unfenced open range. Thus, it is possible that the site could be associated with ranching activities on the Rolling Plains.

On the other hand, it is clear that buffalo hunters were active in the area from about 1874 until winter 1878-1879, and hunting outfits are known to have been active in the vicinity of 41GR528. It would not have been unusual for hunters to have constructed a dugout, one of the property types known to have been associated with buffalo hunting activities. Several buffalo hunters' camps with dugouts are mentioned in historical records pertaining to the area (Freeman 1990a:42), including a dugout that was used in 1876-1877 near present-day Post in Garza County (Woody 1926:1, 1928:1). In addition, the munitions collected from the site are typical of those used by buffalo hunters, and the entire assemblage is suggestive of specialized hunting activities associated with big-game hunting.

Based on these above-mentioned facts, Freeman and Boyd $(1990: 112,118)$ concluded that 41GR528 originally had been a buffalo hunters' camp. The location might have been reused as a ranching line camp after 1879 , particularly if there had been a dugout there. Notably, A. W. McCormick's death 


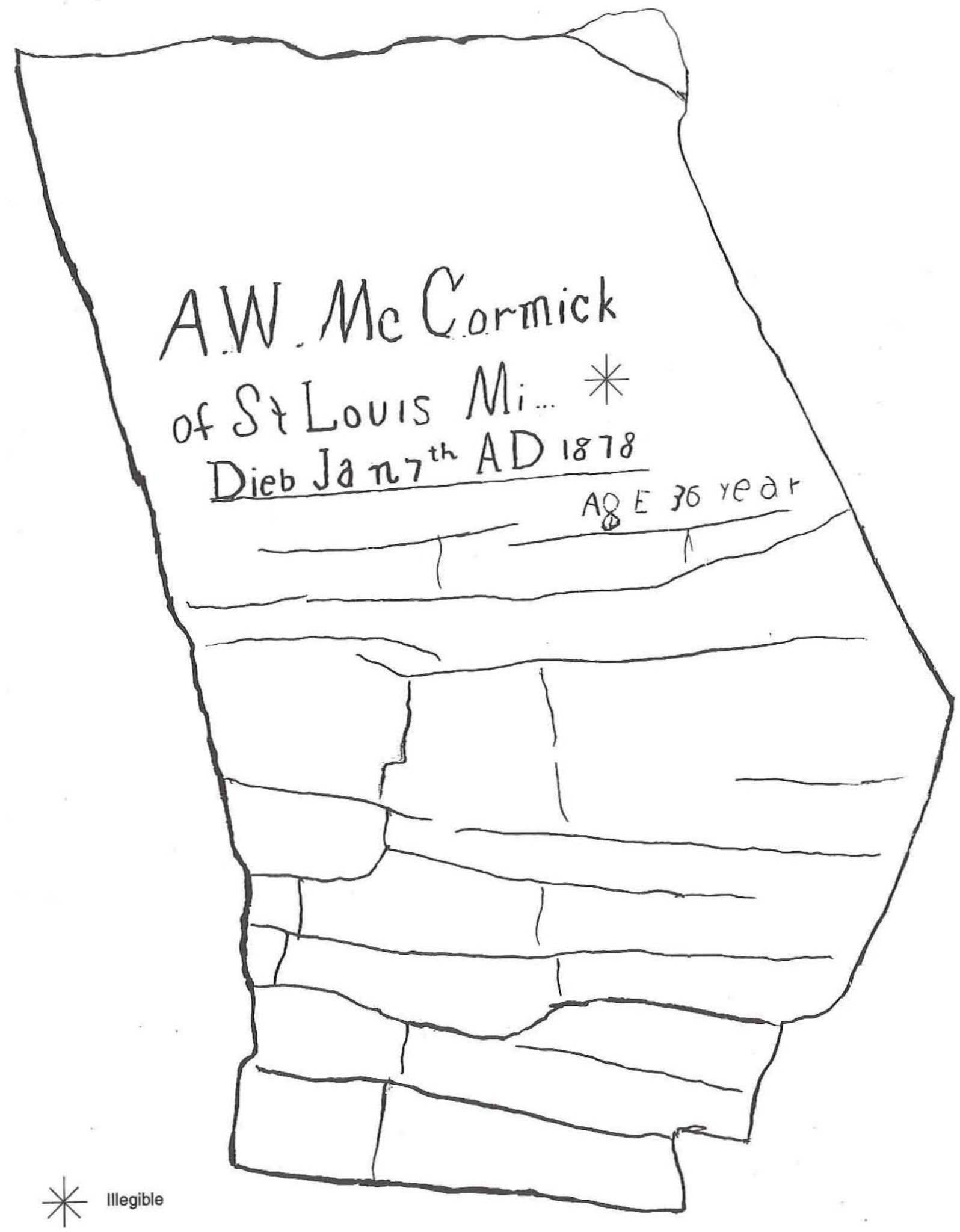

Figure 16. Tracing of hand-carved native sandstone marker of the grave of A. W. McCormick at 41GR528. 


\begin{tabular}{|c|c|c|c|}
\hline ARTIFAC & $\begin{array}{l}13 \\
\text { ED FROM } 4\end{array}$ & & \\
\hline Artifact & $\begin{array}{l}\text { Shedd } \\
\text { Collection }\end{array}$ & $\begin{array}{l}\text { Streety } \\
\text { Collection }\end{array}$ & $\begin{array}{c}1988 \\
\text { Collection }\end{array}$ \\
\hline $\begin{array}{l}\text { Firearms-Related Artifacts } \\
6.5 \text {-mm-diameter Berdan primer } \\
.45-70 \text {-caliber center-fire primers } \\
\text {.44-caliber center-fire primers } \\
.44 \text {-caliber cartridge cases } \\
.44 \text {-caliber lead slugs } \\
\text { Fragments of lead sprue } \\
\text { Distorted lead lumps }\end{array}$ & $\begin{array}{l}- \\
x \\
x \\
x \\
x \\
x \\
-\end{array}$ & $\begin{array}{l}- \\
- \\
- \\
- \\
- \\
\overline{6}\end{array}$ & $\begin{array}{l}1 \\
- \\
- \\
- \\
- \\
\overline{2}\end{array}$ \\
\hline $\begin{array}{l}\text { Clothing and Personal Items } \\
\text { Iron button, 4-hole } \\
\text { Iron suspender buckle } \\
\text { White glass button, 4-hole } \\
\text { Clay pipe bowl fragment } \\
\text { Coarse earthenware fragment (pipe bowl?) }\end{array}$ & $\begin{array}{l}- \\
- \\
\bar{x} \\
-\end{array}$ & $\begin{array}{l}1 \\
1 \\
1 \\
- \\
-\end{array}$ & $\begin{array}{l}- \\
- \\
- \\
\overline{1}\end{array}$ \\
\hline $\begin{array}{l}\text { Kitchen Artifacts } \\
\text { Hole-in-top can fragments } \\
\text { Hole-in-cap can lid } \\
\text { Glass jar top, lightning-type closure* }\end{array}$ & $\begin{array}{l}- \\
- \\
-\end{array}$ & $\begin{array}{l}- \\
- \\
-\end{array}$ & $\begin{array}{c}\mathrm{xx} \\
1 \\
1\end{array}$ \\
\hline $\begin{array}{l}\text { Other and Unidentified-Function Artifacts } \\
\text { Square nails } \\
\text { Horseshoe nails } \\
\text { Brass ring (harness hardware?) } \\
\text { Brass oval (harness hardware?) } \\
\text { Brown bottle (liquor?) glass fragments } \\
\text { Unidentified iron fragment }\end{array}$ & $\begin{array}{l}x \\
x \\
- \\
- \\
- \\
-\end{array}$ & $\begin{array}{l}1 \\
- \\
1 \\
1 \\
- \\
1\end{array}$ & $\begin{array}{l}2 \\
- \\
- \\
- \\
2 \\
-\end{array}$ \\
\hline Totals: & ? & 13 & 10 \\
\hline
\end{tabular}

in the winter of 1878 came at a time when buffalo hunting was still a major economic pursuit in the area. Rather than having been a cowboy, it is quite possible that McCormick was a buffalo hunter who died during the final season of commercial hunting in the Southern Plains.

\section{KT42, Ed Scott Cabin Site}

Site $41 \mathrm{KT} 42$, situated on a colluvial slope on the east side of Grape Creek near its confluence with the Double Mountain Fork of the Brazos River, was recorded in 1987 (Boyd et al. 1989:633-634) and tested in 1988 (Freeman and Boyd 1990:106-
110). Data recovery investigations during the winter of 1990 are reported by Gardner and Boyd (1992). The site consists of a 14-x-20-ft structural foundation of dry-laid native sandstone slabs with a rock rubble concentration on one end marking the chimney location, three smaller surface rock clusters of unknown function (two features could represent small sheds or outbuildings), and an artifact scatter over a large area around the main structural foundation. During the 1988 testing phase, four 1-x-1-m test units were excavated across the southern end (i.e., the entrance) of the slab foundation to define its architectural attributes (see Gardner and Boyd 1992:Figure 7). During data recovery in 1990, the 
main site area was gridded into one hundred fiftyfour $5-\mathrm{x}-5-\mathrm{m}$ collection units, and all surface artifacts within this $55-\mathrm{x}-70-\mathrm{m}$ area were collected and bagged by unit (Figure 17).

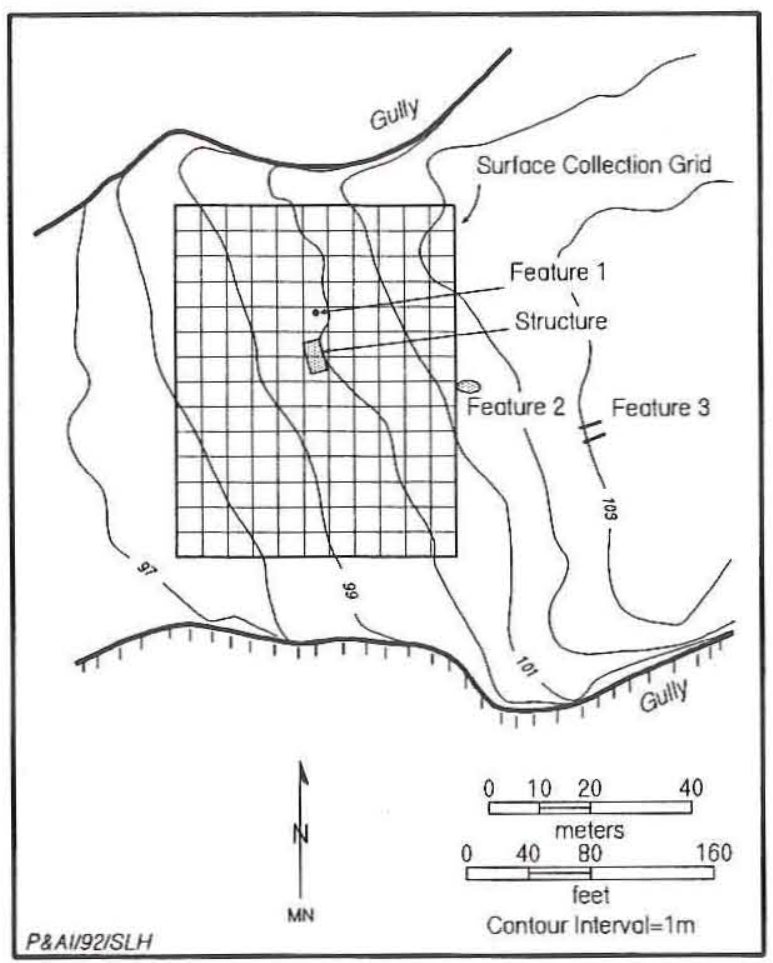

Figure 17. Site map of $41 \mathrm{KT} 42$ showing features and surface collection grid.

A total of 634 artifacts was recovered during all phases of work (Gardner and Boyd 1992:Table 9). Chronologically sensitive metal artifacts included a variety of tin cans, square nails, barbed wire dating to the late $1800 \mathrm{~s}$, and 13 cartridge cases of types that were in common use between 1866 and 1913. Coarse earthenware, whiteware, and ironstone ceramics and a variety of glass fragments common in the late 1800 s also were recovered. Thus, artifactual materials indicated that the site was occupied between ca. 1860 and 1920 , most likely in the 1880 s or 1890 s. Notably, no items that were definitely manufactured after 1900 were found, and use of the site during the twentieth century may have been minimal.

Archival evidence, discussed in detail by Boyd et al. (1989:633-634) and Freeman and Boyd (1990:110), indicates that the land encompassing $41 \mathrm{KT} 42$ was purchased from the State of Texas sometime between 1878 and 1882 by H. T.
Cornelius and former buffalo hunter J. Wright Mooar. Cornelius had started a trading post on Deep Creek (now in Snyder) in 1876, but he sold his store to Pete Snyder in 1878 and went into the ranching business with Mooar. The property was subsequently purchased in 1886 by Andy and Frank Long and became known as the OS Ranch. The OS Ranch was sold to the partnership of Connell, Clark, and Scharbauer in 1901. They controlled it until 1913 , when W. E. Connell bought out the other two partners to become the sole owner of the OS Ranch.

Neither the archival data nor informants could precisely confirm when the structure at $41 \mathrm{KT} 42$ was built, who occupied the site, or the duration of occupations. It might have been built as early as 1878-1882 by Cornelius and Mooar, but informants knew that it had been associated with the Longs and Connell and was used as a line camp for the OS Ranch. Regardless of when it was built, it appears the site was occupied most intensively after 1886, and it may have been in use until 1910 or later. Informants stated that the structure was used by OS Ranch cowboys O. B. Kelly, Oliver Curtis, Ed Scott Sr., and his son Ed Scott Jr. The names O. B. Kelly and Ed Scott (Sr.) were inscribed into sandstone faces elsewhere in the project area in 1897 and 1886 at sites $41 \mathrm{GR} 51$ and 41GR322, respectively (Boyd et al. 1989:Table 22). The site's name is derived from its association with the Scotts, particularly with Ed Scott Jr. (1873-1971), who worked for the OS Ranch for over 60 years after arriving in Garza County in 1889 . The site of the old Scott cabin is well known to locals, many of whom stated that the location occasionally was used as a family picnic area.

Of the total artifacts recovered, 563 surfacecollected specimens were classified by function and subjected to a detailed analysis (Table 14). With regard to site function, the overall assemblage is consistent with what is expected for a pre-1900 ranching line camp. Except for a few clothing and personal items (e.g., buttons, a pipe fragment, and a watch $\operatorname{cog}$ ), the majority of the assemblage is composed of basic functional and utilitarian items representing household activities (primarily food storage and utilitarian cooking artifacts) or ranchrelated and other male-dominated activities (e.g., firearms, fencing, horse gear). Two ceramic doll fragments - $a$ hand and a leg-are not consistent with this interpretation. Although there is no way of knowing how these artifacts got there, it is 
TABLE 14

SURFACE-COLLECTED ARTIFACTS FROM 41KT42

\begin{tabular}{|l|r|c|c|c|c|c|}
\hline Functional Classification & Metal & Ceramics & Glass & Miscellaneous & Totals & Percent \\
\hline Kitchen & 121 & 78 & 250 & - & 449 & 79.8 \\
Architecture & 20 & - & 2 & - & 22 & 3.9 \\
Firearms & 15 & - & - & - & 15 & 2.7 \\
Clothing & 3 & - & - & 1 & 4 & 0.7 \\
Personal & 1 & 1 & - & 1 & 3 & 0.5 \\
Ranching & 54 & 2 & - & - & 56 & 9.9 \\
Unknown & 13 & - & - & 1 & 14 & 2.5 \\
\hline Totals: & 227 & 81 & 252 & 3 & 563 & 100.0 \\
\hline
\end{tabular}

possible that the broken doll parts are related to postoccupation activities (e.g., family picnics).

A detailed spatial analysis was done to define activity areas, and several patterns could be discerned. The artifact distributions (see Gardner and Boyd 1992:Figure 9) indicate that there were two main concentrations of artifacts near the structure, one to the southeast and another to the northwest. In addition, two areas largely devoid of artifacts were noted to the northeast and southwest. The largest concentration of all types of artifacts, located just southeast of the structure, is interpreted as a primary deposit representing the main household dump, which would have been downslope directly in front of the structure's door. This interpretation is logical assuming that the occupants disposed of their trash in the most expedient manner (i.e., with the least effort) possible. A smaller concentration northwest of the structure contained mostly kitchen artifacts. An even smaller concentration to the northeast was composed entirely of kitchen artifacts. Thus, it appears that the north end of the structure could have been a specialized refuse area or, perhaps more likely, an area where specialized activities occurred outdoors.

The combined archeological, archival, and informant evidence indicates that $41 \mathrm{KT} 42$ was probably established as a ranching line camp some time between 1882 and 1886 . It most likely was established before 1890 , and it continued to serve as a ranching line camp until after the turn of the century, perhaps even as late as ca. 1920. Unlike pre-1900 line camps where dugouts were the principal type of shelter, this line camp had a more substantial wooden frame structure with a full rock chimney built over a slab foundation. The surface artifact distributions suggest that much of the original activity patterning remained intact, and the types of activities and activity patterning are consistent with the archivally defined use of the site.

\section{GR474, Jeff Justice Homestead Site}

Site 41GR474 was recorded in the 1987 survey by Boyd et al. (1989:618-619), and 1988 testing of the site was reported by Freeman and Boyd (1990: 100-106). Data recovery investigations in 1992 were reported by Boyd (1994). The site is situated along an erosional remnant bedrock terrace immediately south of the Double Mountain Fork of the Brazos River. The historic component consists of an extensive complex of features and scattered artifacts covering an area of over $150 \times 250 \mathrm{~m}$, located approximately $2 \mathrm{~km}$ east of the community of Justiceburg (Figure 18).

The work completed at $41 \mathrm{GR} 474$ consists of detailed archival and informant research to define the site's history, mapping and recording of the extensive surface features at the site, and complete excavation of the dugout. The site's history is well documented. The area remained undeveloped openrange ranch land prior to the late 1890 s. The FourSection Act of 1895 encouraged people to settle by offering four sections of land, one to live on and three for grazing, to any individual who established a home, made improvements, and then filed an application and proof of residency after three years. Once these requirements were met, individuals could purchase the lands from the State of Texas at very reasonable prices.

Jeff D. Justice filed an application for the land February 17, 1900 (Texas. General Land Office 


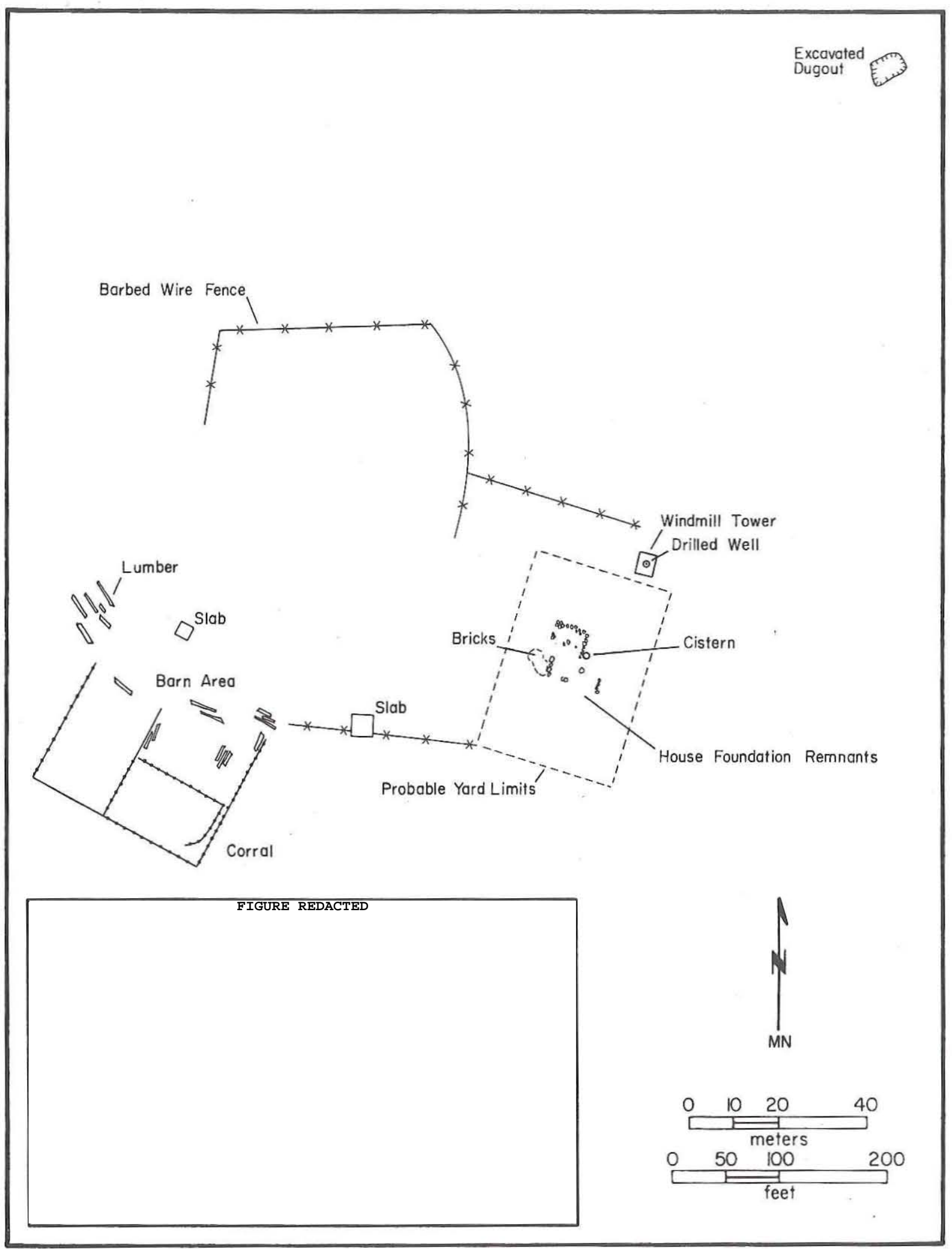

Figure 18. Map of historic component of 41GR474. 
1939). An affidavit made by neighbor T. J. Payne stated that Jeff Justice and others made camp in the area for the purpose of establishing homestead claims by December of 1899 (Texas. General Land Office 1936). Based on this archival information and informant interviews, it was determined that the dugout was probably constructed in 1899 or early 1900 as temporary housing for Jeff Justice, his wife Mattie, and their eight children (see Boyd 1994: Table 35). The dugout apparently was used for only a short time, and the entire family moved into a new three-bedroom frame ranch house within a few years (see Freeman and Boyd 1990:Figure 6). One informant knew that his grandmother, who was one of Jeff and Mattie's children, had lived in a dugout (Hood 1992, 1993), but no informants remembered ever having seen the dugout. Apparently the dugout was abandoned soon after the turn of the century and was forgotten after it fell into ruins. In 1987 at the time it was recorded, the dugout location was indicated only by a very slight depression with an associated artifact scatter. Most of the informants remembered details of the later house and surrounding features, which included a cistern, a drilled water well, an outhouse, a smokehouse, stock pens, a barn with attached tack rooms, and a concreteslabbed garage that was added later for automobiles.

There is conflicting evidence regarding how long the family lived in the dugout. One Garza County history states that the Justice family lived in Snyder until 1899 , when Jeff "moved his family to a one-room shack on the south bank of the Brazos River and started his beautiful ranch home. The family moved into this home in 1900" (Didway 1973:24). The tax records for Garza County (Ad Valorem Tax Rolls 1899-1910), however, tell a slightly different story about when the ranch house was built. Jeff first appears as a landowner in Garza County in the 1901 tax roll, but no significant improvements to the land show up until 1907, when the value of the section where the house sits increased by $\$ 1,280$. Thus, it appears that the house must have been built between the time that the 1906 (August) and 1907 (November) tax rolls were certified. Consequently, it seems likely that the dugout may have been occupied by the Justice family for about six years between 1899/1900 and 1906/1907.

Tax records also indicate that Jeff Justice was very successful at ranching in these early years. His Garza County holdings increased dramatically from
1901 to 1907 (Ad Valorem Tax Rolls 1899-1910). In 1901, Justice owned 1,760 acres of land, 32 horses and mules (valued at \$400), and 300 cattle (valued at $\$ 3,600$ ). By 1907 , his holdings had risen to 12,045 acres of land, 25 horses and mules (valued at $\$ 1,000), 1,000$ cattle (valued at $\$ 10,000$ ), and 20 hogs (valued at \$40). By 1910, Jeff Justice had become a prominent businessman and was actively promoting the community of Justiceburg. The Santa Fe railroad constructed a line through the area between 1909 and 1911, and Justiceburg was platted alongside the tracks on August 9, 1910 (Garza County Map and Plat Record No. 1:18). Jeff Justice continued to live in the ranch house at 41GR474 until he moved to Fort Worth in 1920. The ranch house may have been periodically used and abandoned for many years, and informants indicated that it was rented to various tenants in the 1930s and 1940s. The ranch house appears on a 1941 aerial photo (Texas Highway Department 1941:Photo CVC-3B-191) but was razed before 1960 (Hood 1992).

The archeological testing and data recovery at 41GR474 concentrated on the turn-of-the-century dugout located northeast of the housesite. Complete excavation of the structure revealed much about its construction and architecture and produced two discrete assemblages of artifacts. Excavations also revealed that two main depositional units were represented in the dugout fill (Figure 19). The lower fill was composed primarily of eolian sands but also contained materials that were directly associated with the dugout. Artifacts found at or near the floor level constitute an assemblage associated with the turn-of-the-century occupation/use of the dugout, while large rocks and logs found at various levels in the lower fill represent collapsed wall and roof remnants. These structural elements effectively sealed the underlying dugout assemblage artifacts.

Immediately above the lower fill was a thin basin-shaped lens of laminated sandy loam. This deposit apparently was reworked inside shallow puddles of standing rainwater for a brief period after the dugout had collapsed and partially filled with sand. The uppermost fill consisted primarily of twentieth-century trash mixed with eolian sands. The cultural debris in the upper fill constituted the second artifact assemblage. These materials had been dumped into the dugout depression by people living in the nearby ranch house. 


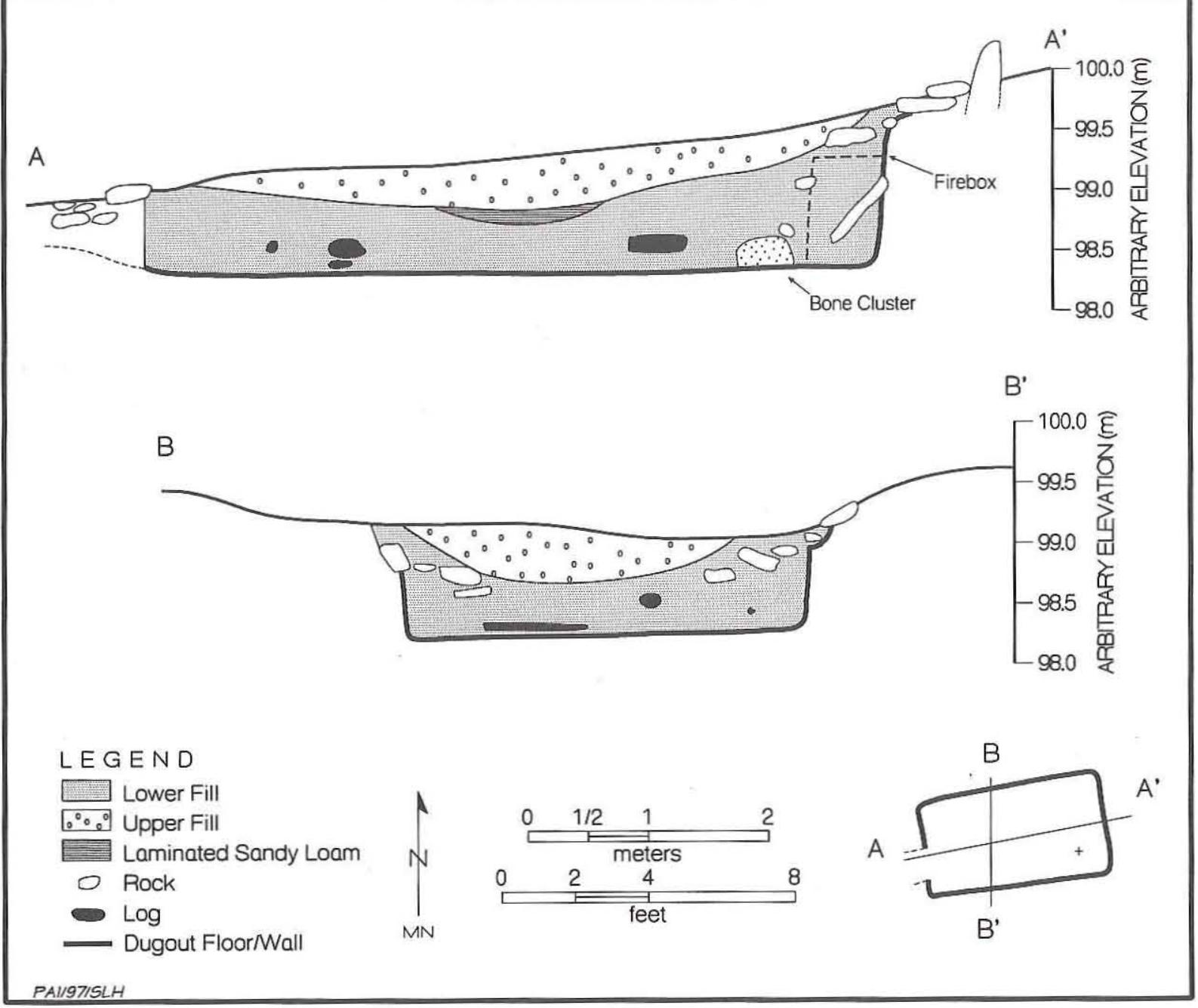

Figure 19. Stratigraphic cross sections of the dugout at 41GR474.

The architectural details of the dugout were reconstructed as the excavations progressed. It became clear that the large rocks in the lower fill represented upper rock walls that had collapsed into the dugout (Figure 20). Continued excavation revealed that the roof had collapsed prior to the collapse of the upper rock portions of the walls. The lower earthen walls and floor of the dugout were intact, with artifacts, wooden logs, and features lying about underneath the layers of collapsed rocks (Figure 21). The framework of the dugout's roof had been made of hand-cut local juniper and likely consisted of a central, longitudinal beam with perpendicular rafters. Not enough wood was found to account for a complete wooden roof frame, but this could be due to differential preservation or scavenging of wood after abandonment. The wooden framework may have supported a roof of wood and brush, hides, and/or earth. The large amount of sterile sandy fill immediately overlying the roof logs and floor, but below the fallen wall rocks, suggests that an earth-covered roof is most likely. A west-facing entryway led downslope toward the river. Just enough rocks were found in the entryway to suggest that the lower portion of the front wall was constructed of rocks. The remainder of the front wall was probably constructed of hides, locally harvested wood, or perhaps cut lumber. There is no archeological evidence indicating that there were any windows in the dugout.

When all the archeological evidence is taken into account, it is clear that this structure was actually a half-dugout. If the upper portion of the half-dugout was frame, that might account for 


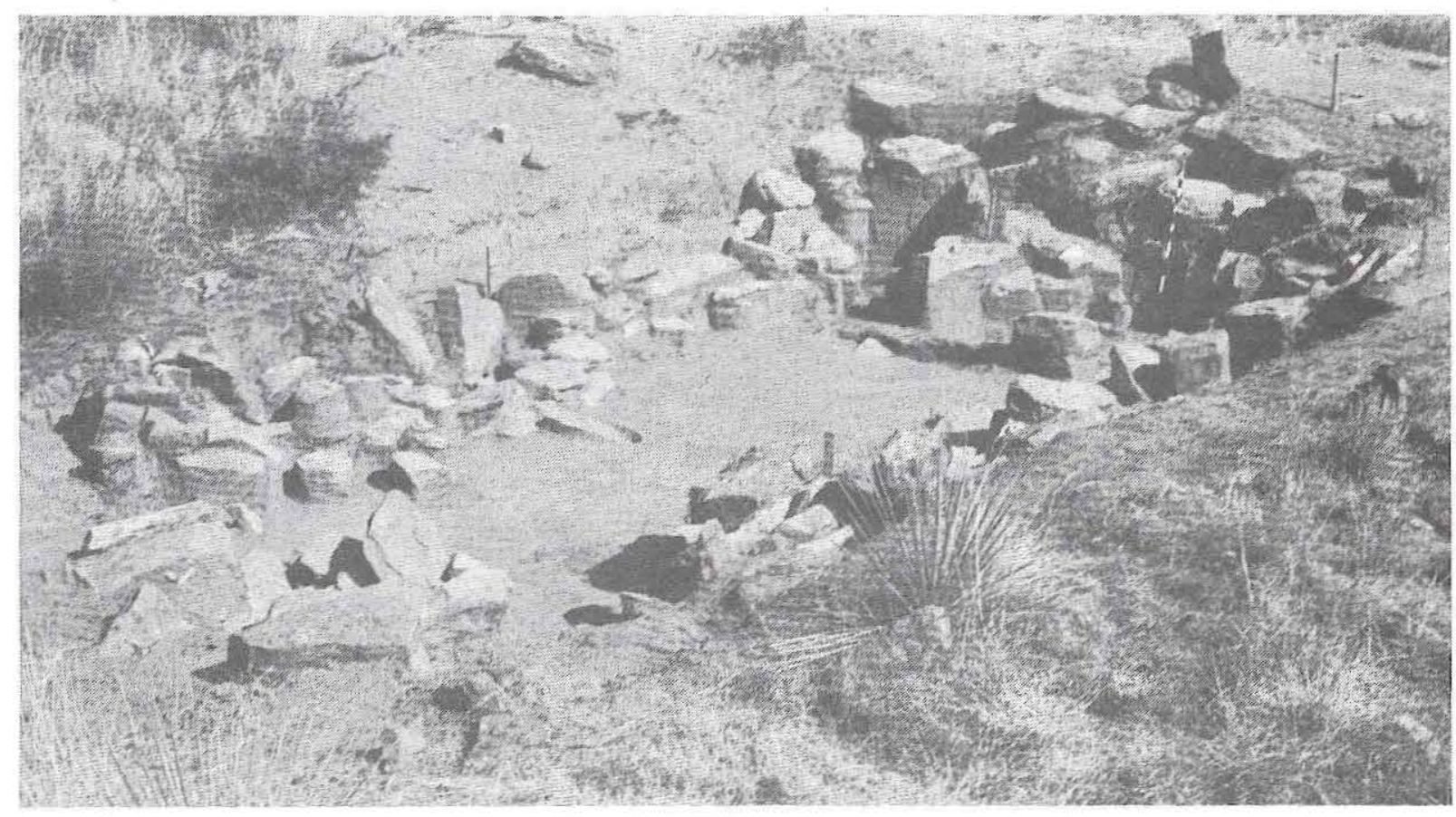

Figure 20. Photograph of the 41 GR474 dugout excavation in progress showing large rocks inside the structure. View is northeast. Central portion of the dugout is excavated to within $35 \mathrm{~cm}$ of the floor.

Didway's (1973:24) reference to the structure as "a one room shack." The Justice Dugout is quite similar in construction, and probably in appearance as well, to the Mayfield Dugout located in Briscoe County (ca. $160 \mathrm{~km}$ north of Lake Alan Henry). Built in 1889, this well-preserved dugout (41BI52) was listed in the National Register of Historic Places in 1973 (Jackson et al. 1973; Steely 1984:28).

Five interior features were encountered in the Justice Dugout. Two large vertical rock slabs along the back wall represent remnants of the fireplace. Large slabs that once formed the top of the firebox had collapsed inward, but the vertical slabs were intact. Although stovepipes were sometimes used to divert fireplace smoke outside, the large amount of rock rubble located along the back wall suggests that this dugout had a rock-lined chimney. Two ash stains and two bone clusters found on the floor around the fireplace are interpreted as dumps of fireplace ash and butchered animal remains. The bone clusters consisted of 81 bones, of which 7 exhibited saw marks and 12 were identifiable as cow, pronghorn, coyote, pig, and duck (see Boyd 1994:Table 37).

A total of 2,761 artifacts was recovered from dugout excavations during testing and data recovery (see Boyd 1994:Tables 34 and 38). Of these, 480 specimens comprise the dugout assemblage, while 2,281 constitute the upper trash fill assemblage. These assemblages contain many temporally diagnostic specimens (i.e., with known years or periods of manufacture) and are chronologically consistent with the archival records indicating deposition of the dugout assemblage between ca. 1899 and 1910 and deposition of the trash fill assemblage between the 1910 s to 1930 s or later. These assemblages, described in detail by Freeman and Boyd (1990:103, 145-152) and Boyd (1994:178-197), were classified by functional categories for comparison. Table 15 highlights the fact that there are significant functional differences between the dugout and trash fill assemblages. The trash fill assemblage is dominated by kitchen artifacts and is consistent with expectations for a household dump. Furniture and clothing items also are overrepresented in the trash fill assemblage. In contrast, bone and firearms-related artifacts significantly dominate the dugout assemblage.

Comparisons of the 41GR474 artifact assemblages with other late-nineteenth- and earlytwentieth-century assemblages are revealing (Table 16). The trash fill assemblage compares favorably, 


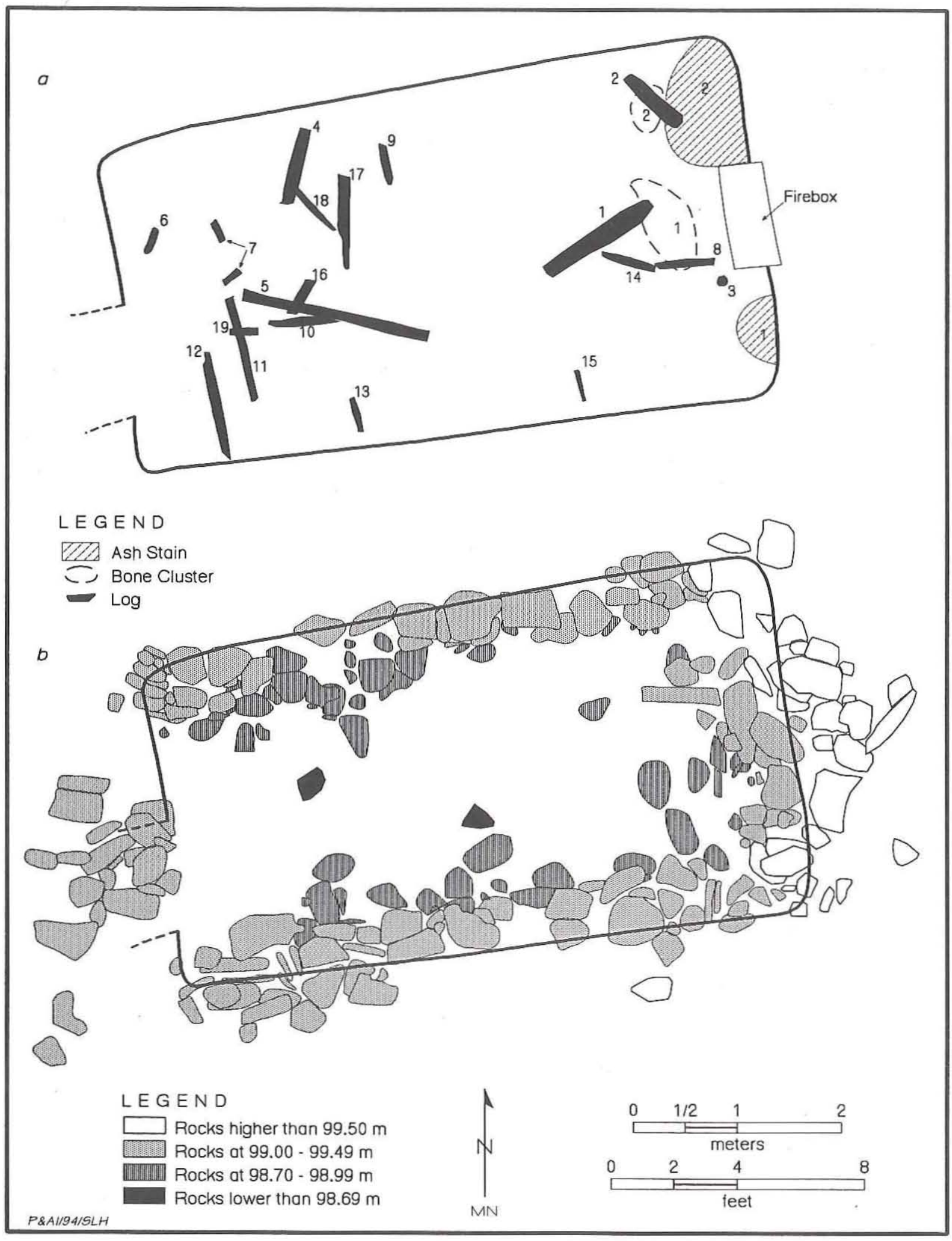

Figure 21. Plan views of the dugout at 41GR474 showing various structural elements. (a) Outline of lower walls showing the fireplace, floor features, and logs; $(b)$ horizontal and vertical distribution of upper wall rockfall. 


\begin{tabular}{|c|c|c|c|c|c|c|}
\hline \multicolumn{7}{|c|}{$\begin{array}{l}\text { TABLE } 15 \\
\text { DF HISTORIC ARTIFACTS IN THE DUGOUT } \\
\text { LL ASSEMBLAGES, } 41 \mathrm{GR} 474^{1}\end{array}$} \\
\hline \multirow{2}{*}{$\begin{array}{r}\text { Functional } \\
\text { Category }^{2}\end{array}$} & \multicolumn{2}{|c|}{ Dugout Assemblage } & \multirow{2}{*}{$\begin{array}{l}\text { Adjusted Standardized } \\
\text { Residuals for Dugout } \\
\text { Assemblage }^{3}\end{array}$} & \multicolumn{2}{|c|}{ Trash Fill Assemblage } & \multirow[b]{2}{*}{ Totals } \\
\hline & Number & Percent & & Number & Percent & \\
\hline $\begin{array}{l}\text { Kitchen } \\
\text { Bone } \\
\text { Architecture } \\
\text { Furniture } \\
\text { Arms } \\
\text { Clothing } \\
\text { Personal } \\
\text { Tobacco } \\
\text { Activities }\end{array}$ & $\begin{array}{r}5 \\
290 \\
13 \\
- \\
28 \\
5 \\
2 \\
3 \\
7\end{array}$ & $\begin{array}{r}1.4 \\
82.2 \\
3.7 \\
- \\
7.9 \\
1.4 \\
0.6 \\
0.8 \\
2.0\end{array}$ & $\begin{array}{r}-23.28 \\
+26.22 \\
+1.78 \\
-2.15 \\
+6.86 \\
-3.86 \\
+1.61 \\
-1.23 \\
-1.31\end{array}$ & $\begin{array}{r}1,068 \\
212 \\
32 \\
20 \\
22 \\
103 \\
2 \\
27 \\
51\end{array}$ & $\begin{array}{r}69.5 \\
13.8 \\
2.1 \\
1.3 \\
1.4 \\
6.7 \\
0.1 \\
1.8 \\
3.3\end{array}$ & $\begin{array}{r}1,073 \\
502 \\
45 \\
20 \\
50 \\
108 \\
4 \\
30 \\
58\end{array}$ \\
\hline Totals: & 353 & 100.0 & & 1,537 & 100.0 & 1,890 \\
\hline $\begin{array}{l}{ }^{1} \text { Excludes all } \\
\text { Freeman } 199 \\
{ }^{2} \text { Follows Sou } \\
{ }^{3} \text { Everitt }(197\end{array}$ & $\begin{array}{l}\text { cts in the } \\
\text { le } 15) \text {. } \\
77: 92-102 \\
8) \text {. Num }\end{array}$ & $\begin{array}{l}\text { wn catege } \\
\text { ove }+1.9\end{array}$ & $\begin{array}{l}\text { ut includes } 417 \text { artifacts } \\
\text { below }-1.95 \text { are signific }\end{array}$ & $\begin{array}{l}\text { om the } 19 \\
\text { it at } .05 \text { le }\end{array}$ & testing (se & yd and \\
\hline
\end{tabular}

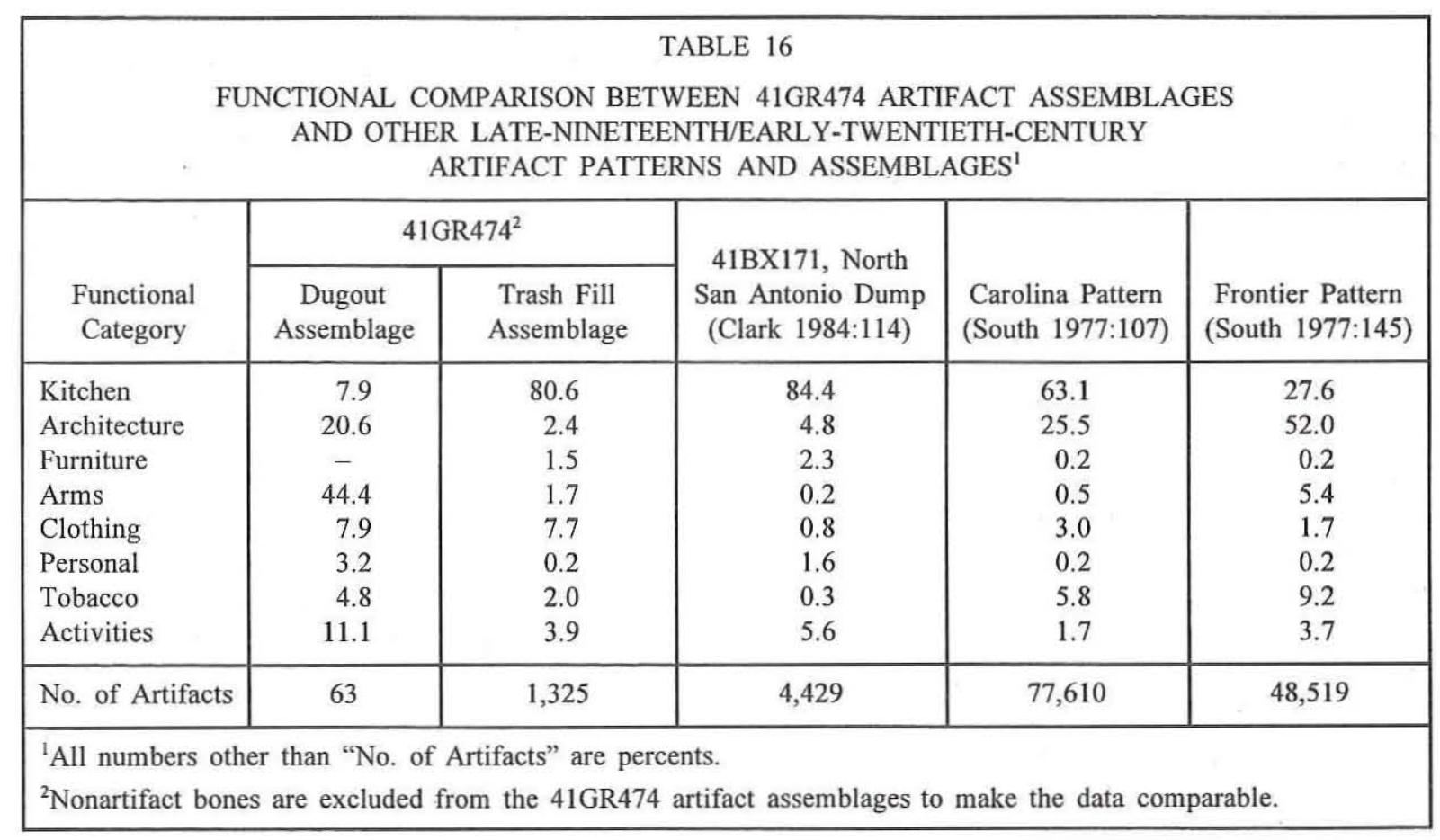


for example, with an early-twentieth-century assemblage from a North San Antonio dump (Clark 1984). Although the San Antonio site was a community dump and contained refuse from many households, the types and frequencies of items discarded were similar to the single-household debris represented in the trash fill assemblage in the Justice dugout. The Justice dugout assemblage does not compare favorably with the post- 1900 trash fill assemblage or the twentieth-century San Antonio dump assemblage. It also is quite different from the Carolina and Frontier artifact patterns, except that the high frequency of arms artifacts is similar to the latter pattern. The dugout assemblage is so unusual, in fact, that Boyd (1994:200-204) interpreted it as evidence that the structure was reused for specialized, multifunctional tasks after its initial abandonment as a dwelling.

The artifacts found lying directly on the floor of the dugout represent the latest occupation/use episodes prior to use for trash disposal and include the following: a few scattered bones; two tin cans and a tin cup; wagon parts, an iron bolt, an axe head, and an unidentified iron object; two square nails and two horseshoe nails; a harmonica reed plate; a metal bottle closure; and four cartridge cases, eight primers, and two lead balls (see Boyd 1994:Figure 73). The floor features and artifacts suggest that the following activities may have taken place inside the dugout: butchering of domestic and wild animals and smoking of meats; storage/repair of ranching equipment, horse tack, and tools; and reloading of cartridges. These activities are not consistent with expectations of domestic activities inside a dwelling. In particular, one would not expect fireplace ashes or butchered animal remains to have been discarded inside when the Justice family was still living in the dugout. One logical interpretation of this physical evidence is that much of the cultural material represents activities that occurred after the dugout was abandoned as a dwelling. Based on interpretations of fill stratigraphy, architectural details, and the kinds and distribution of artifacts, the following sequence of events is proposed for the postabandonment history of the Justice Dugout. The dugout ceased to function as a dwelling in 1906/1907 when the Justice family moved into their new ranch house. The structure was subsequently reused as a multifunctional workshop for a brief time, perhaps only a few years or less. During this time, the 8- to 10-year-old wooden roof began to deteriorate rapidly, but little effort was put into maintaining the structure as new outbuildings were constructed. Being located over $120 \mathrm{~m}$ north of the new house and related facilities, it simply became impractical to continue using the dugout. The structure became so unstable and dangerous that its secondary use was finally terminated. The deteriorated wooden roof then collapsed onto the floor of the dugout. It is possible that blow sands immediately began to fill the structure at this time, or that much or all of the lower fill sands were derived from a sod-covered roof. Lacking the protection of a superstructure, the upper rock walls quickly eroded and collapsed into the structure. Several large sections of the stacked rocks apparently toppled into the depression in inverted positions, with the uppermost rocks ending up in the lowest central portion of the structure (see Figure $21 b$ ). An alternative interpretation to this natural collapse scenario is that the Justices salvaged some structural materials from the dugout and then intentionally collapsed what remained of the roof and rock walls to eliminate the potential dangers of an unstable structure. After the complete collapse of the structure, the depression was exposed and continued to fill with blow sand. Sediments in the lowest portion of the depression were occasionally reworked by water that stood for short periods of time after rains. The Justice family, then living in the ranch house, began to use the old dugout depression as a trash dump. A wide variety of trash, ranging from a large quantity of household items (e.g., broken kitchenware ceramics, glass containers, and tin cans) to a nearly complete windmill (mechanism and blades), was discarded between the 1910s and 1930s. Even the use of the dugout depression as a trash dump ceased during the late 1930s or 1940s, and the existence of the dugout began to fade in peoples' memories.

\section{BRIEF HISTORY OF THE TEXAS PANHANDLE-PLAINS AND REVIEW OF HISTORIC SITES INVESTIGATIONS}

The following is not intended as a comprehensive history of the region or the project area; these tasks have already been accomplished. The reader is referred to Rathjen (1973) for a historical overview of the Panhandle region and to Freeman (1989) and Freeman and Boyd (1990) for detailed histories of the western Rolling Plains and the project area. 
This section also does not attempt to present a comprehensive review of all known historic sites and investigations that have been done in the Texas Panhandle-Plains. This section does summarize historic sites investigations that have been done in the Texas Panhandle-Plains, within a chronologically and topically oriented historic overview.

While there has been widespread local interest in historic sites of all types, and a number of comprehensive architectural surveys of urban areas have been conducted in the Panhandle-Plains region, historic sites are less well represented in archeological literature. Many historic sites are recorded in site files at the Texas Archeological Research Laboratory in Austin and at various museums across the region, but they are not documented in archeological publications. Synthesizing all recorded historic architectural and archeological sites is beyond the scope of this study. As a result, the sites discussed are, for the most part, reported in cultural resource management literature resulting from specific undertakings. The extensive files of the National Register and Architectural Divisions of the Texas Historical Commission are not represented here, and site files at area museums and statewide site files were not consulted. On the other hand, some unpublished investigations and other data sources are mentioned.

Just as historic sites are underrepresented in survey-level archeological literature, so also they are described only infrequently in literature reporting the results of intensive investigations. As reflected in Fox's (1983) overview of historic archeology in Texas, Hays et al.'s (1989) overview of historic archeology in the Southern Plains, and Moore and Moore's (1986) historic archeological bibliography for Texas, it is clear that historic resources in the Texas Panhandle-Plains region have received little attention from the archeological community. While county histories, county museum publications, and National Register surveys and nominations point to an abundance of historic sites in the area, the archeologically focused bibliography by Moore and Moore (1986) cites only four reports published as of ca. 1985 that contain information about historic sites in the 26 counties comprising the Texas Panhandle. The handful of historic site investigations undertaken in the region since then has not appreciably changed the extent to which historic sites appear to be underreported, and they have done nothing to synthesize or integrate the data available from other kinds of inventories and reports.

$$
\begin{aligned}
& \text { Euro-American Exploration, Expansien, } \\
& \text { and Conflict with Native Americans, } \\
& 1540-1870 \text { s }
\end{aligned}
$$

The three centuries following the appearance of Spanish explorers in the southwestern United States were a time of significant change for Europeans and Native Americans alike. During these three centuries, Europeans expanded their power and control over all of the area that now make up the western United States. Concomitantly, Native Americans saw their power and control over their own lives dwindle and disappear under the wave of EuroAmericans that swept the North American continent. What began as explorations of unknown territories eventually led to extensive conflicts among all the cultures involved. The ultimate struggle for control of the New World was not between the white invaders and the native peoples, for the outcome of those conflicts was inevitable. Rather, the true struggle for control was among the various European powers-Spain, France, and England-and the colonies of settlers they spawned. The Southern Great Plains played a pivotal role in these power struggles and in the cultural evolution of the United States.

The earliest Spanish exploration of the area that now encompasses the Texas Panhandle-Plains was Coronado's entrada into the American Southwest in 1540-1542 (Bolton 1949). Coronado led a group of Spanish explorers and Pueblo Indians across the Llano Estacado and into two barrancas, or canyons, that undoubtedly are located somewhere along the Caprock Escarpment (Rhodes 1992). This was the first encounter between local Native Americans and Europeans, but precisely where the expedition went in Texas and what native cultures they encountered are the subject of much debate. Skeels (1972:Figure 4), for example, illustrates five different routes for the Coronado expedition that have been proposed by various researchers. A probable Coronado campsite has been identified in New Mexico (Hordes 1992; Vierra 1989, 1992), but no Coronado sites have been positively identified in Texas. Researchers have speculated on what kinds of artifacts might be associated with the Coronado expedition and suggested some possible locations of Coronado campsites (Flint 1995; Hoyt 1992; Rhodes 1992). Palo Duro Canyon has long been thought to be the 
location of one of the barrancas encountered by Coronado, but no substantive evidence has been found to confirm this. There have been some tantalizing Coronado-period historic artifacts (e.g., a chainmail gauntlet and vest, numerous crossbow bolt heads) found in unsystematic collections made over many years at a series of sites along the White River in Blanco Canyon. Recent investigations have led several researchers (Blakeslee 1994, 1996; Jack Hughes, personal communication 1994; Word 1994) to the conclusion that this portion of Blanco Canyon, ca. $90 \mathrm{~km}$ northeast of Lake Alan Henry in Floyd County, is the location of one of the long sought after barranca camps of the Coronado expedition.

Between 1542 and 1830, parts of the Panhandle-Plains were traversed by Spanish, French, and Anglo-American explorers and travelers (Skeels 1972:Figures 4, 5, and 6). Traffic through the area increased dramatically after New Mexico Governor Juan Bautista de Anza negotiated a long-lasting peace with Plains Indians at Pecos Pueblo in 1786 and Spanish colonists established permanent settlements along the Pecos River (Levine and Freeman 1982:2, 4). Numerous expeditions of Spanish traders (comancheros) and hunters (ciboleros) traveled from the Pecos to Comanche trading and buffalo hunting grounds in the Panhandle-Plains area; encounters between the European and Native American groups were recorded in 1805,1810 , and 1814, particularly in the region of present-day Borden County (Levine and Freeman 1982:199, 202-203, 207, 226). In addition, tentative trade routes opened between San Antonio and Santa Fe when Pedro Vial and Jose Mares made trips through Comancheria. AngloAmericans are known to have explored the same area, where they encountered groups of comancheros (Levine and Freeman 1982:102, 226). Between 1817 and 1819, David G. Burnet traveled to and explored the headwaters of the Colorado River, while Major Stephen H. Long explored the Canadian River in 1830, and Stephen F. Austin's map of 1829 clearly depicted key landmarks in the PanhandlePlains region (Levine and Freeman 1982:22, 33; Rathjen 1973:83, 104-144).

Levine and Freeman (1982:9) contend that comanchero sites on the Plains are elusive because no one is quite sure what they should look like, especially sites that were not semipermanent settlements. They suggest that in order to find archeological remains of comanchero activities, one must look for nineteenth-century Plains Indian encampments in areas where such activities are documented. They provide a good summary of probable nineteenthcentury Plains Indian archeological localities (i.e., tepee ring sites, open sites with historic Indian components, and historic Indian burials) that are in the site files of the Panhandle-Plains Historical Museum. Similarly, archeological localities representing temporary European presence are difficult to find, and there are few known archeological sites associated with pre-1830 European and/or EuroAmerican explorations in the Panhandle-Plains.

Conversely, many Native American rock art images in the Panhandle-Plains may depict European exploration and settlement witnessed by Plains Indians (see Chapter 6). Two examples of such depictions are (1) a Spanish priest depicted at the Lake Alan Henry site called Huddleston Shelter; and (2) the Spanish missions and priest petroglyphs at the nearby Garza County site of Cowhead Mesa. Bilbo (1986) speculates that the Cowhead Mesa images depict a Plains Indian raid on a Spanish mission/settlement.

Between 1830 and ca. 1876, interest in and traffic through the Panhandle-Plains area intensified as comanchero trade and cibolero hunting continued and Mexican sheepmen (pastores) sought new pastures. In addition, American traders, businessmen, and immigrants traversed the area; and the U.S. military was called on to explore the region and then provide protection to citizens moving through it or desiring to settle within its boundaries. After 1850, tensions heightened not only between Euro-American and Native American groups but also between Euro-American and European natives of New Mexico where trade with Comanche and other Southern Plains tribes began to have an impact on populations to the east and south. By the time of the Civil War, comancheros had expanded their endeavors to include supplying guns and whiskey to the Indians in exchange for stolen livestock and even captives taken in raids. The New Mexicans soon acquired the reputation of being ruthless traders who encouraged Indian raiding. In its attempt to subdue the Plains Indians, the U.S. Army also found it necessary to pursue the comancheros, but their efforts were largely unsuccessful. However, a combination of factors - primarily the decimation of the buffalo herds by Anglo hunters and the removal of the Southern Plains tribes to reservations in Oklahoma-eventually brought the comanchero trade to an abrupt end in the mid 1870s (Levine and 
Freeman 1982:8).

The approximate locations of many comanchero trade routes and sites in the Panhandle-Plains are summarized by Haley (1935), Levine and Freeman (1982), and Levine (1983). New Mexican villages that are known to have been connected with the comanchero trade are documented archeologically, but sites in Texas are elusive. Despite the many trading areas documented in archival records, only one comanchero site in Texas has been investigated archeologically. Investigations of the Merrell-Taylor Village site (41FL19) in Floyd County are reported by Guffee (1976). Archival research and excavations of four dugouts produced evidence indicating that the site was occupied originally by comancheros, who may have constructed the dugouts as early as 1865 and used them for about 10 years. After ca. 1875, the site apparently was occupied by Mexican buffalo hunters, or ciboleros, and sheepherders, or pastores. Many of the artifacts and some features, an acequia in particular, are probably associated with the sheepherding occupations rather than the traders. Regardless, there is good evidence that the Merrell-Taylor Village site is the semipermanent comanchero trade settlement on "Los Lengus" [sic] creek that was seen by an Anglo buffalo hunter in 1875 (Guffee 1976:51).

A second habitation site possibly occupied by comancheros has been reported by Guffee (1980), and archeological investigations suggest that the Soda Lake Ruins might have been used by traders. More recently, an archival and archeological study has been specifically aimed at identifying locations of nineteenth-century Plains Indian villages and/or comanchero sites. Privately funded work has concentrated on the well-documented Mucho Que trading locality, located about $40 \mathrm{~km}$ southwest of Lake Alan Henry in Borden County (Don Dorward, personal communication 1995). Detailed maps and records of U.S. Army campaigns led by Colonel Ranald Mackenzie from 1871 to 1876 have been utilized to pinpoint likely locations of Indian encampments frequented by comanchero traders. About a dozen or so probable encampment sites in Borden County have been identified, most within about 12 miles of the Mucho Que peaks. Subsequent field checking has confirmed that historic Indian sites exist at some of these locations, but landowner access has prevented field investigations of some of the most important sites. This study is continuing at present and nothing has been pub- lished, although an unpublished manuscript summarizing some of the preliminary findings has been prepared (Dorward and Meltzer 1995).

Continued comanchero activity in the Panhandle-Plains region was paralleled by increasing Anglo-American commercial and military activity. Traders and explorers such as Josiah Gregg (1831 and 1839), Albert Pike (1832), members of the Texan Santa Fe Expedition (1841-1842), and Joseph Eldredge (1843), were followed by Lieutenant James W. Abert (1845), Captain Randolph B. Marcy (1849 and 1852) and Lieutenant J. H. Simpson (1849), Lieutenant A. W. Whipple (1853), and J. E. Weyss (1857-1860), who traversed the area and described the land and its inhabitants (Levine and Freeman $1982: 39,59,69,121,128,173,174,176)$. Accounts of these expeditions, most of which sought to explore major river systems or seek cross-country routes for the construction of roads or railroads, are numerous (e.g., Archambeau 1954, 1971; Carroll 1941; Foreman 1939; Galvin 1966; Goetzmann 1959; Gregg 1954; Marcy 1853; Parker 1984). They provide very useful information on the environment, ecology, and native peoples of the Panhandle-Plains region. As with the Mexican and Republic of Texas periods, however, the period of Anglo-American exploration is documented primarily in the archives.

With few exceptions, the Panhandle-Plains was largely uninhabited by Anglo-Americans prior to ca. 1880 (see Fox 1983:Figure 7.1). As a result, archeological remains of Anglo-American activities dating to the first three-quarters of the nineteenth century are quite rare. To the authors' knowledge, no sites representing encampments of early AngloAmerican explorers in the Panhandle-Plains have been confirmed by archival and archeological investigations. However, remains of the old Fort Smith-Santa Fe trail traveled by Gregg in 1840 and by Marcy in 1849 may be seen in some parts of the northern Panhandle (Rathjen 1973:photo ff. p. 128). Rathjen (1973:123) estimates that as many as 2,000 travelers may have followed this southerly route to Santa Fe in 1849 alone. Notably, an inscription that reads "USR JUNE 6, 1849" was found at Lake Alan Henry rock art site 41GR333. With backwards letters " $\mathrm{N}$ " and "S" common to the period, the inscription could be associated with early military exploration of the region. However, no military expeditions are known to have gone through this area in 1849. In addition, the rock art site at Rocky Dell in Oldham County was visited by Whipple in 
1853 (see Chapter 6), but despite his having spent enough time to record the Native American art there, no archeological remains of a campsite associated with this railroad reconnaissance expedition have been found.

The 1860 s and early 1870 s in the Texas Panhandle are described by Rathjen (1973:177-227) as the period of military conquest. With the assistance of the U.S. military, Anglo-American settlement spread from the Cross Timbers and southward from the Central Plains. By the late nineteenth century, only the Native Americans on the Southern Plains remained as a serious impediment to progress. Conflicts between the Plains Indians and the encroaching Anglo-American settlers in the Plains states predictably led to intervention by the U.S. Army.

Intensive campaigns to contain and confine the nomadic peoples of the Southern Plains were launched by the U.S. military in the 1860 s and 1870 s. Although there were countless minor clashes involving nonmilitary Anglos in the Texas PanhandlePlains, such as the 1874 Battle of Adobe Walls (Baker and Harrison 1986), it was the progressive disappearance of the buffalo and the relentless pursuit of the Army that ended the Plains equestrian bison hunting lifestyle.

Much has been written about the history of the military conquest of the Southern Plains (see Rathjen 1973:177-227). The final blow to Native American groups was a series of military campaigns led by Captain Ranald S. Mackenzie and others against the Southern Plains tribes between 1871 and 1876. The final showdown was the campaign of 1874 , often referred to as the Red River Wars (Rathjen 1973: 206-224, Figures 5 and 6). At that time, the Texas Panhandle was surrounded by a ring of forts in north- and west-central Texas, New Mexico, Kansas, and Colorado. Among the closest military posts were Forts Concho, Griffin, Belknap, and Richardson, which formed part of the "western line of defense" in Texas (Fox 1983:Figure 9.1). There was not a single military post inside the Panhandle-Plains region, and the U.S. Army knew that the last sizable groups of hostile Comanches, Kiowas, and Cheyennes would settle into the secluded canyonlands there for the winter. Columns of troops were simultaneously sent out of Forts Union in New Mexico, Dodge in Kansas, Sill in Oklahoma, and Concho and Richardson in Texas to converge on the headwaters of the Red River. A series of battles ensued, but the campaign culminated on September 8, 1874, when Mackenzie's 4th Cavalry troops attacked a large village on the Palo Duro. During the Battle of the Palo Duro, the entire village and its food supplies were destroyed, and a large herd of horses was captured. Having learned his lesson in 1872 when Indians recaptured their horses on the evening following another battle, Mackenzie proceeded to a safe location in Tule Canyon and ordered that 1,050 Indian ponies be shot. This coup de grace was devastating. The Army spent the next two months conducting cleanup operations in the Texas Panhandle, rounding up almost all of the hostile Indians and returning them to their Oklahoma reservations.

Archeologically, there are few known sites associated with the Indian wars in the Southern Plains except for military posts and a few battle sites. There have been numerous archeological investigations of many military sites in western Oklahoma, such as the archeological reconnaissance of Fort Sill (Ferring 1978) and the excavation of a trash dump there (Spivey et al. 1977:25-166), excavations of trash dumps at Fort Supply (Briscoe 1989b, 1992), and excavations at the Kiowa and Comanche Indian Agency commissaries (Crouch 1978). In Texas, archeological investigations have been done at Forts Concho (e.g., Mobley 1976), Griffin (e.g., Fox 1976), and Richardson (e.g., Ippolito 1977). Locations of U.S. Army-Plains Indian battles have not been studied archeologically to any extent, and nothing comparable to the detailed archeological investigations of the site of the 1876 Battle of Little Bighorn (Fox 1993; Scott et al. 1989) has been attempted at a Southern Plains battle site. The investigations by Baker and Harrison (1986) at Adobe Walls, the site of a Plains Indian battle with civilian buffalo hunters in 1874 , are the only exception. The approximate locations of some military sites in the Texas Panhandle-Plains, such as those of the Battle of the Palo Duro and the Tule Canyon horse slaughter, have long been known (see Rathjen 1973:Figure 6). However, no serious archeological investigations have been undertaken. Uncontrolled excavations at one important military site, that of Mackenzie's 1871-1874 supply camp in Blanco Canyon (see Rathjen 1973:202), have produced a collection now housed at the Crosby County Pioneer Memorial Museum. A brief summary of the work is reported by Parker (1979), who recorded the locality as site $41 \mathrm{CB} 1$. Subsequent to this work, 
this supply camp was listed in the National Register of Historic Places in 1984 (Seaman 1984).

Little data are available on actual military sites, but the 4th U.S. Cavalry Memorial Reenactors group, based out of Lubbock, Texas, has begun systematically investigating trails, camps, graves, and skirmish and battle sites associated with Colonel Mackenzie's 1871-1876 campaigns in the PanhandlePlains (Jimmy Northcutt, personal communication 1995). Using the military records of campaigns, the group is retracing old routes to locate the archeological remains of these sites.

Some Native American archeological and rock art sites may be associated with the Indian wars in the Southern Plains. Many of the Plains Indian burials found in the region apparently date to the 1860s and 1870s (see Taylor 1995b; Word and Fox 1975), but one in particular is quite interesting. Burgan (1992) presents intriguing evidence that links a historic Indian burial found in Palo Duro Canyon in 1901 with K'ya-been, a Kiowa man who was killed at the Battle of the Palo Duro. Burgan further speculates that Native American pictographs found nearby, at the Giant Boulder Site F (PPHM-A670) reported by Upshaw (1972:76, 85-89), could be an Indian depiction of the 1874 battle. Similarly, Parsons (1987) interprets petroglyphs at the Verbena site in Garza County as a Comanche or Kiowa depiction of an unknown battle with Anglo-Americans, probably soldiers (see Chapter 6).

\section{Development of a Post-Contact Cultural Landscape, 1870s-1945}

Once it was under full control of the United States, the Southern Plains was opened up for settlement, and the U.S. Army directed most of its attention toward the hostile tribes in the Northern Plains and western territories. The military maintained a presence in the Panhandle-Plains after the Red River Wars, and Fort Elliot was established in the northern Texas Panhandle in 1875 to help keep the Plains Indians confined to the Oklahoma Indian Territory. The Army continued to police the Panhandle until Fort Elliot closed in 1890, but the region was rapidly settled during the preceding decade (Rathjen 1973:225-227). For all practical purposes, the entire region was left wide open for exploitation and economic development after organized Native American resistance ended in 1874.
Buffalo hunting, followed immediately by ranching, farming, railroad construction, and town building, were the most widespread and viable economic ventures immediately available to Panhandle-Plains entrepreneurs.

\section{Buffalo Hunting}

Commercial buffalo hunting began in the Panhandle in the early 1870 s and spread to the Rolling Plains after 1874 (Freeman 1990a; Rathjen 1973:145-176). As a commercial business, buffalo hunting in the Panhandle-Plains lasted only a brief time, from ca. 1872 to 1879 , but activities were particularly intense. The demand for hides spurred widespread competition among hunters, who in turn slaughtered animals as fast as they could manage. The once-vast herds on the Southern Plains rapidly decreased in size and had all but disappeared by 1879.

The history of the exploitation of the buffalo as an economic venture has been developed into a historic context by Freeman (1990a). Under the thematic heading of "Natural Resources Exploitation and Development," the context "Buffalo Hunting on the Rolling Plains, 1874-1879" was compiled in conjunction with historic archeological research at Lake Alan Henry. Although no context exists for contemporaneous buffalo hunting in the Panhandle or on the southern Llano Estacado, parts of this context are applicable to these areas as well.

Freeman's context (1990a) details several ideas critical to understanding commercial buffalo hunting on the Great Plains: (1) the prevailing perception that buffalo were a superabundant resource that could be endlessly exploited; (2) the use of and demand for buffalo products (i.e., fur, hides, and meat); (3) the development of railroad transportation and markets that responded to that demand; (4) the development of processing technologies and the market shift from meat for consumption to hides for tanning; (5) the post-1860 systematic exploitation of buffalo and the development of a transportation and marketing infrastructure on the Plains; (6) the rapid decline in the buffalo population caused by intensive exploitation; (7) the geographic shifting of the buffalo hunting range to follow the dwindling herds; and (8) the sudden collapse of the industry on the Southern Plains with the virtual disappearance of buffalo in 1879. Historic records clearly document the demise of the great northern and southern herds 
on the Great Plains from countless millions of animals at the beginning of the nineteenth century to fewer than 100 animals in 1889 (Figure 22).

Property types within the buffalo hunting context may be classified into two groups based on the nature of the commercial industry (Table 17). Sites associated with the acquisition of the product were buffalo hunting stands, where the animals were killed, skinned, and butchered, and buffalo hunters' camps, where products were stockpiled and initially processed. Sites associated with the transportation and marketing of the product included trading posts and stores on the Plains where hunters sold their products and purchased supplies; trails and railroads used to transport the products on and beyond the Plains; and central markets, towns, and mercantile houses for marketing and distributing buffalo products beyond the Plains. Despite the fact that many individual buffalo hunting-related localities in the Southern Plains are documented in archival records, such as those shown in Figure 23 and summarized by Freeman (1990a:Table 4), few actual sites have been located. Archeologically investigated buffalo hunting sites in Texas include only two sites on the Rolling Plains and two in the Panhandle.

Most buffalo hunting camps are ephemeral. While some hunters constructed dugouts, many lived in small tepeelike tents or in wagons. The duration of occupation of such camps was short, and the amount of cultural material left behind was minimal. The investigations of a buffalo hunters' camp at Lake Alan Henry (41GR528) have been described. Thurmond et al. (1981:406-407) recorded a probable buffalo hunters' camp in King County (41KG61). Local tradition suggested that the partially exposed features at this site-a stone structure, a stone wall or corral, and a possible grave - are associated with have been investigated are Adobe Walls and Zulu Stockade. Extensive archival research and archeological excavations at Adobe Walls, a short-lived

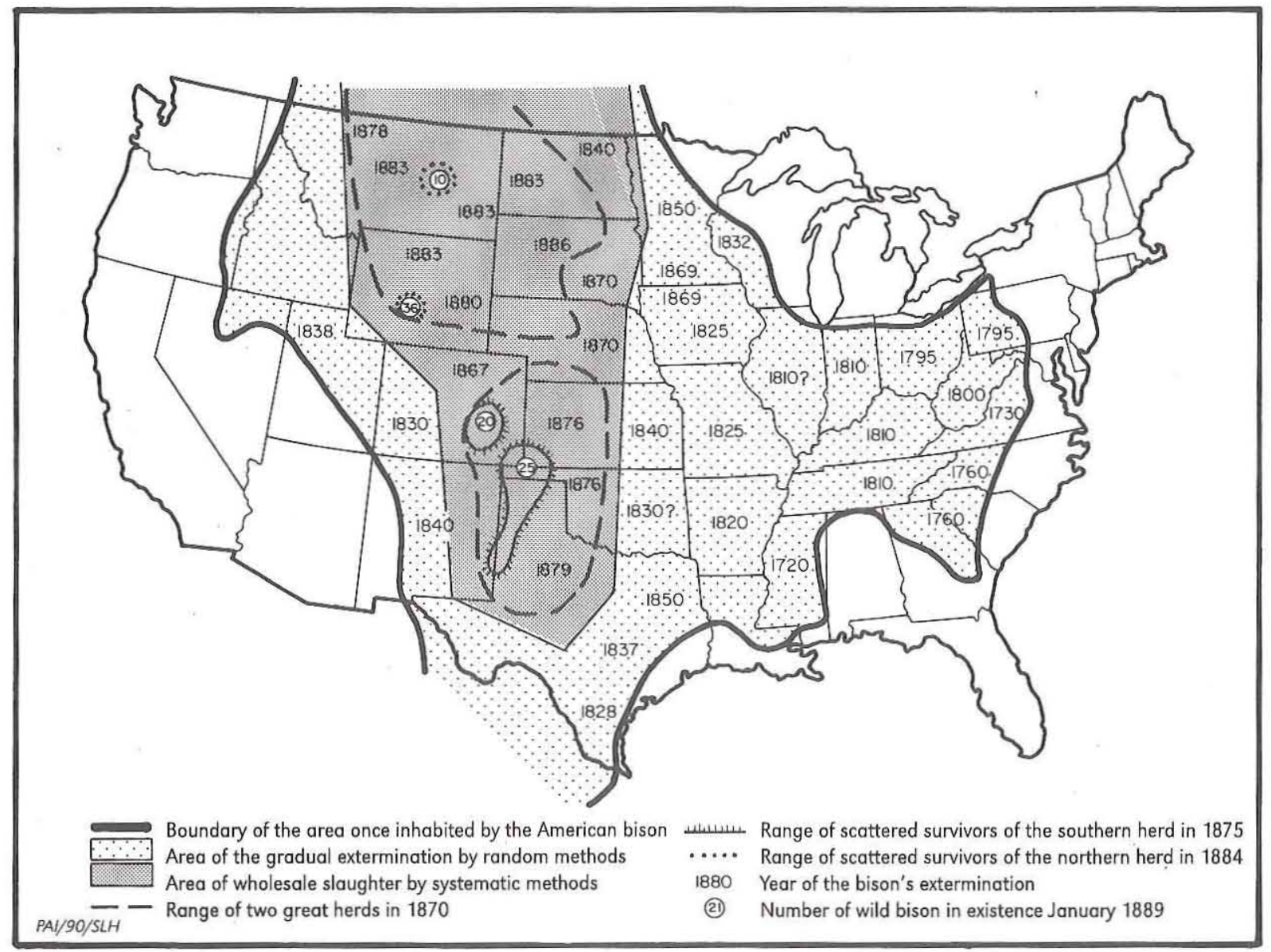

Figure 22. Historic range of the American bison; adapted from Hornaday (1971). 


\begin{tabular}{|c|c|c|}
\hline \multicolumn{3}{|c|}{$\begin{array}{l}\text { BUFFALO HUNTING ON THE ROLLING PLAINS, 1874-1879: } \\
\text { EXPECTED PROPERTY TYPES }\end{array}$} \\
\hline Property Type & Description & Examples \\
\hline Railroads & $\begin{array}{l}\text { Rail lines and railheads located in north-central } \\
\text { Texas in major trade centers; used to transport } \\
\text { buffalo products to eastern and midwestern } \\
\text { markets. }\end{array}$ & Texas and Pacific \\
\hline $\begin{array}{l}\text { Central Markets, } \\
\text { Towns }\end{array}$ & $\begin{array}{l}\text { Towns and cities located in north-central Texas } \\
\text { with direct access to major railroads; locations of } \\
\text { commercial businesses engaged in the buffalo trade } \\
\text { between the fall of } 1874 \text { and } 1879 \text {. } \\
\text { Towns located in west Texas with direct access to } \\
\text { major railroads; locations of commercial businesses } \\
\text { engaged in the buffalo and bone trade after } 1877 \text {. }\end{array}$ & $\begin{array}{l}\text { Denison } \\
\text { Forth Worth } \\
\text { Colorado City }\end{array}$ \\
\hline $\begin{array}{l}\text { Mercantile } \\
\text { Houses }\end{array}$ & $\begin{array}{l}\text { Commercial establishments located in north-central } \\
\text { Texas whose } 1874-1879 \text { income derived principally } \\
\text { from marketing of buffalo products and supplies } \\
\text { sold to hunting outfits. In most cases, owned by } \\
\text { merchants with business ties to other merchants in } \\
\text { Kansas. May have been located in forts at some } \\
\text { distance from the buffalo hunting range. }\end{array}$ & $\begin{array}{l}\text { A. S. Holland, Denison } \\
\text { Joseph H. Brown, Forth Worth } \\
\text { J. L. Hickey, Fort Worth } \\
\text { Frank E. Conrad, Fort Griffin }\end{array}$ \\
\hline $\begin{array}{l}\text { Trading Posts } \\
\text { and Stores }\end{array}$ & $\begin{array}{l}\text { Commercial establishments distant from towns } \\
\text { which provided supplies to hunters and purchased } \\
\text { hides and meat. Such posts often were operated } \\
\text { in conjunction with saloons; typical architectural } \\
\text { forms were dugouts made with poles and buffalo } \\
\text { hides, and sod and picketed structures. }\end{array}$ & $\begin{array}{l}\text { Rath City (Stonewall County) } \\
\text { Cornelius' Store (Scurry County) } \\
\text { Snyder's Store (Scurry County) } \\
\text { Dockum's Store (Dickens County) } \\
\text { Store and dance hall on Red Mud Creek } \\
\quad \text { (Dickens County) } \\
\text { Parrish Store (Dickens County) } \\
\text { Davis Store (Dickens County) }\end{array}$ \\
\hline $\begin{array}{l}\text { Hunting Outfits } \\
\text { and Camps }\end{array}$ & $\begin{array}{l}\text { Often ephemeral sites with or without architectural } \\
\text { features located at some as yet undetermined } \\
\text { distance from trading posts. Architectural features } \\
\text { included dugouts and smokehouses. Sites with } \\
\text { architectural components might include features } \\
\text { associated with tepeelike shelters. }\end{array}$ & $\begin{array}{l}41 \mathrm{KG} 61 \\
41 \mathrm{GR} 528\end{array}$ \\
\hline Stands & $\begin{array}{l}\text { Ephemeral sites up to several miles distant from a } \\
\text { hunting camp. Artifacts associated with shooting } \\
\text { and butchering activities might be present; these } \\
\text { would include ammunition, knife parts, and } \\
\text { evidence of butchered bones. }\end{array}$ & - \\
\hline
\end{tabular}

buffalo hunters, but this interpretation has not been confirmed. No surface artifacts were mentioned.

The two Texas Panhandle trading posts that buffalo hide trading post that was attacked by Plains Indians in 1874, have been reported by Baker and
Harrison (1986). The study of this Hutchinson County site represents the most intensive historic archeological effort in the Panhandle-Plains region, and it is particularly notable for its thoughtful integration of archival and archeological data. This 


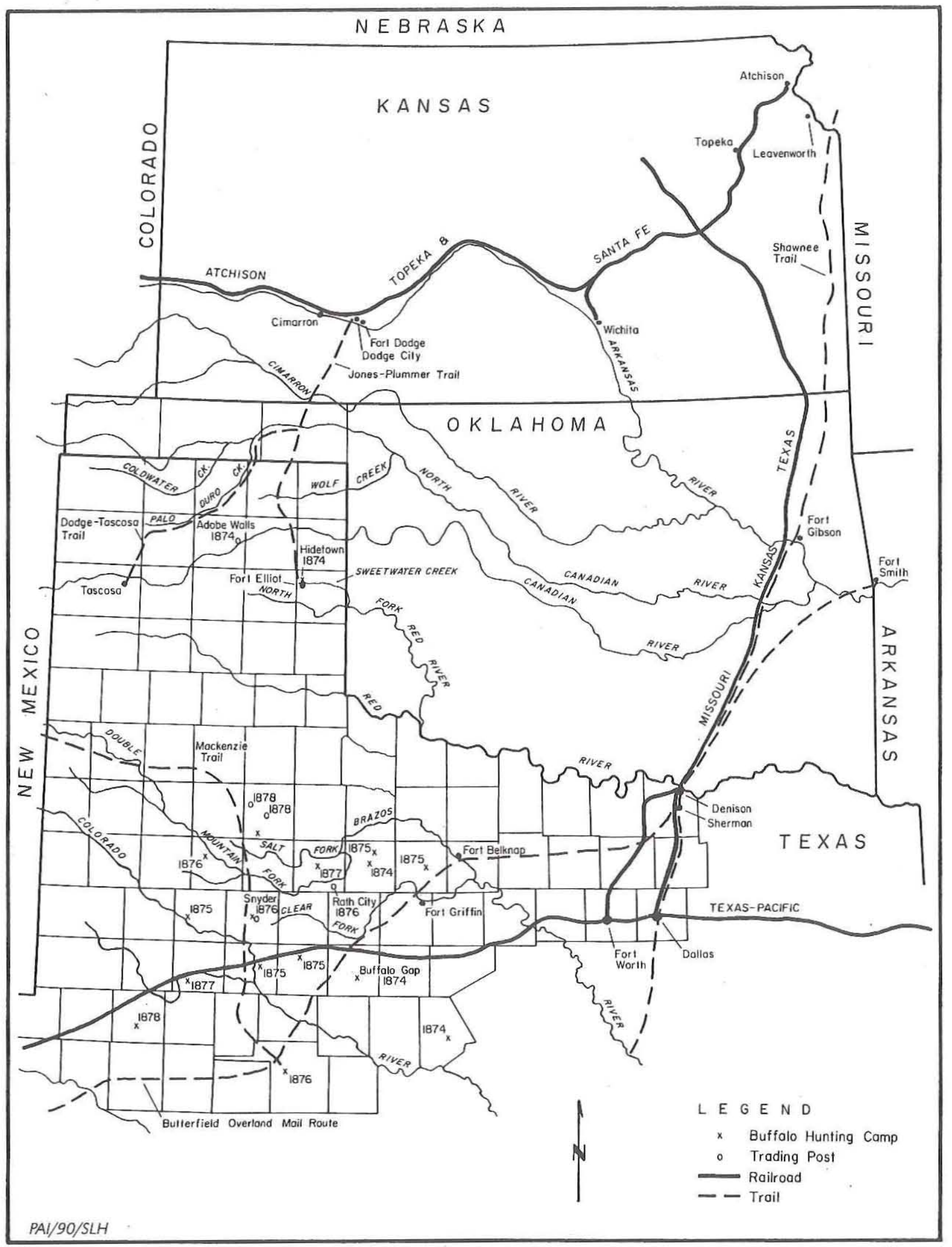

Figure 23. Historic features associated with the buffalo trade in the Southern Plains. 
is a landmark study in terms of buffalo hunting: the "1874 Adobe Walls site is the only known merchants' and buffalo hunters' trading post on the southern Great Plains to be excavated systematically" (Baker and Harrison 1986:289).

The Hansford County site called Zulu Stockade (PPHM-H113) also was investigated archeologically by the Panhandle-Plains Historical Museum. Limited test excavations were conducted there in 1981 and 1982, but the findings are not reported. Presumably named for its wooden stockade and the contemporary conflicts between the British and Zulu Nations, this trading post was established in 1875 by English buffalo hunter James Cator at one of his old hunting camps (Webb 1952:I:310). James Cator had moved south from Dodge City, Kansas, to hunt buffalo in the Texas Panhandle in 1872 , but he switched to trading when the intensity of hunting in the Panhandle increased dramatically. Situated along the old Tascosa-Dodge City Trail, Zulu Stockade was a location well suited to trading buffalo products.

\section{Hispanic Sheepherding}

As the buffalo and Plains Indians disappeared from the region, New Mexicans and Anglo-Americans simultaneously realized the potential benefits of ranching there. While Anglos primarily became cattle ranchers, Hispanic peoples who moved into the region were almost exclusively involved in sheepherding. Known as pastores, New Mexican sheepherders established small settlements or plazas in the Texas Panhandle beginning around 1876. By the time of the first federal census in 1880 , there were nearly 300 Hispanics living in the Texas Panhandle, primarily in the western portion of the Canadian and Red River valleys and along the Caprock Escarpment. In addition, the 1880 census indicated that sheep outnumbered cattle (Connor 1954:69; Guffee 1976:17-18; Rathjen 1973:102). Hispanic sheepherders spread throughout much of the PanhandlePlains region to take advantage of the free use of the rangeland. Sheepherding by New Mexican pastores lasted for less than a decade, however, because the General Land Office terminated the free use of state-owned Panhandle rangelands and began leasing them in 1884 (Havins 1960:30; Taylor et al. 1983).

At Lake Alan Henry, site 41GR443 contains a rock structure (possibly a half-dugout, or chosa) and corral that apparently were constructed by pastores prior to Anglo settlement in the area. Local informants confirmed that Mexican sheepherders were the first occupants of the site, and the features are typical of pastor sites in the Panhandle. Including 41GR443, 50 New Mexican pastor sites have been recorded archeologically in the Texas PanhandlePlains (Table 18). The largest group of sites was documented during archeological surveys for the Texas Historical Commission in 1979 (Taylor 1980) and 1983 (Taylor et al. 1983). Of ca. 41 pastor sites recorded or revisited during these surveys, 16 had sufficient archeological integrity to warrant nomination to the National Register of Historic Places in 1983 (Taylor et al. 1983). All of these sites were occupied by sheepherders in the 1870 s and 1880 s and were nominated under the thematic heading of "New Mexican Pastor Sites in the Texas Panhandle." These sites subsequently were listed in the National Register of Historic Places in 1984 (Steely 1984:179-181). Pastor sites are classified into the following property types by Taylor et al. (1983): permanent habitation sites, seasonal habitation sites, isolated pens, isolated stone walls, and acequia remnants.

Despite the archival evidence for intensive Hispanic sheepherding and the initial documentation of many archeological sites associated with pastores, only one such site has been thoroughly investigated. Guffee (1976) reported the archeological excavations of four dugouts at the Merrell-Taylor Village site (41FL19) in Floyd County. He concluded that they were probably built and originally used by comancheros. The occupants (ciboleros) may have done some buffalo hunting also, but it is likely that the hunts were done for subsistence rather than commercial purposes. Much of the archival and archeological evidence points to intensive use of the location by pastores. The presence of an acequia indicates that the settlement was semipermanent and suggests that some horticulture was practiced. Other material culture (i.e., a Spanish lance blade and micaceous Taos pottery) provides evidence that the occupants were of New Mexican origin. In addition, unlike Anglo dugouts which featured central fireplaces centered along back walls, the three habitation dugouts at the Merrell-Taylor Village site had Mexican-style corner fireplaces.

Guffee (1980) reported on archeological investigations at one other site that may have been occupied by pastores. The Soda Lake Ruins, located in the sandhills near Blackwater Draw in Lamb County, 
TABLE 18

SUMMARY OF NEW MEXICAN PASTOR SITES IN THE TEXAS PANHANDLE-PLAINS

\begin{tabular}{|c|c|c|c|c|}
\hline County & \multicolumn{3}{|l|}{ Sites } & Reference \\
\hline Armstrong & 41AM5* & \multicolumn{2}{|l|}{ 41AM6* } & Taylor et al. 1983 \\
\hline Deaf Smith & \multicolumn{3}{|l|}{$41 \mathrm{DF} 12$} & Taylor et al. 1983 \\
\hline Floyd & 41FL19 & \multicolumn{2}{|l|}{$41 F L 62 *$} & Guffee 1976; Taylor et al. 1983 \\
\hline Garza & \multicolumn{3}{|l|}{$41 \mathrm{GR} 443$} & Boyd et al. 1989:140, 609-611 \\
\hline Hartley & $\begin{array}{l}\text { 41HT13* } \\
\text { 41HT17* }\end{array}$ & $\begin{array}{l}41 \mathrm{HT} 15 \\
41 \mathrm{HT} 20\end{array}$ & $\begin{array}{l}41 \mathrm{HT} 16 \\
41 \mathrm{HT} 21\end{array}$ & Taylor et. al. 1983 \\
\hline Hutchinson & $41 \mathrm{HC} 105$ & \multicolumn{2}{|l|}{ PPHM-A114 } & Taylor et al. 1983; Bousman 1974b \\
\hline King & \multicolumn{3}{|l|}{$41 \mathrm{KG} 19$} & Etchieson et al. 1979:243-246 \\
\hline Lubbock & \multicolumn{3}{|l|}{$41 \mathrm{LU} 48$} & Taylor et al. 1983 \\
\hline Oldham & $\begin{array}{l}41 \text { OL50* } \\
41 \text { OL247 } \\
41 \text { OL250* } \\
41 \text { OL256* } \\
41 \text { OL262 } \\
41 \text { OL266 } \\
41 \text { OL268 } \\
41 \text { OL271 } \\
41 \text { OL274 } \\
41 \text { OL277 }\end{array}$ & $\begin{array}{l}41 \text { OL235* } \\
41 \text { OL248 } \\
41 \text { OL253* } \\
41 \text { OL257* } \\
41 \text { OL263 } \\
41 \text { OL266 } \\
41 \text { OL269 } \\
41 \text { OL272 } \\
41 \text { OL275 }\end{array}$ & $\begin{array}{l}41 \text { OL246* } \\
41 \text { OL249* } \\
41 \text { OL254* } \\
41 \text { OL259 } \\
41 \text { OL264 } \\
41 \text { OL267 } \\
41 \text { OL270 } \\
41 \text { OL273 } \\
41 \text { OL276 }\end{array}$ & $\begin{array}{l}\text { Taylor et al. 1983; } \\
\text { Marmaduke and Whitsett 1975:93, } \\
\text { Figure } 18\end{array}$ \\
\hline Potter & $\begin{array}{l}\text { 41PT84* } \\
\text { 41PT88 }\end{array}$ & $\begin{array}{l}\text { 41PT85 } \\
\text { 41PT89 }\end{array}$ & $\begin{array}{l}\text { 41PT87* } \\
41 \mathrm{PT} 110\end{array}$ & Taylor et al. 1983 \\
\hline
\end{tabular}

consist of two sets of substantial rock ruins made of local caliche. One is a circular (ca. $39 \mathrm{ft}$ in diameter) corral with an attached rectangular double room that may have served as a storage area and chicken coop. The other consists of two adjoining rectangular rooms that are interpreted as a dwelling (with a central fireplace along one wall) and a workshop. A smaller probable third structure was not excavated, but four circular holes in a nearby caliche outcrop are interpreted as remnants of the bottoms of hand-dug water wells.

Based on the artifacts and architectural details, Guffee (1980:47-49) noted that the occupations dated to the late nineteenth century but ruled out the use of the site by buffalo hunters, mustangers, commercial wolf hunters, cattle ranchers, or cattle rustlers. He suggested that this site was occupied by a small group, possibly a single family, that was involved in small-scale farming (i.e., dune agriculture) and sheepherding. It is not clear whether the occupants were Hispanic or Anglo. The rock slab construction is reminiscent of pastor site architecture, but the material culture, dimensions of the buildings (in English units), and the location of the fireplace all suggest that the occupants were Anglos.

While Hispanic sheepherding sites may fall under the historic ranching contexts mentioned above, the associated archeological sites are different from those of Anglo sheep ranchers. The activities of all sheepherders were similar, but Hispanic sites generally exhibit characteristics that denote their ethnicity. The identifying characteristics have not been studied in detail, but there are differences in architecture and spatial patterning of structures, 
features, and activities that are probably peculiar to pastor sites. For example, the use of acequias for irrigation, corner fireplaces for heating and cooking, occasional use of adobe blocks for construction, and the tendency for some permanent habitations (i.e., small villages) to be laid out around a central plaza are particularly diagnostic of pastor sites (Taylor et al. 1983). In addition, the system of sheep raising used by pastores in the Texas Panhandle may be unique to that area. The New Mexican herders established migratory circuits along the Canadian and Red Rivers, moving their herds seasonally throughout the region following cycles of lambing and shearing (Freeman 1990b:64; Taylor 1980:20-21).

\section{Ranching and Farming}

Many hunters who suddenly found themselves out of work when the buffalo disappeared in 1879 turned to ranching. Once the exclusive domain of the buffalo, the empty expanses of rangeland were perfectly suited to grazing cattle and sheep. Ranching became the primary occupation of PanhandlePlains residents during the late 1870 s and 1880 s and remained the dominant industry employing most people into the twentieth century. Crop raising began on a small scale due to the need for selfsufficiency at isolated ranches and became increasingly important through time. Due largely to the introduction of new pumping technologies that facilitated the development of ground water irrigation, farming developed into one of the region's most productive commercial industries shortly after 1900.

Initially, ranching took the form of sheepraising by New Mexican Hispanic immigrants who mainly utilized the western half of the Canadian River valley. Later, Anglo-American ranchers and European investors raised sheep, hogs, and cattle. Cattle ranching became the dominant form of ranching throughout the region by 1890 . During the early stages of the industry's development, large ranches were established to run livestock on the open range. However, subsequent legislation, particularly in the form of the Four-Section Act of 1895, promoted permanent settlement throughout the region. In some cases, passage of the Four-Section Act together with the economically devastating impact of the national Panic of 1893, led to the disappearance of the open range and the breakup of large ranches. Land then became available to smaller operators and to the thousands of new immigrants brought to the Panhandle-Plains region by land and railroad agents. In other cases, ranch owners and employees cooperated to circumvent the intent of the Four-Section Act. Hands filed claims that subsequently were bought out by their employers. In cases where water was readily available and soils and climate were appropriate, some operators who had focused on livestock diversified their economic pursuits and began growing and selling alfalfa, wheat, cotton, vegetables, and fruits which they marketed to rapidly developing urban centers via a growing system of railroads.

The intensive exploitation of abundant rangelands by ranchers and farmers has been used as the topic for development of two historic contexts for different parts of the Panhandle-Plains region. For the Lake Alan Henry project, Freeman (1990b) developed a context under the broad thematic heading of "Agriculture in Texas" entitled "Ranching on the Western Rolling Plains, 1877-1945" (see Chapter 4). Archival records document dozens of ranches on the western Rolling Plains, the vast majority of which were cattle ranches. Their locations are shown on Figure 24, and they are summarized by Freeman (1990b:Table 7). Property types associated with cattle ranching in this context area are identified as ranching headquarters and line camps, the latter being associated mainly with openrange ranching. Historic records identify over 100 such sites in the six-county area of Dickens, Crosby, Garza, Kent, Scurry, and Borden Counties. While dwellings made of wood, stone, and earth are associated with ranching sites, earthen dugouts are identified as the type of structure most commonly associated with both ranching headquarters and camps. Freeman (1990b:Table 6) summarizes the archival data on dugouts (locations, environmental settings, and descriptions) in the western Rolling Plains.

At Lake Alan Henry, the vast majority of historic archeological sites are associated with ranching (see Table 11). Seven ranching sites41GR263, 41GR392, 41GR443, 41GR474 (discussed above), 41KT42 (discussed above), 41KT84, and $41 \mathrm{KT} 150$ - consist of or contain components that are associated with open-range ranching prior to ca. 1900. Of the seven sites, one (41GR443) was probably a pre-1880 Hispanic sheepherding camp that was reused by Anglo ranchers during the openrange period, and two were occupied only during the 


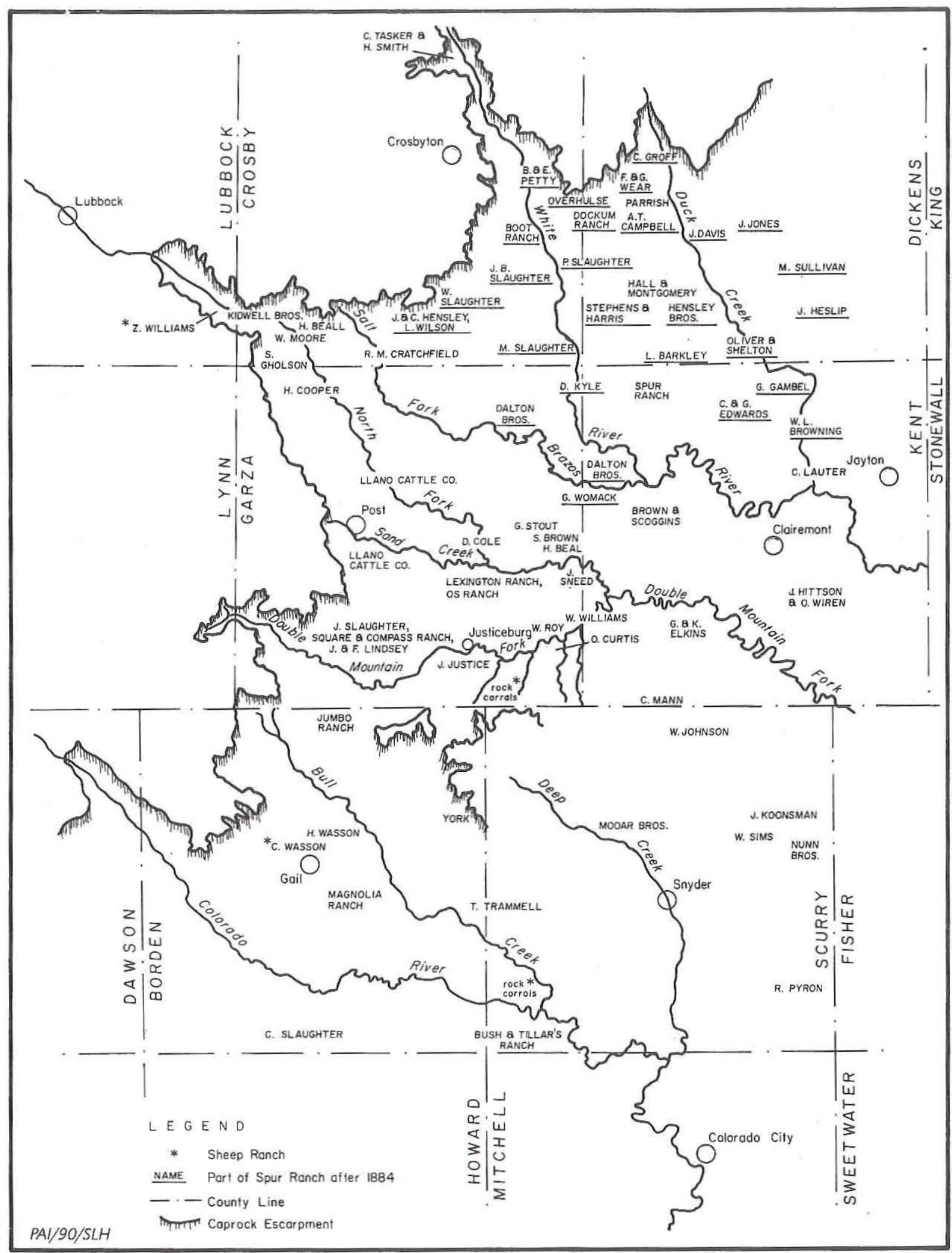

Figure 24. Ranches on the western Rolling Plains, from 1877. Compiled from information in Holden (1970) and Snyder, Texas Unit of the Ranch Headquarters Association (1986). 
open-range period. The other four open-range sites continued to be used after ca. 1900 into the closedrange period. Dugouts, the most common type of housing found at early ranching sites in the Panhandle-Plains, are present at six of the seven open-range ranching sites (all except for 41KT42, which had a wood frame house). Additional Lake Alan Henry ranching sites associated only with the closed-range period are 41GR13, 41GR250, 41GR412, 41GR565, 41GR586, and 41KT58. Of the dozen or so Lake Alan Henry sites known to be associated with the ranching industry, only two were intensively investigated.

A similar context was developed for the Palo Duro Reservoir project in the northern Panhandle. Under the thematic heading of "Agriculture in the Context Area," which is defined as the northern Texas Panhandle, Oklahoma Panhandle, and southwestern Kansas (Figure 25), Freeman (1990c) developed a context entitled "Livestock and Crop Production, 1870-1945." Expanding on and modifying the earlier agricultural context developed for Lake Alan Henry, Freeman pointed out the similarities and differences between the western Rolling Plains region, which was culturally and economically oriented to the Southern Plains and urban centers such as Colorado City, and the northern Panhandle, which was oriented to the Central Plains and urban centers such as Amarillo and Dodge City. After ca. 1875 , the Palo Duro region was typified by a more broadly based economy that included stock farming and cropping on a commercial level as well as the more traditional forms of open- and closed-range ranching typical of the Lake Alan Henry region. The most common property types identified in this context area were farm and ranch headquarters and line camps associated with ranching. Archival records identifying the various types of architecture associated with farm and ranch sites were summarized by Freeman (1990c:Tables 1-3). Farm and ranch houses were made of wood (plastered and unplastered), stone, and earth; the last consisted of sod and adobe dwellings typical of the Central Plains and Midwest, as well as dugouts.

Quigg, Lintz, Oglesby, Earls et al. (1993:9) stated that 14 historic sites were reported in the initial reconnaissance of the vicinity of Palo Duro Reservoir by Guidry et al. (1979), but Petersen (1988:Appendix A) noted only 5 sites associated with ranching in the reservoir project area. Subsequent investigations revealed that one additional site, originally thought to be prehistoric, also was associated with ranching. Detailed architectural documentation was done at four ranching/farming sites that included earthen, stone, frame, and stucco homes and outbuildings; but intensive archeological investigations were conducted at only two historic agricultural sites. Earls (1993a) reported the excavations of a two-room rock structure with an attached cellar at an 1895-1920 site (41HF8) and of the ca. 1870-1905 Rocky Fill Dugout (41HF113).

The two historic contexts (Freeman 1990b, 1990c) provide information for understanding the archeological and architectural remains relating to the ranching and farming industries in the Texas Panhandle-Plains. They also provide regional comparative data for identifying and evaluating sites for National Register eligibility. Despite the large number of historic locations identified in archival records, however, the number of actual farm and ranch sites that have been documented in the Panhandle-Plains is very small, and fewer still have been investigated archeologically.

Within the Panhandle-Plains, the greatest amount of historic archeological attention has been devoted to dugouts. Archival evidence indicates that the dugout was the most common property type or feature associated with ranching across the entire region. Dugouts were the predominant type of structure used during the open-range period, and even during the closed-range period most homesteaders first built a dugout before building an aboveground home. Hundreds of dugouts were constructed and occupied in the Panhandle-Plains region during the late nineteenth and early twentieth centuries, yet few dugout sites are known today.

Freeman (1990b:Table 6) summarized data on dugouts in the Panhandle-Plains, and O'Neill (1993:Table J.2) subsequently summarized data on these same dugouts, plus data on some additional examples. Both of these studies used archival data for the most part, but they also included archeological data for a few dugouts. O'Neill's study tabulated locational and architectural data for 82 dugouts, including 58 dugouts from the Texas and Oklahoma Panhandles. The remainder are from unknown locations or are from eastern New Mexico, western Kansas, and Nebraska. Based on these data, Earls (1993b:479-483) summarized the architectural variability of Plains dugouts.

While the dugout sample in the archival records is good, the archeological sample is not as robust. 


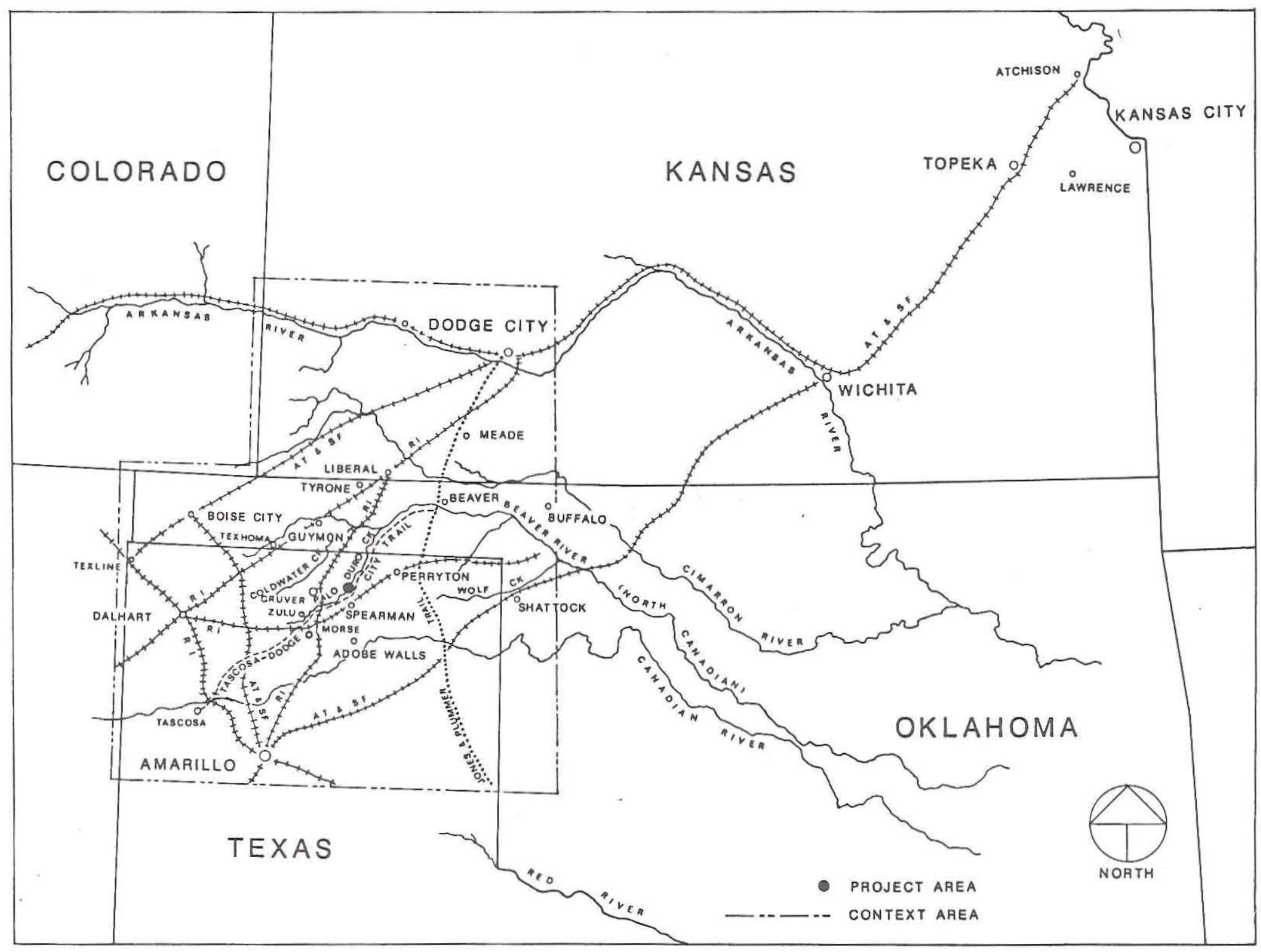

Figure 25. Map of the context area for "Livestock and Crop Production, 1870-1945." From Freeman (1990c:Figure 2). 
Although additional dugouts are reported in museum site files (such as at the Panhandle-Plains Historical Museum), only 35 dugouts at 27 sites have been reported in the archeological literature (Table 19). Of these, only seven dugouts have been archeologically investigated beyond survey-level documentation, and almost no information is available for one of these. The Post West and Mayfield Dugouts are the only two that have been listed in the National Register of Historic Places. Earls (1993b:480) mentioned other dugouts that have been excavated outside the Panhandle-Plains in Texas (one in McMullen County was reported by Fox [1986]) and Oklahoma (four in Payne and Pawnee Counties were reported by Young [1978]). Other excavated dugouts are reported, including one in Greer County, Oklahoma (Northcutt 1979:53-61), one in Tom Green County, Texas (Riemenschneider 1994c), and several in the Lake O. H. Ivie area of west-central Texas (Earls et al. 1993).

A dozen or more dugouts have been recorded recently in Borden County during a reconnaissance survey for possible Plains Indian/comanchero sites (Don Dorward, personal communication 1995). Data on these sites have not yet been published, but one contains an intact rock-walled dugout associated with the Slaughter Ranch. Except for the Mayfield Dugout in Briscoe County, this is the only other intact Panhandle-Plains dugout known to the authors.

\section{The Railroad, Town Building, and Industrial Development}

Around the turn of the century, the spread of railroad systems encouraged economic development and diversification of the farm and ranch industries by providing immediate access to markets throughout the Panhandle-Plains and beyond. Railroads also brought more people into the region to settle and spurred growth of many towns and industries (Freeman 1989).

The railroad came to the Lake Alan Henry area in 1911, when the Santa Fe Railroad completed its line between Lubbock and Coleman. This new line linked Post and the communities of Justiceburg and Burnham to the entire region. Justiceburg and the former community of Burnham are located primarily outside the Lake Alan Henry area, but sites inside the project area include the Justiceburg community cemetery (41GR522), where many of the pioneers of Garza County are buried, and one site (41GR331) associated with Burnham. The Santa Fe Lake complex (41GR470, also called Justiceburg Lake) was built as a water supply facility by the Santa Fe Railroad to serve its steam engines heading north up the Caprock. The site consists of a dam, reservoir, and pumphouse, and the rock ruins of a caretaker's house (41GR203) are located nearby.

Although many historic railroad properties such as depots, rail yards, and their associated archeological sites are preserved all over the Panhandle-Plains, there has been no attempt to systematically describe these resources. Thus, the variability in types of railroad properties is not known, nor is it clear what types of information can be derived from archeological investigations of such sites. Although the site is located south of the Panhandle-Plains, the archeological remains of an 1888 railroad roundhouse in San Angelo, Texas, were the focus of emergency salvage investigations (Riemenschneider 1994a). Forgotten by all except the oldest San Angelo residents, the railroad roundhouse had been covered over by another building and was accidentally discovered when the later structure was razed. The published information is limited to a brief summary of the findings, but it demonstrates' that much can be learned from archeological investigations of railroad sites.

As a historic property type, late-nineteenth- and early-twentieth-century urban centers are numerous in the Panhandle-Plains, and a number of them (such as Lubbock and Amarillo) have been the objects of comprehensive architectural surveys. In addition, limited architectural surveys have been conducted in many smaller towns, as well as generally throughout the Southern and Central Plains regions. On the other hand, these cities and towns generally have not been dealt with archeologically, despite the fact that they have extant historic buildings and districts (such as town squares and courthouses, railroad yards and depots, jails, schools, homes, and other community and industrial buildings) and/or historic archeological remains where buildings and features were located. Other urban areas have been completely abandoned and exist today as ghost towns or only as subsurface archeological remains. Many of these former towns were victims of the railroad. For example, Old Mobeetie (a trading post near Fort Elliot established in 1875 at the location of the former buffalo hunters' trade center called Hidetown), Tascosa (an early 1870 s pastor settlement that grew into a major shipping point for cattle headed for Dodge City), 
TABLE 19

SUMMARY OF ARCHEOLOGICAL INVESTIGATIONS OF TEXAS PANHANDLE-PLAINS DUGOUTS ASSOCIATED WITH LATE-NINETEENTH- AND EARLY-TWENTIETH-CENTURY RANCHING

\begin{tabular}{|c|c|c|c|}
\hline County & Site Name and Number & Level of Investigation and Comments & Reference \\
\hline Briscoe & Mayfield Dugout, 41BI52 & $\begin{array}{l}\text { Intact dugout; listed in National } \\
\text { Register in } 1973\end{array}$ & $\begin{array}{l}\text { Malone } 1970: 25-27 \\
\text { Jackson et al. } 1973 \\
\text { Steely } 1984: 28\end{array}$ \\
\hline Foard & 41FD35 & Site recorded only & $\begin{array}{l}\text { Etchieson et al. 1979: } \\
249-250\end{array}$ \\
\hline Floyd & 41 FL19 (4 dugouts) & $\begin{array}{l}\text { All four dugouts completely excavated } \\
\text { in } 1974 \text { and } 1975 \text {; archival research; } \\
\text { associated with Hispanic activities; } \\
\text { probably occupied by comancheros, } \\
\text { ciboleros, and/or pastores }\end{array}$ & Guffee 1976 \\
\hline \multirow[t]{6}{*}{ Garza } & Post West Dugout, $41 \mathrm{GR} 189$ & $\begin{array}{l}\text { Site recorded only; listed in National } \\
\text { Register in } 1978\end{array}$ & $\begin{array}{l}\text { Williams and Clark } 1976 \\
\text { Steely 1984:69 }\end{array}$ \\
\hline & Roy Dugout, 41GR263 & Site recorded only; historical research & $\begin{array}{l}\text { Boyd et al. } 1989 \\
\text { Freeman and Boyd } 1990\end{array}$ \\
\hline & Curtis Dugout, $41 \mathrm{GR} 392$ & Site recorded only; historical research & $\begin{array}{l}\text { Boyd et al. } 1989 \\
\text { Freeman and Boyd } 1990\end{array}$ \\
\hline & $41 \mathrm{GR} 443$ & $\begin{array}{l}\text { Site recorded only; probable dugout } \\
\text { associated with Hispanic sheepherding }\end{array}$ & $\begin{array}{l}\text { Boyd et al. } 1989 \\
\text { Freeman and Boyd } 1990\end{array}$ \\
\hline & Justice Dugout, $41 \mathrm{GR} 474$ & $\begin{array}{l}\text { Completely excavated in } 1993 \text {; } \\
\text { extensive historical research }\end{array}$ & Boyd 1994 \\
\hline & $\begin{array}{l}\text { W. G. Williams Dugout, } \\
41 \text { GR586 }\end{array}$ & Site recorded only & Boyd et al. 1991 \\
\hline \multirow[t]{3}{*}{ Hansford } & $\begin{array}{l}\text { Andrews Ranch Headquarters, } \\
41 \mathrm{HF} 73\end{array}$ & Site recorded only; historical research & Freeman et al. 1990 \\
\hline & $\begin{array}{l}\text { A. E. Williams Ranch } \\
\text { Headquarters, } 41 \mathrm{HF} 75\end{array}$ & Site recorded only; historical research & Freeman et al. 1990 \\
\hline & Rocky Fill Dugout, $41 \mathrm{HF} 113$ & $\begin{array}{l}\text { Completely excavated in } 1990 \text {; } \\
\text { extensive historical research }\end{array}$ & Earls 1993a \\
\hline \multirow[t]{4}{*}{ Kent } & Tanksley Half-Dugout, 41KT29 & Site recorded only & $\begin{array}{l}\text { Thurmond et al. 1981: } \\
400-401\end{array}$ \\
\hline & $41 \mathrm{KT} 30$ & Site recorded only & $\begin{array}{l}\text { Thurmond et al. 1981: } \\
401-402\end{array}$ \\
\hline & OS Ranch Line Camp, 41KT84 & Site recorded only & Freeman and Boyd 1990 \\
\hline & Williams Dugout, 41KT150 & Site recorded only & Freeman and Boyd 1990 \\
\hline
\end{tabular}




\begin{tabular}{|c|c|c|c|}
\hline \multicolumn{4}{|c|}{ Table 19 , continued } \\
\hline County & Site Name and Number & Level of Investigation and Comments & Reference \\
\hline \multirow[t]{5}{*}{ King } & $41 \mathrm{KG19}$ (3 dugouts) & $\begin{array}{l}\text { Site recorded only; possibly associated } \\
\text { with Hispanic sheepherding }\end{array}$ & $\begin{array}{l}\text { Etchieson et al. 1979: } \\
243-246\end{array}$ \\
\hline & $41 \mathrm{KG} 29$ & Site recorded only & Thurmond et al. 1981 \\
\hline & $41 \mathrm{KG} 30$ & Site recorded only & Thurmond et al. 1981 \\
\hline & 41KG56 (3 dugouts) & Site recorded only & Thurmond et al. 1981 \\
\hline & Martin Dugout, 41KG60 & Site recorded only & Thurmond et al. 1981 \\
\hline Knox & $41 \mathrm{KX} 66$ & Dugout completely excavated in 1977 & $\begin{array}{l}\text { Etchieson et al. 1978: } \\
202-219\end{array}$ \\
\hline Potter & $\begin{array}{l}\text { Allie Bates Dugout, } \\
\text { LMRA No. } 260\end{array}$ & Site recorded only & Bousman 1974a, 1974b* \\
\hline Randall & 41RD51 (2 dugouts) & $\begin{array}{l}\text { One dugout tested, one dugout almost } \\
\text { completely excavated by Smithsonian } \\
\text { Institution in } 1972 \text { and 1973; no } \\
\text { detailed information reported }\end{array}$ & $\begin{array}{l}\text { Wedel } 1975 \\
\text { Lintz } 1995\end{array}$ \\
\hline Stonewall & $\begin{array}{l}\text { Portwood-Halsell Dugout, } \\
\text { 41SN72 }\end{array}$ & Site recorded only & Thurmond et al. 1981 \\
\hline \multirow[t]{2}{*}{ Swisher } & 41SW14 & Site recorded only & Malone 1970:25-27 \\
\hline & 41SW20 & Site recorded only & Malone 1970:25-27 \\
\hline
\end{tabular}

and Old Clarendon (established ca. 1878-late 1880s and now under the waters of Lake Greenbelt), thrived in the late nineteenth and early twentieth centuries only to have their populations move away when railroad lines bypassed them (Webb 1952:I: 353, 625, II:220, 708). Population shifts and movements of towns due to the placement of railroads are patterns repeated many times in the Panhandle-Plains. In Garza County, the town of Burnham was abandoned in favor of Justiceburg because of its proximity to the railroad (Boyd et al. 1989:151).

The Panhandle-Plains Historical Museum conducted excavations at Old Clarendon prior to the completion of Lake Greenbelt, but the investigations are not reported. Additional work at Old Clarendon was done during the 1996 Texas Archeological Society field school, but it is not yet reported (Suzanna Katz, personal communication 1996).
Other unreported investigations of a similar nature may have been done, and occasional documentation of individual components of townsites is reported (such as recording of the Justiceburg Cemetery or a housesite in Burnham during the Lake Alan Henry project). However, there has been no extensive archeological work done at Texas Panhandle-Plains townsites. Lees (1977) reported on an extensive archeological project that investigated the Oklahoma Panhandle townsite of Old Hardesty. Investigations at the 1886-1906 townsite included archival and informant research, extensive surface collections, and archeological excavations of selected structures and areas. The combined data were used to address research questions related to the history and development of the town itself, rather than individual components within it. Like many Texas PanhandlePlains sites, Old Hardesty served as a regional trade center located along a major trail until the railroad 
came and its people moved away.

The final economic boom to come to the region prior to 1945 was the petroleum industry, which began in the Panhandle-Plains in the 1920s. Only one site at Lake Alan Henry (41GR449) is related to the early petroleum industry, but the first oil well in Garza County was located somewhere in the lake area east of Justiceburg. No systematic investigations of early Panhandle-Plains petroleum sites have been done, and it remains to be seen what the research potential of such sites may be. The farm, ranch, and petroleum industries have continued to develop and are still among the most important economic interests in the region. 


\section{SUMMARY OF NATIVE AMERICAN ARCHIEOLOGY AT LAKE ALAN HENRY}

by Douglas K. Boyd and Steve A. Tomka

The five seasons of investigations at Lake Alan Henry produced considerable archeological data, supplemented by a wide range of other related nonarcheological data (e.g., geomorphological) that have many implications for understanding Native American prehistory and history. The data are presented in six technical reports describing the various phases of work. The intent of this chapter is to summarize what has been learned by these investigations and present data only as necessary to clarify and support the interpretations.

In this chapter, the term Native American is used in a general sense to refer to all archeological remains (sites, features, and artifacts) associated with Native American peoples. In this context, it includes prehistoric sites and remains, as well as those of the protohistoric and historic Indian periods. Rock art sites with Native American images also are discussed in this chapter, but because of their unique nature, they are discussed separately from the other sites.

This chapter is divided into five sections. The first presents an overview of the chronological data for the project area and introduces the cultural chronology for the Caprock Canyonlands. The second section is a review of the geomorpological studies, culminating with a geomorphic history of the project area. An understanding of the chronology and geomorphology is essential before one can fully appreciate the sections that follow. The third section summarizes the archeological database for the project area, which includes 290 sites with evidence of Native American occupation; its scope is limited to broad interpretations based mainly on survey and testing level data. The fourth section is a summary of the Native American rock art, found at 34 sites in the project area, along with a synthesis of the regional perspective for the Texas Panhandle-Plains. The final section is a summary of the intensive data recovery investigations conducted at 11 sites; it presents interpretations of site function and subsistence and identifies the data recovery analysis units that are analyzed further in Chapter 7.

\section{CHRONOLOGY}

Although other absolute and relative dating techniques were employed, the archeological chronology of the Lake Alan Henry project area was established primarily using radiocarbon dates. While the other techniques, such as thermoluminescence and archeomagnetic dating and artifact typology and seriation are important, the radiocarbon data are considered to be the most reliable age indicators and provide the basic temporal framework for reconstructing culture history (see Chapter 4).

Radiocarbon dating was employed during all phases of work, and 106 dates were obtained from three radiocarbon laboratories (see Appendix B). The temporal distribution of the 106 dates is revealing (Table 20). Most of the dates (75 percent) are from archeological sites and are useful for interpreting the culture history of the project area: Almost all of the on-site dates are associated with cultural features and contexts, but a few $(n=12)$ are from noncultural geomorphic contexts. The remaining 
TABLE 20

TEMPORAL DISTRIBUTION OF 106 RADIOCARBON DATES FROM ALL PHASES OF ARCHEOLOGICAL INVESTIGATION AT LAKE ALAN HENRY

\begin{tabular}{|c|c|c|c|c|c|c|}
\hline Years B.P. & Survey & Testing & $\begin{array}{c}\text { Data Recovery, } \\
\text { Season } 1\end{array}$ & $\begin{array}{c}\text { Data Recovery, } \\
\text { Season } 2\end{array}$ & $\begin{array}{c}\text { Data Recovery, } \\
\text { Season } 3\end{array}$ & All Dates \\
\hline $0-1000$ & $2(3)$ & $15(2)$ & $1(4)$ & 27 & 9 & $54(9)$ \\
\hline $1000-2000$ & $3(1)$ & $4(2)$ & $4(4)$ & & 11 & $22(7)$ \\
\hline $2000-3000$ & & $2(2)$ & & 1 & & $3(2)$ \\
\hline $3000-4000$ & & & (2) & & & (2) \\
\hline $4000-5000$ & (2) & & & & & (2) \\
\hline \multicolumn{7}{|l|}{$5000-6000$} \\
\hline $6000-7000$ & & & & (1) & & (1) \\
\hline \multicolumn{7}{|l|}{$7000-8000$} \\
\hline $8000-9000$ & & & (1) & & & (1) \\
\hline \multicolumn{7}{|l|}{$9000-10,000$} \\
\hline $10,000-11,000$ & & (1) & & & & (1) \\
\hline \multicolumn{7}{|l|}{$11,000-12,000$} \\
\hline $12,000-13,000$ & & (1) & & & & (1) \\
\hline $13,000-14,000$ & (1) & & & & & (1) \\
\hline
\end{tabular}

Note: Dates are grouped by millenium based on data presented in Appendix B; numbers in parentheses indicate off-site geomorphic dates; all others are on-site dates. Dates from the survey are uncorrected; all others are $\delta^{13} \mathrm{C}$ corrected.

dates (25 percent) were obtained from off-site geomorphic localities specifically to provide chronological evidence for inferring the geomorphic history of the project area.

When all the radiocarbon dates are considered, the vast majority $(n=97,91.5$ percent) are less than 3,000 years old, and only nine dates ( 8.5 percent) are older than 3,000 years. This skewed temporal distribution has many implications for understanding the geomorphic history of the project area and the geographical distribution of sites across the landscape. This topic is discussed in more detail later, but it is noteworthy that the same skewed pattern is evident in the temporal distribution of all sites in the project area (with most age estimates being based mainly on diagnostic artifacts).

The generalized cultural chronology that is recognized for the Texas Panhandle-Plains region is divided into four cultural stages or periods that go by various names: Paleoindian, Archaic/Mesoindian, Ceramic/LatePrehistoric/Neoindian, and Protohistoric and/or Historic. Except for differences in terminology and minor variations in timing of the transition between periods, the Caprock Canyons cultural chronology (established for Lake Alan Henry and used in this report) is essentially the same as Jack Hughes's (1991) chronology for the Texas High Plains and Eileen Johnson's (1987) Lubbock Lake chronology for the Texas South Plains (Figure 26). In fact, the Caprock Canyonlands chronology is basically a modified version of the well-dated Lubbock Lake chronology, and the Paleoindian and Early-Middle Archaic periods are identical, chiefly because none of the Lake Alan Henry archeological 


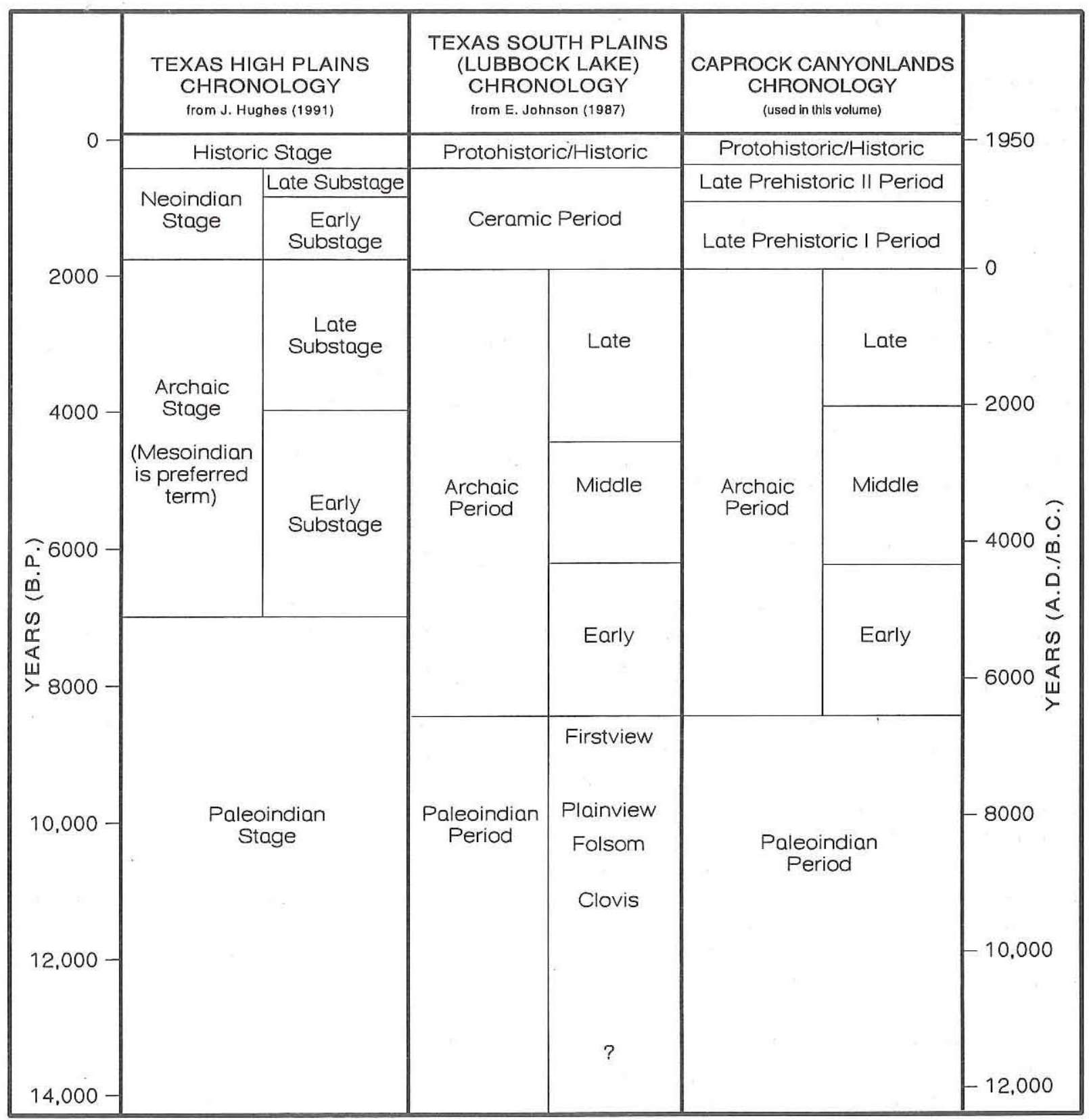

Figure 26. Selected cultural chronologies for the Texas Panhandle-Plains region.

data pertain to these periods. The later periods (i.e., Late Archaic, Late Prehistoric I and II, and Protohistoric) in the Caprock Canyonlands chronology were refined during the data recovery investigations, but they approximate the Late Archaic through Historic stages on the High Plains as defined by Jack Hughes (1991).

While the author agrees with Hughes (1991:10) that the various temporal/cultural names can be misleading (and even confusing), it does not matter which terms are selected as long as the manner in which they are defined and used is explicit. As they are used here, the cultural periods may be viewed as both periods of time and stages of cultural development. The timing of the transitions between the periods admittedly is subjective and undoubtedly will change as more data become available. Furthermore, these transitions were not abrupt cultural changes; they probably took place as gradual shifts over a period of time. A case in point is the transition 
from the Late Archaic to the Late Prehistoric I period. The change is traditionally marked by the introduction of ceramics and beginning of the use of the bow and arrow, but these did not necessarily, and probably did not, occur at the same time. The scenario is further complicated by the fact that darts, presumably propelled by atlatls, may have been in use for quite some time after the bow and arrow were introduced. Although cultural chronologies should strive to reflect cultural reality (e.g., charting the technological and social developments of specific groups of people), there are not yet enough regional archeological data to support such detailed interpretations. Thus, the various chronological schemes used for the Texas Panhandle-Plains region are currently little more than convenient tools for classifying and organizing archeological data.

\section{GEOMORPHOLOGY}

Both on- and off-site geomorphological studies were conducted during all phases of work. On-site investigations were usually tailored to meet specific needs based on individual research problems, while off-site investigations were geared toward defining the variability in the geomorphic settings throughout the project area, understanding the geomorphic processes involved with their development, and defining the evolution of the modern landscape.

Geoarcheological investigations at Lake Alan Henry include the initial geomorphic reconnaissance (including 20 backhoe trenches and work at three geomorphic localities) during the 1987 reservoir survey by Blum (1989) and intensive geomorphic investigations (including 77 backhoe trenches and additional work at one of the geomorphic localities) during the 1988 testing phase by Abbott (1990). Following these studies, a collaborative synthesis effort by Blum, Abbott, and Valastro summarized the findings, put them into regional perspective, and concluded with a discussion of the implications for site preservation and visibility in the archeological record (Blum et al. 1992). During subsequent phases, additional geomorphic work was done by Bousman in conjunction with the survey of wildlife mitigation lands (Bousman 1991) and during Season 1 of data recovery (Bousman 1992). Kibler conducted additional studies during data recovery Seasons 2 and 3 (Boyd et al. 1993, 1994). A brief summary of the results of these studies is presented below.
The canyonlands in the project area are characterized by three major depositional environments: alluvial floodplains; alluvial/colluvial fans at the base of steep valley walls; and the uplands. All of the geomorphologists involved attempted to locate and date a wide range of sediments of different ages from these various depositional contexts. Thus, the 27 radiocarbon dates from geomorphic localities in the project area, along with the many dates from archeological sites, are considered to be an adequate sample of the ages of the various landforms found throughout the project area. Notably, most of the geomorphic locality dates $(n=18,67$ percent) are less than 3,000 years old, while the nine oldest ones are from only three locations in the lower portion of the reservoir (Figure 27). Four dates, including the three oldest ones, are from deeply buried sediments in Grape Creek (three are from ca. $5 \mathrm{~m}$ deep in a cutbank designated as Geomorphic Locality 3, and one is from Backhoe Trench 1987-9), two dates are from upland sand sheet deposits (Geomorphic Locality 1 and Morgan Playa), and three are from a remnant of an upper or older alluvial terrace of the Double Mountain Fork between Grape and South Sage Creeks (Backhoe Trenches 1991-1 and 2). Older sediments were identified in the upper portion of the reservoir (i.e., at Geomorphic Locality 3 and in Backhoe Trenches 1988-8, 9, and 10), but no radiocarbon dates are available.

During the project, it became increasingly clear that landforms are distributed unequally in time and through space. Despite several attempts to identify and date older remnants of sediment (i.e., anything over 3,000 years old), few localities where ancient sediments were preserved were identified. Within the segment of the Double Mountain Fork valley encompassed by the project area, there are only three areas where ancient sediments are known to be preserved: (1) deeply buried in the broad floodplain of the lower reservoir where the canyon widens in the vicinity of Grape and South Sage Creeks; (2) in the upland sand sheet around the margins of the canyons; and (3) in the broad floodplain of the upper reservoir before the river cuts through the sandstone and becomes restricted in the canyon. Older floodplain sediments are absent in the narrow canyons that characterize most of the Double Mountain Fork valley and the lower sections of almost all of its tributaries.

The initial geomorphic study of the proposed reservoir area (Blum 1989) noted that the valley of 


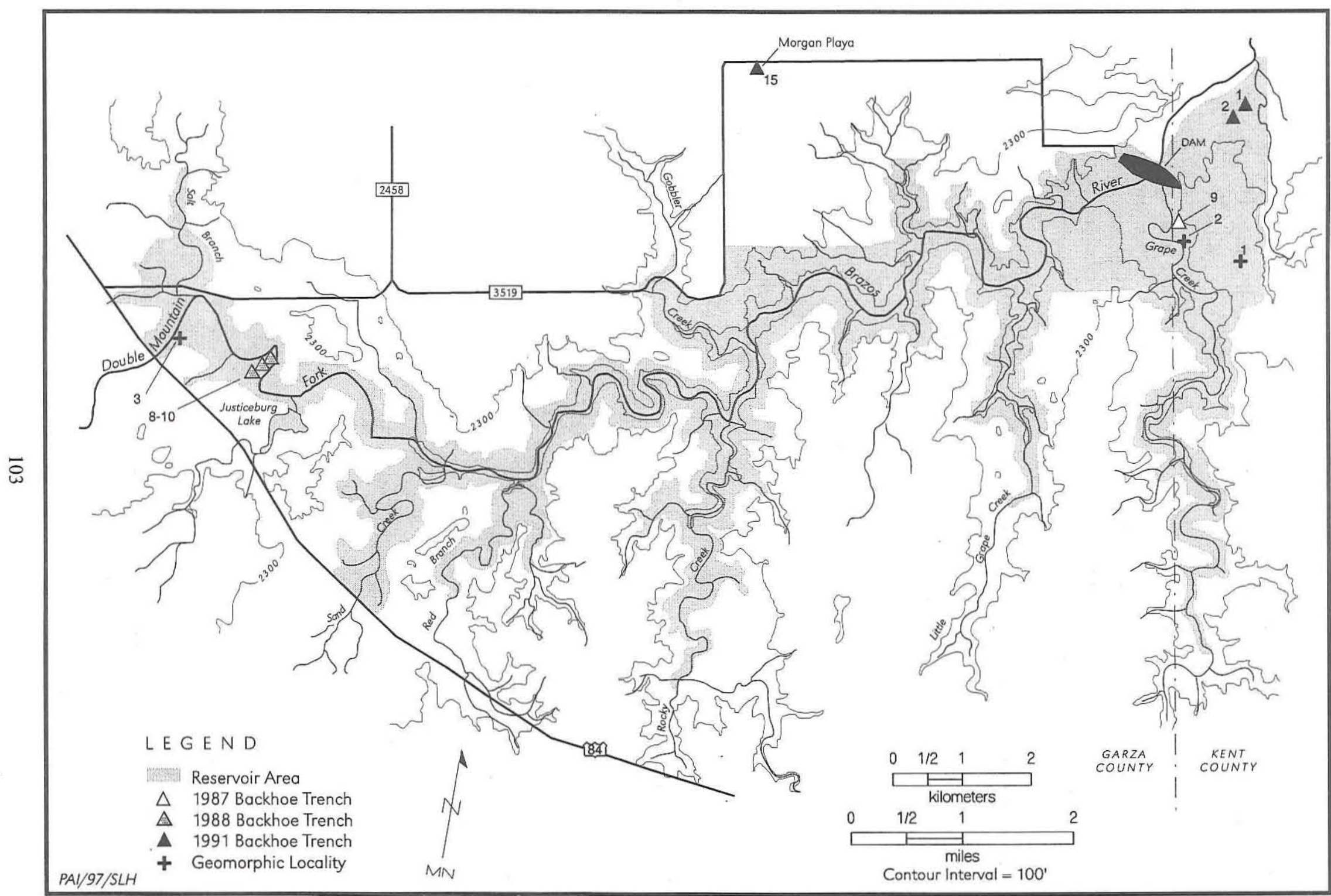

Figure 27. Map of the Lake Alan Henry project area showing geomorphic locations where ancient sediments (older than 3,000 years) have been identified. 
the Double Mountain Fork of the Brazos River changes significantly from west to east across the project area. This study defined three sections of the reservoir - the upstream, central, and downstream segments - characterized by different topography and depositional environments (Figure 28). All three segments have three geomorphic landforms in common (the river channel, active floodplains, and younger terraces of the Double Mountain Fork), but each segment also encompasses other landforms that are unique to it (Figure 29). The uplands surround- ing the canyonlands were defined as a fourth geomorphic setting.

\section{The Upstream Segment}

The upstream segment is characterized by a wide valley with low relief and includes two additional landforms: older terraces of the Double Mountain Fork and eolian dunes located proximal to the river channel (Figure 30). Although there are no radiocarbon ages for the older terraces in the upper
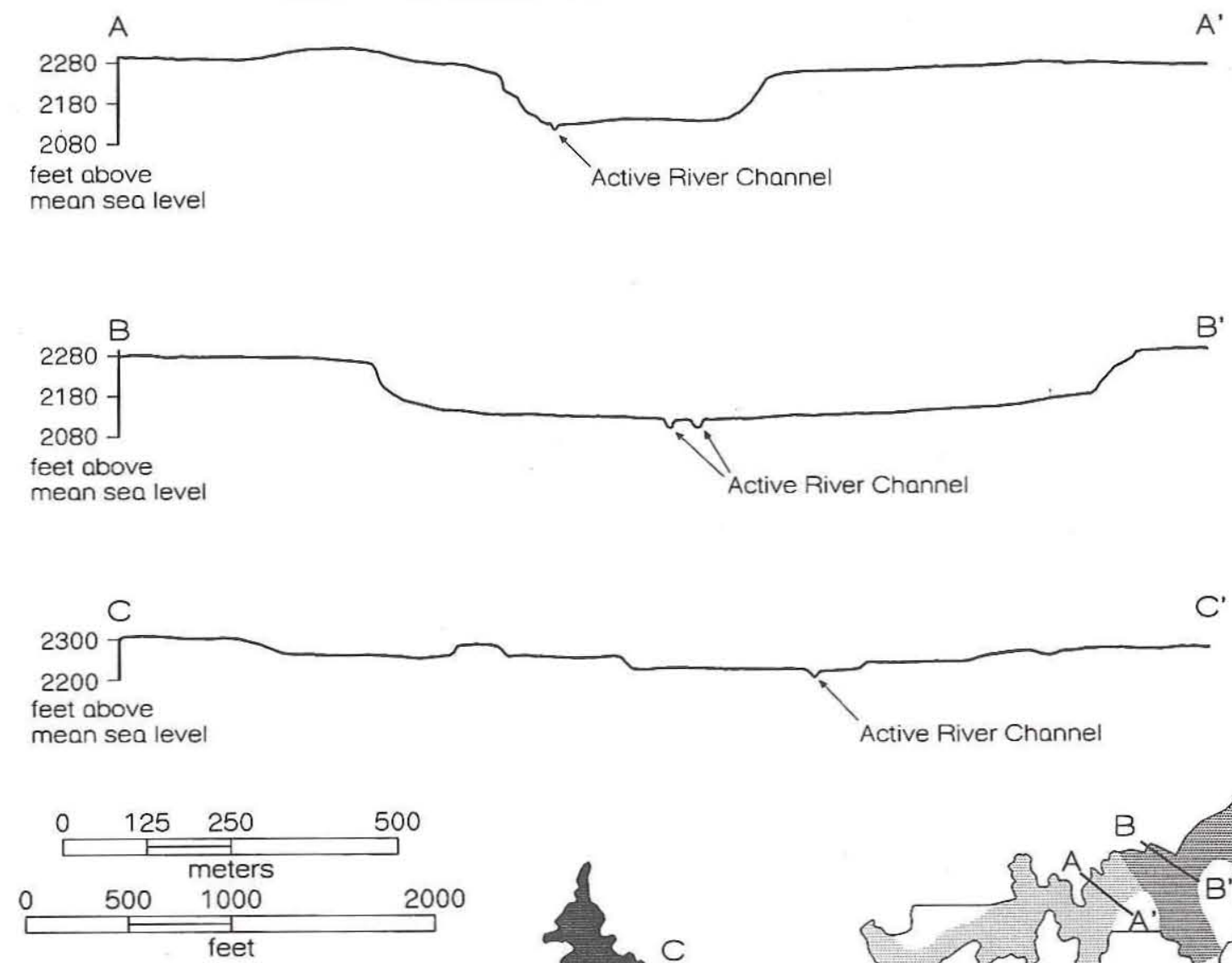

LEGEND

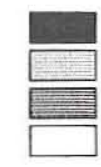

\section{Upstream Segment Central Segment Downstream Segment} Upland Area

PAI/97/SLH

Figure 28. Generalized valley cross sections showing the topography of different segments of the Double Mountain Fork of the Brazos River in the project area. The central segment is shown as A- $\mathrm{A}^{\prime}$; the downstream segment is shown as $\mathrm{B}-\mathrm{B}^{\prime}$; and the upstream segment is shown as $\mathrm{C}-\mathrm{C}^{\prime}$. 


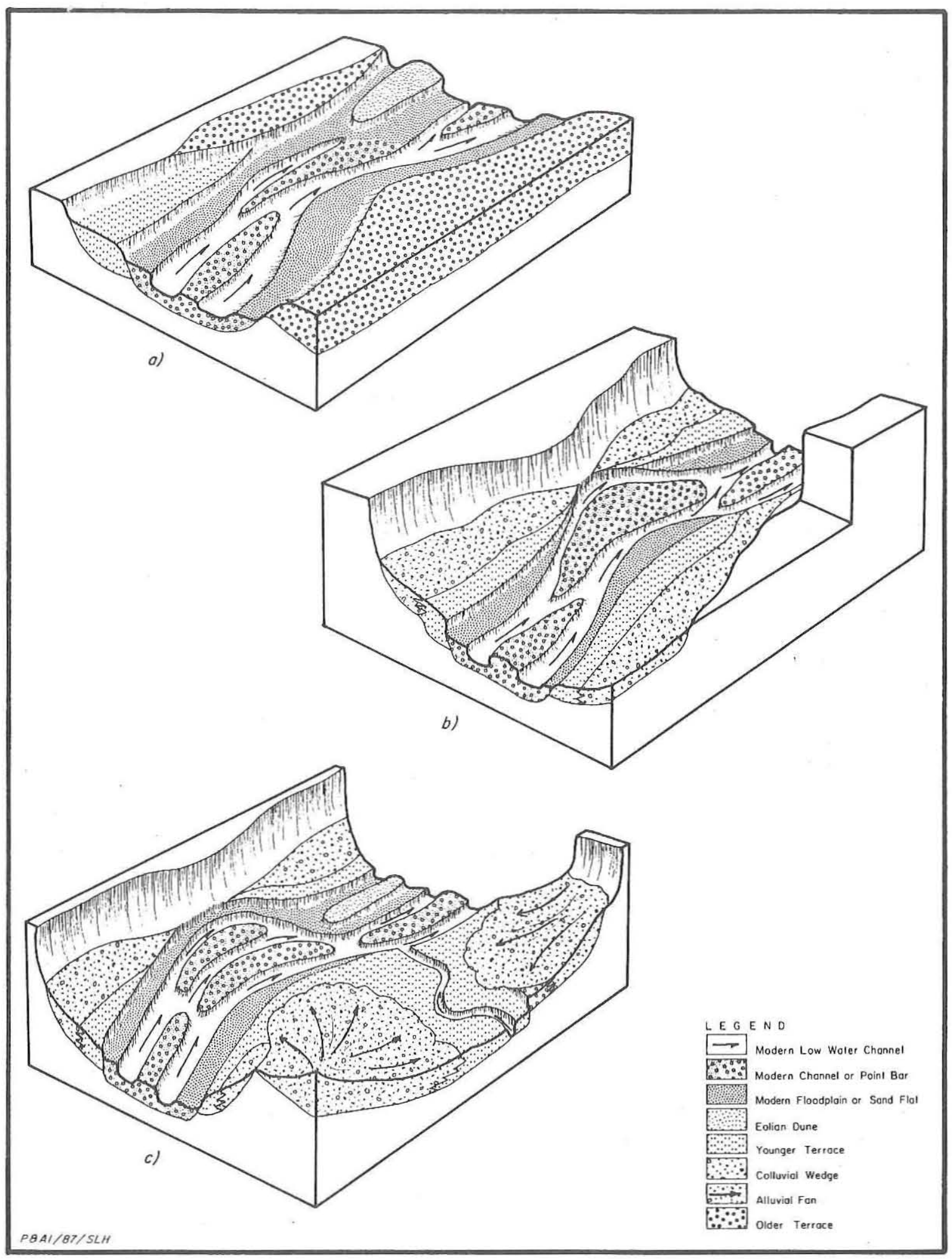

Figure 29. Schematic illustration of erosional and depositional landforms of the Double Mountain Fork of the Brazos River in the vicinity of Lake Alan Henry. (a) The wide valley upstream segment; $(b)$ the narrow canyon central segment; (c) the wide canyon downstream segment at the mouth of Grape Creek. 


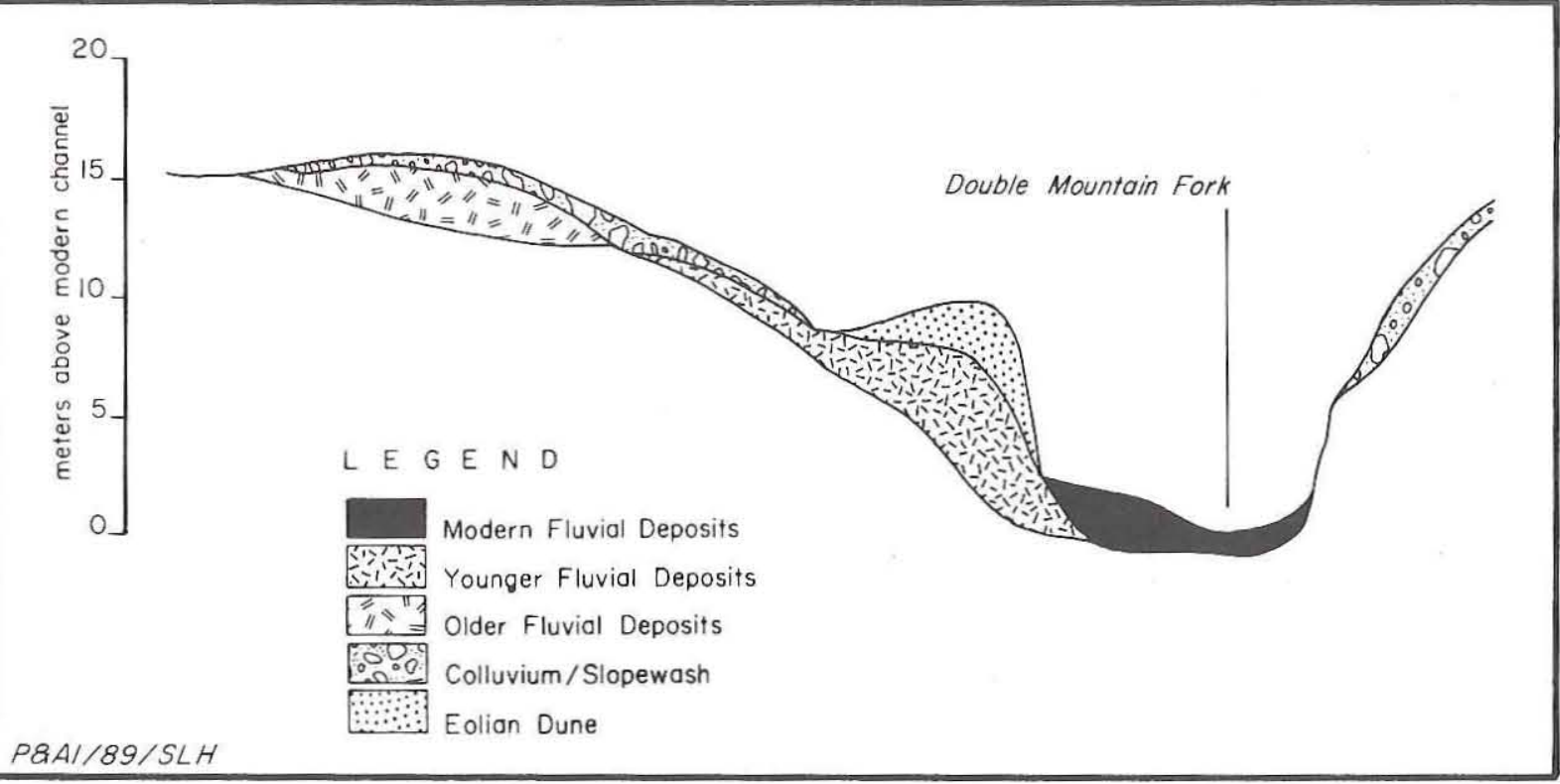

Figure 30. Generalized geomorphic cross section of the Double Mountain Fork valley in the upstream segment of Lake Alan Henry.

reservoir area (none were run because it was far away from the primary project impact area), Abbott (1990:38) suggested that the terraces were early to middle Holocene in age. Although undated, the eolian dunes are found on the younger terraces and are relatively recent in age. Their occurrence in the upper reservoir area is thought to be related to the constriction of the Double Mountain Fork valley in this vicinity. Apparently, the prevailing southwesterly and westerly winds picked up river sediments and carried them down the channel until the winds lost their energy and dropped their load at the point where the valley constricts. The process is still occurring today, and on one particularly windy day in the upper reservoir, the senior author witnessed this type of eolian deposition taking place.

Kibler's geomorphic work during data recovery excavations at Boren Shelter No. 2 (41GR559) provides additional data related to eolian deposition in the upper reservoir area. This shelter is located along a small canyon tributary overlooking its confluence with the Double Mountain Fork, less than $1 \mathrm{~km}$ downstream from the point where the valley constricts. The lower deposits in the shelter are composed of light brown sandy loam with numerous larger angular sandstone fragments. They are interpreted as endogenous sediments and are composed mainly (70-99 percent) of fine-grained materials (ca. 63 percent sands and 37 percent clays and silts) derived from in situ weathering of the friable sandstones inside the shelter. The coarse fraction (i.e., angular sandstone clasts of cobble, pebble, and gravel sizes) makes up only a small percentage (ca. 1-30 percent) of the sediments and represents materials introduced by spalling and roof fall. Notably, there are large boulders (many that are several meters in maximum length) which indicate that major roof fall episodes occurred prior to and during the deposition of the lower zone sediments.

An abrupt transition in the shelter stratigraphy provides a vivid contrast between the lower and upper deposits. The upper sediments are a reddish brown sandy loam composed partly of endogenous materials, with the reddish color being due to the presence of a significant amount of eolian materials. The eolian sediments are exogenous and were derived from the Double Mountain Fork channel upstream from the shelter. On windy days, crews excavating in the shelter observed this process in action (i.e., reddish sediments from the riverbed blowing downstream and being deposited in the shelter). The reddish color of these wind-blown sediments is due to the fact that they were originally derived from the iron-rich Triassic redbeds in the Double Mountain Fork valley west of the shelter. In addition, some of the reddish brown eolian materials may have came from the Blackwater Draw Formation on the Southern High Plains, much of 
which was originally derived from Permian redbeds in the Pecos River valley (Holliday 1989b).

The boundary between the lower and upper zones is interpreted as evidence of a sudden climatic shift that resulted in increased deposition of exogenous eolian sediments. The evidence seems to indicate increasing xeric conditions which allowed the riverbed to remain dry for extended periods (perhaps shifting from a perennial to an intermittent stream) and become a source of wind-blown sediments. Radiocarbon dates on cultural features (i.e., Features 3 and 27) at Boren Shelter No. 2 that bracket this stratigraphic boundary indicate that the shift in depositional regimes inside the shelter occurred at around A.D. 1100 (calibrated). This estimate appears consistent with other evidence indicating a drying trend in the Southern Plains beginning ca. 1,000 years ago (e.g., Hall 1982, 1988; Holliday 1985b; Meltzer 1991).

\section{The Central Canyon-Confined Segment}

The central segment is characterized by a narrow canyon-confined valley with high relief, and it includes only one additional landform: steep colluvial fans episodically shed from the canyon walls (Figure 31). A sizable portion of the ca. 8,600 acres that were originally surveyed, perhaps 50 percent or more, can be classified as narrow can- yons. While backhoe access was limited in some areas, other portions of the narrow canyons were explored extensively. In spite of this, Abbott (1990:38-44) notes that there are no remnants of old terraces in the narrow canyon areas that make up the central segment of the Double Mountain Fork valley and most of the prominent tributary valleys. In the most-canyon-confined valley areas, there are only discontinuous terrace wedges that represent deposits no older than 3,000 years. The alluvial/colluvial aprons that flank the canyon walls and spill onto these terraces are even more recent and have practically no soil development.

Abbott (1990) and Kibler (in Boyd et al. 1993:271-272) did extensive work in central canyonconfined Grape Creek valley and found that it also contains only young terraces. Numerous radiocarbon dates on sediments indicate that these terraces are no older than ca. 3,000 years. Based on these studies, it was concluded that most of the early deposits were eroded out of the canyon-confined areas of the Double Mountain Fork valley and its tributaries prior to 3000 B.P.; sedimentation began again soon after.

\section{The Downstream Segment}

The downstream segment is characterized by a broad valley within steep-walled canyons, and it includes relatively recent natural levee deposits and

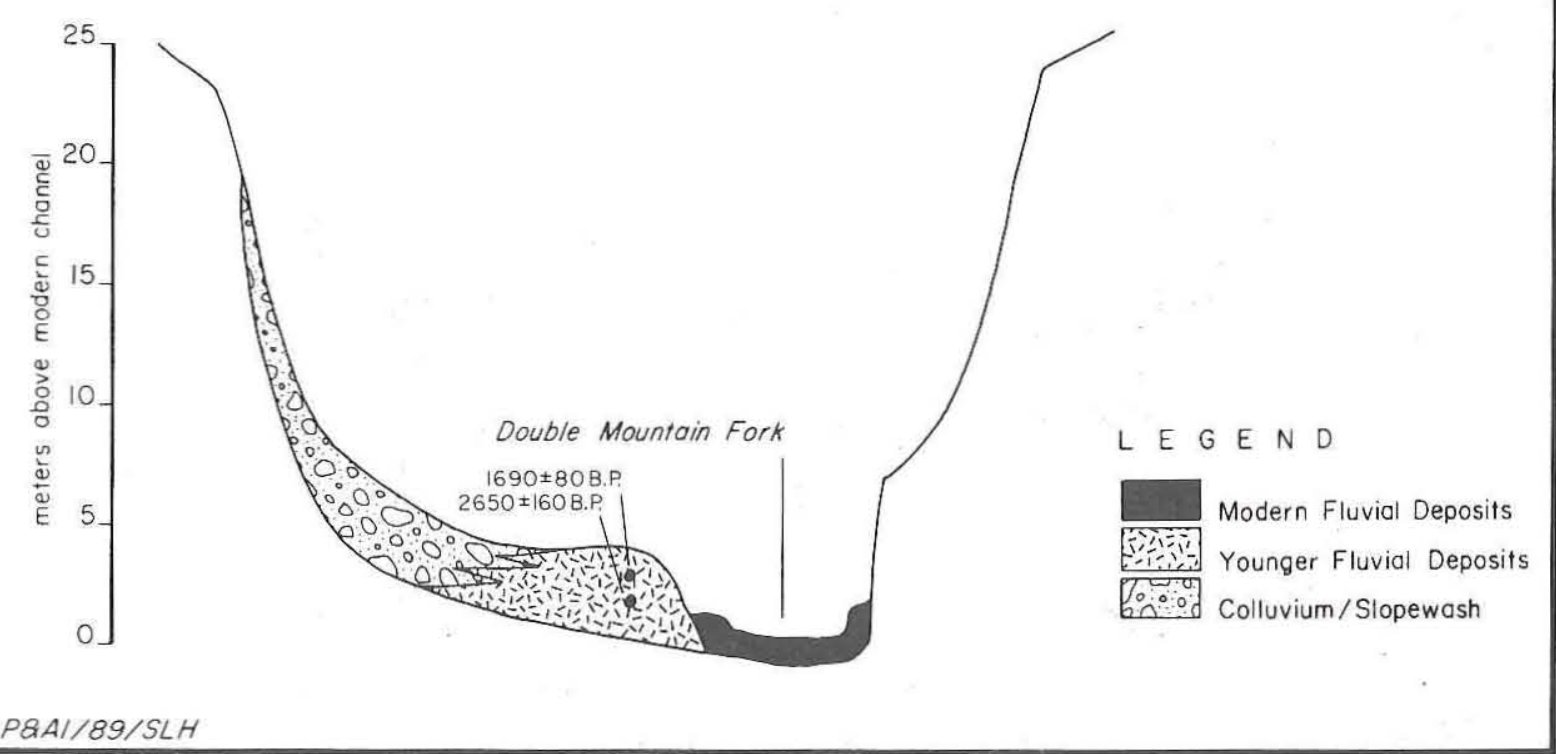

Figure 31. Generalized geomorphic cross section of the Double Mountain Fork valley in the central canyon-confined segment of Lake Alan Henry (radiocarbon ages are uncalibrated). 
eolian dunes located proximal to the main river channel, remnants of older terraces, and large alluvial/colluvial fans. While most of the alluvial deposits in this area are relatively young, older terrace remnants were identified in two places: in the lower Grape Creek valley and adjacent to the south canyon wall between Grape and South Sage Creeks.

In the lower section of Grape Creek, the sediments on the west side are quite recent, while a 10-15-m-high vertical cutbank on the east side (Geomorphic Locality 2) exposes two depositional units that are quite old (Figure 32). A buried Pleistocene terrace remnant rests unconformably on Permian-age mudstones of the Quartermaster Formation and is capped by a thick alluvial/colluvial fan deposit (Abbott 1990:47-49; Blum 1989:92-96). Sediment samples from a cumulic soil near the top of the ca. 2-m-thick terrace remnant produced radiocarbon ages of 12,670 and 13,500 B.P. The soil is immediately overlain by an alluvial/colluvial fan that appears to have accumulated continuously since late Pleistocene times. Sediments from the lower portion of the fan (ca. $50 \mathrm{~cm}$ above the buried soil) are dated to 10,960 B.P., while those higher up in the profile are dated to 4780 and 810 B.P. The dates for the upper fan deposit are laterally separated (with the oldest being closest to the valley wall and the youngest being closest to Grape Creek) and indicate that the feature becomes progressively younger creekward.

Below the dam area, Bousman (1992:138-140) identified an older terrace of the Double Mountain Fork, situated nearly $10 \mathrm{~m}$ above the river and butted up next to the south canyon wall (Figure 33). A buried soil (in Backhoe Trench 1991-2) in this terrace remnant was radiocarbon dated to 8690 B.P., indicating that it may have begun to form during the late Pleistocene. Most of this terrace was eroded away some time after 8700 B.P., but the preserved section was protected from erosion by a bedrock ridge (a remnant of which is still visible today) that jutted out from the canyon wall and deflected the river channel. Another buried soil, located in an erosional scar immediately on top of the old terrace, was radiocarbon dated to 3320 B.P. Bousman (1992: 140,142 ) suggests that this unconformity represents the end of the middle Holocene erosional sequence

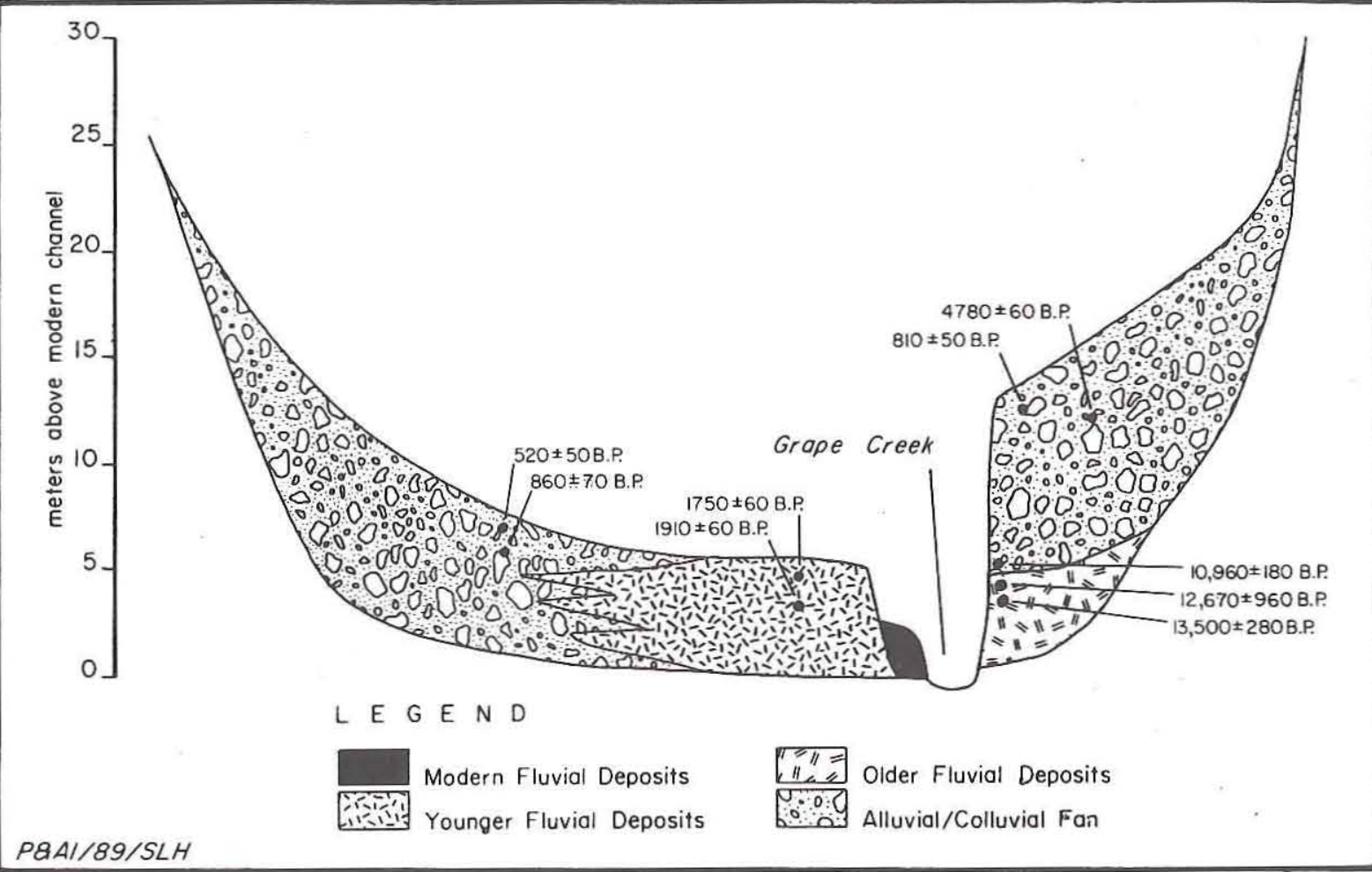

Figure 32. Generalized geomorphic cross section of the lower Grape Creek valley at its confluence with the Double Mountain Fork in the downstream segment of Lake Alan Henry (radiocarbon ages are uncalibrated). 


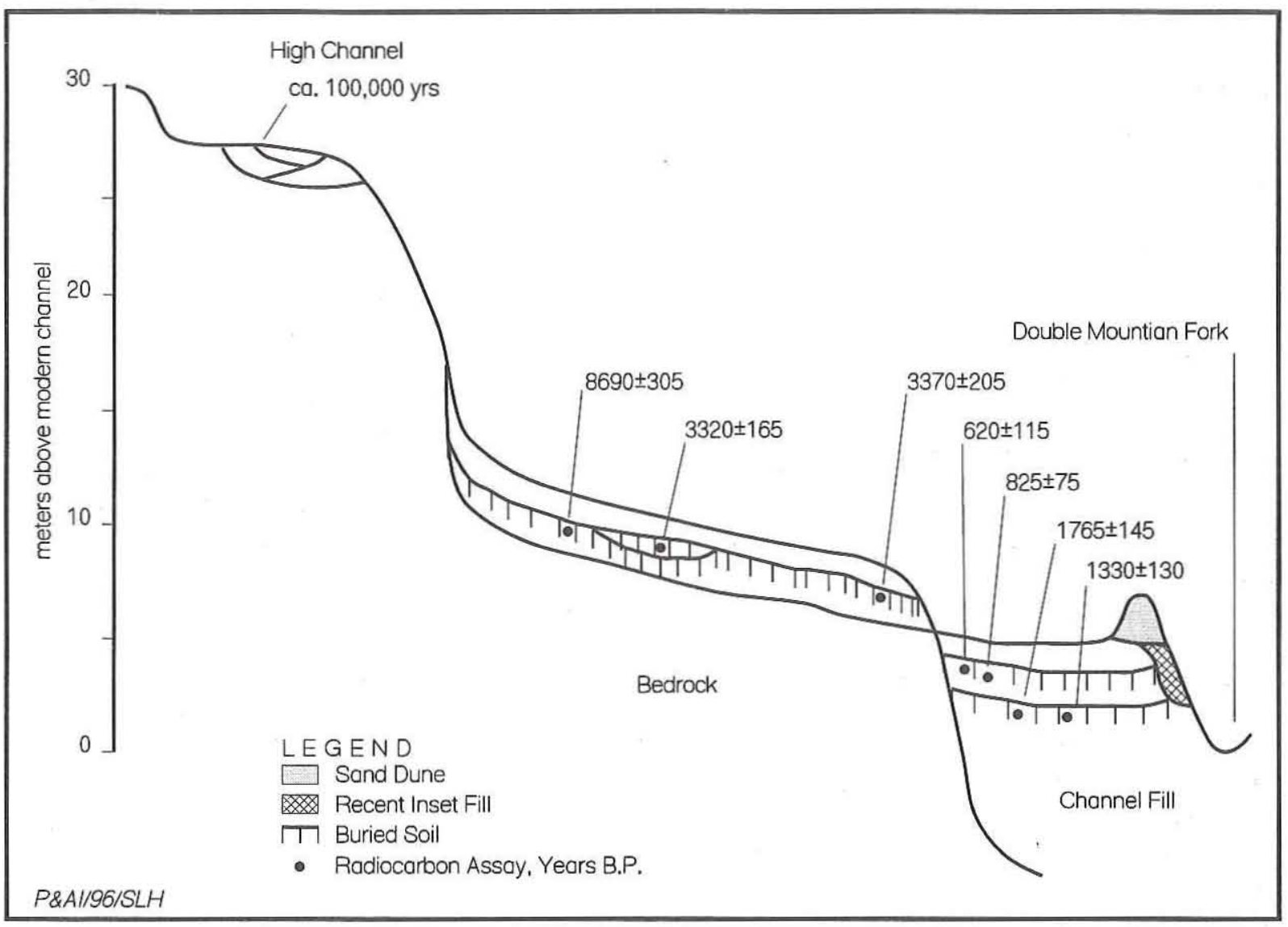

Figure 33. Generalized geomorphic cross section of the Double Mountain Fork valley in the downstream segment of Lake Alan Henry (radiocarbon ages are uncalibrated).

at around 3000 B.P.

In the Double Mountain Fork floodplain, Bousman (1992:140-142) dated buried soils in the upper $2 \mathrm{~m}$ that indicate at least two periods of soil development at $600-1000$ and $1300-1800$ B.P. These terraces are quite thick, ca. 18-19 $\mathrm{m}$ deep according to geotechnical bore logs near the dam axis, but none of the deeper deposits have been dated.

Also in the downstream segment, Bousman (1992:138) identified an ancient channel gravel perched on top of the south canyon rim. The deposit is nearly $30 \mathrm{~m}$ above the current river channel and only 5-6 $\mathrm{m}$ below the level of the upland plains. This deposit clearly predates human occupation in the region and reveals evidence of the geomorphic processes that formed the modern valley. It is estimated to be ca. 100,000 to 150,000 years old and is interpreted as a remnant channel of the Double Mountain Fork during its initial stage of valley incision.

\section{The Uplands}

In addition to the three geomorphic settings in the Double Mountain Fork valley, the upland sediments that surround the canyons of the central and downstream segments of the reservoir also were studied. Blum (1989:99-101) suggested that a radiocarbon date of 4730 B.P. (on sediments $90 \mathrm{~cm}$ below the surface at Geomorphic Locality 1) represented a minimum age for the eolian deposition of the upland sand sheet (between Grape and South Sage Creeks) and the beginning of soil development. Abbott (1990:51-53) conducted intensive investigations in the same area and dated upland sediments (from $80-90 \mathrm{~cm}$ below the surface in a backhoe trench) to 2770 B.P. and suggested that soil development on the upland surface has been progressing since the mid Holocene. The upland deposits are clearly much earlier than are most of the alluvial sediments, and they have the potential to contain 
archeological remains from all ages. It was originally thought that the upland sand sheet was predominantly an eolian deposit, but analysis of upland sediments from 13 backhoe trenches indicates that the

[p]arent materials on the uplands are an admixture of the native Triassic sandstone and dissected remnants of old alluvial fans shed off the retreating Caprock Escarpment and have been heavily reworked by slopewash and eolian processes. . . . Prolonged slopewash and eolian activity have resulted in extensive additional sorting of the material [Abbott 1990:51].

Further compounding interpretation of the upland sands is the fact that the deposits being reworked, i.e., the Lingos Formation (upper member), contain sediments originally deposited by both fluvial and eolian processes (Caran and Baumgardner 1990:782-783). Holliday (1989b:1605) notes that eolian sediments of the Lingos Formation are genetically related to those of the Blackwater Draw Formation. Consequently, while the upland sand sheet sediments are known to be composed of alluvial/colluvial- and eolian-derived materials (much of which is from the Lingos Formation via the Blackwater Draw Formation), the relative amounts of sediments contributed by these processes are unclear.

Bousman (1991) conducted a more intensive investigation (including 14 backhoe trenches) of the upland sediments in the wildlife mitigation lands (now called wildlife habitat area) located north of the dam. No radiocarbon dates were obtained, but the upland sand sheet on the north side of the reservoir appeared generally comparable to the upland deposits on the south side. Bousman (1991: 47) observed, however, that the upland deposits on the south side contained finer grained sediments with a higher degree of pedogenic development than the upland deposits on the north side. It was suggested that this was related to the prevailing wind direction (south to southwest) and distance from sediment sources, with coarse sediments on the north side being derived from the Double Mountain Fork valley and river channel and the south side uplands being farther from a primary sediment source for eolian deposition.

Another interesting characteristic observed north of the river is that calcium carbonate $\left(\mathrm{CaCO}_{3}\right)$ cemented gravels were encountered at the bottom of six backhoe trenches (while others revealed that the upland sand sheet was lying directly on Triassic sandstones). Bousman (1991:47) stated that the " $\mathrm{CaCO}_{3}$-cemented gravels are probably truncated Pleistocene alluvial/colluvial fan deposits associated with the erosion of the Caprock and may be the local expression of the basal unit of the informally defined Lingos formation (Caran and Baumgardner 1988)." The Lingos Formation is now formally defined, and Caran and Baumgardner (1990:Figure 1) have mapped a large outcrop of Lingos Formation on the north side of the Double Mountain Fork, just west of Lake Alan Henry. This raises the possibility that the upland sand sheet north of the dam discussed by Bousman (1991) actually represents a thin but intact section of Lingos Formation (with lower and upper members) rather than redeposited sandy sediments overlying a truncated section of lower Lingos Formation gravels.

Playas also are found in the uplands around the project area and constitute a unique geomorphic setting. The playas located off the Caprock escarpment are probably analogous to many of the smaller playas on the Llano Estacado, but they are certainly much younger than the large Pleistocene-age playas on the Southern High Plains (Reeves 1976:215-223). These small playas in the Lower Plains have not been investigated to any extent, but one such locality, called Morgan Playa, was investigated by Kibler (Boyd and Kibler 1993) during data recovery work at Lake Alan Henry. Morgan Playa, located ca. $3.0 \mathrm{~km}(1.9 \mathrm{~m})$ north of the Double Mountain Fork (see Figure 27), is a circular deflationary basin that is 3.2 hectares ( 8 acres) in size. A 2.5 -m-deep backhoe trench in the center of the basin revealed a sequence of $205 \mathrm{~cm}$ of lacustrine clays on top of $45 \mathrm{~cm}$ of loam, the latter representing a truncated or deflated soil (Bk horizon). A radiocarbon assay on organic-rich lacustrine sediments at $170-180 \mathrm{~cm}$ below the surface yielded a corrected radiocarbon age of $6840 \pm 140$ B.P., which calibrates to 78757531 B.P. This date is interpreted as evidence that the underlying soil had formed by the late Pleistocene, perhaps as much as $10,000-12,000$ years ago, but was subsequently truncated some time prior to 8000 B.P. The lacustrine sediments appear to have accumulated more or less continuously since that time. The deflation (or erosional truncation) of Morgan Playa clearly predates the well-documented middle Holocene severe xeric conditions (i.e., the Altithermal), but other evidence seems to suggest 
that episodic eolian sedimentation and surface deflation began on the High Plains as early as 9000 B.P. (Holliday 1989b).

Sediment samples were submitted for pollen and phytolith analyses to determine their state of preservation. Three samples (from $40-82 \mathrm{~cm}$ below the surface) were subjected to pollen analysis by Dering (1993b), who concluded that the fossil pollen was too degraded to provide interpretable paleoenvironmental data. On the other hand, 25 sediment samples (from all levels) were found to have wellpreserved phytoliths that could be used for paleoenvironmental interpretation. Fredlund (1993) suggested that the phytolith data from these samples provided evidence of a cooler-climate-adapted mixed-grass prairie during the early Holocene (ca. 9000 B.P.), followed by a gradual shift to true shortgrass prairie that was stabilized by the middle Holocene (ca. 5600 B.P.). Short-grass prairie conditions prevailed throughout the remainder of the sequence until very late (ca. 600 B.P.), although the late shift may be related to historic land-use and the introduction of non-native species. Without additional radiocarbon dates to support the assumption that the lacustrine sediments at Morgan Playa represent continuous accumulation since late Pleistocene or early Holocene times, these interpretations are quite tenuous. The data do indicate, however, that phytolith analysis of sediments from playas has considerable potential.

\section{SURVEY AND TESTING ARCHEOLOGY}

At Lake Alan Henry, the site is the basic unit of inventory for identifying and managing archeological remains, and activity areas within sites are generally recognized by the presence of features and artifact distribution patterns. Using the archeological concepts of sites and features, this section provides a broad overview of the Native American archeological remains encountered at Lake Alan Henry, based primarily on data derived from the survey and limited testing. Artifacts are discussed in considerable detail in subsequent chapters and are not considered here.

\section{Sites}

Sites are classified by function (i.e., based on interpretations of cultural activities) and into catego- ries that represent time (i.e., sites may contain one or more components assigned to different time periods) and space (i.e., a site's location within the landscape). Classification and analysis of sites by functional, temporal, and spatial groups is useful for inferring human behavior through time and space.

The primary site classification scheme used at Lake Alan Henry places sites into groups that broadly approximate functional categories (Table 21). These archeological sites are simply locations where evidence of past human activities was identified, and they range from small lithic scatters to extensive campsites covering thousands of square meters and encompassing many types of features and artifacts. However, not all site types are equally important for comparative purposes. Fifty-four prehistoric isolated finds were recorded (and 45 of these were assigned site numbers during the survey phase), but they are not considered here. In addition, sites containing only Native American rock art are excluded from consideration in this section but are discussed later in this chapter. By excluding the isolated finds and rock art localities, the Lake Alan Henry site data are more comparable to most of the regional archeological survey data (with some exceptions noted below).

Of the 290 Native American sites documented (excluding isolated finds and rock art sites), the vast majority ( $\mathrm{n}=237,81.7$ percent) are known only through survey-level data (Table 22). More information is generally known for 42 sites ( 14.5 percent) that were subjected to limited to moderate levels of subsurface testing, and the greatest amount of data is available for the 11 sites ( 3.8 percent) that saw data recovery investigation. The intensity of testing and data recovery excavations varies considerably, with the number of hand-excavated $1-x-1-m$ units ranging from 1 to 11 for tested sites and 7 to 340 for data recovery sites. The intensity of mechanical testing also varied considerably, with as many as $\mathbf{3 6}$ backhoe trenches being put into a single site.

If all 290 sites are considered, the 11,280-acre project area has a density is one site per 38.9 acres. If the 32 sites containing only Native American rock art are considered also, then the 322 sites are distributed at a density of one site per 35 acres. This latter figure is perhaps the most realistic for comparing with other regional survey data because it represents all of the documented Native American activity locations (excluding isolated finds). As discussed in Chapter 3, the site density at Lake Alan Henry is comparable to other areas in the Caprock 


\begin{tabular}{|c|c|}
\hline & $\begin{array}{l}\text { TABLE } 21 \\
\text { SITE TYPE DEFINITIONS USED AT LAKE ALAN HENRY }\end{array}$ \\
\hline $\begin{array}{c}\text { Lithic Procurement } \\
\text { Areas }\end{array}$ & $\begin{array}{l}\text { Natural outcrops of Quaternary (Lingos Formation) gravels that exhibit evidence of use } \\
\text { as a lithic source area. Almost all lithic outcrops in the project area contain natural } \\
\text { gravel nodules, tested nodules, cores, primary flakes, core choppers, and hammerstones. } \\
\text { Finished artifacts and most cultural materials are obviously related to testing of source } \\
\text { materials and early stages of lithic reduction. Lithic procurement areas differ from } \\
\text { quarries in that the gravels are exposed on the surface and digging is not required to } \\
\text { obtain usable raw materials. }\end{array}$ \\
\hline Open Campsites & $\begin{array}{l}\text { Distinguished mainly by the presence of burned (or fire-cracked) rocks, evidence of later } \\
\text { stages of lithic reduction (thinning flakes, etc.), and occasional finished stone tools. No } \\
\text { distinction is made between temporary and base camps at the survey level. Classification } \\
\text { as a campsite assumes that food preparation (i.e., cooking) is represented by the burned } \\
\text { rocks and that these activities took place mainly at habitation sites. }\end{array}$ \\
\hline $\begin{array}{l}\text { Lithic Procurement/ } \\
\text { Open Campsites }\end{array}$ & Utilized gravel outcrops that also have characteristics of open campsites. \\
\hline Rockshelters & $\begin{array}{l}\text { Overhangs in or beneath erosion-resistant rock layers (e.g., the upper canyon-rim-forming } \\
\text { bluff). Rockshelters occur throughout the project area; most have shallow to no soil } \\
\text { accumulations, but only locations that produced cultural materials are classified as } \\
\text { rockshelters. }\end{array}$ \\
\hline Faunal Localities & $\begin{array}{l}\text { Locations containing large mammal bones but no definite cultural materials. The bones } \\
\text { are articulated or semiarticulated and represent at least one animal. These sites are } \\
\text { considered archeological because of their potential to represent isolated kills or portions } \\
\text { of kill sites or to produce other cultural evidence. }\end{array}$ \\
\hline Lithic Scatters & $\begin{array}{l}\text { Similar to campsites, but they contain only sparse evidence of late-stage lithic reduction. } \\
\text { Finished artifacts and late-stage manufacturing failures are rare; fire-cracked rocks and } \\
\text { burned rock features are sparse or absent. These sites are not situated in gravel outcrop } \\
\text { areas. }\end{array}$ \\
\hline Isolated Finds & $\begin{array}{l}\text { Single surface artifacts with no associated materials or features, or surface sites with an } \\
\text { artifact density of less than one item in } 20 \mathrm{~m}^{2} \text { and no potential for association with buried } \\
\text { cultural materials. }\end{array}$ \\
\hline Rock Art Sites & $\begin{array}{l}\text { Locations where markings are found on rock surfaces. Rock art made by Native } \\
\text { Americans consists of images that were painted on (pictographs) or carved into } \\
\text { (petroglyphs) rock surfaces. }\end{array}$ \\
\hline
\end{tabular}

Canyonlands and is considerably higher than observed on the Llano Estacado or in the Rolling Plains.

The most common sites throughout the project area are open campsites, lithic procurement areas, and combination lithic procurement areas/campsites. Collectively, these sites account for 91 percent $(\mathrm{n}=$ 265) of all recorded sites. Camping activities were observed at 69 percent $(n=201)$ of the sites, while lithic procurement activities were observed at 48 percent $(n=138)$. While these activities (i.e., heating and cooking, lithic procurement, and stone tool manufacture) were important prehistorically, they are certainly overrepresented by artifact classes (i.e., chipped stones and burned rocks) that are ubiquitous and are not biased by preservation. In contrast, the paucity of faunal localities (two of which were subsequently identified as probable kill/butchering localities) is related to preservation and does not reflect the true importance of prehistoric hunting activities. Faunal localities were only found buried in alluvial deposits of very recent age (i.e., less than 500 years old) and are not likely to be preserved in other settings. 


\begin{tabular}{|c|c|c|c|c|c|}
\hline \multicolumn{6}{|c|}{$\begin{array}{c}\text { TABLE } 22 \\
\text { SUMMARY OF NATIVE AMERICAN SITES AT LAKE ALAN HENRY } \\
\text { BY LEVEL OF INVESTIGATION }\end{array}$} \\
\hline Site Type & Survey Only & Survey and Testing & $\begin{array}{l}\text { Survey, Testing, } \\
\text { and Data Recovery }\end{array}$ & Total No. & Total \% \\
\hline $\begin{array}{l}\text { Lithic Procurement Area } \\
\text { Open Campsite } \\
\text { Lithic Procurement Area/ } \\
\text { Open Campsite } \\
\text { Faunal Locality } \\
\text { Rockshelter } \\
\text { Lithic Scatter }\end{array}$ & $\begin{array}{r}60 \\
98 \\
\\
66 \\
1 \\
3 \\
9\end{array}$ & $\begin{array}{r}4 \\
20 \\
\\
8 \\
9 \\
- \\
1\end{array}$ & $\begin{array}{l}\overline{9} \\
- \\
\overline{2} \\
-\end{array}$ & $\begin{array}{r}64 \\
127 \\
\\
74 \\
10 \\
5 \\
10\end{array}$ & $\begin{array}{r}22.1 \\
43.8 \\
\\
25.5 \\
3.4 \\
1.7 \\
3.4\end{array}$ \\
\hline Totals: & 237 & 42 & 11 & 290 & - \\
\hline Percents: & 81.7 & 14.5 & 3.8 & - & 100 \\
\hline
\end{tabular}

The relative scarcity of lithic scatters is not particularly meaningful because of the absolute abundance of lithic procurement areas and campsites. Most lithic reduction activities took place on or near gravel outcrops that served as source areas or at campsites. In contrast, the scarcity of rockshelters that were inhabited by people is related more to geomorphic processes than anything else. Small rockshelters are common in the Lake Alan Henry area, and many of them probably were occupied prehistorically. The lack of cultural evidence probably is due, in part, to the facts that rockshelters develop and collapse relatively quickly in the Triassic Dockum Group formations and shelter deposits may have been scoured out periodically by wind or rain (see Boyd et al. [1990:243-244] for a discussion of rockshelter development and collapse). Consequently, it is assumed that many rockshelters that once were occupied are now gone or that the cultural deposits have eroded away.

The correlations between site locations and topographic settings (Table 23) relate to a number of factors, but a detailed analysis of spatial distributions is not possible because the relative areas encompassed by various landforms within the project area cannot be accurately estimated. A crude estimate is that the survey area is comprised of approximately 15 percent upland, 25-30 percent upland margin, 20 percent valley slope (perhaps equal portions of talus slope, erosional remnant, and bedrock terrace), and 35-40 percent valley bottom. The latter zone includes a significant amount of active river/tributary channels, and it is likely that alluvial terraces make up only around 20 percent of the total area. The two rarest settings are isolated mesas and eolian dunes on terraces. Each probably makes up less than 1-2 percent of the total area.

Based on these estimates, a few general observations on the spatial distributions of sites are warranted (beyond the obvious correlations inherent in the site definitions, such as the occurrence of rockshelters only along bluffs). Campsite and lithic procurement activities occur in all areas that are conducive to their preservation, and, not surprisingly, the lithic procurement areas are most abundant along the upland margin where in situ Lingos Formation gravels are ubiquitous. Lithic procurement sites are common in the valley slopes where gravels have been redeposited onto erosional remnants and bedrock terraces, but they are rare in valley bottoms because only small amounts of gravels have washed down and remain intact on alluvial terraces. Sites are less abundant in upland settings, as opposed to upland margins. Lithic procurement sites are absent because gravel outcrops are not found in the uplands, and campsites are rare because of the distance to water. The low number of mesa and eolian dune sites simply reflects the fact that these landforms are rare in the project area. Conversely, the low number of sites on talus slopes is due to the nature of the landform. It is likely that few cultural activities took place on talus slopes, and because talus slopes 
TABLE 23

SPATIAL DISTRIBUTION OF NATIVE AMERICAN SITES AT LAKE ALAN HENRY

\begin{tabular}{|c|c|c|c|c|c|c|c|c|}
\hline \multirow{2}{*}{$\begin{array}{l}\text { Topographic } \\
\text { Setting }\end{array}$} & \multirow{2}{*}{$\begin{array}{l}\text { Lithic } \\
\text { Procurement } \\
\text { Area }\end{array}$} & \multirow{2}{*}{$\begin{array}{l}\text { Open } \\
\text { Campsite }\end{array}$} & \multirow{2}{*}{$\begin{array}{l}\text { Lithic } \\
\text { Procurement } \\
\text { Area/Campsite }\end{array}$} & \multirow{2}{*}{$\begin{array}{l}\text { Faunal } \\
\text { Locality }\end{array}$} & \multirow{2}{*}{$\begin{array}{l}\text { Rock- } \\
\text { shelter }\end{array}$} & \multirow{2}{*}{$\begin{array}{l}\text { Lithic } \\
\text { Scatter }\end{array}$} & \multicolumn{2}{|c|}{ Totals } \\
\hline & & & & & & & No. & $\%$ \\
\hline Upland & & 11 & - & - & - & - & 11 & 3.8 \\
\hline Upland Margin & $4 \overline{0}$ & 34 & 46 & - & - & 6 & 126 & 43.4 \\
\hline Bluff & - & - & - & - & 5 & - & 5 & 1.7 \\
\hline Talus Slope & 1 & - & - & - & - & - & 1 & 0.3 \\
\hline Isolated Mesa & 1 & 1 & 2 & - & - & - & 4 & 1.4 \\
\hline Erosional Remnant & 13 & 22 & 11 & - & - & - & 46 & 15.9 \\
\hline Bedrock Terrace & 6 & 11 & 8 & - & - & 1 & 26 & 9.0 \\
\hline Alluvial Terrace & 3 & 45 & 7 & 10 & - & 3 & 68 & 23.4 \\
\hline Eolian Dune & - & 3 & - & - & - & - & 3 & 1.0 \\
\hline Totals: & 64 & 127 & 74 & 10 & 5 & 10 & 290 & - \\
\hline Percents: & 22.1 & 43.8 & 25.5 & 3.4 & 1.7 & 3.4 & - & 100 \\
\hline
\end{tabular}

are actively eroding, it is likely that most evidence of such activities has been destroyed.

The 290 sites include 314 individual components that are defined and classified by time period and site type in Table 24. The age classifications correspond to the Caprock Canyonlands cultural chronology discussed earlier in this chapter (see Figure 26). The six site type categories are generalized and have only vague functional connotations, but they are useful and appropriate classifications for survey-level data. The age of most sites cannot be identified based on survey data, ${ }^{3}$ and this is particularly true for certain site types (e.g., lithic procurement areas, lithic scatters, and faunal localities) that generally do not produce temporally diagnostic artifacts. The temporal placement of components is more precise for the sites that were tested or excavated, and 94 components have been assigned to time periods.

The most obvious pattern to the temporal distribution is the abundance of late sites and the near-absence of early sites. No Paleoindian sites

\footnotetext{
${ }^{3}$ As a cautionary note, several sites that were thought to have Archaic components were found to be primarily of Late Prehistoric age during subsequent testing or data recovery. In addition, dart points recovered from Protohistoric occupations at Lake Alan Henry (Boyd et al. 1993:145) and at the Lubbock Lake site (E. Johnson 1987:111) provide clear evidence that earlier artifacts commonly were picked up and reused by later peoples.
}

were found and only three Early to Middle Archaic sites are recorded (Boyd et al. [1989:110, 340] report that a spurred end scraper from one site might be a Paleoindian tool, but this interpretation is tentative). In contrast, 76 (96 percent) of the 79 components that can be assigned to a specific time period (other than general Archaic) are of Late Archaic, Late Prehistoric, or Protohistoric age. This lopsided distribution, which mirrors the skewed temporal distribution of the on-site radiocarbon dates from cultural contexts shown in Table 20, is thought to be a realistic sample of the human occupational evidence that is preserved in the project area. The sample is somewhat biased because the archeological testing and data recovery were confined to the main part of the reservoir and a few construction areas, thus eliminating potentially older sites in the uplands and upland margins from consideration for investigation. For most of the project area, however, it appears that almost all of the archeological remains are less than 3,000 years old. The geomorphic data described earlier in this chapter help explain this temporal bias.

Based on the archeological and geomorphic data (see Blum et al. [1992] for a more detailed discussion of the archeological implications), archeological remains dating to the Paleoindian and Early to Middle Archaic periods are likely to be rare throughout the Caprock Canyonlands because (1) they were probably rare to begin with due to low human population density (relative to later times); 
TABLE 24

SUMMARY OF NATIVE AMERICAN ARCHEOLOGICAL COMPONENTS AT 290 LAKE ALAN HENRY SITES

\begin{tabular}{|c|c|c|c|c|c|c|c|c|}
\hline \multirow[b]{2}{*}{ Period } & \multirow{2}{*}{$\begin{array}{l}\text { Lithic } \\
\text { Procurement } \\
\text { Area }\end{array}$} & \multirow{2}{*}{$\begin{array}{l}\text { Open } \\
\text { Campsite }\end{array}$} & \multirow{2}{*}{$\begin{array}{l}\text { Lithic } \\
\text { Procurement } \\
\text { Area/Campsite }\end{array}$} & \multirow{2}{*}{$\begin{array}{l}\text { Faunal } \\
\text { Locality }\end{array}$} & \multirow{2}{*}{$\begin{array}{l}\text { Rock- } \\
\text { shelter }\end{array}$} & \multirow{2}{*}{$\begin{array}{l}\text { Lithic } \\
\text { Scatter }\end{array}$} & \multicolumn{2}{|c|}{ Totals } \\
\hline & & & & & & & No. & $\%$ \\
\hline $\begin{array}{l}\text { Protohistoric/ } \\
\text { Historic }\end{array}$ & - & 3 & - & 5 & 2 & - & 10 & 3.2 \\
\hline Late Prehistoric II & - & 11 & 1 & 1 & 2 & - & 15 & 4.8 \\
\hline Late Prehistoric I & - & 10 & - & - & 1 & - & 11 & 3.5 \\
\hline $\begin{array}{l}\text { Undefined Late } \\
\text { Prehistoric }\end{array}$ & - & 10 & 9 & - & 1 & - & 20 & 6.4 \\
\hline Late Archaic & - & 10 & 10 & - & - & - & 20 & 6.4 \\
\hline $\begin{array}{l}\text { Early-Middle } \\
\text { Archaic }\end{array}$ & - & 3 & - & - & - & - & 3 & 1.0 \\
\hline Undefined Archaic & - & 7 & 8 & - & - & - & 15 & 4.8 \\
\hline Paleoindian & - & - & - & - & - & - & 0 & 0.0 \\
\hline Undefined & 64 & 87 & 53 & 4 & 2 & 10 & 220 & 70.1 \\
\hline Totals: & 64 & 141 & 81 & 10 & 8 & 10 & 314 & - \\
\hline Percents: & 20.4 & 45.0 & 25.8 & 3.2 & 2.5 & 3.2 & - & 100 \\
\hline
\end{tabular}

(2) most of the older alluvial sediments (i.e., late Pleistocene and early Holocene) were removed by erosion during the mid-Holocene Altithermal period; and (3) remnants of older alluvial sediments are few and have low archeological visibility because they are deeply buried and minimally exposed. Previous researchers have recognized that the archeology in other areas along the Caprock Escarpment is skewed toward later time periods and have speculated that this bias is due to climatic events such as Antevs's (1948, 1955) Altithermal period (see Chapter 8).

When the spatial and temporal distributions of the 314 components are considered (Table 25), it is notable that components of all ages, including the Early-Middle Archaic, are represented in the upland margin and erosional remnant settings. Sites in the alluvial terraces and in terrace dunes are only assigned to the Late Archaic and later periods. Again, geomorphic processes are probably responsible for this skewed distribution.

\section{Features}

Features are the basic archeological unit representing identifiable activity areas within sites. When features are excavated and seen in their entirety (i.e., in conjunction with other features and spatial patterns of associated artifacts), a great deal of functional and contextual information may be obtained. However, survey-level data generally are constrained by incomplete views of portions of features that often are disturbed by erosion. The features encountered at Lake Alan Henry include many generically defined feature types known from survey data to precisely defined features revealed by testing and excavation. Because of the large sample of sites, the various types of features summarized below are considered representative of the cultural features throughout the Caprock Canyonlands. The most common features encountered during survey (see Boyd et al. 1989:112-123) and limited testing (Boyd et al. 1990:236-244) are summarized below. Additional feature types defined during data recovery are mentioned, but they are described in more detail later in this chapter.

\section{Burned and Fire-Cracked Rock Features}

The most common features encountered throughout the project area are scatters or clusters of burned and fire-cracked rocks. Burned rock features are 


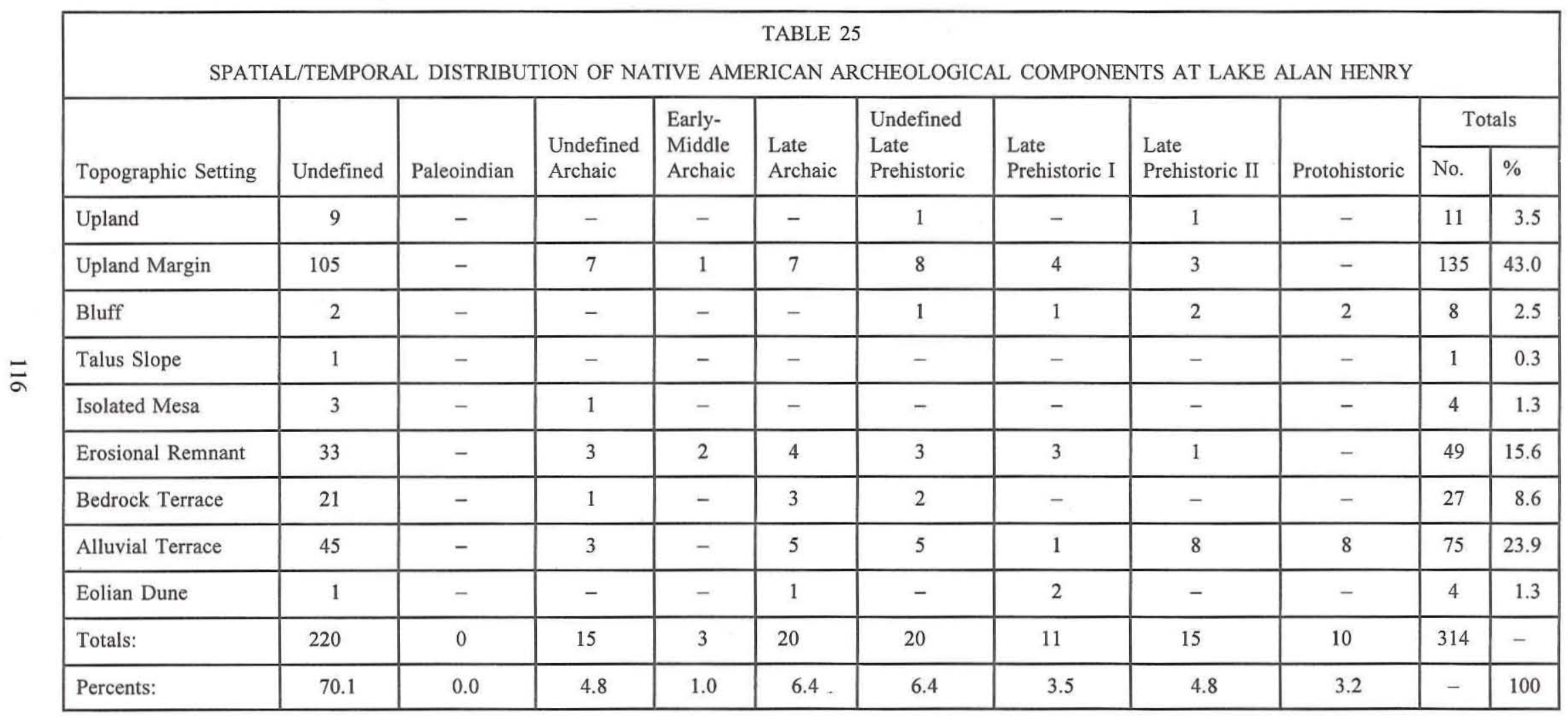


composed primarily of heat-altered sandstones that are identifiable by distinctive interior colors but lack prominent angular fracturing. Fire-cracked rock features are composed primarily of heat-altered quartzitic rocks (generally Potter chert and Ogallala quartzites, and occasionally limestone) that have distinctive, angular thermal fractures. Some features are composed of several types of burned and firecracked rocks, but they are more commonly composed of only one rock type.

Burned rock features seem to represent a variety of activities, but during survey it is usually impossible to determine what a particular feature represents. Discrete scatters and clusters may represent disturbed hearths, while extensive scatters are probably indicative of accumulations on living surfaces. Irregular piles of burned sandstone may represent dumps, and data recovery excavations suggest that some of these piles are accumulations of debris discarded from baking pits.

Fire-cracked rock features also are thought to represent various types of activities. These features may represent disturbed hearthlike features or baking pits, dumps of debris discarded from baking pits, or accumulations on living surfaces. In addition, some small clusters of fire-cracked rocks are thought to represent dumps of boiling stones. One probable boiling stone dump, found adjacent to a slab-lined hearth, was excavated at 41GR287 during the testing phase (see Boyd et al. 1990:Figure 42). Unfortunately, attempts to differentiate rocks that were cracked in fires from those that may have been used in stone boiling were not successful. Informal experimental studies suggest that Potter chert and Ogallala quartzites fracture the same whether they are only heated in a fire or are heated and then dumped into cold water (although they tend to fracture more easily if used as boiling stones).

A large accumulation of burned sandstone was encountered during survey at site 41GR383 (see Boyd et al. 1989:Figure 19). This feature was originally thought to be something akin to a burned rock midden, but subsequent data recovery excavations at the site revealed several large rock piles (see Boyd et al. 1992:Figure 15) accumulated around baking pits. In addition, buried irregular concentrations of burned sandstone found at 41GR303B were interpreted as debris discarded from baking pits (see Boyd et al. 1993:Figures 45-50).

\section{Hearths}

Although the term hearth is often used generically for any cluster of burned or fire-cracked rocks, the Lake Alan Henry project reserved the term for intact rock-lined features that were patterned in some way, suggesting intentional placement and in situ heating. Hearths most commonly are lined with tabular sandstone slabs, and they are usually either flat or slightly basin shaped. These features were commonly found during surveys, but most were in various stages of deterioration, having been exposed by sheet erosion or in cutbanks. Subsequent excavations revealed that many intact rock-lined hearths are uniform and easily recognized (see Boyd et al. 1990:Figure 31 and Boyd et al. 1992:Figure 26).

A slightly different type of burned rock feature, distinctive from slab-lined hearths, is the baking pit. Baking pits are distinguished by being deep pits as opposed to shallow basins. No baking pits were positively recognized during survey or testing, but several identified in data recovery excavations are discussed later in this chapter. One baking pit at 41 GR291 is interpreted as intact (i.e., never reopened to extract the cooked contents), but most appear to have been only rock-lined bottoms with disturbed upper portions.

Basin-shaped hearths which were not lined with rocks but had burned clay bottoms were identified in excavations at two Protohistoric sites (41KT51 and 41KT53). These unlined hearths are interpreted as cooking/heating hearths used inside tipi shelters (Boyd et al. 1993:105, 109, 123, 215), but these types of features are not likely to be found during surveys (except perhaps in cutbank profiles).

\section{Middens}

An extensive concentration of dark organic-rich sediment and cultural debris (i.e., burned rocks, lithic debris, and bone fragments) was observed in a cutbank at one site (41KT79) during survey. This feature was interpreted as a trash midden (Boyd et al. 1989:120), but no additional work was done to confirm this. Data recovery excavations at 41GR291 revealed a similar middenlike feature (discussed later in this chapter).

\section{Cairns}

Numerous rock cairns (i.e., piles of unburned 
rocks, usually sandstone) were found at several sites during the survey (Boyd et al. 1989:121). Rock piles were commonly used in the region to cover human interments, and it was thought that some of these features might be burial cairns. However, shovel testing of many of these features failed to reveal their function. A cairn burial was found during data recovery at 41GR291 (see Boyd et al. 1994:Figure 20). This rock cluster was barely exposed on the surface, and it appeared to be a small hearth. It was not recognized as a cairn until the excavation completely exposed the pile. Consequently, it is likely that there are many rock cairns in the project area, some probably covering burials, that cannot be recognized on the surface.

\section{Bedrock Mortars}

Pointed-oval, or boat-shaped, bedrock mortars are common in the Lake Alan Henry area, a fact originally noted by Kirkpatrick (1978). The reservoir survey documented over 30 mortars at 8 (possibly 11) sites (see Boyd et al. 1990:Table 13); 5 mortars were documented at 2 sites during testing (Boyd et al. 1990:89, 95-96); and the survey of wildlife mitigation lands documented an additional 26 mortars at 6 sites (Boyd et al. 1991:Table 6). Although a few isolated examples have been found, these mortars are generally on sandstone outcrops near campsites, and they are assumed to be associated with the nearby occupations. Unfortunately, mortars cannot be independently dated, so finding pestles in good archeological contexts is of considerable importance. Only recently have flat oval pestles, of the type used in the pointed-oval mortars, been identified, and several were found at Lake Alan Henry. During testing, an irregular sandstone slab pestle was found in a mortar at 41GR456 (Boyd et al. 1990:Figure 25), and a large ferruginous sandstone pestle was found on the surface at site 41GR471 (Boyd et al. 1990:Figure 73b). Data recovery at $41 \mathrm{GR} 383$ produced a manuport (without definite use wear) that apparently had been shaped and is almost certainly a complete pestle (Boyd et al. 1992:75, 80). This specimen was found in an excavated context and is apparently of Late Prehistoric I age. Two broken pestles were recovered from 41GR291 (see Boyd et al. 1994:Figure 36a, b), and one was in a well-dated Late Prehistoric I context (on the floor of a pithouse). Thus, it appears that there is now good archeological evidence for the use of oval mortars and pestles during the Late Prehistoric I period, although this does not preclude their use at other times.

In a recent study, Forrester (1991) suggested that ovate pestles and boat-shaped mortars in western central Texas were used around A.D. 200-700, exclusively by people who made Zephyr dart points. While Zephyr points and boat-shaped mortars are both common in that area, this interpretation is based primarily on investigations at one site in Stephens County. Forrester's (1991:Figure 2) map showing the distribution of boat-shaped mortars is misleading, and it excludes many areas where they are commonly found. Notably, boat-shaped mortars are very common in the Caprock Canyonlands, but Zephyr points are very rare (see Prewitt 1995:52). Since pointed-oval mortars are found over a vast area, at least as far north as the Canadian River valley and as far west as southern Lea County, New Mexico, it cannot be stated that they belong to a single culture or time period. A more complete analysis of their distribution is needed, but it seems that the distribution of pointed-oval mortars generally coincides with the distribution of Triassic and Permian sandstone outcrops in the Texas PanhandlePlains. In contrast, round mortars and cylindrical pestles appear to be common in areas where limestone outcrops but no tabular sandstones are present. The shape of mortars within an area may be dictated largely by the types of materials available for manufacturing pestles.

\section{Structures and Related Features}

Data recovery excavations revealed two types of structures and related features that are discussed later in this chapter. A pithouse and storage pits were identified at 41GR291, and tipis and extramural features (e.g., postholes thought to have supported drying racks or shade arbors) were identified at 41KT53. These types of features are not likely to be identifiable based only on surface evidence. A surficial rock scatter at one upland site (41GR585) may represent disturbed tipi rings (Boyd et al. 1991:25). This cannot be confirmed without excavations, but stone tipi rings are documented in the Texas Panhandle-Plains (Hughes 1978:46), although they are much less common than are stone circles in the Central and Northern Plains.

\section{NATIVE AMERICAN ROCK ART}

Thirty-four sites at Lake Alan Henry contain 
Native American rock art. These images document human behavior that is very different from the technology- and subsistence-related behavior evidenced in the archeological remains recovered from most sites. Recent rock art studies in the Texas Panhandle-Plains reveal that several varieties or styles of rock art are represented, indicating that different groups made the images. It also is likely that the production of images on rock faces served different functions for different groups. This section summarizes the rock art at Lake Alan Henry and places it into a broader regional context.

\section{Rock Art at Lake Alan Henry}

Prior to the 1987 survey, only three rock art sites were known to exist in the project area. Riggs (1965a) presented a preliminary recording of petroglyphs at the Dorward Ranch site, a popular picnic spot that is well known to local residents. During the 1966 excavations at Reed Shelter (41GR54), a few simple petroglyphs were found on the back shelter wall and a simple pictograph was discovered across the creek (41GR390). The rock art at these two sites was originally reported by Riggs (1966).

Because of the high probability of encountering rock art sites, the surveys intentionally targeted all rock faces, particularly those in prominent locations along the bluffs forming the canyon rim. The intensive coverage of these areas resulted in the discovery of 30 additional rock art sites and rerecording of the previously known sites. All sites were documented according to the standards set forth by Swartz (1981). The original documentation of these 30 sites, along with data for the 3 previously recorded sites, is presented by Boyd et al. (1989: 157-188). During the 1988 testing phase, moredetailed documentation was completed for 11 of the 33 sites (see Boyd 1990:209-234). One additional rock art site, which was missed during the 1987 survey, was discovered by a construction worker in 1993 and was subsequently recorded (Boyd et al. 1994:Appendix I), bringing the total number of Native American rock art sites in the 11,280-acre project area to 34. Additional studies of the rock art of Garza County and the Lake Alan Henry area are presented by Riggs (1965a, 1969), Bilbo (1986), Parsons (1987), Boyd (1990, 1991, 1992), and Boyd and Kibler (1993).

One of the most important observations resulting from the rock art research is that the vast majority of Panhandle-Plains rock art sites are probably of relatively recent age. This is supported by the fact that many sites contain identifiable historic motifs and by geological and archeological evidence. Throughout the region, no rock art of any significant antiquity has been recognized, and the geology and climate are not conducive to long-term preservation of exposed rock formations. None of the rockshelters at Lake Alan Henry or elsewhere in the Caprock Canyonlands are known to preserve deposits older than Late Archaic, and the sandstone canyon rim and bluff edges (where rockshelters and rock art occur most commonly) erode at a relatively fast rate. Geologic studies of the rate of erosion for the Caprock Escarpment (e.g., Gustavson and Simpkins 1989; Simpkins and Gustavson 1987) support this idea. No rock art sites or rockshelters of any antiquity are documented in the limestones exposed at the southern end of the High Plains, either, although it is possible that these Cretaceous formations do not erode quite as rapidly as Ogallala caliche and the Triassic and Permian sandstones and mudstones of the Caprock Canyonlands. It is probably a fair guess that most of the rock art in the Panhandle-Plains is no older than a few thousand years, but this has yet to be confirmed through independent dating of rock art images. Unfortunately, a recent attempt to radiocarbon date pigments from Native American pictographs failed (see Appendix C).

The Lake Alan Henry rock art sites are summarized in Table 26. Petroglyphs are the most common type of rock art, and 29 sites contain only images that were carved, scratched, or etched into rocks. Two sites contain only pictographs, and one site contains separate petroglyphs and pictographs. Rarer still are sites that contain images made using a combination of techniques. Painted petroglyphs are represented only at sites 41GR423 and 41GR344, and the latter site is quite complex and has many separate petroglyphs and a few pictographs. Painted petroglyphs, made by painting selected portions of incised images, have not been reported at any other sites in the Texas Panhandle-Plains, and their occurrence at Huddleston Shelter suggests that the combined use of these technique dates to Protohistoric times.

In terms of recognizable motifs, simple geometric figures are the most abundant representations, but tally marks and human figures (anthropomorphs) also are common (Table 27). Less common are various 


\begin{tabular}{|c|c|c|c|c|c|c|}
\hline \multicolumn{7}{|c|}{$\begin{array}{l}\text { TABLE } 26 \\
\text { SUMMARY OF NATIVE AMERICAN ROCK ART SITES AT LAKE ALAN HENRY }\end{array}$} \\
\hline $\begin{array}{l}\text { Reference to } \\
\text { Figure } 34\end{array}$ & Site No. and Name & Technique & $\begin{array}{l}\text { No. of } \\
\text { Panels }\end{array}$ & $\begin{array}{l}\text { No. of } \\
\text { Elements }\end{array}$ & Motifs & Styles Represented \\
\hline \multicolumn{7}{|c|}{ Garza County } \\
\hline 4 & $\begin{array}{l}41 \mathrm{GR} 51 \\
\text { Dorward Ranch }\end{array}$ & Petroglyph & 1 & $9+$ & $\begin{array}{l}\text { Wagons pulled by oxen, human figures, European } \\
\text { dress, horse and rider, cart pulled by horse, } \\
\text { buildings }\end{array}$ & $\begin{array}{l}\text { Plains Biographic } \\
\text { (late) }\end{array}$ \\
\hline 5 & $41 \mathrm{GR} 54$ & Petroglyph & 2 & 5 & Human figures, deer, snake(?), geometric figures & - \\
\hline 6 & $41 \mathrm{GR} 238$ & Petroglyph & 1 & 1 & Unidentified animal (cat?) & - \\
\hline 7 & $\begin{array}{l}\text { 41GR282, Ward } \\
\text { Petroglyph Site }\end{array}$ & Petroglyph & 5 & $2+$ & $\begin{array}{l}\text { Horse and rider, numerous human figures, deer, } \\
\text { geometric figures }\end{array}$ & Plains Biographic \\
\hline 8 & $41 \mathrm{GR} 315$ & Petroglyph & 1 & 4 & Geometric figures, possible human figures & - \\
\hline 9 & $41 \mathrm{GR} 317$ & Petroglyph & 1 & 1 & Geometric figures only & - \\
\hline 10 & $41 \mathrm{GR} 333$ & Petroglyph & 1 & 1 & Geometric figures only & - \\
\hline 11 & $\begin{array}{l}\text { 41GR344 } \\
\text { Huddleston Shelter }\end{array}$ & $\begin{array}{l}\text { Petroglyph and painted } \\
\text { petroglyph (red and black) }\end{array}$ & 1 & $25+$ & $\begin{array}{l}\text { Human figures, historic priest(?), European dress, } \\
\text { crosses, tipis, buildings, oxen, geometric figures }\end{array}$ & $\begin{array}{l}\text { Plains Biographic } \\
\text { (early) }\end{array}$ \\
\hline 12 & $41 \mathrm{GR} 352$ & Petroglyph & 1 & 1 & 3 tally marks or abrading grooves & - \\
\hline 13 & 41GR353 & Petroglyph & 1 & 2 & Geometric figures, tally marks & - \\
\hline 14 & 41GR354 & Petroglyph & 1 & 1 & 2 tally marks & - \\
\hline 15 & $41 \mathrm{GR} 390$ & Pictograph (red and black) & 1 & 4 & Human figure holding shield & - \\
\hline 16 & 41GR409 & Petroglyph & 1 & 1 . & Human figure & - \\
\hline 17 & $41 \mathrm{GR} 410$ & Petroglyph & 1 & 3 & Animals (deer?), tally marks & - \\
\hline 18 & $41 \mathrm{GR} 420$ & Petroglyph & 1 & 1 & Geometric figures (?) & - \\
\hline 19 & $41 \mathrm{GR} 423$ & Painted (red) petroglyph & 1 & 2 & Human figures & - \\
\hline 20 & 41GR424 & Petroglyph & 1 & 1 & Geometric figures only & - \\
\hline
\end{tabular}




\begin{tabular}{|c|c|c|c|c|c|c|}
\hline \multicolumn{7}{|c|}{ Table 26, continued } \\
\hline $\begin{array}{l}\text { Reference to } \\
\text { Figure } 34\end{array}$ & Site No. and Name & Technique & $\begin{array}{l}\text { No. of } \\
\text { Panels }\end{array}$ & $\begin{array}{l}\text { No. of } \\
\text { Elements }\end{array}$ & Motifs & Styles Represented \\
\hline 21 & $41 \mathrm{GR} 426$ & Pictograph (red) & 1 & 1 & Negative human handprint & - \\
\hline 22 & $41 \mathrm{GR} 437$ & $\begin{array}{l}\text { Pictograph (black or } \\
\text { green) and petroglyph }\end{array}$ & 3 & 5 & Geometric figures, tally marks & - \\
\hline 23 & $41 \mathrm{GR} 445$ & Petroglyph & 1 & 1 & Geometric figure only (shield?) & - \\
\hline 24 & 41GR457 & Petroglyph & 5 & $5+$ & Geometric figures & - \\
\hline 25 & 41GR472 & Petroglyph & 1 & 1 & Geometric figure or tally marks & - \\
\hline 26 & $41 \mathrm{GR} 490$ & Petroglyph & 2 & 3 & Geometric figures (possible human figure?) & - \\
\hline 27 & 41GR491 & Petroglyph & 3 & 6 & Geometric figure & - \\
\hline 28 & $41 \mathrm{GR} 494$ & Petroglyph & 2 & $6+$ & Geometric figure, tally marks & - \\
\hline 29 & 41GR517 & Petroglyph & 1 & 1 & Geometric figure & - \\
\hline 30 & $41 \mathrm{GR} 545$ & Petroglyph & 1 & 1 & Geometric figure & - \\
\hline 31 & $41 \mathrm{GR} 567$ & Petroglyph & 1 & 1 & Human handprint & - \\
\hline \multicolumn{7}{|c|}{ Kent County } \\
\hline 1 & $41 \mathrm{KT} 50$ & Petroglyph & 3 & 5 & $\begin{array}{l}\text { Geometric figures only (possible animal } \\
\text { figures) }\end{array}$ & - \\
\hline 2 & $41 \mathrm{KT} 55$ & Petroglyph & 4 & 6 & $\begin{array}{l}\text { Geometric figures, tally marks, possible } \\
\text { animal figures }\end{array}$ & - \\
\hline 3 & $41 \mathrm{KT} 57$ & Petroglyph & 3 & $6+$ & Geometric figures, tally marks & - \\
\hline 4 & $41 \mathrm{KT} 65$ & Petroglyph & 3 & $10+$ & Geometric figures, tally marks, human figures & - \\
\hline 5 & 41KT68 & Petroglyph & 1 & $5+$ & $\begin{array}{l}\text { Geometric figures (shield?), tally marks, } \\
\text { human figure(s)? }\end{array}$ & - \\
\hline 6 & $\begin{array}{l}\text { 41KT164 } \\
\text { Callahan Site }\end{array}$ & Petroglyph & 6 & 18 & $\begin{array}{l}\text { Geometric figures (shield?), numerous human } \\
\text { figures, } 2 \text { stylized human figures, horse }\end{array}$ & $\begin{array}{l}\text { Plains Biographic (late) } \\
\text { and Southwestern } \\
\text { (possibly Rio Grande or } \\
\text { Jornada style) }\end{array}$ \\
\hline
\end{tabular}




\section{TABLE 27}

FREQUENCY OF IDENTIFIABLE MOTIFS IN NATIVE AMERICAN ROCK ART AT LAKE ALAN HENRY

\begin{tabular}{|l|c|c|}
\hline Motif & $\begin{array}{l}\text { No. of Sites } \\
\text { Where Motif } \\
\text { Occurs }\end{array}$ & $\begin{array}{l}\text { Total No. of } \\
\text { Examples }\end{array}$ \\
\hline General & 23 & $72+$ \\
Geometric figure & 2 & 2 \\
Shield & 11 & $52+$ \\
Human figure & 2 & 2 \\
Human hand & 12 & 16 \\
Tally mark & 1 & 2 \\
Deer & 1 & 1 \\
Snake & 6 & 8 \\
Unidentified animal & 1 & 1 \\
Tipi & & 3 \\
\hline Historic & 2 & 2 \\
Horse & 2 & 1 \\
Horse and rider & 1 & 9 \\
Horse and cart & 1 & 1 \\
Wagon-oxen drawn & 1 & $4+$ \\
Oxen (longhorn) & 2 & $6+$ \\
Building & 2 & $1(?)$ \\
European dress & $1(?)$ & \\
Gun & & \\
\hline
\end{tabular}

animal figures (zoomorphs), shieldlike symbols, human hands, and a single example of a tipi. When viewed independently, most of these general motifs cannot be assigned to a specific cultural group, time period, or style. Possible exceptions are that some of the geometric glyphs at sites 41GR494 and 41KT65 are similar to the Fort Chadbourne type petroglyphs, and unusual anthropomorphs found at $41 \mathrm{KT} 164$ are likely of Southwestern origin or influence (discussed below).

Historic motifs are prominent at four rock art sites at Lake Alan Henry, and it is possible to speculate that some of the general motifs were made by Protohistoric or Historic Native Americans based on their concurrence with historic motifs. The Dorward Ranch, Ward Petroglyph, Huddleston Shelter, and Callahan Petroglyph sites are the largest and most complex rock art sites at Lake Alan Henry, and most of the images at these sites probably were made by Indians who were coming under European and/or American influences. The rock art at these sites, which has been illustrated and described in detail in several publications (Boyd 1990,
1992; Boyd et al. 1990:Chapter 7, 1994:Appendix I), provided the incentive to conduct a regional literature review to place the Native American iconography in a broader perspective. Studies by Boyd $(1990,1992)$ provided the first comprehensive look at the rock art of the Texas Panhandle-Plains. The following summary and discussion is taken largely from Boyd (1990), but it has been updated to include some new data.

\section{Rock Art in the Texas Panhandle-Plains}

The first Anglo-American explorers and settlers in the region were at least curious about the Native American images they encountered. Rock art in prominent locations is invariably accompanied by historic inscriptions. These people undoubtedly wondered about the strange images they saw, and the presence of the Indian images probably enticed them to scratch their names and dates nearby. Many Native American rock art sites contain a considerable amount of historic information in the form of inscriptions, but many of these sites have been seriously vandalized, particularly in recent times.

The earliest example of Anglo-American interest in Panhandle-Plains rock art dates to 1853 , when a U.S. Army surveying expedition stumbled onto the impressive site of Rocky Dell in Oldham County (Whipple et al. 1856:36-38). While the expedition was at Rocky Dell, Lieutenant Whipple took the time to record the Indian images there. Serious interest in the rock art of the region did not begin, however, until the 1930s. As with so many areas in Texas, A. T. Jackson and Forrest Kirkland were the first to record Panhandle-Plains rock art sites and study them as evidence of past cultures. Jackson (1938) reported a number of important sites in the Panhandle-Plains, studied the different design elements, and mapped their distributions in an attempt to classify the artwork. Kirkland and his wife devoted much of their lives to recording rock art sites and reported on sites in the "Abilene district" and the Panhandle (Kirkland 1941, 1942). It was, in fact, Kirkland's 1933 visit to the famous Paint Rock site in Concho County that spurred his lifelong interest in rock art (Kirkland and Newcomb 1967:3).

Kirkland and Newcomb's The Rock Art of Texas Indians (1967) describes and illustrates most of the Texas rock art sites known to Kirkland in 1941, but no sites were reported between central Texas and the 
southern end of the Llano Estacado. The 18-county area which is omitted includes the Lake Alan Henry project area in Garza and Kent Counties. Since that time, many rock art sites have been reported throughout northern Texas. Much of the work has been accomplished by amateur archeologists and local archeological societies or by interested professional researchers and cultural resources management projects. The number of rock art sites is low, however, given the vast size of the region. A synthesis of computerized Texas archeological site data (Biesaart et al. 1985), providing information current to 1983, reported only 25 rock art sites in the 72 counties that make up the High Plains and Lower Plains of Texas. The literature review conducted during the Lake Alan Henry project (Boyd 1990) located information on 74 sites in the same area, many of which were not recorded as archeological localities. The regional review has been updated here to provide information on 79 sites (Figure 34 and Table 28), but it does not pretend to provide a comprehensive understanding of Panhandle-Plains rock art. Rather, this brief summary only attempts to provide some interesting insights and observations intended to spur further research.

There are no true rock art styles that are indigenous or exclusive to the Panhandle-Plains region. Schaafsma (1985:246-253) defines a rock art style as being attributable to a particular time, place, and culture, and too little regional data are available to adequately define such styles. Two types of rock art, called the Fort Chadbourne and Antelope Creek types, may represent distinctive styles but cannot yet be defined. Some Panhandle-Plains rock art motifs are similar to Southwestern, perhaps Rio Grande or Jornada style, images while others exhibit similarities with the Pecos River style. These images are well outside the known geographic ranges for their styles and may represent interregional influence or contact. In addition, a significant number of sites contain motifs that may be classified into Plains Biographic style, a style originally defined for the Northern Plains and recently applied to the Southern Plains. Each of these rock art types/styles is discussed below.

\section{Fort Chadbourne Type}

The closest approximation to an indigenous rock art style in the Panhandle-Plains is the "Fort Chadbourne type" petroglyphs recorded near Abilene, Texas (Kirkland 1941; Kirkland and Newcomb 1967: 166-169). These are linear geometric figures that are more complex than simple tally marks. Kirkland (1941:71) states that these designs resemble abrading marks resulting from sharpening tools but also mentions that certain artistic design elements have been added. He described three rockshelters, two in Coke County and one in Taylor County, as having 
TABLE 28

NATIVE AMERICAN ROCK ART SITES IN THE TEXAS HIGH PLAINS AND LOWER PLAINS REGIONS

\begin{tabular}{|c|c|c|c|}
\hline County & Site* & Name or Description & Reference \\
\hline \multirow{8}{*}{ Armstrong } & 1 & "Unknown Armstrong County Site" & $\begin{array}{l}\text { Jackson } 1938 \text { (site 165) } \\
\text { Upshaw 1972:96-97 }\end{array}$ \\
\hline & 2 & Harrell Ranch Complex, Site A & $\begin{array}{l}\text { Kirkland 1942:24 } \\
\text { Kirkland and Newcomb 1967:210-212 } \\
\text { Upshaw 1972:51-64 }\end{array}$ \\
\hline & 3 & Harrell Ranch Complex, Site B & Upshaw 1972:51-71 \\
\hline & 4 & Harrell Ranch Complex, Site C & Upshaw $1972: 51-64,72-73$ \\
\hline & 5 & Harrell Ranch Complex, Site D & Upshaw 1972:51-64, 71 \\
\hline & 6 & Blue Canyon Petroglyphs & McKown 1981 \\
\hline & 7 & Giant Boulder Site & Upshaw 1972:76, 85-89 \\
\hline & 8 & Opal Cave Site & Upshaw 1972:89-94 \\
\hline \multirow{2}{*}{ Briscoe } & 1 & Sandstone Ledger Site & Hughes and Willey 1978:254-264 \\
\hline & 2 & Dark Canyon Shelter & Taylor $1995 \mathrm{a}$ \\
\hline \multirow[b]{2}{*}{ Coke } & 1 & Fort Chadbourne type site & $\begin{array}{l}\text { Kirkland 1941:68-69 } \\
\text { Kirkland and Newcomb 1967:166-167 }\end{array}$ \\
\hline & 2 & Fort Chadbourne shelter & $\begin{array}{l}\text { Sayles } 1930 \\
\text { Kirkland 1941:68-69 } \\
\text { Kirkland and Newcomb 1967:166-169 }\end{array}$ \\
\hline Concho & 1 & Paint Rock & $\begin{array}{l}\text { Jackson } 1938 \text { (site 150) } \\
\text { Kirkland and Newcomb 1967:146-158 } \\
\text { Steely 1984:38 }\end{array}$ \\
\hline Dawson & 1 & Fingerprint Caves & Quinn and Holden 1949 \\
\hline Ector & 1 & None & Riggs 1982 \\
\hline \multirow{5}{*}{ Garza } & 1 & Cowhead Mesa & $\begin{array}{l}\text { Riggs 1965a } \\
\text { Lorrain and Parsons } 1968 \\
\text { Bilbo } 1986\end{array}$ \\
\hline & 2 & Verbena Site & $\begin{array}{l}\text { Riggs } 1965 \text { a } \\
\text { Parsons } 1987\end{array}$ \\
\hline & 3 & $\begin{array}{l}\text { OS Ranch or Yellowhouse } \\
\text { Crossing Mesa }\end{array}$ & $\begin{array}{l}\text { Riggs } 1969 \\
\text { Steely 1984:68 }\end{array}$ \\
\hline & $4-31$ & $\begin{array}{l}\text { Sites in Justiceburg } \\
\text { Reservoir (see Table 26) }\end{array}$ & $\begin{array}{l}\text { Riggs } 1966 \\
\text { Boyd et al. } 1989 \\
\text { Boyd et al. } 1990\end{array}$ \\
\hline & 32 & Kirkpatrick Ranch & Unrecorded site visited by author \\
\hline
\end{tabular}




\begin{tabular}{|c|c|c|c|}
\hline County & Site & Name or Description & Reference \\
\hline \multirow{2}{*}{ Hansford } & 1 & None & Kirkland 1942:24 \\
\hline & 2 & $41 \mathrm{HF} 2$ & Peterson 1988:120, 220 \\
\hline \multirow[t]{2}{*}{ Hutchinson } & 1 & $\begin{array}{l}\text { Alibates Creek } \\
\text { (near Alibates Ruin) }\end{array}$ & $\begin{array}{l}\text { Kirkland } 1942: 23 \\
\text { Kirkland and Newcomb 1967:213-214 } \\
\text { Green 1986:110 }\end{array}$ \\
\hline & 2 & Gulf Camp & Kirkland and Newcomb 1967:213, 215 \\
\hline Kent & $1-6$ & $\begin{array}{l}\text { Sites in Justiceburg } \\
\text { Reservoir (see Table 26) }\end{array}$ & $\begin{array}{l}\text { Boyd et al. } 1989 \\
\text { Boyd et al. } 1990 \\
\text { Boyd et al. } 1994\end{array}$ \\
\hline Motley & 1 & None & Jackson 1938 (site 167) \\
\hline \multirow[t]{2}{*}{ Nolan } & 1 & $\begin{array}{l}\text { Brownfield Ranch } \\
\text { Petroglyphs }\end{array}$ & $\begin{array}{l}\text { Jackson } 1938 \text { (site 152) } \\
\text { Kirkland and Newcomb 1967:164-166 }\end{array}$ \\
\hline & 2 & Champion Creek & Kirkland and Newcomb 1967:163-164 \\
\hline \multirow{6}{*}{ Oldham } & 1 & Rocky Dell & $\begin{array}{l}\text { Whipple et al. 1856:36-38 } \\
\text { Mallery 1886:33 } \\
\text { Studer 1931:74 } \\
\text { Jackson } 1938 \text { (site 162) } \\
\text { Kirkland 1942:10-13 } \\
\text { Kirkland and Newcomb 1967:203-208 } \\
\text { Steely 1984:140 }\end{array}$ \\
\hline & 2 & Castle Rock & $\begin{array}{l}\text { Jackson } 1938 \text { (site 163) } \\
\text { Kirkland and Newcomb 1967:206-207 }\end{array}$ \\
\hline & 3 & Mujares Creek & $\begin{array}{l}\text { Kirkland 1942:13-19 } \\
\text { Kirkland and Newcomb 1967:208-209 } \\
\text { Parsons } 1987\end{array}$ \\
\hline & 4 & Brown's Camp & $\begin{array}{l}\text { Kirkland 1942:24 } \\
\text { Kirkland and Newcomb 1967:210-211 }\end{array}$ \\
\hline & 5 & Agua Piedra Creek & $\begin{array}{l}\text { Kirkland 1942:20-25 } \\
\text { Kirkland and Newcomb 1967:210-211 }\end{array}$ \\
\hline & 6 & Landergin Mesa & Lintz 1990:199-205 \\
\hline \multirow{4}{*}{ Potter } & 1 & Lahey Creek & $\begin{array}{l}\text { Kirkland 1942:20-25 } \\
\text { Kirkland and Newcomb 1967:212-213 }\end{array}$ \\
\hline & 2 & Chimney Rock & $\begin{array}{l}\text { Kirkland 1942:19-25 } \\
\text { Kirkland and Newcomb 1967:212-214 }\end{array}$ \\
\hline & 3 & Alibates Flint Quarry & Steely $1984: 144$ \\
\hline & 4 & Footprint Site & Green 1986:84-86, Figure 50 \\
\hline
\end{tabular}




\begin{tabular}{|l|c|l|l|}
\hline \multicolumn{4}{|l|}{ Table 28, continued } \\
\hline \multirow{4}{*}{ County } & Site & Name or Description & Reference \\
\hline \multirow{3}{*}{ Randall } & 1 & None & Jackson 1938 (site 164) \\
\cline { 2 - 4 } & 2 & Pour-Off Site & Upshaw 1972:64, 74-84 \\
\cline { 2 - 4 } & 3 & Cliff Shelter Site & Upshaw 1972:94-96, 100 \\
\hline \multirow{3}{*}{ Scurry } & 1 & 41SC3 & Riggs 1982 \\
\cline { 2 - 5 } & 2 & None & Portis et al. 1968 \\
\hline \multirow{2}{*}{ Taylor } & 1 & Tulia Canyon & $\begin{array}{l}\text { Jackson 1938 (site 166) } \\
\text { Kirkland and Newcomb 1967:215 }\end{array}$ \\
\hline \multirow{3}{*}{ Tom Green } & 1 & Blowout Mountain & $\begin{array}{l}\text { Kirkland 1941:71-74 } \\
\text { Kirkland and Newcomb 1967:166-169 }\end{array}$ \\
\cline { 2 - 4 } & 2 & Red Arroyo Hunting Scene & $\begin{array}{l}\text { Thoms 1979 } \\
\text { Jaquier 1986 }\end{array}$ \\
\hline
\end{tabular}

Fort Chadbourne type petroglyphs consisting of many almost straight, more or less parallel grooves, perpendicular to the floor. These grooves are ornamented with connecting straight or zigzag lines which distinguish the petroglyphs from so-called abrading marks. The width of the grooves varies from one-fourth to one inch wide; the depth reaches an inch in a few cases. Most of the grooves have round, smooth bottoms as if they had been rubbed into the rock with some round pointed object [Kirkland and Newcomb 1967:167].

Fort Chadbourne does not constitute a true rock art style, and it is based on only three sites that cannot be temporally or culturally defined. Similar geometric glyphs have been found at two sites in the Lake Alan Henry project area (41GR494 and 41KT65) and at a few other sites, but the cultural implications of these sites are not known. So little is known about Fort Chadbourne type glyphs that one can only guess who the artists were and when and why they made these images.

\section{Antelope Creek Type}

A single motif may be identified as belonging to the Antelope Creek phase of the Canadian River valley, which represents a Plains Village group of bison hunter/horticulturalists at A.D. 1200 to 1500 . Footprint petroglyphs have been found near Antelope Creek villages at the Alibates Creek (on a boulder immediately adjacent to Alibates Ruin) and Gulf Camp sites in Hutchinson County (Kirkland 1942; Kirkland and Newcomb 1967:213-215). Even more revealing is the presence of two footprint glyphs on a portable dolomite slab found in a slab-lined pithouse, radiocarbon dated to ca. A.D. 1300, at the Footprint site in Potter County. The dolomite slab was found along the center of the back wall and may have served as an altar. Green (1986:110) notes that

the presence of the carvings at the Footprint site, Alibates Ruin, and in the Stinnett area closely links these carved footprints with the Antelope Creek Focus, and the special placement and careful execution of the Footprint site specimen indicate that the art form had some special religious or mystical significance.

Turtle glyphs have been found in association with footprint glyphs and also may have been made by Antelope Creek peoples. No systematic study of Antelope Creek rock art has been done, however, 
and although many sites are known, most of the rock art has not been adequately documented or published. The presence of Southwestern-influenced and Plains Biographic images at rock art sites in the Canadian River valley further compounds the problem of identifying the artists.

\section{Southwestern Styles}

The evidence for Puebloan influence at Rocky Dell in Oldham County is most convincing. While a U.S. Army surveying expedition was camped at Rocky Dell in September of 1853, they encountered a group of people who regularly visited the site. These apparently were Anasazi and were identified as "traders from the pueblos of New Mexico, in search of Comanches, whom they expect to find at this season upon the Canadian" (Archambeau 1971: 89). They informed Lieutenant Whipple, the commanding officer, that Puebloan peoples were responsible for many of the painted images at the site, including a 13-foot-long horned serpent overlooking the spring (Whipple et al. 1856:36-38). The horned serpent is a common Puebloan motif found in Rio Grande style rock art of northern New Mexico (Schaafsma 1980:252-299). Schaafsma (1992:124) notes that "the Pueblo horned and feathered serpent, maize bringer and guardian of springs and god of underworld water, is also related to the [Mesoamerican] plumed serpent Quetzalcoatl." When Kirkland (1942) recorded the rock art 88 years later, many of the pictographs recorded by Lieutenant Whipple, including the serpent, had changed very little, while others had been obliterated.

Puebloan or Jornada Mogollon influence is present at the OS Ranch site in Garza County (Riggs 1969), the Giant Boulder site in Armstrong County (Upshaw 1972:85-89), and the Pour-Off site in Randall County (Upshaw 1972:74-84). Kokopelli, the humpbacked fluteplayer, is depicted in a petroglyph at the OS Ranch site and in a pictograph at the Giant Boulder site. Kokopelli is a common motif in the Jornada style rock art of south-central New Mexico and far western Texas and in the Rio Grande style (Schaafsma 1980:199-242, 252-299). Rock art at the Pour-Off site includes images of masks and human figures that are reminiscent of Jornada Mogollon rock art at Hueco Tanks near El Paso, Texas (Upshaw 1972:74).

The Callahan site at Lake Alan Henry (see
Table 26) includes two stylized anthropomorphs that are unique in the Panhandle-Plains region. These rectilinear stick figures exhibit traits that are similar to New Mexico's Jornada and Rio Grande styles and to Mescalero Apache rock art at Hueco Tanks (Boyd et al. 1994:Appendix I). These different interpretations are not necessarily contradictory because all three of these types of rock art are related. The Rio Grande style may have evolved out of, or at least was influenced by, the Jornada style. In addition, the Mescalero and other Apache groups were heavily influenced by the Anasazi, and it is not surprising that their rock art looks much more Southwestern than Plains.

It is likely that the Southwestern-looking figures at the Callahan site postdate A.D. 1000, and there is circumstantial evidence indicating that some may be of Protohistoric or Historic age. The Callahan site is located along the canyon rim overlooking a creek valley where extensive remains of seventeenth-century occupations were found at the Longhorn and Headstream sites (discussed later in this chapter; see also Boyd and Peck 1992). It is possible that the glyphs are associated with these occupations; one historic image (a horse) is present as well, although not in direct association with the Southwestern figures.

The significance of Southwestern-style images in the Panhandle-Plains is not fully understood, but there is strong archeological evidence for Puebloan influence in the region (see Chapters 10 and 11). Some form of interaction between Jornada Mogollon and Southern Plains peoples occurred as early as Late Prehistoric I times. Jornada influence disappeared before A.D. 1200-1400, and Anasazi influence became increasingly dominant in Late Prehistoric II times, a trend that continued into the Protohistoric period. Although much more remains to be learned, Panhandle-Plains rock art provides additional evidence of Pueblo-Plains interaction.

\section{Pecos River Style}

Pecos River style motifs may be present at the Brownfield Ranch petroglyph site in Nolan County. Kirkland and Newcomb (1967:164) note that some of the petroglyphs are strikingly similar to painted images on the Lower Pecos River. Since the Brownfield Ranch is some $320 \mathrm{~km}$ (200 miles) outside the generally accepted range of the Pecos River style rock art, the site has some interesting 
implications. Are the similarities a coincidence, are the Nolan County petroglyphs copies of Pecos River rock art made by Plains people who traveled to the Lower Pecos, or were they made by Lower Pecos peoples traveling far from their homeland? Kirkland and Newcomb (1967:166) state that "a good case can be made for some sort of connection between the Nolan County petroglyphs and Pecos River style pictographs, but to draw any hard and fast conclusions from such skimpy evidence is unwarranted."

\section{Plains Biographic Style}

Until recently, historic motifs in Native American rock art of the Panhandle-Plains have gone unrecognized, been misinterpreted, or been virtually ignored by archeologists. Northern Plains Indian rock art has been documented and studied extensively, and a Plains Biographic style of rock art was proposed by Connor and Connor (1971) and elaborated by Keyser $(1987,1992)$. The Biographic style, which corresponds with Plains Indian art on other media (e.g., hide paintings, tipi covers, and ledger book drawings), is a form of picture-writing which evolved through time under increasing AngloAmerican influence and dominance. It is an extremely useful tool for interpreting Northern Plains rock art, and this style recently has been recognized in Texas (Boyd 1990, 1992; Parsons 1987; Turpin 1989a, 1989b).

Bilbo (1986) and Parsons (1987) were the first to apply the concept of Plains Indian biographic art to the interpretation of Panhandle-Plains rock art sites. Bilbo (1986) recognized that most of the images in the extensive petroglyph panel at Cowhead Mesa in Garza County were made by Plains Indians and probably depict a raid on a Spanish mission/ settlement. Parsons (1987) interprets the elaborate petroglyphs at Mujares Creek in Oldham County as representing a coup-recounting station where Comanche or Kiowa artists depicted specific events during their war with the southern Cheyenne between 1826 and 1840. A series of petroglyphs at the Verbena site are interpreted by Parsons (1987) as a Plains Indian representation of a battle with EuroAmericans. This interpretation is contrary to the interpretations of the original recorder who thought that the Verbena site contained no historic elements (Riggs 1965a). The failure to recognize Plains Indian symbolism used in biographic art has undoubtedly led to many misinterpretations. One additional case in point is that Burgan (1992) has recently suggested that pictographs at the Giant Boulder site in Armstrong County (see Table 28) may represent a Plains Indian depiction of an 1874 battle scene. Although speculative, this interpretation is very different from that offered by the original investigator (Upshaw 1972).

In the Panhandle-Plains, 19 sites contain historic motifs and artistic conventions comparable to the Plains Biographic style (Table 29), and examples of historic motifs are strikingly similar to their Northern Plains counterparts (Figures 35 and 36). Within the Panhandle-Plains, the highest density of sites containing historic motifs is in the vicinity of Lake Alan Henry, and seven sites are reported for Garza and Kent Counties (four are in the project area). This is apparently due to the intensity of rock art research in this area rather than any cultural phenomenon.

As in the Northern Plains, horses with and without riders are the most common motifs and are found at 15 of the sites (see Figures $35 a, c$ and 36a-e). Horse accoutrements also are represented, such as the decorated halter at the Ward Petroglyph site in Garza County (see Figure 35d). Longhorn cattle or oxen, with the characteristic curved horns, are found at eight sites (see Figure 36f). These are sometimes depicted with half or all of the interior of the petroglyph rubbed smooth (see Figures $35 b$ and $36 \mathrm{~g}$ ). Historic petroglyphs with smoothed interiors, having the appearance of being shaded, are present at four sites in the Panhandle-Plains. Kirkland (1942:14; Kirkland and Newcomb 1967:208) first suggested that this artistic technique dates after European contact, and no findings yet contradict this. Further evidence of this includes a painted bison scapula, found in the "Comanche country of Texas," which depicts a half-painted longhorn along with a mounted Indian and two standing Europeans in a probable combat scene (Mallery 1893:206; Jackson 1938:338). Missions and/or missionaries, common themes in historic Indian rock art in the American Southwest where Spanish influence was strongest, are found at four Panhandle-Plains sites. A priest wearing a brimmed hat and with a cross etched into his red-painted chest is clearly depicted at Huddleston Shelter in Garza County (see Figure $35 \mathrm{~g}$ ). In addition, it is possible that the rectangular outlines and ladderlike figures at Huddleston Shelter depict a Pueblo village where a Spanish mission was located. The stair-stepped structures depicted at 
TABLE 29

HISTORIC MOTIFS AND ARTISTIC CONVENTIONS IN TEXAS PANHANDLE-PLAINS ROCK ART SITES

\begin{tabular}{|c|c|c|c|c|c|c|c|c|c|c|c|c|c|c|c|c|c|c|c|c|}
\hline \multirow[b]{3}{*}{ Attribute } & \multicolumn{19}{|c|}{ County and Site No. ${ }^{1}$} & \multirow{3}{*}{$\begin{array}{c}\text { No. of } \\
\text { Sites }\end{array}$} \\
\hline & \multicolumn{4}{|c|}{ Armstrong } & \multirow{2}{*}{$\begin{array}{c}\text { Concho } \\
1 \\
\end{array}$} & \multicolumn{6}{|c|}{ Garza } & \multirow{2}{*}{$\frac{\text { Kent }}{6}$} & \multicolumn{4}{|c|}{ Oldham } & \multicolumn{2}{|c|}{ Potter } & \multirow{2}{*}{$\begin{array}{c}\text { Scurry } \\
1 \\
\end{array}$} & \\
\hline & 2 & 3 & 6 & 8 & & 1 & 2 & 3 & 4 & 8 & 12 & & 1 & 3 & 4 & 5 & 1 & 2 & & \\
\hline \multicolumn{21}{|c|}{ Historic Motifs } \\
\hline Horses & & $\mathrm{x}$ & $\mathrm{x}$ & & $\mathrm{x}$ & & & & $\mathrm{x}$ & $\mathrm{x}$ & & $\mathrm{x}$ & & $\mathrm{x}$ & $\mathrm{x}$ & $\mathrm{x}$ & & & & 9 \\
\hline Longhorn/oxen & & & & $\mathrm{x}$ & & $\mathrm{x}$ & & & $\mathrm{x}$ & & $\mathrm{x}$ & & $\mathrm{x}$ & $\mathrm{x}$ & & $\mathrm{x}$ & & $?$ & & 8 \\
\hline Europeans & & & & & $\mathrm{x}$ & & & & $?$ & & $\mathrm{x}$ & & & $\mathrm{x}$ & & & & & & 4 \\
\hline Missionary/priest & & & & & & $\mathrm{x}$ & & & & & $\mathrm{x}$ & & & & & & & & & 2 \\
\hline Mission/church & & & & & $\mathrm{x}$ & $\mathrm{x}$ & & & & & & & & $\mathrm{x}$ & & & & & & 3 \\
\hline Buildings & & & & & & $\mathrm{x}$ & & & $\mathrm{x}$ & & & & & & & & & & & 2 \\
\hline Wagons/carts & & & & & & & & & $\mathrm{x}$ & & & & & & & & & $?$ & & 2 \\
\hline Guns & & & & & $?$ & & $\mathrm{x}$ & & & & & & & $\mathrm{x}$ & & & & $\mathrm{x}$ & & 4 \\
\hline \multicolumn{21}{|c|}{ Artistic Conventions } \\
\hline Indication of tense $\mathrm{e}^{2}$ & & & & & & $\mathrm{x}$ & $\mathrm{x}$ & & $\mathrm{x}$ & & & & & & & & & & & 3 \\
\hline Posture and weapon placement ${ }^{2}$ & & & & & & $\mathrm{x}$ & $\mathrm{x}$ & & & $?$ & & & & $\mathrm{x}$ & & & & & & 4 \\
\hline Use of multiple objects ${ }^{2}$ & & $?$ & & & & & $\mathrm{x}$ & & $\mathrm{x}$ & & & & & & & & $\mathrm{x}$ & & & 4 \\
\hline Characteristic ethnic dress $^{2}$ & $\mathrm{x}$ & & & & $\mathrm{x}$ & $?$ & & & $\mathrm{x}$ & $\mathrm{x}$ & $\mathrm{x}$ & & $\mathrm{x}$ & $\mathrm{x}$ & & & & & & 8 \\
\hline Speech and name glyphs ${ }^{2}$ & $?$ & & & & & & & & & & & & & $?$ & & & & & & 2 \\
\hline Interior glyph smoothing & & & & & & $\mathrm{x}$ & & & & $\mathrm{x}$ & & & & $\mathrm{x}$ & & & & $\mathrm{x}$ & & 4 \\
\hline
\end{tabular}




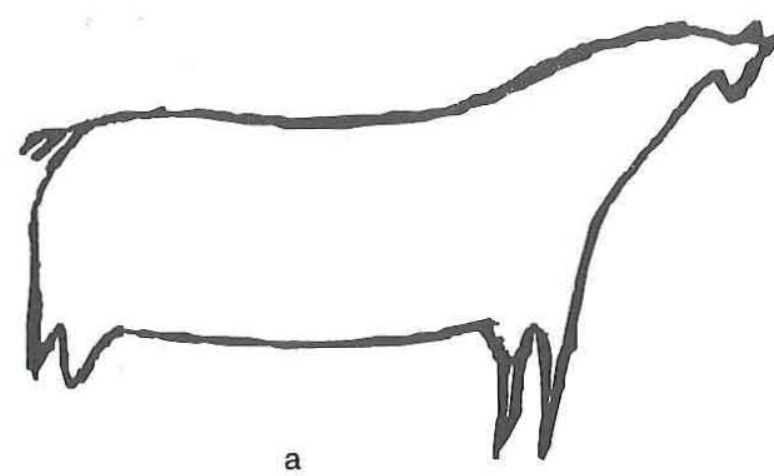

a

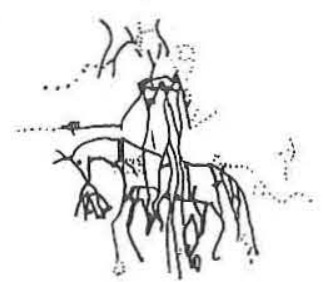

d

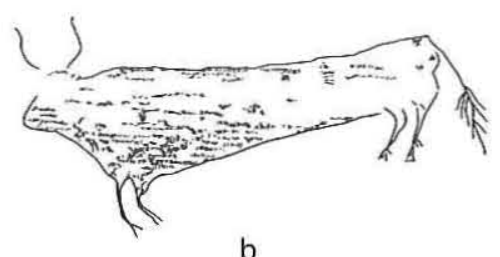

e

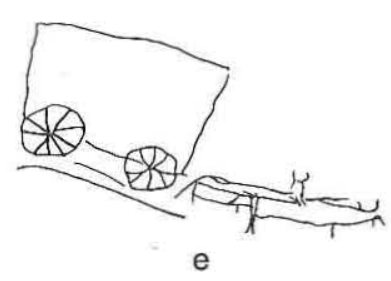

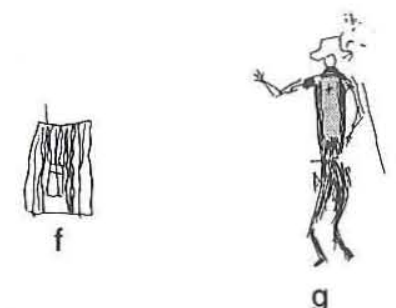

g

Figure 35. Examples of historic motifs from Lake Alan Henry rock art sites (drawings not to scale). (a) Horse from 41KT164; $(b)$ longhorn from 41GR344; $(c)$ horse and rider from 41GR51; $(d)$ horse with decorated halter and rider from 41GR282; $(e)$ oxen-pulled wagon from 41GR51; $(f)$ wooden building from 41GR51; $(g)$ Spanish priest from $41 \mathrm{GR} 344$.

Cowhead Mesa in Garza County (see Figure 36h) are similar to a pictograph at Hueco Tanks near El Paso (Kirkland and Newcomb 1967:Plate 133) and to an image in a Spanish Colonial rock art scene at Caballo Shelter in Val Verde County (Turpin 1989b).

At least three sites contain representations of guns. They probably depict captured weapons at Mujares Creek in Oldham County (see Figure 36i, $j$ ), but they are incorporated into an attack biography at the Verbena site in Garza County (Parson 1987: 267, 271; see Figure $36 k$ ). Other historic motifs include wagons and wooden buildings (see Figure $35 e, f)$.

Several artistic conventions described for the Plains Biographic style (Keyser 1987:62-66) also are present in the Panhandle-Plains region. Indications of tense (such as weapons firing or tracks depicting movement), use of multiple objects to convey relative numbers (such as horse hooves to symbolize mounted warriors and rifles symbolizing soldiers), and characteristic ethnic dress (such as brimmed hats for Europeans; see Figure $36 k, i, m$ ), are portrayed at 10 Panhandle-Plains sites. Two possible occurrences of speech and name glyphs are known (see
Figure $35 d$ ). At least three sites depict posture and weapon placement suggesting that they represent combat autobiographies (see Figure $36 l, m$ ). These artistic conventions are more characteristic of late Plains Indian art of the Historic period and provide evidence that Indian artists were increasingly influenced by Euro-American art. Unlike the late art, early Plains Biographic rock art of the Protohistoric period evolved out of the Plains Ceremonial style and is characterized by rigid and static figures with no attempt to depict action or movement.

\section{Summary and Conclusions}

This study summarizes limited data available for 79 rock art sites in the Texas Panhandle-Plains region (see Figure 34). Despite the low number of sites, several important conclusions can be reached: (1) all rock art sites in the region are likely to be of relatively recent age; (2) the Fort Chadbourne type petroglyphs could represent an indigenous PanhandlePlains rock art style, but it cannot be properly defined based on the limited data available; (3) a few sites in west-central Texas contain motifs reminiscent of the Pecos River style, but the rela- 


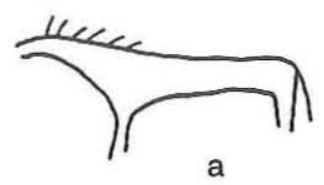

a

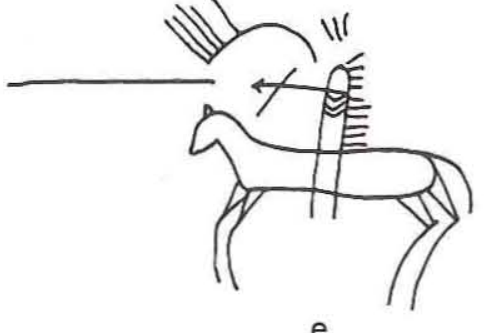

e

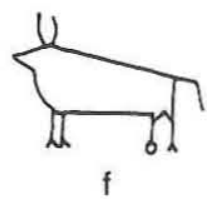

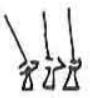

i

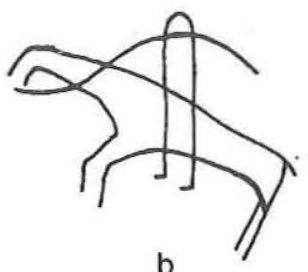

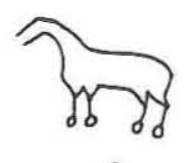

C

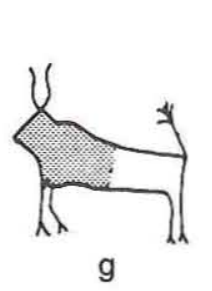

g
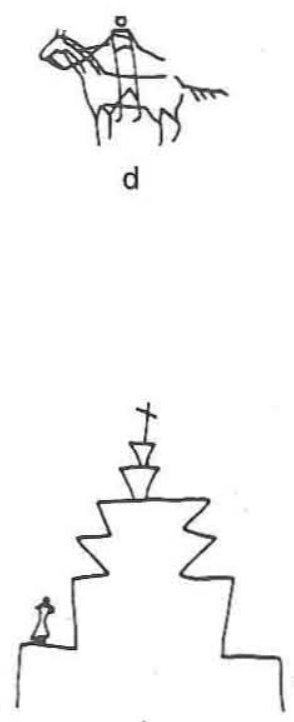

h

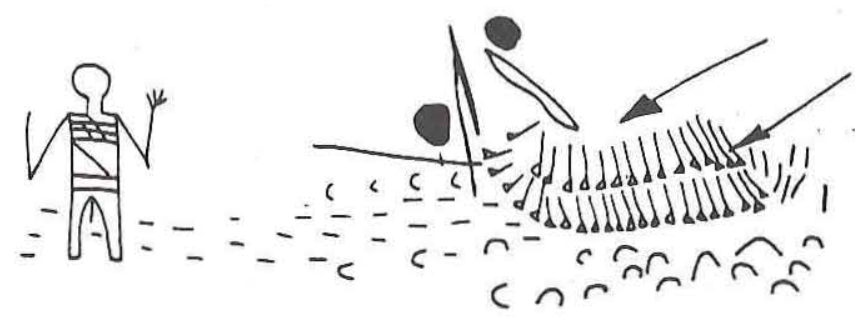

k

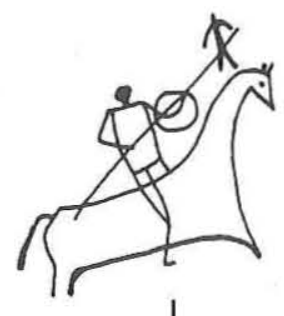

I

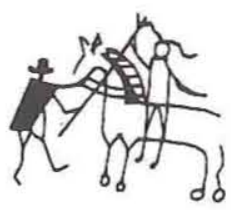

$\mathrm{m}$

Figure 36. Examples of historic motifs from other Texas Panhandle-Plains rock art sites (drawings not to scale). $(a, b)$ Harrell Ranch site B, Armstrong County (Upshaw 1972:Plate VIII); $(c, d, f, g, i, j, m)$ Mujares Creek, Oldham County (Kirkland and Newcomb 1967:Plates 153 and 154); (e) Harrell Ranch site A, Armstrong County (Upshaw 1972:Plate III); ( $h, l$ ) Cowhead Mesa, Garza County (drawings made from photographs by the author); $(k)$ Verbena site, Garza County (Parsons 1987:Figure 11).

tionships between these areas are poorly understood; (4) many sites contain motifs that are similar to the iconography of the Rio Grande and Jornada styles, and these images probably represent influence from Southwestern Puebloan cultures; and (5) many sites contain historic motifs and artistic conventions representative of the Plains Biographic style. The latter is perhaps the most significant finding since numerous sites containing historic motifs may now be interpreted as biographic in nature. From a functional standpoint, the biographic rock art may have served to illustrate stories of tribal, band, or individual exploits. It is less clear who told the stories or who they were being told to, although many of the images seem to depict combat events. Such rock art sites may have been used by military 
groups (e.g., warrior societies) to recount the battle exploits of its members.

One of the underlying assumptions of the Plains Biographic style is that various groups (or tribes) produced similar artwork because they had a similar lifestyle. Northern and Southern Plains Indian culture became increasingly homogeneous after European contact, despite the variety of linguistic and ethnic affiliations of its participants. It is not surprising, then, that Plains Indian artwork, including rock art, exhibits a similar degree of homogeneity.

\section{DATA RECOVERY ARCHEOLOGY}

Nine sites occupied by Native Americans were investigated during the three seasons of data recovery: sites 41GR383, 41GR484, and 41KT33 in 1990-1991 during Season 1 (Boyd et al. 1992); sites 41KT51 and 41KT53 in 1991 during Season 2 (Boyd et al. 1993; see also Boyd and Peck 1992); and sites 41GR291, 41GR303B, 41GR546, and 41GR559 in 1992 during Season 3 (Boyd et al. 1994). The data recovery investigations and interpretations are discussed below, and pertinent data are summarized in Tables 30-32. These brief descriptions are intended only as site summaries, and readers should consult the references mentioned above for more details on the investigations and findings for each site. To avoid confusion, this chapter uses the radiocarbon date calibrations done using the 1987 computerized version (Rev. 2.0) of Stuiver and Reimer (1986), as they were originally reported. The radiocarbon dates summarized in Appendix B, however, are calibrated using the 1993 version (Rev. 3.0) of Stuiver and Reimer (1993).

\section{GR291, Sam Wahl Site}

Located within the Sam Wahl Recreation Area, site 41GR291 is located in the upland margin, ca. $150-300 \mathrm{~m}$ north of the Double Mountain Fork of the Brazos River. At the time of discovery, the northern portion of the site consisted of intact upland sandy sediments exposed only in an east-west ranch road that cut down into the cultural zone. Since that time, a paved road providing access to the Lake Alan Henry boat ramp has been constructed in approximately the same location. The site extends southward along two ridges and lower bedrock benches separated and flanked by drainages. In the southern area, the cultural zone remains buried in some places, but eolian deflation and sheet erosion along the margins of the ridges have exposed abundant cultural materials. A freshwater spring and small pool are located in the main drainage between the site and the river.

The site was discovered in 1987, and artifacts and burned rock clusters were observed in the lower eroded areas and in the ranch road. No diagnostics were recovered, but shovel testing indicated that the northern portion of the site probably contained intact buried cultural remains. Archeological testing in 1988 included 1 backhoe trench, 24 auger tests, and six 1-x-1-m test units and confirmed that intact cultural materials and features were present. A total of 392 artifacts was recovered during survey and testing, with the majority (66 percent) being from the surface. Diagnostic and unusual artifacts consisted of four arrow points (including one Scallorn and one Deadman's), an untyped dart point, two plain brownware sherds (cf. Jornada or Roswell Brown), and a fragment of a pendant made of nonlocal kaolinite that is visually identical to the hydrothermally altered kaolinite found at Burro Mesa in Big Bend National Park (Alex 1990). No radiocarbon dates were obtained, and a thermoluminescence date on a burned rock yielded an erroneous age (see Appendix B).

Data recovery investigations in 1992 consisted of mechanical excavation of three long blade cuts with a maintainer (road grader), thirty-six backhoe trenches, and hand excavation of one hundred six 1-x-1-m units (Figures 37 and 38). The extensive mechanical excavations were done in a successful effort to locate buried structures and features. The pithouse and storage pits (described below) were first encountered in maintainer cuts and backhoe trenches and might not have been discovered otherwise.

The cultural zone in the northern area is found within a 50-60-cm-thick, strongly developed, cumulic sandy to clay loam soil that is typical of the upland sand sheet in the project area. At its bottom, the upland sediments grade into a zone of intensively weathered sandstone bedrock that becomes less weathered and more intact with depth. The underlying Triassic sandstone ledges are exposed along the eroding edge of the uplands. The upland sediments are thought to be derived from a combination of in situ weathering of the sandstone substrate and deposition and reworking by colluvial 
TABLE 30

SUMMARY OF INVESTIGATIONS AT DATA RECOVERY SITES AT LAKE ALAN HENRY

\begin{tabular}{|c|c|c|c|c|c|c|}
\hline \multirow{2}{*}{$\begin{array}{l}\text { Site No./ } \\
\text { Site Type }\end{array}$} & \multirow[b]{2}{*}{ Excavations } & \multirow{2}{*}{$\begin{array}{l}\text { Site Size } \\
\left(\mathrm{m}^{2}\right)\end{array}$} & \multirow{2}{*}{$\begin{array}{l}\% \text { Manual } \\
\text { Excavation }\end{array}$} & \multicolumn{2}{|c|}{ Total Artifacts } & \multirow{2}{*}{$\begin{array}{l}\text { Artifact } \\
\text { Density }\end{array}$} \\
\hline & & & & Surface & Excavation & \\
\hline $\begin{array}{l}\text { 41GR291 } \\
\text { Campsite }\end{array}$ & $\begin{array}{l}1 \text { backhoe trench } \\
3 \text { maintainer cuts } \\
24 \text { auger tests } \\
1 \text { shovel test } \\
6 \text { test units } \\
106 \text { excavation units }\left(112 \mathrm{~m}^{2}\right)\end{array}$ & 37,500 & 0.2 & 262 & 3,708 & 33.1 \\
\hline $\begin{array}{l}\text { 41GR303B } \\
\text { Campsite }\end{array}$ & $\begin{array}{l}2 \text { test units } \\
35 \text { excavation units }\left(37 \mathrm{~m}^{2}\right)\end{array}$ & 1,875 & 2.0 & 224 & 2,571 & 69.5 \\
\hline $\begin{array}{l}\text { 41GR383 } \\
\text { Campsite }\end{array}$ & $\begin{array}{l}1 \text { shovel test } \\
11 \text { auger tests } \\
8 \text { test units } \\
53 \text { excavation units }\left(61 \mathrm{~m}^{2}\right)\end{array}$ & 30,000 & 0.2 & 107 & 2,396 & 39.3 \\
\hline $\begin{array}{l}\text { 41GR484* } \\
\text { Campsite }\end{array}$ & $\begin{array}{l}2 \text { backhoe trenches } \\
5 \text { test units } \\
17 \text { excavation units }\left(22 \mathrm{~m}^{2}\right)\end{array}$ & 10,200 & 0.2 & 34 & 60 & 2.7 \\
\hline $\begin{array}{l}\text { 41GR546 } \\
\text { Rockshelter }\end{array}$ & $\begin{array}{l}1 \text { shovel test } \\
1 \text { test units } \\
6 \text { excavation units }\left(7 \mathrm{~m}^{2}\right)\end{array}$ & 12 & 58.3 & - & 2 & 0.3 \\
\hline $\begin{array}{l}\text { 41GR559 } \\
\text { Rockshelter }\end{array}$ & $\begin{array}{l}4 \text { shovel tests } \\
3 \text { test units } \\
27 \text { excavation units }\left(30 \mathrm{~m}^{2}\right)\end{array}$ & 60 & 50.0 & - & 169 & 5.6 \\
\hline $\begin{array}{l}41 \mathrm{KT} 33 \\
\text { Campsite }\end{array}$ & $\begin{array}{l}4 \text { backhoe trenches } \\
2 \text { shovel tests } \\
63 \text { test units } \\
69 \text { excavation units }\left(75 \mathrm{~m}^{2}\right)\end{array}$ & 91,200 & $<0.1$ & 69 & 2,271 & 30.3 \\
\hline $\begin{array}{l}\text { 41KT51 } \\
\text { Campsite }\end{array}$ & $\begin{array}{l}5 \text { backhoe trenches } \\
1 \text { shovel test } \\
3 \text { test units } \\
86 \text { excavation units }\left(89 \mathrm{~m}^{2}\right)\end{array}$ & 6,400 & 1.4 & 26 & 4,473 & 50.3 \\
\hline $\begin{array}{l}41 \mathrm{KT} 53 \\
\text { Campsite }\end{array}$ & $\begin{array}{l}14 \text { backhoe trenches } \\
2 \text { shovel tests } \\
13 \text { test units } \\
328 \text { excavation units }\left(340 \mathrm{~m}^{2}\right)\end{array}$ & 12,000 & 2.8 & 3 & 9,026 & 26.5 \\
\hline
\end{tabular}


TABLE 31

ARTIFACTS RECOVERED FROM ALL PHASES OF WORK AT DATA RECOVERY SITES AT LAKE ALAN HENRY

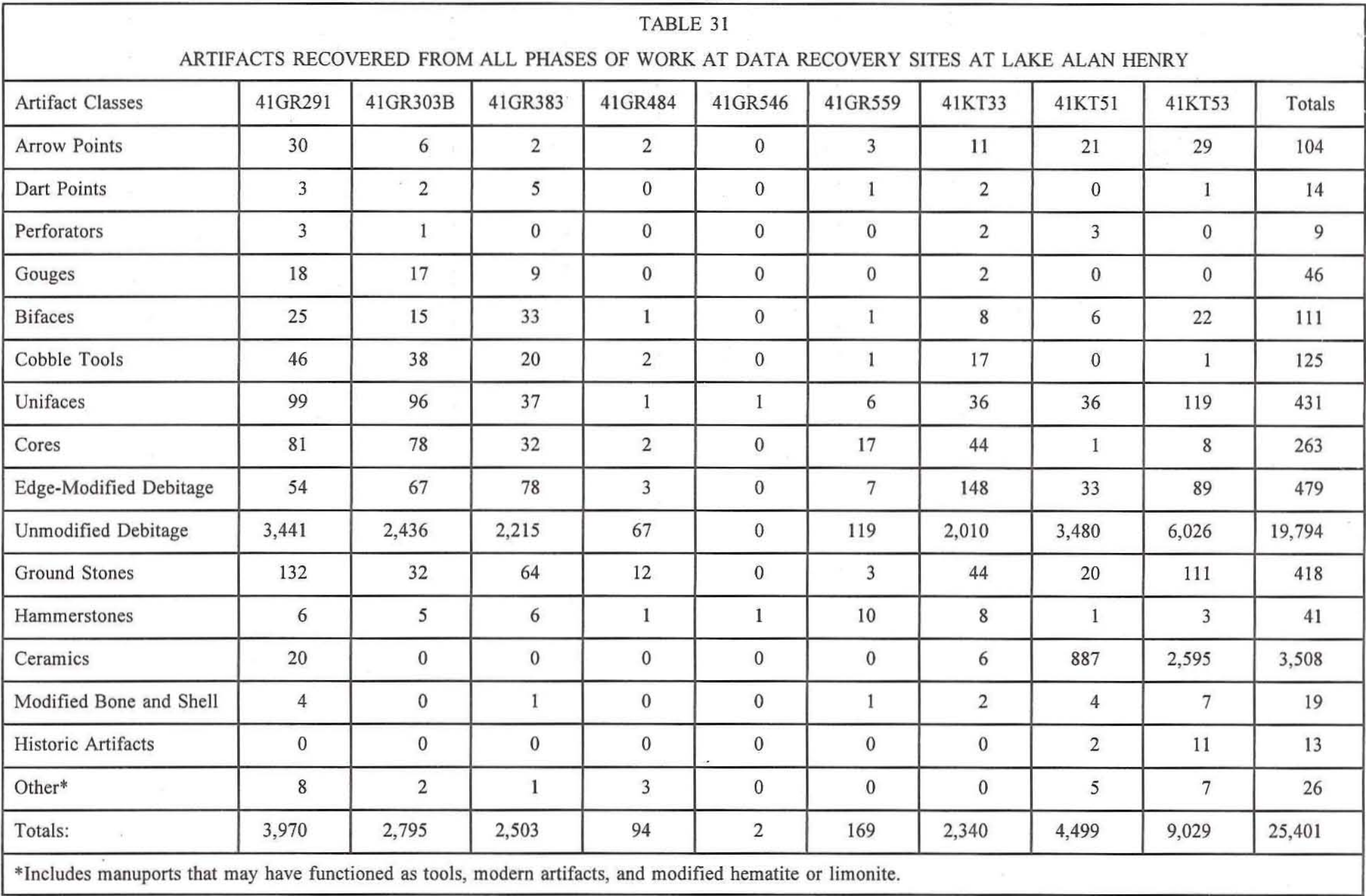




\begin{tabular}{|c|c|c|c|}
\hline \multicolumn{4}{|c|}{$\begin{array}{l}\text { TABLE } 32 \\
\text { ON DATES FROM CULTURAL CONTEXTS } \\
\text { YY SITES AT LAKE ALAN HENRY }\end{array}$} \\
\hline Feature Number & Material & Corrected Age в.P. & Calibrated Dates A.D.; 1-Sigma Range (with intercepts) \\
\hline $\begin{array}{l}\text { 41GR291 } \\
\text { F23 } \\
\text { F29 } \\
\text { F19 } \\
\text { F17 } \\
\text { F41 } \\
\text { F37 } \\
\text { F37 } \\
\text { F12 } \\
\text { F12 } \\
\text { F21 }\end{array}$ & $\begin{array}{l}\text { bone } \\
\text { charcoal } \\
\text { charcoal } \\
\text { charcoal } \\
\text { charcoal } \\
\text { charcoal } \\
\text { charcoal } \\
\text { charcoal } \\
\text { charcoal } \\
\text { sediment } \\
\text { charcoal }\end{array}$ & $\begin{aligned} 1720 & \pm 60 \\
1380 & \pm 90 \\
1390 & \pm 60 \\
1250 & \pm 80 \\
1200 & \pm 80 \\
1030 & \pm 90 \\
970 & \pm 80 \\
820 & \pm 60 \\
730 & \pm 110 \\
730 & \pm 60 \\
710 & \pm 60\end{aligned}$ & $\begin{array}{l}238(265,281,333) 399 \\
600(654) 685 \\
609(651) 669 \\
669(772) 883 \\
689(812,847,852) 897 \\
897(1007) 1039 \\
990(1027) 1163 \\
1166(1225) 1265 \\
1216(1272) 1379 \\
1252(1272) 1285 \\
1262(1277) 1290\end{array}$ \\
\hline $\begin{array}{l}\text { 41GR303B }{ }^{1} \\
- \\
\text { F8 } \\
\text { F5 }\end{array}$ & $\begin{array}{l}\text { charcoal } \\
\text { sediment } \\
\text { charcoal }\end{array}$ & $\begin{aligned} 1880 & \pm 50 \\
1250 & \pm 50 \\
810 & \pm 195\end{aligned}$ & $\begin{array}{l}71(118) 197 \\
681(772) 852 \\
1020(1230) 1382\end{array}$ \\
\hline $\begin{array}{l}\text { 41GR383 } \\
- \\
\text { F13 } \\
\text { F13 } \\
-\end{array}$ & $\begin{array}{l}\text { sediment } \\
\text { charcoal } \\
\text { sediment } \\
\text { sediment }\end{array}$ & $\begin{aligned} 1865 & \pm 140 \\
1390 & \pm 65 \\
1215 & \pm 140 \\
450 & \pm 125^{2}\end{aligned}$ & $\begin{array}{l}10 \text { B.C. (126) } 331 \\
606(651) 671 \\
660(787) 980 \\
1400(1440) 1626\end{array}$ \\
\hline $\begin{array}{l}\text { 41GR484 } \\
\text { F1 }\end{array}$ & charcoal & $260 \pm 70$ & $1519(1648) 1953$ \\
\hline $\begin{array}{l}\text { 41GR546 } \\
\text { F2 }\end{array}$ & charcoal & $275 \pm 210$ & $1430(1643) 1950$ \\
\hline $\begin{array}{l}\text { 41GR559 } \\
\text { F16 } \\
\text { F13/26 } \\
\text { F24 } \\
\text { F22 } \\
\text { F5 } \\
\text { F3 } \\
\text { F27 } \\
\text { F18 } \\
\text { F9/12 }\end{array}$ & $\begin{array}{l}\text { charcoal } \\
\text { charcoal } \\
\text { charcoal } \\
\text { charcoal } \\
\text { charcoal } \\
\text { charcoal } \\
\text { charcoal } \\
\text { charcoal } \\
\text { bone }\end{array}$ & $\begin{aligned} 1930 & \pm 70 \\
1720 & \pm 80 \\
1530 & \pm 90 \\
1300 & \pm 110 \\
1180 & \pm 210 \\
855 & \pm 190 \\
930 & \pm 60 \\
790 & \pm 80 \\
280 & \pm 70\end{aligned}$ & $\begin{array}{l}2 \text { в.C. }(72) 129 \\
227(265,281,333) 412 \\
420(544) 622 \\
640(681) 860 \\
650(880) 1030 \\
990(1191) 1290 \\
1021(1043,1105,1112,1150) 1169 \\
1169(1252) 1277 \\
1506(1642) 1663\end{array}$ \\
\hline $\begin{array}{l}41 \mathrm{KT} 33 \\
\text { F12 }\end{array}$ & charcoal & $1005 \pm 110$ & 898 (1017) 1160 \\
\hline \multicolumn{4}{|c|}{$\begin{array}{l}\text { Note: Radiocarbon dates from all cultural contexts are included in this table. Most samples are associated with } \\
\text { cultural features, but where no feature number is given, the sample is from the cultural zone. }\end{array}$} \\
\hline
\end{tabular}




\begin{tabular}{|c|c|c|c|}
\hline Feature Number & Material & Corrected Age B.P. & Calibrated Dates A.D.; 1-Sigma Range (with intercepts) \\
\hline $\begin{array}{l}\text { 41KT51 } \\
- \\
\text { F9 } \\
\text { F3 } \\
\text { F3 }\end{array}$ & $\begin{array}{l}\text { charcoal } \\
\text { charcoal } \\
\text { charcoal } \\
\text { charcoal }\end{array}$ & $\begin{array}{l}300 \pm 50 \\
270 \pm 60 \\
260 \pm 40 \\
190 \pm 40\end{array}$ & $\begin{array}{l}1505 \text { (1636) } 1651 \\
1519(1645) 1663 \\
1636(1648) 1660 \\
1656(1669,1776,1793,1948,1953) 1955\end{array}$ \\
\hline $\begin{array}{l}\text { 41KT53 } \\
\text { F4 } \\
\text { F44 } \\
\text { F19 } \\
\text { F8 } \\
\text { F1 } \\
\text { F9 } \\
\text { F10 } \\
\text { F39 } \\
\text { F32 } \\
\text { F48 } \\
\text { F37 } \\
\text { F55 } \\
\text { F21 } \\
\text { F35 } \\
\text { F27 } \\
\text { F12 } \\
\text { F11 } \\
\text { F54* }\end{array}$ & $\begin{array}{l}\text { sediment } \\
\text { wood } \\
\text { charcoal } \\
\text { sediment } \\
\text { charcoal } \\
\text { charcoal } \\
\text { wood } \\
\text { charcoal } \\
\text { charcoal } \\
\text { charcoal } \\
\text { charcoal } \\
\text { charcoal } \\
\text { charcoal } \\
\text { charcoal } \\
\text { charcoal } \\
\text { charcoal } \\
\text { charcoal } \\
\text { charcoal }\end{array}$ & $\begin{aligned} 840 & \pm 50 \\
530 & \pm 60 \\
430 & \pm 80 \\
330 & \pm 50 \\
295 & \pm 80 \\
300 & \pm 50 \\
300 & \pm 50 \\
270 & \pm 60 \\
250 & \pm 50 \\
250 & \pm 50 \\
200 & \pm 50 \\
220 & \pm 30 \\
190 & \pm 50 \\
190 & \pm 50 \\
180 & \pm 50 \\
140 & \pm 40 \\
130 & \pm 40 \\
20 & \pm 50\end{aligned}$ & $\begin{array}{l}1162(1216) 1253 \\
1322(1409) 1434 \\
1418(1445) 1509 \\
1474(1519,1587,1623) 1642 \\
1477(1637) 1662 \\
1505(1636) 1651 \\
1505(1636) 1651 \\
1519(1645) 1663 \\
1636(1651) 1666 \\
1641(1655) 1953 \\
1651(1660) 1953 \\
1651(1660) 1953 \\
1654(1669,1776,1793,1948,1953) 1955 \\
1654(1669,1776,1793,1948,1953) 1955 \\
1657(1673,1753,1796,1945,1955) 1955 \\
1672(1686,1736,1808,1930,1955) 1946 \\
1675(1689,1732,1811,1926,1955) 1942 \\
1898(1955) 1955\end{array}$ \\
\hline
\end{tabular}

slopewash and eolian processes. The sand sheet is thin along the eroded southern edge of the upland, but it becomes thicker (in places over $1 \mathrm{~m}$ deep) at the far northern end of the site. In the area of the excavation blocks, the cultural zone is generally buried from 10 to $30 \mathrm{~cm}$ below the surface, except for features that are intrusive into the bedrock.

By the end of the data recovery investigations, 37 cultural features had been documented and 3,970 artifacts had been recovered (see Table 31). As shown in Figure 39, site chronology is established by 11 radiocarbon dates (see Table 32) that indicate numerous occupations over a long period of time. When the features, calibrated radiocarbon dates, and artifacts were analyzed, it was clear that they fell into three time periods that were defined as separate analysis units (Table 33). Of the 16 features that could not be assigned to an analysis unit, 14 were uninvestigated (i.e., exposed on the surface or in blade cuts).

The burial component consists of a single cairn-covered human burial (Feature 23) radiocarbon dated to A.D. 238-399 (calibrated). The human skeletal materials in the oval pit were interpreted as a secondary (i.e., bundle) burial of a middle-aged male. The orientation of the bones, extremely fragmented and jumbled in a tight cluster in one portion of the pit, suggested that they might have been confined inside an organic container such as a basket or a hide bag. The only grave inclusions were a ground and faceted piece of hematite (i.e., paint stone) and a 6-cm-long, corner-notched Scallorn arrow point. The latter was found in a position suggesting that an arrow had been laid across the bone cluster. It is unusual because it is one of the largest and earliest arrow points found in a good archeological context anywhere in the Southern Plains (see Chapter 9).

The burial appears to be earlier than, and perhaps unrelated to, the earliest occupation at the site, which is represented by a second group of features radiocarbon dated to ca. A.D. 500/600 to 


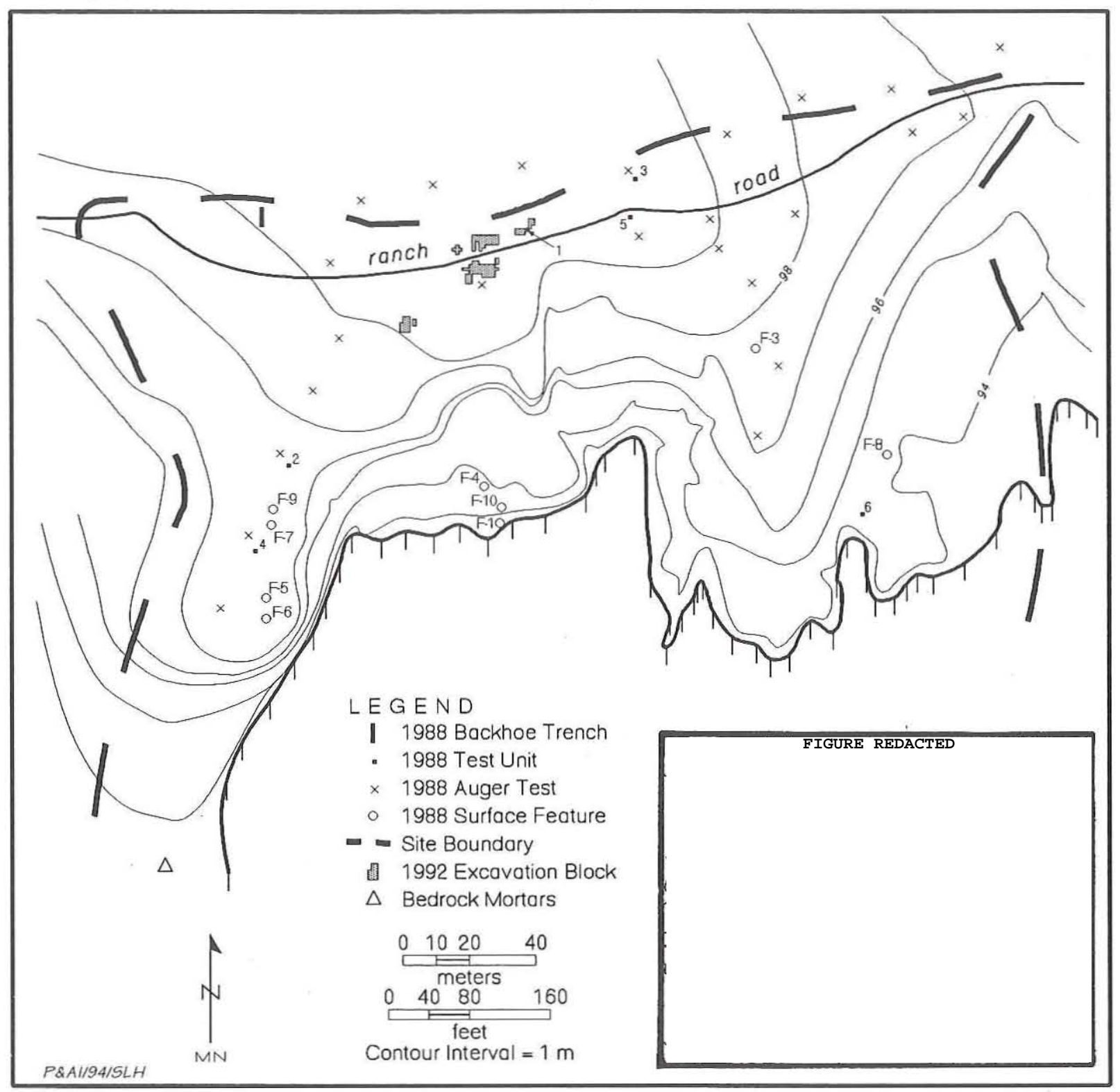

Figure 37. Map of 41 GR291 showing extent of the site, surface features, 1988 test excavations, and 1992 excavation blocks. (Bedrock mortars are Features 26 and 27; Feature 2 is subsurface feature in Test Unit 5.)

1050/1100 (calibrated). The early occupation period is characterized by a feature complex that consists of a pithouse, 10 storage pits, and 2 baking pits. The pithouse (Feature 37) is a 3-x-3.5-m, oval depression that was dug down ca. $40 \mathrm{~cm}$ below the former ground surface into the bedrock substrate (Figure 40). Two large oval-basin metates were found cached (i.e., stored upside down) inside the pithouse, and a third slab-type metate, found in the initial backhoe trench, may also have been cached.
Charred mesquite beans recovered from the floor of the pithouse are probable plant food remains. A broken pestle on the floor of the pithouse may be evidence that mesquite beans were processed in bedrock mortars. Subtle burned spots in the central floor area may represent an interior hearth(s); no definite entryway was identified, but one may have existed to the southwest. Two radiocarbon dates on charcoal from on and near the floor place the age of the pithouse's abandonment at ca. A.D. 1000 (see 


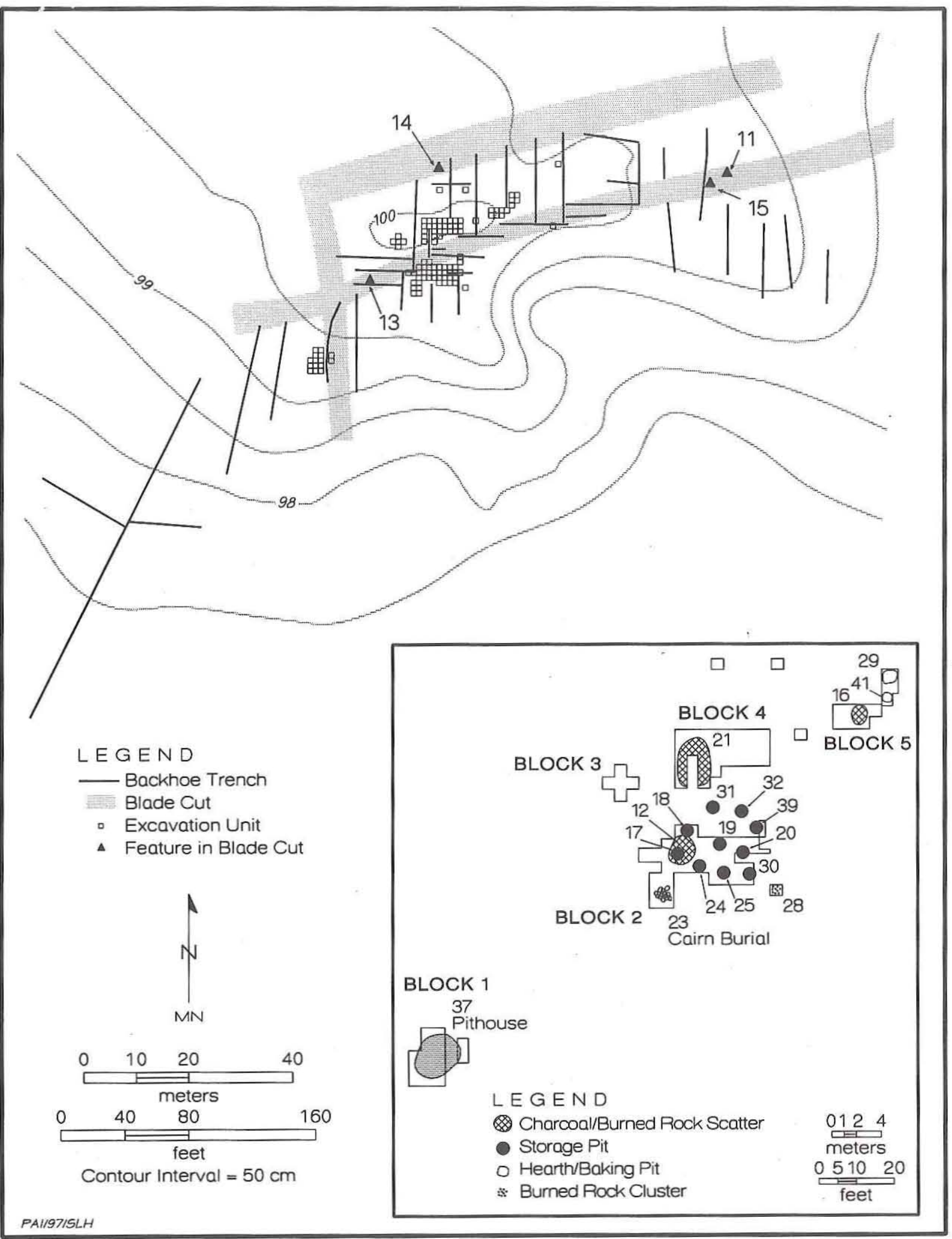

Figure 38. Map of north-central portion of 41 GR291 showing locations of data recovery mechanical excavations, hand excavations, and cultural features. 


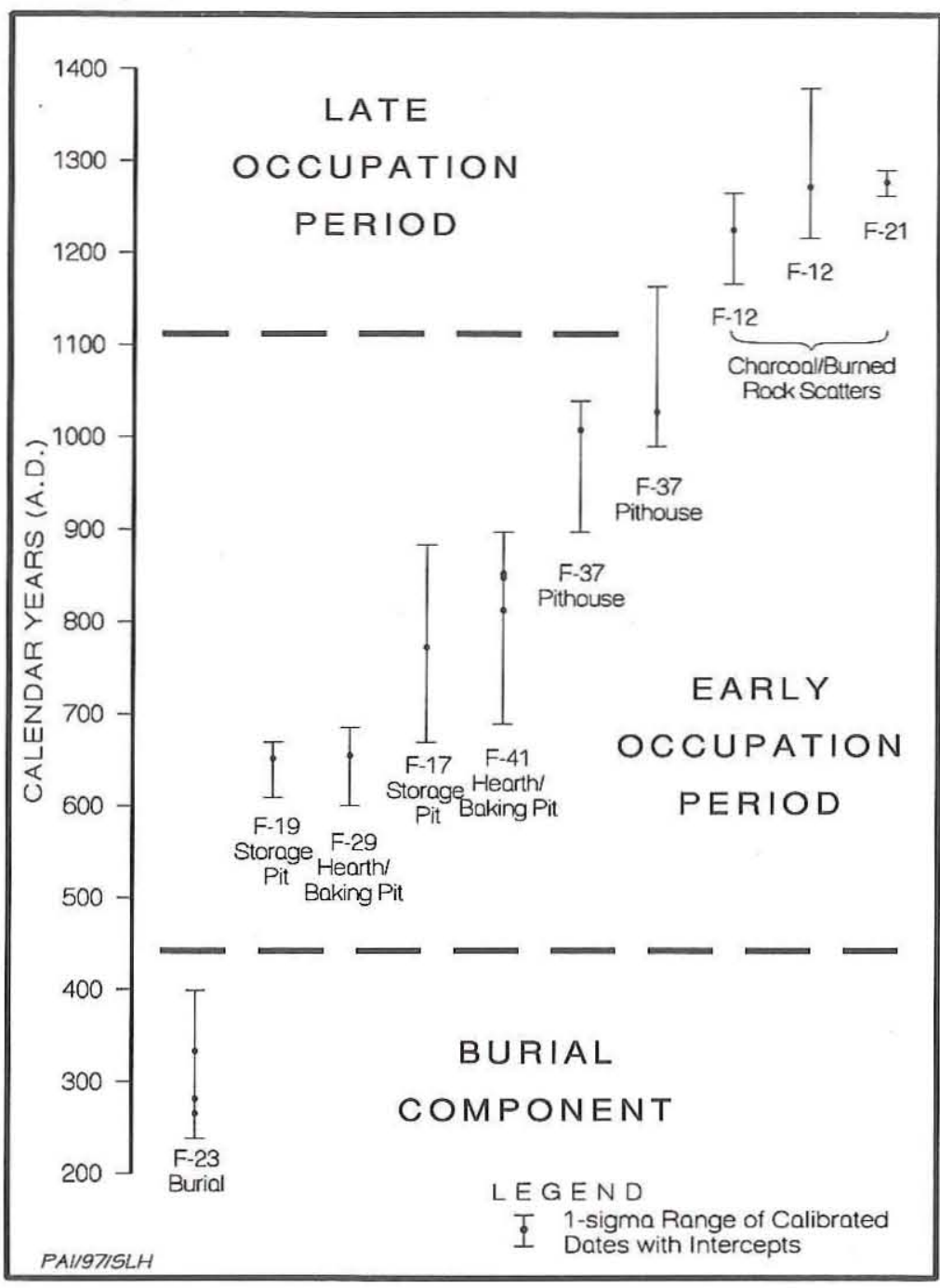

Figure 39. Graph of calibrated radiocarbon dates from 41GR291.

cached upside down on top of the pit. Variations in the fill reflect different abandonment and postabandonment processes. Only one of the pits appeared to have been backfilled with trash while the others had relatively clean sandy fill. Some had large rocks in their fill (see Figure 41a,c). They may represent collapsed rocks that had been used to weight down a covering.

The archeological evidence leaves little doubt that these features represent storage pits. Although there is no direct archeological evidence of what was stored (fossil pollen was poorly preserved and macrobotanical remains recovered from flotation yielded equivocal results), ethnographic evidence suggests that plant foods are the most likely candidate. All 10 pits are clustered in an 8-x-8-m area (see Figure 38 ), and it is hypothesized that they were located in this particular spot and dug into the bedrock to provide rodent-proof storage. Estimated storage capacities range from $0.24-0.31 \mathrm{~m}^{3}$ for the smallest pit to $0.53-0.68 \mathrm{~m}^{3}$ for the largest. Radiocarbon dates on charcoal fragments from pit fill place the approximate the age of

Figure 38).

No other definite pithouses were found despite the extent of the mechanical testing. One dark stained area observed in a backhoe trench was tested and found to be extensively disturbed by rodent activity. There is a possibility that this area represents a pithouse, but it was deemed to be too disturbed to be worth pursuing.

The 10 storage pits (Features 17, 18, 19, 20, $24,25,30,31,32$, and 39) are all quite similar in size and morphology, being round in plan view, ranging from 85 to $110 \mathrm{~cm}$ in diameter and 50 to $80 \mathrm{~cm}$ in depth, and having rounded to flat bottoms and sides that taper slightly inward (Figure 41). All of the pits extend ca. $40-60 \mathrm{~cm}$ into bedrock, and two of these features had large oval-basin metates abandonment of two of the pits at ca. A.D. 650 and 770 (see Figure 39). These dates suggest that the pits were abandoned at various times. There is no good archeological evidence indicating when the pits were constructed, but their uniformity and horizontal spacing may be interpreted as evidence of contemporaneous construction and/or use.

Two clusters of burned sandstone (Features 29 and 41) are interpreted as baking pits used to cook plant foods. One appears to be a stone-lined base with the upper rocks having been removed. The other appears to be intact and was still capped by a covering layer of stones (Figure 42). It is possible that the contents of this intact feature were never cleaned out, but flotation of the fill failed to yield definitive macrobotanical evidence. Notably, the 
TABLE 33

SUMMARY OF FEATURES BY TYPE AND TEMPORAL AFFILIATION, 41GR291

\begin{tabular}{|c|c|c|c|c|c|}
\hline \multirow[b]{2}{*}{ Feature Type } & \multicolumn{4}{|c|}{ Feature Nos. ${ }^{1}$} & \multirow[b]{2}{*}{$\begin{array}{l}\text { Total No. } \\
\text { of Features }\end{array}$} \\
\hline & $\begin{array}{c}\text { Burial } \\
\text { Component } \\
\end{array}$ & $\begin{array}{c}\text { Early Occupation } \\
\text { Period }\end{array}$ & $\begin{array}{c}\text { Late Occupation } \\
\text { Period }\end{array}$ & $\begin{array}{l}\text { Temporally } \\
\text { Unidentified }^{2}\end{array}$ & \\
\hline Burial & 23 & & & & 1 \\
\hline Pithouse $^{3}$ & & 37 & & & $1(3)$ \\
\hline Storage pit & & $\begin{array}{l}17,18,19,20,24 \\
25,30,31,32,39\end{array}$ & & & 10 \\
\hline Hearth/baking pit & & 29,41 & & 2 & 3 \\
\hline $\begin{array}{l}\text { Charcoal/burned rock scat- } \\
\text { ter }\end{array}$ & & & $12^{4}, 21$ & 16 & 3 \\
\hline Fire-cracked rock cluster & & & & 1,10 & 2 \\
\hline Burned rock cluster & & & & $\begin{array}{l}3,4,5,6,7,8,9 \\
11,13,14,15,28\end{array}$ & 12 \\
\hline Bedrock mortar & & 26(?), 27(?) & & & 2 \\
\hline Total No. of Features & 1 & 15 & 2 & 16 & $34(3)$ \\
\hline \multicolumn{6}{|c|}{$\begin{array}{l}\text { 'Excludes seven noncultural features }(22,33,34,35,36,38 \text {, and } 40) \text {. } \\
{ }^{2} \text { Features } 16 \text { and } 28 \text { were not investigated; all other temporally unidentified features were excavated. } \\
{ }^{3} \text { Encompasses three floor features }(42,43 \text {, and } 44) \text {. } \\
{ }^{4} \text { Possible structural floor. }\end{array}$} \\
\hline
\end{tabular}

burned rocks in this feature include 25 fragments of ground stone (mano, metate, and indeterminate fragments) representing 31 percent of the total rocks. A radiocarbon date on charcoal from the intact feature indicates that it was contemporaneous with one of the storage pits at ca. A.D. 650. Two bedrock mortars (Features 26 and 27) cannot be dated directly, but the pestle found in the pithouse indicates that they were probably used during the early occupation period along with the pithouse/storage pit/baking pit complex.

Only two features can be assigned confidently to the late occupation period, ca. A.D. $1050 / 1100$ to 1300 (see Figure 39 and Table 33). One (Feature $21)$ is a large $(3 \times 3.5 \mathrm{~m})$ irregular charcoal-stained area (up to $18 \mathrm{~cm}$ thick) with abundant burned rocks; it is interpreted as a midden scatter. The other (Feature 12) is a well-defined, ovate $(2 \times 3 \mathrm{~m})$ charcoal-stained area with considerably fewer burned rocks. This feature is superimposed on but not directly associated with storage pit Features 17 and
18 (Figure 43). The stain is only a few centimeters thick along most of its edges, but it is $15-20 \mathrm{~cm}$ thicker toward the center and dips down into a circular (15 cm diameter) charcoal-filled pit along one edge. The charcoal-filled pit appears to represent a small hearth, and the feature is tentatively interpreted as the floor of a structure, possibly a surface house (as opposed to the pithouse); it definitely postdates the storage pits.

Excluding the artifacts associated with the burial component, the material culture recovered from the excavation blocks was assigned to either the early or late occupation periods based on relative stratigraphic positions and associations with dated features. Since no natural stratigraphic zones were identified, the artifacts were assigned to time periods on a block-by-block basis. Since Block 1 is entirely encompassed by the pithouse, it was all assigned to the early occupation period. In Blocks $2-5$, the lower materials were assigned to the early occupation period and the upper materials were assigned to 


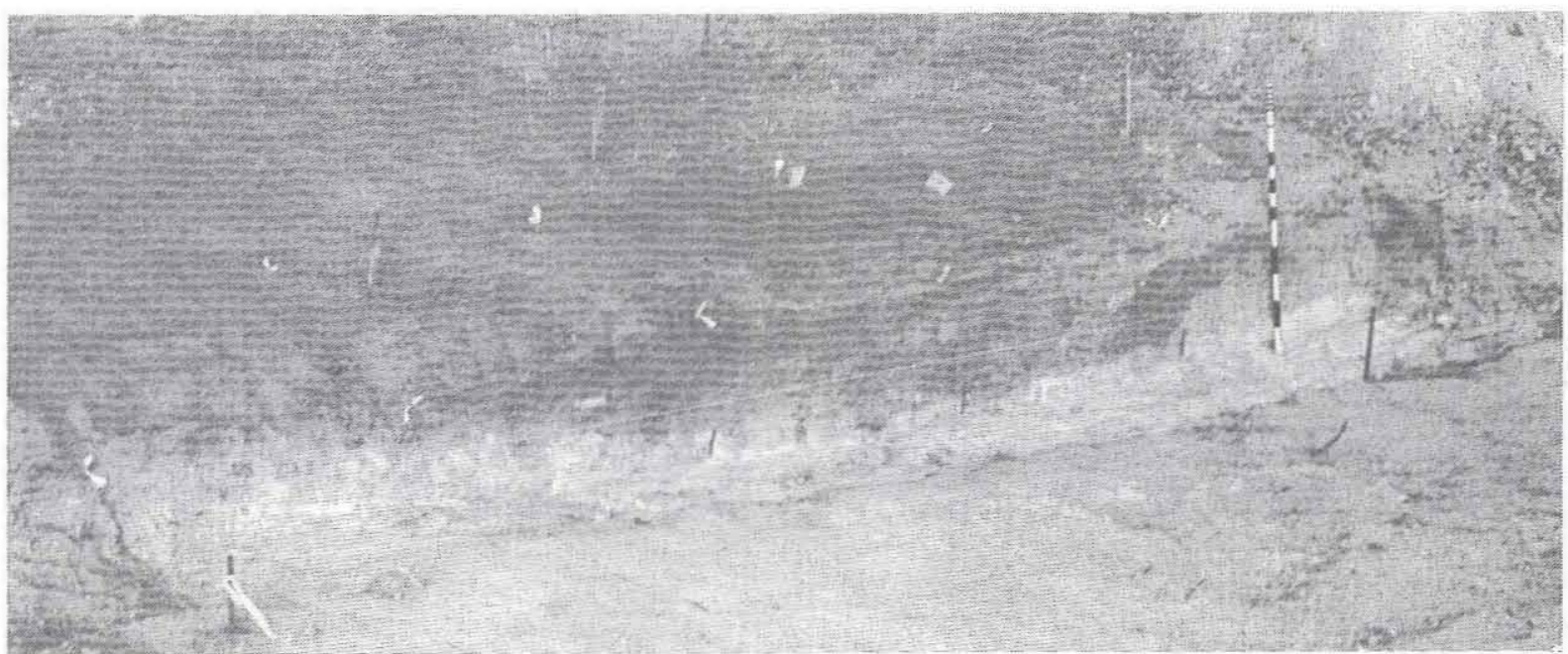

a
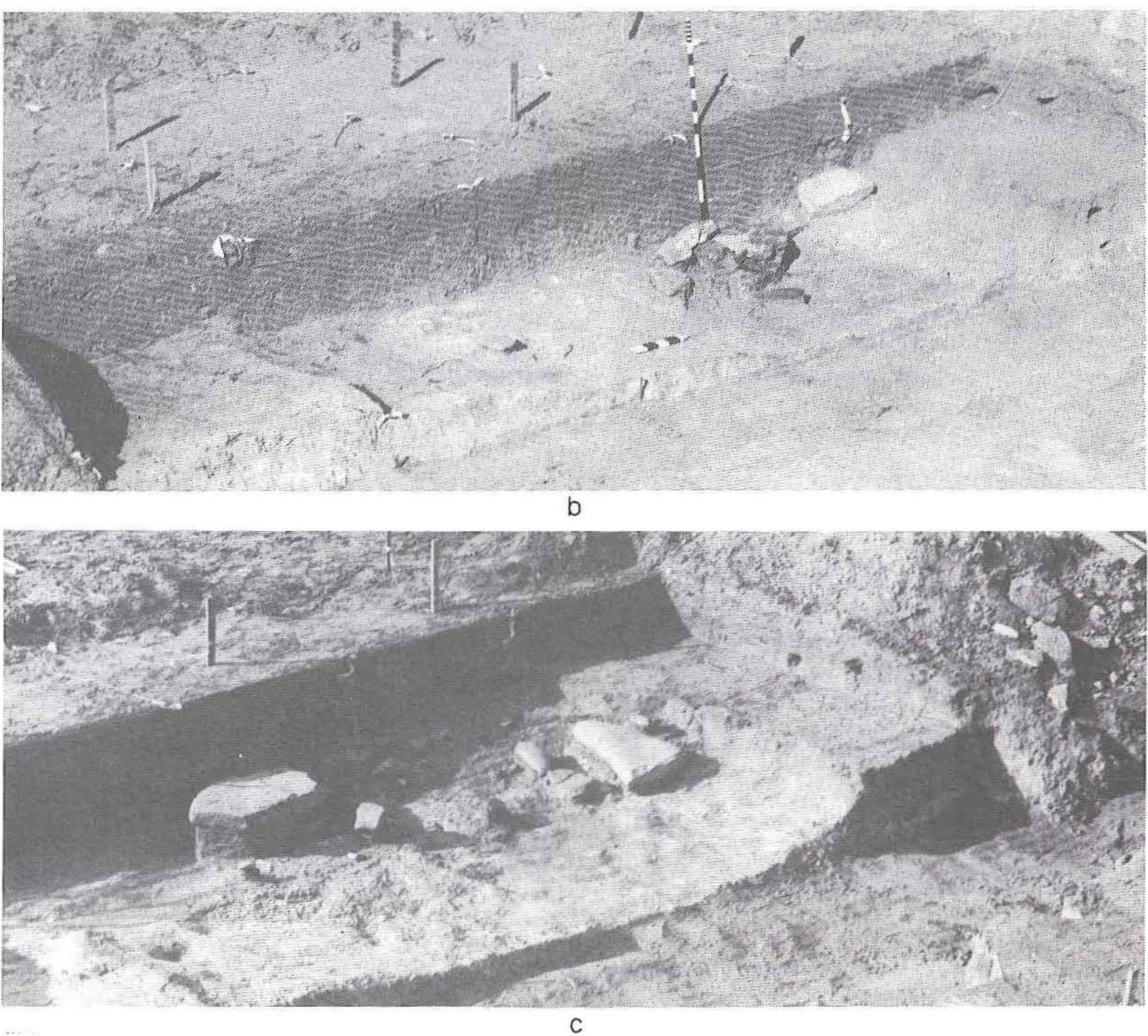

Figure 40. Series of photographs showing excavation of the pithouse, 41GR291. (a) Profile of pithouse as first seen after cleaning the wall of the backhoe trench; $(b)$ pithouse after first row of 1-x-1-m units was excavated; $(c)$ pithouse after second row of 1-x-1-m units was excavated. The two largest rocks are upside-down metates. Backhoe Trench is in foreground. 


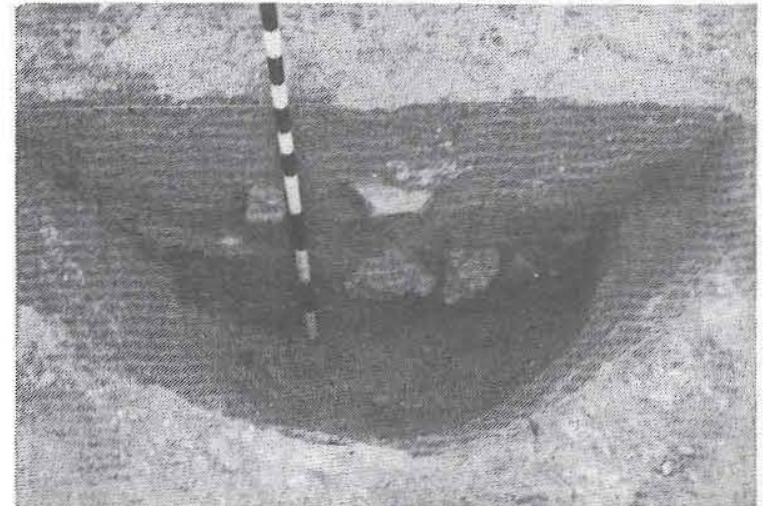

a

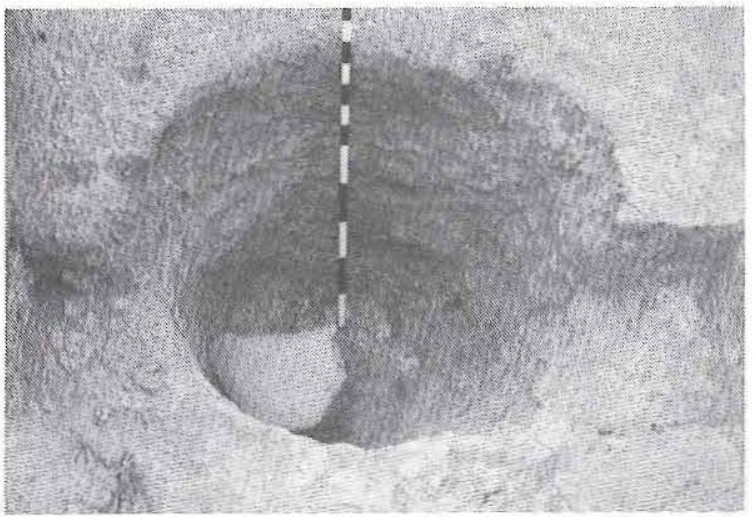

C

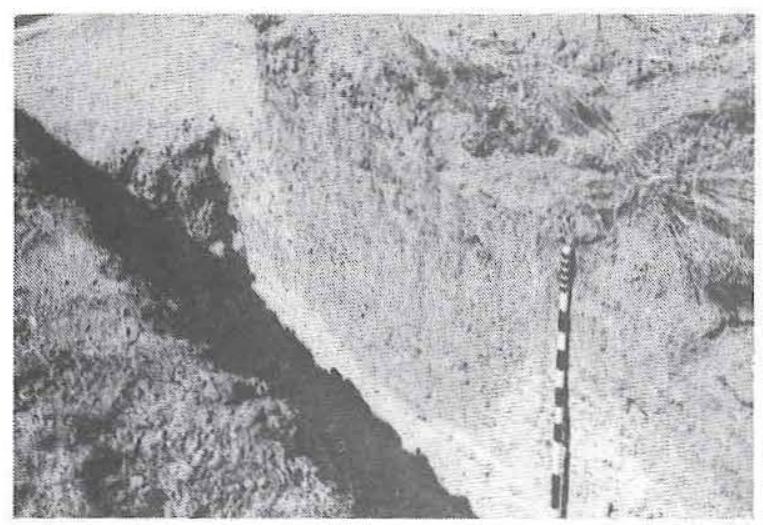

e

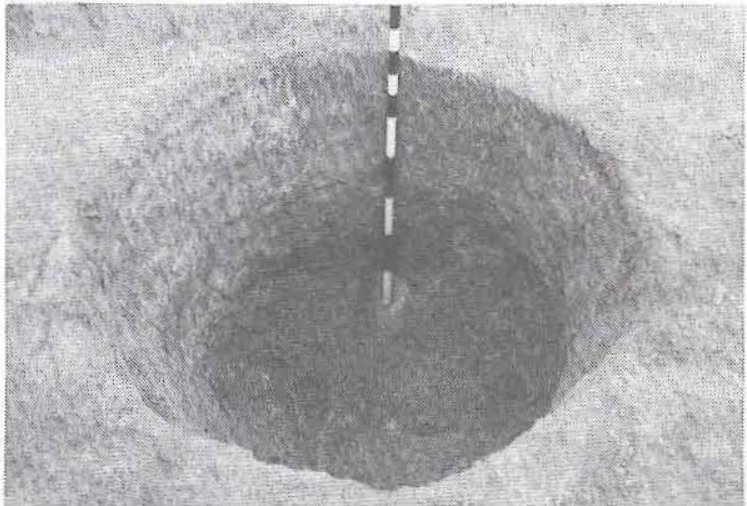

b

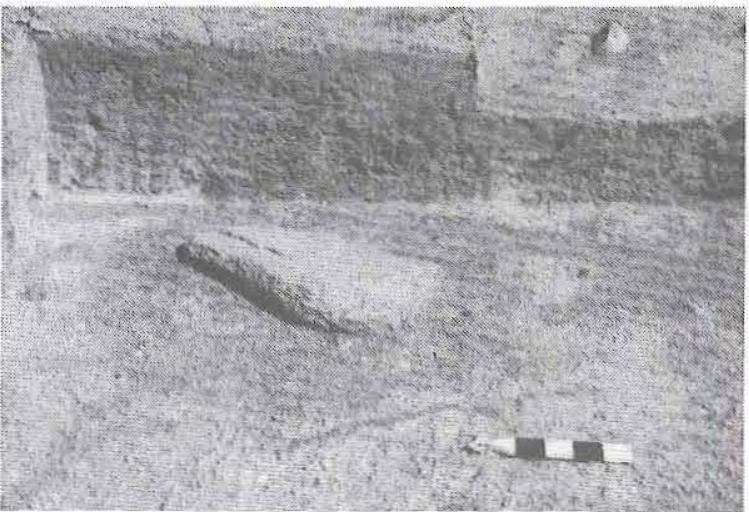

d

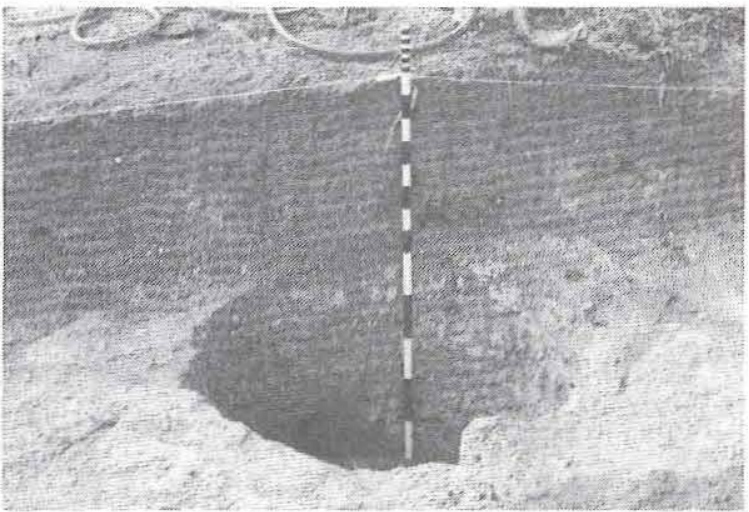

f

Figure 41. Storage pits at various stages of excavation, 41GR291. (a) Feature 17, half excavated; (b) Feature 17, completely excavated; (c) Feature 18, completely excavated with large rock in the bottom; (d) Feature 19, unexcavated with pit outline and metate exposed; (e) Feature 20 exposed in a backhoe trench; $(f)$ Feature 24, completely excavated showing relationship of pit and overlying sediment. 


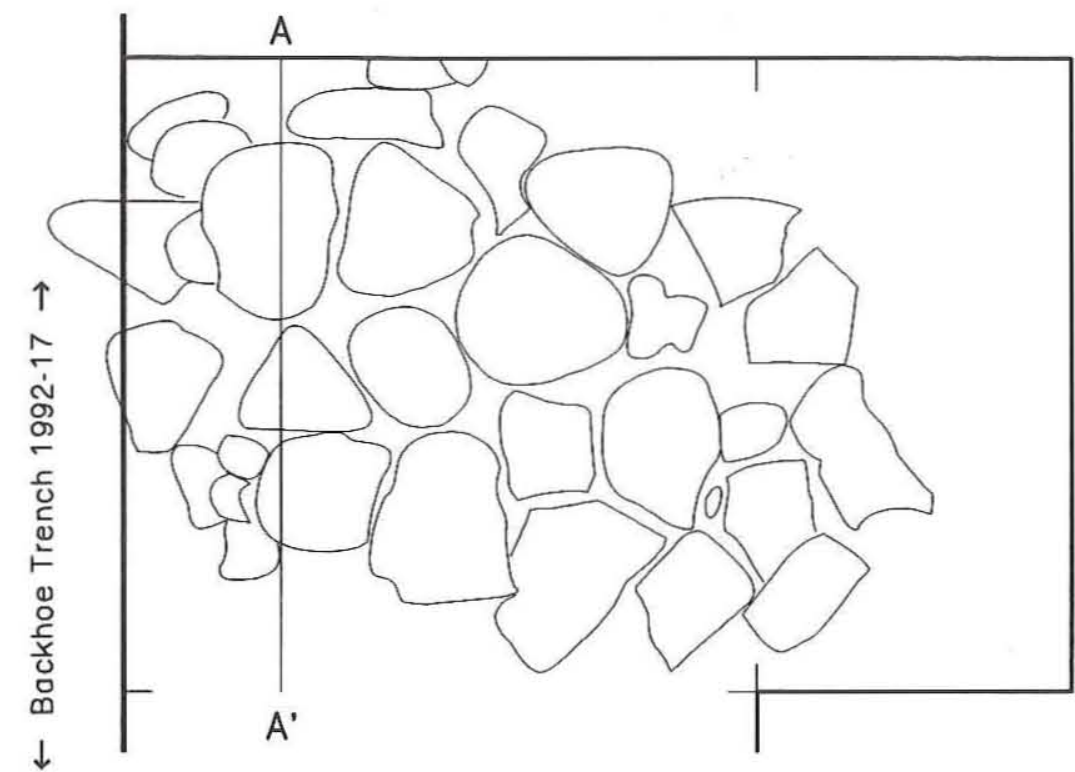

$$
\begin{aligned}
& \text { LE G E N D } \\
& 0 \quad \text { Rock } \\
& \begin{array}{l}
\text { Dark-stained Sediment } \\
\text { with Charcoal } \\
\text { I Stratigraphic Unit }
\end{array}
\end{aligned}
$$
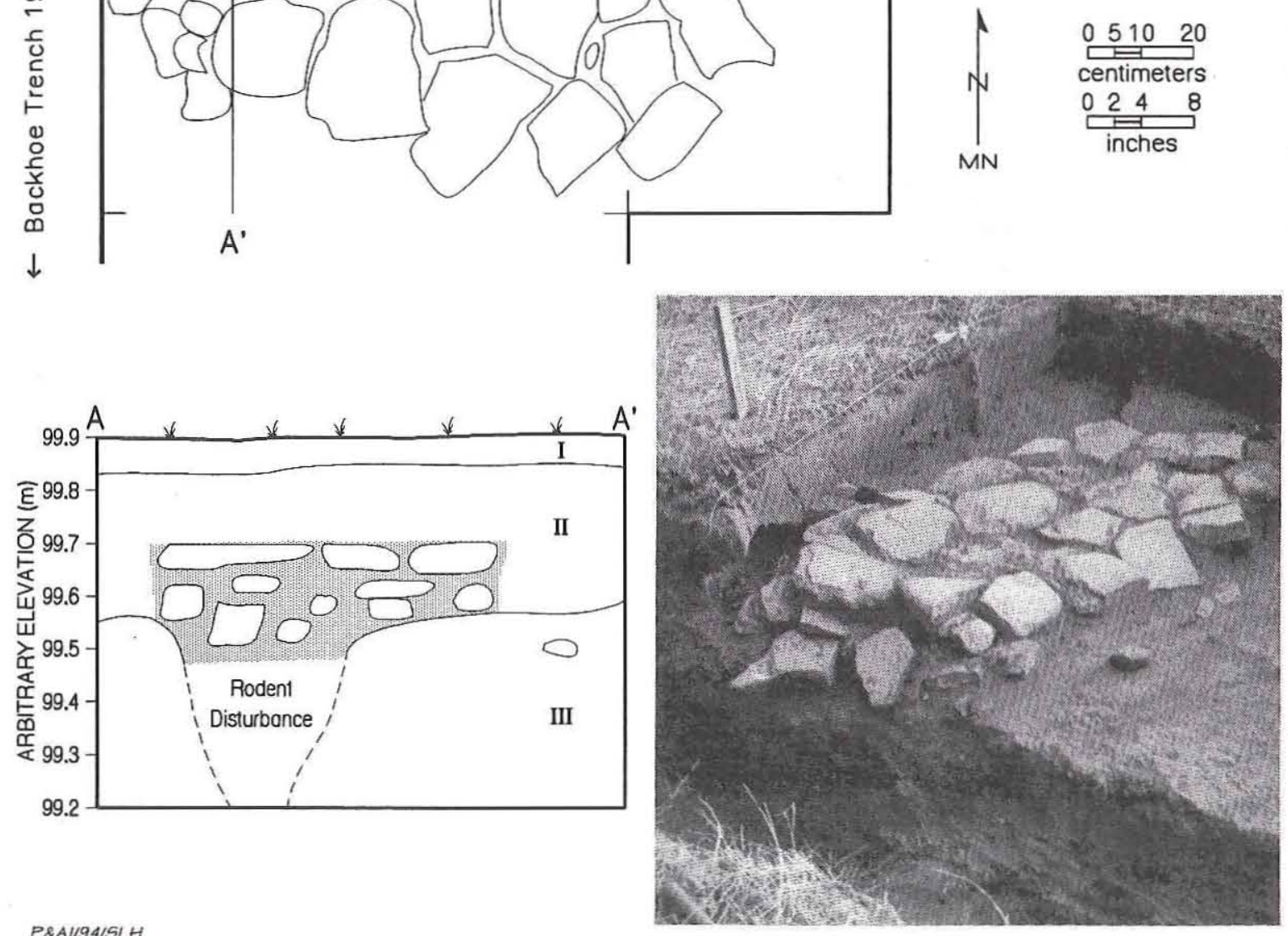

P\&AI/94/SLH

Figure 42. Plan, profile, and photograph of baking pit Feature 29, 41GR291.

the late occupation period. These materials were separated in a gross fashion by arbitrary excavation levels, but the resulting assemblages generally corresponded with the levels of the dated features assigned to their respective time periods.

The early and late artifact assemblages (Table 34) were analyzed using adjusted standardized residuals to account for variability in sample sizes and to identify statistically valid differences. Overall, the assemblages are quite similar. In particular,
Jornada brownware ceramics seem to be present during both periods, suggesting that the occupants maintained some connection with the Jornada Mogollon area.

However, there are some statistically significant differences between the assemblages that are broadly interpreted as evidence of changes in site function and subsistence strategies. In general, the early occupation period is characterized by a greater dependence upon plant processing (i.e., more and 


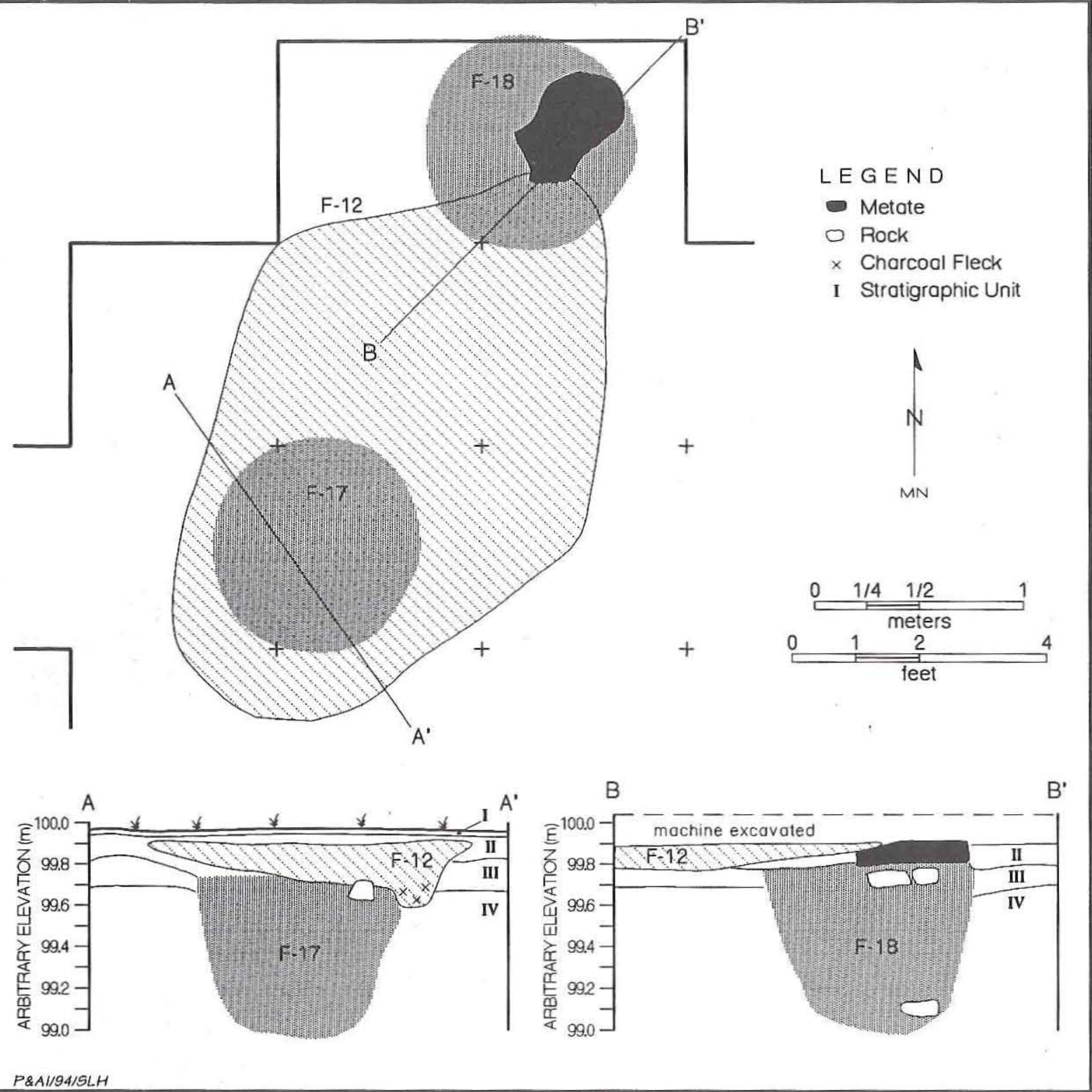

Figure 43. Plan and profile drawings of Feature 12, 41GR291. Note relationship of Feature 12 to storage pit Features . 17 and 18 .

larger ground stone tools), and the late occupation period is characterized by a greater reliance upon hunting (i.e., more arrow points) and an increase in the manufacture of chipped stone tools (i.e., more unmodified debitage). These interpretations are supported by the differences in feature types.

The early occupation is characterized as a small pithouse village, probably occupied on a seasonal basis, where plant procurement, processing, and storage were major activities. Except for the mesquite beans found in the pithouse, the specific plants utilized are not well documented. Charred remains of some other plants, such as Chenopodium and cucurbit seeds, may represent food resources, but their archeological contexts do not confirm this interpretation. The cucurbit seeds cannot be identified to species and may have come from wild rather than cultivated varieties, but the absence of domesticated plants in the macrobotanical samples from 41GR291 does not necessarily mean an absence of agriculture altogether. Since the lack of cultigens could be due to differential preservation or the use 


\begin{tabular}{|c|c|c|c|c|}
\hline \multicolumn{5}{|c|}{$\begin{array}{l}\text { TABLE } 34 \\
\text { N OF ARTIFACT ASSEMBLAGES ASSIGNED TO THE } \\
\text { Y AND LATE OCCUPATION PERIODS, 41GR291 }\end{array}$} \\
\hline Artifact Class & $\begin{array}{l}\text { Early Occupation } \\
\text { Period }\end{array}$ & $\begin{array}{l}\text { Adjusted Standardized } \\
\text { Residuals for Early } \\
\text { Occupation Assemblage }\end{array}$ & $\begin{array}{l}\text { Late Occupation } \\
\text { Period }\end{array}$ & Totals \\
\hline Arrow Points ${ }^{2}$ & 4 & -2.36 & 18 & 22 \\
\hline Bifaces & 5 & -0.95 & 11 & 16 \\
\hline Perforators & 1 & -0.34 & 2 & 3 \\
\hline Gouges & 3 & -1.26 & 9 & 12 \\
\hline Cobble Tools & 17 & +1.17 & 15 & 32 \\
\hline Unifaces & 31 & -0.68 & 48 & 79 \\
\hline Cores & 33 & +1.40 & 31 & 64 \\
\hline Edge-Modified Flakes & 16 & +0.33 & 19 & 35 \\
\hline Unmodified Debitage & 1,242 & -3.74 & 1,728 & 2,970 \\
\hline Ground Stone Tools & 78 & +7.69 & 18 & 96 \\
\hline Hammerstones & 1 & -0.34 & 2 & 3 \\
\hline Ceramic Sherds & 8 & -0.08 & 11 & 19 \\
\hline Modified Hematite & 3 & +0.77 & 2 & 5 \\
\hline Modified Shells & 2 & +1.63 & 2 & 4 \\
\hline Totals: & 1,444 & & 1,916 & 3,360 \\
\hline \multicolumn{5}{|c|}{$\begin{array}{l}{ }^{1} \text { Everitt (1977:46-48). Numbers above }+1.95 \text { or below }-1.95 \text { are statistically significant at the } .05 \text { level of } \\
\text { confidence. }\end{array}$} \\
\hline
\end{tabular}

of plant processing techniques that did not result in charred remains, the question of whether the early occupants were involved in farming remains open. The archeological evidence from the early occupations suggests an intensity of plant processing and storage that is not generally attributed to a pure hunter/gatherer lifestyle.

The late occupation evidence at 41GR291 seems to indicate that a dramatic change in site function and subsistence occurred around A.D. 1050/1100. Hunting seems to have been increasingly important, and the inhabitants may have shifted from living in pithouses to living in surface houses (or the pithouses evolved into surface houses) at this time. These changes are coincident with major cultural changes that are thought to have occurred throughout the Southwest and Southern Plains ca. A.D. $1000-1200$.

The burial component cannot be assigned to a cultural complex with any confidence, but the early occupations appear to be a manifestation of the Palo Duro complex (Cruse 1992; J. Hughes 1991). There is not enough evidence to determine whether the late occupations represent a late variant of the Palo Duro complex or something else entirely.

\section{GR303B, Cat Hollow Site}

The Cat Hollow site, 41GR303, is located in the upland margin west of Cat Hollow within the Sam Wahl Recreation Area, ca. 300 m northwest of the confluence of Cat Hollow and the Double Mountain Fork. It occupies an isolated, eastwardprojecting upland ridge at ca. $2300-2310 \mathrm{ft} \mathrm{msl}$ and extends down onto a series of lower bedrock benches at $2240-2300 \mathrm{ft} \mathrm{msl}$. The edges of the ridges and portions of the lower benches are severely eroded and contain abundant exposures of sandstone. An unimproved ranch road runs eastwest along the top of the ridge, but no other land alterations were observed. Area A occupies the flat portion of the upland ridge, while Area B is on a lower bedrock bench north of Area A and adjacent to Cat Hollow. The data recovery investigations concentrated on Area B.

Area B is an isolated $25-\mathrm{x}-75-\mathrm{m}$ remnant of 
sediment on a bedrock bench between Cat Hollow and the upland ridge (Figure 44). The sediments consist of up to $1 \mathrm{~m}$ of sandy loam representing a colluvial deposit directly on a bedrock bench or strath terrace of Triassic Dockum Group sandstone. All of the sediments were derived locally from erosion of the surrounding sandstone. Radiocarbon dates suggest that the deposit aggraded rapidly between A.D. 1 and 1000, after which the colluvial deposit remained stable (or aggraded very slowly) long enough for a weak soil (A horizon) to develop. The cessation of deposition at ca. A.D. 1000 may have been due to the onset of increasingly xeric conditions in the vicinity (e.g., Abbott 1990; Blum et al. 1992). Some time after A.D. 1000, the colluvial sediments began to erode, possibly due to loss of vegetation cover and channel incision. Erosion continued to the present, and 41GR303B was reduced to a long oval knoll perched 10-11 m above the Cat Hollow streambed and exposed on all sides by erosional channels cut into bedrock. The edges of the meter-high mound are beveled by erosion, exposing considerable amounts of cultural materials.

Site 41GR303 was recorded in 1987 as an extensive scatter of surface artifacts with numerous pockets of intact sediment isolated by erosion. Subsequent testing in 1988 examined the upper ridge (Area A) and the colluvial remnant on the lower bedrock bench to the north (Area B). Two 1-x-1-m test units in Area B confirmed that there were buried cultural materials throughout the deposit to a depth of $110 \mathrm{~cm}$. A large surface collection obtained from a $10-\mathrm{x}-10-\mathrm{m}$ unit on the eroding edge of the sandy knoll provided an additional sample of cultural materials. No artifacts were collected from Area B during the survey, but 478 were recovered during testing (of which 38 percent were surface collected).

The 1992 data recovery investigations in Area B consisted of hand excavation of 35 additional units, bringing the total number of units to 37 . Twenty-eight units were in a single contiguous block, and 35 were clustered within a 9-x-10-m area. From all phases of work, 2,795 artifacts were recovered (see Table 31), and 4 features were recorded. Two features are burned rock concentrations that appear to be dumps of heated rocks, while the other two are interpreted as remnants of baking pits. In addition to these individual features, an extensive scatter of burned rocks was observed across the entire area (Figure 45). Burned rocks were scattered throughout all levels, but the majority were concentrated within a zone varying in depth from 10 to $20 \mathrm{~cm}$ below the surface on the west to as much as 50 to $60 \mathrm{~cm}$ below the surface on the east. Although this zone was more deeply buried to the east, it generally followed the natural eastward slope of the modern ground surface and is interpreted as a scatter of burned rocks on an old stable surface. The two baking pit features appear to be intrusive from this old surface, and it is speculated that the entire burned rock zone may be the result of cleaning out and discarding debris from baking pits.

Preservation of charred remains or microstratification was very poor in the sandy sediments, but three radiocarbon dates were obtained; the calibrated ages indicate that occupations at 41GR303B began as early as A.D. 71 and lasted as late as A.D. 1382 (see Table 32). The earliest date is A.D. 71-197 and came from charcoal at $93-103 \mathrm{~cm}$ below the surface, well below the burned rock zone. The second date, A.D. $681-852$, came from Feature 8 which (along with Feature 6) is interpreted as the lower portion of a baking pit. This sediment date should represent a minimum age for this baking pit, and, if most of the other burned rocks represent an associated accumulation of baking pit debris, this date is a minimum age for the burned rock zone as well. The third date, A.D. 1020-1382, came from charcoal in the upper levels and represents cultural activities that postdate the accumulation of the burned rock zone.

The site contains good evidence of multiple occupations over a long period of time; for analysis purposes, the top of the burned rock zone was used to separate the features and artifacts into different time periods. In all of the contiguous excavation block units, the burned rock zone was well defined and was used to define upper and lower zones. Although the chronological and stratigraphic control is tenuous, the data do indicate that the lower zone, encompassing the burned rock zone and everything below it, dates to the Late Prehistoric I period. The upper zone, encompassing everything at the top of and above the burned rock zone, dates to the Late Prehistoric II period. Since most of the burned rocks and all of the features were in the lower zone, the evidence suggests that plant processing was the dominant activity during the Late Prehistoric I occupations.

When the cultural materials are divided into lower and upper zone assemblages, the majority (66 percent) are attributed to the Late Prehistoric II 


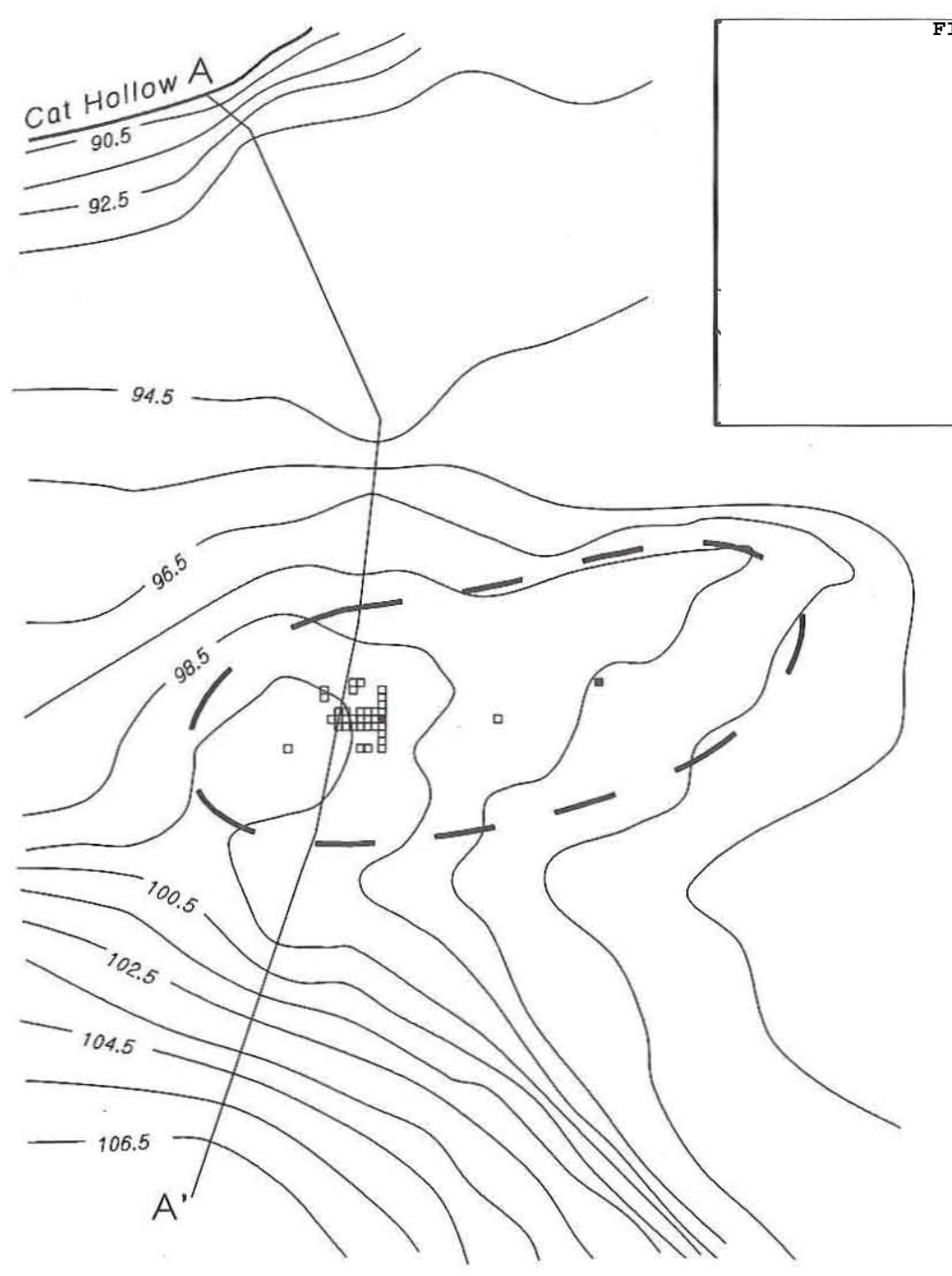

IGURE REDACTED

LEGEND

- 1992 Excavation Unit

- 1988 Test Unit
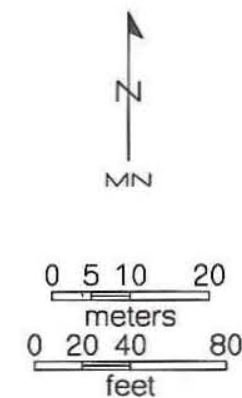

Contour Interval $=1 \mathrm{~m}$

A

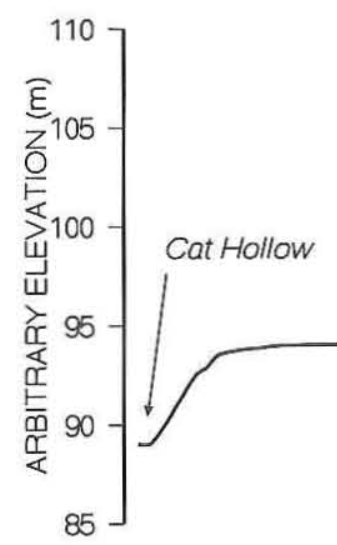

41GR303A

PAIISTISLH

Figure 44. Map of 4IGR303B showing the topographic setting, 1988 test units, and 1992 excavation units. 


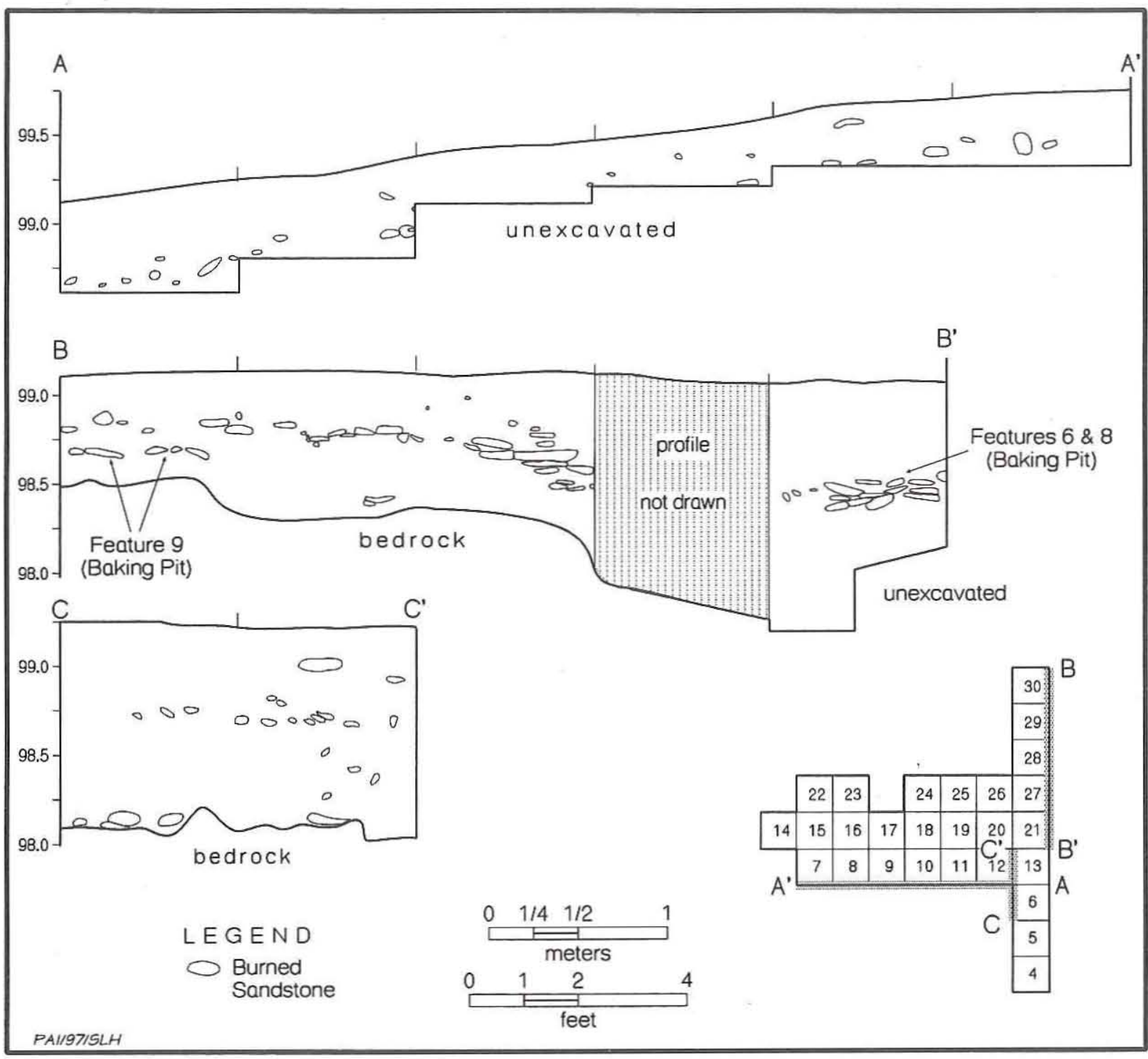

Figure 45. Three profiles showing the burned rock scatter in the main excavation block, 41GR303B.

occupations (Table 35). The analysis, utilizing adjusted standardized residuals to account for variability in sample sizes, determined that cores, cobble tools, and ground stones were overrepresented in the lower zone while unmodified debitage was overrepresented in the upper zone. Although not statistically significant, it is notable that arrow points were found in the upper zone but not in the lower. These differences are interpreted as evidence of a greater emphasis on plant food processing (i.e., grinding and refurbishing of grinding surfaces using cobble tools) during the earlier occupations. Conversely, the data suggest a shift toward hunting-oriented activities during the later occupations.

\section{GR383, Gobbler Creek Bridge Site}

Site 41GR383 is located on the upland margin on the west side of Gobbler Creek approximately $1.5 \mathrm{~km}$ upstream from its confluence with the Double Mountain Fork of the Brazos River. It covers a large 150-x-200-m area at an elevation of 2240-2280 $\mathrm{ft} \mathrm{msl}$. At the time of discovery, an east-west county road bisected the site and crossed Gobbler Creek immediately below the site. Farm-toMarket Road 3519, constructed by the Texas Department of Transportation in 1991, now bisects the site into northern and southern segments in the same approximate location as the former county road. A 
TABLE 35

SUMMARY OF ARTIFACTS FROM THE LOWER AND UPPER ZONES, 41GR303B

\begin{tabular}{|c|c|c|c|c|}
\hline Artifact Class ${ }^{1}$ & $\begin{array}{l}\text { No. in } \\
\text { Lower Zone }\end{array}$ & $\begin{array}{l}\text { Adjusted Standardized Residual } \\
\text { for the Lower Zone }{ }^{2}\end{array}$ & $\begin{array}{l}\text { No. in } \\
\text { Upper Zone }\end{array}$ & Totals \\
\hline $\begin{array}{l}\text { Arrow Points } \\
\text { Bifaces } \\
\text { Unifaces } \\
\text { Cores } \\
\text { Edge-Modified Flakes } \\
\text { Cobble Tools } \\
\text { Ground Stones } \\
\text { Gouges } \\
\text { Unmodified Debitage }\end{array}$ & $\begin{array}{r}- \\
4 \\
18 \\
22 \\
10 \\
13 \\
11 \\
4 \\
539\end{array}$ & $\begin{array}{l}-1.24 \\
+0.96 \\
+0.63 \\
+2.69 \\
-0.33 \\
+3.72 \\
+2.95 \\
+0.40 \\
-3.85\end{array}$ & $\begin{array}{r}3 \\
4 \\
29 \\
19 \\
22 \\
4 \\
5 \\
6 \\
1,114\end{array}$ & $\begin{array}{r}3 \\
8 \\
47 \\
41 \\
32 \\
17 \\
16 \\
10 \\
1,653\end{array}$ \\
\hline Totals: & 621 & & 1,206 & 1,827 \\
\hline \multicolumn{4}{|c|}{$\begin{array}{l}{ }^{1} \text { Artifacts from contiguous excavation block units, excluding a reworked dart point from the lower zone } \\
\text { and a dart point from the upper zone. }\end{array}$} & \\
\hline
\end{tabular}

new bridge constructed as part of the project gives the site its name. The northern segment is heavily deflated and eroded by slopewash leading to a small gully that flows into Gobbler Creek. The southern portion of the site is more intact, with upland colluvial sediments protected from erosion by a series of sandstone benches which act as retainers. This area slopes moderately eastward down to a vertical sandstone bluff overlooking Gobbler Creek.

The bedrock consists of alternating layers of hard and friable Triassic sandstones that are overlain by a mantle of sandy sediments that ranges from 30 to $200 \mathrm{~cm}$ thick. The sediments are sandy loams to loamy sands derived largely from in situ weathering of the friable sandstones. Various degrees of soil development were observed in different areas, dependent mainly upon the thickness of the sediment mantle. Cultural materials were generally confined to the upper $50-60 \mathrm{~cm}$, even in areas were the sediment is more than $1 \mathrm{~m}$ deep.

The 1987 survey documented a high density of surface artifacts in the northern portion of this open campsite, but intact cultural deposits were buried in the southern portion. The southern edge of the roadcut provided an excellent cross section of the site sediments, revealing an extensive pavement of burned rocks and artifacts. Only two artifacts were collected, but numerous grinding stones and an arrow point tip were observed. A cluster of seven manos on the surface undoubtedly represented a relic collector's cull pile.

Testing in 1988 included surface collection of scattered diagnostic artifacts, surface collection of all artifacts from a 1-m-wide, 60 -m-long corridor along the roadcut, 11 auger tests, and hand-excavation of eight 1-x-1-m test units (see Boyd et al. 1992:Figure 10). Ten surface features (three pointed-oval bedrock mortars and seven burned rock concentrations) were recorded, and two burned rock clusters were encountered in test units. A total of 341 artifacts was recovered, including 4 untyped dart points (2 have expanding stems) and a Granbury arrow point. Although it lacked well-defined natural or cultural stratigraphy, site 41GR383 was considered to contain evidence of terminal Archaic and Late Prehistoric occupations that might be vertically separable into two components.

The data recovery plan was based on artifact densities encountered during testing, and it was estimated that a $30-\mathrm{m}^{2}$ excavation block in the southern portion of the site would yield an interpretable sample of artifacts. During data recovery in 1990 and 1991, the level of excavation effort was expanded to account for a lower-than-expected artifact density and the lack of separable components. The investigations consisted of detailed site mapping and excavation of fifty-three 1-x-1-m units; 51 are contiguous block units and 2 are isolated 
(Figure 46). The block excavations continued until all units had been dug to bedrock at depths ranging from 31 to $96 \mathrm{~cm}$ below the surface. The cultural zone was dispersed throughout the upper $50 \mathrm{~cm}$ of sediment in the deeper units but was compressed into $30-40 \mathrm{~cm}$ over most of the block. The excavations documented three additional features, for a total of 15 features, and recovered 2,160 artifacts for a total of 2,503 artifacts (see Table 31). The three excavated features are concentrations of burned rocks; Features 13 and 14 are interpreted as either disturbed hearths or hearth dumps on a living surface while the third, Feature 15 , is interpreted as a baking pit (Figure 47).

Four radiocarbon ages were obtained for 41GR383 (see Table 32). Two dates associated with Feature 13 include a sediment date of $1215 \pm$ 140 B.P. and an AMS charcoal date of $1390 \pm$ 65 B.P. and provide an age estimate for the main part of the cultural zone (i.e., $10-13 \mathrm{~cm}$ below the surface). A sediment sample from the lower portion of the cultural zone $(35-45 \mathrm{~cm}$ below the surface)

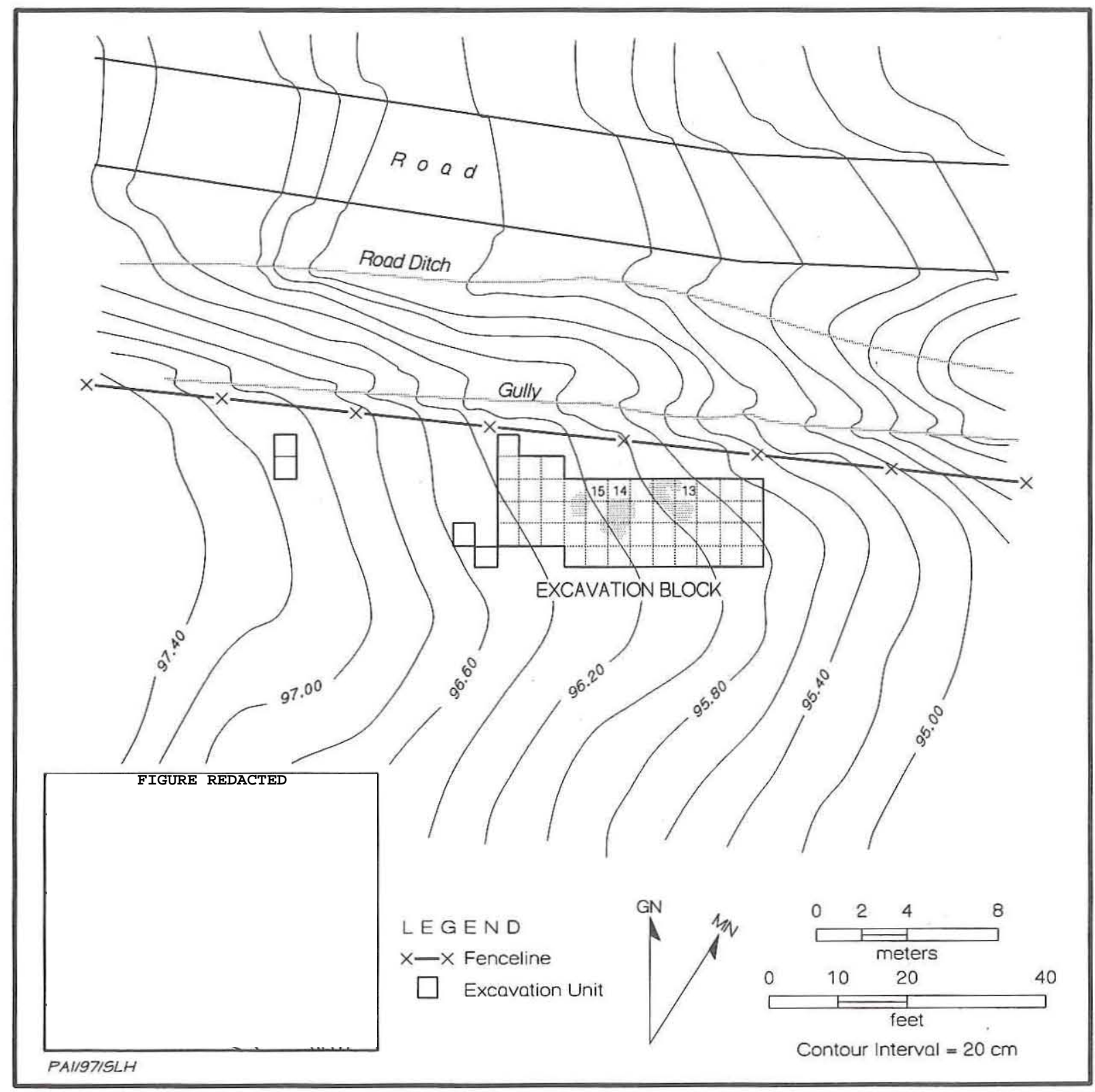

Figure 46. Detailed map of the excavation block at $41 \mathrm{GR} 383$ showing locations of excavated features. 


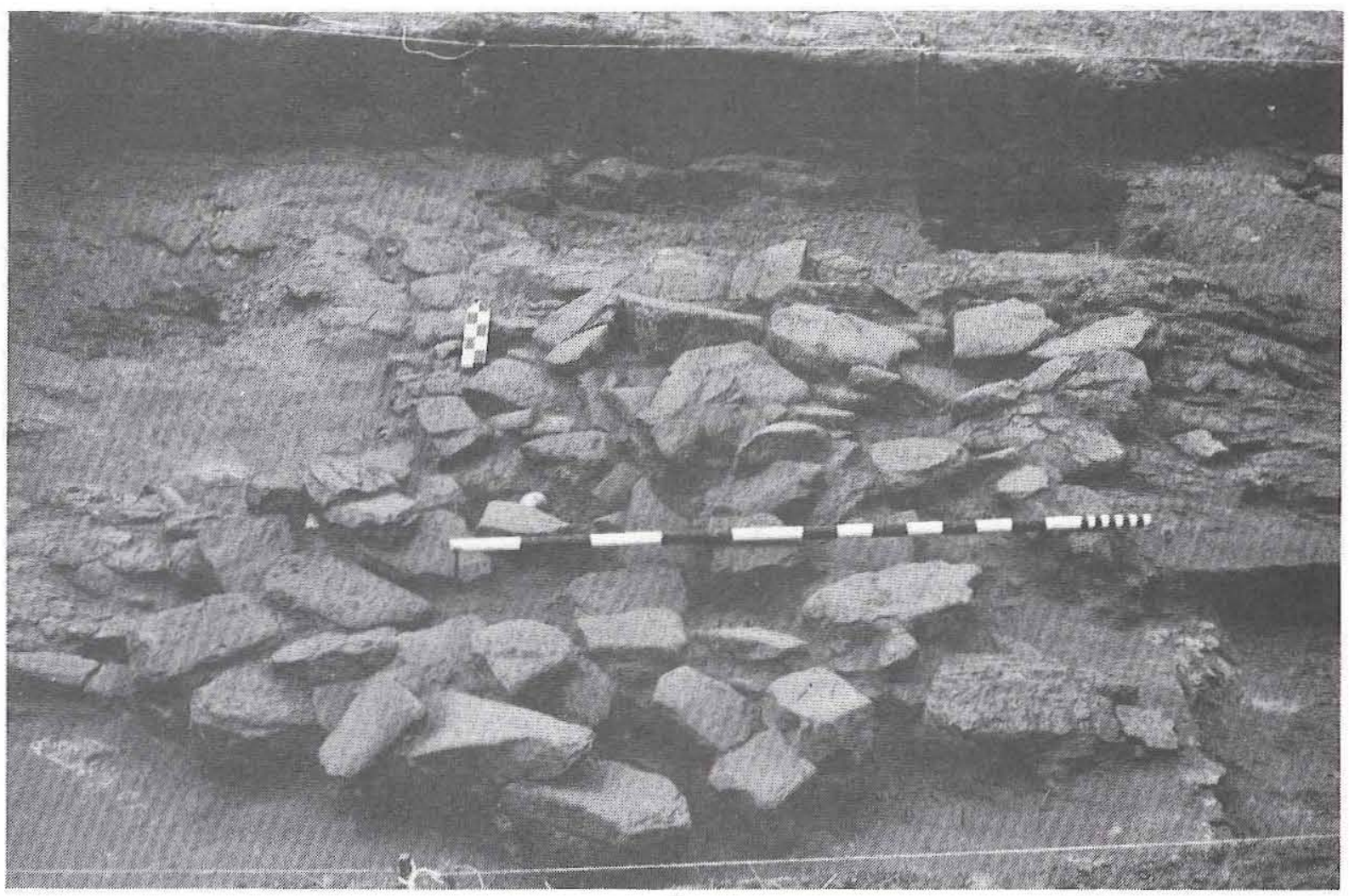

a

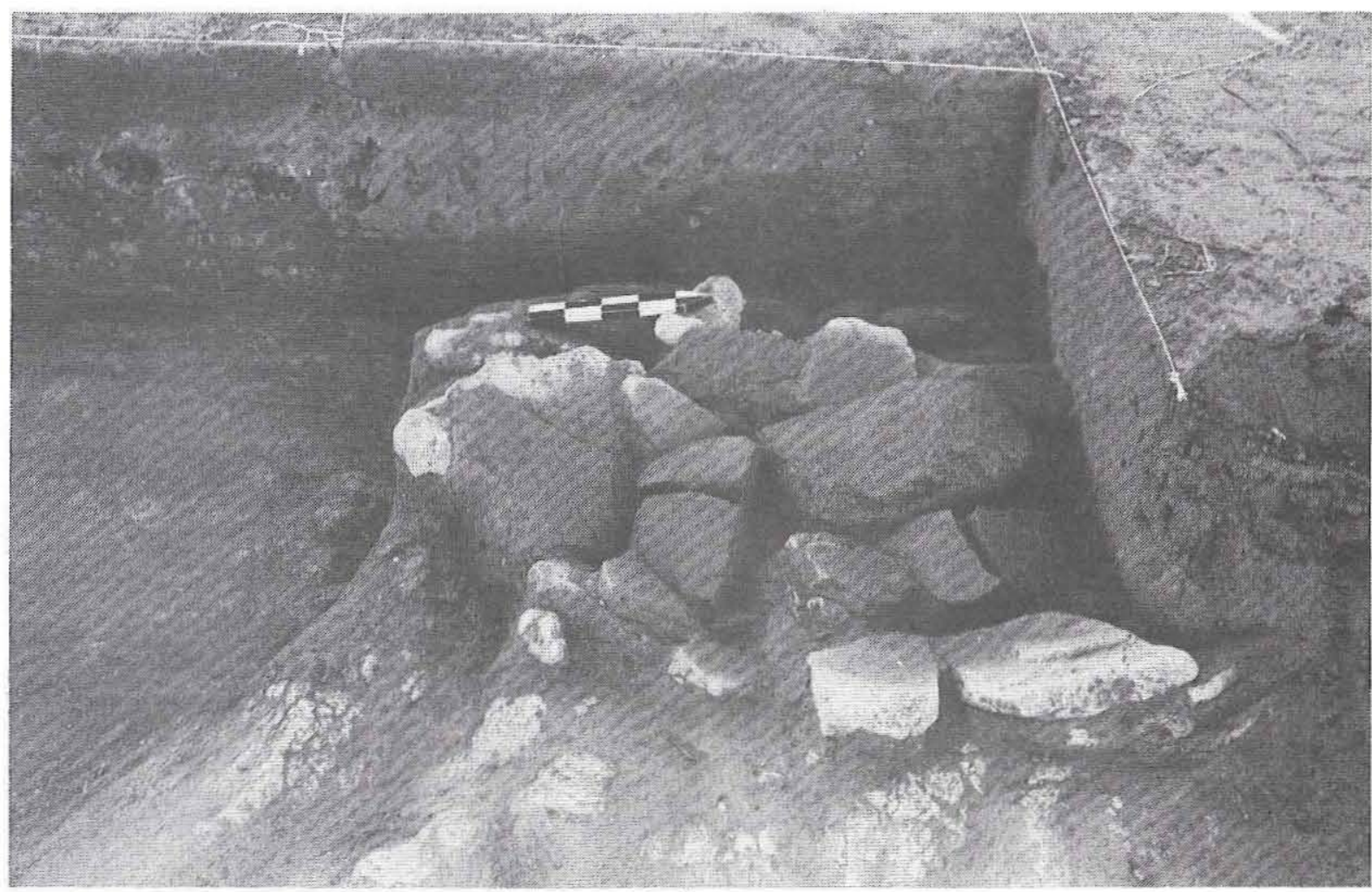

b

Figure 47. Photographs of burned rock features, 41GR383. (a) View north of large burned rock cluster (Feature 14) with surrounding area exposed to bedrock; $(b)$ view west of partially exposed baking pit (Feature 15). 
yielded a date of $1865 \pm 140$ B.P., providing an age estimate for the beginning of occupations. A second sediment sample from the lower cultural zone (also at $35-45 \mathrm{~cm}$ below the surface) yielded a date of $450 \pm 125$ B.P. This latter date is much younger than expected and is thought to have been contaminated by recent carbon leaching down from the surface.

The data recovery evidence is interpreted as representing multiple occupations during the transitional period from Late Archaic to Late Prehistoric I, but none of the artifacts or features can be separated into discrete components. The site is interpreted as a multifunctional campsite since a wide variety of activities is evident. Chipped stone tools and debitage indicate that tool rejuvenation was a primary activity but that manufacture of new tools was limited. Hunting is indicated by the presence of projectile points and unifacial scraping and cutting tools that may have been used on animal hides and meat. Vertebrate faunal remains were not well preserved, but mussel shell fragments were relatively common. The overall amount of shell recovered suggests that mussels were only a minor food resource, however. A possible drill hole in one shell fragment may indicate that mussels were more important as a source of shell for making ornaments than as food.

Plant processing is perhaps the best-represented cultural activity at 41GR383. The presence of a baking pit and substantial accumulations of burned rocks, along with the relatively high frequency of ground stone tools and the presence of numerous ground stones recycled as hearthstones, are interpreted as evidence of intensive plant food processing,. The chopper tools may have functioned as bone-crushing implements, or they could have served as hammerstones for shaping sandstone into ground stone tools and/or for resharpening (i.e., pecking) the grinding surfaces of manos and metates. Unfortunately, flotation of sediment samples from features did not yield any macrobotanical remains, and fossil pollen was found to be poorly preserved in the sediments. The presence of three pointed-oval bedrock mortars is further evidence that plant processing occurred on-site. While mortars cannot be independently dated, they are associated here with the data recovery materials because a probable pestle was recovered from the excavation block. It is a thin ovate manuport, made of a Permian sandstone not present in the immediate vicinity of the site, that was apparently chipped into shape and subsequently worn down. Although there is no identifiable use wear on this specimen, striations would not preserve well on this type of sandstone, and its distinctive shape is characteristic of sandstone-slab pestles in the region (see Forrester 1991).

Due mainly to the lack of diagnostic artifacts, the occupations at $41 \mathrm{GR} 383$ cannot be assigned to a regional cultural complex with confidence. However, the occupations are contemporaneous with those of the Palo Duro complex (Cruse 1992; J. Hughes 1991; Willey and Hughes 1978b).

\section{GR484, Grape Creek Bench Site}

The Grape Creek Bench site (41GR484) was an open campsite situated along the edge of a prominent colluvial terrace in the Double Mountain Fork valley at the mouth of Grape Creek. Because it was located in the footprint of the dam, the entire site area has been destroyed by construction activities. In the vicinity of the site, the vertical cutbank was 4-8 $\mathrm{m}$ high and consisted of 1-2 $\mathrm{m}$ of colluvial deposits lying unconformably on top of bedrock (Triassic Dockum Group mudstones). Cultural materials were contained in the upper meter of deposits, and the site covered an estimated area of $50 \times 200 \mathrm{~m}$ at an elevation of $2130-2150 \mathrm{ft} \mathrm{msl}$.

The survey investigation consisted of a surface examination, excavation of a backhoe trench, and the recovery and dating of a charcoal sample from a slab-lined hearth (Feature 1) exposed in the cutbank. A calibrated radiocarbon age of A.D. 1519 (1648) 1953 (see Table 32) indicated that the hearth dates to the Protohistoric period, and bulk carbon sediment dates from below the cultural zone indicate that the colluvial deposits were relatively recent at approximately 1,160 years old at $100 \mathrm{~cm}$ below the surface and 1,830 years old at $150 \mathrm{~cm}$ below the surface (Backhoe Trench 1987-14; see Appendix B). No artifacts were collected during the survey.

Testing investigations consisted of a backhoe trench, surface collection of a $15-\mathrm{x}-15-\mathrm{m}$ area, and excavation of five isolated $1-\mathrm{x}-1-\mathrm{m}$ test units. A rock from Feature 1 was analyzed for organic remains, but no interpretable quantities of residue were found. A second slab-lined hearth (Feature 2) exposed in the cutbank was excavated in Test Unit 4. A total of 65 stone artifacts was recovered, including an untypeable arrow point fragment found on the surface. The site was interpreted as a multi- 
functional campsite consisting of a discrete occupation zone with a relatively low artifact density.

The 1990-1991 data recovery investigations included detailed topographic mapping and excavation of eight dispersed and nine contiguous 1-x-1-m units (Figure 48). The original data recovery plan called for excavation of up to 10 isolated units and an excavation block of 64 units. The excavations revealed that the artifact density was much lower than expected, and it became obvious that an interpretable sample of artifacts would not be recovered without a substantial increase in effort. It was subsequently determined that such an increase was not warranted, and the data recovery work at 41GR484 was terminated with only 14 percent ( 9 units) of the targeted 64-unit excavation block having been completed.

The data recovery excavation block was centered around the radiocarbon-dated hearth. Excavations completely exposed Feature 1 and revealed that it was superimposed directly on top of another slablined hearth, designated as Feature 3 (Figure 49). While substantial charcoal was preserved in Feature 1, none was observed in Feature 3, perhaps indicating that it had been exposed for some time prior to being buried. The differential preservation of charcoal, along with the superimposition, clearly indicates that at least two occupations occurred at 41GR484. Notably, all three features encountered at 41GR484 were large slab-lined hearths ranging in maximum dimension from 70 to $150 \mathrm{~cm}$. Fossil pollen associated with the features was found to be

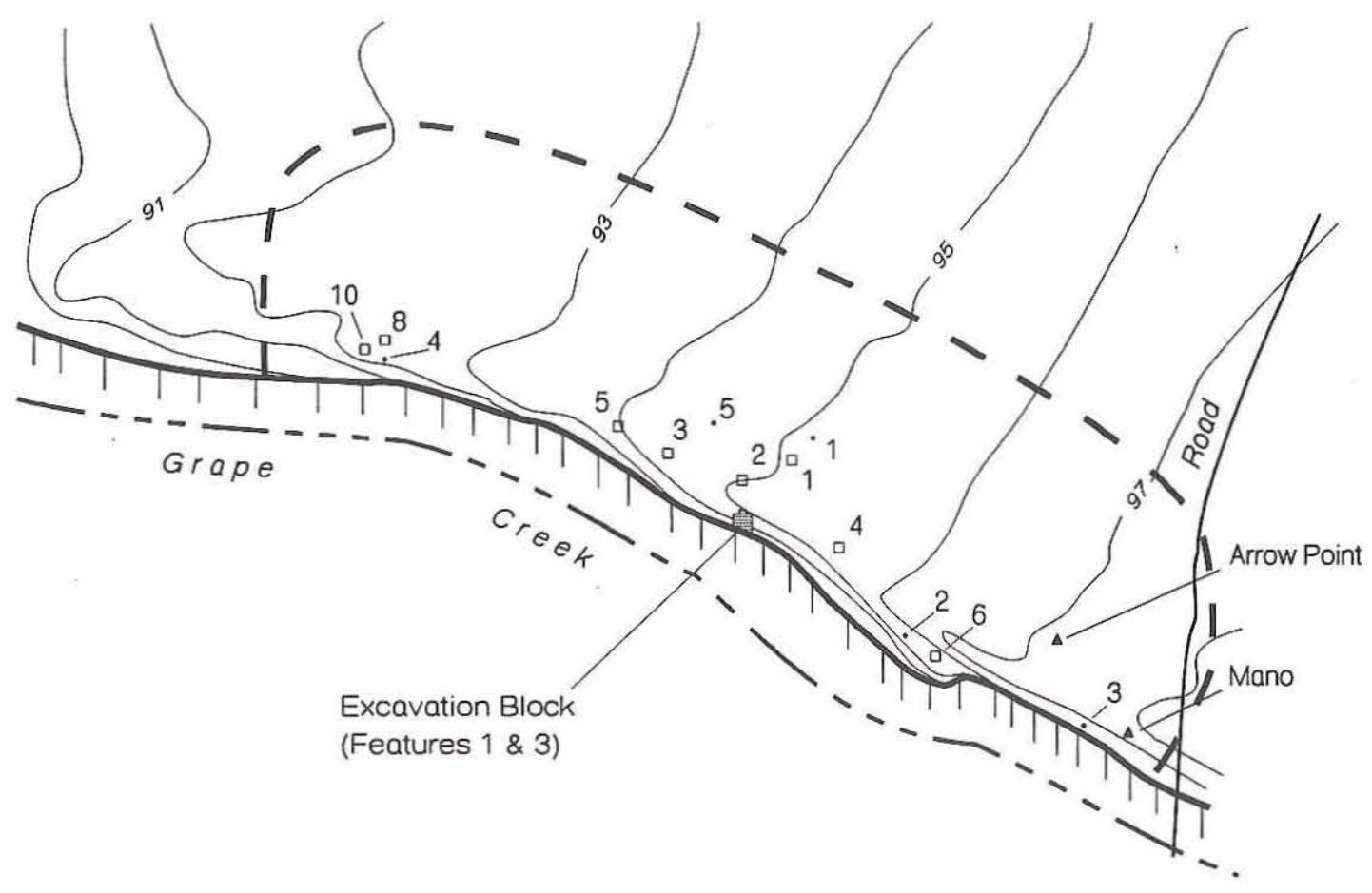

$$
\begin{aligned}
& \text { LE G E N D } \\
& =\text { - Site Boundary } \\
& \text { - Excavation Unit } \\
& \text {. 1988 Test Unit } \\
& \Delta \quad \text { Surface Artifact }
\end{aligned}
$$

PAI/97/SLH
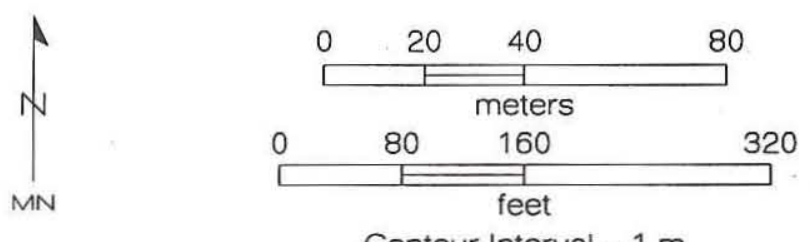

Contour Interval $=1 \mathrm{~m}$

Figure 48. Site map, 41GR484. 


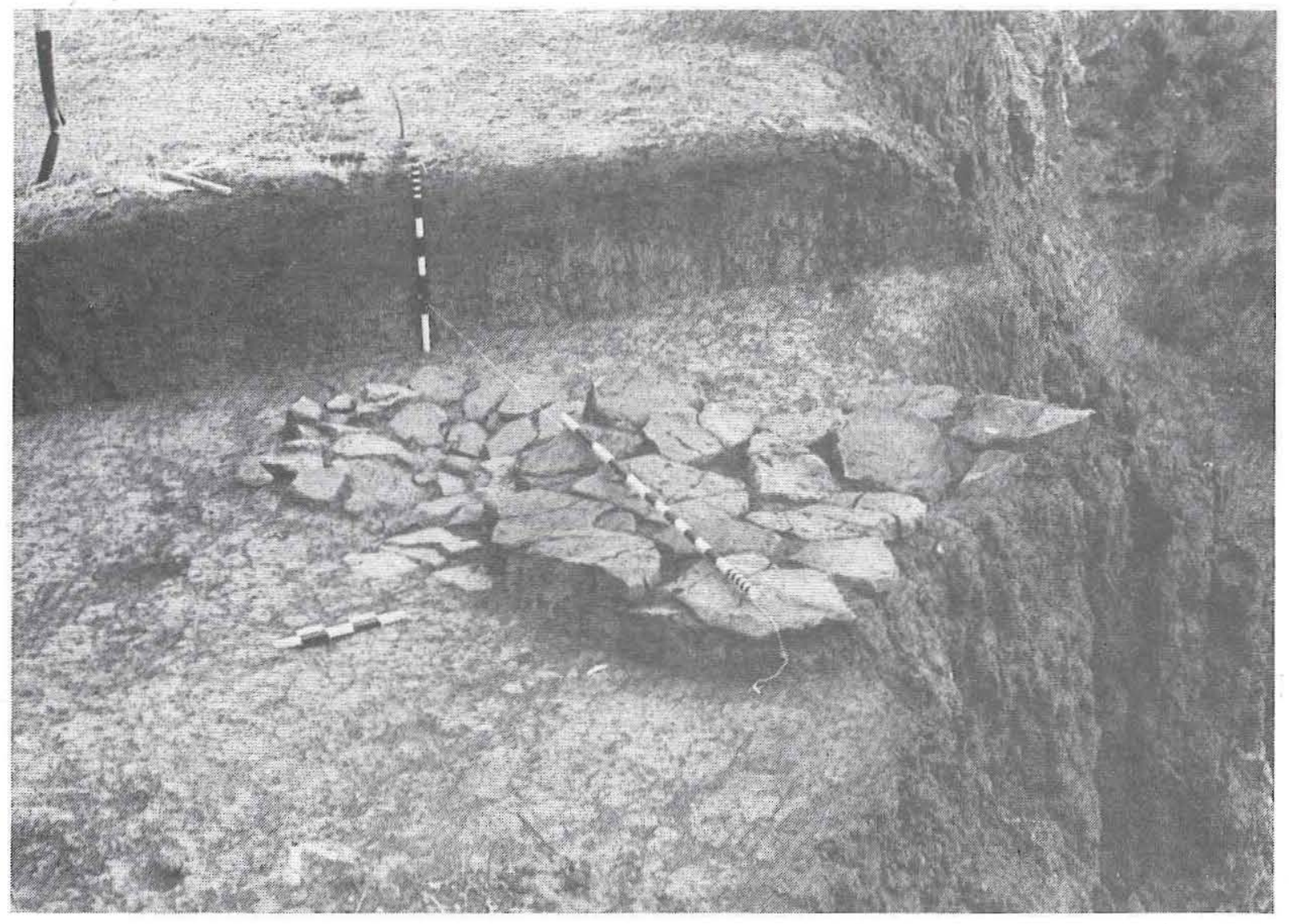

Figure 49. Superimposed hearths (Features 1 and 3) at 41GR484. View is to the southeast with Feature 1 in the foreground along the edge of the Grape Creek cutbank; Feature 3 is immediately to the left of Feature 1. Horizontal scale on Feature 1 is $100 \mathrm{~cm}$; vertical scale is $50 \mathrm{~cm}$.

poorly preserved and uninterpretable, but flotation of sediment from Feature 1 yielded considerable charcoal that was identified as Carya sp. It could be either hickory or pecan, neither of which is found in the area today. Based on the modern distribution of these species, pecan is the more likely candidate.

Data recovery work yielded only 29 artifacts. Of the 94 artifacts recovered from all phases of work (see Table 31 ), only 60 (64 percent) were found in excavated contexts. One of the more unusual aspects of this assemblage is the relatively high frequency of ground stone tools (12.8 percent of the assemblage) and the overall paucity of chipped stone artifacts. The archeological evidence seems to indicate that 41GR484 was a special activity site devoted to processing of plant foods. The cultural zone, found at $20-40 \mathrm{~cm}$ below the surface in the excavation block and at $50-70 \mathrm{~cm}$ below the surface in the vicinity of Test Unit 4 , is interpreted as a relatively discrete single component.
Geomorphological investigations revealed that Grape Creek actively meandered eastward during the last two millennia, and this trend has continued to the present time. An unknown, and perhaps significant, portion of the site was destroyed by the stream's eastward migration during the last 200-300 years. Consequently, it is apparent that the remaining portion of 41GR484 encompassed only the northern margin of a once larger site. A resurvey of a borrow area in the alluvial terrace directly across the creek ( $200 \mathrm{~m}$ southwest) from 41GR484 revealed another shallowly buried site, 41GR606, which is very similar. Initial root plowing of the previously undisturbed borrow area exposed cultural features and artifacts over a $200-\mathrm{x}-200-\mathrm{m}$ area. Although no organic remains suitable for radiocarbon dating or temporally diagnostic artifacts were recovered, the occupations at site 41GR606 are thought to be approximately contemporaneous with those at 41GR484. Geomorphic evidence indicates that the 
alluvium containing the 41GR606 cultural zone was deposited during Grape Creek's eastward migration. A buried soil found below the cultural zone at $100 \mathrm{~cm}$ below the surface (in Backhoe Trench 1987-5) was radiocarbon dated to $1750 \pm 60$ B.P. (see Appendix B). This date confirms that this portion of the terrace was established by ca. A.D. 200 and that the upper meter of deposits, containing 41GR606, slowly aggraded throughout Late Prehistoric times (see Figure 32).

Over 20 large slab-lined hearths were encountered at 41GR606, along with numerous ground stone tools but very few chipped stone tools (Boyd et al. 1993:238). The features and cultural materials are quite similar to those at $41 \mathrm{GR} 484$. It appears that 41GR606 may have been an extension of the same occupations as at 41GR484, and it appears that the mouth of Grape Creek may have been a favorite camping location for Protohistoric peoples while they gathered and processed plant foods. It is not known if the occupants of these sites had horses and/or metal tools, but this is possible since the occupation of 41GR484 (or at least a portion of it) dates to the middle of the seventeenth century. The wide valley is suitable for horses in terms of forage acreage, and the presence of metal tools could be a factor explaining the paucity of chipped stone tools and debitage. Alternatively, chipped stone tools may be rare there because the specialized processing activities did not require their use.

Site 41GR484 cannot be assigned to a regional cultural complex with any degree of confidence, but the Protohistoric occupation(s) is contemporaneous with the Garza Complex (Runkles 1964). This site also is contemporaneous with intensive occupations at two other data recovery sites on Grape Creek: 41KT51 and 41KT53 (described below).

\section{GR546, Boren Shelter No. 1}

Boren Shelter No. 1, 41GR546, is a small rockshelter along the edge of the uppermost sandstone bluff forming the canyon rim of an unnamed drainage, ca. $40 \mathrm{~m}$ north of its confluence with the Double Mountain Fork of the Brazos River. The view from inside the west-facing shelter overlooks the mouth of the drainage and the river channel. Formed by erosion of the friable sandstone immediately below the harder sandstone canyon rim, the shelter area is less than $4 \mathrm{~m}$ deep. Large roof-fall blocks enclose an effective floor area of only $12 \mathrm{~m}^{2}$, and the low ceiling varies in height (above the modern ground surface) from $0.6 \mathrm{~m}$ at the back to $1.8 \mathrm{~m}$ at its dripline.

The unconsolidated fill inside the rockshelter varies from only a few centimeters thick at the edges to over $100 \mathrm{~cm}$ thick at the front center. The fill is a fine sandy loam matrix with abundant gravel-, pebble-, and cobble-sized angular clasts. All of the fill is endogenous and is derived from grainby-grain disintegration and spalling of the sandstone walls and ceiling. The shelter may have formed and begun filling long ago (sediments in nearby Boren Shelter No. 2 had begun to accumulate as much as 2,000 years ago), but a radiocarbon-dated feature indicates that at least the upper $30 \mathrm{~cm}$ of fill accumulated within the last 300 years.

When site 41GR546 was recorded in 1987, lithic debris on the floor and in a shovel test indicated that the shelter had been occupied. Possible smoke-blackening of the ceiling also was observed. A 1-x-1-m test unit was excavated to bedrock (at $70-96 \mathrm{~cm}$ below the surface) in the center of the shelter during the 1988 testing phase. Portions of two basin-shaped, rock-lined hearths, designated as Features 1 and 2, were encountered at $20-35 \mathrm{~cm}$ and $12-40 \mathrm{~cm}$ below the surface, respectively. A radiocarbon assay on a charcoal sample from Feature 1 yielded a calibrated date of A.D. 1430 (1643) 1950 (see Table 32).

The 1992 data recovery investigations consisted of excavating six more $1-x-1-m$ units around the central test unit, essentially removing all of the shelter's deposits (Figure 50). The remaining portions of Features 1 and 2 were exposed, and a third stone-lined hearth (Feature 3) was found at $29-41 \mathrm{~cm}$ below the surface, directly beneath Feature 2.

The sparse lithic debris recovered during the survey and testing phases was reanalyzed during data recovery and discounted as being noncultural. Only two definite artifacts were recovered (see Table 31). One is unifacial scraper of Potter chert, and the other is a broken hammerstone of purple quartzite; both are local materials. Several specimens were identified as manuports (materials that could not occur naturally in the shelter), but these are unmodified and do not appear to have been tools. A few unburned rodent bones and eggshell fragments were found, but these are probably intrusive.

The limited cultural remains at 41 GR5 46 indicate that this small shelter was occupied on at 


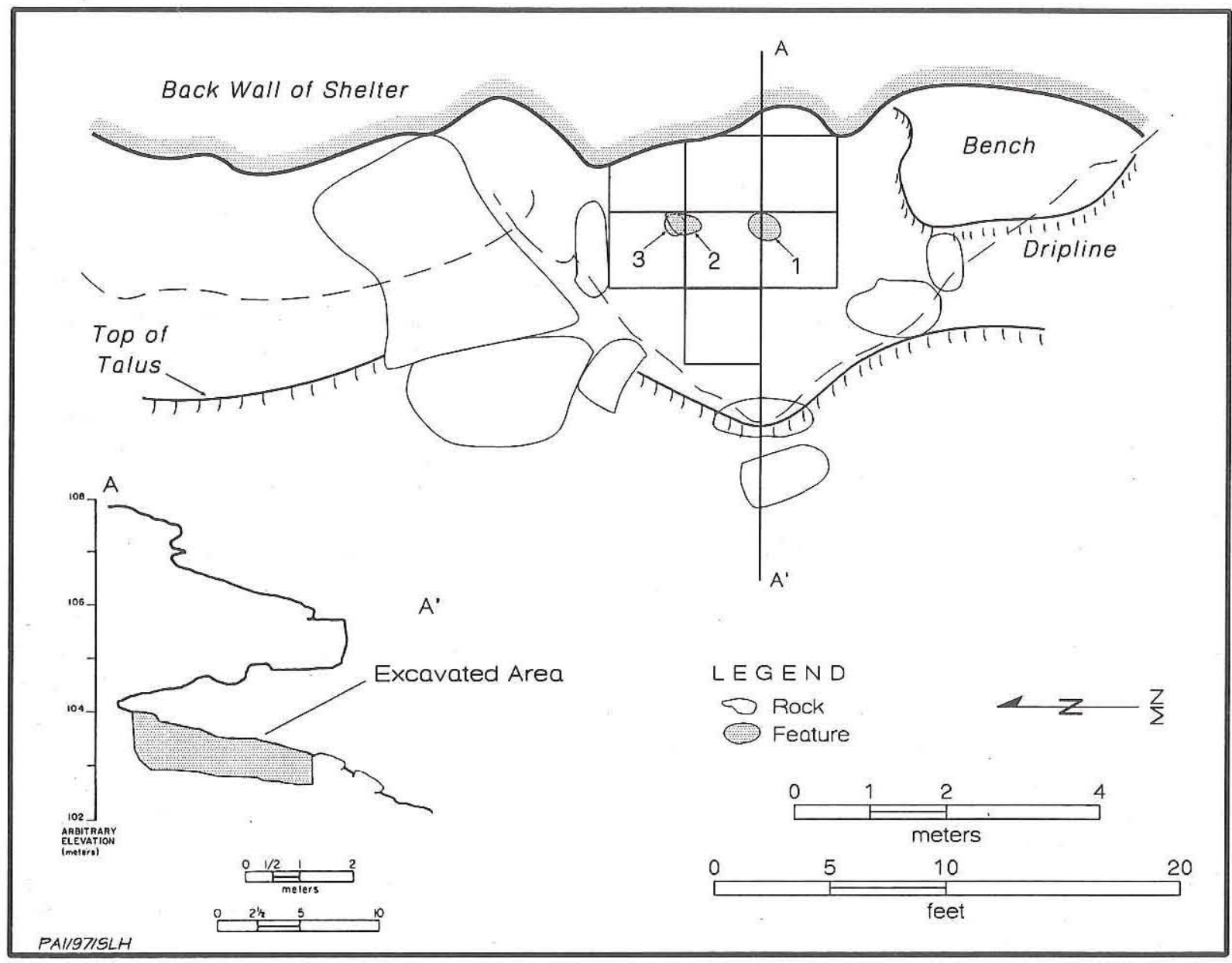

Figure 50. Plan and profile of rockshelter 41GR546.

least two, and possibly three or more, occasions, but each occupation episode was apparently very short. The shelter may have been used as an overnight camp by a single individual or very small group (i.e., no more than three people). The calibrated radiocarbon date indicates that the uppermost hearths were utilized around A.D. 1643 while the lower hearth was used some time earlier. The calibrated radiocarbon date on bison bone from nearby site 41 GR559 (discussed below) indicates that the talus area bone midden was deposited around A.D. 1642, and it is possible that the two shelters were occupied simultaneously and/or that the people who occupied 41 GR546 discarded the butchered animal carcasses found in the talus area at 41GR559.

\section{GR559, Boren Shelter No. 2}

Boren Shelter No. 2, 41GR559, is located $60 \mathrm{~m}$ north of Boren Shelter No. 1 along the uppermost sandstone bluff forming the east canyon rim of an unnamed drainage (Figure 51). The smaller shelter can be seen from 41GR559, which faces south and offers a strategic vantage point overlooking the lower portion of the drainage and a segment of the Double Mountain Fork channel. This shelter was formed in Triassic Dockum Group sandstones by erosion of friable sandstone layers immediately below the hard bluff-forming sandstone and conglomerate ledges. The shelter was once considerably larger, but a collapsed section on the eastern end is now a jumble of large roof-fall rocks. The intact portion of the shelter (Figure 52) has a floor area of ca. $30 \mathrm{~m}^{2}$, and an additional $30-\mathrm{m}^{2}$ talus area in front of the shelter is contained and protected from erosion by a line of boulders $2-5 \mathrm{~m}$ out from the dripline. Beyond the line of boulders, the talus slope drops sharply into the valley. Inside the 


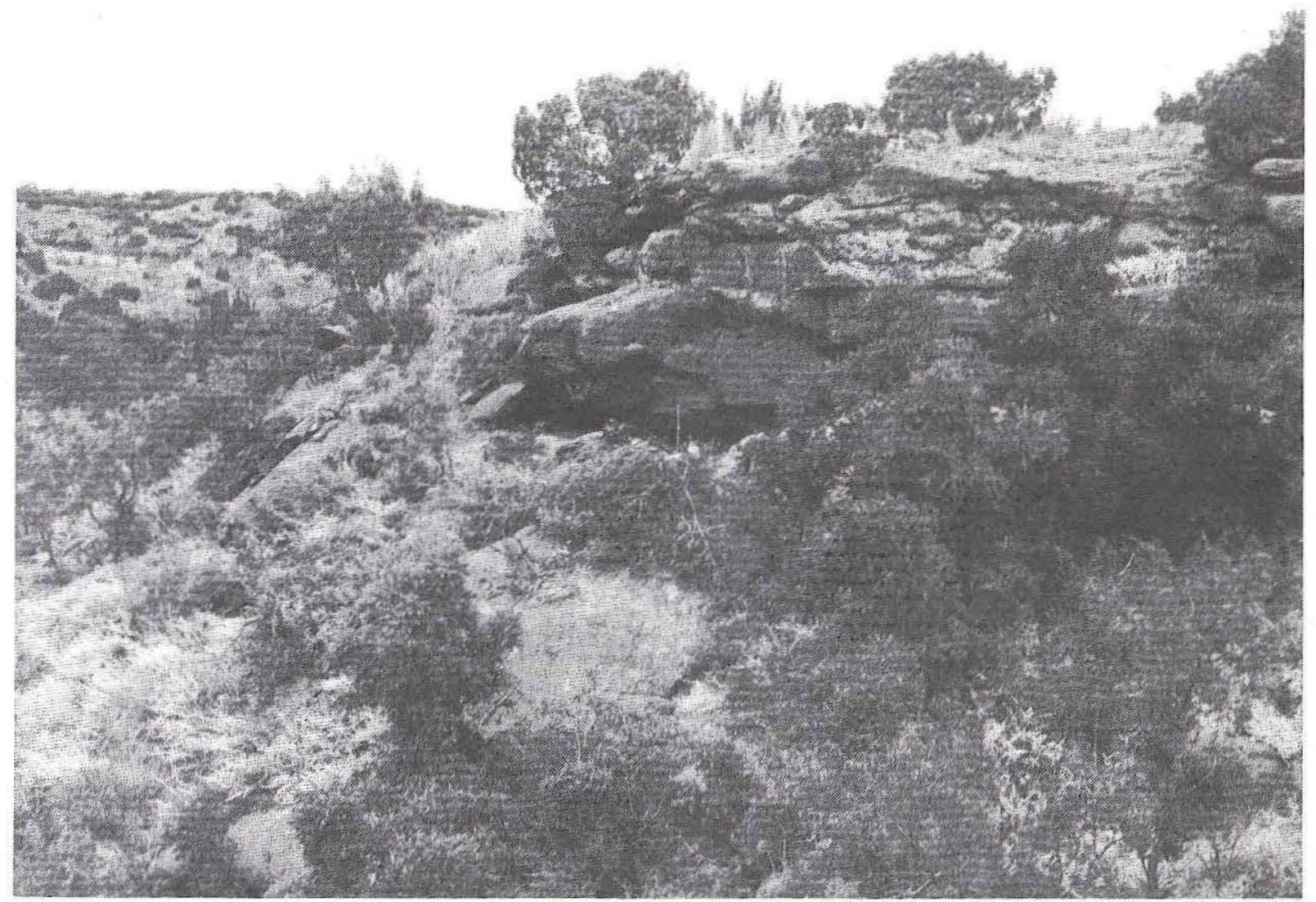

Figure 51. Rockshelter 41GR559. View is to the northwest from the canyon rim just north of $41 \mathrm{GR} 546$.

shelter, the floor is quite level, and the ceiling height (from the modern ground surface) is $0.4 \mathrm{~m}$ at the back wall and varies from $1.5 \mathrm{~m}$ to over $4.0 \mathrm{~m}$ along the dripline.

The sediments inside the shelter vary in thickness due to the undulations of the bedrock substrate and presence of large roof-fall blocks from $40 \mathrm{~cm}$ to over $100 \mathrm{~cm}$. Based on radiocarbon assays from cultural features, sedimentation within the shelter has been ongoing for the last ca. 2,000 years. While there is considerable microstratification, there are only two well-defined stratigraphic zones that can be traced across the shelter (Figure 53). The upper zone is a $20-50-\mathrm{cm}$-thick stratum of reddish brown sediments which dips eastward, and the lower zone is a $30-80-\mathrm{cm}$-thick stratum of light brown sediments immediately overlying weathered bedrock. The stratigraphic break between the two zones is dated to ca. A.D. 1000-1200 based on calibrated radiocarbon assays on two features that occur just above and straddle the contact. Visual and granulo- metric studies of these sediments indicate that they are similar, with both zones dominated by endogenous deposits consisting of fine sandy loam (fine fraction) with sandstone cobbles, pebbles, and gravels (coarse fraction). There are minor differences between these two zones, however, and microscopic examination of the sand fractions indicates that these differences are evidence of a shift in depositional environments. The lower light brown zone is interpreted as representing an endogenous deposit resulting almost entirely from in situ weathering of the ceiling and walls, with a minor colluvial component derived from rainfall washing local materials into the shelter. The upper reddish zone also is dominated by endogenous materials but has a minor exogenous eolian component. A thick upper zone of the same reddish brown sediment also is present throughout the protected talus area in front of the shelter. Although the talus area is $35-60 \mathrm{~cm}$ lower than the shelter floor, the upper reddish brown zone represents a single depositional unit. Rounded 


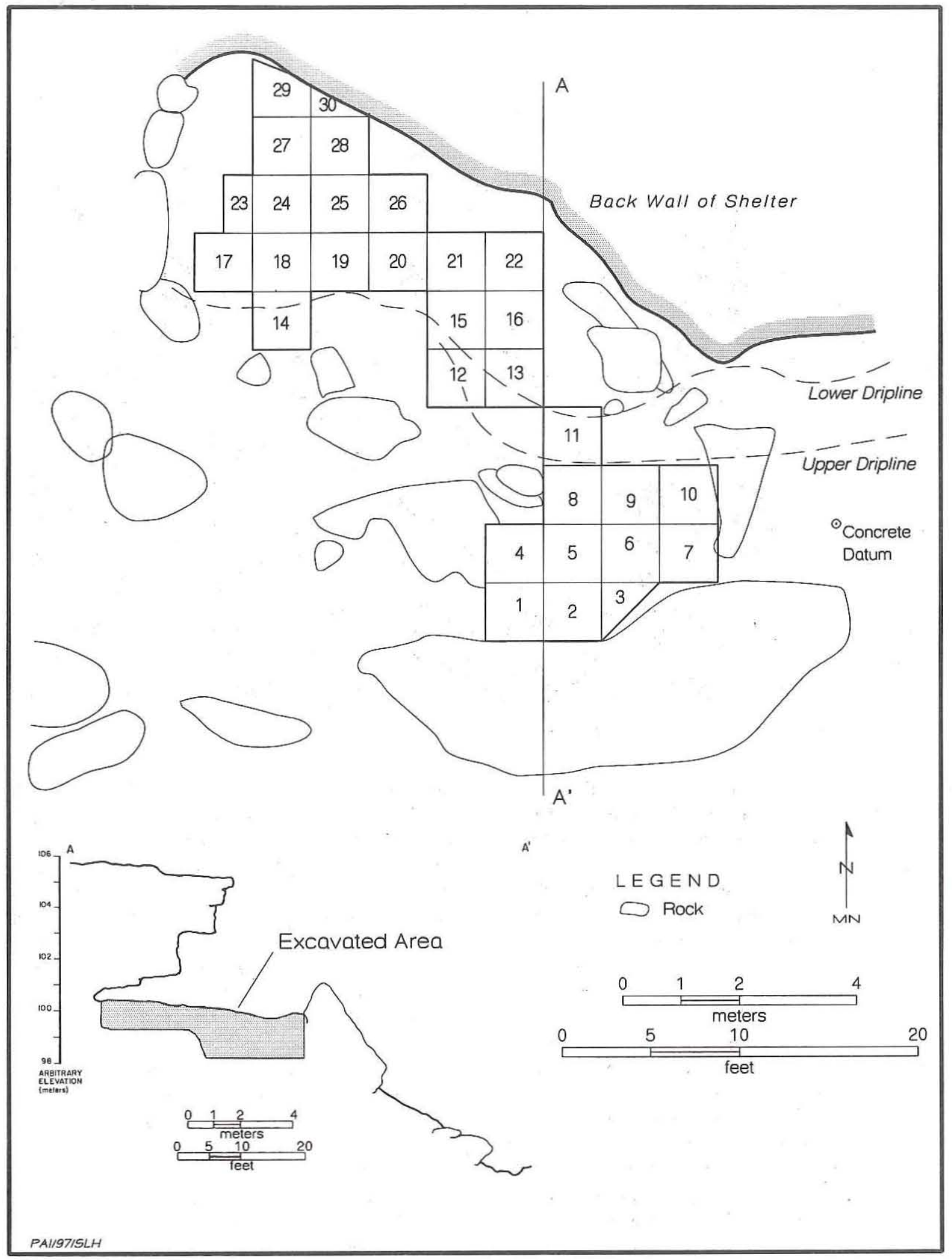

Figure 52. Plan and profile of rockshelter 41GR559. 


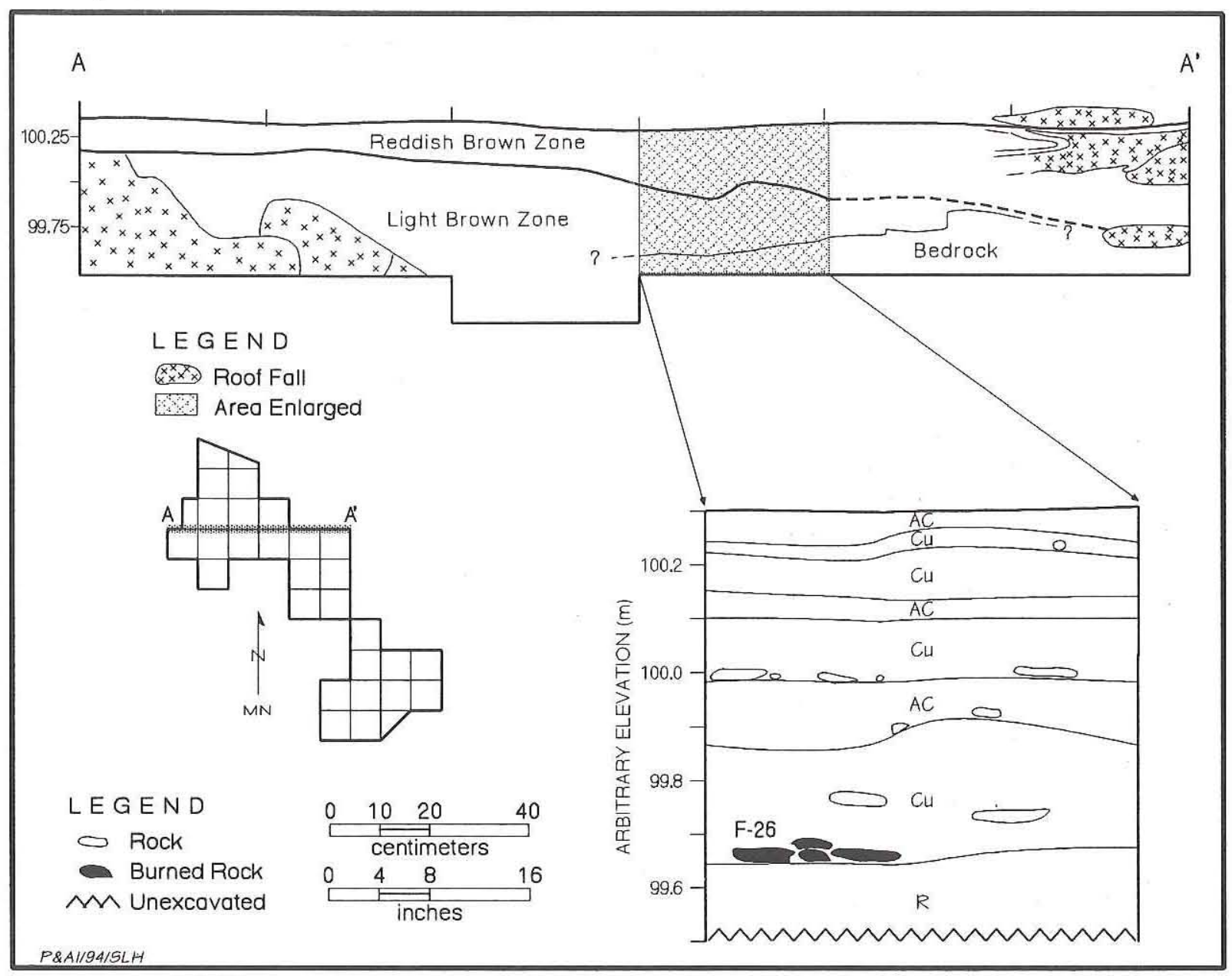

Figure 53. East-west profile of rockshelter fill depicting two sediment zones and detailed profile of Excavation Unit 20, 41 GR559.

fine sand grains indicative of eolian deposition are common in the upper zone inside the shelter and in the talus deposit. The reddish brown hue is attributed to this eolian material, consisting of clays and silts derived from the Triassic redbeds and/or the Blackwater Draw Formation to the west (the latter having been ultimately derived from Permian redbeds in the Pecos Valley according to Holliday 1989b:1606). The prevailing southwesterly winds generally blow directly into Boren Shelter No. 2, which acts as a sediment trap. In contrast, the prevailing winds blow past 41GR546, and no reddish eolian sediments were observed in this small shelter.

The geomorphic evidence indicates that all of the sediments were dominantly derived by endogenous deposition but that colluvial processes were more active during the early period of sedimentation while eolian processes became more prevalent after ca. A.D. 1100. This change in depositional regimes is thought to be related to a shift to increasingly xeric conditions hypothesized to have occurred throughout the Southern Plains and adjacent regions (e.g., Abbott 1990; Ferring 1986; Hall 1982, 1988; Holliday 1985b; Meltzer 1991).

When site 41GR559 was recorded in 1987, no cultural evidence was observed on the surface, but two shovel tests yielded cultural materials from 30 to $75 \mathrm{~cm}$ below the surface. Testing in 1988 included two shovel tests and three 1-x-1-m test units. A shovel test and shovel probing in the eastern collapsed shelter area yielded no cultural evidence. Since some of the roof boulders are apparently lying on bedrock, it is hypothesized that the collapsed section was never occupied or its deposits were scoured out long ago.

All of the subsurface tests in the shelter and 
talus area were positive. Inside the shelter, a bone cluster was encountered at $8-22 \mathrm{~cm}$ below the surface in Test Units 1 and 2 (now EU 16 and 22, respectively), and portions of five burned rock features were encountered at various depths (from $12-83 \mathrm{~cm}$ below the surface) throughout Test Unit 3 (now EU 19). A shovel test in the talus area (in the vicinity of EU 2) recovered numerous bones, mostly canid (possibly a wolf/dog hybrid), including one with cut marks. These remains suggested the presence of a midden.

Data recovery excavations in 1992 removed most of the accessible cultural deposits inside and outside the main shelter (see Figure 52). Twentyseven additional units (mostly 1-x-1-m units, but a few were partial) were excavated to bedrock at depths ranging from 33 to $120 \mathrm{~cm}$, bringing the total number of units at the site to 30 . At the conclusion of data recovery, 196 artifacts had been recovered (see Table 31), and 25 cultural features had been documented (Figure 54). In addition, the preservation of faunal remains was very good, and a substantial bone assemblage was recovered and analyzed in detail by Shaffer (1994). The animal bones from 41GR559 constitute the largest and most interpretable faunal assemblage from the project area.

Site chronology was established by nine radiocarbon dates on cultural features (see Table 32), indicating that the site was occupied or utilized during the Late Prehistoric I, Late Prehistoric II, and Protohistoric periods. Based on radiocarbon dates and the stratigraphic and horizontal distributions of features, the excavated deposits and features, artifacts, and faunal remains were divided into three analysis units representing different time periods - the Lower Shelter, Upper Shelter, and Talus Area (Tables 36-38).

The lower shelter deposits (i.e., the light brown zone) encompass evidence of sporadic ephemeral use of the shelter by small groups of generalized huntergatherers from ca. 2 B.C. to A.D. 1030, while the upper shelter deposits (i.e., the reddish brown zone) encompass evidence of continued sporadic ephemeral occupations from ca. A.D. 1000 to 1300 (Figure 55). Artifacts and cultural features are more numerous in the lower zone, but this appears to be related to the length of time involved rather than a greater intensity of occupation. The lower zone represents ca. 1,000 years of deposition while the upper zone represents ca. 300 years, and the accumulation rates are consistent for both zones at ca. 11-12 artifacts/ century and 1.3-1.6 features/century. Not only does the intensity of occupation appear to have remained stable, but there are only minor differences in artifact and feature types. The lower zone contains ground stones while the upper does not, and the upper zone contains a cobble tool, a biface, and a modified shell while the lower does not. These may reflect minor differences in the activities (e.g., ground stones may indicate more plant processing in the Late Prehistoric I), but the overall similarities suggest that the manner in which this shelter was used and the range of activities that occurred were essentially the same for the Late Prehistoric I and II periods. All but one of the features in the upper and lower zones appear to be related to heating and/or cooking. A bone midden in the upper zone may hint at refuse disposal inside the shelter in Late Prehistoric II times, or since this would have been one of the latest activities at the site, it is possible that it represents an extension of the Protohistoric talus area bone midden.

Temporally diagnostic artifacts inside the shelter are limited to three specimens. A Scallorn-like arrow point (missing its base) is definitely associated with the lower zone while a side-notched Washita is definitely associated with the upper zone. A heavily reworked Ellis dart point is associated with the upper zone and apparently represents scavenging and reuse of earlier materials.

The talus area deposits include a hearth dump at the bottom and scattered bones throughout, but they are dominated by six bone clusters grouped into two different areas (see Figure 54). Refits between these two areas indicate that the deposits occurred simultaneously, and the entire talus area is interpreted as a single bone midden that was probably deposited quickly. All of the bone clusters were found in reddish brown sediments that are equivalent to the upper zone inside the shelter. The bone midden is dated to ca. A.D. 1506-1663 (calibrated; see Table 32) and most likely represents a Protohistoric use episode. It is not certain how the hearth dump is related, but it must have been deposited only a short time before the bone dump. Direct evidence of human activity in the talus area is limited to the hearth, 16 artifacts (including 5 hammerstones), and 23 occurrences of spiral fractures and/or burning on bones. An untyped arrow point fragment was the only diagnostic artifact recovered from the talus area.

The talus area bone assemblage is interpreted as 


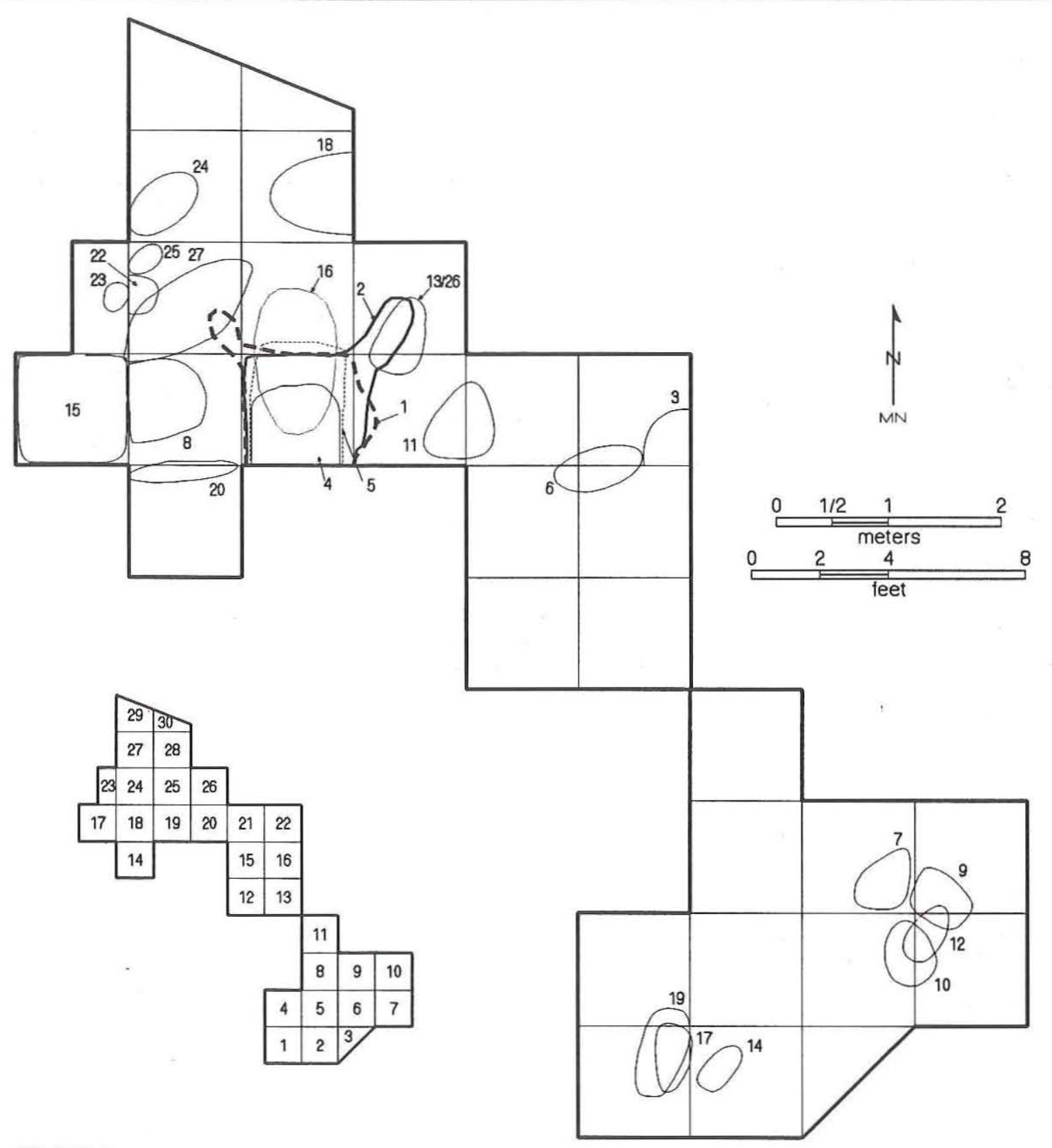

P\&AI/94/SLH

Figure 54. Plan of cultural features, 41GR559.

a cultural dump and is notable for several reasons. The assemblage is diverse (i.e., over 20 different taxa are represented), but it is dominated by various species of carnivores (i.e., wolf, fox, unidentified canids, and bobcat). The assemblage is unusual in that only selected body parts of the larger mammals seem to be represented. For example, eight or nine wolves and unidentified canids, a fox, and a bobcat are represented almost exclusively by skulls, cranial or mandibular fragments and teeth, and/or limb bones; bison is represented only by the lower back legs of a single individual. The near-absence of ribs, scapulae, and sacrae of these animals indicates that the high-meat-yield portions (i.e., shoulders, hump, spinal column, and rib cage) are missing. Also represented in the talus area bone assemblage 
TABLE 36

FEATURES FROM ALL PHASES OF WORK AT 41GR559

\begin{tabular}{|l|c|c|c|c|}
\hline \multirow{2}{*}{ Feature Type } & \multicolumn{3}{|c|}{ Feature Nos. } & \multirow{2}{*}{ Total No. of Features } \\
\cline { 2 - 4 } & Lower Shelter & Upper Shelter & Talus Area & 2 \\
\hline Unlined hearth & 16,24 & & & 7 \\
Stone-lined hearth & $8,13 / 26,22,25$ & $3,27,18$ & & 5 \\
Disaggregated hearth & $2,4,5,11$ & 1 & & 1 \\
Burned rock concentration & 15 & & & 2 \\
Hearth dump & 23 & & $7,9,10,12,14,17$ & 7 \\
Wind deflector & 20 & 6 & 7 & 25 \\
Bone cluster & 13 & 5 & & 1 \\
\hline Total No. of Features & & & \\
\hline
\end{tabular}

\begin{tabular}{|l|c|c|c|c|}
\hline \multicolumn{5}{|c|}{ TABLE 37} \\
\hline Artifact Type & Lower Shelter & Upper Shelter & Talus Area & Totals \\
\hline Unifaces & 5 & 1 & - & 6 \\
Hammerstones & 3 & 2 & 5 & 10 \\
Ground stones & - & 3 & - & 3 \\
Cores & 11 & 3 & 3 & 17 \\
Edge-modified flakes & 5 & - & - & 7 \\
Cobble tool & 1 & - & - & 1 \\
Biface & 1 & 2 & 1 & 4 \\
Projectile points & 1 & - & 7 & 119 \\
Unmodified debitage & 88 & - & - & 1 \\
Modified (?) shell & 1 & $37(22 \%)$ & $16(9 \%)$ & $169(100 \%)$ \\
\hline Totals: & $116(69 \%)$ & & & \\
\hline
\end{tabular}

are other animals that may have been food resources - rabbits, rodents, mink, and skunk.

There is no evidence of gnawing on any of the bones, thus eliminating the possibility that the bones were deposited by carnivores. Given the presence of a few artifacts, minimal evidence of human modification, the diversity of the taxa, and the skewed nature of the large mammal body parts represented, the faunal assemblage in the talus area must be interpreted as a bone dump of human origin (i.e., they represent the discarded remains of butchered animals). Almost all of the animals in the talus area bone midden are fur-bearing mammals, and they might have been hunted for their pelts as well as for food. It is possible that the shelter was occupied at the time the bone midden was deposited but there is no definitive evidence for this. Alternatively, it is possible that the shelter was utilized only as a kill/ butchering locality and was not occupied at the time the bone midden accumulated. Notably, nearby Boren Shelter No. 1 (described earlier) apparently was occupied contemporaneous with the deposition of the 41 GR559 bone midden, and the two could be related.

\section{KT33, South Sage Creek Site}

Site $41 \mathrm{KT} 33$ is an open campsite located on an 


\begin{tabular}{|c|c|c|c|}
\hline \multicolumn{4}{|c|}{$\begin{array}{c}\text { VERTEBRATE FAUNAL REMAINS FROM ALL PHASES } \\
\text { OF WORK AT } 41 \text { GR559 }\end{array}$} \\
\hline Taxon & Lower Shelter & Upper Shelter & Talus Area \\
\hline Vertebrata & 243 & 89 & 402 \\
\hline Anura & 1 & - & - \\
\hline Lacertilia & - & 1 & - \\
\hline Serpentes & 1 & 1 & - \\
\hline Colubridae & 1 & 2 & 4 \\
\hline Aves & 2 & - & 6 \\
\hline Emberizidae & - & 1 & - \\
\hline Mammalia & 71 & 45 & 1,782 \\
\hline Leporidae & 8 & 2 & 12 \\
\hline Lepus sp. & 1 & 1 & 6 \\
\hline Sylvilagus sp. & 25 & 14 & 9 \\
\hline cf. Sylvilagus sp. & 2 & 1 & - \\
\hline Rodentia & 103 & 65 & 10 \\
\hline Sciuridae & 1 & - & 1 \\
\hline Geomyidae & 1 & 3 & - \\
\hline Cricetidae & 1 & 2 & - \\
\hline cf. Liomys irroratus & 2 & - & - \\
\hline Perognathus sp. & - & - & 3 \\
\hline Dipodomys sp. & - & - & 1 \\
\hline Peromyscus sp. & - & - & 2 \\
\hline Sigmodon sp. & - & 4 & 16 \\
\hline Neotoma sp. & 14 & 19 & 38 \\
\hline cf. Neotoma sp. & - & - & 1 \\
\hline Carnivora & - & 1 & 49 \\
\hline cf. Mustela vison & - & - & 1 \\
\hline cf. Mephitis mephitis & - & - & 12 \\
\hline Canidae & 1 & - & 22 \\
\hline cf. Canidae & - & - & 15 \\
\hline Vulpes sp. & - & - & 7 \\
\hline Canis sp. & 4 & - & 275 \\
\hline cf. Canis sp. & - & - & 60 \\
\hline cf. Canis lupus & - & - & 241 \\
\hline Felis rufus & - & - & 68 \\
\hline cf. Felis rufus & - & - & 10 \\
\hline Odocoileus sp. & - & 15 & - \\
\hline cf. Odocoileus sp. & - & 9 & - \\
\hline Bison bison & - & - & 10 \\
\hline Bos/Bison & - & - & 1 \\
\hline Totals: & 482 & 275 & 3,064 \\
\hline
\end{tabular}

alluvial/colluvial terrace at the confluence of South Sage Creek and the Double Mountain Fork of the Brazos River. It is situated $400 \mathrm{~m}$ south of the river on an elevated terrace that forms a broad ridge between the river and the creek (Figure 56). The terrace surface is relatively flat but slopes gently to the northeast, dropping off sharply into the river floodplain on the north and gradually sloping down to South Sage Creek on the east. The site covers an area $240 \mathrm{~m}$ north-south by $380 \mathrm{~m}$ east-west at an elevation of $2150-2170 \mathrm{ft}$ msl.

Abbott (1990:44-51) identified this geomorphic feature, perched $12-15 \mathrm{~m}$ above the active floodplain, as a remnant of an "older terrace" of the 


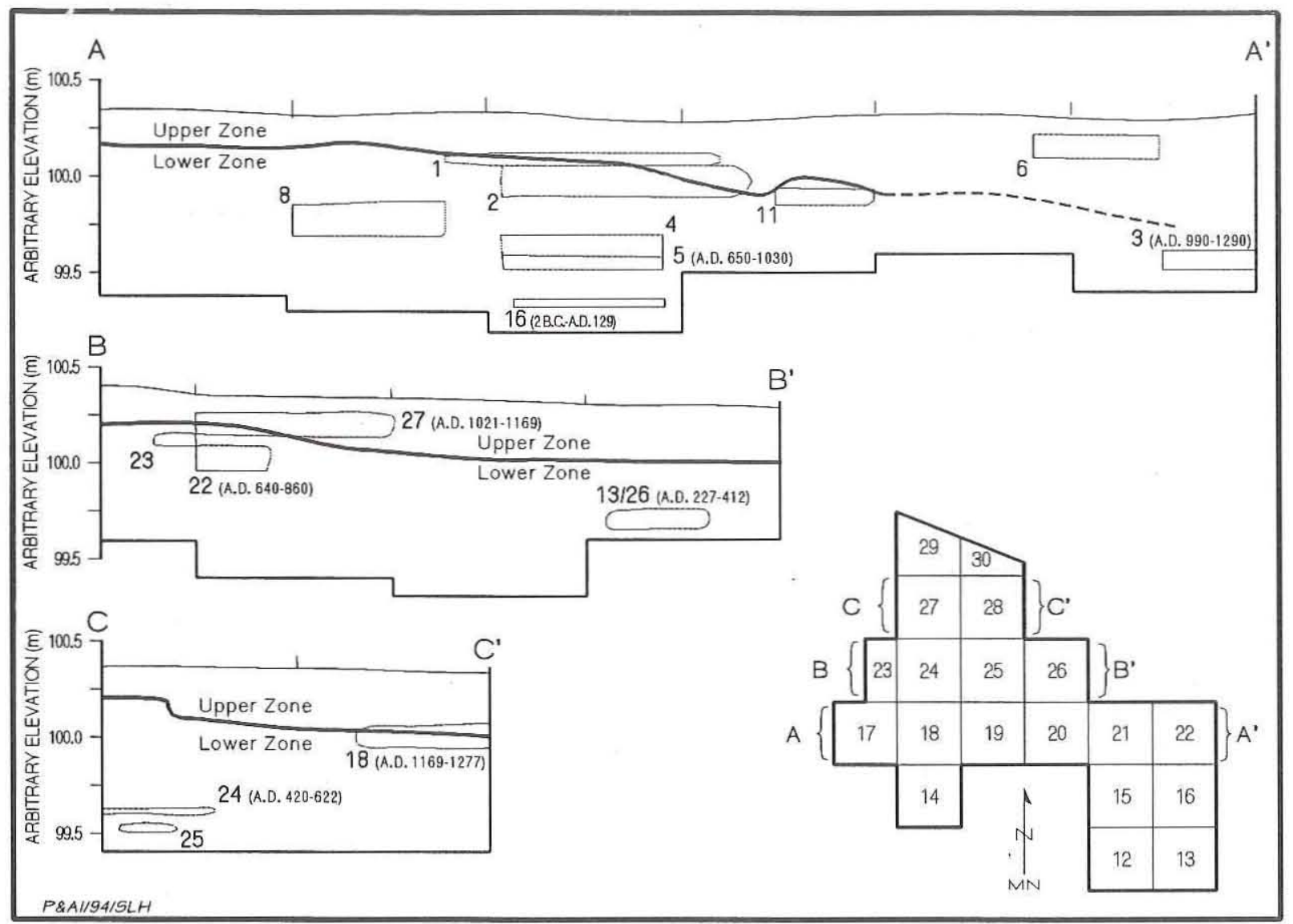

Figure 55. Collapsed east-west profiles indicating the stratigraphic positions of features and corresponding calibrated radiocarbon date ranges inside rockshelter 41 GR559.

Double Mountain Fork. This older terrace was further defined by Bousman (1992:138-140), who confirmed that it is an extensive alluvial terrace capped by a thin layer of colluvial deposits (with a minor eolian component). Bedrock remnants immediately upstream from the site apparently protected portions of this terrace from being destroyed by erosion. The terrace is best preserved close to the valley wall (i.e., south of the site in the vicinity of Backhoe Trench 1991-2), where deposits were radiocarbon dated to $8690 \pm 305$ B.P. (see Appendix B). This represents a minimum age for the terrace, which was beveled by erosion during the middle Holocene ca. 3,500 years ago and subsequently covered over with colluvial/eolian deposits.

In the vicinity of the excavation block (Backhoe Trench 1991-1), the deposits consist of $265 \mathrm{~cm}$ of unconsolidated sediments resting unconformably on bedrock. The upper $25-35 \mathrm{~cm}$ is a thin veneer of colluvial/eolian deposits, overlying ca. $230 \mathrm{~cm}$ of the truncated alluvial terrace. The upper colluvial/ eolian deposit has been pedogenically altered to form a weak A horizon and is radiocarbon dated to ca. 1000 B.P. (Bousman 1992:Figure 46). The cultural zone at $41 \mathrm{KT} 33$ is contained within the younger colluvial/eolian deposits.

The 1987 survey encountered numerous burned rocks, chipped and ground stone tools, and debitage scattered over this extensive site. Two ranch roads, one abandoned and one in use, cut north-south across the central and eastern portions of the site and, along with shovel testing, provided evidence of buried cultural deposits and partially exposed at least four burned rock features. No temporally diagnostic artifacts were found, but eight stone artifacts were collected.

Three backhoe trenches excavated during the 1988 testing phase provided additional exposures of the buried cultural zone. In addition, all surface artifacts were collected from a 10-m-diameter sample 


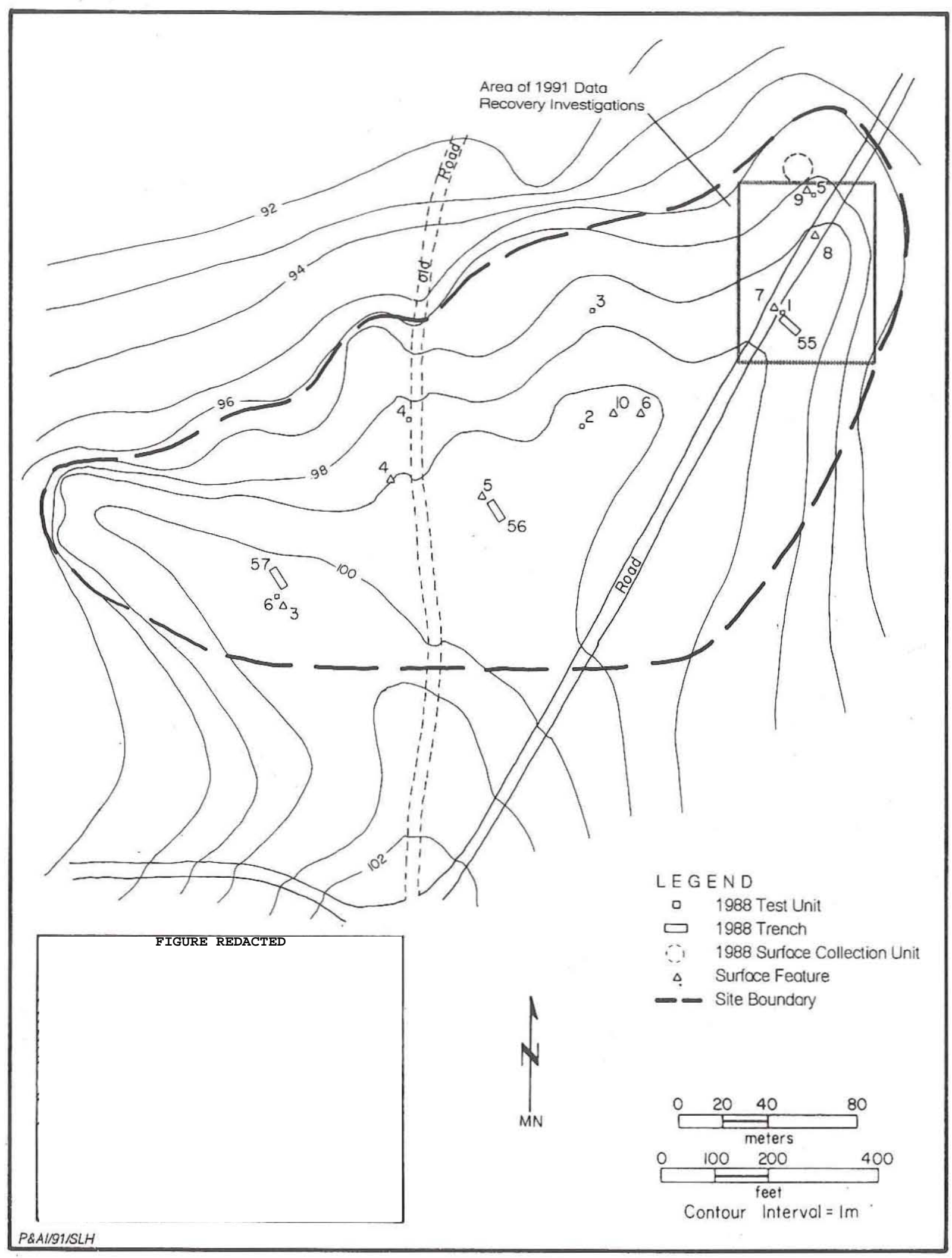

Figure 56. Site map, 41KT33. 
area, and six test units (four $1 \times 1 \mathrm{~m}$, one $1 \times 1.5 \mathrm{~m}$, and one $1 \times 2 \mathrm{~m}$ ) were excavated in various parts of the site. Ten clusters of burned rocks (Features 1-10) were recorded, and two of these were tested: Feature 1 in Test Unit 4 and Feature 2 in Test Unit 6. Most of these features were clusters of burned sandstone, but Feature 1 proved to be a $100-\mathrm{x}-120-\mathrm{cm}$ pile of fire-cracked Potter chert, limestone, and quartzite, along with some burned sandstone. It was interpreted as a burned rock dump, perhaps representing residue cleaned out of a roasting pit. Feature 2 turned out to be a $60-\mathrm{x}-80-\mathrm{cm}$ cluster of burned sandstone and was interpreted as a slab-lined hearth. No charcoal was recovered from these features; a thermoluminescence date on a Feature 2 burned rock was obtained, but it is considered to be erroneous (see Appendix B). Testing recovered 220 lithic artifacts, including two untyped expanding-stem dart points and a very large, complete oval basin metate (sandstone). At the conclusion of the testing, site $41 \mathrm{KT} 33$ was thought to represent a singlecomponent site, probably Late Archaic in age.

Data recovery in 1991 targeted the eastern portion of the site where the most discrete buried deposits were found. The investigations consisted of detailed mapping of the eastern area and excavation of seven 1-x-1-m random sample units, sixty-two $1-\mathrm{x}-1-\mathrm{m}$ contiguous units, and one backhoe trench (1991-1) adjacent to the excavation block (Figure 57). Two additional features were exposed, and 2,112 additional artifacts were recovered, bringing the total number of features to 12 and the total number of artifacts from all phases of work to 2,340 (see Table 31). Two backhoe trenches (1991-2 and 1991-2b) were excavated south of the site to confirm that the truncated soil underlying the cultural zone was a remnant of the older terrace.

The random sample units were excavated with two goals in mind. The first was to initiate a systematic sampling program, as suggested by the Advisory Council on Historic Preservation (ACHP), on a trial basis to assess the interpretive utility of this strategy. The second goal was to define further the buried archeological deposits in the eastern portion of the site to select the best location for the excavation block. The ACHP felt that a systematic unaligned (i.e., random) sampling program would reveal more activities and site structure than would be evident in the block excavation alone. This method has been utilized successfully for sampling complex sedentary village sites in the Southwest, such as in the Dolores Archeological Program in Colorado (Kane and Robinson 1988), but its usefulness for investigating pre-village Plains open campsites had not been demonstrated. The eastern portion of site $41 \mathrm{KT} 33$ was identified as the sample universe and was divided into 18 sample blocks, each being $15 \times 15 \mathrm{~m}$ and containing two hundred twenty-five 1-x-1-m units. Within each block, a randomly generated number indicated which $1-x-1-m$ sample unit was selected for excavation. After seven of the random sample units had been completed, sufficient data were available to select an excavation block area. The block excavations began before continuing with the random sample units. However, as the block progressed, ceramics and arrow points but no dart points were recovered, and it soon became apparent that the site might consist of at least two components (i.e., Late Archaic and Late Prehistoric). Because of the probability of multiple components and the distances between the block and the random sample units, it was uncertain how the sample units related to the block. The absence of well-defined natural or cultural stratigraphy made it impossible to determine if the random sample artifacts belonged to the same occupation, component, or even gross time period as the block artifacts. Because multiple overlapping and interfingering occupations and/or components apparently existed, it was not clear exactly what was being sampled. Consequently, the random sample program was terminated with only 7 of the projected 18 sample units having been completed (see Boyd et al. [1992:97-100] for a more complete discussion of the random sample program).

The main excavation block was expanded until 62 units had been excavated to depths ranging from 33 to $66 \mathrm{~cm}$ below the surface. A rather discrete cultural zone was encountered at $10-30 \mathrm{~cm}$ below the surface across the entire block. The ca. $20-\mathrm{cm}-$ thick cultural zone was deposited over an unknown, but presumably limited, span of time. Multiple occupations may have occurred, but the deposit was interpreted as representing a single component. The two features exposed in the excavation block, Features 11 and 12, consist mainly of burned sandstone slabs and appear to be a small $(30 \times 35 \mathrm{~cm})$ displaced hearth and a larger $(120 \times 160 \mathrm{~cm})$ partially disturbed circular hearth, respectively. Fossil pollen from these features was poorly preserved and uninterpretable, and flotation of feature sediments yielded no identifiable plant remains. A 


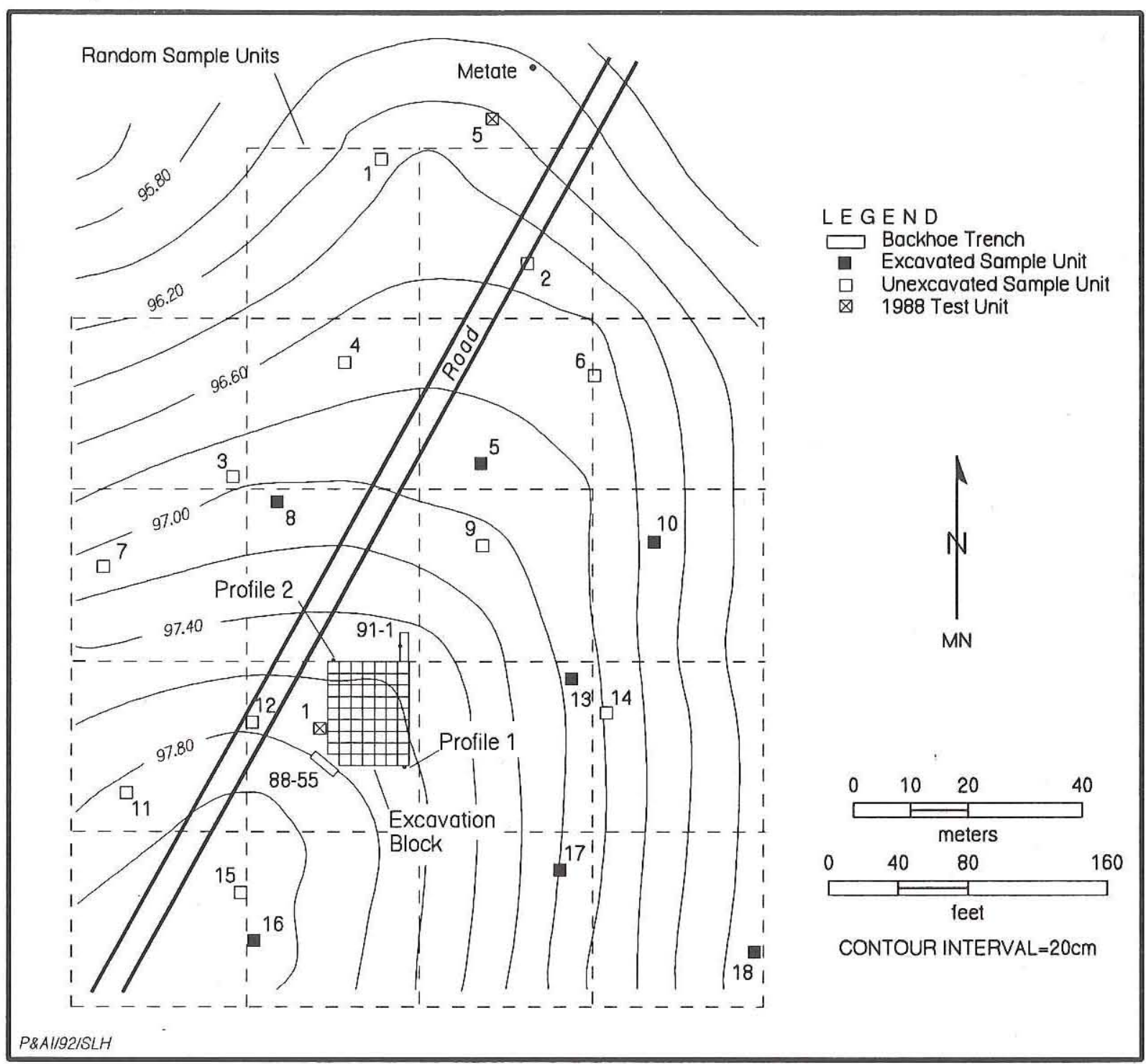

Figure 57. Detailed map of the eastern portion of site $41 \mathrm{KT} 33$ showing locations of random sample units and all excavations.

radiocarbon assay on charcoal from Feature 12 yielded a calibrated date of A.D. 898 (1017) 1160 (see Table 32).

The artifacts recovered from all phases of work (see Table 31) indicate a definite Late Prehistoric component and a possible Late Archaic component. However, all of the excavation block materials appear to be consistent with a Late Prehistoric I (or transitional Late Prehistoric I/II) occupation, as indicated by the radiocarbon date on Feature 12. The block assemblage includes 10 arrow points: 3 corner-notched Scallorns; 1 side- and basal-notched Harrell; 1 unnotched triangular specimen, cf.
Granbury; and 5 untyped fragments. Six sherds of undecorated brownware were visually identified as some variant of Jornada Brown, perhaps Jelinek's (1967) Middle Pecos Micaceous Brown. Petrographic analysis confirmed that these sherds are tempered with crushed volcanic rock and are nonlocal in origin.

Vertebrate faunal remains were poorly preserved, but freshwater mussel shell fragments were common in the excavation block. The total amount of shell material was quite small (ca. $117 \mathrm{~g}$ ), however, suggesting that mussels were not an important source of food. Two modified pieces of shell (one 
with a serrated edge and one bivalve with a hole drilled through it) indicate that musseis may have been important as a source of material for manufacturing shell ornaments.

The chipped stone artifacts and debitage represent all stages of lithic reduction and manufacture and use of a variety of unifacial and bifacial tools. The relatively high frequency of edge-modified flakes suggests an emphasis on expedient tools. Ground stones also are relatively common, and many broken specimens were recycled as hearthstones. Due to the limited size of the excavation block and the potential for overlapping multiple occupations, interpretations of intrasite structure and activity pattering were extremely limited.

Site $41 \mathrm{KT} 33$ is interpreted as a multifunctional campsite for a hunter-forager group, but most of the evidence suggests that plant processing was of primary importance. This site has many characteristics that are reminiscent of the early occupation period at 41GR291 (discussed above). The overall composition of the artifact assemblages is quite similar, and, in particular, the arrow point styles and nonlocal Jornada Mogollon ceramics suggest that the occupations may be related. The ground stone assemblages are noteworthy for their similarities as well. Although it was not recovered from the excavation block, the oval-basin metate surface collected from the surface is similar to those at 41GR291, and these large metates were not recovered from any other sites in the project area. Considerable reuse of ground stone fragments as hearthstones also was observed at both sites. The excavation block assemblage at $41 \mathrm{KT} 33$ is thought to be roughly contemporaneous with the occupation of the pithouse at 41GR291 at around A.D. 1000. The South Sage Creek site is interpreted as a Palo Duro complex component, and the possibility that this site could encompass similar pithouses is discussed in Chapter 10.

\section{KT51, Headstream Site}

Site 41KT51 is situated on an alluvial terrace on the east side of Grape Creek, ca. $2.1 \mathrm{~km}$ upstream from its confluence with the Double Mountain Fork (Figure 58). It occupies a slight rise formed by a natural levee adjacent to the creek channel, opposite a point bar in a prominent meander bend. The natural levee is the major topographic feature on an otherwise featureless alluvial terrace. The site covers the entire $160-\mathrm{x}-40-\mathrm{m}$ rise, oriented northeast-southwest. An unimproved ranch road across the long axis of the rise exposes some cultural materials and is the only disturbance to the site. An artificial levee has been constructed at the southern end of the natural levee, but no cultural deposits appear to have been disturbed.

The site sediments consist of a series of levee and crevasse splay deposits representing increments of sediment that were built up over time through successive flood events. Pedogenic structures, common throughout the levee deposits, provide evidence of stable interflood periods. Although the levee deposits are over $2 \mathrm{~m}$ thick in places, all of the cultural materials are contained within the upper $50 \mathrm{~cm}$. Except for a weakly developed soil on the surface of the levee, there is no natural or cultural stratification in the upper $50 \mathrm{~cm}$. The lack of stratigraphy in the cultural zone is due in part to compaction, oxidation, and leaching associated with repeated wetting/drying, but it also indicates continual deposition during the time that the site was occupied.

Geomorphic evidence indicates that Grape Creek was actively downcutting around 1000 B.P., and Kibler (in Boyd et al. 1993:44-46) suggests that channel entrenchment was a response to a drop in local water tables, decreasing vegetation cover, and increasing slopewash, all of which were ultimately caused by a climatic shift toward more-xeric conditions. Downcutting began around $980 \pm 60$ B.P., as indicated by a radiocarbon age on a buried soil at the base of the levee deposit (Backhoe Trench 19915; see Appendix B), and floodplain and levee building began soon after the channel incision. Additional radiocarbon dates indicate that these same fluvial processes were still active some 200-300 years ago, and they have continued to the present time.

Sparse cultural materials were observed in the road during the 1987 survey, and a single shovel test indicated the presence of buried cultural materials (three unmodified flakes were collected). The 1988 testing investigations included a surface collection and the excavation of one backhoe trench and three 1-x-1-m units. Cultural materials were encountered in the fill of the backhoe trench and at $0-40 \mathrm{~cm}$ below the surface in all three test units. The 83 artifacts recovered consisted of 5 stone tools, 65 unmodified flakes, and 13 ceramic sherds. Among the latter, three ceramic types were identified as 


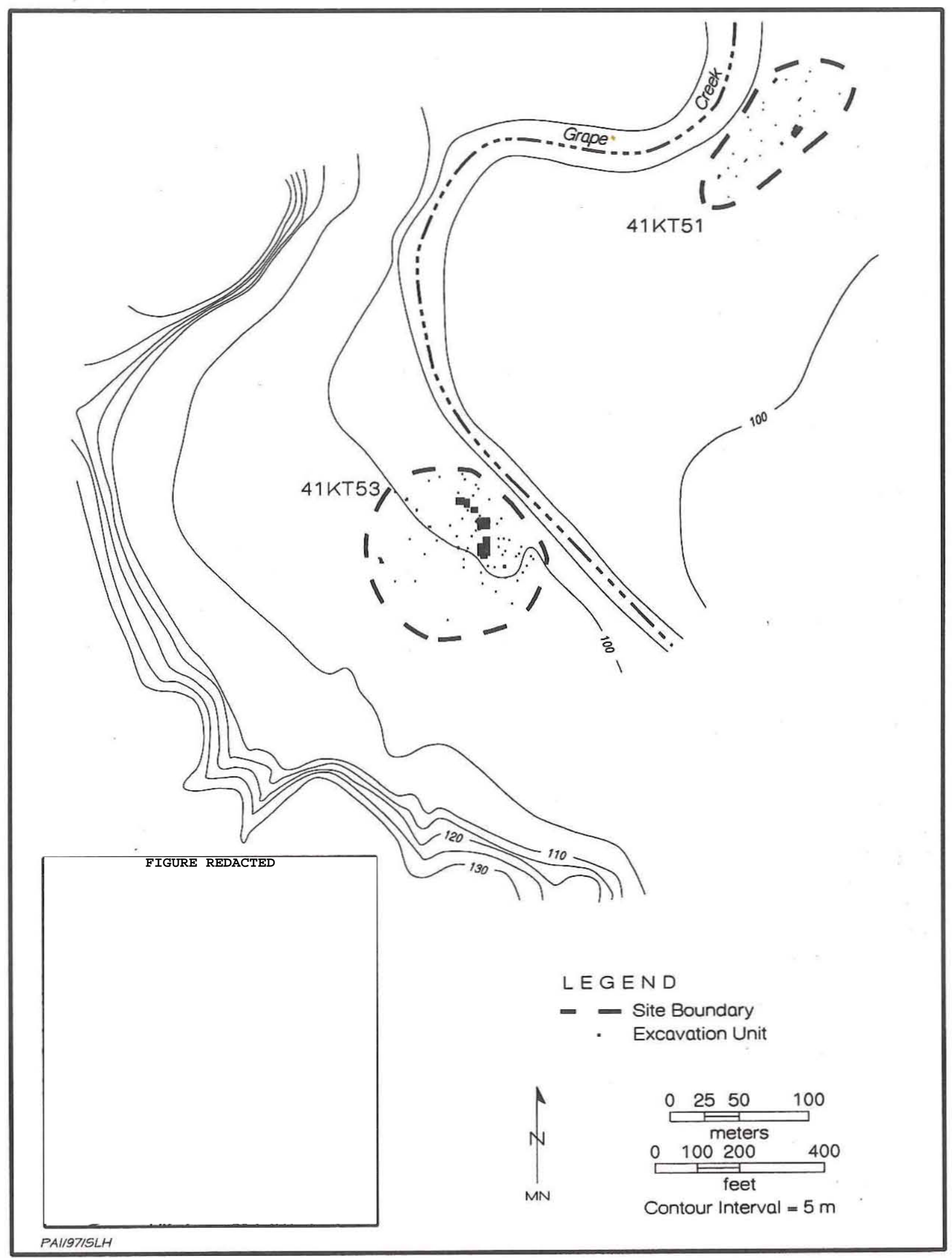

Figure 58. Topographic map of the Grape Creek valley showing the locations of 41KT51 and $41 \mathrm{KT} 53$. 
Pecos Glaze Polychrome V $(n=6)$, faint-striated plainware $(n=6)$, and unidentified plainware $(n=$ 1).

Data recovery investigations in 1992 (Season 3) consisted of detailed topographic mapping and excavation of seven backhoe trenches (four inside the site area and three nearby) and eighty-six 1-x-1$m$ units (Figure 59). Seventeen of the hand-dug units were isolated (in addition to the three 1988 test units), while 69 units were in six excavation blocks. Five of the excavation blocks consisted of 3-8 units and the largest one, Block 3, consisted of 46 units.

Nine features were recorded during the data recovery excavations, but four were determined to be noncultural. The five cultural features include a midden, a disturbed rock-lined hearth, two small unlined basin hearths, and a baking pit. Four radiocarbon dates (one from a nonfeature context, two from Feature 3, and one from Feature 9) indicate that the site was occupied during the mid seventeenth century (see Table 32). In addition, archeomagnetic samples from features yielded date ranges of A.D. 1384-1562 for Feature 3, A.D. 15181686 for Feature 8, and A.D. 1648-1695 for Feature 9. While the Feature 9 archeomagnetic date corresponds with its associated radiocarbon date, the Feature 3 archeomagnetic date does not overlap with either of the Feature 3 radiocarbon dates (see Appendix B). For various reasons, the archeomagnetic age estimates are considered less reliable than are the radiocarbon dates (see Gose 1993).

The data recovery investigations recovered 4,413 specimens, bringing the total number of artifacts to 4,499 (see Table 31). The total assemblage is composed of 79.6 percent chipped stones, 0.5 percent ground and battered stones, 19.7 percent ceramics, and 0.2 percent other (i.e., modified shells, glass beads, and modern artifacts). Of the 21 arrow points, 6 are classified to types (5 Fresno and 1 Lott-like) while the remainder are classified as untyped triangular, concave base $(n=2)$; untyped triangular, straight base $(n=1)$; untyped expanding stem, concave base $(n=4)$; untypeable fragments $(n=5)$; and preforms $(n=3)$. Notable in the chipped stone assemblage is the large number of unifacial tools $(n=36)$, which are more abundant than any other tool class. Of 15 unifacial end scrapers, 13 are made on large blades or bladelike flakes and are morphologically consistent with Plains-style end scrapers. Five of these exhibit haft wear. Lithic debitage is dominated by single-faceted tertiary flakes, apparently derived from the manufacture and rejuvenation of unifacial tools. Although bifacial reduction also is evident, it was significantly less important.

The data recovery ceramic assemblage consists of 887 sherds representing a minimum of 7 vessels and 3 pipes (Table 39). One of the latter is a Pecos-style pipe that may have been made at Pecos Pueblo. The vessel sherds $(n=879)$ are grouped into five categories based on ware type: plain utility, micaceous utility, redware, glazeware, and matte paint ware. The minimum number of vessels is a conservative estimate, and it is likely that several additional vessels are represented, particularly in the plain utility category. Visual examinations identified a variety of wares and/or types, including Tewa Polychrome, red-slipped sherds of the Tewa tradition, unslipped and slipped redware sherds of Puebloan origin, and Pecos Glaze V polychrome. The sources of the plain and micaceous utility wares could not be positively identified, but the majority are similar to Puebloan-made plain and striated utility wares (such as Pecos Faint Striated defined by Kidder and Shepard 1936) or to the Tierra Blanca Plain type (defined by Habicht-Mauche 1987, 1988). Eight of the sherds (three plain utility, three redware, one glazeware, and one matte paint ware) were included in a detailed petrographic study by Boyd and Reese-Taylor (1993:362-368), and the resulting data generally support the visual identifications. The petrographic study also noted that most of the plainware samples are similar in composition to decorated Puebloan-made wares, suggesting that most of the plainwares may have come from the same Puebloan sources.

The diversity of features and artifacts encountered at 41KT51 indicates that the site was a multifunctional base camp occupied repeatedly over an unknown period of time. Although the baking pit is probably associated with cooking of plant foods, the relatively high frequencies of arrow points and unifaces are interpreted as evidence that people at $41 \mathrm{KT} 51$ were heavily involved in hunting and the processing of hides. The preforms suggest that arrow points were manufactured there and that the site may have served as a hunting camp. Abundant evidence of unifacial rejuvenation (i.e., numerous unifacial rejuvenation flakes and extensive use wear on unifaces) indicates that these tools, particularly end scrapers, were utilized intensively. Three flakes of obsidian were recovered and sourced by trace 


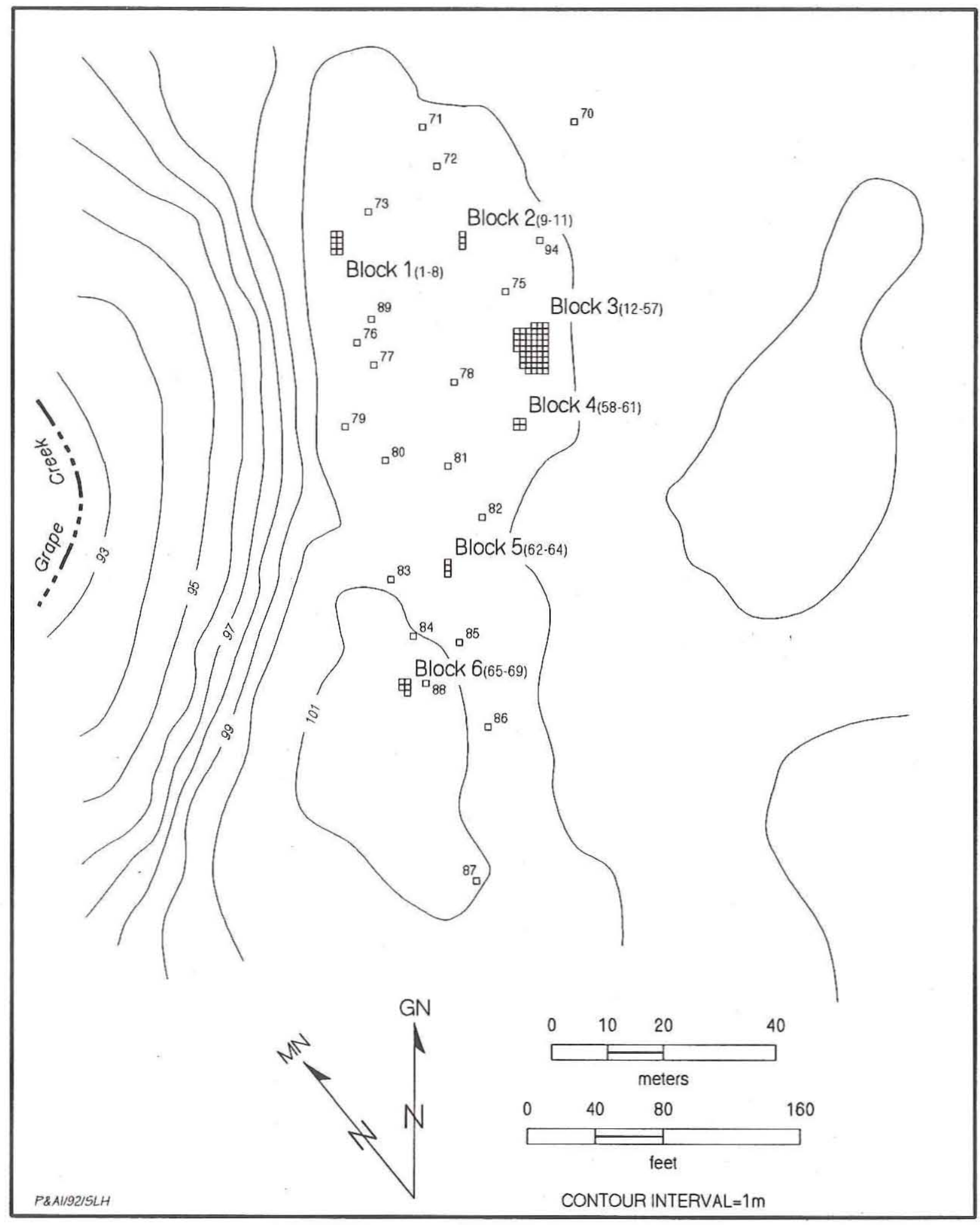

Figure 59. Site map, 41KT51. 1988 Test Units 1-3 are numbered as Excavation Units 87-89; backhoe trench locations are not shown. 
TABLE 39

SUMMARY OF CERAMICS FROM DATA RECOVERY AT 41KT51

\begin{tabular}{|c|c|c|c|}
\hline Ware Type & $\begin{array}{l}\text { Vessels and } \\
\text { Sherd Groups }\end{array}$ & $\begin{array}{l}\text { Total No. } \\
\text { of Sherds }\end{array}$ & $\begin{array}{l}\text { Description and Possible Source(s) of Manufacture Based } \\
\text { on Visual Identification and Petrographic Analysis }\end{array}$ \\
\hline \multirow{2}{*}{$\begin{array}{l}\text { Plain Utility* } \\
(\mathrm{n}=738)\end{array}$} & Vessel 1 & 3 & Plain sherds from jars with everted rim; source unknown \\
\hline & 10 sherd groups & 735 & $\begin{array}{l}\text { Plain and striated sherds ( } 25 \text { with fingernail punctates) } \\
\text { from cooking vessels; source unknown }\end{array}$ \\
\hline \multirow{2}{*}{$\begin{array}{l}\text { Micaceous Utility } \\
(\mathrm{n}=4)\end{array}$} & Vessel 1 & 2 & Striated sherds from cooking vessel; source unknown \\
\hline & 1 sherd group & 2 & Striated sherds from cooking vessel; source unknown \\
\hline \multirow{4}{*}{$\begin{array}{l}\text { Redware } \\
(\mathrm{n}=129)\end{array}$} & Vessel 1 & 71 & $\begin{array}{l}\text { Red-slipped bowl, possibly from a southern pueblo (i.e., } \\
\text { Salinas area); petrographic analysis noted similarities } \\
\text { with wares made at Pecos Pueblo }\end{array}$ \\
\hline & Vessel 2 & 16 & $\begin{array}{l}\text { Red-slipped ware, unknown form; unidentified Puebloan } \\
\text { source }\end{array}$ \\
\hline & Vessel 3 & 6 & $\begin{array}{l}\text { Red-slipped ware, unknown form; unidentified Puebloan } \\
\text { source (not Tewa) }\end{array}$ \\
\hline & 2 sherd groups & 36 & $\begin{array}{l}\text { Red-slipped sherds of glazeware tradition and red-slipped } \\
\text { sherds of Tewa tradition; petrographic analysis supports } \\
\text { visual type identification }\end{array}$ \\
\hline $\begin{array}{l}\text { Glazeware } \\
(\mathrm{n}=7)\end{array}$ & Vessel 1 & 7 & $\begin{array}{l}\text { Glaze-painted wide-mouthed jar, possibly Glaze V from } \\
\text { Pecos Pueblo; petrographic analysis supports visual } \\
\text { type identification }\end{array}$ \\
\hline $\begin{array}{l}\text { Matte Paint Ware } \\
(\mathrm{n}=1)\end{array}$ & Vessel 1 & 1 & $\begin{array}{l}\text { Tewa polychrome tradition but not necessarily Tewa } \\
\text { polychrome type; petrographic analysis supports visual } \\
\text { type identification }\end{array}$ \\
\hline \multirow{3}{*}{$\begin{array}{l}\text { Pipes } \\
(\mathrm{n}=8)\end{array}$} & Pipe 1 & 1 & $\begin{array}{l}\text { Pecos-style, rectangular-bodied pipe; probably from Pecos } \\
\text { Pueblo }\end{array}$ \\
\hline & Pipe 2 & 6 & Form and source unknown \\
\hline & Pipe 3 & 1 & Form and source unknown \\
\hline Totals: & $\begin{array}{l}7 \text { vessels } \\
3 \text { pipes } \\
13 \text { sherd groups }\end{array}$ & 887 & \\
\hline & $\cos 2 \cos 20$ & $c$ & $\begin{array}{l}\text { uld be locally made but that most are similar in } \\
\text { orated wares. }\end{array}$ \\
\hline
\end{tabular}

element analysis to the Cerro del Medio locality in New Mexico's Jemez Mountains. Two faceted cobalt-blue glass beads, one of simple construction and the other compound, are the only artifacts indicative of Euro-American contact, but their source of manufacture is not known.
In many ways, $41 \mathrm{KT} 51$ is quite similar to nearby $41 \mathrm{KT} 53$ (i.e., similarities between lithic and ceramic assemblages and some feature types), and both are interpreted as sites occupied primarily during the seventeenth century by bison-hunting nomads. One notable difference is that no definitive 
evidence of structures was found at 41KT51. The unlined basin hearths are similar to features at $41 \mathrm{KT} 53$ that are interpreted as interior tipi hearths, however. Because of the overall similarities, these two sites are thought to represent closely related occupations by the same group(s) of people. The Headstream site is considered to be affiliated with the Garza complex (see Chapter 11).

\section{KT53, Longhorn Site}

The Longhorn site is situated on an alluvial terrace on the west side of Grape Creek, ca. $2.25 \mathrm{~km}$ upstream from its confluence with the Double Mountain Fork of the Brazos River (see Figure 58). The site occupies a $100-\mathrm{x}-120-\mathrm{m}$ segment of the level terrace at an elevation of $2170 \mathrm{ft} \mathrm{msl}$. The location is noteworthy because it is within an unusually wide, 29-hectare (72-acre) valley bottom that is well protected on all sides by 30 -m-high canyon walls. Site $41 \mathrm{KT} 53$ is only 0.8 $\mathrm{km}$ south-southwest of 41KT51 (discussed above).

The site consists of a shallowly buried cultural zone at $10-25 \mathrm{~cm}$ below the surface, within a dense layer of dark gray loam representing sediments deposited by overbank flooding of Grape Creek. Toward the western end of the site, these alluvial sediments are intermixed with alluvial/colluvial fan sediments shed off the canyon wall, but the lower eastern end of the terrace is composed of a series of well-developed soils representing stable periods between episodic floods. Geomorphic evidence indicates that the terrace surface has aggraded slowly but consistently for at least the last 1,000 years.

Immediately above the cultural zone is a burned zone that is weakly defined in some areas and well defined in others. Scattered charcoal and occasional burned tree stumps indicate that the terrace's vegetation was burned off some time after the site was abandoned. A radiocarbon date on a burned stump (Feature 54) suggests that this burning occurred during the twentieth century (see Appendix B).

This multicomponent site was discovered in 1987. An early lower component was evidenced by a rock-lined hearth exposed at $1 \mathrm{~m}$ below the surface in the edge of the terrace. The upper component was identified by very sparse surface artifacts and materials recovered in the upper $50 \mathrm{~cm}$ of a shovel test. One Plains-style end scraper was found on the surface, and 27 sherds of a glaze- painted polychrome bowl were found in the backdirt of an animal burrow. Plainware sherds were recovered in a shovel test, indicating the presence of a shallow cultural zone. The ceramics were identified as Pecos Glaze Polychrome V and Pecos Faint Striated.

The 1988 testing consisted of a magnetometer survey, site mapping, excavation of 8 backhoe trenches, and hand excavation of 13 test units. The proton magnetometer survey covered a portion of the site area (one 40-x-40-m block and one 30-x-30-m block) in an attempt to locate buried features (Abbott and Frederick 1990). Due to technical problems, the data derived from the larger block were uninterpretable, but the smaller survey block provided useful magnetic data. The hand excavations targeted selected magnetic anomalies, but some nonanomaly areas also were tested. The testing of magnetic anomalies successfully located three features - a burned post (Feature 1), an unlined basin hearth (Feature 4), and a ceramic cluster (Feature 6) - that most likely would not have been found using traditional site sampling strategies. One noncultural feature, a probable postoccupation burned tree stump (Feature 2), also was located by the magnetometer. The testing also targeted the cluster of polychrome ceramics (Feature 5) disturbed by the animal burrow and the rock-lined hearth associated with the lower component (Feature 3). No additional evidence of the lower component was found in the backhoe trenches, but the upper component was identified as a well-preserved Protohistoric campsite.

Data recovery investigations in 1992 targeted only the late component and consisted of the following: (1) hand clearing of vegetation and an extensive proton magnetometer survey; (2) excavation of magnetometer test units and other isolated units; (3) excavation of a stratified random sample of units over the core site area; (4) an on-site geomorphic assessment that included six additional backhoe trenches; and (5) excavation of large block areas. At the conclusion of the data recovery investigations, three hundred twenty-seven 1-x-1-m units had been excavated, bringing the total hand-excavated area to ca. $340 \mathrm{~m}^{2}$ with the majority of units $(\mathrm{n}=268 ; 79$ percent) being located in 4 large blocks (Figures 60 and 61). The large excavation block areas were originally selected based on the results of the magnetometer and random sample testing, but they were subsequently expanded to follow out and identify 


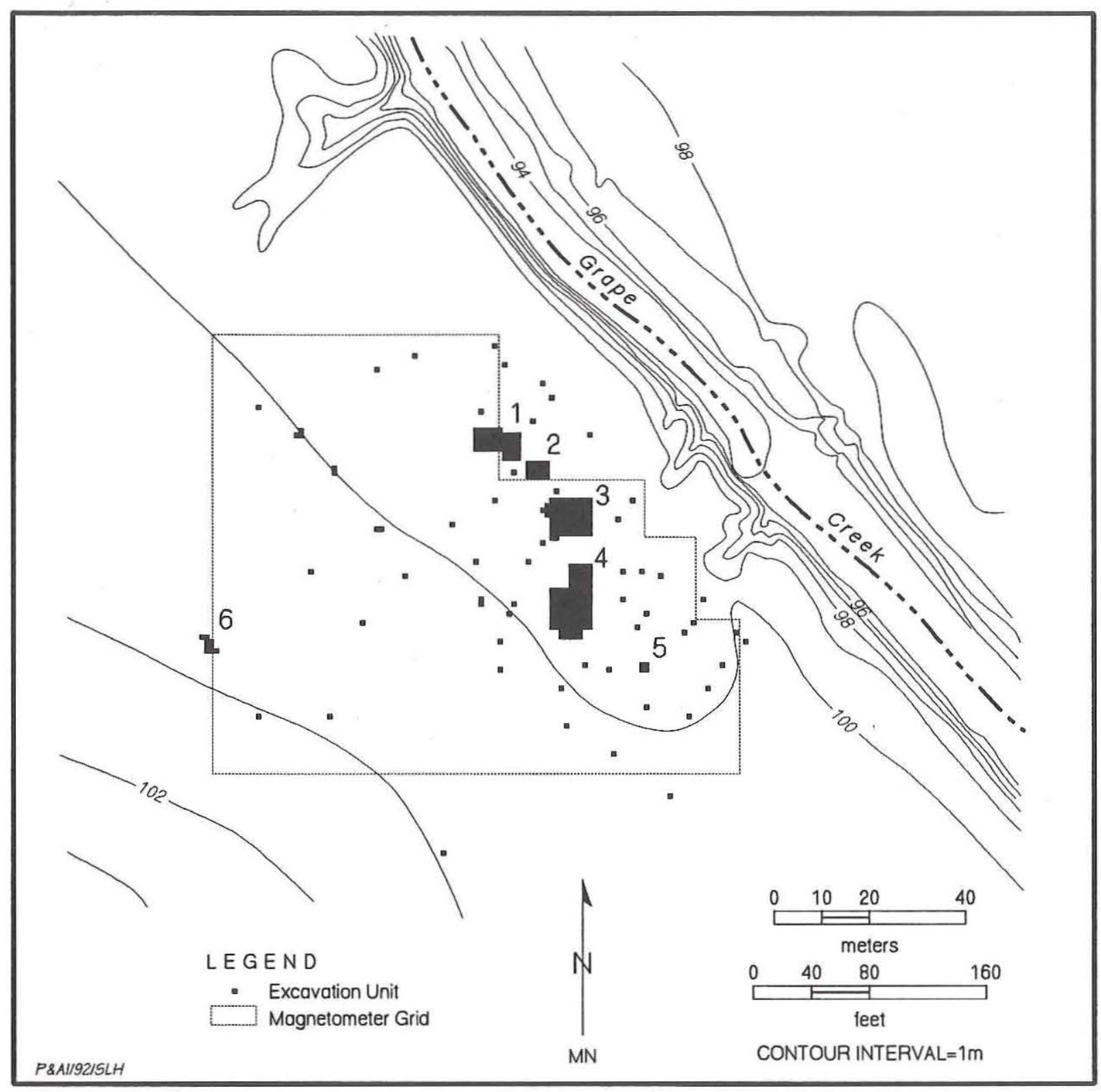

Figure 60. Map of 41KT53 showing the extent of the magnetometer survey, all excavation units, and numbered excavation blocks.

feature and artifact distribution patterns.

The 1992 magnetometer survey (Abbott and Frederick 1993) covered seven additional 30-x-30-m blocks and several smaller blocks adjacent to the successful 1988 magnetometer block. Combined with the 1988 data, the total area covered by magnetometer survey is roughly $90 \times 110 \mathrm{~m}$. After the survey, the most promising magnetic anomalies were targeted for excavation. In the eastern half of the survey area, anomaly testing successfully located additional buried cultural features, but the majority of the magnetic anomalies turned out to be related to the postoccupational burning episode. The results of anomaly testing in the western half of the survey area were ambiguous, and it was concluded that the magnetic data related mainly to the underlying alluvial/colluvial fan sediments, thus masking any cultural feature anomalies. In addition to the test units targeting magnetic anomalies, isolated test units were strategically placed to target nonanomaly areas and to fill in large areas that had not been tested. Testing results indicated that the buried cultural zone 


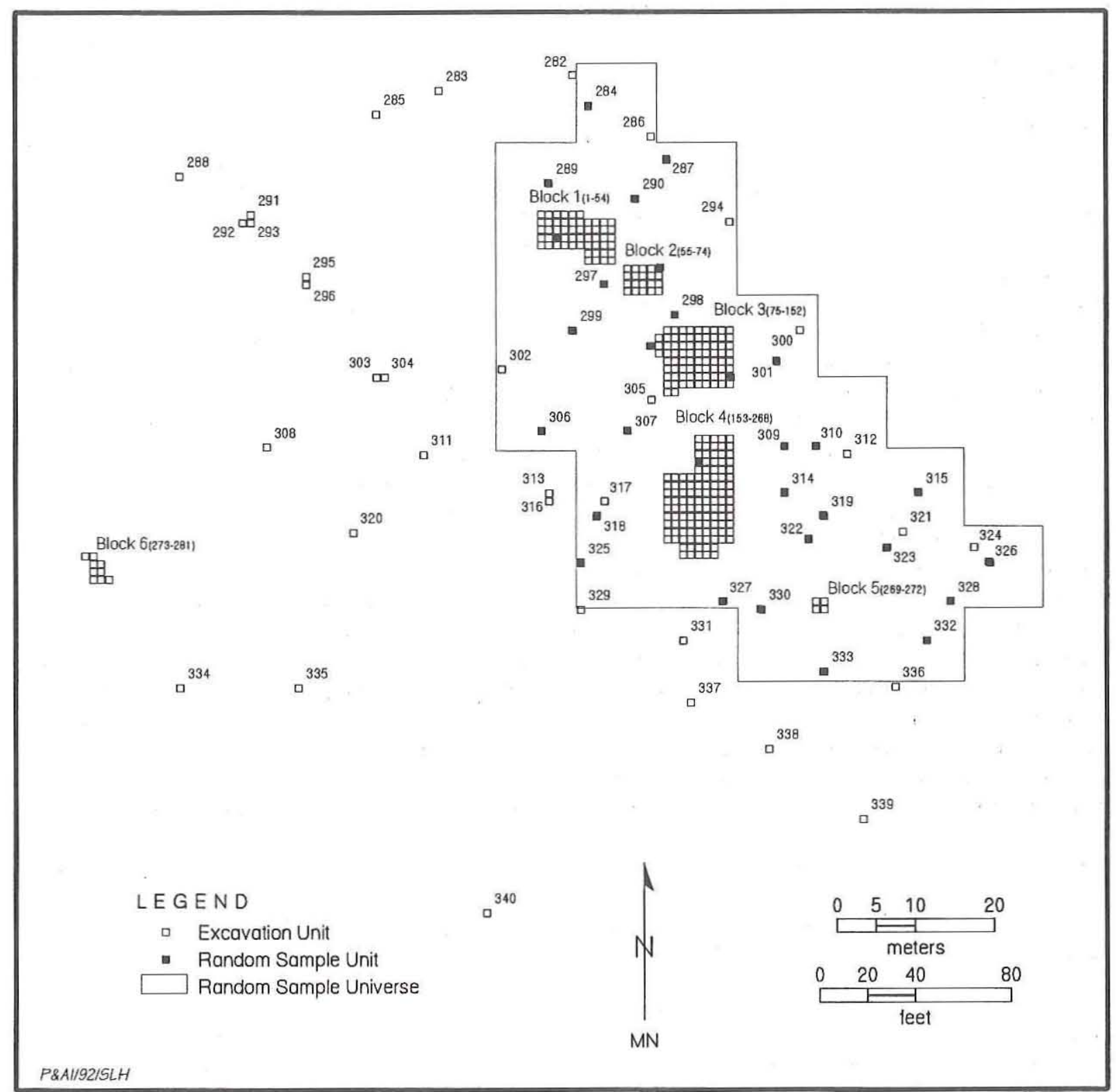

Figure 61. Map of 41KT53 showing locations and numbers of excavation units (including the random sample units) and the position of the random sample grid; 1988 test units are renumbered as excavation units and backhoe trench locations are not shown.

was densest and most discrete in the eastern portion of the site, parallel to the edge of the creek.

A $60-\mathrm{x}-80-\mathrm{m}$ core area was selected for intensive investigation. The first task was a series of random sample units excavated with two goals in mind. The first goal was to further define the archeological deposits within the core area to aid in selecting the best locations for block excavations. The second goal was to experiment with a systematic unaligned random sampling program that was implemented in consultation with the Advisory Council for Historic Preservation (ACHP). The intent was to enhance the interpretability of the archeological data by providing an unbiased sample of a much larger portion of the site, hence revealing more activities and site structure than would be revealed by excavation blocks alone. This strategy was previously attempted at $41 \mathrm{KT} 33$ (discussed above) but was terminated because potential multiple components made it impossible to relate the random 
sample unit recovery to the block excavations with any certainty. This type of sampling was potentially more meaningful at $41 \mathrm{KT} 53$, however, because all data recovery materials were definitely associated with the same component.

The random sample program consisted of dividing the core site area into thirty $10-\mathrm{x}-10-\mathrm{m}$ sample blocks, each containing one hundred $1-\mathrm{x}-1-\mathrm{m}$ units. Within each block, a randomly generated number determined which $1-\mathrm{x}-1-\mathrm{m}$ unit was to be excavated as part of the systematic random sample. The 30 random sample units represent a 1 percent sample of the core site area (see Figure 61).

The random sample units were useful in providing a more complete picture of the core site area, and the data were helpful in selecting locations for block excavations. The random sampling program was not particularly effective as a sampling strategy for augmenting block excavation data, however. Because of the diversity and complexity of the cultural features and artifacts at $41 \mathrm{KT} 53$, the 1 percent sample was determined to be inadequate to provide new insights into site function and structure. While the random sample of artifacts roughly approximated the total artifact sample recovered from the site, it revealed no additional artifact types indicative of cultural activities that were not recognized in the block excavations. The random sample units located one noncultural feature (a burned tree stump) but only two additional cultural features (a post mold and an ephemeral basin hearth). Because the sample units yielded insufficient contextual information, it was impossible to interpret the function of the two cultural features in isolation or to understand their relationships to overall site structure. Thus, the random sample data provided no meaningful information that was not revealed by the excavation blocks.

The combined archeological investigations identified 50 cultural features (Table 40) and recovered 9,029 artifacts (see Table 31). Eighteen radiocarbon dates provide the main evidence for chronological placement of the cultural component (see Table 32). Three archeomagnetic dates also were obtained on cultural features (see Appendix B). They generally agree with the radiocarbon dates, but for technical reasons, they are considered less reliable than the radiocarbon dates (see Gose 1993).

The archeological data are interpreted as evidence that 41KT53 was a tipi encampment most intensively occupied during the seventeenth century. Occupation may have begun as early as the fifteenth century and continued as late as the early eighteenth century. Based on their characteristics and distributions, clusters of contemporaneous features are interpreted as representing three separate tipi struc-

\begin{tabular}{|c|c|c|c|c|c|c|c|c|}
\hline \multirow[b]{3}{*}{ Feature Type } & \multicolumn{6}{|c|}{$\begin{array}{c}\text { TABLE } 40 \\
\text { SUMMARY OF CULTURAL FEATURES AT 41KT53 }\end{array}$} & \multirow[b]{3}{*}{ Nonblock } & \multirow[b]{3}{*}{ Totals } \\
\hline & \multicolumn{6}{|c|}{ Excavation Blocks } & & \\
\hline & 1 & 2 & 3 & 4 & 5 & 6 & & \\
\hline Basin hearths & 1 & - & 1 & 1 & - & - & - & 3 \\
\hline Ephemeral hearths & - & - & - & 2 & - & - & 1 & 3 \\
\hline Hearth dumps & 1 & - & - & 2 & - & - & - & 3 \\
\hline Rock clusters & 1 & - & - & 2 & - & - & - & 3 \\
\hline Unidentified pit & - & - & - & 1 & - & - & - & 1 \\
\hline Bone stake & 1 & - & - & - & - & - & - & 1 \\
\hline Grinding basin & - & - & - & 1 & - & - & - & 1 \\
\hline Ceramic clusters & - & - & - & 1 & - & 1 & - & 2 \\
\hline Post molds & 9 & 1 & 5 & 17 & - & - & 1 & 33 \\
\hline Totals: & 13 & 1 & 6 & 27 & 0 & 1 & 2 & 50 \\
\hline
\end{tabular}


tures (Figure 62). Each hypothesized structure area has a well-defined, unlined basin hearth with an intensively burned (oxidized) bottom and gray ashy fill containing burned and unburned debitage and bone fragments (Figure 63). The intensive burning and complete oxidation are evidence of a wellcontrolled interior fire, and the high frequencies of small lithic debris and bone fragments are probably the result of intentional discard into the fire.

Two interesting features were located within $50 \mathrm{~cm}$ of two of the suspected tipi hearths. A small post mold filled with burned hackberry wood was located near one hearth, while a vertical Bos horn core (from whence the Longhorn site derives its name) was located near another. These features are interpreted as representing small stakes that served as tie-downs for securing the tipi foundations. The third suspected tipi area had a post mold about $1 \mathrm{~m}$ away from its central hearth; it also probably represents a tie-down stake. Tipi tie-downs are well documented in the ethnographic and archeological literature. Each hypothesized tipi structure had a small angled post mold located ca. $2.5 \mathrm{~m}$ away from the central hearth. These posts are tentatively interpreted as representing smoke-flap tie-down stakes located just outside the tipi.

Three basin hearths other than those associated with the tipi structures were discovered. These are more ephemeral and could represent tipi hearths that were utilized less intensively or exterior hearths. In addition, three features consist of small concentrations of hearth fill (similar to the fill in the basin hearths) without any evidence of in situ burning. These are interpreted as hearth dumps and probably represent fill that was cleaned out of the tipi hearths and dumped outside the structures.

The most common features were post molds, and they exhibit a wide variety of sizes and fill characteristics. Of the 33 post molds (including those mentioned above), 20 represent stakes or small posts $(<10 \mathrm{~cm}$ in diameter and $<25 \mathrm{~cm}$ deep), 3 represent small-medium posts $(>10 \mathrm{~cm}$ in diameter and $25-35 \mathrm{~cm}$ deep), and 10 represent large posts $(>10 \mathrm{~cm}$ diameter and $>35 \mathrm{~cm}$ deep). The larger post molds are all vertical and probably represent large posts that may have supported racks for storage, hide drying, or shade arbors. Ethnographic evidence and historic photographs indicate that such features were common at Plains Indian encampments. In a few cases, pairs of large posts were identified by similarities in size and fill characteris- tics, but no definitive interpretations regarding the number, configuration, or functions of racks can be offered.

The fill inside the post molds reflects their use life and abandonment histories, which appear to be quite varied and sometimes complex. These features were variously filled with sediment, organic debris (e.g., snails and dark sediment), cultural debris, charred seeds, charred wood, and occasional unburned wood fragments. One post mold contained solid charcoal indicating complete in situ burning of one post, and 12 had charred wood indicating that the posts had burned down below ground level. Identification of charred woods indicated that hackberry, mesquite, elm, oak, and willow were used as posts. These burned posts may be evidence of a widespread fire, perhaps similar to the postoccupational burning episode, during, between, or immediately following occupation(s). In contrast, the burning of only the bottoms of at least seven posts probably represents intentional charring by the site occupants. As mentioned in some ethnographic accounts, these posts could have been charred before they were put into the ground to harden their tips and/or deter termites and other bugs.

One unusual feature is a small grinding basin in which an odd-shaped mano/pestle was recovered. Based on ethnographic analogies, it is possible that this tool was used in conjunction with a bison-hide mortar that lined the small pit. The functions of the unidentified pit and rock cluster are not known.

The artifact assemblage reflects a complex combination of various activities conducted at the site, differential use lives, discard rates, and curation behaviors. The overall lithic assemblage is characterized by a high percentage ( 76 percent) of nonlocal materials, dominantly Edwards cherts derived from south of the project area. The lithic tool assemblage is unusual because of the high frequency of unifacial tools, predominantly Plains-style end scapers. These hafted tools are thought to be related to processing of bison hides. In contrast, projectile points and bifaces (particularly beveled knives) are not well represented. Projectile point forms include Fresno (n =6), Washita and Harrell-like $(\mathrm{n}=3)$, and Lott and Lott-like $(n=3)$. The poor representation of hunting-related tools could indicate that hunting was a relatively unimportant activity when the site was occupied (i.e., during nonhunting seasons), or it may reflect a skewed stone tool assemblage because of the adoption and careful curation of metal knives 


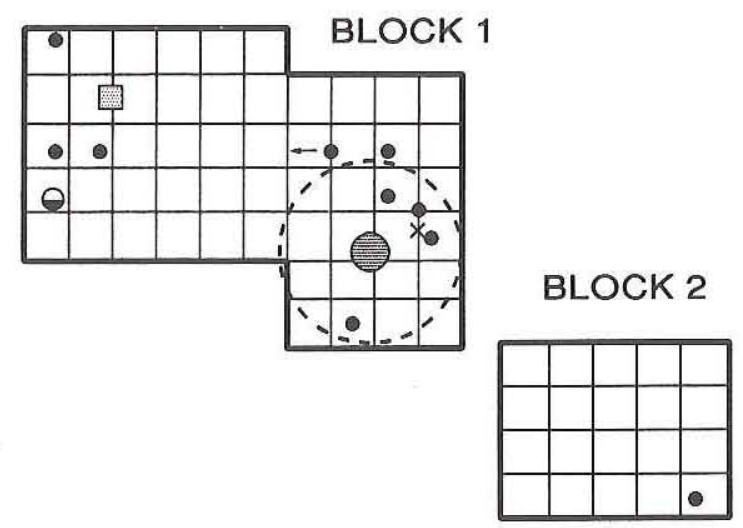

LEGEND

Basin Hearth

BLOCK 3

Ephemeral Hearth

Hearth Dump

- Rock Cluster

- Postmold

$\times$ Bone Stake

ه Grinding Basin

$\therefore$ Ceramic Cluster

Unidentified Pit

¿- Probable Tipi Structure

—Direction of Post Angle

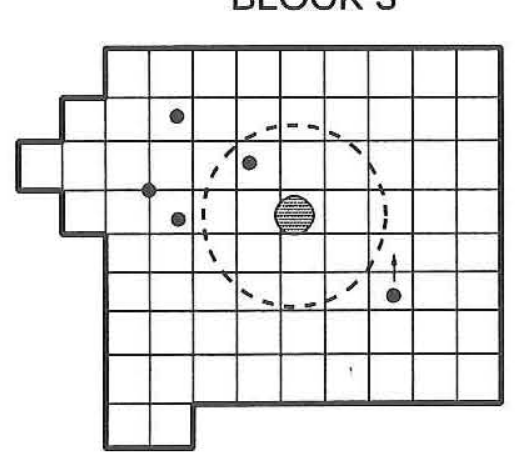

BLOCK 4
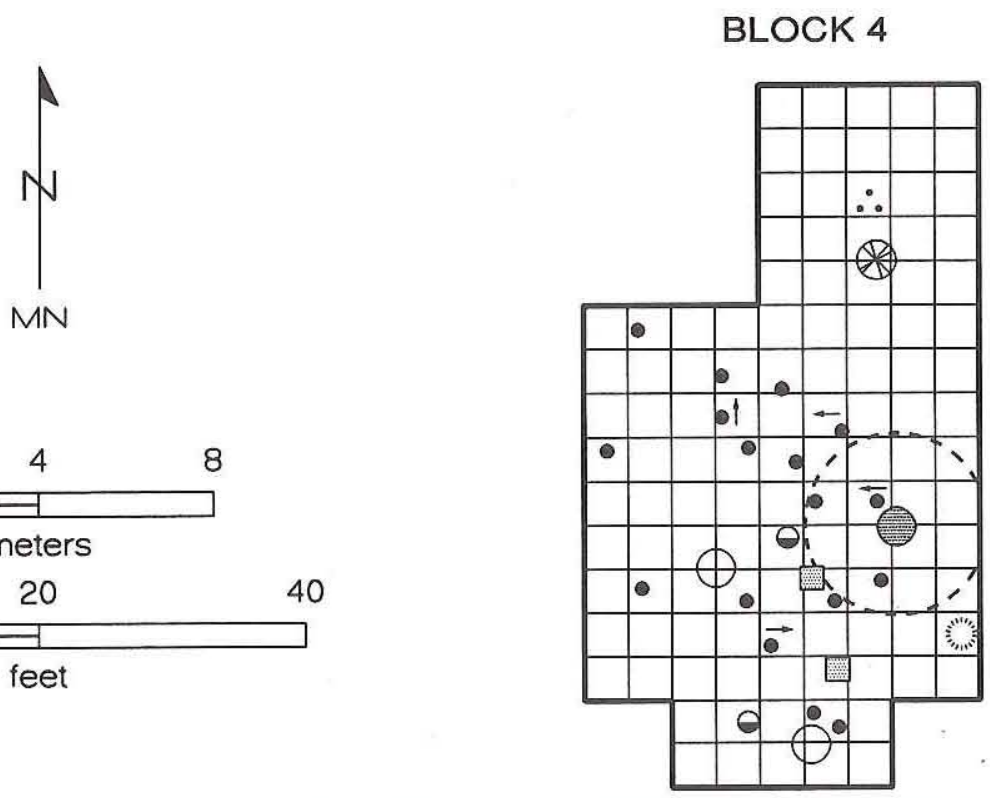

PAII97ISLH
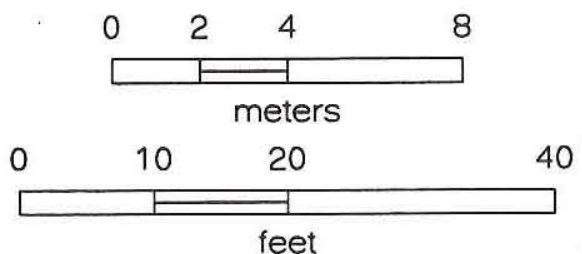

Figure 62. Distribution of cultural features and hypothesized tipi structures at 41KT53. 


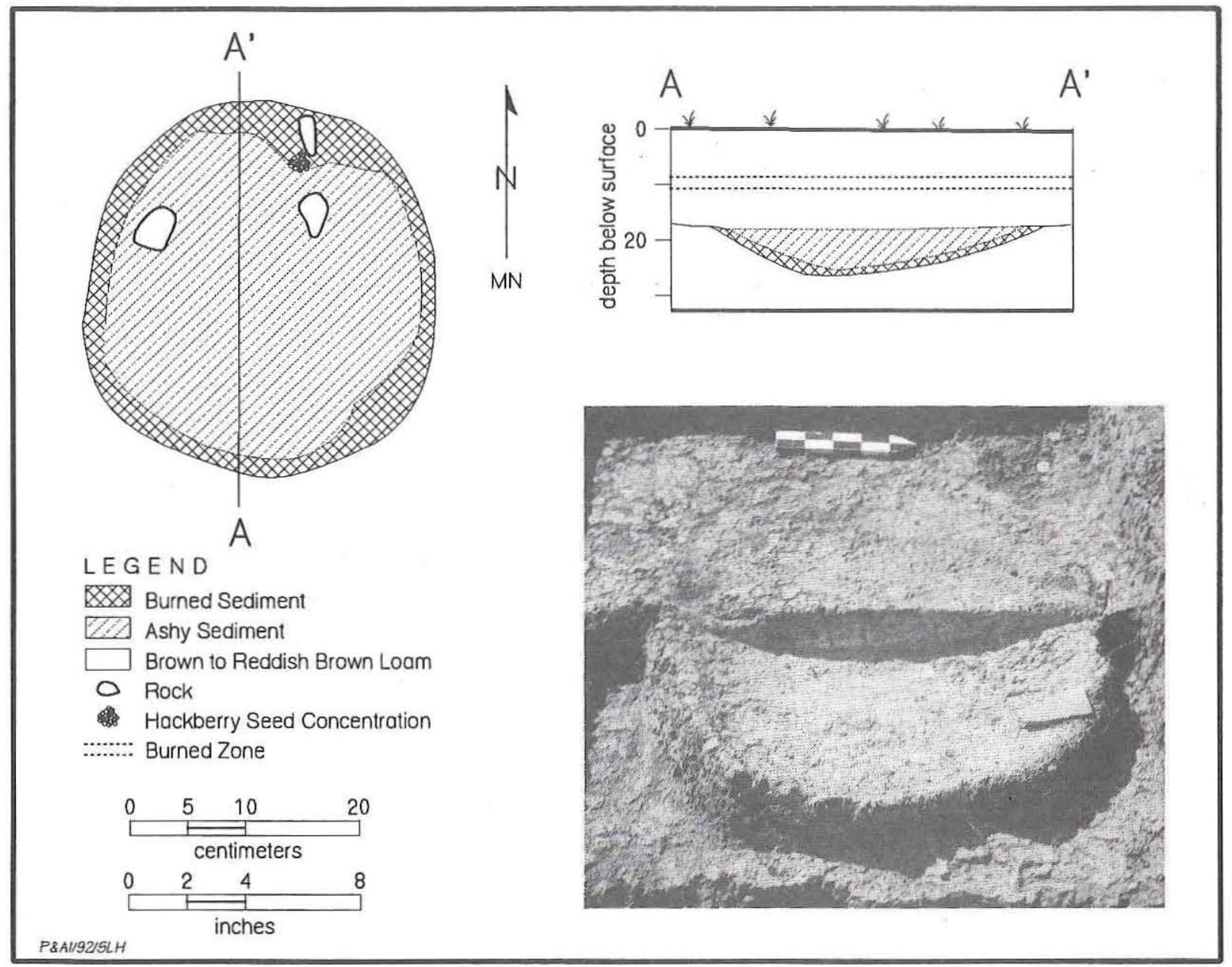

Figure 63. Plan, profile, and photograph of unlined basin hearth (Feature 4) at 41KT53. It is interpreted as an interior hearth associated with a tipi structure.

and arrow points. Perhaps more likely, the variable tool frequencies are related to a combination of these and other factors.

One unique aspect of the site is its extremely variable ceramic assemblage, which consists of 2,595 sherds representing a minimum of 24 vessels and 4 pipes (Table 41). Two of the four pipes are rectangular-bodied, elaborate Pecos-style pipes, and a significant portion of the ceramics are known to be of Puebloan manufacture. The following Puebloan wares and types were recognized by Southwestern ceramic experts: (1) Tewa Polychrome; (2) Pecos Glaze V Polychrome; (3) glaze-painted wares of various Glaze E and/or F forms; (4) Salinas Redware; (5) redwares of various Glaze $\mathrm{E}$ and/or F forms; and (6) a heavily micaceous plainware from the Taos/Picuris area. Additional Southwestern influence is evident in the artifact assemblage in the form of Olivella shell and turquoise beads (one each).

Micaceous vessel 1 is identified as a probable Puebloan-made ware from the Taos/Picuris area. The other micaceous utility wares are more problematic, largely because there is considerable confusion regarding micaceous ceramics found on the Plains, which are often lumped into nebulous groups (e.g., Perdido Plain or Apache Micaceous) whose origins are unknown or disputed. Type names are often assigned on the basis of where the sherds are found rather than any definitive evidence that they were made by a particular group or in a particular area.

The source of manufacture for the plain utility wares (striated and unfinished varieties) is unknown, but they are similar to Puebloan-made utility vessels (i.e., common bean pots). The striated plainwares are very similar to Kidder and Shepard's (1936) Pecos 


\begin{tabular}{|c|c|c|c|}
\hline \multicolumn{4}{|c|}{$\begin{array}{l}\text { TABLE } 41 \\
\text { UMMARY OF CERAMICS FROM DATA RECOVERY AT 41KT53 }\end{array}$} \\
\hline Ware Type & $\begin{array}{l}\text { Vessel and } \\
\text { Sherd Groups }\end{array}$ & $\begin{array}{l}\text { Total No. } \\
\text { of Sherds }\end{array}$ & $\begin{array}{l}\text { Description and Possible Source(s) of Manufacture Based } \\
\text { on Visual Identification and Petrographic Analysis }\end{array}$ \\
\hline \multirow{7}{*}{$\begin{array}{l}\text { Plain Utility } \\
(\mathrm{n}=1,239)\end{array}$} & Vessel 1 & 19 & $\begin{array}{l}\text { Plain sherds from a globular jar with everted rim (i.e., bean } \\
\text { pot); petrographic analysis shows similarities with Pecos- } \\
\text { made ceramics }\end{array}$ \\
\hline & Vessel 2 & 3 & $\begin{array}{l}\text { Plain sherds from a jar with everted rim; petrographic } \\
\text { analysis shows similarities with Pecos-made ceramics }\end{array}$ \\
\hline & Vessel 3 & 1 & $\begin{array}{l}\text { Striated rim sherds; petrographic analysis shows similarities } \\
\text { with Puebloan-made ceramics from the Salinas area }\end{array}$ \\
\hline & Vessel 4 & 5 & $\begin{array}{l}\text { Striated rim sherds; petrographic analysis shows similarities } \\
\text { with Pecos-made ceramics }\end{array}$ \\
\hline & Vessel 5 & 6 & $\begin{array}{l}\text { Striated rim sherds; petrographic analysis shows similarities } \\
\text { with Pecos-made ceramics }\end{array}$ \\
\hline & Vessel 6 & 7 & $\begin{array}{l}\text { Plain rim sherds; petrographic analysis shows similarities } \\
\text { with Pecos-made ceramics }\end{array}$ \\
\hline & 8 sherd groups & 1,198 & $\begin{array}{l}\text { Plain and striated sherds ( } 4 \text { with fingernail punctates) from } \\
\text { cooking vessels; petrographic analysis shows similarities } \\
\text { with Pecos-made ceramics }\end{array}$ \\
\hline \multirow{5}{*}{$\begin{array}{l}\text { Micaceous Utility } \\
(\mathrm{n}=911)\end{array}$} & Vessel 1 & 668 & $\begin{array}{l}\text { Plain sherds from a wide-mouthed jar (i.e., bean pot); } \\
\text { heavily micaceous ware from Taos/Picuris area; } \\
\text { petrographic analysis supports visual type identification }\end{array}$ \\
\hline & Vessel 2 & 119 & $\begin{array}{l}\text { Plain sherds from a jar; petrographic analysis shows } \\
\text { similarities with Pecos-made ceramics }\end{array}$ \\
\hline & Vessel 3 & 71 & $\begin{array}{l}\text { Plain sherds from a jar with everted rim; source unknown; } \\
\text { petrographic analysis supports visual type identification }\end{array}$ \\
\hline & Vessel 4 & 31 & $\begin{array}{l}\text { Plain sherds; petrographic analysis shows similarities with } \\
\text { Pecos-made ceramics }\end{array}$ \\
\hline & 2 sherd groups & 22 & $\begin{array}{l}\text { Plain sherds; petrographic analysis shows similarities with } \\
\text { Pecos-made ceramics }\end{array}$ \\
\hline $\begin{array}{l}\text { Engraved Ware } \\
(\mathrm{n}=17)\end{array}$ & Vessel 1 & 17 & $\begin{array}{l}\text { Polished and engraved sherds of probable Caddoan origin } \\
\text { or influence, source unknown; petrographic analysis } \\
\text { supports visual type identification }\end{array}$ \\
\hline \multirow{2}{*}{$\begin{array}{l}\text { Redware } \\
(\mathrm{n}=207)\end{array}$} & Vessel 1 & 7 & $\begin{array}{l}\text { Unfinished sherds from a bowl, Glaze E or F form, Salinas } \\
\text { Redware; petrographic analysis supports visual type } \\
\text { identification }\end{array}$ \\
\hline & Vessel 2 & 3 & $\begin{array}{l}\text { Unfinished sherds from a bowl, Glaze F form, similar to } \\
\text { Salinas Redware; petrographic analysis supports visual type } \\
\text { identification }\end{array}$ \\
\hline
\end{tabular}




\begin{tabular}{|c|c|c|c|}
\hline \multicolumn{4}{|l|}{ Table 41, continued } \\
\hline Ware Type & $\begin{array}{l}\text { Vessel and } \\
\text { Sherd Groups }\end{array}$ & $\begin{array}{l}\text { Total No. } \\
\text { of Sherds }\end{array}$ & $\begin{array}{l}\text { Description and Possible Source(s) of Manufacture Based } \\
\text { on Visual Identification and Petrographic Analysis }\end{array}$ \\
\hline \multirow{5}{*}{$\begin{array}{l}\text { Redware, } \\
\text { continued }\end{array}$} & Vessel 3 & 1 & $\begin{array}{l}\text { White-slipped redware rim sherd, Glaze F jar form, } \\
\text { probably from Pecos Pueblo; petrographic analysis supports } \\
\text { visual type identification }\end{array}$ \\
\hline & Vessel 4 & 5 & $\begin{array}{l}\text { Red-slipped rim sherds from a bowl; Puebloan made but } \\
\text { specific source is unknown }\end{array}$ \\
\hline & Vessel 5 & 1 & $\begin{array}{l}\text { Brown-slipped rim sherd, Glaze F bowl form, possibly } \\
\text { from Pecos Pueblo; petrographic analysis shows similarities } \\
\text { with Puebloan-made ceramics from the Salinas area }\end{array}$ \\
\hline & Vessel 6 & 1 & $\begin{array}{l}\text { Unfinished rim sherd, Glaze E bowl form, similar to } \\
\text { Salinas Redware; petrographic analysis shows similarities } \\
\text { with Pecos-made ceramics }\end{array}$ \\
\hline & 6 sherd groups & 189 & $\begin{array}{l}\text { Unfinished and slipped redware sherds, Puebloan made but } \\
\text { specific sources are unknown; petrographic analysis shows } \\
\text { similarities with Pecos-made ceramics }\end{array}$ \\
\hline \multirow{7}{*}{$\begin{array}{l}\text { Glazeware } \\
(\mathrm{n}=175)\end{array}$} & Vessel 1 & 119 & $\begin{array}{l}\text { Glaze-painted polychrome bowl, probably Glaze V from } \\
\text { Pecos Pueblo or Glaze E from Galisteo Basin; petrographic } \\
\text { analysis shows similarities with Puebloan-made ceramics } \\
\text { from Pecos Pueblo and the Salinas area }\end{array}$ \\
\hline & Vessel 2 & 2 & $\begin{array}{l}\text { Glaze-painted bowl rim sherds, Glaze E form, possibly } \\
\text { from Pecos Pueblo or Galisteo Basin; petrographic analysis } \\
\text { shows similarities with Pecos-made ceramics }\end{array}$ \\
\hline & Vessel 3 & 3 & $\begin{array}{l}\text { Glaze-painted bowl rim sherds, Glaze F form, probably } \\
\text { from Pecos Pueblo or Salinas area; petrographic analysis } \\
\text { shows similarities with Pecos-made ceramics }\end{array}$ \\
\hline & Vessel 4 & 2 & $\begin{array}{l}\text { Glaze-painted olla rim sherds, Glaze E or F form, probably } \\
\text { from Salinas area; petrographic analysis supports visual } \\
\text { type identification }\end{array}$ \\
\hline & Vessel 5 & 1 & $\begin{array}{l}\text { Glaze-painted jar handle, Glaze E form, probably from } \\
\text { Pecos Pueblo; petrographic analysis shows similarities with } \\
\text { Pecos-made ceramics }\end{array}$ \\
\hline & Vessel 6 & 1 & $\begin{array}{l}\text { Glaze-painted jar handle, Glaze V form, probably from } \\
\text { Pecos Pueblo; petrographic analysis shows similarities with } \\
\text { Pecos-made ceramics }\end{array}$ \\
\hline & 7 sherd groups & 47 & $\begin{array}{l}\text { Various glaze-painted sherds, mostly Glaze E or F; possible } \\
\text { sources include Pecos Pueblo, Salinas area, and Galisteo } \\
\text { Basin; petrographic analysis shows similarities with } \\
\text { Puebloan-made ceramics from Pecos Pueblo and the Salinas } \\
\text { area }\end{array}$ \\
\hline $\begin{array}{l}\text { Matte Paint Ware } \\
(\mathrm{n}=10)\end{array}$ & Vessel 1 & 10 & $\begin{array}{l}\text { Tewa Polychrome bowl rim and body sherds; petrographic } \\
\text { analysis supports visual type identification }\end{array}$ \\
\hline
\end{tabular}




\begin{tabular}{|l|l|c|l|}
\hline \multicolumn{4}{|l|}{ Table 41, continued } \\
\hline \multirow{2}{*}{ Ware Type } & $\begin{array}{l}\text { Vessel and } \\
\text { Sherd Groups }\end{array}$ & $\begin{array}{l}\text { Total No. } \\
\text { of Sherds }\end{array}$ & $\begin{array}{l}\text { Description and Possible Source(s) of Manufacture Rased } \\
\text { on Visual Identification and Petrographic Analysis }\end{array}$ \\
\hline $\begin{array}{l}\text { Unidentified } \\
\text { Wares (n = 17) }\end{array}$ & 5 sherd groups & 17 & Various unidentified sherds; sources unknown \\
\hline \multirow{3}{*}{$\begin{array}{l}\text { Pipes } \\
\text { (n = 19) }\end{array}$} & Pipe 1 & 10 & Rectangular Pecos-style pipe; probably from Pecos Pueblo \\
\cline { 2 - 5 } & Pipe 2 & 7 & $\begin{array}{l}\text { Rectangular Pecos-style pipe; probably from Pecos Pueblo; } \\
\text { petrographic analysis supports visual type identification }\end{array}$ \\
\cline { 2 - 5 } & Pipe 3 & 1 & Form and source unknown \\
\cline { 2 - 5 } & Pipe 4 & 1 & Form and source unknown \\
\hline Totals: & $\begin{array}{l}24 \text { vessels } \\
4 \text { pipes } \\
28 \text { sherd groups }\end{array}$ & 2,595 & \\
\hline
\end{tabular}

Faint Striated or to Tierra Blanca Plain defined by Habicht-Mauche $(1987,1988)$. Like the micaceous wares, the origin of these plainwares is controversial (see Chapter 11).

Thirty-seven sherds from 41KT53 (11 plain utility, 5 micaceous utility, 1 engraved ware, 7 redware, 11 glazeware, 1 matte paint ware, and 1 Pecos-style pipe) were included in a detailed petrographic study by Boyd and Reese-Taylor (1993: 362-368). The resulting data generally support the visual identifications of the various Puebloan types and demonstrate that most of the plain utility samples are similar in composition to decorated Puebloan-made wares. This study suggests that most of the striated and unfinished plainwares at 41KT53 probably were obtained from Puebloan sources.

While the Southwestern influences are clear, a single engraved vessel is from an unknown manufacturing source but is stylistically similar to Caddoanmade ceramics. Caddoan ceramic specialists could not identify this vessel but acknowledged that it must represent a trade item or influence from the Caddoan area.

The abundance of ceramic vessels and diversity of types is interesting, especially in light of the fact that some vessels are represented by single sherds while three vessels are represented by as many as 119 to 668 sherds. This variability is related to site function and the number, duration, and intensity of occupations. The diverse ceramic assemblage is characteristic of residential base camps occupied (or reoccupied) for long periods of time. The numbers of painted vessels $(n=7)$ and smoking pipes $(n=$ 4) also suggest a long-term residential base rather than a brief encampment. A large number of ceramic refits over a broad area (Figure 64) provides additional evidence of multiple and/or lengthy occupations.

Historic artifacts consist of five sherds of blueon-white majolica (representing at least two vessels), an unidentifiable iron fragment, a lead ball, and four possible native-made gunflints. Also notable is the representation of European-introduced animals in the faunal assemblage. Besides the longhorn horn core used as a stake, a horse tooth also was recovered from an isolated unit.

The site apparently functioned as a residential base camp that was repeatedly occupied on a periodic, perhaps seasonal, basis. The site location would have been a good late fall or winter camp, but there is no convincing evidence for seasonality. Also, there is no particular reason to think that the site was occupied during only one season or that every occupation occurred at the same time of the year.

There is considerable indirect ethnographic evidence and circumstantial archeological evidence to suggest that the people who lived at 41KT53 were bison hunters. Bison hunting was apparently not a major activity during the majority of the time the site was occupied, however, and the inhabitants seem to have had a generalized hunter-gatherer lifestyle exploiting a wide range of plant and animal resources (Dering 1993a; Shaffer 1993). Hide 


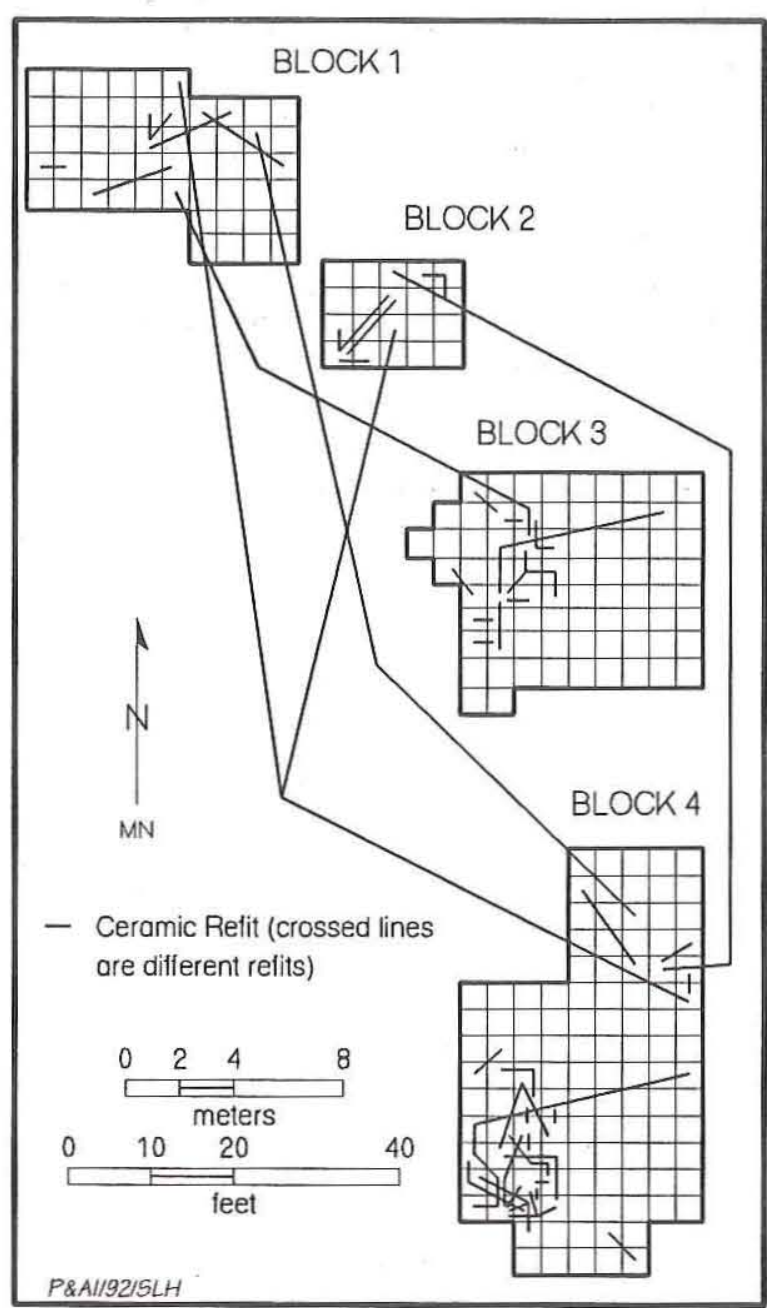

Figure 64. Ceramic refits, 41KT53. Refits within individual units are not shown.

processing and bone grease manufacture do appear to have been important activities. though. There are two opposing interpretations to explain this seemingly contradictory evidence. One is that the site was occupied by bison hunters primarily during nonhunting seasons when late-stage final processing of stored hides was a major activity. Alternatively, the inhabitants may have hunted bison during the times they occupied the site, but the archeological evidence for bison hunting is limited because they used metal arrow points and knives (which were not preserved) rather than stone tools and/or because they had horses, hunted and butchered animals some distance from the camp, and brought few bones back to the site.

Because the majority of the occupations occurred during the late seventeenth and early eigh- teenth centuries, it is likely that these later inhabitants possessed horses. The wide Grape Creek valley surrounding the site would have provided abundant forage, and, because it restricts north and south of the site, this portion of the canyon forms a natural enclosure for corralling horses. The use of horses may help explain the occupants' apparently high mobility, evidenced by the high frequency of nonlocal lithics, imported ceramics and beads, and European artifacts. The site's occupants also appear to have been regular participants in the Plains/Pueblo trade, and intensive processing of bison hides may have figured prominently in this interaction. The Longhorn site is thought to be affiliated with the Garza complex (see Chapter 11).

\section{Chronology and Definition of Analysis Units}

The nine sites that were investigated during the three seasons of data recovery at Lake Alan Henry provide more interpretable data than most of the other sites because the intensive investigations revealed contextual relationships that allowed for the definition and chronological placement of discrete analysis units. As used here, analysis units are defined as groupings of material culture and features that can reasonably be attributed to a particular time period. The association of artifacts and features with a particular time period is based on a correlative analysis of several lines of evidence, including, but not limited to, (1) radiocarbon dates on featureassociated organic remains, (2) associations between features based on similarities in feature types and stratigraphic contexts, and (3) vertical and horizontal spatial contexts and relationships between material culture assemblages and features. An analysis unit may approximate a component in that a "close contextual relationship among artifacts" can be demonstrated (L. Johnson 1987:3). Such is the case with the burial at 41GR291. For most of the other analysis units, however, there is no evidence indicating that they represent discrete (i.e., short duration) occupations or even activities by a single group. In fact, the archeological evidence at most sites appears to represent multiple and inseparable occupation episodes that occurred within a definable, but often extended, period of time. Consequently, it is appropriate to consider most of the analysis units as periods of occupation rather than as true components.

The chronological placement of the analysis 
units was based on 52 radiocarbon dates on charcoal $(n=41)$, sediment $(n=7)$, wood $(n=2)$, and bone $(n=2)$ from various archeological contexts (Figure 65). Most of these dates are directly associated with cultural features. Fourteen analytical units are defined for the nine sites in Table 42, spanning the period from A.D. 1 to 1750 (see Table 32).

In Chapter 7, the analysis units provide the basis for interpreting cultural changes that occurred in the project area during the past two millennia. There are significant differences between the types of artifacts and features found during different time periods. This variability in the archeological record is evidence of changing cultural patterns through time, and the inferences derived from the Lake Alan Henry data have important implications for understanding the Late Prehistoric and Protohistoric periods in the Caprock Canyonlands.

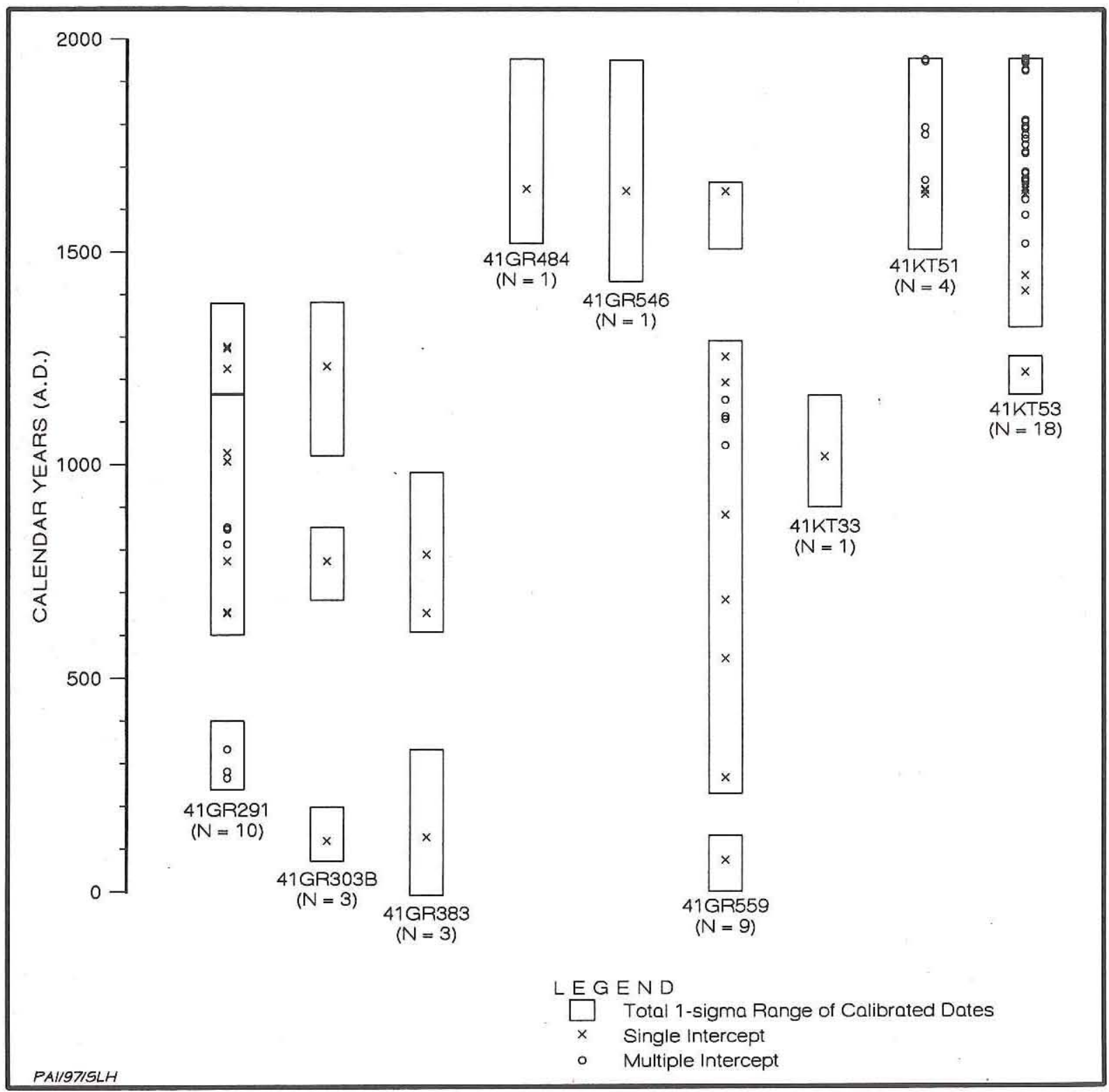

Figure 65. Graph of calibrated radiocarbon dates from data recovery sites at Lake Alan Henry (using data from Table 32). 
TABLE 42

SUMMARY OF ANALYSIS UNITS. FOR DATA RECOVERY SITES AT LAKE ALAN HENRY

\begin{tabular}{|c|c|c|c|c|}
\hline $\begin{array}{l}\text { Site No. and } \\
\text { Analysis Unit }\end{array}$ & Definition & $\begin{array}{l}\text { Estimated } \\
\text { Age, A.D. }\end{array}$ & $\begin{array}{l}\text { Cultural } \\
\text { Period }\end{array}$ & $\begin{array}{l}\text { Total No. of } \\
\text { Artifacts }\end{array}$ \\
\hline $\begin{array}{l}\text { 41GR291 } \\
\text { Burial Component }{ }^{2}\end{array}$ & $\begin{array}{l}\text { A single human interment (Feature 23) } \\
\text { and associated materials only. }\end{array}$ & $240-400$ & $\begin{array}{l}\text { Late } \\
\text { Prehistoric I }\end{array}$ & 2 \\
\hline $\begin{array}{l}41 \mathrm{GR} 291 \\
\text { Early Occupation }\end{array}$ & $\begin{array}{l}\text { All Block } 1 \text { materials and lower level } \\
\text { materials (ca. } 20-50 \mathrm{cmbs} \text { ) in Blocks } 2-5 \text {; } \\
\text { includes } 13-15 \text { features. Represents } \\
\text { multiple occupations of a residential base } \\
\text { camp with pithouse structure(s). }\end{array}$ & $600-1050$ & $\begin{array}{l}\text { Late } \\
\text { Prehistoric I }\end{array}$ & 1,445 \\
\hline $\begin{array}{l}41 G R 291 \\
\text { Late Occupation }\end{array}$ & $\begin{array}{l}\text { Upper level materials (ca. } 0-20 \mathrm{cmbs} \text { ) in } \\
\text { Blocks 2-5; includes at least two features. } \\
\text { Represents multiple occupations of a } \\
\text { residential base camp (with possible } \\
\text { surface houses). }\end{array}$ & $1150-1400$ & $\begin{array}{l}\text { Late } \\
\text { Prehistoric II }\end{array}$ & 1,916 \\
\hline $\begin{array}{l}\text { 41GR303B } \\
\text { Lower Zone }\end{array}$ & $\begin{array}{l}\text { All Block } 1 \text { materials and features below } \\
\text { and including the burned rock zone. } \\
\text { Represents multiple occupations of a } \\
\text { specialized plant processing campsite. }\end{array}$ & $70-850$ & $\begin{array}{l}\text { Late } \\
\text { Prehistoric I }\end{array}$ & 623 \\
\hline $\begin{array}{l}\text { 41GR303B } \\
\text { Upper Zone }\end{array}$ & $\begin{array}{l}\text { All Block } 1 \text { materials and features above } \\
\text { the burned rock zone. Represents multiple } \\
\text { occupations of a multifunctional campsite. }\end{array}$ & $1020-1380$ & $\begin{array}{l}\text { Late } \\
\text { Prehistoric II }\end{array}$ & $\begin{array}{r}1,207 \\
\ddots\end{array}$ \\
\hline $41 \mathrm{GR} 383$ & $\begin{array}{l}\text { All materials and features from data } \\
\text { recovery excavations. Represents multiple } \\
\text { occupations of a specialized plant } \\
\text { processing campsite. }\end{array}$ & $100-800$ & $\begin{array}{l}\text { Late } \\
\text { Prehistoric I }\end{array}$ & 2,160 \\
\hline $41 \mathrm{GR} 484^{2}$ & $\begin{array}{l}\text { All materials and features. Represents } \\
\text { multiple occupations of a special activity } \\
\text { campsite. }\end{array}$ & ca. 1650 & Protohistoric & 94 \\
\hline $41 \mathrm{GR} 546^{2}$ & $\begin{array}{l}\text { All materials and features. Represents } \\
\text { multiple sporadic occupations of } \\
\text { rockshelter as a temporary camp. }\end{array}$ & ca. 1650 & Protohistoric & 2 \\
\hline $\begin{array}{l}\text { 41GR559 } \\
\text { Lower Shelter }^{2}\end{array}$ & $\begin{array}{l}\text { All materials and features in the lower } \\
\text { stratigraphic zone. Represents multiple } \\
\text { sporadic occupations of rockshelter as a } \\
\text { multifunctional camp. }\end{array}$ & $1-1030$ & $\begin{array}{l}\text { Late } \\
\text { Prehistoric I }\end{array}$ & 116 \\
\hline $\begin{array}{l}\text { 41GR559 } \\
\text { Upper Shelter }^{2}\end{array}$ & $\begin{array}{l}\text { All materials and features in the upper } \\
\text { stratigraphic zone. Represents multiple } \\
\text { sporadic occupations of rockshelter as a } \\
\text { multifunctional camp. }\end{array}$ & $1000-1300$ & $\begin{array}{l}\text { Late } \\
\text { Prehistoric II }\end{array}$ & 37 \\
\hline $\begin{array}{l}41 \mathrm{GR} 559 \\
\text { Talus Area }\end{array}$ & $\begin{array}{l}\text { All materials and features in the talus area } \\
\text { (consists mainly of a bone midden). } \\
\text { Represents a refuse disposal area for } \\
\text { hunting group camped nearby (perhaps at } \\
\text { 41GR546). }\end{array}$ & ca. 1640 & Protohistoric & .16 \\
\hline
\end{tabular}




\begin{tabular}{|c|c|c|c|c|}
\hline \multicolumn{5}{|c|}{ Table 42, continued } \\
\hline $\begin{array}{l}\text { Site No. and } \\
\text { Analysis Unit }\end{array}$ & Definition & $\begin{array}{l}\text { Estimated } \\
\text { Age, A.D. }\end{array}$ & $\begin{array}{l}\text { Cultural } \\
\text { Period }\end{array}$ & $\begin{array}{l}\text { Total No. of } \\
\text { Artifacts }\end{array}$ \\
\hline $41 \mathrm{KT} 33$ & $\begin{array}{l}\text { All materials and features from data } \\
\text { recovery excavation block. Represents } \\
\text { multiple occupations of a multifunctional } \\
\text { campsite (or residential base?). }\end{array}$ & $890-1160$ & $\begin{array}{l}\text { Late } \\
\text { Prehistoric I }\end{array}$ & 2,055 \\
\hline 41KT51 & $\begin{array}{l}\text { All materials and features. Represents } \\
\text { multiple occupations of a multifunctional } \\
\text { campsite or residential base. }\end{array}$ & $1500-1700$ & Protohistoric & 4,490 \\
\hline $41 \mathrm{KT} 53$ & $\begin{array}{l}\text { All materials and features. Represents } \\
\text { multiple occupations of a residential base } \\
\text { (i.e., tipi encampment) }\end{array}$ & $1400-1750$ & Protohistoric $^{3}$ & 9,028 \\
\hline \multicolumn{5}{|c|}{$\begin{array}{l}\text { 1Estimated age is based on calibrated radiocarbon dates, stratigraphic contexts, and archeological associations. } \\
{ }^{2} \text { These analytical units did not yield sufficient artifacts to constitute statistically viable samples. }\end{array}$} \\
\hline
\end{tabular}




\section{ANALYSIS OF ARCHEOLOGICAL DATA FROM LAKE ALAN HENRY}

by Steve A. Tomka and Douglas K. Boyd

The data recovery investigations at Lake Alan Henry resulted in the accumulation of a large amount of archeological data. Individual site descriptions, along with definitions of analysis units within sites, are presented in Chapter 6. The chapters that follow view the Lake Alan Henry results from a regional perspective, first addressing the issue of late Holocene environments (Chapter 8) and then presenting cultural-historical reconstructions for the Late Archaic (Chapter 9), Late Prehistoric I (Chapter 10), and Late Prehistoric II and Protohistoric (Chapter 11) periods. This chapter looks at the data recovery information from Lake Alan Henry by itself, focusing on four particular issues: use intensity, temporally diagnostic artifacts, chipped and ground stone technology, and ceramic technology. The chronological sequence of the 14 analytical units discussed in this chapter is presented in Figure 66.

\section{USE INTENSITY INDEX}

One way to look at culture change through time is to translate excavated artifact data into a measure of the intensity of occupation that is comparable from site to site. Use intensity indexes have been used by researchers (e.g., Fields 1993) as an objective method of gauging overall intensity of human activities within individual site components/occupation periods.

The use intensity index used here is simple. It is the total number of stone artifacts/excavation area/duration of occupation (Table 43). The excavation area is the size of the area excavated manually (in $\mathrm{m}^{2}$ ), and the duration of occupation is an estimate of the total length of time, based on radiocarbon assays, represented by an analysis unit (in millennia).

As Fields (1993:234) states, "The primary assumption underlying the use of this index is that, despite variability in lithic technology through time and across space, there is a positive correlation between the number of artifacts deposited on a site and the aggregate length of time the site was occupied." There also are two secondary assumptions. One is that the estimated duration of occupation for any given analysis unit is accurate. For Lake Alan Henry, it is acknowledged that the degree of accuracy of these estimates varies. For example, the length of occupations at 41KT53 is established based on 18 radiocarbon dates from a good geomorphic context, while some of the estimates for other analysis units are based on single radiocarbon dates and less than ideal geomorphic contexts.

The other secondary assumption is that stone tools are the most useful class of material culture for this kind of comparison. While one can envision many intensive cultural activities that generate little or no stone residue, stone artifacts were an integral part of at least some of the activities conducted at all of the investigated Lake Alan Henry sites. Largely because of the nature of the archeological record, including differential preservation, and the techniques used to extract information from it, human activities involving stone artifacts are relatively easily recognized and interpreted. Thus, stone, and in particular chipped stone, artifact 


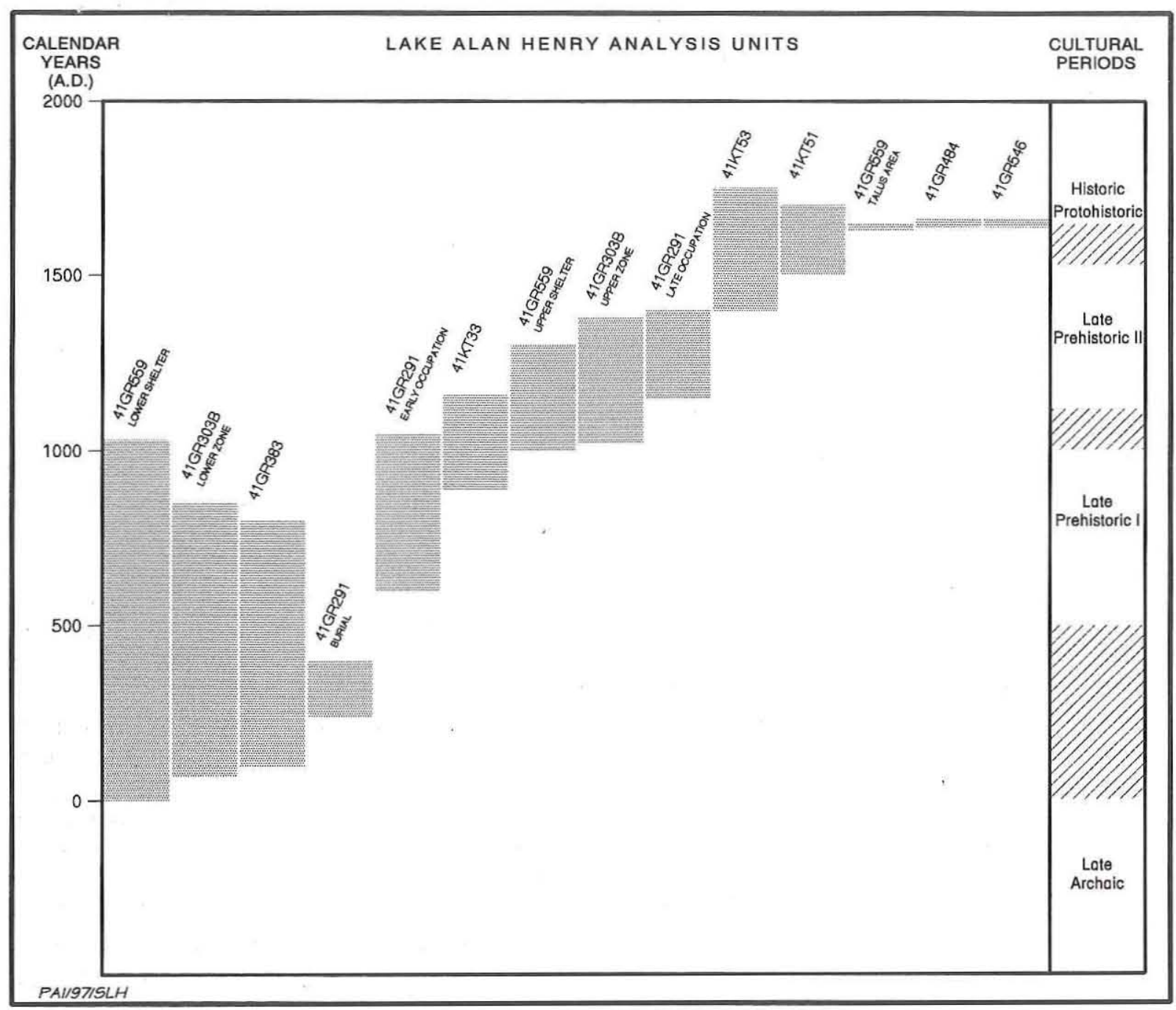

Figure 66. Schematic illustration showing chronological sequence of the analytical units defined for data recovery sites at Lake Alan Henry.

assemblages constitute the primary cultural residue that is directly comparable from site to site.

The use intensity index is considered to be a gross but quantifiable representation of the relative occupation intensity for comparing analysis units. Differences in the index value might relate to the following factors: (1) the duration of individual occupation episodes; (2) the frequency of reoccupation; (3) group size; and (4) site use and function. Interpretations of all of these are speculative to some degree, but the first three are especially difficult. The fourth variable, differential site use/function (i.e., the variable use of stone tools at different types of sites), is perhaps most evident in the index values for these sites, particularly when linked with interpretations of use/site function based on other lines of evidence.

Figure 67 illustrates the use intensity values for the analysis units. The rockshelters have the lowest use intensity of all three site types. Rockshelters at Lake Alan Henry are small, prohibiting activities involving many people or requiring much space. Thus, the low use intensity relates to site function in that fewer activities were carried out at these sites during all time periods. In spite of the variable duration of occupations (ranging from less than 100 years for the deposition of the 41GR559 talus area midden to ca. 1,000 years for the accumulation of the lower shelter deposits at 41GR559), the low use intensities are consistent with other evidence (i.e., stratigraphy and features) indicating that occupations of the two shelters were sporadic and short term and 
TABLE 43

USE INTENSITY FOR DATA RECOVERY ANALYSIS UNITS

\begin{tabular}{|l|c|c|c|c|}
\hline Site No./Analysis Unit & $\begin{array}{c}\text { Total No. of } \\
\text { Stone Artifacts }\end{array}$ & $\begin{array}{c}\text { Area of Manual } \\
\text { Excavation }\left(\mathrm{m}^{2}\right)\end{array}$ & $\begin{array}{c}\text { Duration of Site Occupation } \\
(1,000 \text { years })\end{array}$ & $\begin{array}{c}\text { Use Intensity } \\
\text { Index* }\end{array}$ \\
\hline 41GR291, Early Occupation & 1,431 & 94 & 0.45 & 34 \\
41GR291, Late Occupation & 1,901 & 87 & 0.25 & 87 \\
41GR303B, Lower Zone & 621 & 27 & 0.78 & 29 \\
41GR303B, Upper Zone & 1,206 & 27 & 0.36 & 124 \\
41GR383 & 2,158 & 53 & 0.70 & 58 \\
41GR484 & 60 & 22 & 0.10 & 27 \\
41GR546 & 2 & 7 & 0.10 & 8 \\
41GR559, Lower Component & 116 & 15 & 1.03 & 7 \\
41GR559, Upper Component & 37 & 18 & 0.30 & 15 \\
41GR559, Talus Area & 16 & 11 & 0.10 & 122 \\
41KT33 & 2,047 & 62 & 0.27 & 54 \\
41KT51 & 3,597 & 89 & 0.20 & 54 \\
41KT53 & 6,409 & 340 & 0.35 & \\
\hline *Use intensity index $=$ total artifacts/excavation area/duration of occupation. \\
\hline
\end{tabular}

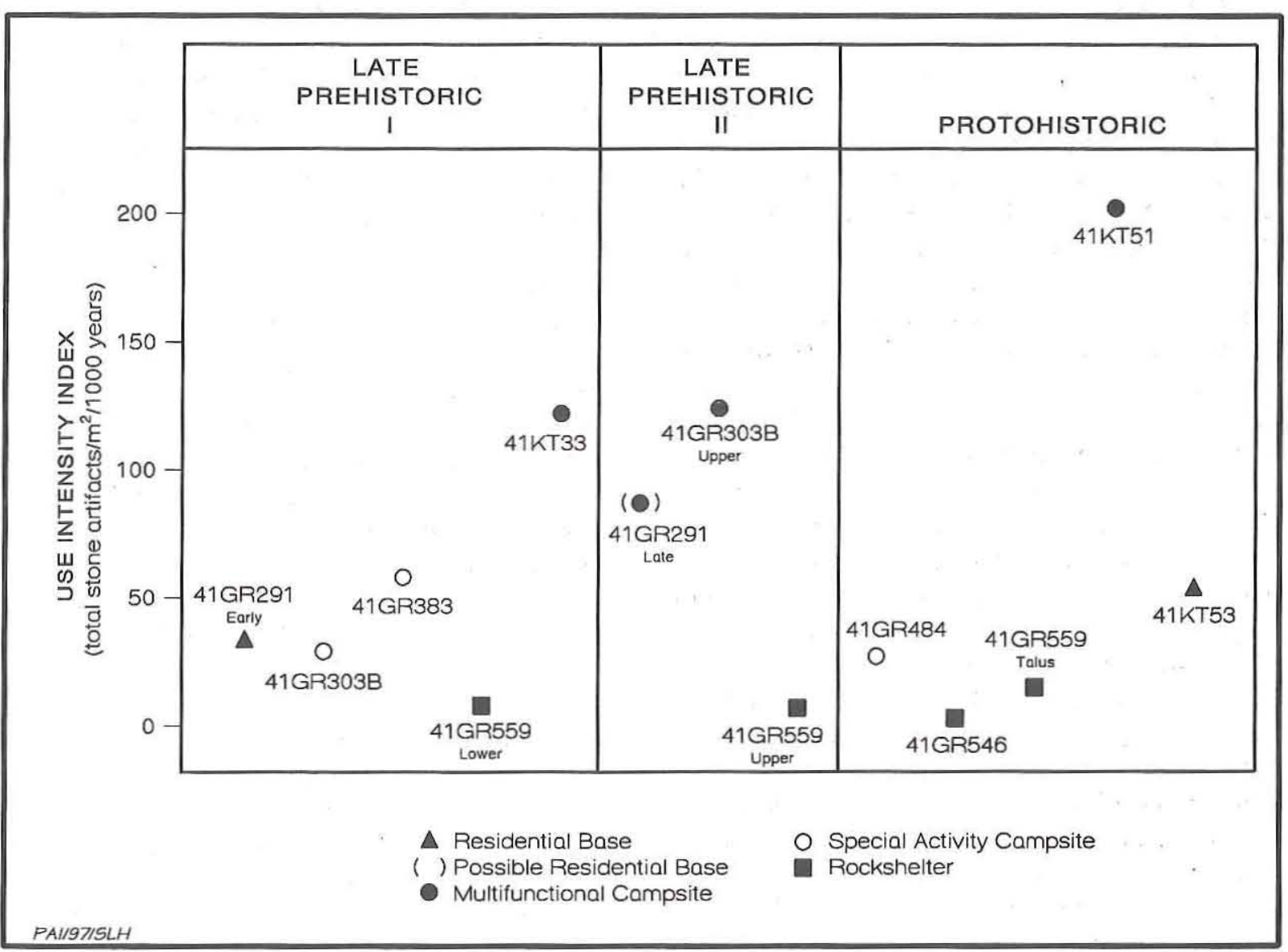

Figure 67. Comparison of use intensity indexes for data recovery analysis units by cultural period and site type. 
that the activities were very limited. This interpretation also is in general agreement with ethnographic evidence showing a general paucity of cultural residues in small rockshelters (e.g., Gamble and Boismier 1991). Based on their study of Australian Aborigines, Nicholson and Cane (1991:273-288) conclude that hunter-gatherers used small rockshelters primarily as ceremonial/sacred areas and as temporary habitations. In a general sense, this same pattern has been noted in the Lake Alan Henry area where rockshelters contain only rock art or sparse cultural debris.

Three special-activity sites, where other evidence (i.e., burned rock features and high frequencies of ground stone tools) indicates an emphasis on plant processing, have relatively low use intensity indexes. Although these sites were used more intensively than the rockshelters, they were used less intensively than the multifunctional campsites. The low use intensity at 41GR484 may be related, in part, to the short span of occupation (i.e., less than 100 years). The other two sites (the lower zones of 41GR303B and 41GR383) were occupied for much longer spans (ca. 700-780 years), and one suspects that their specialized functions might be important factors contributing to their low use intensity.

The multifunctional campsites exhibit variable use intensities that could be due to many factors, but the total duration of occupations is comparable for all of these sites (estimates range from 200-360 years). Assuming the other factors were approximately equal (i.e., group size and duration and frequency of occupation), it can be speculated that the activities conducted at multifunctional campsites included substantially more manufacture and maintenance of chipped stone tools than did activities at the specialized plant processing campsites. This interpretation is logical if hunting and butchering activities, which required more and better quality chipped stone tools, were less common at specialized plant processing campsites.

The two residential bases, where pithouse (41GR291, early) and tipi (41KT53) structures were evident, have low use intensity indexes that are comparable to those of the special activity campsites. The low values for these sites probably do not relate to total duration of occupations since both sites had multiple occupations over a period of $350-450$ years. Alternatively, it is likely that specialized site functions played a role in limiting the amount of stone artifacts deposited at these sites, particularly at
41GR291. Other archeological evidence (i.e., plant processing and storage features, macrobotanical remains, and multiple grinding tool kits) indicates that intensive plant processing was the dominant activity represented in the 41GR291 early occupation period. Consequently, it is not surprising that the index for the pithouse occupation period at 41GR291 is comparable to the values for the specialized plant processing campsites.

Boyd et al. (1993:203-235) present a detailed discussion of the complexities of interpreting the archeological remains from $41 \mathrm{KT} 53$, and it is likely that the site's low use intensity is related to a combination of factors. Archeological evidence indicates that the range of activities at this site may have been somewhat limited and specialized. While evidence for plant processing is minimal and hunting/butchering activities are not particularly well represented, hide processing seems to have been an extremely important activity as indicated by the high frequency of end scrapers and unifacial rejuvenation debitage. The manufacture and maintenance of end scrapers generates relatively little lithic waste compared to most bifacial reduction, and the low index value can be explained if hunting activities were limited while hide processing was predominant. If the people who lived at $41 \mathrm{KT} 53$ in the seventeenth and early eighteenth centuries had access to metal tools and horses, which seems likely given the presence of large amounts of Puebloan pottery and some majolica, then the picture is even more complex. The greater mobility afforded by the use of horses may have affected hunting and lithic procurement strategies in a way that resulted in less stone residue being deposited at the site. The use of metal arrow points for hunting and metal knives for butchering would have further limited the amount of stone residue.

\section{TEMPORALLY DIAGNOSTIC ARTIFACTS}

In terms of material culture, not all of the analysis units yielded comparable data. Six units have artifact samples that are too small for most intersite comparison and valid statistical analyses. These analysis units were excluded from consideration; the other eight were grouped according to their ages (Table 44). Four analysis units date to the Late Prehistoric I period, two date to the Late Prehistoric II period, and two date to the Protohistoric 


\begin{tabular}{|c|c|c|c|c|c|}
\hline \multicolumn{6}{|c|}{$\begin{array}{l}\text { SUMMARY OF ARTIFACT ASSEMBLAGES FOR SELECTED DATA RECOVERY } \\
\text { ANALYSIS UNITS BY CULTURAL PERIOD }\end{array}$} \\
\hline \multirow[b]{2}{*}{ Site and Analysis Unit } & \multicolumn{4}{|c|}{ No. of Artifacts } & \multirow[b]{2}{*}{ Totals } \\
\hline & Stone $^{1}$ & Ceramics & Other $^{2}$ & Historic $^{3}$ & \\
\hline \multicolumn{6}{|c|}{ LATE PREHISTORIC I } \\
\hline $\begin{array}{l}\text { 41GR291, Early Occupation } \\
\text { 41GR303B, Lower Zone } \\
\text { 41GR383 } \\
\text { 41KT33 }\end{array}$ & $\begin{array}{r}1,432 \\
622 \\
2,158 \\
2,047\end{array}$ & $\begin{array}{l}8 \\
0 \\
0 \\
6\end{array}$ & $\begin{array}{l}5 \\
1 \\
2 \\
2\end{array}$ & $\begin{array}{l}0 \\
0 \\
0 \\
0\end{array}$ & $\begin{array}{r}1,445 \\
623 \\
2,160 \\
2,055\end{array}$ \\
\hline Totals: & 6,259 & 14 & 10 & 0 & 6,283 \\
\hline Percents: & 99.6 & 0.2 & 0.2 & 0.0 & 100 \\
\hline \multicolumn{6}{|c|}{ LATE PREHISTORIC II } \\
\hline $\begin{array}{l}\text { 41GR291, Late Occupation } \\
\text { 41GR303B, Upper Zone }\end{array}$ & $\begin{array}{l}1,901 \\
1,207\end{array}$ & $\begin{array}{r}11 \\
0\end{array}$ & $\begin{array}{l}4 \\
0\end{array}$ & $\begin{array}{l}0 \\
0\end{array}$ & $\begin{array}{l}1,916 \\
1,207\end{array}$ \\
\hline Totals: & 3,108 & 11 & 4 & 0 & 3,123 \\
\hline Percents: & 99.5 & 0.4 & 0.1 & 0.0 & 100 \\
\hline \multicolumn{6}{|c|}{ PROTOHISTORIC } \\
\hline $\begin{array}{l}41 \mathrm{KT} 51 \\
41 \mathrm{KT} 53\end{array}$ & $\begin{array}{l}3,597 \\
6,409\end{array}$ & $\begin{array}{r}887 \\
2,595\end{array}$ & $\begin{array}{r}4 \\
13\end{array}$ & $\begin{array}{r}2 \\
11\end{array}$ & $\begin{array}{l}4,490 \\
9,028\end{array}$ \\
\hline Totals: & 10,006 & 3,482 & 17 & 13 & 13,518 \\
\hline Percents: & 74.0 & 25.8 & 0.1 & 0.1 & 100 \\
\hline \multicolumn{6}{|c|}{$\begin{array}{l}{ }^{1} \text { Stone artifacts consist of all modified lithics (chipped, battered, and ground stones). } \\
{ }^{2} \text { Other artifacts consist of modified bones and shells, modified hematite and limonite, a stone (turquoise) } \\
\text { bead, and a manuport that probably functioned as a tool. }\end{array}$} \\
\hline
\end{tabular}

period. These are the primary focus of intersite material culture comparisons in this chapter.

Dart points do not occur in large numbers, but they were more common in the Late Prehistoric I period $(n=3)$ than later (Late Prehistoric II, $n=1$; Protohistoric, $n=1)$. On the other hand, arrow points (typed, untyped, and untypeable) outnumber darts points 5 to $1(\mathrm{n}=15), 18$ to $1(\mathrm{n}=18)$, and 50 to $1(\mathrm{n}=50)$ in the Late Prehistoric I, II, and Protohistoric periods, respectively.

Although a solid projectile point type sequence has not been established for the Texas PanhandlePlains region, it is generally accepted that cornernotched and some stemmed (i.e., Scallorn, Scallorn- like, and Deadman's) arrow points precede small unnotched triangular, side-notched, and single basenotched (i.e., Fresno, Washita, Harrell, Garza, and Lott) arrow points. Of the 91 points recovered from the eight selected analysis units, 48 can be categorized into one of the three classes of points: dart, early arrow, and late arrow. The 5 dart points consist of 1 Darl, 3 untyped expanding stem, and 1 untyped fragment. The 14 early arrow points consist of specimens classified as Scallorn, Granbury-like, and untyped corner notched. The 29 late arrow points consist of specimens typed as Fresno, Harrell, Lott-like, Washita, untyped triangular, and untyped triangular side notched and multi-side notched. The 
remaining 43 specimens are untypeable arrow point fragments.

Although the sample is small, the data show an expected pattern (Figure 68). The changing frequencies of these broad morphological groups through time support the following observations and interpretations: (1) dart points were present primarily during the Late Prehistoric I period, and they may have still been in use during this time; (2) dart points were rare in subsequent periods, probably representing heirlooms or scavenged artifacts; (3) untypeable arrow point fragments were common in the Late Prehistoric I period and steadily increased in frequency in later periods; (4) early arrow points were most common in the Late Prehistoric I period and were still the dominant form in the Late Prehistoric II; (5) late arrow points may have appeared toward the end of the Late Prehistoric I period, although the single occurrence could be misleading; and (6) the frequency of late arrow points increased in the Late Prehistoric II period, and they were clearly the dominant point form by the Protohistoric period.

One point, an unusually large Scallorn arrow point associated with the burial component at 41GR291 (Boyd et al. 1994:Figure 21d), is from a well-dated context. The specimen is associated with a radiocarbon date of A.D. 265-415, placing its use in the transitional Archaic period. Morphologically, the specimen is an early arrow point that looks very similar to corner-notched Late Archaic dart points. This find has important implications for understanding the transitional Archaic period in the Texas Panhandle-Plains (see Chapter 9).

Ceramics, another diagnostic time marker, are represented in all three time periods (see Table 44). Pottery was relatively rare in the Late Prehistoric I and II periods, but its use increased dramatically during the Protohistoric period. The types of pottery used changed during the Late Prehistoric and Proto-

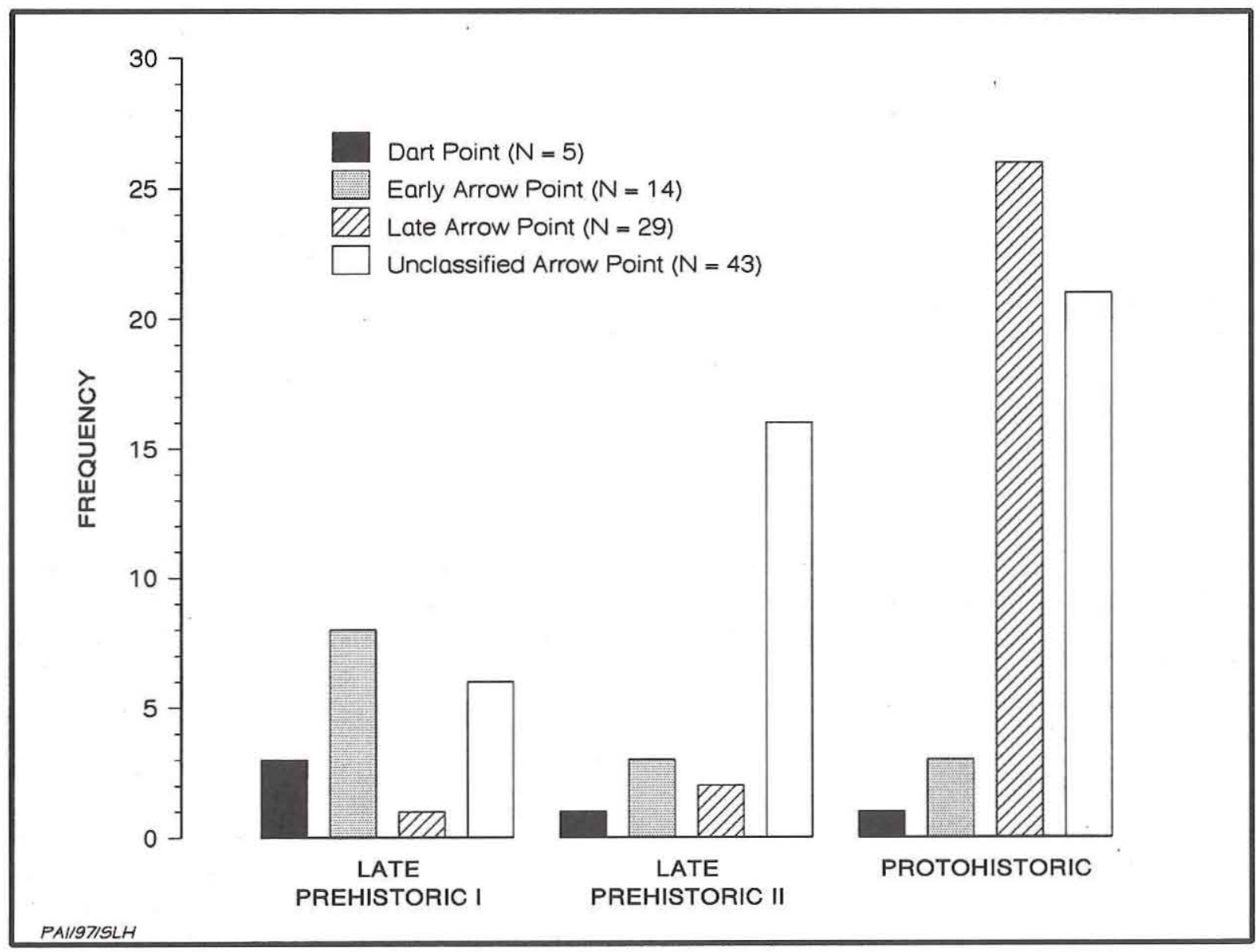

Figure 68. Comparison of projectile point frequencies for selected analysis units by time period. Total sample $=91$. 
historic periods, and the Protohistoric period is characterized by a significant increase in the variability of ware types and source areas (see Ceramic Technology).

The only other diagnostic time markers are the 13 artifacts of European manufacture, origin, or influence found in the Protohistoric sites (see Table 45). These consist of four probable native-made gunflints, five majolica sherds, a lead ball, an iron fragment, and two glass beads. Two additional items, a modified bovid horn corn (used as a tipi stake) and an unmodified horse tooth, suggest that the occupations of the Protohistoric sites extended into the mid to late seventeenth century (Boyd et al. 1993:208).

A few other chipped stone tool classes have been proposed as diagnostic markers. Beveled knives (or Harahey knives) are considered to be a diagnostic tool of the Late Prehistoric II and Protohistoric periods, but only two specimens were recovered from one Protohistoric site (41KT53). Distinctive Plains-style snub-nosed end scrapers are generally very common in the Late Prehistoric II and Protohistoric periods, but they are not exclusively diagnostic of this time period. Numerous specimens were recovered, and, as expected, they are most common in the Protohistoric sites. Gouges have been considered to be diagnostic Archaic tools by some researchers, but this notion is challenged based on numerous occurrences of specimens in Late Prehistoric I sites (see Chapter 10).

\section{CHIPPED AND GROUND STONE TECHNOLOGY}

As discussed in Chapter 4, the research design for the project presented a number of expectations regarding the nature of prehistoric chipped and ground stone tool assemblages. The expectations can be grouped under three major headings: (1) assemblage composition (e.g., the richness and evenness of the tool classes, morphofunctional categories of artifact types); (2) local vs. nonlocal raw material procurement and use; and (3) tool design. This section characterizes the chipped and ground stone technologies of the Late Prehistoric I, Late Prehistoric II, and Protohistoric period analysis units on the basis of these three aspects.

\section{Assemblage Composition}

Because the analyses of the artifact collections were conducted within the same analytical framework and by the same analysts, the comparison of assemblages is not fraught with problems of inconsistent classification as is often the case when such regional studies are attempted (cf. Shott 1990). Nonetheless, because some artifact subcategories (e.g., end scrapers, side scrapers, choppers, wedges) are small, it is necessary to lump them into moreinclusive groupings. Eleven artifact categories are employed: arrow points, dart points, bifaces, perforators, unifaces, gouges, edge-modified flakes, cobble tools, cores, hammerstones, and ground stones. Tables 45-47 show the breakdown of artifact categories within the analysis units grouped by time period, providing the basis for an examination of differences and similarities in assemblage composition.

\section{Richness and Evenness}

The richness of the four Late Prehistoric I analysis units ranges from 8 to 11 artifact categories with a mean of 9.5 categories $(\sigma=1.3)$. The assemblages from the two Late Prehistoric II components also have a mean richness of 9.5 artifact categories $(\sigma=0.71)$, while the two Protohistoric assemblages have a somewhat lower mean richness $(\bar{x}=8.5, \sigma=0.71)$. Although a regression plot of the common $\log$ (base 10) of richness against sample size indicates no relationship between the two $\left(R^{2}=\right.$ $.1854, p=.2861)$, it is still important to compare individual assemblages to determine which are abnormally rich or poor in numbers of artifact categories. This can be accomplished by comparing the richness of each assemblage to the expected richness of assemblages of various sizes drawn at random from the combined tool collections from the eight analysis units (see Kintigh 1984). This is the basic logic behind the Monte Carlo simulation approach developed by Kintigh $(1984,1989)$ to account for the effect of sample size on richness and evenness in archeological assemblages. In addition, the technique can be used to evaluate the actual diversity characteristics of samples relative to their expected richness and evenness.

Figure 69 is a plot of the number of artifact categories against sample size for the eight assemblages. Figure 70 shows the plot of evenness against sample size. The plots were generated using the software programs for quantitative analysis developed by Kintigh (1992). The solid lines 


\begin{tabular}{|c|c|c|c|c|c|}
\hline & $\begin{array}{r}\text { IPARISON OF AR } \\
\text { WITHIN TH }\end{array}$ & $\begin{array}{l}\text { TABLE } 45 \\
\text { ACT CATEG } \\
\text { ATE PREHIS }\end{array}$ & $\begin{array}{l}\text { S BY AN } \\
\text { IC I SAM }\end{array}$ & S UNIT & \\
\hline Artifact Category & $\begin{array}{c}\text { 41GR291 } \\
\text { Early Occupation }\end{array}$ & $\begin{array}{c}\text { 41GR303B } \\
\text { Lower Zone }\end{array}$ & $41 \mathrm{GR} 383$ & $41 \mathrm{KT} 33$ & Totals \\
\hline $\begin{array}{l}\text { Arrow Points } \\
\text { Dart Points } \\
\text { Perforators } \\
\text { Gouges } \\
\text { Bifaces } \\
\text { Cobble Tools } \\
\text { Unifaces } \\
\text { Cores } \\
\text { Edge-Modified Flakes } \\
\text { Hammerstones } \\
\text { Ground Stones }\end{array}$ & $\begin{array}{r}4 \\
1 \\
1 \\
3 \\
5 \\
17 \\
31 \\
33 \\
16 \\
1 \\
78\end{array}$ & $\begin{array}{r}0 \\
1 \\
0 \\
4 \\
4 \\
13 \\
18 \\
22 \\
10 \\
0 \\
11\end{array}$ & $\begin{array}{r}1 \\
1 \\
0 \\
2 \\
25 \\
10 \\
11 \\
29 \\
56 \\
5 \\
50\end{array}$ & $\begin{array}{r}10 \\
0 \\
2 \\
0 \\
6 \\
10 \\
27 \\
40 \\
137 \\
4 \\
36\end{array}$ & $\begin{array}{r}15 \\
3 \\
3 \\
9 \\
40 \\
50 \\
87 \\
124 \\
219 \\
10 \\
175\end{array}$ \\
\hline Totals: & 190 & 83 & 190 & 272 & 735 \\
\hline
\end{tabular}

\begin{tabular}{|l|r|r|r|}
\hline \multicolumn{3}{|c|}{ TABLE 46 } \\
\multicolumn{3}{|c|}{ COMPARISON OF ARTIFACT CATEGORIES BY ANALYSIS UNIT } \\
WITHIN THE LATE PREHISTORIC II SAMPLE \\
\hline Artifact Category & 41GR291, Late Occupation & 41GR303B, Upper Zone & Totals \\
\hline Arrow Points & 18 & 3 & 21 \\
Dart Points & 0 & 1 & 1 \\
Perforators & 2 & 0 & 2 \\
Gouges & 9 & 6 & 15 \\
Bifaces & 11 & 4 & 15 \\
Cobble Tools & 15 & 4 & 19 \\
Unifaces & 48 & 29 & 77 \\
Cores & 31 & 19 & 50 \\
Edge-Modified Flakes & 19 & 22 & 41 \\
Hammerstones & 2 & 0 & 2 \\
Ground Stones & 18 & 5 & 23 \\
\hline Totals: & 173 & 93 & 266 \\
\hline
\end{tabular}

represent the mean richness and evenness, respectively, of 500 samples of distinct size (e.g., 1, 2, 3, $4,5,6,7,8,9,10,20,30,40,50$, etc.) drawn from the combined population of artifacts $(n=1,471)$. The broken lines define the area containing 90 percent of the mean richness and evenness values of the 500 trials. The symbols show the actual richness and evenness values of the eight archeological assemblages.

The great majority of the assemblages fall within the 90 percent confidence interval. The single exception is the assemblage from the early occupation of 41GR291, which is richer than expected. The higher-than-expected richness of this assemblage suggests that the site was the locus of a greater range of activities than other sites in the sample. Although no assemblages have lower-than-expected richness, the values of four analysis units - the lower zone of $41 \mathrm{GR} 303 \mathrm{~B}, 41 \mathrm{KT} 33$, and the two Protohistoric sites - fall near the lower-than-expected 


\begin{tabular}{|l|r|r|r|}
\hline \multicolumn{4}{|c|}{ TABLE 47 } \\
\multicolumn{4}{|c|}{ COMPARISON OF ARTIFACT CATEGORIES BY ANALYSIS UNIT } \\
WITHIN THE PROTOHISTORIC SAMPLE \\
\hline Artifact Category & 41 KT51 & 41 KT53 & Totals \\
\hline Arrow Points & 21 & 29 & 50 \\
Dart Points & 0 & 1 & 1 \\
Perforators & 3 & 0 & 3 \\
Gouges & 0 & 0 & 0 \\
Bifaces & 6 & 22 & 28 \\
Cobble Tools & 0 & 1 & 1 \\
Unifaces & 36 & 8 & 155 \\
Cores & 1 & 89 & 9 \\
Edge-Modified Flakes & 33 & 3 & 4 \\
Hammerstones & 1 & 80 & 97 \\
Ground Stones* & 17 & 352 & 470 \\
\hline Totals: & 118 & & \\
\hline$*$ Does not include flakes removed from ground stone tools $(41 \mathrm{KT} 51, \mathrm{n}=3 ; 41 \mathrm{KT} 53, \mathrm{n}=31)$. \\
\hline
\end{tabular}

90 percent confidence interval.

The assemblages from the early occupation at 41GR291, 41KT33, and the two Protohistoric sites have lower-than-expected evenness. The assemblage from the late occupation at 41GR291 has a higherthan-expected evenness. One of the two Late Prehistoric I assemblages with lower-than-expected evenness, 41KT33, also has lower-than-expected richness. The other Late Prehistoric I assemblage with lower-than-expected evenness, the early occupation from 41GR291, has higher-than-expected richness. The two Protohistoric assemblages with lowerthan-expected evenness are also characterized by lower-than-expected richness.

The higher-than-expected richness and lowerthan-expected evenness of the early occupation assemblage from 41GR291 might be representative of an occupation involving a significant residential component but focusing on or specializing in the exploitation of a limited number or range of resources. The data are consistent with the low use intensity index (34) and are indicative of short-term seasonal occupations and infrequent but seasonspecific reoccupations associated with the exploitation of a specific resource. The low richness and nearly average evenness of the assemblage from 41GR303B could represent an occupation associated with a narrow range of activities and a weak residential component. These data, in conjunction with the low use intensity index (29), suggest short occupations with infrequent reoccupation in the pursuit of a narrow range of resources. The assemblage from $41 \mathrm{GR} 383$, with its average richness but lower-than-average evenness, is characteristic of residential sites occupied during the exploitation of a specific or very narrow range of resources. The moderately high use intensity index (58) suggests frequent site reoccupation or longer individual stays characterized by relatively consistent site use and function. The lower-than-expected evenness of the $41 \mathrm{KT} 33$ assemblage coupled with its low richness suggest a specialized occupation focusing on a narrow range of activities and a weak residential component. In light of these data, the high use intensity index (122) suggests short individual occupations and frequent reoccupation with unchanging site use and function.

The two Late Prehistoric II assemblages are characterized by average richness and average or greater-than-expectedevenness. These characteristics are suggestive of relatively generalized tool assemblages used in the procurement and processing of a broad range of resources, accompanied by a strong residential component (base camps). Given the moderate (41GR291, Late Occupation $=87)$ and high $(41 \mathrm{GR} 303 \mathrm{~B}$, Upper Zone $=124)$ use intensity values, the two analysis units might represent long individual occupations and/or frequent reoccupation associated with the exploitation of a broad range of resources. 


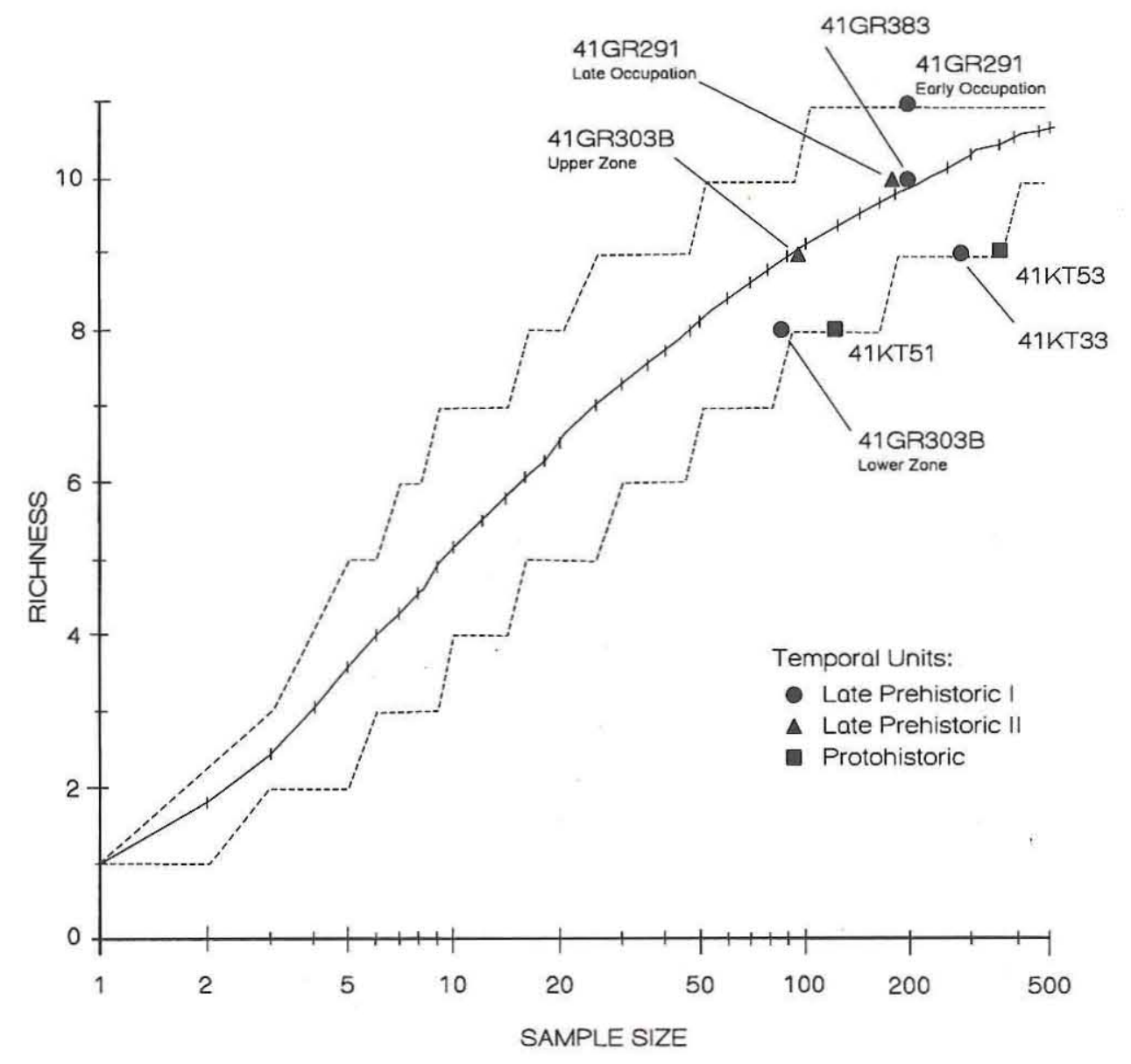

PAII97ISLH

Figure 69. Monte Carlo simulation of assemblage richness vs. sample size.

The two Protohistoric assemblages are characterized by below-average richness and lower-thanexpected evenness. These characteristics are consistent with a relatively narrow and specialized range of activities associated with only a weak residential component. These characteristics, in conjunction with moderate $(41 \mathrm{KT} 53=54)$ to high $(41 \mathrm{KT} 53=$ 202) use intensity values, suggest relatively short occupations and infrequent reoccupation associated with the procurement and/or processing of a specific resource.

The fact that all four of the Late Prehistoric I and both of the Late Prehistoric II assemblages differ in terms of richness and evenness while the two Protohistoric assemblages are alike suggests greater intersite differences during the earlier periods. These might imply that the project area was utilized in a more varied manner during the Late Prehistoric I and II periods than during the Protohistoric period. Assuming that the variability in land-use practices is related to the types and structure of the subsistence resources exploited, it is likely that the Late Prehistoric I and II populations of the project area utilized a broader range of resources and were present within the project area for a greater proportion of the annual round than Protohistoric groups. The lower-than-expected richness and evenness of the two Protohistoric assemblages implies the utilization of a narrower range of resources and the more limited presence of groups in the project area during the annual subsistence round. 


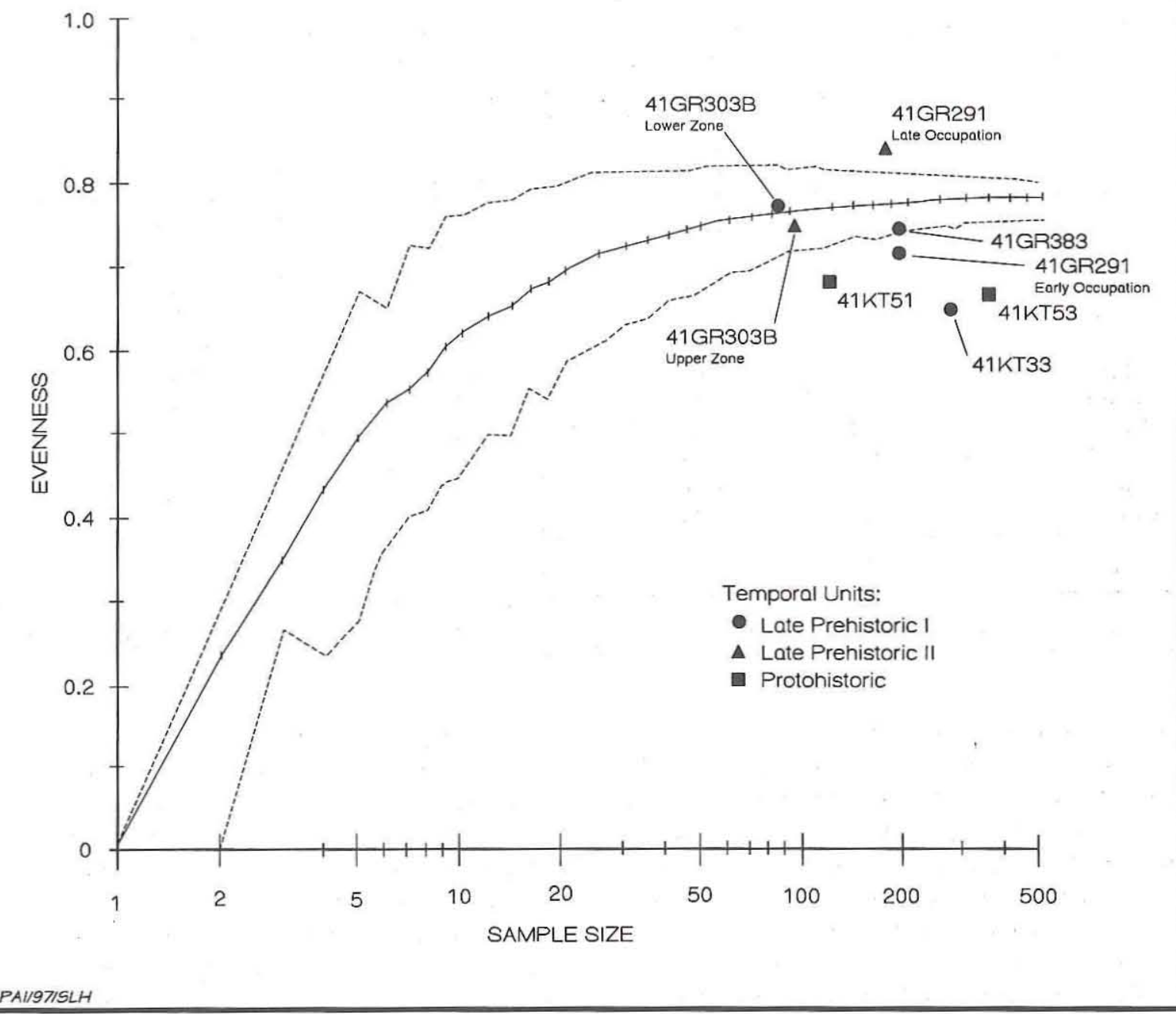

Figure 70. Monte Carlo simulation of assemblage evenness vs. sample size.

\section{Morphofunctional Categories}

Given the broad differences in land-use patterns outlined above, the next task is to identify the differences in assemblage composition between analysis units. Although the length of individual occupation episodes and changes in the economic zonation of the landscape strongly condition the types of artifacts discarded at specific locations (Binford 1983; Schiffer 1975; Shott 1989), assemblage composition can aid in the definition of the use (e.g., activities carried out) and function (e.g., the role of the site within the regional land-use pattern) of sites.

The comparison of the frequencies of the different artifact categories by time period results in a significant chi-square value $\left(X^{2}=272.39\right.$, $p<.0001)$. The adjusted standardized residuals allow one to examine the deviations between observed and expected values in individual cells (Everitt 1977). This helps identify the specific artifact categories responsible for differences in assemblage composition.

Table 48 shows the artifact assemblages and adjusted standardized residuals by time period. A number of the adjusted standardized residuals are significant at the .05 level. The combined Late Prehistoric I collection is characterized by an overrepresentation of cobble tools, cores, edge-modified flakes, and ground stone tools and an underrepresentation of arrow points and unifaces. The combined Late Prehistoric II collection is characterized by an 


\begin{tabular}{|c|c|c|c|c|c|c|c|}
\hline \multirow[b]{3}{*}{ Artifact Category } & \multicolumn{6}{|c|}{$\begin{array}{c}\text { TABLE } 48 \\
\text { BINED ARTIFACT ASSEMBLAGES BY TIME PERIOD }\end{array}$} & \multirow[b]{3}{*}{ Totals } \\
\hline & \multicolumn{2}{|c|}{ Late Prehistoric I } & \multicolumn{2}{|c|}{ Late Prehistoric II } & \multicolumn{2}{|c|}{ Protohistoric } & \\
\hline & No. & $\begin{array}{l}\text { Adjusted } \\
\text { Residuals }\end{array}$ & No. & $\begin{array}{l}\text { Adjusted } \\
\text { Residuals }\end{array}$ & No & $\begin{array}{l}\text { Adjusted } \\
\text { Residuals }\end{array}$ & \\
\hline Arrow Points & 15 & -6.22 & 21 & +1.57 & 50 & +5.37 & 86 \\
\hline Dart Points & 3 & +0.45 & 1 & +0.11 & 1 & -0.57 & 5 \\
\hline Perforators & 3 & -0.71 & 2 & +0.51 & 3 & +0.34 & 8 \\
\hline Gouges & 9 & -1.23 & 15 & +5.70 & 0 & -3.38 & 24 \\
\hline Bifaces & 40 & -0.33 & 15 & -0.00 & 28 & +0.36 & 83 \\
\hline Cobble Tools & 50 & +3.68 & 19 & +2.02 & 1 & -5.61 & 70 \\
\hline Unifaces & 87 & -9.16 & 77 & +3.18 & 155 & +7.20 & 319 \\
\hline Cores & 124 & +5.14 & 50 & +3.47 & 9 & -8.38 & 183 \\
\hline Edge-Modified Flakes & 219 & +3.35 & 41 & -4.34 & 122 & -0.01 & 382 \\
\hline Hammerstones & 10 & +1.01 & 2 & -0.58 & 4 & -0.60 & 16 \\
\hline Ground Stones & 175 & +3.59 & 23 & -5.13 & 97 & +0.38 & 295 \\
\hline Totals: & 735 & . & 266 & & 470 & & 1,471 \\
\hline
\end{tabular}

overrepresentation of gouges, cobble tools, unifaces, and cores and an underrepresentation of edgemodified flakes and ground stone tools. Finally, the combined assemblages from the two Protohistoric sites are characterized by an overrepresentation of arrow points and unifaces and an underrepresentation of gouges, cobble tools, and cores.

These patterns suggest that the activities at Late Prehistoric I sites tended to emphasize the processing of plant resources (e.g., ground stones) and the refurbishing of worn ground stone tools (e.g., cobble tools [Boyd et al. 1994:76-79, 145]). Activities involving expedient tools (e.g., edge-modified flakes) were also common as was lithic raw material procurement and processing (e.g., cores). The underrepresentation of arrow points may be related more directly to the age of the components vis-à-vis the appearance of the bow and arrow rather than the reduced role of hunting. However, the small number of dart points may indicate that, at least at the investigated sites, animal protein procurement was less important than in subsequent periods. The underrepresentation of unifaces in the combined Late Prehistoric I collection supports the conclusion on animal procurement, assuming that unifaces were used in the processing of animal products.

The characteristics of the Late Prehistoric II collection suggest a shift in subsistence practices.
The overrepresentation of unifaces and the tendency for arrow points to occur in higher-than-expected numbers suggest an increased emphasis on hunting. In addition, the overrepresentation of gouges might indicate activities associated with wood working and, potentially, tool manufacture and/or repair. And finally, the overrepresentation of cores might indicate the continued emphasis on lithic tool manufacture, while the underrepresentation of edge-modified flakes (and overrepresentation of formal unifaces) might represent a shift in the organization of technology toward an emphasis on reusable curated tools. This shift might relate to a greater degree of planning within the annual subsistence round. More planning might also reflect the need for readily available tools in case the resources procured and/or processed were encountered unexpectedly.

The strong overrepresentation of arrow points and unifaces in the combined Protohistoric collection appears to represent a heavy reliance on bow-andarrow hunting and hide processing. The underrepresentation of gouges, cobble tools, and cores suggests a de-emphasis of activities not associated with animal protein procurement and processing, particularly in contrast to the Late Prehistoric I period.

These patterns most likely represent differences in subsistence practices, raw material procurement strategies, and differences in the organization of 
technology between the three time periods. It is also likely that some of the differences reflect differences in the site types contained in the sample for each period. That is, while the combined artifact assemblages represent a summary perspective on the nature of the activities during a particular time period, some differences can be noted between sites within time periods as well. For instance, the adjusted standardized residuals in Table 49 show numerous differences in artifact composition between the four Late Prehistoric I analysis units. The artifact assemblage from 41GR291 is characterized by an underrepresentation of bifaces and edgemodified flakes and overabundance of unifaces and ground stone tools. The 41GR303B assemblage is characterized by an overrepresentation of gouges, cobble tools, unifaces, and cores. With the exception of unifaces, these tool types are not significantly overabundant at any of the other sites. Interestingly, the two assemblages that have higher-than-expected formal unifacial tools have lower-than-expected edge-modified flakes. This suggests a greater reliance on formal curated tools at 41GR291 and 41GR303B compared to 41KT33. In the latter case, edge-modified flakes constitute about 50 percent of the tool collection. The overrepresentation of arrow points and the primarily expedient nature of the $41 \mathrm{KT} 33$ assemblage suggest an emphasis on hunting and the performance of ancillary maintenance and food processing activities within an organizational stance characterized by less planning than the occupations at 41GR291 and 41GR303B. With the exception of the underrepresentation of unifaces and overrepresentation of bifaces, the assemblage from 41 GR383 does not seem to differ significantly from those of the other sites.

The two Late Prehistoric II assemblages are more alike than different (Table 50), except that edge-modified flakes are overabundant at 41GR303B and arrow points are overrepresented at 41GR291. Although ground stone tools are underrepresented at 41GR303B, this difference is not statistically significant at the .05 level. The two Protohistoric assemblages are similar to one another as well (Table 51). The two collections differ only in the overabundance of arrow points and perforators at $41 \mathrm{KT} 51$ and their scarcity at 41KT53. Although ground stone tools are somewhat underrepresented at $41 \mathrm{KT} 51$, this difference is not statistically significant.

TABLE 49

COMPARISON OF LATE PREHISTORIC I ARTIFACT ASSEMBLAGES

\begin{tabular}{|c|c|c|c|c|c|c|c|c|c|}
\hline \multirow[b]{2}{*}{$\begin{array}{l}\text { Artifact } \\
\text { Category }\end{array}$} & \multicolumn{2}{|c|}{$\begin{array}{l}\text { 41GR291 } \\
\text { Early Component }\end{array}$} & \multicolumn{2}{|c|}{$\begin{array}{l}\text { 41GR303B } \\
\text { Lower Zone }\end{array}$} & \multicolumn{2}{|c|}{$41 \mathrm{GR} 383$} & \multicolumn{2}{|c|}{$41 \mathrm{KT} 33$} & \multirow{2}{*}{ Totals } \\
\hline & No. & $\begin{array}{l}\text { Adjusted } \\
\text { Residuals }\end{array}$ & No. & $\begin{array}{l}\text { Adjusted } \\
\text { Residuals }\end{array}$ & No. & $\begin{array}{l}\text { Adjusted } \\
\text { Residuals }\end{array}$ & No. & $\begin{array}{l}\text { Adjusted } \\
\text { Residuals }\end{array}$ & \\
\hline Arrow Points & 4 & +0.07 & 0 & -1.40 & 1 & -1.71 & 10 & +2.40 & 15 \\
\hline Dart Points & 1 & +0.30 & 1 & +1.21 & 1 & +0.30 & 0 & -1.33 & 3 \\
\hline Perforators & 1 & +0.30 & 0 & -0.62 & 0 & -1.02 & 2 & +1.07 & 3 \\
\hline Gouges & 3 & +0.52 & 4 & +3.16 & 2 & -0.25 & 0 & -2.31 & 9 \\
\hline Bifaces & 5 & -1.98 & 4 & -0.27 & 25 & +5.44 & 6 & -2.96 & 40 \\
\hline Cobble Tools & 17 & +1.36 & 13 & +3.40 & 10 & -0.98 & 10 & -2.58 & 50 \\
\hline Unifaces & 31 & +2.22 & 18 & +2.95 & 11 & -3.00 & 27 & -1.23 & 87 \\
\hline Cores & 33 & +0.21 & 22 & +2.49 & 29 & -0.69 & 40 & -1.20 & 124 \\
\hline Edge-Modified & & & & & & & & & \\
\hline Flakes & 16 & -7.48 & 10 & -3.75 & 56 & -0.11 & 137 & +9.35 & 219 \\
\hline Hammerstones & 1 & -1.15 & 0 & -1.14 & 5 & +1.76 & 4 & +0.20 & 10 \\
\hline Ground Stones & 78 & +6.48 & 11 & -2.40 & 50 & +0.94 & 36 & -5.16 & 175 \\
\hline Totals: & 190 & & 83 & & 190 & & 272 & & 735 \\
\hline
\end{tabular}

Note: Adjusted residuals above +1.95 or below -1.95 are statistically significant at the .05 level of confidence. 
TABLE 50

COMPARISON OF LATE PREHISTORIC II ARTIFACT ASSEMBLAGES

\begin{tabular}{|c|c|c|c|c|}
\hline Artifact Category & $\begin{array}{l}\text { 41GR291 } \\
\text { Late Occupation }\end{array}$ & $\begin{array}{c}\text { Adjusted Standardized } \\
\text { Residuals for } 41 \text { GR291 } \\
\text { Late Occupation }\end{array}$ & $\begin{array}{l}\text { 41GR303B } \\
\text { Upper Zone }\end{array}$ & Totals \\
\hline Arrow Points & 18 & +2.07 & 3 & 21 \\
\hline Dart Points & 0 & -1.37 & 1 & 1 \\
\hline Perforators & 2 & +1.04 & 0 & 2 \\
\hline Gouges & 9 & -0.42 & 6 & 15 \\
\hline Bifaces & 11 & +0.69 & 4 & 15 \\
\hline Cobble Tools & 15 & +1.32 & 4 & 19 \\
\hline Unifaces & 48 & -0.59 & 29 & 77 \\
\hline Cores & 31 & -0.50 & 19 & 50 \\
\hline Edge-Modified Flakes & 19 & -2.73 & 22 & 41 \\
\hline Hammerstone & 2 & +1.04 & 0 & 2 \\
\hline Ground Stones & 18 & +1.39 & 5 & 23 \\
\hline Totals: & 173 & & 93 & 266 \\
\hline
\end{tabular}

\begin{tabular}{|c|c|c|c|c|}
\hline \multicolumn{5}{|c|}{$\begin{array}{l}\text { TABLE } 51 \\
\text { COMPARISON OF PROTOHISTORIC ARTIFACT ASSEMBLAGES }\end{array}$} \\
\hline Artifact Category & $41 \mathrm{KT} 51$ & $\begin{array}{l}\text { Adjusted Standardized } \\
\text { Residuals for } 41 \mathrm{KT} 51\end{array}$ & $41 \mathrm{KT} 53$ & Totals \\
\hline Arrow Points & 21 & +2.91 & 29 & 50 \\
\hline Dart Points & 0 & -0.58 & 1 & 1 \\
\hline Perforators & 3 & +3.00 & 0 & 3 \\
\hline Bifaces & 6 & -0.46 & 22 & 28 \\
\hline Cobble Tools & 0 & -0.58 & 1 & 1 \\
\hline Unifaces & 36 & -0.66 & 119 & 155 \\
\hline Cores & 1 & -0.98 & 8 & 9 \\
\hline Edge-Modified Flakes & 33 & +0.58 & 89 & 122 \\
\hline Hammerstone & 1 & 0.00 & 3 & 4 \\
\hline Ground Stones & 17 & -1.93 & 80 & 97 \\
\hline Totals: & 118 & & 352 & 470 \\
\hline
\end{tabular}

\section{Lithic Material Procurement}

To document the prehistoric patterns of lithic material procurement and use, comparative samples of raw material were collected from sources within the project area, in the immediate vicinity of the project area, and in selected areas (i.e., where access could be easily obtained) from the project area southward to the Callahan Divide (Boyd et al. 1994:16-23). From early in the project it was evident that some obviously nonlocal lithics (i.e., Alibates agate, Tecovas jasper, and obsidian) were present in the collections. An additional group of yellow/brown/gray/black fine-grained cherts was 
thought to be of Cretaceous origin. Because the local materials, in the form of the ubiquitous Lingos Formation gravels, also contain a small amount of cobbles redeposited from Cretaceous formations, it was important to distinguish between the local and nonlocal fine-grained cherts.

To accomplish this, a series of "local" samples was used to define the Lingos Formation materials in the project area and stream gravels in nearby drainages. Although the latter samples are from as far as $40 \mathrm{~km}$ from the project area, they are representative of the mixed stream gravels within a general $25-\mathrm{km}$ radius. These samples are dominated by materials ultimately derived from the Ogallala Formation and, to a much lesser extent, materials from Triassic and Cretaceous sources (see Chapter 2). A second series of samples was used to characterize "nonlocal" Cretaceous Edwards Group cherts that occur as primary deposits (i.e., bedded in limestone) or as major secondary deposits a short distance from Edwards Group limestones (Figure 71). Most of these samples were obtained from localities between 75 and $150 \mathrm{~km}$ from the project area, in the Callahan Divide (Nolan and Taylor Counties) and in the Big Spring area (Howard County). One significant secondary source of Edwards chert, however, is located approximately $35 \mathrm{~km}$ south-southwest of the project area (northeast Borden County). Based on the distribution of Edwards Group limestones (see Figure 71), it is possible that there are some yet to be discovered Edwards chert sources along the northern edge of the Fluvanna Cap (ca. $15 \mathrm{~km}$ southwest of Lake Alan Henry) or at Flat Top Mountain (ca. $15 \mathrm{~km}$ southeast), but a cursory examination of the streams coming from these areas failed to produce any cherts. Thus, the closest source of Edwards chert is probably at least $25 \mathrm{~km}$ away, along the southern edge of the Fluvanna Cap. Based on recent work by Frederick and Ringstaff (1994), the Edwards Group includes almost all of the dominant Cretaceous chert-bearing formations, and it is appropriate to call them by the generic name, Edwards chert.

All of the fine-grained cherts from these comparative collections of local and nonlocal sources were classified by color groups, and all fine-grained lithic artifacts obtained during data recovery were compared with and assigned to these specific color groups. In this manner, all of the fine-grained chert artifacts were sorted into specimens that most closely resemble cherts of local origin (and were obtained within $25 \mathrm{~km}$ of Lake Alan Henry) and those that most closely resemble the nonlocal Edwards cherts (and were obtained from $25-150 \mathrm{~km}$ from the project area). ${ }^{4}$

The local lithics include a wide range of material types and considerable variation in quality (Table 52). Although the list of local raw materials is extensive, most of the material types are hard and difficult to flake. While there appears to be no practical size limitation to these raw materials and they are well suited for the manufacture of heavyuse tool types (e.g., choppers and gouges), they can be reduced into small bifacial artifacts (e.g., projectile points) only with considerable effort. Heat treating does improve the quality of some of these materials, but evidence of such treatment is difficult to identify. Other local materials (e.g., fine-grained cherts, chalcedony, opalized caliche, and silicified wood) are much easier to flake, but they generally have one or more of the following disadvantages: small size, low densities, and inconsistent quality.

Edwards chert is by far the dominant nonlocal material and only three other nonlocal materials were identified in the data recovery collections: Tecovas jasper, Alibates agate, and obsidian. Tecovas jasper is a distinctive material derived from the Triassic Dockum Group formations that outcrop in the Canadian River Valley and all along the Caprock Escarpment (see Chapter 2). Despite the large areal extent of the Dockum Group exposures, only three source areas for Tecovas jasper are known: (1) northeast of Amarillo in eastern Oldham County; (2) in Palo Duro Canyon, Armstrong County; and (3) in the vicinity of Quitaque in Briscoe and Floyd Counties (Banks 1990; Holliday and Welty 1981; Mallouf 1989). While the latter is the closest known source area, some $135 \mathrm{~km}$ from Lake Alan Henry, there may be other source areas located in Motley, Dickens, Crosby, and Garza Counties that have not been documented. Emmett Shedd (personal communication 1991), for example, states that there is one small Tecovas source locality in northern Garza County.

\footnotetext{
${ }^{4}$ For more information on the lithic material comparative collection, individual sample areas are illustrated and the materials are described in Boyd et al. (1994:Figure 4 and Table 1). Holliday and Welty (1981) provide the most concise summary of lithic resources in the Texas Panhandle-Plains.
} 


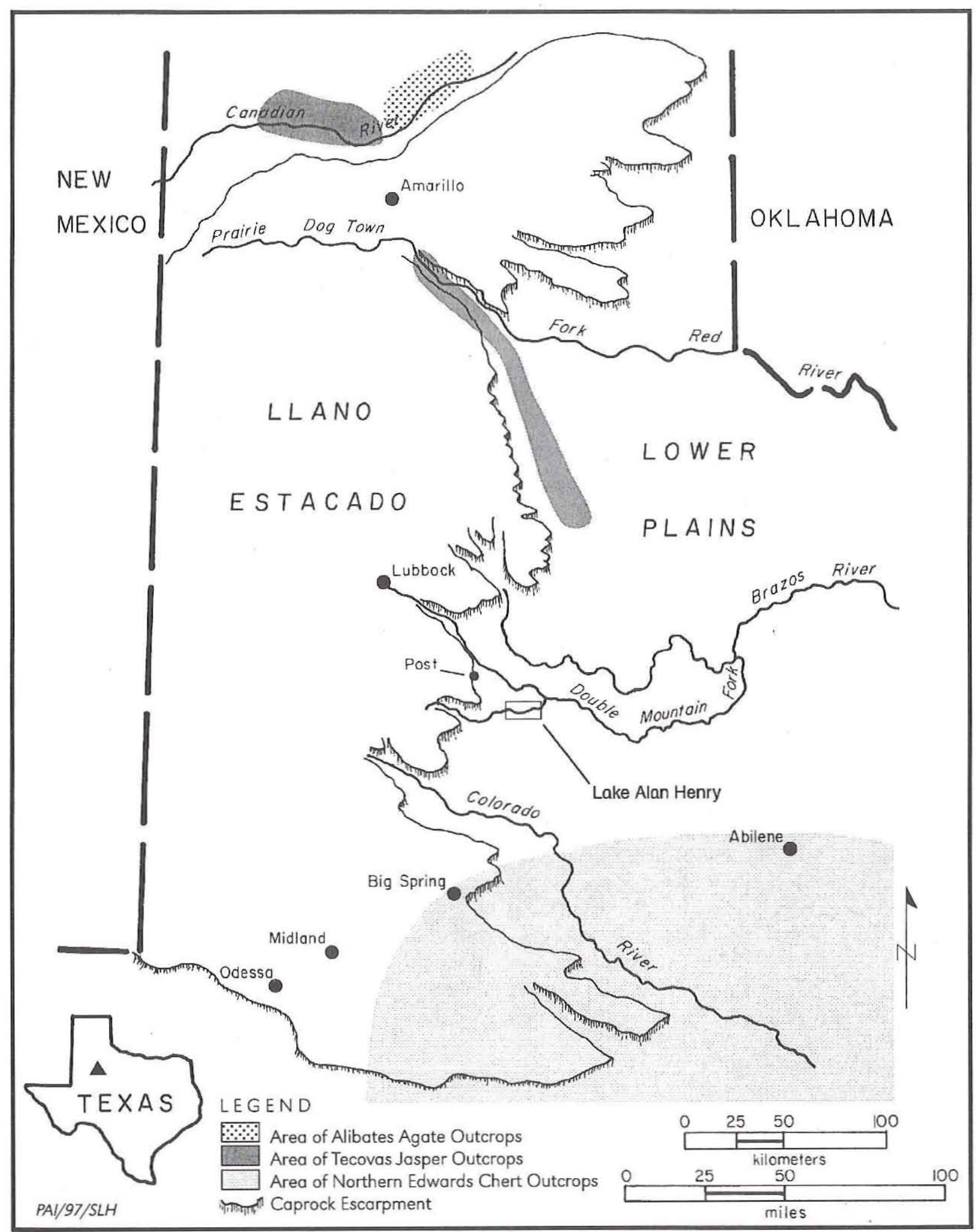

Figure 71. Map of nonlocal Texas chert sources represented in the Lake Alan Henry chipped stone assemblages. Lithic source areas are defined after Holliday and Welty (1981), Banks (1990), Frederick and Ringstaff (1994), and Bureau of Economic Geology (1992). 
TABLE 52

LOCAL LITHIC MATERIALS FOUND IN THE LAKE ALAN HENRY AREA

\begin{tabular}{|c|c|c|}
\hline Material Type & Knapping Quality & Size and Quality \\
\hline Fine-grained Potter chert & $\begin{array}{l}\text { Poor quality, very hard (improves with } \\
\text { heat treatment) }\end{array}$ & No practical size limitations and abundant \\
\hline Coarse-grained Potter chert & Poor quality, very hard and grainy & No practical size limitations and abundant \\
\hline Fine-grained quartzite & Medium quality & \\
\hline Coarse-grained quartzite & Poor & \\
\hline Fine-grained chert & Good quality & Small cobbles present but not abundant \\
\hline Coarse-grained chert & Medium & \\
\hline Silicified wood & Unusable to good quality & Generally very small and very rare \\
\hline Chalcedony & Medium to good & \\
\hline Opalized caliche & Variable & \\
\hline Silicified caliche & Poor quality & Generally small and rare \\
\hline
\end{tabular}

Alibates agate is found in primary geological context in localized outcrops only in Permian-age deposits in the vicinity of Lake Meredith in Potter County. Alibates agate also may be found as stream gravels downstream from this location and has been found as far east as western Oklahoma (Wyckoff 1989). The closest source of Alibates agate is the main quarry area, located some $290 \mathrm{~km}$ north of Lake Alan Henry.

Obsidian was recovered from only two data recovery analysis units, and specific sources were identified by trace element analysis. Two obsidian flakes from 41GR291 were identified as being from the Malad, Idaho, source, over $800 \mathrm{~km}$ north of Lake Alan Henry (Boyd et al. 1994:84). One flake was tentatively assigned to each of the two occupation periods, and thus the Malad source could be represented in Late Prehistoric I and II times. Three flakes recovered from the Protohistoric occupation at $41 \mathrm{KT} 51$ were identified as being from the Cerro del Medio source in the Jemez Mountains, over $500 \mathrm{~km}$ northwest of the project area (Boyd et al. 1993:61).

The patterns of procurement of local and nonlocal raw materials within the mitigated sites are shown in Table 53. Local raw materials range from 56 to 94 percent in the debitage and edge-modified flakes from the four Late Prehistoric I analysis units. The same pattern is evident among the tools, although nearly 20 percent more tools are made of local raw materials compared to debitage within the 41GR383 assemblage. Overall, the Late Prehistoric I lithic assemblages are dominated by the use of locally available raw materials, followed by moderate use of nonlocal Edwards cherts and little reliance on Tecovas jasper, Alibates agate, and obsidian (Figure 72). The dominance of locally available raw materials and use of small amounts of Tecovas jasper and obsidian also characterize the two Late Prehistoric II assemblages. Alibates agate is not present (see Figure 72). A different pattern is seen in the assemblages from the two Protohistoric sites. Locally available raw materials constitute only 14 and 15 percent of the manufacturing debris and only 13 and 20 percent of the tools. The Protohistoric assemblages exhibit a major shift in raw material use compared to previous time periods. This collection is dominated by nonlocal Edwards cherts with only a moderate use of local resources and a very low reliance on Tecovas jasper, Alibates agate, and obsidian (see Figure 72).

These comparisons indicate relative consistency in raw material procurement strategies between the Late Prehistoric I and II periods, followed by a significant change during the Protohistoric period. The predominance of nonlocal Edwards cherts in the Protohistoric assemblages and the relative distribution of nonlocal materials might reflect changes in the annual range of the populations utilizing the project area. The Late Prehistoric I and II raw material origin patterns are suggestive of annual land-use patterns that might have encompassed a large area, but the populations might have resided in the project area and its vicinity during much of the year. The Protohistoric period raw material origin patterns suggest an even larger annual range, with the greater proportion of west-central Texas materials perhaps indicating a relatively specialized and/or shorter-term utilization of the project area. The large number of 


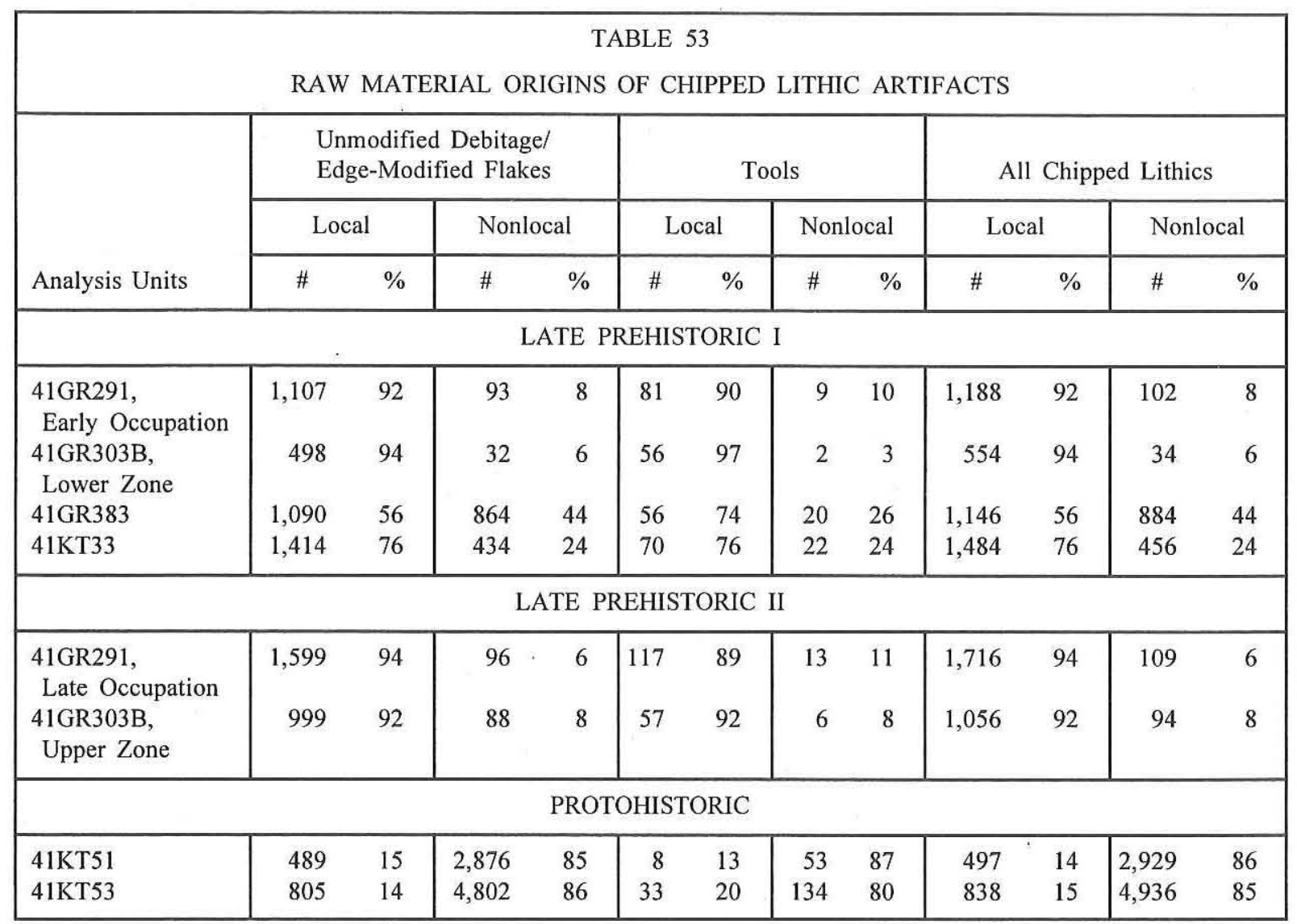

debitage and tools of nonlocal materials, the absence of cores, and the presence of substantial quantities of debitage derived from uniface resharpening (Boyd et al. 1993:63, 155) seem to suggest that the tool kits used at $41 \mathrm{KT} 51$ and $41 \mathrm{KT} 53$ were organized within the context of a "gearing-up" strategy (Binford 1979). This suggests logistical resource procurement associated with the exploitation of bulk resources (i.e., bison) available during a limited part of the year.

\section{Tool Design and the Nature of the Artifact Assemblages}

Two groups of tools that appear to signal changes in the land-use practices among the inhabitants of the project area through time are the grinding tools and the unifacial scraping tools. In addition to the earlier-described changes in the frequencies of these tools relative to other classes, the collections of grinding stones and unifacial scraping tools exhibit morphological changes that appear to represent technological adjustments to changing land- use and resource procurement practices.

The Late Prehistoric I sites have substantially higher frequencies of ground stone tools than the Late Prehistoric II sites (Table 54). One of the two Protohistoric sites (41KT51) has a small number of ground stone tools, while the other assemblage (41KT53) contains high frequencies.

A closer examination of the manos indicates that quartzite specimens represent higher percentages of the Late Prehistoric I and II collections, while sandstone manos dominate the Protohistoric collection (Table 55). Given that the quartzite manos tend to have moderately to substantially convex working surfaces while the sandstone manos have flat working faces (see Boyd et al. 1992:Figure 74, 1994: Figures 32 and 58), these raw material differences might have functional significance. In particular, these morphological differences between manos translate into different wear patterns on metates paired with them. Even though both types can be used on slab metates, the convex quartzite manos tend to create basin-shaped working surfaces while the sandstone manos maintain flat working surfaces. 

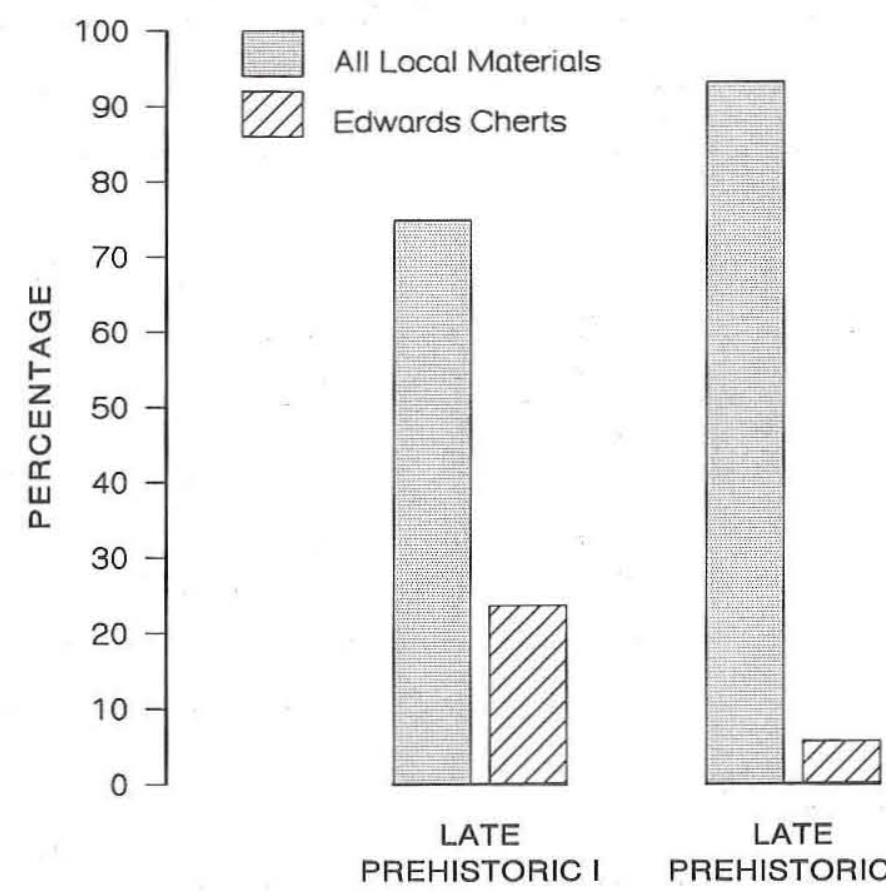

LATE
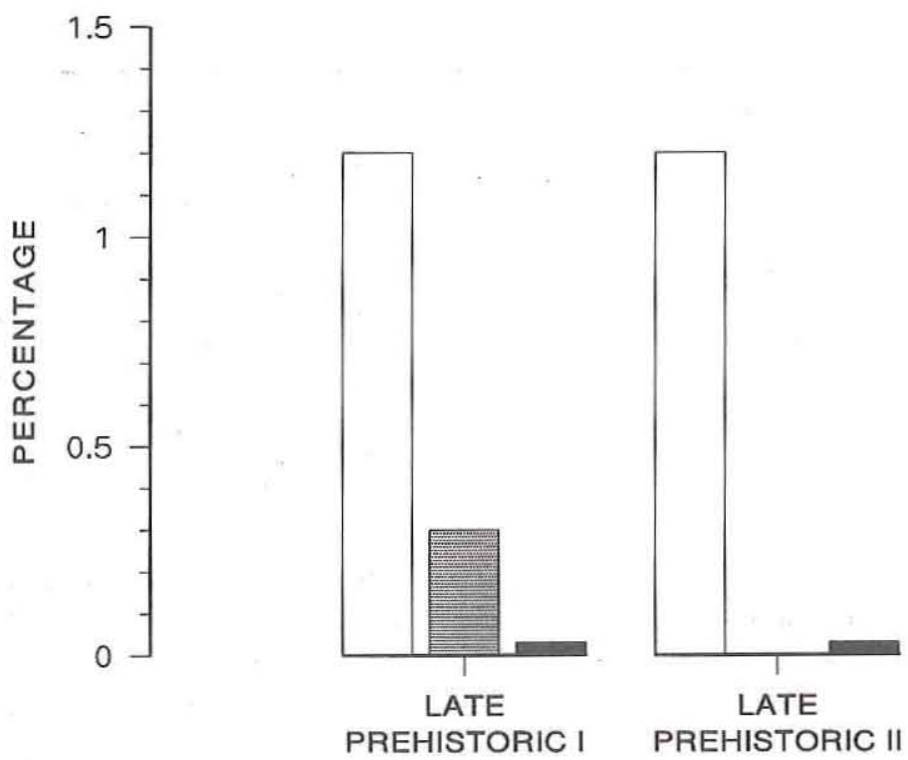

PREHISTORIC PREHISTORIC ॥

PREHISTORIC I PREHISTORIC II

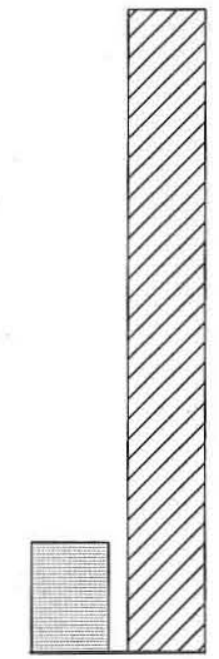

PROTOHISTORIC
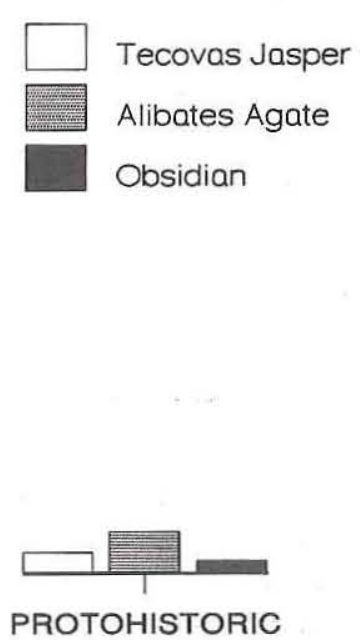

Figure 72. Bar graphs of lithic material use through time. 
TABLE 54

COMPARISON OF GROUND STONE TOOLS BY ANALYSIS UNIT AND TIME PERIOD

\begin{tabular}{|c|c|c|c|c|}
\hline Analysis Units & Manos & Metates & Other* & Totals \\
\hline \multicolumn{5}{|c|}{ LATE PREHISTORIC I } \\
\hline $\begin{array}{l}\text { 41GR291, Early Occupation } \\
\text { 41GR303B, Lower Zone } \\
\text { 41GR383 } \\
\text { 41KT33 }\end{array}$ & $\begin{array}{r}15 \\
5 \\
15 \\
11\end{array}$ & $\begin{array}{r}53 \\
5 \\
35 \\
25\end{array}$ & $\begin{array}{r}10 \\
1 \\
0 \\
0\end{array}$ & $\begin{array}{l}78 \\
11 \\
50 \\
36\end{array}$ \\
\hline Totals: & 46 & 118 & 11 & 175 \\
\hline \multicolumn{5}{|c|}{ LATE PREHISTORIC II } \\
\hline $\begin{array}{l}\text { 41GR291, Late Occupation } \\
\text { 41GR303B, Upper Zone }\end{array}$ & $\begin{array}{l}7 \\
4\end{array}$ & $\begin{array}{l}5 \\
1\end{array}$ & $\begin{array}{l}6 \\
0\end{array}$ & $\begin{array}{r}18 \\
5\end{array}$ \\
\hline Totals: & 11 & 6 & 6 & 23 \\
\hline \multicolumn{5}{|c|}{ PROTOHISTORIC } \\
\hline $\begin{array}{l}41 \mathrm{KT} 51 \\
41 \mathrm{KT} 53\end{array}$ & $\begin{array}{l}6 \\
9\end{array}$ & $\begin{array}{r}5 \\
39\end{array}$ & $\begin{array}{r}6 \\
32\end{array}$ & $\begin{array}{l}17 \\
80\end{array}$ \\
\hline Totals: & 15 & 44 & 38 & 97 \\
\hline
\end{tabular}

\begin{tabular}{|l|rc|cc|cc|}
\hline \multicolumn{8}{|c|}{ TABLE 55 } \\
\hline \multirow{4}{*}{ COMPARISON OF RAW MATERIAL FOR MANOS BY TIME PERIOD } \\
\hline \multirow{2}{*}{ Temporal Units } & \multicolumn{2}{c|}{ Sandstone } & \multicolumn{2}{c|}{ Quartzite } & \multicolumn{2}{c|}{ Totals } \\
\cline { 2 - 8 } & Number & Percent & Number & Percent & Number & Percent \\
Late Prehistoric I & 18 & 39 & 28 & 61 & 46 & 100 \\
Late Prehistoric II & 3 & 27 & 8 & 73 & 11 & 100 \\
Protohistoric & 12 & 80 & 3 & 20 & 15 & 100 \\
\hline
\end{tabular}

Both quartzite and sandstone manos were utilized through time, but the collection of ground stone tools from Lake Alan Henry suggests that the range of grinding activities for which these manos were used changed through time.

Ethnographic research indicates that rounded quartzite manos tend to be used in processing a variety of materials, such as crushing salt, bones, and small seed condiments (e.g., pepper) in basin metates, or inactivities such as hide processing (Adams 1988). On the other hand, the flat-surfaced manos tend to be associated more consistently with the grinding of cultigen seeds (Mauldin and Tomka 1988). Research by Hard (1990) and Mauldin (1991, 1993) suggests that these patterns of association are conditioned by the relationship between the size of the working surface area and the efficiency of the grinding technology. Based on this relationship, these authors have suggested that an increase in the intensity of grinding activities, derived from increased exploitation of either wild resources or cultigens, should result in a shift toward moreefficient grinding technology (e.g., increased grinding surface areas). 
Mauldin's (1993) analysis of changes in grinding technology in the Mogollon area indicates that during the Early Pit House period the average grinding area on manos measured about $155 \mathrm{~cm}^{2}$. By the Late Pit House period, the average surface area increased to approximately $164 \mathrm{~cm}^{2}$ as agricultural intensity increased. By the Late Pueblo period, when agricultural intensity was high, the mean mano grinding surface area increased to about $200 \mathrm{~cm}^{2}$.

The numbers of complete manos from data recovery analysis units at Lake Alan Henry are too small to allow a meaningful analysis of changes in working surface areas through time. Nonetheless, the analysis of all of the complete manos $(n=74)$ collected during the various phases of work provides some interesting suggestions. A frequency distribution of these specimens based on working surface area indicates three potential groupings (Figure 73). Group I $(\mathrm{n}=10)$ contains specimens with working surfaces smaller than $50 \mathrm{~cm}^{2}$, Group II $(\mathrm{n}=38)$ contains specimens with working surfaces between 50 and $110 \mathrm{~cm}^{2}$, and Group III $(\mathrm{n}=26)$ contains specimens with working surfaces greater than 110 $\mathrm{cm}^{2}$. The mean working surface areas for these three groups are $38 \mathrm{~cm}^{2}(\sigma=7.0), 80 \mathrm{~cm}^{2}(\sigma=$ $13.6)$, and $159 \mathrm{~cm}^{2}(\sigma=34.6)$, respectively.

The temporal affiliation of only a handful $(\mathrm{n}=$ 20,27 percent) of these 74 specimens is known. Of the 14 Late Prehistoric I complete manos, 6 (43 percent) each are in Groups I and II and 2 (14

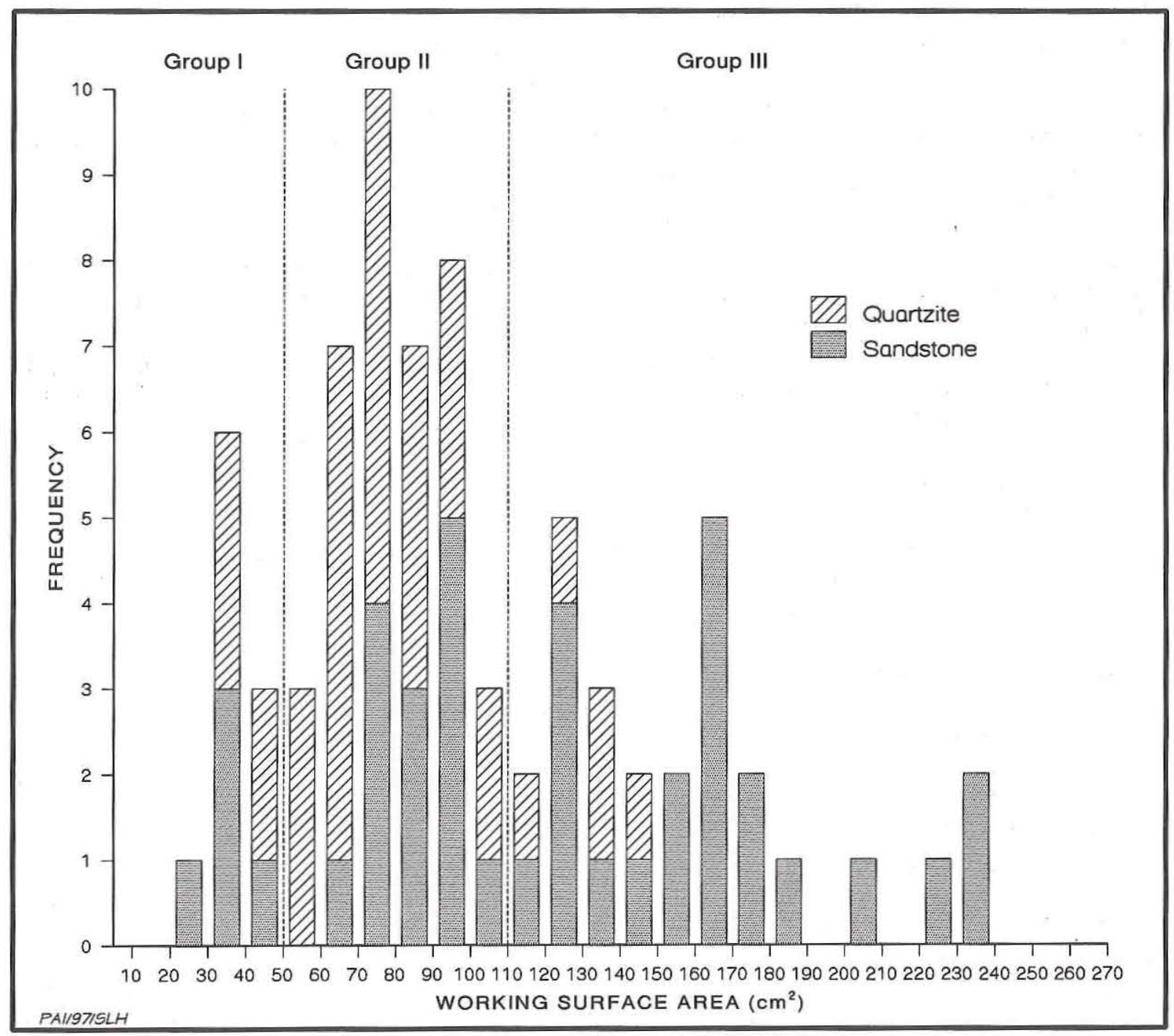

Figure 73. Frequency distribution of complete manos based on working surface area. 
percent) are in Group III. Of the 4 Late Prehistoric II manos, 1 (25 percent) is in Group I, 2 (50 percent) are in Group II, and 1 ( 25 percent) is in Group III. Both of the Protohistoric manos are in Group III.

While a large percentage ( 81 percent, $n=21$ ) of the 26 manos in the larger size group are sandstone, the middle and small size groups contain higher percentages of quartzite manos (63 percent and 50 percent, respectively (see Figure 73). Of the 14 Late Prehistoric I manos, 7 (50 percent) each are sandstone and quartzite, while 3 (75 percent) of the Late Prehistoric II manos are quartzite and only 1 (25 percent) is sandstone. Both Protohistoric specimens are sandstone. This increase in the percentage of sandstone manos during the Protohistoric period and the fact that both specimens have large working surfaces might indicate an increase in grinding intensity during the Protohistoric period.

The metates recovered from the Late Prehistoric I data recovery sites suggest a different, or perhaps more-complex, scenario. Six of the seven large to very large complete metates recovered from the early occupation at 41GR291 are basin metates that appear to have been paired with relatively rounded quartzite manos (see Boyd et al. 1994:Figures 33-35). The seventh specimen is a slab metate. A large metate from 41KT33 also appears to have a shallow basin, probably worn by a quartzite mano (see Boyd et al. 1992:Figure 39). These metates are larger than any of the other complete specimens recovered from other project area sites.

The changes in the frequencies of ground stone tools through time (see Table 54) suggest that Late Prehistoric I and Protohistoric populations might have relied more heavily on the processing of plant resources (e.g., seeds) than Late Prehistoric II populations. In addition, the contrasts in mano and metate shapes potentially suggest that different plant resources were processed during the Late Prehistoric I and Protohistoric periods. Finally, the increase in the size of the manos suggests a shift toward increased efficiency of the grinding technology during the Protohistoric period.

How can we reconcile these interpretations, and in particular the role of plant processing during the Protohistoric period, with the initial hypotheses (see Chapter 4) that subsistence practices were geared primarily to the exploitation of bison? Although one interpretation might be that these results contradict the initial hypotheses, two alternative interpretations can also be offered. First, it is possible that, since the two Protohistoric sites may represent fall/winter occupations (Boyd et al. 1993:281), the activities that occurred at these sites were not limited to meat procurement but also included the gathering and processing of wild seeds available during the fall. Accepting the earlier argument that wild seeds are often processed by smaller rounded manos (e.g., quartzite) in basin metates, however, we should expect larger numbers of quartzite manos and basin metates from Protohistoric sites. As noted above, at least within the manos, the pattern in raw material use is exactly the opposite, and large basin metates are found in the Late Prehistoric I rather than Protohistoric assemblages.

A second interpretation is that, while the occupants of the two Protohistoric sites were involved in some sort of plant processing during the fall/winter occupations of the sites, the resource was of a domesticated nature, namely corn. Although there is no direct archeological evidence of corn from either of the sites, the larger mean working surface areas of the Protohistoric manos might represent an adjustment in grinding technology in response to the presence of larger and harder grains. That is, the increase in mean mano working surface area might have been due to a change in the type of grain being processed rather than greater quantities of grain needing to be processed. Within the context of interregional exchange of bison meat and hides for corn and other agricultural products from the southwest (Creel 1991; Spielmann 1983, 1991), it is possible that the relatively small mean working surface area of the largest manos reflects a shift to a low intensity of processing of corn that was received in exchange rather than cultivated by the Lake Alan Henry groups.

The second aspect of tool design addressed here is that of differences in unifacial tool morphology through time. The unifacial tools can be divided into two categories: (1) formal, rather extensively retouched and morphologically standardized specimens with well-defined haft elements; and (2) minimally retouched and morphologically irregular specimens without haft elements. Based on the number of flake removals needed in manufacture, these groups represent different manufacture costs and can be considered as products of curated and expedient technologies, respectively. Although no direct evidence exists in support, it is assumed that the formal unifaces tend to be more effective than 
the minimally retouched specimens due mainly to their longer and more-uniform working edges and the greater force which might be applied to a worked material with a hafted rather than unhafted tool. Although the formal tools might require slightly higher manufacture costs than minimally retouched specimens, they also tend to have longer use lives, often being resharpened numerous times, compared to the minimally retouched unifaces which appear to have been task-specific tools.

While many of the unifaces could not be categorized because they are too fragmentary, only slightly more than one-third of the specimens in the Late Prehistoric I and II collections are formal unifaces while the majority are minimally retouched tools (Table 56). In contrast, the majority of the unifaces from Protohistoric assemblages are formal specimens with extensively retouched lateral and distal margins and standardized forms, i.e., Plains-style end scrapers (see Table 56).

What are the factors that might account for this adjustment of the unifacial tool kits through time? It has been proposed that, given the gradual increase in bison populations after A.D. 1100 in the Southern Plains, Late Prehistoric II period populations began shifting toward a greater reliance on bison and that Protohistoric populations were even more intensively involved in bison hunting. How would this gradually increased focus on bison hunting have affected tool assemblages?

It is likely that the generalized procurement of medium-sized ungulates, such as deer and antelope, would have required basically the same tool types (projectiles, knives, and scrapers) as the generalized or infrequent procurement of bison. There is no reason why a bison could not be brought down and processed with the same tool kit as that used in the procurement and processing of smaller animals such as deer and antelope. However, the procurement of large numbers of animals during somewhat limited periods of availability (summer and fall) might have placed significantly different constraints upon the organization of the hunting practices, as well as on the design of the tool kits employed.

Numerous authors involved in the study of prehistoric technologies (Bleed 1986; Boydston 1989; Hayden 1986; Jochim 1981; Torrence 1989) have noted that, within the context of resource procurement under some degree of time stress and particularly under conditions of subsistence risk and uncertainty, prehistoric populations should have adjusted their technologies to assure that the maximum amount of resources could be procured within the time period during which the resource was accessible. Most authors have emphasized that the availability of efficient procurement technology was one effective organizational strategy that allowed populations to cope with this type of variability in resources. In addition, the procurement of bulk quantities of resources required an appropriately efficient technological component which allowed the effective processing of the resource.

Specifically within the context of bison hunting, the procurement of the annual supply of meat to be eaten and in some cases traded with neighboring groups during two well-delimited hunting periods required relatively complex organizational adjustments in terms of labor coordination (e.g., task group organization in communal hunting). This was aided by the increased hunting efficiency afforded by the horse and the bow and arrow. The processing of large quantities of meat required effective butchering tool kits (e.g., beveled knives) and intensive use of meat preservation techniques (e.g., pemmican). Similarly, the processing of the doubtless hundreds of hides obtained during the annual hunts required an effective hide processing tool kit (e.g., hafted scrapers).

Although three beveled bifaces were recovered 
from the two Protohistoric assemblages, their scarcity may be due to the replacement of stone cutting tools with metal knives that tended to have longer use lives (Boyd et al. 1993:209-210). Similar replacement of stone tools with more-durable, and in some cases more-efficient, metal tools has occurred in other cases of cultural contact (e.g., Hudson 1993; Toom 1979). It is possible that the continued use of stone scrapers and ground stone technology well into the Protohistoric period in the Southwest (e.g., the large number of end scrapers in sites with large quantities of contact period items) may be due to the technological superiority of the traditional tools over the Euro-American alternatives.

Although this scenario might account for the relative lack of beveled knives and the abundance of end scrapers in the two Protohistoric assemblages, the absence of large collections of bison skeletal remains at these sites might be interpreted as contradicting the hypothesized bison hunting focus of these populations. In other words, there is no direct conclusive evidence for bison hunting at these sites, and the end scrapers might just as well have been used in processing deer or antelope hides since the bones of these animals were recovered in small numbers. Furthermore, in the absence of microwear analysis indicating the materials actually processed, it is even possible that the unifaces were employed in plant processing (cf. Bement and Turpin 1987).

Lacking conclusive evidence, why do we suggest that the Protohistoric peoples of the Lake Alan Henry area were bison hunters? This interpretation is not based purely on the composition of the lithic tool assemblages, but it also considers other lines of archeological evidence (e.g., site structure, types of features; Boyd et al. 1993:203-235). Further, ethnohistoric accounts of communally organized seasonal bison hunts describe the procurement of large quantities of bison hides. Due to the quantity of hides and the pace of work associated with kill and processing sites, it appears that during the hunting season many of these hides saw only primary field processing (e.g., fleshing) to prepare them for temporary storage. The secondary processing of these hides (e.g., actual tanning) occurred at the end of the hunting season either in the base camps or over-wintering camps (e.g., Dunbar 1918:613). Such a strategy also implies that the skeletal remains of bison were left at the kill/processing sites and not returned to these sites. The stage processing of the hides obtained during the seasonal hunts may ac- count for the large number of end scrapers at the two Protohistoric sites. This explanation also implies that at least some of the end scrapers should exhibit microwear derived from the processing of dry hides rather than fresh hides. It might also account for the lack of bison bones at the two sites.

Within a broader context, the effectiveness of formal tools under conditions of time stress similar to those associated with the procurement of large numbers of bison offers an additional perspective for the large numbers of beveled knives and end scrapers consistently found on Toyah phase sites (Creel 1991). It is also probable that some characteristics of these formal tools (e.g., beveling, Sollberger 1971) might be responses to the need to extend tool use lives under circumstances of high seasonal mobility and the concomitantly low predictability of raw material availability associated with bison hunts (Berlandier 1969; Bolton 1949; Roper 1991).

\section{CERAMIC TECHNOLOGY}

Most of the pottery from data recovery investigations at Lake Alan Henry represents two very different ceramic traditions during two different time periods. The Jornada brownware tradition is represented by 25 potsherds recovered from two Late Prehistoric sites (see Table 44). These sherds are associated with three components: a Late Prehistoric I special activity campsite (41KT33); a functionally specialized Late Prehistoric I residential base (41GR291, early occupation); and a Late Prehistoric II multifunctional campsite or possible residential base (41GR291, late occupation). All of the sherds are from stratigraphic zones dated to the Late Prehistoric I or II periods, but none were found in direct association with any radiocarbon-dated materials.

Based on visual and microscopic examinations, at least three varieties are represented; they have been typed by Southwestern ceramicists (see Chapter 6) as possibly being Jornada Brown, Middle Pecos Micaceous Brown, and/or South Pecos Brown. Petrographic analyses of these sherds (Robinson 1992, 1994) confirm that there are several different paste composition groups that generally correlate with the type groupings. Because most of the sherds are so small and only one rim sherd was found, very little can be said about vessel form (except that one was a bowl) and function.

The 3,482 potsherds recovered from $41 \mathrm{KT} 51$ and 
$41 \mathrm{KT} 53$ are from entirely different ceramic traditions and provide some valuable insights into the Protohistoric period in the Texas Panhandle-Plains. Since much of the pottery is nonlocal, it seems likely that the Protohistoric peoples were much more mobile than their prehistoric counterparts. This also is evident in the high percentage of nonlocal lithic materials in the Protohistoric assemblages. Two factors may account for their increased mobility. One is that their lifestyle had changed significantly due to the increased importance of bison hunting, and the other is that the acquisition of the horse in the mid to late seventeenth century (Worchester 1944) had a major impact on mobility. These factors are not mutually exclusive, and Late Prehistoric II/early Protohistoric pedestrian nomads may have been increasingly mobile prior to the introduction of the horse to the Southern Plains.

Visual identifications of these sherds by various ceramic experts (see Chapter 6), along with a detailed petrographic study, provide evidence of manufacturing sources and ceramic traditions/styles represented in the assemblages (Table 57). A minimum of 43 percent of the sherds are of nonlocal origin. A very small percentage, less than 1 percent, represent a single engraved vessel that is stylistically Caddoan- or Wichita-like, but its manufacturing source is unknown. Puebloan tradition ceramics, some of which were manufactured at Pecos Pueblo, in the Salinas area, possibly in the Galisteo Basin, and in the Taos/Picuris and Tewa areas of northern New Mexico, include 1,216 sherds representing 35 percent of the assemblage. If one looks at the minimum number of vessels represented, however, the frequency is much higher, with at least 50 percent of the 38 vessels (i.e., the minimum number of vessels in the total assemblage) being Puebloanmade.

The plain utility wares, and some of the micaceous utility wares (and the few unidentified vessel and pipe sherds), are another matter. These wares are generally characterized by very dark brown to black colors resulting from reduced firing, smoothed to well-polished interiors, and variable exterior surface treatments. Many sherds have unfinished exteriors with a rough texture resulting from poor scraping/smoothing. Others have faint to deep irregular grooves, or striations, resulting from smoothing with grass, corncobs, or some other rough-textured tool. Striations were observed on about half of the sherds. It is likely that many of the unfinished sherds, particularly the smaller ones, are from striated vessels on which the striations have been obliterated. Fingernail punctates are present on 29 sherds, representing only about 1 percent of the plain utility category.

The plain utility sherds are identical in vessel form, degree of reduction, and surface treatment to Puebloan-made Rio Grande striated and plain utility wares such as Pecos Faint Striated (Kidder and Shepard 1936:316) and Corona series plainwares (Hayes et al. 1981:65). These wares, particularly the striated variety, are characteristic of late Puebloan utility wares that became popular in the Rio Grande and eastern pueblos during the seventeenth century and are most frequently associated with Glaze $\mathrm{E}$ (or Glaze V at Pecos Pueblo) pottery (Snow 1982). They cannot be considered to be of Puebloan origin solely on the basis of these similarities, however. Understanding the composition of these wares (i.e., the paste and temper) is crucial to identifying manufacturing sources. There is a long history of confusion regarding the late plainwares in the Southern Plains, and a plethora of type names have been used for various types of striated and micaceous wares. The most common type name, Perdido Plain, was originally defined by Gunnerson and Gunnerson (1971). It has been widely used and misused for almost any thin, dark, striated plainware found in the Texas Panhandle-Plains. Perdido Plain and many variations of micaceous and/or striated plainwares are often generically called "Apache pottery." There is considerable disagreement as to what Perdido Plain represents and whether there is any such thing as Plains Apache pottery. Some researchers attribute all micaceous and striated pottery found in eastern New Mexico and the Texas Panhandle-Plains to the Plains Apaches (e.g., Gunnerson 1960). Others believe that, except for the pottery-making Jicarilla Apache who lived in the Taos/Picuris area but were not true Plainsmen, there is no good evidence for a widespread ceramic tradition or even limited ceramic production among the Plains Apache (Opler 1983:383). About the only things most researchers now agree on are that visual type identifications of such wares are tentative at best and that Perdido Plain has never been adequately defined (Brugge 1982; Opler 1971, 1983). Recent petrographic studies have attempted to address the question of plainware ceramic origins, but the data are subject to different interpretations (see detailed discussion in Boyd and Reese-Taylor 1993). 


\begin{tabular}{|c|c|c|c|}
\hline \multicolumn{4}{|c|}{$\begin{array}{l}\text { TABLE } 57 \\
\text { SUMMARY OF CERAMICS FROM PROTOHISTORIC SITES 41KT51 AND 41KT53 } \\
\text { BY CERAMIC TRADITION/STYLE AND MANUFACTURING SOURCE }\end{array}$} \\
\hline Ware Type & $\begin{array}{l}\text { Total No. } \\
\text { of Sherds }\end{array}$ & $\begin{array}{l}\text { Minimum No. } \\
\text { of Vessels }\end{array}$ & Identification/Manufacturing Sources \\
\hline \multicolumn{4}{|c|}{ PUEBLOAN TRADITION — VARIOUS PUEBLOS } \\
\hline Redware & 336 & 9 & $\begin{array}{l}\text { Glaze V from Pecos Pueblo, Glazes E and F from Salinas area, } \\
\text { and possibly other Puebloan sources }\end{array}$ \\
\hline Glazeware & 182 & 7 & $\begin{array}{l}\text { Glaze V from Pecos Pueblo; Glazes E and F from Salinas area, } \\
\text { and possibly Galisteo Basin and other Puebloan sources }\end{array}$ \\
\hline Matte Paint Ware & 11 & 2 & $\begin{array}{l}\text { Tewa Polychrome from one of the northern New Mexico Tewa } \\
\text { pueblos }\end{array}$ \\
\hline Micaceous Utility & 668 & 1 & Probably Taos/Picuris pueblo area (possibly of Jicarilla origin) \\
\hline Pecos Pipes & 19 & 4 & Pecos Pueblo \\
\hline \multicolumn{4}{|c|}{ CADDOAN STYLE - SOURCE UNCERTAIN } \\
\hline Engraved & 17 & 1 & Definitely nonlocal, possibly of Caddoan/Wichita origin \\
\hline \multicolumn{4}{|c|}{ PUEBLOAN STYLE - SOURCES UNKNOWN } \\
\hline Micaceous Utility & 247 & 7 & $\begin{array}{l}\text { Unknown sources, could be of Puebloan 'or local manufacture, } \\
\text { or both. }\end{array}$ \\
\hline Plain Utility & 1,977 & 7 & $\begin{array}{l}\text { Unknown sources, could be of Puebloan or local manufacture, } \\
\text { or both. }\end{array}$ \\
\hline \multicolumn{4}{|c|}{ UNKNOWN STYLE/TRADITION AND SOURCES } \\
\hline Unidentified & 17 & 0 & $\begin{array}{l}\text { Unknown sources, could be of Puebloan or local manufacture, } \\
\text { or both }\end{array}$ \\
\hline $\begin{array}{l}\text { Unidentified } \\
\text { Pipes }\end{array}$ & 8 & 3 & $\begin{array}{l}\text { Unknown sources, could be of Puebloan or local manufacture, } \\
\text { or both }\end{array}$ \\
\hline Totals: & 3,482 & 38 & - \\
\hline
\end{tabular}

Habicht-Mauche (1987, 1988, 1991) conducted a petrographic study on striated utility wares found in the Texas Panhandle-Plains (most analyzed sherds were from Tierra Blanca complex sites but some were from Garza complex sites) and a few Puebloan sherds from Pecos Pueblo and the Galisteo Basin. Without comparing the petrographic data in any detail, the Tierra Blanca study concluded that most of the striated pottery in the Southern Plains are actually locally made wares patterned after Puebloan prototypes. Tierra Blanca Plain was proposed as a new type name for the indigenous Puebloan-like pottery. This type name was further strengthened by a 1985 ceramic conference that proposed that the Tierra Blanca Plain type should be included under Llano Estacado Gray Wares of the Amarillo Series (Baugh and Eddy 1987).

The conclusions reached during the petrographic analysis of the pottery from the Protohistoric sites at Lake Alan Henry were quite different. . Boyd and Reese-Taylor (1993) concluded that the consistency in composition between the plain and micaceous utility sherds and the Puebloan-made glazeware and redware sherds indicated that almost all of the 
nondecorated wares were likely to be Puebloanmade. Using a combination of visual identifications and petrographic evidence, it was estimated that the majority, and perhaps as much as 95 percent, of all of the ceramics from 41KT51 and 41KT53 were Puebloan-made (Boyd et al. 1993:278). Some of the plain utility and unidentified wares are considered to be candidates for having been local or Plains-made wares, but these constitute only a small percentage of ceramic sample. When the striated utility sherds from the Lake Alan Henry petrographic study were compared with the "Tierra Blanca Plain" sherds used in the Tierra Blanca petrographic study, they were virtually indistinguishable.

Because the Lake Alan Henry interpretations contradicted the results obtained by Habicht-Mauche (1987, 1988, 1991), the Tierra Blanca petrographic data were reviewed by Boyd and Reese-Taylor (1993:369-375). This reexamination discovered that the petrographic data for four of the so-called Tierra Blanca Plain sherds, which represent the vast majority of such wares from the Texas Panhandle Tierra Blanca complex sites, were little different from those of the six Pecos Pueblo sherds that were analyzed. Boyd and Reese-Taylor (1993:375) concluded that:

there is no strong evidence to support the conclusion that Tierra Blanca Plain is a distinctive, indigenous Plains ceramic type. It appears that most of the Tierra Blanca Plain ceramics identified at Texas sites in Habicht-Mauche's (1988) petrographic study fall within the range of variability for Pecos Pueblo, while others could easily be Corona series plainwares made in various pueblos in the Salinas district. If this is correct, only a very small percentage of the striated utility wares from the Tierra Blanca complex sites are of unknown origin and might represent Plains-made wares. Thus, Tierra Blanca Plain may not be a useful taxonomic classification for "all of the striated culinary pottery from the Southern Plains" (HabichtMauche 1991:58). . . U. Until it can be demonstrated more convincingly that striated plainwares found on the Plains are actually Plains-made rather than Puebloan-made, the use of Tierra Blanca Plain as a ceramic type will only cause further confusion.
The abundance of pottery at the Lake Alan Henry Protohistoric sites, representing 26 percent of all artifacts from these sites, contrasts with the paucity of sherds in the Late Prehistoric I and II components, which represent a mere 3 percent of all artifacts (see Table 44). Certainly, increased mobility was a factor in that acquiring and transporting pots must have been easier, but the large number of pots also shows that the Protohistoric people relied more heavily upon ceramic vessels for various purposes.

In terms of vessel form, the overall assemblage is composed of 45 percent jars, 32 percent bowls, and 23 percent unknown form (Table 58). Of the 12 identifiable plain and micaceous utility pots, 9 vessels were identified as globular bean pot-type jars (see Boyd et al. 1993:Figure 71). Although most of the sherds could not be assigned to particular vessels, scarred exteriors and accumulations of carbonized residue on the interiors clearly indicate that plain and micaceous utility pots were used primarily for cooking. The five jars of redware and glazeware appear to be large ollas that probably served as storage vessels, while nine of the identifiable vessels are bowls (possibly used as storage and/or serving containers). The most complete of these was a shallow carinated bowl that was easily identifiable as Glaze E Polychrome (see Boyd et al. 1993:Figure 78). A single carinated bowl is the only recognizable vessel form in the Tewa matte paint wares. The presence of both plainware cooking pots and painted ollas and bowls has been interpreted as evidence that these Protohistoric sites were residential bases.

Besides the containers, at least seven ceramic pipes are represented in the two Protohistoric sites (see Table 57). Four of these, including two partially reconstructed pipes (see Boyd et al. 1993: Figure 82), are identified as Pecos-style tubular pipes that are identical in paste composition and form to those made at Pecos Pueblo. Pipe smoking was a common occurrence in Protohistoric times, but there is no evidence for it in the Late Prehistoric components at Lake Alan Henry. The use of pipes at Pecos Pueblo dates back to Glaze I times (Kidder 1932:181-182), and it is possible that pipe smoking became popular with the Southern Plains groups during Late Prehistoric II times. 


\begin{tabular}{|c|c|c|c|c|c|c|c|c|c|}
\hline \multicolumn{10}{|c|}{$\begin{array}{c}\text { TABLE } 58 \\
\text { SUMMARY OF CERAMIC VESSELS FROM PROTOF }\end{array}$} \\
\hline \multirow[b]{3}{*}{ Ware Type } & \multicolumn{4}{|c|}{$41 \mathrm{KT} 51$} & \multicolumn{4}{|c|}{$41 \mathrm{KT} 53$} & \multirow{3}{*}{$\begin{array}{l}\text { Total } \\
\text { Minimum } \\
\text { No. of } \\
\text { Vessels }\end{array}$} \\
\hline & \multirow{2}{*}{$\begin{array}{l}\text { Total } \\
\text { Sherds }\end{array}$} & \multicolumn{3}{|c|}{ Minimum No. of Vessels } & \multirow{2}{*}{$\begin{array}{l}\text { Total } \\
\text { Sherds }\end{array}$} & \multicolumn{3}{|c|}{ Minimum No. of Vessels } & \\
\hline & & Bowl & Jar & Unknown & & Bowl & Jar & Unknown & \\
\hline Plain Utility & 738 & - & 1 & - & 1,239 & - & 6 & - & 7 \\
\hline Micaceous Utility & 4 & - & - & 1 & 911 & - & 2 & 2 & 5 \\
\hline Engraved & - & - & - & - & 17 & - & - & 1 & 1 \\
\hline Redware & 129 & 1 & - & 2 & 207 & 5 & 1 & - & 9 \\
\hline Glazeware & 7 & - & 1 & - & 175 & 3 & 3 & - & 7 \\
\hline Matte Paint Ware & 1 & - & - & 1 & 10 & 1 & - & - & 2 \\
\hline Unidentified & - & - & - & - & 17 & - & - & - & 0 \\
\hline Totals: & 879 & 1 & 2 & 4 & 2,576 & 9 & 12 & 3 & 31 \\
\hline
\end{tabular}




\section{LATE HOLOCENE PALEOENVIRONMENT OF THE SOUTHERN TEXAS PANHANDLE-PLAIINS}

Since one cannot understand human behavior without understanding the environmental factors that affect it, paleoenvironmental concerns are usually integrated into prehistoric research designs and historic contexts that guide archeological research. Paleoenvironmental reconstruction was an important part of the Lake Alan Henry cultural resources studies, and a variety of kinds of data contribute to our understanding of past climatic conditions in the project area and throughout the region. The Lake Alan Henry data integrate well with paleoenvironmental data from many other study areas, and a relatively coherent picture of late Holocene climate changes and environmental conditions is emerging.

Paleoenvironmental data take many different forms, but translating the data into climatic interpretations is seldom precise and often involves many assumptions that are controversial (Caran 1994). Lintz, Treece et al. (1993:261-266) suggest seven factors that must be considered when reconstructing regional paleonvironments: (1) magnitude and rate of environmental change; (2) lag time in response to environmental change; (3) primary vs. secondary context of samples; (4) differential preservation and adequacy of sample sizes; (5) cultural biases affecting results; (6) scale of the studies and application to regional interpretations; and (7) chronological control and correlation of results. A comprehensive evaluation, reanalysis, and reinterpretation of paleoenvironmental data for the entire region is beyond the scope of this chapter, but it is appropriate to review the most important paleoenvironmental interpretations that have a direct bearing on under- standing past relationships between man and environment in and around the Caprock Canyonlands.

This chapter begins with a summary of key paleoenvironmental interpretations for the Lake Alan Henry project, and then expands to discuss interpretations from other paleoenvironmental study areas within a $250-\mathrm{km}$ radius of the lake (Figure 74). The individual studies within this area vary considerably in terms of the quantity, diversity, and quality of the data and interpretations, but collectively they demonstrate a considerable degree of continuity. The discussion at the end of the chapter presents a late Holocene paleoenvironmental reconstruction for the southern Panhandle-Plains area and brings in pertinent paleoenvironmental interpretations from farther afield. Although many of the study areas mentioned in this chapter have produced Pleistocene and early Holocene data, the discussions concentrate on the middle and late Holocene periods.

\section{LAKE ALAN HENRY}

\section{Geoarcheological Evidence}

Perhaps the most important result of the geomorphic studies (see Chapter 6) is the definition of a fairly detailed geomorphic history of the project area (Figure 75). The following sequence of four geomorphic phases was proposed by Abbott (1990: 55-57) and is based largely on his geomorphic study and the previous study conducted by Blum (1989). A detailed summary of Blum and Abbott's findings is presented by Blum et al. (1992). The data 


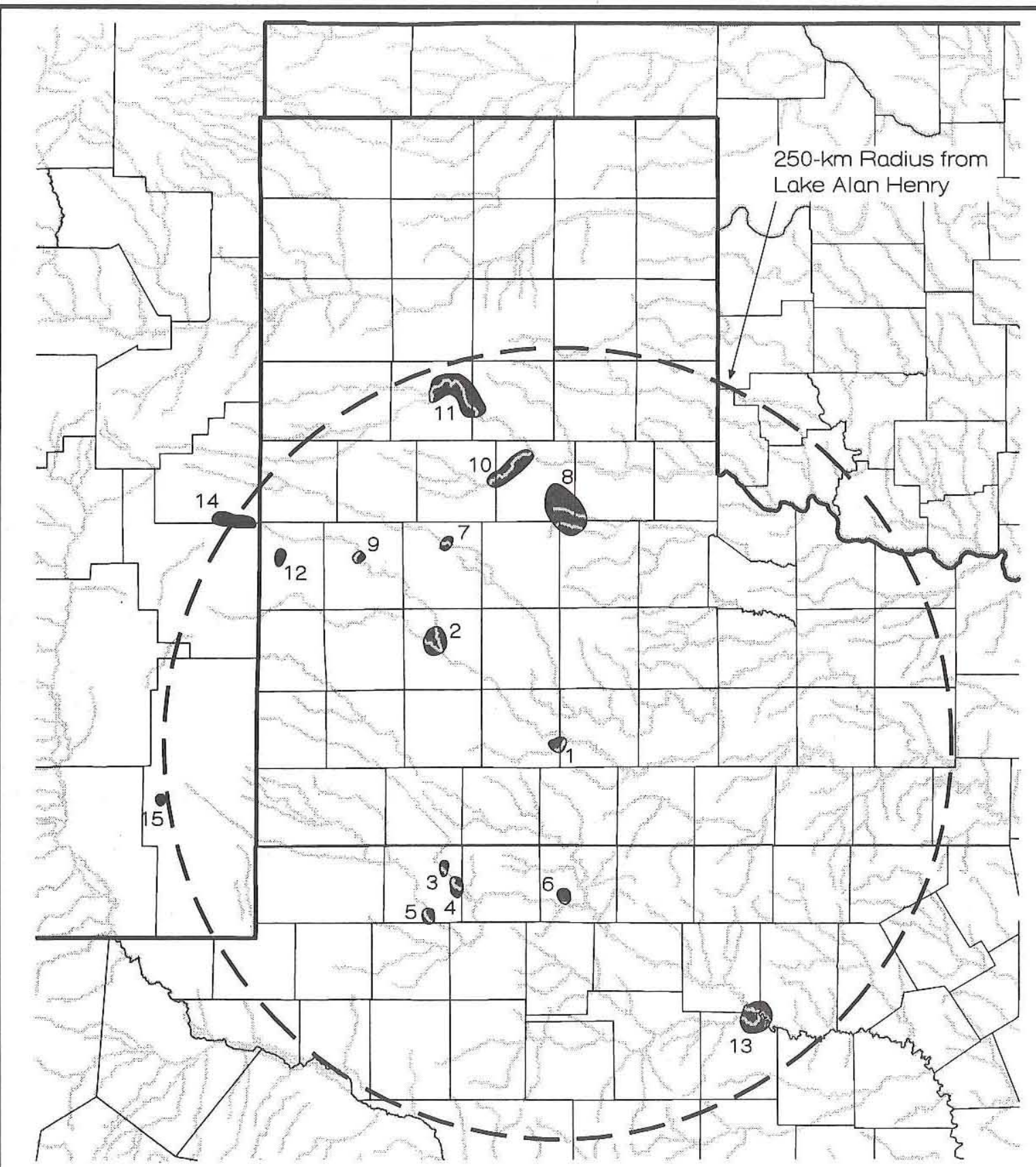

PALEOENVIRONMENTAL STUDY AREA

1 Lake Alan Henry

2 Lubbock Lake Landmark \& Vicinity

9 Marks Beach

3 Sulphur Springs Draw

4 Red Lake Dam

5 Mustang Springs

6 Mitchell Reservoir

7 Running Water Draw

PAIISTISLH

10 Palo Duro Canyon

11 Mackenzie Reservoir \& Lower Tule Canyon

12 Bailey County Sand Hills

13 Lake O. H. Ivie

14 Blackwater Draw

15 Rattlesnake Draw

8 Caprock Canyons State Park \& Vicinity

Figure 74. Middle to late Holocene paleoenvironmental study areas within a $250-\mathrm{km}$ radius of Lake Alan Henry. 
derived from subsequent geomorphic studies at Lake Alan Henry by Bousman (1991, 1992) and Kibler (Boyd and Kibler 1993; Boyd et al. 1994:215-220) and from other studies in the Southern Plains support the basic geomorphic history described below. Given the limited data available at this time, this geomorphic history appears to be applicable for much or all of the Caprock Canyonlands region.

The geomorphic sequence begins with Phase I, a period of slow to moderate alluviation and contemporaneous soil development that started before 13,500 B.P. and lasted through at least 11,000 B.P. Phase $I$ is characterized by stable geomorphic conditions associated with a climate that was moister and cooler than today. This characterization is in general agreement with other data from the region (e.g., Hall 1988; J. Hughes 1991; E. Johnson 1987).

Exactly.what transpired during the terminal Pleistocene and early Holocene is not clear from the Lake Alan Henry data. Abbott (1990:56) notes that the timing of this shift is "unclear due to the lack of sediment preservation" in the project area and elsewhere in the region and that

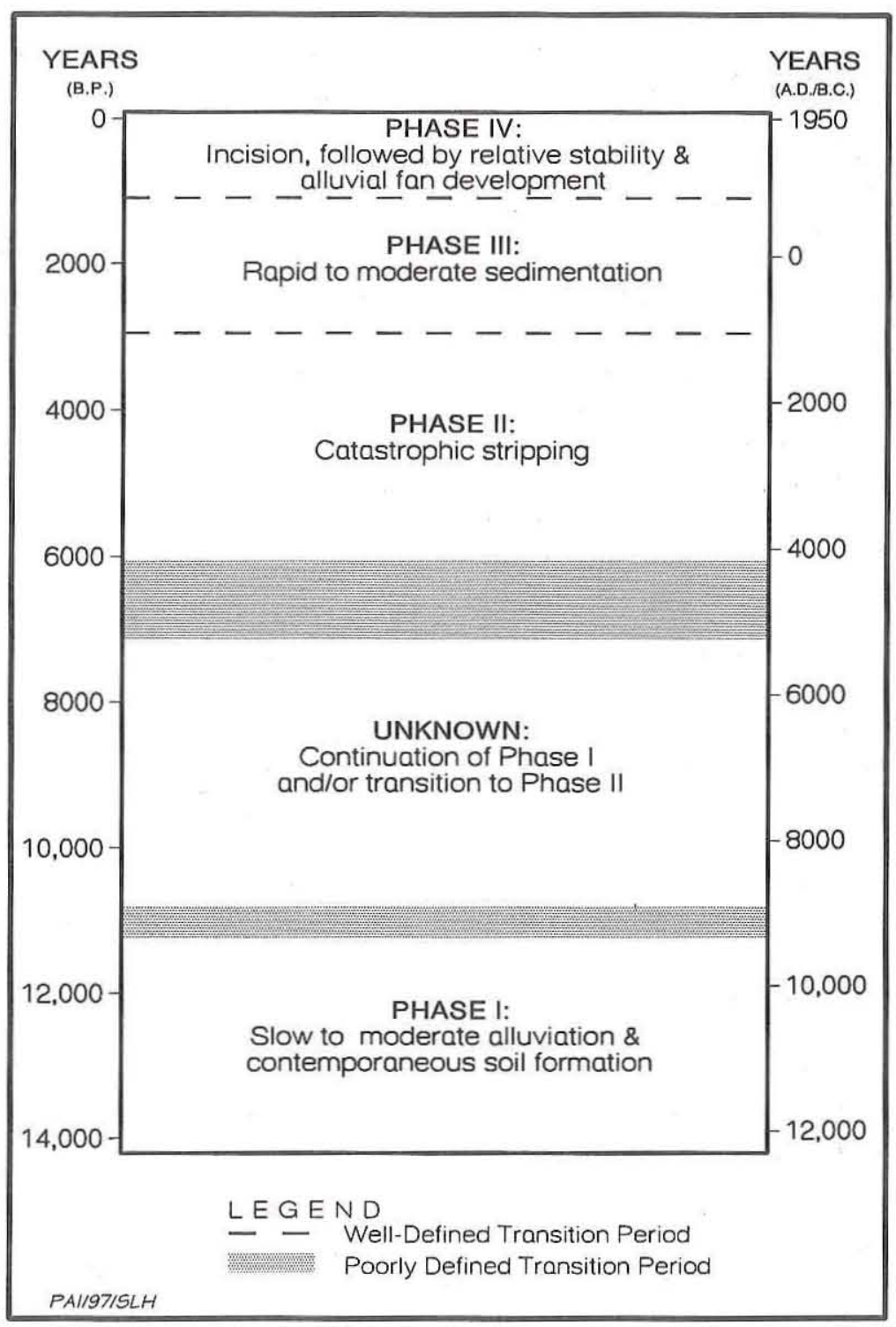

Figure 75. Geomorphic history of the Double Mountain Fork of the Brazos River valley in the vicinity of Lake Alan Henry. substantial periods of late Pleistocene/early Holocene alluviation are suggested from a number of surrounding locations in the southern Great Plains and desert Southwest and are commonly interpreted as the result of increasing temperature and decreasing humidity, accompanied by concomitant decrease in vegetative cover and an increase in erosion by slopewash [Haynes 1968; Knox 1983].

Late Pleistocene fluvial aggradation is reported at the
Lubbock Lake site (Holliday 1988), the Plainview and Clovis sites (Holliday 1985c), the Edwards Plateau (Blum 1987), and Mustang Springs (Meltzer and Collins 1987). Hall (1988:204), on the other hand, notes that the "environmental conditions for the early Holocene, extending from 10,000 to 7,000 years ago, are unknown" and that due to the "paucity of localities dating from this time period, the early Holocene history of stream valley deposition and erosion has yet to be determined." Consequently, it is possible that Phase I may have continued until ca. $8500-7000$ B.P.; alternatively, it is 
possible that there was a more or less gradual trend toward increasing aridity from 11,000 to 7,000 B.P. and that this entire period represents a transition between Phases I and II.

Phase II, a period of catastrophic stripping, began in the early Holocene and lasted until ca. 3000 B.P. In the project area, evidence indicates that

a period of erosion and channel incision occurred that completely removed sediments in the canyon-confined segment and truncated soils developed in the upper and lower sections of the reservoir, sparing only those buried under subsequent fan deposits. Erosion and retreat of the valley walls were also probably accelerated at this time [Abbott 1990:56].

This phase apparently represents a long period of extremely arid conditions (i.e., droughts) and correlates with Antevs's $(1948,1955)$ proposed Altithermal period. Evidence elsewhere in the Southern Plains (e.g., Hall 1988; Haynes 1968; Holliday 1985a, 1985b; Meltzer and Collins 1987) suggests that the Altithermal began around 7000 B.P., but there are no independent data from Lake Alan Henry to support or contradict this.

Around 3000 B.P., the long period of erosion gave way to Phase III, a period of substantial alluviation followed by a relatively stable soilforming interval that lasted until ca. 1000 B.P. Abbott (1990:57) notes:

Beginning about 3,000 years ago, the floodplain of the Double Mountain Fork and its tributaries began to aggrade again. Radiocarbon assays of sediment samples obtained from deposits of the terraces in Grape Creek and the canyon-confined reaches of the Double Mountain Fork demonstrate that aggradation was well under way by approximately 2700 B.P. and that the present elevation of the terrace complex was achieved by approximately 1100 B.P., although data from the lower Double Mountain Fork indicate that localized sedimentation in swales continued for several hundred more years.

Archeological materials seem to be more concentrated in the upper meter of terrace deposits in most areas, perhaps reflecting a combination of increased frequency of human activities and a decreased rate of sedimentation toward the end of Phase III. Relative to the previous phase, Phase III was much more mesic.

Phase IV is characterized as a brief period of incision, followed by a period of relative stability and alluvial fan development, all of which occurred from 1000 to 200 B.P. Abbott (1990:57) states:

Approximately 1,000 years ago, probably due to a shift to more arid conditions, widespread floodplain aggradation in the study area ceased and the streams began to incise into their deposits, creating the younger terrace[s]. At approximately the same time, the rate of alluvial fan formation increased markedly. Although not well dated, the formation of eolian dunes in the valleys appears to have begun at approximately the same time, further supporting a shift to drier conditions.

Geomorphic evidence from a rockshelter in the Lake Alan Henry area supports the interpretation of an onset of drier conditions around 1,000 years ago. Kibler's study of sediments inside Boren Shelter No. 2 (in Boyd et al. 1994:215-220) defined a significant shift in the depositional processes between A.D. 1000 and 1100 . From A.D. 0 to 1000 , the sediments were derived primarily from in situ weathering and disintegration of sandstone inside the shelter. These processes continued after A.D. 1000, but there was an additional influx of reddish brown eolian sands (derived ultimately from Triassic Dockum Group mudstones or the Blackwater Draw Formation) deposited by southeast winds blowing down the channel of the Double Mountain Fork.

\section{Pollen/Phytolith Evidence}

In order to assess the preservation and interpretive potential of fossil pollen in the project area, five separate palynological studies were conducted. The overwhelming conclusion of these studies is that fossil pollen is poorly preserved in almost all settings throughout the project area. Poor preservation is due to a complex set of variables related to the depositional environments of the sediments (i.e., frequent hydration/dehydration, high $\mathrm{pH}$, high $\mathrm{Eh}$, soil chemistry, mechanical agents, and temperature fluctuation). The result is that significant portions of the pollen record have been lost, and pollen that is preserved is insufficient to support interpretations 
of paleoenvironmental conditions (Bryant 1993:442; Dering 1994:335; Dering and Bryant 1992:218; Jones 1990). To date, no depositional settings conducive to the preservation of fossil pollen have been found, and even sediments from a small upland playa yielded no interpretable pollen (Dering 1993b).

Somewhat better results have been obtained from phytolith studies. A total of 59 samples was analyzed in four separate studies, but interpretations of the data are hampered by the current state of the art and the lack of precise chronological control. An initial phytolith study by Cummings (1990) showed that the technique has considerable potential for paleoenvironmental interpretation, but Dering (1994:335) notes that phytolith studies in the region are relatively new and detailed interpretation of phytolith data "requires an extensive regional reference collection of modern plant samples, which currently does not exist for the Southern Plains." In spite of this, one of the studies does support limited paleoclimatic inferences. A column of 25 sediment samples from Morgan Playa provides a tentative paleoclimatic reconstruction based on interpretations of changing grassland environments. While the pollen samples from this 220-cm-deep sample column were poorly preserved and uninterpretable (Dering 1993b), the phytolith samples analyzed by Fredlund (1993) were found to be fairly well preserved and may be cautiously interpreted. Located $3 \mathrm{~km}$ north of the Double Mountain Fork and about $20 \mathrm{~km}$ east of the Caprock Escarpment, Morgan Playa is much smaller and younger than most playas on the Llano Estacado. Lower Plains playas act as sediment traps and appear to contain good stratigraphic/paleoenvironmentalrecords. Acknowledging that the sample column is dated by a single radiocarbon assay (a corrected radiocarbon age of 6840 B.P. from $175 \mathrm{~cm}$ below the surface) and that a constant rate of sedimentation is assumed, the phytolith data seem to provide gross evidence for significant changes in the composition of the grass communities around the playa, with cooler-climate mixed grasses dominating prior to 7000 B.C. and warmer-climate short grasses gradually increasing in frequency after that time. Short grasses may have become dominant during the dry Altithermal, and they continued to be dominant until sometime within the past 600 years. This seems to reflect the establishment of short-grass prairies in the Southern Plains during the middle Holocene. Because of the lack of chronological control, this phytolith evidence cannot be directly correlated with the Lake Alan Henry paleoclimatic reconstruction based on geomorphic evidence.

\section{Macrobotanical Evidence}

Macrobotanical remains recovered from flotation at Lake Alan Henry were an important source of data for interpreting economic use of plants by humans, but the data are only minimally useful for paleoenvironmental interpretations. Charred Carya sp. wood recovered from a slab-lined hearth at $41 \mathrm{GR} 484$ was radiocarbon dated to $260 \pm 70$ B.P., which calibrates to ca. A.D. 1650 (see Table 32). This wood is from either hickory or pecan, neither of which are found in the immediate area today. Based on the modern distribution of these trees, which generally occur farther to the south, it most likely is pecan (Dering 1992). Blakeslee (1994) reports that remnant stands of pecan trees are present in Blanco Canyon in Crosby County, some 20-25 km north of Lake Alan Henry.

The presence of several remnant groves of live oak trees in the project area also is notable. These trees have been identified as Quercus fusiformis (small), commonly called scrub or escarpment live oak. Benny Simpson (personal communication 1992) originally recognized the northern limit of live oaks in northwest Texas as being around Nolan County but now extends their range into Garza County. Some of these trees are ca. 200 years old (see Appendix C), but it is not known how long live oaks have been in the area.

These northerly remnant populations of pecans and live oaks may be evidence that conditions were generally wetter in the vicinity of the project area at some time in the past. Like the remnant populations of Rocky Mountain juniper (see Chapter 2), pecan and live oak may have been present throughout the southern Caprock Canyonlands at one time. It is possible that these species are holdovers from when more-mesic conditions prevailed in the region prior to A.D. 1000 . This interpretation is tentative, however, and more research is needed.

\section{OTHER PALEOENVIRONMENTAL STUDY AREAS}

\section{Lubbock Lake Landmark and Vicinity}

In paleoenvironmental terms, the most intensively studied area anywhere in the Southern Plains 
is the Lubbock Lake Landmark. Because it contains stratified deposits dating back to Pleistocene times, the Lubbock Lake site, 41LU1, has been the scene of extensive geoarcheological research for many decades. The stratigraphic chronology has been established by hundreds of radiocarbon dates, and a paleoclimatic sequence has been inferred from sedimentological, pollen, and faunal data. The Lubbock Lake paleoclimatic reconstruction, best summarized by Eileen Johnson (1987), is based primarily on geoarcheological evidence presented by Holliday (e.g., 1982, 1983a, 1983b, 1985a, 1985b) and Holliday and Allen (1987).

Lubbock Lake was considerably cooler and wetter in Clovis times than it is today, but a long drying trend began around 11,000 B.P. and continued until around 6300 B.P. The paleoenvironmental evidence provides a clear record of at least two intense drought episodes during the Middle Archaic, at $6300-5500$ B.P. and at $5000-4500$ B.P. The climate seems to have returned to more or less modern conditions some time soon after 4500 B.P. Climatic conditions were relatively stable (compared to the intense middle Holocene droughts) between 4500 and 1000 B.P., as evidenced by the development of the Lubbock Lake soil. The climate again began to get drier and warmer sometime around or shortly after 1000 B.P., and the last 1,000 years is characterized by episodic aridity.

There also is evidence for eolian sedimentation during the Altithermal in small playa lakes on the southern High Plains in the vicinity of Lubbock. Such evidence was observed at Gentry Pit, an excavation in a playa $10 \mathrm{~km}$ northeast of the Lubbock Lake site (Holliday 1983b, 1985b). The stratigraphy there includes a band of eolian sands within the clay lacustrine deposits. Radiocarbon dates from Gentry Pit indicate that the eolian deposit dates to the middle Holocene and probably accumulated when the playa was partially or completely dry for an extended period of time.

Eolian dunes on the lee, or downwind side, of most small playas were deposited during the Holocene, and soils formed in these dunes may correlate with soil formation episodes noted in High Plains draws. One such locality, known as the Dune site, is located adjacent to Cone Playa $2 \mathrm{~km}$ north of the Lubbock Lake site. The soils at the Dune site, radiocarbon dated and studied by Holliday (1983b, 1985b), are approximately equivalent in age to soils at Lubbock Lake. One of the Dune site soils formed during a period of landscape stability just prior to the beginning of the Altithermal around 6000 B.P. and is equivalent to the Yellowhouse soil at Lubbock Lake. Also represented at the Dune site is an equivalent of the Lubbock Lake soil which formed just prior to the droughtlike conditions that began around 1000 B.P.

\section{Sulphur Springs Draw}

Recent archeological investigations at Sulphur Springs Draw, on the southern Llano Estacado in Martin County, Texas, are reported by Quigg et al. (1994), and the detailed geomorphic investigations in and along the margins of the draw are reported by Frederick (1994a). The deposits in the valley floor are generally similar in chronology and composition to other draw deposits on the Llano Estacado, but there are some differences that are not fully understood. Despite the inconsistencies, Frederick (1994a) was able to propose a geomorphic history for the draw. Marsh-pond basins that had previously held water were apparently filled in with a sandy deposit of unknown origin (either fluvial or eolian) during early to middle Holocene times, ca. 8600-6300 B.P., followed by deposition of a calcareous lacustrine or palustrine marl.

Sporadic eolian deposition occurred between 6,300 and ca. 3,000 years B.P. and was followed by a period of marsh conditions on the valley floor that persisted between ca. 3,000 and 420 years B.P. Around 1,000 years B.P., the ground water table dropped enough to allow desiccation of at least one pond on the valley floor, and concomitantly fostered clay dune construction along the eastern valley margin [Frederick 1994a:80].

Fluvial sedimentation resumed in the valley sometime after 420 B.P.

Two (possibly three) water wells found in the alluvial sediments in the valley floor were dated by radiocarbon and optically stimulated thermoluminescence techniques. These wells were dug between 8300 and 3400 B.P., most likely around 5,000-8,000 years ago during the middle Holocene. The water wells, along with the eolian deposition between 6300 and 3000 B.P., are interpreted as evidence for a lower water table and increased eolian activity during the dry Altithermal period. 
Other significant paleoclimatic evidence from the Sulphur Draw study was found in the uplands along the valley margin. Upland clay dune (or lunette) development apparently accelerated about 1000 B.P., probably in response to a drop in the water table and the onset of drier conditions. However, the drop in the water table was not severe enough to affect the formation of marshes in the valley bottom. This apparent contradiction is explained as representing a change in the seasonality of precipitation or the occurrence of very brief but significant droughts. Frederick (1994a:51, 1994b) notes that the evidence from the Sulphur Springs Draw lunette correlates with other regional data indicating increased aridity around A.D. 1000.

\section{Red Lake Dam}

Investigations at Red Lake Dam (Quigg, Frederick, and Lintz 1993), in Martin County about $3 \mathrm{~km}$ southeast of Sulphur Springs Draw, produced similar geomorphic evidence. Although the investigations were less intensive than those at Sulphur Springs Draw, Frederick (1993:49) reports that three arc-shaped dunes or lunettes represent "sand and clay aggregates eroded by wind from the basin floor during low lake stages and deposited in dunes that fringed the edge of the lake." The larger two are Pleistocene in age and are farthest from the lake, while the smaller lunette (L3) is immediately adjacent to the lake and was formed during the late Holocene. Although it is undated, the formation of the smaller lunette may be related to the onset of arid conditions around A.D. 1000, as proposed for the nearby Sulphur Springs Draw locality. Frederick (1993:42) notes that lunettes adjacent to other saline lakes (i.e., White Lake in Bailey County and Seven Lakes in Terry County) on the Llano Estacado are similar and may be of late Holocene age (see Hester 1975:21, 24).

\section{Mustang Springs}

Mustang Springs, located in a wide and deep valley segment of Mustang Draw in Martin County, Texas, has been extensively studied by Meltzer and Collins (1987) and Meltzer (1991). Mustang Draw is an intermittent stream today, but before modern irrigation lowered the local Ogallala water table there were permanent freshwater springs in the immediate area, as confirmed by U.S. Army explora- tions in 1849 (Marcy 1850:63). Meltzer (1991:237) notes that "there is unmistakable evidence, however, that the springs failed during the Altithermal." Evidence indicates that the water table began to drop soon after 8000 B.P., and the Mustang Springs ponds became brackish and completely dried up by 6800 B.P. Between ca. 6800 and 6000 B.P., the water table dropped some $3 \mathrm{~m}$ and people were forced to dig wells to obtain water in the arid landscape. Geoarcheological investigations at Mustang Springs have discovered 63 prehistoric water wells dating to the middle Holocene. One may debate the details, such as the dating of these events and the extent to which the water table dropped, but the suggestion that "these were harsh times on the southern High Plains" is not easily disputed (Meltzer 1991:261).

\section{Mitchell Reservoir}

Geoarcheological investigations at Mitchell Reservoir (Lintz, Trierweiler et al. 1991; Quigg, Lintz, Oglesby, and Treece 1993), a chloride control project on a tributary of the Colorado River immediately adjacent to the southern edge of the Llano Estacado, produced sufficient evidence to infer a generalized geomorphic history of the project area (Doering and McFaul 1991). The drainage basin was apparently flushed to bedrock during the middle Holocene, and alluvial deposition began before 4500 B.P. and continued until around 1000 B.P. A buried soil (A horizon) present in many parts of the reservoir basin is radiocarbon dated to ca. 1000 B.P. This is interpreted as evidence that the rate of deposition began to decrease after ca. 2500 B.P. and that the terraces stabilized and soil formation began prior to 1000 B.P. Soon after 1000 B.P., the stable terrace surfaces were buried by eolian and/or fluvial sediment and channel incision began again. A weakly developed buried soil, formed in a post1000 B.P. channel fill, indicates that there were periods of landscape stability during the last millennium. Doering and McFaul (1991:35) note that the geomorphic events after 1000 B.P. correlate with late Holocene eolian sedimentation, stream entrenchment, and weak soil development noted elsewhere (e.g., Blum and Lintz 1993; Hall 1990; Holliday 1985b). Thus, the Mitchell Reservoir evidence indicates intensive erosion and aridity during the Altithermal, followed by a return to moderate, or more-mesic, conditions and a second, less-intensive xeric period 
around A.D. 1000.

\section{Running Water Draw}

Geoarcheological work along middle Running Water Draw, in the vicinity of the Plainview site in Plainview, Texas, concentrated on the Paleoindian remains and sediments but some middle to late Holocene data have been obtained (Holliday 1985b, 1990; Holliday, ed. 1983). Although not well dated, the Holocene alluvial stratigraphy is basically similar to that of Blackwater Draw and Lubbock Lake. The most significant similarity is the presence of a massive sandy eolian deposit that accumulated over 3,500 years ago and that correlates with Stratum 4 at Lubbock Lake (Holliday 1985b:333-334). Stratum 4 includes an eolian accumulation up to $3 \mathrm{~m}$ thick (Substratum 4B) that was deposited between ca. 5000 and 4500 B.P. (E. Johnson 1987:19). These eolian deposits apparently occurred during the dry Altithermal period.

\section{Caprock Canyons State Park and Vicinity}

Like Lake Alan Henry, Caprock Canyons State Park (Bagot and Hughes 1979; Etchieson et al. 1977) has a paucity of early sites and an abundance of late sites (i.e., dating to the late Holocene). No geomorphic studies were done in connection with these archeological surveys, but subsequent studies suggest that the geomorphic history of the park area is similar to that of Lake Alan Henry. Consequently, the archeological remains may be biased toward younger sites because of erosion during the middle Holocene. In a geological guidebook of the Quaternary stratigraphy and geomorpology of the Rolling Plains, Gustavson (1986) reports on investigations of 15 geologic localities in and near Caprock Canyons State. Park (all are within $10 \mathrm{~km}$ of Quitaque in Briscoe, Hall, and Motley Counties). Bearing in mind that the chronologies are based on soil humate dates, three of the localities have sufficient (albeit gross) chronological control to support late Holocene paleoclimatic interpretations (i.e., Stops 5, 11, and 15).

Guidebook Stop 5 is a 9-m-high terrace of the upper Little Red River located in Caprock Canyons State Park. It was investigated by Baumgardner (1986), and three buried paleosols were radiocarbon dated. A well-developed soil near the bottom of the terrace (at $7.5 \mathrm{~m}$ below the surface) was dated to 2140 B.P., indicating that the entire alluvial sequence had been deposited within the last 3,000-4,000 years. Thus, the original channel incision episode may have been related to the Alithermal drought period. The only other paleosols, at $3 \mathrm{~m}$ and $1 \mathrm{~m}$ below the surface, were radiocarbon dated to ca. 1495 and 1465 B.P., respectively, indicating a rapid accumulation of $4.5 \mathrm{~m}$ of alluvial sediments with landscape stability and soil formation occurring late in the sequence. After ca. 1465 B.P., the rate of alluviation slowed considerably. Baumgardner (1986:26) suggests that it stopped at around 840 B.P. in response to arid conditions. Although there is no direct evidence of a more-arid climate at this stratigraphic location, this interpretation is based on similarities with stratigraphic sequences at Stops 11 and 15 .

Guidebook Stop 11 is reported by Baumgardner and Caran (1986a). It consists of three stratigraphic sections exposed in a railroad cut $1.6 \mathrm{~km}$ north of Turkey, Texas. Eight radiocarbon dates indicate that the sections represent a more or less continuous record for the past 12,000 years. Stop 11A is not well dated but consists of a 6-m exposure of late Pleistocene fluvial and lacustrine deposits (the latter due in part to local subsidence) that are partially truncated by fluvial downcutting (perhaps related to Altithermal droughts), followed by renewed sedimentation. An upper stratigraphic zone is dated to ca. 1235 B.P., and its upper contact is scoured by erosion and overlain by eolian deposits. Stop 11B consists of $8 \mathrm{~m}$ of late Pleistocene/early Holocene deposits, unconformably overlain by a thin $(1 \mathrm{~m}$ thick) veneer of sediments that are thought to be late Holocene in age. This section is not well dated, but the erosional episode may date to middle Holocene times. Stop 11C consists of a 3-m section, the middle of which contains a substantial buried paleosol radiocarbon dated to 6400 to 4130 B.P. This paleosol apparently represents a stable surface during the middle Holocene. The uppermost meter of the section includes a paleosol dated to ca. 1260-830 B.P., which is overlain by eolian sand. The surface of the paleosol exhibits evidence of erosion that is thought to be due to arid conditions around 1,000 years ago.

Guidebook Stop 15, reported by Baumgardner and Caran (1986b), consists of three alluvial sections along Los Lingos Creek. Eleven radiocarbon dates were obtained from the sections. Stop $15 \mathrm{C}$ is the 
best-dated stratigraphic sequence with three sets of paired dates that are stratigraphically consistent. The 5-m-thick section contains a lacustrine deposit dated to ca. 6300 B.P. at $4 \mathrm{~m}$ below the surface. It is overlain by a buried paleosol dated to ca. 1680 B.P. at $2.5 \mathrm{~m}$ below the surface. A weak paleosol near the top of the profile at Stop $15 \mathrm{C}$, at about $0.5 \mathrm{~m}$ below the surface, is dated to ca. 330 B.P. Baumgardner and Caran (1986b:71) suggest that the Stop 15 sections provide evidence for 6,000 years of stream aggradation, interrupted periodically by stability and soil formation.

All three of these localities (Stops 5, 11, and 15) exhibit some evidence for middle Holocene erosion and/or landscape stability that may be related to arid conditions. Perhaps the most important consistency between these three localities is that they all exhibit evidence of a period of landscape stability and soil formation between 2500 and 1000 B.P., followed by erosion and/or fluvial/eolian deposition around or after 1000 B.P., apparently reflecting the onset of drier and/or warmer conditions (Baumgardner and Caran 1986a:55). An increase in eolian activity also is notable in the deposits of the last 1,000 years. Similar stratigraphy along Quitaque and Los Lingos Creeks (Stops 12, 13, and 14) suggests that post-1000 B.P. erosion was widespread, and a buried paleosol at Stop 14 near Quitaque is dated to ca. 2970 to 1000 B.P.

Ferring (1992:12-13) notes that the late Holocene soil in the Quitaque area, which he informally calls the Quitaque soil, was forming as late as 1500 to 1400 B.P. (at Stop 15C) but apparently terminated between 1200 and 800 B.P. due to erosion and/or burial. This is contemporaneous with late Holocene soils elsewhere in the Southern Plains (such as the Caddo and Copan soils in Oklahoma and the West Fork soil in north-central Texas [Ferring 1992: Figures 1-3]). The significance of this correlation is that the late Holocene soil formation observed over a large portion of the Southern Plains was suddenly interrupted by erosion/burial, probably induced by climatic change, between 1200 to 800 B.P. (Ferring 1992:13). This was synchronous with widespread channel trenching and erosion that probably represents a shift from mesic to xeric conditions (Hall 1990:344).

\section{Marks Beach}

Preliminary interpretations of geoarcheological work at the Marks Beach site, located along Blackwater Draw between Blackwater Draw Locality No. 1 and the Lubbock Lake site, are reported by Honea (1980). In its geologic setting and stratigraphy, Marks Beach is similar to the Lubbock Lake site, but interpretations of the Marks Beach data are minimal because the chronology is not well established. One radiocarbon date was obtained for a Paleoindian level, but the age of the remainder of the stratigraphic sequence is crudely estimated through associations with diagnostic artifacts. Two dart points and a probable water well associated with Zone III (Honea 1980:262, 267) are thought to be approximately 4,000 years old and may be associated with arid conditions during the Altithermal. Despite the fact that no dates or diagnostic artifacts are directly associated with the well feature, its geologic context indicates that it is probably of middle Holocene age. Presumably, the well was dug to reach a lowered water table due to drought conditions.

\section{Palo Duro Canyon}

No detailed paleoenvironmental studies have been done in the Palo Duro Canyon area, but Jack Hughes $(1969,1978: 44,1991: 27)$ notes that remains of the prairie vole Microtus ochrogaster have been found in two rockshelters in the area (and at Deadman's Shelter in Mackenzie Reservoir, discussed below). Prairie vole remains were found in Level 4 of Canyon City Club Cave, dated A.D. 262-874 (calibrated), and in a stratum at Blue Spring Shelter dated A.D. 815-1100 (uncorrected, uncalibrated). Since this species exists today north and east of the Texas Panhandle, its occurrence in canyonland rockshelters may indicate that the climate was wetter and/or cooler during the first millennium A.D. (see Mackenzie Reservoir discussion below).

Alluvial sediments in Chalk Hollow gorge in the Palo Duro drainage show evidence of repeated channel cutting followed by renewed deposition in Late Archaic times. Wedel (1975:273) speculated that Chalk Hollow might have been occupied by Paleoindians and Early Archaic peoples but that the deposits from this time period had been "swept away by canyon-scouring floods before, during, or just after the Altithermal." While the geomorphology has not been studied in detail, this suggests that the geomorphic history of Lake Alan Henry (discussed above) may be applicable to Chalk Hollow and other 
areas of Palo Duro Canyon. In his review of the archeology of Palo Duro Canyon, Jack Hughes (1978:40) noted that Late Archaic and Late Prehistoric sites are much more common and suggested an increase in the intensity of human occupation. The Chalk Hollow evidence, albeit meager, would suggest that differential preservation and erosional destruction of earlier sites are significant factors.

\section{Mackenzie Reservoir and Lower Tule Canyon}

No intensive geomorphic or paleoenvironmental studies were conducted during the archeological investigations at Mackenzie Reservoir (Hughes and Willey 1978; Malone 1970), but some useful data were obtained. The remains of Microtus ochrogaster were found in Strata B and C of Deadman's Shelter. Stratum C may date as early as A.D. 383 (based on two calibrated dates from the underlying Stratum D), and Stratum B is dated A.D. 432-883 (two calibrated dates). These remains have been interpreted as evidence that the climate was wetter during this time period (Hughes and Willey 1978; Schultz and Rawn 1978). This species of prairie vole lived in central Texas during late Pleistocene times, but its modern range is in the wetter and cooler areas much farther to the north (see Hall 1982:Figure 8; Schultz and Rawn 1978:Figure 65).

The presence of prairie vole remains in at least three rockshelters (see Palo Duro discussion above) indicates that they ranged into the Caprock Canyonlands during the first millennium A.D. but did not live in the area after ca. A.D. 1000. Hall (1982: 400-401), Frederick (1994a:51), and others have cautioned that this evidence may be interpreted in different ways. It is possible that prairie voles may not have lived in the canyonlands during the late Pleistocene or that they lived in the canyonlands in Pleistocene times but died out soon after (e.g., during the Altithermal). In either of these cases, their presence during the first millennium A.D. may indicate that mesic conditions allowed populations to move into (or return to) the area. If, however, the prairie voles represent relict populations that survived in isolated areas of the canyonlands since late Pleistocene times, then their presence is not necessarily evidence of a first millennium A.D. mesic period. Regardless, Hall (1982:401) states that "prairie vole populations are sensitive to extremes in climate and succumb to prolonged drought" and suggests that the drier conditions after A.D. 1000 may have contributed to the extinction of the prairie vole (and a few other moisture-loving mammals) in the Texas Panhandle.

The archeological remains found at Mackenzie Reservoir are dominated by sites dating to the Late Archaic, Late Prehistoric, and Historic periods. As has been suggested for Lake Alan Henry, this skewed archeological record is probably due, at least in part, to differential preservation. Although no geomorphic studies were done, the archeological sites found and tested in lower Tule Canyon, immediately below the dam at Lake Mackenzie, also exhibit the same temporal bias (Katz and Katz 1976). Sites and sediments of late Holocene age are well represented (about a dozen sites produced Late Archaic dart points, arrow points, and/or pottery) while no earlier occupations were found. Since these areas are physiographically and geomorphically similar to Lake Alan Henry, it is likely that late Pleistocene and early Holocene sediments (and sites) in Mackenzie Reservoir and lower Tule Canyon were severely eroded during the middle Holocene period.

\section{Bailey County Sand Hills}

The sand hills in Bailey County are part of a large east-west-trending belt of eolian dunes in the western portion of the Llano Estacado. This sand dune belt is the northernmost of three belts that parallel the modern and ancient river valleys crossing the western half of the Llano Estacado (see Holliday 1985b:Figure 14.3). These dune fields "appear to be entirely of late Quaternary age" (Holliday 1985b:341), having formed during the late Pleistocene and early Holocene as the climate became drier.

Gile $(1979,1981,1983)$ has identified a series of Holocene sediments, soils, and surfaces in the dunes around a large playa blowout in Bailey County. The sand hills stratigraphic data reflect alternating dry periods when the dune fields were actively migrating and wetter periods (generally comparable to modern conditions or more mesic) when the dunes were relatively stable and soil formation occurred (Holliday 1985b:343). The timing of the eolian deposits and soil formation in the dunes generally appear to correlate with depositional and pedogenic episodes at Lubbock Lake, suggesting that the middle to late Holocene climate proposed for Lubbock Lake (see E. Johnson 1987: 
Figure 2.7) may be applicable for the dune belt as well. Gile (1983:141) suggests that the depositional sequence of the Longview sediments (dune Stratum VII) is related to the Altithermal droughts and consists of eolian accumulation between 6500 and 6000 B.P., a period of stability and soil formation between 6000 and 5000 B.P., and additional eolian deposition between 5000 and 4500 B.P. (the Longview I and II correlate with Strata 3 and 4 at Lubbock Lake). Holliday (1985b:346-347) observed that the Longview dune sediments were derived primarily from the floor of the playa basin, indicating that it was dry at the time that the dunes accumulated. From ca. 4000 to 70 B.P. (the latter date being when ground water pumping permanently lowered the water table in the vicinity), alternating periods of eolian accumulation and dune stability/soil formation are represented, but the sequence is not well dated (Gile 1983:138-140).

\section{Lake O. H. Ivie}

Extensive geoarcheological studies were conducted in conjunction with the cultural resources investigations at Lake O. H. Ivie (Lintz, Blum et al. 1993) at the confluence of the Concho and Colorado Rivers in Concho, Coleman, and Runnels Counties, Texas. Unlike riverine areas in the Caprock Canyonlands (e.g., Palo Duro Canyon, Mackenzie Reservoir, and Lake Alan Henry), the alluvial sequence at Lake O. H. Ivie is relatively complete and is not severely biased by erosional removal of late Pleistocene and early Holocene deposits (although they are deeply buried). Based on 60 radiocarbon-dated sediment samples, Blum and Lintz (1993:313, Figure 5.13) propose the following geomorphic history: (1) the Concho and Colorado River valleys had been excavated to their maximum size by 10,000 B.P.; (2) slow lateral migration, channel aggradation, and floodplain construction characterized the rivers between 10,000 and 5000 B.P.; (3) the channels incised to bedrock between 5000 and 4600 B.P., and soil formation occurred on the abandoned floodplain surfaces; (4) slow channel aggradation and floodplain construction were again under way between ca. 4500 and 1000 B.P., and the middle Holocene soils were buried during this time; and (5) the channels were again incised to bedrock during the last 1,000 years and soil formation and/or eolian deposition occurred on late Holocene floodplains.
Although the chronology should be considered approximate since the sediment dates represent minimum ages of deposition, the proposed sequence of geomorphic events does denote climatic changes of large magnitude (i.e., macroscale); it apparently does not document minor (i.e., microscale) changes, however. Thus, one may infer that the climate was very dry for extended periods when the river channels incised to bedrock during the middle Holocene (ca. 5000 B.P.) and again after 1000 B.P. Relative to these xeric times, climatic conditions during the previous, intervening, and subsequent periods must have been more mesic, but it is uncertain how wet these periods were relative to each other or to the modern climate.

\section{Blackwater Draw}

Geoarcheological work at Blackwater Draw (in the vicinity of the Clovis site, Blackwater Draw Locality No. 1) in Roosevelt County, New Mexico, has concentrated primarily on the Paleoindian period, but some of the evidence relates to later times. The stratigraphy of Blackwater Draw has been studied since the 1930s (see Haynes 1975; Haynes and Agogino 1966), and recent summaries by Holliday (1985b, 1985c, 1988) indicate that the Holocene alluvial stratigraphy at Blackwater Draw generally correlates with the Lubbock Lake stratigraphic sequence. At Blackwater Draw, there is good evidence for early Holocene lacustrine (i.e., pond) deposits from 11,500 to ca. 8500 B.P. Eolian deposition occurred on the valley margin between 10,000 and 8500 B.P. indicating the onset of drier conditions. In the valley, the ponds apparently dried up, and a paleosol began developing around 8500 B.P. This surface must have remained stable for some time after 8500 B.P., but development of the paleosol ended when the deposit was buried by eolian sedimentation, which continued until around 5000 B.P. This period of middle Holocene eolian sedimentation is attributed to dry conditions during the Altithermal. Holliday (1985b:339) also notes that there is evidence for renewed eolian deposition in Blackwater Draw between 1000 and 500 B.P.

Additional evidence for a middle Holocene drought at Blackwater Draw includes 19 water wells reported by Evans (1951), Green (1962c), Hester (1972), and Warnica (1966). Most of the original investigators attributed the wells to the Altithermal period based primarily on their geologic contexts, 
but one well was thought to be from late Paleoindian times (see Quigg et al: 1994:Table 8.1). The stratigraphy and chronology of these wells is discussed by Meltzer and Collins (1987:17-18), who conclude that they most likely date between 8500 and 5000 B.P.

\section{Rattlesnake Draw}

Based on its geologic context, Smith et al. (1966:306) report that a water well found at Rattlesnake Draw in western Lea County, New Mexico, is around 7,000 years old and suggest that it was excavated during the Altithermal period. No radiocarbon dates or diagnostic artifacts are associated with this feature, but Meltzer and Collins (1987: 18-19) note that its stratigraphic context is quite similar to that of the Blackwater Draw wells. Without independent dating, there is some doubt as to its age, but the circumstantial evidence for a middle Holocene age is good.

\section{DISCUSSION}

The geomorphic history of Lake Alan Henry explains the biased archeological record in that project area and seems to be a reasonable explanation for the temporally skewed archeological remains encountered elsewhere in the Caprock Canyonlands (e.g., Mackenzie Reservoir and Palo Duro Canyon). The Lake Alan Henry geomorphic history also meshes well with the paleoenvironmental data and interpretations from Lubbock Lake and from other parts of the southern Panhandle-Plains. When all of the paleoenvironmental studies within $250 \mathrm{~km}$ of Lake Alan Henry are considered as a group, there is a substantial body of similar evidence (the bulk of which is geoarcheological) and a consensus of interpretations. Based on the various study areas described above, a general reconstruction of middle to late Holocene geomorphic and climatic conditions may be offered (Figure 76). Two periods stand out in the paleoenvironmental record as being characterized by lengthy and/or intensive xeric or drought conditions - the middle Holocene Altithermal period and a late Holocene period around or after A.D. 1000. Conditions more mesic than today may have prevailed during the period from A.D. 1 to 1000. The southern Panhandle-Plains evidence for these climatic changes is summarized below.

Originally termed the Altithermal by Antevs
(1948, 1955), there is increasing evidence that there was an extended period of arid conditions throughout the Southern Plains during the early to middle Holocene (Holliday 1989a; Meltzer 1991). The Altithermal was once thought to have been a single drought, but it has recently been hypothesized that there were two intensive droughts (E. Johnson 1987) or that this period is much more complex and cannot be adequately explained by a single or twodrought scenario (Holliday 1989a). While the details (such as the timing, number, and intensity of drought episodes) are still being debated, there seems little doubt that conditions were significantly drier in the Southern Plains during the mid Holocene (Meltzer and Collins 1987:20). Meltzer (1991:261) states that "on the southern High Plains, geoarcheological evidence suggests that the Altithermal is not absent, just unseen and largely unexamined." The Altithermal was the most significant climatic event in the Southern Plains during Holocene times, and it is evident throughout the Great Plains that its impact on human populations was significant (e.g., Sheehan 1994).

On the Llano Estacado, the Altithermal is considered to represent a period of reduced precipitation with corresponding loss of vegetation cover, a drop in the water table of the underlying Ogallala aquifer, and an increase in eolian activity resulting in development of dune fields, deflation of uplands and playas, and deposition in draws. Holliday (1989a:80) states that "valleys aggraded, the High Plains surface was deflated, and dune fields were built up" and that there was "a significant impact on the flora, fauna, and human populations of the region." Human activities may have been minimal, but people did not totally abandon the southern High Plains. Evidence from Lubbock Lake indicates that ephemeral human activities still occurred at these times (E. Johnson 1987), and people were apparently forced to dig water wells at a number of locations on the Llano Estacado (see Meltzer 1991; Quigg et al. 1994).

The prehistoric water wells provide one of the best lines of evidence for the severity of the drought conditions. The five locations with wells discussed above (i.e., Mustang Springs, Sulphur Springs Draw, Blackwater Draw, Rattlesnake Draw, and Marks Beach) are all along draws on the southern Llano Estacado (see Quigg et al. [1994:Table 8.1] for the most recent summary of prehistoric water well finds). Based on the similarities in stratigraphic 


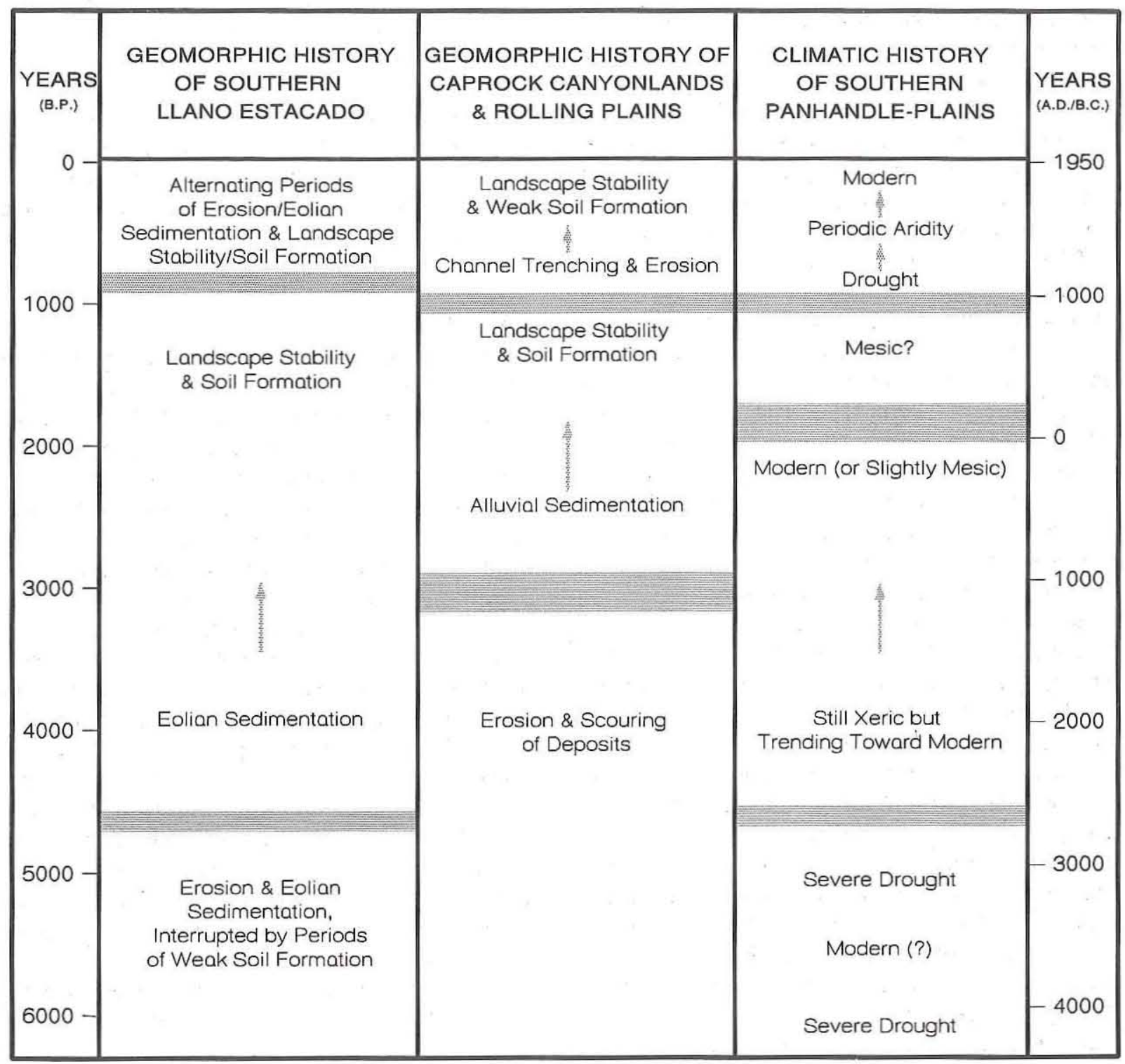

Figure 76. Generalized geomorphic and paleoclimatic reconstruction for the southern Panhandle-Plains of Texas.

contexts and/or associations with dated strata, most of these wells appear to have been dug during the middle Holocene. The only exceptions are that one of the wells at Blackwater Draw may date to Paleoindian times, and a U.S. Army expedition in 1875 documented water wells dug by historic Comanches at several locations (Shafter 1933). Water wells may have been dug during droughts at any time, but the evidence suggests that the middle Holocene drought(s) on the southern High Plains were particularly severe and resulted in a significant drop in the water table.

In the Caprock Canyonlands (and perhaps to some extent in the Rolling Plains), the mid-Holocene droughts had a great impact on the landscape. The arid conditions apparently caused a loss of vegetation and an increase in erosion. The end result was the wholesale removal of most older alluvial sediments, biasing the archeological record. Many researchers have noted the paucity of early sites along the Caprock Escarpment and suggested that severe erosional episodes during the mid Holocene were responsible. This is why Paleoindian and Early to Middle Archaic sites are so rare (see Blum et al. 1992).

The regional evidence suggests that, following 
the Pleistocene, conditions became increasingly xeric from 10,000 to 6500 B.P. and that the Altithermal drought(s) occurred primarily between ca. 6500 and 4600 B.P. After 4600 B.P., conditions seem to have improved. The climate between 4600 and 3000 B.P. must have been wetter but still may have been relatively dry since erosion and scouring of alluvial deposits occurred in the canyonlands as late as 3000 B.C. The evidence is not sufficient to determine if conditions were more or less modern, or if they were still drier than modern during some or all of this time. Conditions may have been essentially modern, or perhaps slightly mesic between 3000 to 2000 B.P., as indicated by soil formation on the Llano Estacado and by alluvial deposition in the Caprock Canyonlands.

There is limited regional geomorphic and faunal (i.e., prairie vole) evidence indicating that conditions between 2000 and 1000 B.P. may have been wetter than today. Circumstantial archeological evidence supports this inference, but more paleoenvironmental and archeological data are sorely needed. Unlike drying trends, the mesic periods may be less visible in the paleoenvironmental record, and supporting data may be difficult to obtain.

Paleoenvironmental and archeological data from outside the Texas Panhandle-Plains support an interpretation of a widespread mesic interval during the first millennium A.D. Researchers have noted evidence for such an interval in central and southeastern Oklahoma (Albert 1981; Albert and Wycoff 1984; S. Hall 1977). Based on his work at Delaware Canyon in west-central Oklahoma, Ferring (1986) notes similar evidence and suggests that the alluvial sediments aggraded slowly and the Caddo Paleosol formed during a wet period between 2000 and 1000 B.P. Molluscan fauna provide evidence of local ponding and marshy habitats during the latter half of the first millennium A.D. Vertebrate fauna recovered from archeological sites also are interpreted as evidence of wetter conditions during this time (i.e., Plains Woodland period).

After this brief mesic interval, there is considerable evidence for the onset of drier conditions in the southern Panhandle-Plains of Texas around A.D. 1000. Four lines of evidence-widespread channel trenching and erosion in fluvial systems, increased eolian sedimentation in canyonland rockshelters, increased eolian activity and clay dune formation on the High Plains, and extinction of some floral and faunal species-support this argument.
Channel incision at around A.D. 1000 is well documented in the Lake Alan Henry and Lake O. H. Ivie areas and appears to be represented in parts of the Caprock Canyonlands (such as Palo Duro Canyon and Lake Mackenzie) that have not been intensively studied. Abbott (1990:57) noted that a "period of incision, commencing between 1000 and 700 B.P." is evident at Lake Alan Henry and at many other localities in the Southern Plains (e.g., Ferring 1982, 1986; Hall 1988; Hall and Lintz 1984; Knox 1983).

Outside the Texas Panhandle-Plains, Hall (1990) demonstrates that there is widespread evidence for fluvial channel incision around 1000 B.P. in 15 alluvial sequences in north-central Texas and central and western Oklahoma. Two of the sequences in Hall's (1990) study are the Lake Alan Henry and Lake O. H. Ivie areas, while the other 13 are located farther to the east and north. Prior to 1000 B.P., all of the study areas were characterized by slow alluvial sedimentation and soil formation on stable surfaces, with several lines of evidence indicating a regionally moist climate. The regional climate is thought to have shifted from moist to dry around 1000 B.P., and widespread channel trenching occurred simultaneously in large and small streams in the Arkansas, Red, Trinity, Brazos, and Colorado River basins. By all accounts, channel trenching was intensive but relatively brief, lasting less than 200 years. This was followed by a period of renewed alluviation, but dry conditions apparently remained the norm for some time.

A significant change in the depositional regime in a rockshelter at Lake Alan Henry provides evidence for a drier climate after ca. A.D. 1000 (Kibler in Boyd et al. 1994:215-220). An increase in exogenous eolian sediments in Boren Shelter No. 2 at this time is interpreted as evidence for an increase in aridity and loss of vegetation. Jack Hughes (personal communication 1992) has noted similar depositional changes in other rockshelters in the Texas Panhandle-Plains, but the stratigraphic contact has only been dated at Boren Shelter No. 2 .

The third line of evidence for increased aridity around A.D. 1000 is the sudden increase in eolian activity and the formation of clay dunes (lunettes) around pluvial lakes and spring-fed ponds in draws on the southern Llano Estacado. Increased eolian activity is evident at this time in the Lubbock Lake stratigraphic record (Holliday and Allen 1987) and in late Holocene clay dunes on the southern Llano 
Estacado. The most intensively studied and bestdated clay dune, the Sulphur Springs Draw lunette, apparently formed around A.D. 1000 in response to a drop in the water table that dried up the valley floor ponds (at least on a seasonal or intermittent basis) and provided a source of eolian sediments (Frederick 1994a, 1994b). Other parts of the High Plains are currently being studied, and Frederick (1994a:51) states that

in a forthcoming summary of Llano Estacado paleoenvironmental and stratigraphic studies, Holliday . . notes that eolian deposits throughout the region during the period 3,000 to 500 years B.P. suggest an increasingly dry climate but that a number of lines of evidence (isotopic, vertebrate and invertebrate paleontological) indicate more arid conditions beginning around 1000 B.P.

The fourth line of evidence for arid conditions after A.D. 1000 is that at least one moisture-loving animal (i.e., prairie vole) may have become extinct in parts of the Southern Plains. Hall (1982) also presents pollen and snail evidence indicating that some species in the Osage Hills of northeastern Oklahoma may have become extinct or reduced to remnant populations due to drying conditions after A.D. 1000 .

The late Holocene paleoenvironmental reconstruction for Delaware Canyon closely mirrors the paleoenvironmental interpretations from the southern Panhandle-Plains of Texas. Ferring (1986) notes that there is substantial evidence for increasingly mesic conditions from ca. A.D. 200 to 1000 , followed by a sudden shift to a drier climate. The well-developed Caddo Paleosol formed during the mesic interval (i.e., the Plains Woodland period), but it is truncated by erosion in most parts of Delaware Canyon and occasionally is cut by deeply incised gullies. The erosional episode coincided with a rapid decrease in the number and diversity of moisture-loving molluscan species and an increase in dry-prairie-adapted species. Other areas outside the Texas Panhandle-Plains also exhibit evidence of drier conditions after A.D. 1000. This climatic phenomenon appears to have been widespread and is observed in the paleoenvironmental record of the central Osage Plains of Oklahoma (Hall 1988) and throughout central, north, and west Texas (Lintz, Blum et al. 1993).
When the paleoclimatic reconstruction offered here for the southern Panhandle-Plains of Texas is compared with four recent regional paleoenvironmental reconstructions for different parts of Texas and Oklahoma, there is considerable agreement among them (Figure 77). In particular, there is a great deal of consistency between the southern Panhandle-Plains model and the central, north, and west Texas model proposed by Lintz, Blum et al. (1993) as part of the Lake O. H. Ivie cultural resources investigations. Some similarities are expected since the latter study does incorporate some of the Llano Estacado data.

Based on a variety of evidence (e.g., geomorphic, pollen, and faunal data), Hall's (1988) reconstruction of the paleoenvironment of the central Osage Plains in Oklahoma also follows the same general trends as the southern Panhandle-Plains and central, north, and west Texas models except that the dry middle Holocene climate lasts much later (until after 1000 B.C.). Hall's (1990) study of channel trenching in the Southern Plains shows a similar paleoclimatic reconstruction for the last 3,000 years.

After critically reevaluating the chronological and paleoenvironmental evidence for the Texas Edwards Plateau, Johnson and Goode (1994) presented a paleoenvironmental reconstruction that is in general agreement with the other models, with the exception that they proposed that mesic conditions prevailed during the middle Holocene. Their interpretation of a mesic climate between 7000 and 3000 B.C. is a radical departure from other paleoclimatic interpretations and has not been widely accepted (see Collins 1995). For example, faunal data from Halls Cave in Kerr County (Toomey 1993; Toomey et al. 1993) and geoarcheological and sedimentary carbon isotope data from Fort Hood in Bell and Coryell Counties (Nordt 1992, 1993) were originally interpreted as evidence of a dry (rather than wet) climate during the early to middle Holocene. Consequently, the early to middle Holocene climate proposed by Johnson and Goode (1994) for the eastern Edwards Plateau is likely to be controversial. Regardless, the proposed eastern Edwards Plateau paleoclimate for the last 5,000 years is generally consistent with the other regional interpretations. The most recent paleoenvironmental reconstruction for central Texas (Collins 1995:378-380, Table 2) also presents a strong argument for extreme aridity during the Early-Middle Archaic (ca. $9000-4000$ B.P.). 


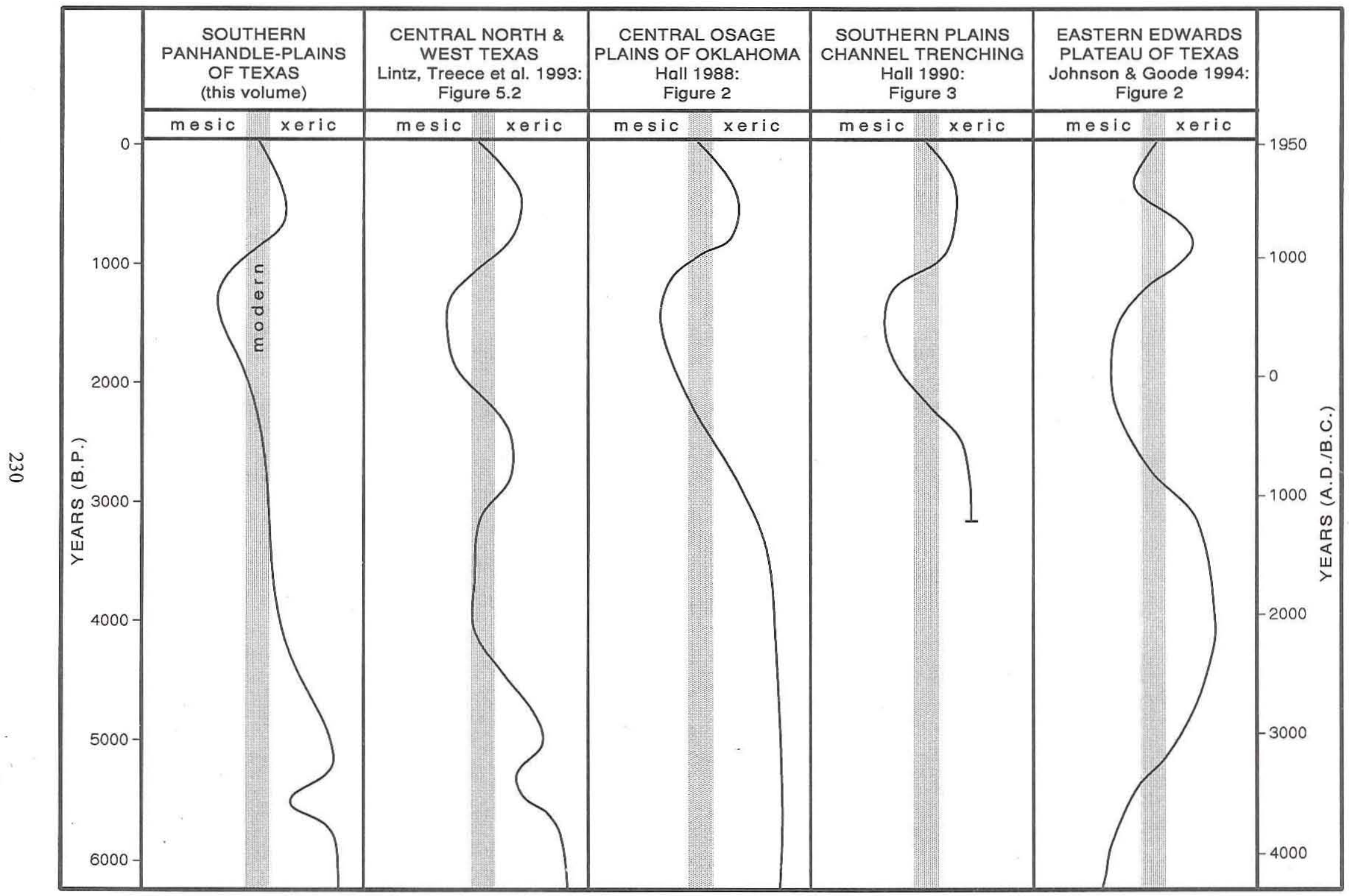

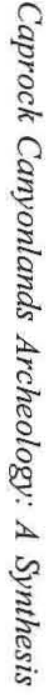

Figure 77. Comparison of regional paleoenvironmental reconstructions for the Southern Plains. 
When the paleoclimatic model and cultural chronology for the southern Panhandle-Plains are integrated, the cultural period climatic sequence may be summarized as follow: the Early to Middle Archaic (6000 to 2500 B.C.) climate was extremely arid; the Late Archaic (2500 B.C. to A.D. 1) climate was generally xeric in the beginning but became increasingly mesic, and essentially modern (or perhaps slightly mesic) conditions may have prevailed during the latter half of the period; the transitional Archaic (A.D. 1-500) climate may have shifted from modern to mesic; the Late Prehistoric I (A.D. 500-1100) climate was generally mesic and perhaps wettest toward the end of the period; the Late Prehistoric II (A.D. 1100-1600s) climate was more xeric, perhaps brought on by a brief but intense drought, but conditions were probably not nearly as dry as during the Early to Middle Archaic; and the Protohistoric and Historic (1600s to 1800 s) climate shifted toward moderate or modern conditions but was punctuated by brief xeric intervals. 

